\title{
THE 1973 MISSISSIPPI RIVER BASIN FLOOD: \\ COMPILATION AND ANALYSES OF METEOROLOGIC, STREAMFLOW, AND SEDIMENT DATA
}

Report prepared jointly by the U.S. Geological Survey and the National Oceanic and Atmospheric Administration

U.S. DEPARTMENT OF THE INTERIOR • U.S. DEPARTMENT OF COMMERCE
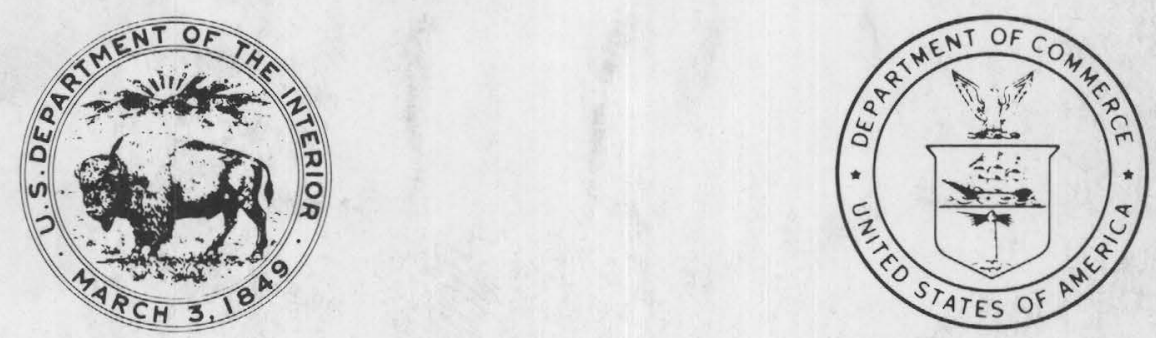



\section{THE 1973 MISSISSIPPI RIVER}

BASIN FLOOD:

COMPILATION AND ANALYSES OF

METEOROLOGIC, STREAMFLOW,

AND SEDIMENT DATA

By EDWIN H. CHIN of the National Weather Service, National Oceanic and Atmospheric Administration, and JOHN SKELTON and HAROLD P. GUY of the U.S. Geological Survey

GEOLOGICAL SURVEY PROFESSIONAL PAPER 937

Report prepared jointly by the U.S. Geological Survey and the National Oceanic and Atmospheric Administration
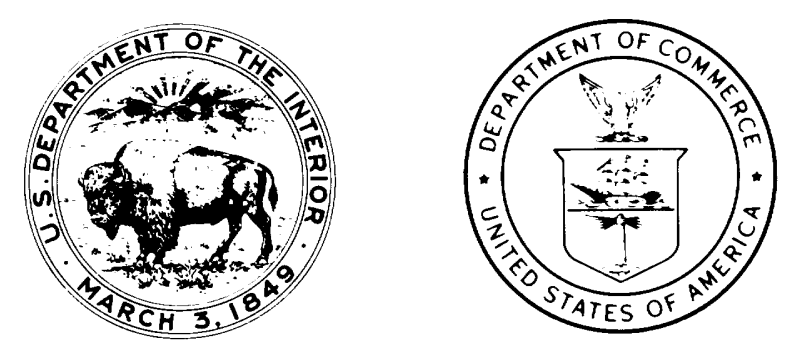

UNITED STATES GOVERNMENT PRINTING OFFICE, WASHINGTON : 1975 
UNITED STATES DEPARTMENT OF THE INTERIOR THOMAS S. KLEPPE, Secretary GEOLOGICAL SURVEY V. E. McKelvey, Director
UNITED STATES DEPARTMENT OF COMMERCE ROGERS C.B. MORTON, Secretary NATIONAL OCEANIC AND ATMOSPHERIC ADMINISTRATIC Robert M. White, Administrator

Library of Congress Cataloging in Publication Data

Chin, Edwin $\mathbf{H}$

The 1973 Mississippi River Basin flood.

(Geological Survey professional paper ; 937)

Bibliography: $\mathrm{p}$.

Includes index.

Supt. of Docs. no.: I 19.16:937

1. Mississippi River-Flood, 1973. I. Skelton, John, 1934- joint author. II. Guy, Harold P., joint author. III. United States. Geological Survey. IV. United States. National Oceanic and Atmospheric Administration. V. Title. VI. Series: United States. Geological Survey. Professional paper ; 937. GB1217,C45 $551.4^{\prime} 8 \quad 75-61925$

For sale by the Superintendent of Documents, U.S. Government Printing Office Washington, D.C. 20402 


\section{FOREWORD}

The U.S. Geological Survey and the National Weather Service have a long history of cooperation in monitoring and describing the Nation's water cycle-the movement of water as atmospheric moisture, as precipitation, as runoff, as streamflow, as ground water, and finally, through evaporation, its return to the atmosphere to begin the cycle over again. The cooperative effort has been a natural dovetailing of technical talent and responsibility: the National Weather Service as the Federal agency responsible for monitoring and predicting atmospheric moisture and precipitation, for forecasting riverflow, and for issuing warnings of destructive weather events ; and the U.S. Geological Survey as the primary agency for monitoring the quantity and quality of the earthbound water resources, including both ground water and surface water.

This report represents another step in the growth of our cooperative efforts. In some ways, this closer working arrangement has been spurred by five major flood disasters that have struck the Nation in the last 6 years. In August 1969, the remnants of Hurricane Camille caused flooding of the James River and other streams in central Virginia that left 152 people dead or missing. In February 1972, the failure of a coal-waste dam sent a flood wave down the Buffalo Creek Valley of West Virginia, leaving 118 people dead or missing. On June 9, 1972, extremely heavy rains over the eastern Black Hills of South Dakota produced record-breaking floods on Rapid Creek and other streams, leaving 237 dead and 8 missing. Beginning on June 18, 1972, the remains of Hurricane Agnes produced floods in the eastern United States from Virginia to New York that killed 117 people in what has been called the worst natural disaster in American history. Most recently, the spring 1973 floods on the Mississippi River produced a record 88 days of floodflow at Vicksburg, Miss., and 77 days at St. Louis, Mo.; inundated more than 12 million acres of land; and damaged over 30,000 homes.

These disasters have underlined the need to know more about the force and flow of floodwater and have given impetus to further cooperation between the U.S. Geological Survey and the National Weather Service to combine their respective studies and information about flood events into single, unified reports. Hopefully, this documentation of the 1973 Mississippi River basin flood will aid the understanding of such flood disasters and will help improve human preparedness for coping with future floods of a similar catastrophic magnitude.

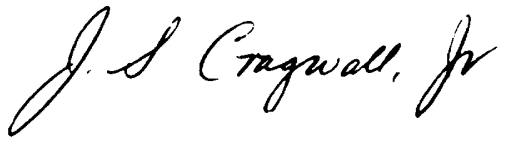

Joseph S. Cragwall, JR.

Chief Hydrologist

U.S. Geological Survey

Department of the Interior

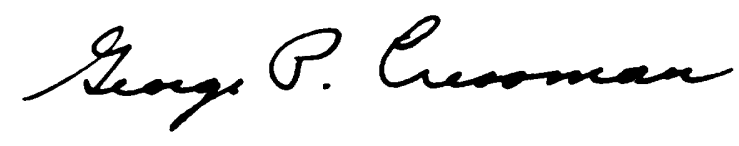

George P. Cresssman

Director

National Weather Service

Department of Commerce 



\section{CONTENTS}

Foreword

Glossary

Abstract

Introduction

Conversion of English units to international system of units

Meteorological settings of the flood episode

Antecedent precipitation

Highlights for selected weeks

March 5-11 _.....

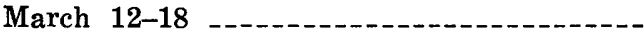

April 16-22

Precipitation events in the Mississippi basin during the spring of 1973

Areal precipitation

Seasonal stratification of precipitation events ....

Storm combinations

The storm of April 19-22, 1973, over the central

Mississippi Basin

Storm history

Parcel trajectories leading into

Associated synoptic conditions

Proximity soundings related to the storm

Polar jet axis and precipitation center .........

Precipitation centered at Moberly, Mo., and in other locations
Estimation of water loss in the Mississippi basin in spring 1973

Some concluding remarks (meteorology) -.--_--.--

Data at stream-gaging stations

Magnitude and frequency of flood peaks and volumes_.

The floods

Mississippi River main stem

Flood peaks

duration and volume

Suspended sediment _..._._._._. 58

Tributary streams-flooding and suspended sediment

streams in Minnesota

Tributary streams in Wisconsin _...-_-_. 67

Tributary streams in Iowa

Tributary streams in Illinois _-_._._. 69

Tributary streams in Missouri _....... 71

Tributary streams in Kentucky _...... 71

Tributary streams in Tennessee _....... 73

Tributary streams in Arkansas _...... 74

Tributary streams in Mississippi _...-_-_-_ $\quad 74$

Tributary streams in Louisiana _-_-_._- $\quad 74$

Water and sediment discharge to Lake Pontchartrain

and the Gulf of Mexico

Selected references -

41 Index of stream-gaging station names

\section{ILLUSTRATIONS}

[Plates 1-9 are in pocket]

Plate 1. National Weather Service 24-hour precipitation maps at 7:00 a.m. e.s.t. for March 1973.

2. National Weather Service 24-hour precipitation maps at 7:0C a.m. e.s.t. for April 1973.

3. National Weather Service 24-hour precipitation maps at 7:00 a.m. e.s.t. for May 1973.

4. Daily surface weather maps at 7:00 a.m. e.s.t. for March 1973.

5. Daily surface weather maps at 7:00 a.m. e.s.t. for April 1973.

6. Daily surface weather maps at 7:00 a.m. e.s.t. for May 1973.

7. Daily 500-mb height contours at 7:00 a.m. e.s.t. for March 1973.

8. Daily 500-mb height contours at 7:00 a.m. e.s.t. for April 1973.

9. Daily 500-mb height contours at 7:00 a.m. e.s.t. for May 1973. 


\section{ILLUSTRATIONS}

FIGURE 1. Map of the Mississippi River basin, showing general area of flooding streams, spring 1973

2. Map showing total winter precipitation in 3-month period prior to March 1973

3. Map showing total winter precipitation in 3-month period prior to March 1973 as a percentage of normal winter precipitation

4. Map showing total precipitation in February 1973

5. Map showing total precipitation in February 1973 as a percentage of normal February precipitation

6. Map showing depth of snow on the ground, March 5, 1973

7. Map showing depth of snow on the ground, March 19, 1973

8. Map showing mean 700-mb contours in decametres for March 1973; departure from normal mean 700-mb height in metres for March 1973; mean 700-mb geastrophic windspeed for March 1973

9. Map showing mean 700-mb contours in decametres for April 1973; departure from normal of mean 700-mb height in metres for April 1973; mean 700-mb geostrophic windspeed for April 1973

10. Map showing temperature departure, March 1973, from 30-year mean March temperature -

11. Map showing temperature departure, April 1973, from 30-year mean April temperature

12. Map showing total precipitation in March 1973.

13. Map showing total precipitation in March 1973 as a percentage of normal March precipitation

14. Map showing total precipitation in April 1973

15. Map showing total precipitation in April 1973 as a percentage of normal April precipitation

16. Map showing mean percentage of possible sunshine, March 1973

17. Map showing mean percentage of possible sunshine, April 1973

18. Map showing mean sky cover, sunrise to sunset, March 1973

19. Map showing mean sky cover, sunrise to sunset, April 1973

20. Map showing Palmer Index on March 31, 1973

21. Map showing Palmer Index on April 21, 1973

22. Graphs showing cumulative percentage departures of precipitation amounts from station normals, January to May 1973

23. Graphs showing cumulative percentage departures of precipitation amounts from station normals, January to May 1973

24. Graph showing dimensionless temporal patterns of four storms over the basin

25. Surface weather chart for 6:00 p.m. c.s.t., April 19, 1973

26. $850-\mathrm{mb}$ chart for 6:00 p.m. c.s.t., April 19, 1973

27. 700-mb chart for 6:00 p.m. c.s.t., April 19, 1973

28. 500-mb chart for 6:00 p.m. c.s.t., April 19, 1973

29. Surface weather chart for 6:00 a.m. c.s.t., April 20, 1973

30. 850-mb chart for 6:00 a.m. c.s.t., April 20, 1973

31. 700-mb chart for 6:00 a.m. c.s.t., April 20, 1973

33. Surface weather chart for 6.00 p.m.

34. 850-mb chart for 6:00 p.m. c.s.t., April 20, 1973

36. 500 -mb chart for 6:00 p.m. c.s.t, April $20,1973 \ldots$

37. Map showing 24-hour trajectories ending at 700-mb at 6:00 p.m. c.s.t., April 20, 1973

38. Map showing 24-hour trajectories ending at 850-mb at 6:00 p.m. c.s.t., April 20, 1973

39. Map showing 24-hour surface trajectories ending at 6:00 p.m. c.s.t., April 20, 1973

40. Map showing 24-hour trajectories ending at 700-mb at 6:00 p.m. c.s.t., April 5, 1973

41. Map showing 12-hour net vertical displacement of air parcels reaching 700-mb at 6:00 a.m. c.s.t., April 21, 1973

42. Map showing some synoptic features at 6:00 a.m. c.s.t., April 20, 1973, before the inception of a small line in northern Missouri

43. Map presentation of analysis of precipitable water (in) from surface to $500 \mathrm{mb}$ and lifted index for $6: 00$ a.m. c.s.t., April 21, 1973

44. Graph showing sounding for Little Rock, Ark., at 600 a.m. c.s.t., April 20, 1973

45. Graph showing sounding for Peoria, Ill., at 6:00 p.m. c.s.t., April 20, 1973

U.S. cloud cover, April 20, 1973, 1800 G.m.t. from NOAA satellite photograr

47. Map showing position of jet axis at (a) 6:00 a.m. c.s.t. April 20, 1973, (b) 6:00 p.m., April 20, 1973, (c) 6:00 a.m. c.s.t., April 21, 1973. Precipitation center in northern Missouri with more than 4 inches in 12 hours ending 6:00 a.m. c.s.t., April 21, 1973, also shown

48. Map of total storm rainfall April 19-22, 1973, near storm center at Moberly, Mo., showing area with 2 inches or more rain

Page 
FIGURE 49. Graph showing mass curves of rainfall for (1) Moberly Radio KWIX, (2) Higbee 7S, (2) Hannibal Waterworks, and (4) Columbia WSO for April 19-22, 1973

50. Map of total rainfall April 16-22, 1973, showing areas with 2 inches or more rain

51. Map showing location of flood determination and sediment data sites in the Mississippi River basin --.--

52. Graphs for determining flood-frequency for the $M$ ississippi River

53. Graph showing comparison of monthly mean flows for October 1972-June 1973 with average monthly flows; selected stations in the Mississippi River basin

54. Graph showing comparison of monthly mean flows for October 1972-June 1973 with average monthly flows; selected stations in the Mississippi River basin

55-58. Photographs showing effects of Mississippi River flooding, spring 1973

59-65. Flood-crest profiles of Mississippi River

66. Discharge hydrographs at selected gaging stations on the Mississippi River, March-May 1973 -.-----

67. Map showing data collection points in Lakes Ponchartrain and Borgne, La

68. Flood-crest profiles of Turtle and Little Turtle Creeks, Rock and Walworth Counties, Wis -...----

69. Photograph showing effects of Turtle Creek flooding at Beloit, Wis., April 21, 1973

70. Flood-crest profiles of Big Creek and Skunk River in Iowa

71. Flood-crest profiles of Rock River, Illinois and Wisconsin

72. Flood-crest profiles of North Fabius and North Rivers, Mo

73. Map showing extent of flooding during March 1973 in the Mississippi River Delta region of northwest Mississippi

74. Graph showing March-June 1973 suspended sediment discharge at selected points in the Mississippi River basin

\section{TABLES}

TABLE 1. Record and near record monthly precipitation in the Mississippi River basin in spring 1973

2. Average sky cover and percentage of possible sunshine for selected stations in the Mississippi River basin, March and April 1973, versus climatological normals

3. Weekly precipitation totals and cumulative departures (in) from normal, February 26-May 20, 1973

4. A sample of precipitation events in the Mississippi basin in March and April 1973

5. Comparison of past significant storm rainfalls within a 200-mile radius of Moberly, Mo., with the observed rainfall at Moberly Radio KWIX in the storm of April 19-22, 1973

6. Comparison of the April 20-21, 1973, storm near Moberly, Mo., with the Illinois model 12-hour severe rain-

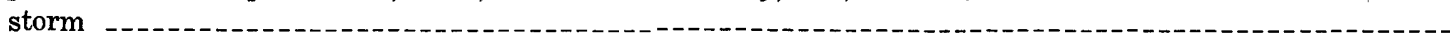

7. Comparison of daily average solar radiation for March and April 1973 received at the surface with the climatic normal solar radiation

8. Comparison of evaporation for March and April 1973 with climatic mean monthly evaporation

9. Flood-crest elevations on the Mississippi River

10. Chloride and suspended-sediment data, Lake Pontchartrain, L

11. Summary of sediment and rated La Pontehartrain, La -

1973 Mississippi River flood

12. Station descriptions and discharge and suspended-sediment data

\section{GLOSSARY}

Albedo. The ratio of the amount of radiation reflected by a body to the amount incident upon it, commonly expressed as a percentage.

Bed material. The sediment mixture of which the moving bed is composed.

Concentration of sediment, by weight. The ratio of the weight of dry solids in a water-sediment mixture to the weight of the mixture in milligrams per litre.

Depth-integrating sediment sampler. An instrument that is moved vertically at an approximately constant rate between the water surface and a point a few inches above the streambed. It collects a representative water-sediment mixture at all points along the sampling vertical.
Dew point (or dew point temperature). The temperature to which a given parcel of air must be cooled at constant pressure and constant water-vapor content in order for saturation to occur.

Discharge-weighted concentration. The dry weight of sediment in a unit volume of stream discharge, or the ratio of the discharge of dry weight of sediment to the discharge by weight of water sediment mixture.

Fine material. That part of the total stream sediment load composed of sizes not found in appreciable quantities in the bed material; normally the silt and clay sizes (less than $0.062 \mathrm{~mm}$ ). 
Flood peak. The highest value of the stage or discharge attained by a flood.

Flood profile. A graph of the elevation of water surface of a river in a flood, plotted as ordinate, against distance, measured in the downstream direction, plotted as abscissa.

Flood stage. The approximate elevation of the stream when overbank flooding begins.

Front. The interface or transition zone between two airmasses of different density.

Jet stream. Relatively strong winds concentrated within a narrow stream in the atmosphere.

$K$ Index. A measure of the airmass moisture content and stability,

$$
K=\left(T_{850}-T_{500}\right)+T_{d, 850}-\left(T_{700}-T_{d, \text {; } 00}\right),
$$

$T$ and $T_{d}$ are temperature and dew point respectively in degrees Celsius $\left({ }^{\circ} \mathrm{C}\right)$; subscripts denote pressure levels.

Lifted Index. Difference in ${ }^{\circ} \mathrm{C}$ between the observed $500-\mathrm{mb}$ temperature and the computed temperature which a parcel characterized by the mean temperature and dew point of the $50-\mathrm{mb}$ thick surface layer would have if it were lifted from $25 \mathrm{mb}$ above the surface to $500 \mathrm{mb}$.

Moist tongue. An extension or protrusion of moist air into a region of lower moisture content.

$\mathbf{N}$-year precipitation (rain). A precipitation amount which can be expected to occur, on the average, once every $N$ years.

Occluded cyclone. Any cyclone within which there has developed an occluded front.

Occluded front (occlusion). A composite of two fronts, formed as a cold front overtakes a warm front or quasistationary front. This is a common process in the late stages of cyclone development.

Particle size. The diameter of a particle measured by settling, sieving, micrometric, or direct measurement methods.

Particle size distribution. The relative amount of a sediment sample having a specific size, usually in terms of percent by weight finer than a given size, $D$ percent.

Point-integrating sediment sampler. An instrument designed to collect a representative sample of the water-sediment mixture at a selected depth in a stream vertical over a specific time period.

Precipitable water. The total atmospheric water vapor contained in a vertical column of unit cross-sectional area extending from the surface up to a specified pressure level, usually $500 \mathrm{mb}$.
Recurrence interval. Frequency of flooding is normally expressed by the Geological Survey in terms of recurrence interval in years. This designation indicates that a flood of a given magnitude will be exceeded once in an average interval of time. For example, a 50-year flood discharge will be exceeded on the average of once in 50 years; in terms of probability, there is a 2-percent chance that such a flood will occur in any year.

Ridge. An elongated area of relatively high atmospheric pressure.

Saturation. The condition in which the partial pressure of water vapor is equal to its maximum possible partial pressure under the existing environmental conditions.

Sediment. Solid particles usually derived from rocks or earth material that have been or are being transported laterally or vertically from one or more places of origin.

Sediment discharge. The average quantity of sediment carried past any cross section of a stream per unit of time. The term may be qualified as, for example, suspendedsediment discharge, bedload discharge, bed-material load discharge, or total sediment discharge.

Sediment yield. The total sediment outflow from a watershed or past a given location in a specified period of time. It includes stream bedload as well as suspended load and is usually expressed in tons per year.

Showalter Index. A measure of the local static stability of the atmosphere. It is determined by raising an air parcel from $850 \mathrm{mb}$ dry-adiabatically to saturation, then saturation-adiabatically to $500 \mathrm{mb}$. At $500 \mathrm{mb}$ the environment temperature minus the parcel temperature and expressed as a nondimensional numeral is the index.

Sounding. A single complete radiosonde observation of the upper atmosphere.

Squall line. Any non-frontal line or narrow band of active thunderstorms; a mature instability line.

Suspended sediment. Organic and inorganic particulate matter that moves in suspension in streamflow and is maintained in suspension by the upward components of turbulent currents or by colloidal suspension.

Trough. An elongated area of relatively low atmospheric pressure.

Vapor pressure. The pressure exerted by the molecules of a given vapor; in meteorology, this term is used exclusively to denote the partial pressure of water vapor. 


\section{THE 1973 MISSISSIPPI RIVER BASIN FLOOD: COMPILATION AND ANALYSES OF METEOROLOGIC, STREAMFLOW, AND SEDIMENT DATA}

By Edwin H. ChIN of the National Weather Service, National Oceanic and Atmospheric Administration, and John Skelton and Harold P. Guy of the U.S. Geological Survey

\section{ABSTRACT}

The severe 1973 spring flood in the Mississippi River basin had its beginnings in the mild, wet fall and winter of 1972. Many tributary streams and reservoir levels were well above normal throughout the basin when heavy spring rains began to fall. Frequent and prolonged warm rains associated with extratropical cyclones and frontal activities fell over large areas of the Mississippi basin in March and April 1973. The cumulative effect of these rainfalls led to the 1973 Mississippi River basin flood, characterized by its long duration, high volumes of runoff, and large coincident tonnage of sediment transported.

New records for consecutive days above flood stage were set for most main-stem gaging stations from southern Iowa to Louisiana. For example, the Mississippi River remained above flood stage for a record number of consecutive days at St. Louis, Mo. (77 days), Chester, Ill. (97 days), Thebes, Ill. (95 days), Memphis, Tenn. (63 days), and Vicksburg, Miss. (88 days). The total sediment discharge to the Gulf of Mexico during March through June was approximately 240 million tons, including 15 million into Lake Pontchartrain.

The 1973 main-stem flood stages were the highest ever observed in the reach of the Mississippi extending approximately $370 \mathrm{mi}(595 \mathrm{~km})$ upstream from Cape Girardeau, Mo. At St. Louis, Mo., for example, the maximum stage of $43.23 \mathrm{ft}$ $(13.177 \mathrm{~m})$ exceeded the stage of $41.32 \mathrm{ft}(12.594 \mathrm{~m})$ that was observed in June 1844, and the flood peak of April 1785 that may have reached $42 \mathrm{ft}(12.80 \mathrm{~m})$.

Peak stages and discharges far exceeding the estimated values for the 100-year flood occurred in April 1973 on many tributaries in Wisconsin, Iowa, Illinois, and Missouri. Most tributary streams throughout the Mississippi River basin experienced some degree of flooding during March-May 1973, contributing to the outstanding main-stem flooding which continued into June.

Described in this report are the meterological setting of the flood, an account of the general characteristics of associated precipitation, and an analysis of a sample of significant precipitation events with return periods exceeding 100 years. The storm of April 19-21, 1973, with precipitation centered in northern Missouri, is analyzed as a case study. An estimation of evapotranspiration based on relevant meteorological factors indicates a probable reduction of such loss during the flood episode.

This report also contains summaries of stream stages, discharges, and flood volumes for gaging stations where outstand- ing flood events occurred and includes sediment data where available. The recurrence interval of the event is shown for many of the peaks and volumes. Also included are flood-profile data for the main stem and selected tributary streams.

\section{INTRODUCTION}

The Mississippi basin flood in the spring of 1973 was exceptional in its duration, magnitude, and areal extent. Flooding began along portions of the Upper Mississippi River in early March as a result of much heavier than normal precipitation, and by April 3 the main stem was above flood stage along its entire course below Cairo, Ill. All major tributaries experienced continuous flooding with parts of 10 States affected to some extent-Minnesota, Wisconsin, Iowa, Illinois, Missouri, Tennessee, Kentucky, Arkansas, Mississippi, and Louisiana (fig. 1). More than 12 million acres (30 million ha) of land were inundated during the worst of the flooding, and 28 deaths were attributed to the floods. Fifty thousand people were evacuated from their homes and total damages were estimated by the Corps of Engineers to be over $\$ 400$ million. It was not until May that the history-making floods began to recede.

The Mississippi River rises in northern Minnesota and flows southward for about $2,470 \mathrm{mi}(3,970 \mathrm{~km})$ into the Gulf of Mexico. The main stem, together with its tributaries, extends over 31 States, and the drainage basin of $1,243,700 \mathrm{mi}^{2} \quad\left(3,221,200 \mathrm{~km}^{2}\right)$ covers 41 percent of the land area in the conterminous United States. In order for widespread flooding to occur over a basin drained by a river system of such extent and capacity, extraordinary precipitation events must occur at critical locations in the system. The precipitation events. relevant to the flood and their associated meteorological situations are analyzed in a later section of the report, and comparisons are made with climatological precipitation 


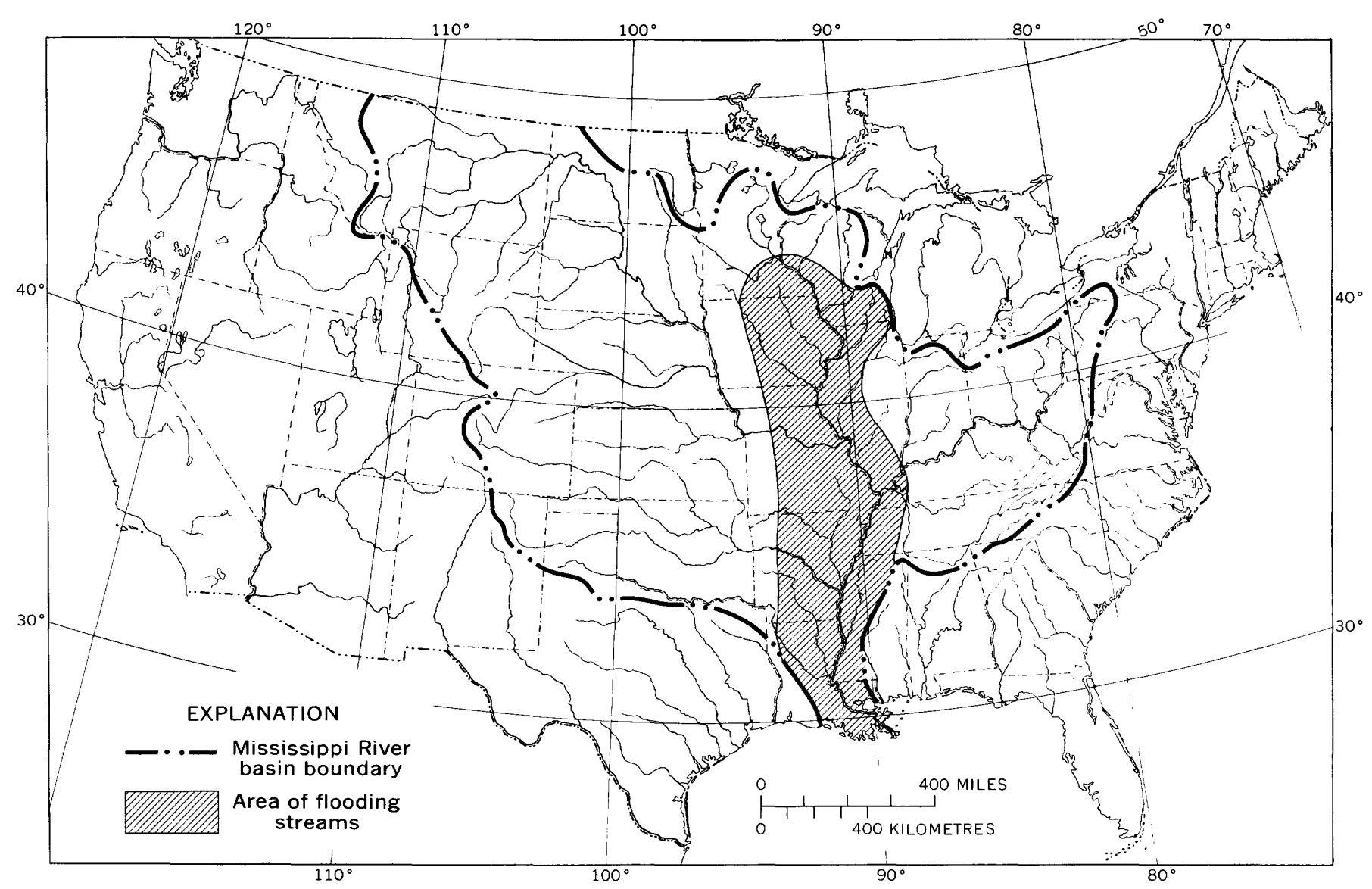

FIGURE 1.-The Mississippi River basin, showing general area of flooding streams, spring 1973.

events of various return periods. A case study of cyclone and frontal systems associated with tropical maritime airmass intrusion into the "heartland" of the basin is also presented later in the report. Estimation of water loss over the basin in March and April 1973 is made.

The Mississippi basin as a whole received above normal precipitation in every month except one from October 1972 through February 1973. As a consequence, tributary flooding over a part of the basin had been in progress prior to the onset of the mainstem flooding in early March 1973. The contributions of the antecedent precipitation, the snowmelt factor, and the unusually prolonged and sometimes heavy storm rainfalls that began in March 1973 are assessed in a later section.

The floods on the main stem of the Mississippi River and its major tributaries are described in some detail in this report. Upstream from Winona, Minn., the main-stem flooding was minor; recurrence intervals of peaks were less than 10 years. However, from approximately $420 \mathrm{mi}(676 \mathrm{~km})$ above Cairo, Ill., to Cape Girardeau, Mo., the maximum 1973 flood stages set alltime high records. Further downstream, the main stem reached its highest stages since 1937.

National Weather Service forecasts and warnings of record and near-record flooding were timely and accurate during the record-breaking period. The forecast for the record crest of April 28 on the Mississippi River at St. Louis was made at a time when major levee failures were occurring upstream, producing additional complications in the forecast problem. As a result of these forecasts and warnings, protective measures were taken throughout the flood areas that have been estimated to have averted over $\$ 500$ million in additional losses. Undoubtedly, the warnings also prevented the loss of many lives.

An outstanding facet of the 1973 flood was the high volume of flow in the Mississippi River and many of its tributaries for an extended period of time. At Vicksburg, Miss., the average runoff for the Mississippi River from October 1972 through June 1973 was much greater than any comparable period since records have been collected.

The record Mississippi River crests in late April 1973 were preceded by headwater floods on many 
tributary streams only a few days earlier. Such almost simultaneous events created lakes of water that could not drain from the land. These backwater areas allowed the relatively heavy sediment loads of the tributaries to partly settle out, thus helping to assure relatively low concentrations of suspended sediment in the Mississippi River main stem. However, backwater floods also caused much damage, particularly in the flat Missisisippi Delta region.

An important feature of most floods is that of sediment erosion, transport, and deposition, and the 1973 flooding was no exception. The main categories of visually apparent sediment damages during the flood were scour and deposition on roads, culverts, and bridges, streambank erosion, erosion and deposition on agricultural land, and deposition in structures and on furnishings. Erosion of the uplands by raindrop splash and overland runoff was caused by precipitation and fresh exposure of the land surface, whereas stream channel erosion was caused by flow intensity and perhaps some manmade channel controls.

This flood serves to illustrate that a flood plain is really an enlarged part of the associated river or stream. Those who are engaged in any activity on or near flood plains need to be aware that the risk of devastating floods in these areas, even though small in any given year, is nevertheless a very real risk. Manmade controls in the form of reservoirs, diversions, and levees can reduce but never completely erase the threat.

\section{PURPOSE AND SCOPE}

This report is one of a continuing series of joint flood reports undertaken by the Department of the Interior, U.S. Geological Survey, and the Department of Commerce, NOAA, National Weather Service. The cooperative effort represents a natural dovetailing of technical talent and responsibility. The National Weather Service is the agency responsible for monitoring and predicting atmospheric moisture and precipitation, for forecasting river stage, and for issuing warnings of destructive weather events. Therefore, its contribution to this report is in the area of meteorological events related to the flood. The Geological Survey is the primary agency for monitoring the quantity and quality of the terrestrial water resources, including both ground water and surface water. Therefore, its contribution is in the area of documenting the flood itself, the magnitude and frequency of the flood peaks and volumes, and the fluvial sediment data. The compilation of this information in one report will serve as a ready refer- ence for this major event and hopefully will be of value in future water-management planning.

Basic precipitation data collected by the National Weather Service are published routinely by NOAA Environmental Data Service in the Climatological Data series and the Hourly Precipitation Data series each month and are readily available through the National Climatic Center in Asheville, N.C. Therefore, when treating precipitation in this report the emphasis is on utilizing these data to arrive at coherent information, such as daily isohyetal patterns and significant precipitation events associated with the flood. The daily surface weather maps and the $500 \mathrm{mb}$ (millibar) charts included in this report should provide a basic frame of reference of the meteorological setting for the flood. More specific analyses of meteorological events relevant to the flood are presented in the text.

Likewise, detailed streamflow and sediment data collected by the Geological Survey are published routinely in State reports, and again this report utilizes these data to assemble coherent information about the flow and sediment characteristics of the flood. Additional flood information is contained in files and publications of district offices of the Geological Survey in each State.

Flood data for 72 sites, including 24 sites having sediment data, are shown near the end of this report. The time period chosen for reporting flood information was March through May 1973 for tributary streams and main-stem stations on the Upper Mississippi River because the outstanding flood peaks and volumes occurred during this period. However, the base period was extended through June 1973 to include the periods of significant flood runoff for some stations, mostly in the Lower Mississippi basin.

A tabulation of daily mean discharge is provided for many stations. For many sites on tributary streams, the stage, discharge, and sediment data are shown at selected times during significant flood events so that more accurate flood hydrographs can be drawn than would be possible by using only the daily mean values.

Flood-volume-duration data are presented for a number of sites where continuous streamflow records were available. These data can be useful in the planning, design, construction, and operation of projects that include the storage of flood waters. The recurrence intervals of the flood volumes and peak discharges are also shown.

\section{ACKNOWLEDGMENTS}

The meteorological and rainfall analyses contained in this report are mainly based upon National 
Weather Service data or products and therefore represent the collective effort of many professional people. The author of the NOAA portion of this report is especially grateful to Mr. John F. Miller, Chief, Water Management Information Division, for his interest in this work and his many helpful comments. Sincere thanks are also extended to $\mathbf{M r}$. Francis K. Schwarz of that same division and to Dr. Charles N. Hoffeditz of the Hydrologic Research Laboratory for their valuable discussions.

Much of the flood and sediment data appearing in this report were collected and reported as part of cooperative programs between the U.S. Geological Survey and the States of Minnesota, Wisconsin, Iowa, Illinois, Missouri, Tennessee, Kentucky, Arkansas, Mississippi, and Louisiana. Much additional data were furnished by the St. Paul, Rock Island, St. Louis, Kansas City, Memphis, Little Rock, Vicksburg, and New Orleans districts of the U.S. Army Corps of Engineers. Other Federal and State agencies, municipalities, and corporations also provided some data.

\section{CONVERSION OF ENGLISH UNITS TO} INTERNATIONAL SYSTEM OF UNITS

For use of those readers who may prefer to use metric units rather than English units, the conversion factors for the terms used in this report are listed below :

\begin{tabular}{|c|c|c|}
\hline $\begin{array}{c}\text { Multiply English } \\
\text { units }\end{array}$ & $B y$ & $\begin{array}{c}\text { To obtain } \\
\text { metric units }\end{array}$ \\
\hline Inches (in.) & 25.4 & Millimetres $(\mathrm{mm})$ \\
\hline Feet $(\mathrm{ft})$ & 0.3048 & Metres (m). \\
\hline Yards (yd) & 0.9144 & Metres (m). \\
\hline Miles (mi) & 1.609 & Kilometres $(\mathrm{km})$. \\
\hline $\begin{array}{l}\text { Nautical miles } \\
\quad(\text { nmi) }\end{array}$ & 1.85 & Kilometres $(\mathrm{km})$. \\
\hline Knots (kn) & 1.85 & $\begin{array}{l}\text { Kilometres per } \\
\text { hour }(\mathrm{km} / \mathrm{hr})\end{array}$ \\
\hline Acres & 4,047 & $\begin{array}{l}\text { Square metres } \\
\qquad\left(\mathrm{m}^{2}\right) .\end{array}$ \\
\hline Acres & 0.4047 & Hectares (ha). \\
\hline $\begin{array}{l}\text { Square miles } \\
\qquad\left(\mathrm{mi}^{2}\right)\end{array}$ & 2.590 & $\begin{array}{l}\text { Square kilometres } \\
\quad\left(\mathrm{km}^{2}\right) .\end{array}$ \\
\hline $\begin{array}{l}\text { Acre-feet } \\
\quad(\text { acre-ft })\end{array}$ & 1,233 & $\begin{array}{l}\text { Cubic metres } \\
\left(\mathrm{m}^{3}\right)\end{array}$ \\
\hline $\begin{array}{l}\text { Acre-feet } \\
\quad \text { (acre-ft) }\end{array}$ & $1.233 \times 10^{-3}$ & $\begin{array}{l}\text { Cubic hectometres } \\
\qquad\left(\mathrm{hm}^{3}\right) .\end{array}$ \\
\hline $\begin{array}{l}\text { Cubic feet per } \\
\text { second }\left(\mathrm{ft}^{3} / \mathrm{s}\right)\end{array}$ & 0.02832 & $\begin{array}{l}\text { Cubic metres per } \\
\text { second }\left(\mathrm{m}^{3} / \mathrm{s}\right)\end{array}$ \\
\hline Gallons (gal) & $3.785 \times 10^{-3}$ & Cubic metres $\left(\mathrm{m}^{3}\right)$ \\
\hline $\begin{array}{l}\text { Degrees Fahren- } \\
\text { heit }\left({ }^{\circ} \mathrm{F}\right)\end{array}$ & $5 / 9(F-32)$ & $\begin{array}{l}\text { Degrees Celsius } \\
\quad\left({ }^{\circ} \mathrm{C}\right)\end{array}$ \\
\hline
\end{tabular}

\section{METEOROLOGICAL SETTINGS OF THE FLOOD EPISODE}

\section{ANTECEDENT PRECIPITATION}

To provide some background for the flood event, antecedent precipitation since late fall 1972 will be briefly examined. Precipitation for October 1972 was more than twice the normal in parts of the southern Plains and the Lower Mississippi Valley. Cairo, Ill., had 7.05 in. $(179 \mathrm{~mm})$ of rain in October 1972, which was 4.17 in. (106 mm) above normal. November 1972 was another wet month for the Ohio River Valley, the Lower Missouri River Valley, and coastal Louisiana. But, for other areas of the basin, it was nearly normal. December precipitation over the Mississippi basin was near normal or above, except for the relatively dry southern Plains. January precipitation was twice its normal in the Central Great Plains and below normal in the Ohio Valley but was about normal in other parts of the Mississippi basin (Environmental Data Service and Statistical Reporting Service, 1973).

The amount of precipitation in the 3-month period prior to March 1, 1973, and this amount as a percentage of normal precipitation are shown in figures 2 and 3. It is evident that the winter season precipitation over the whole Mississippi basin averaged out close to the climatic normal. Since, in considering antecedent events, the immediate past should be given most weight, the precipitation map for February 1973 is also shown in figures 4 and 5 . For about 90 percent of the basin area, February was a rather dry month; and considerable areas in the Missouri and Mississippi River headwater region, Arkansas River basin, and Ohio River basin had less than 50 percent of normal precipitation.

Due to the heavier than normal precipitation in late fall 1972, some sections of the Mississippi River system did not fall to their normal low levels in the winter of 1972. Heavy rainfall and flooding occurred in the Cumberland and Lower Ohio tributaries in December. In January 1973, above-normal streamflow conditions persisted in large areas of the Missouri basin and the Middle Mississippi basin. Here, the term "above (below) normal" applies to streamflows within the highest (lowest) 25 percent of record for a specific month. But this area of abovenormal flow in the midsection of the country reduced considerably after a dry February.

Another relevant factor that should be examined is snowmelt. During the latter part of February 1973 , there was some reduction of the snow cover over the headwater regions of the Mississippi and 


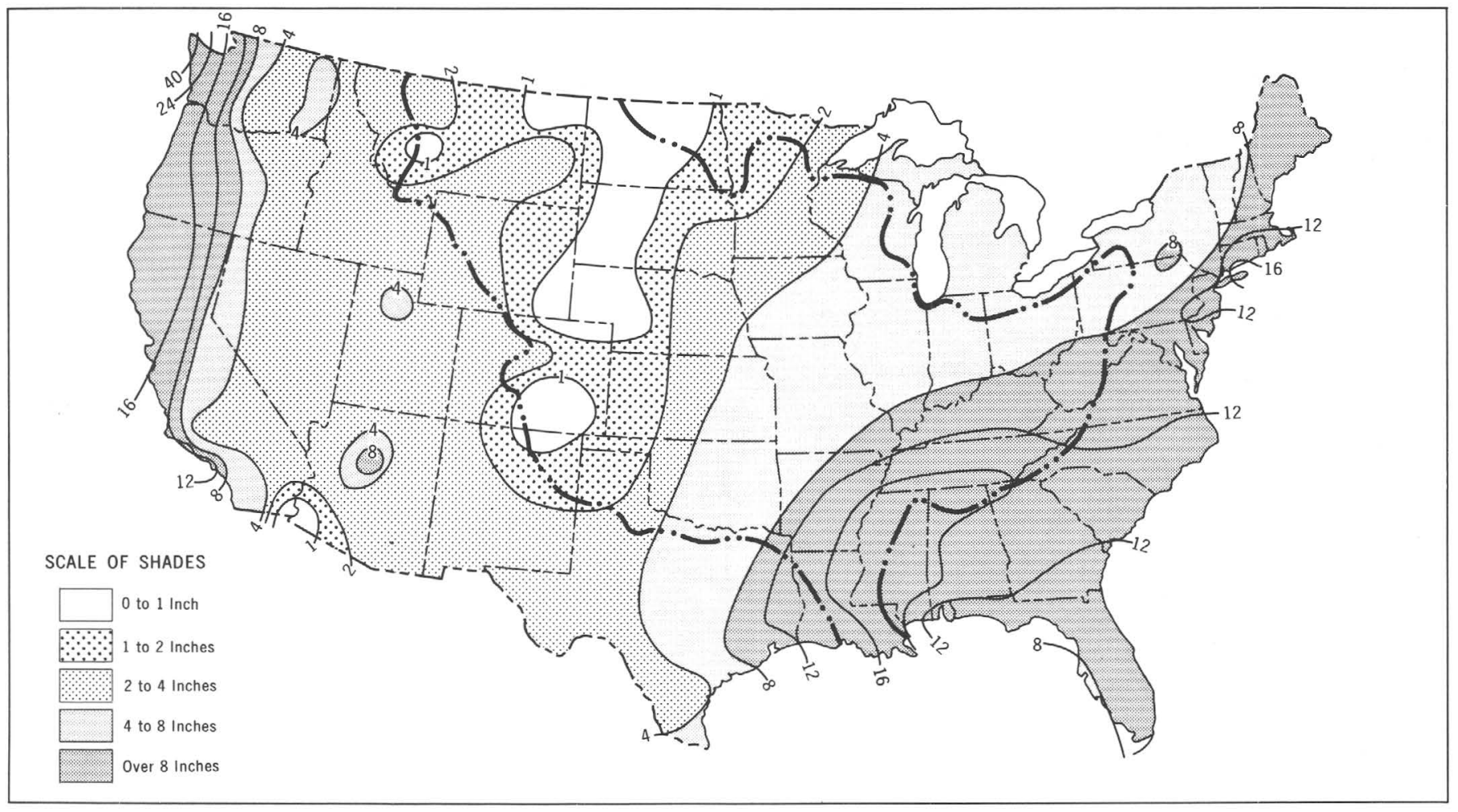

FIGURE 2.-Total winter precipitation in 3-month period prior to March 1973.

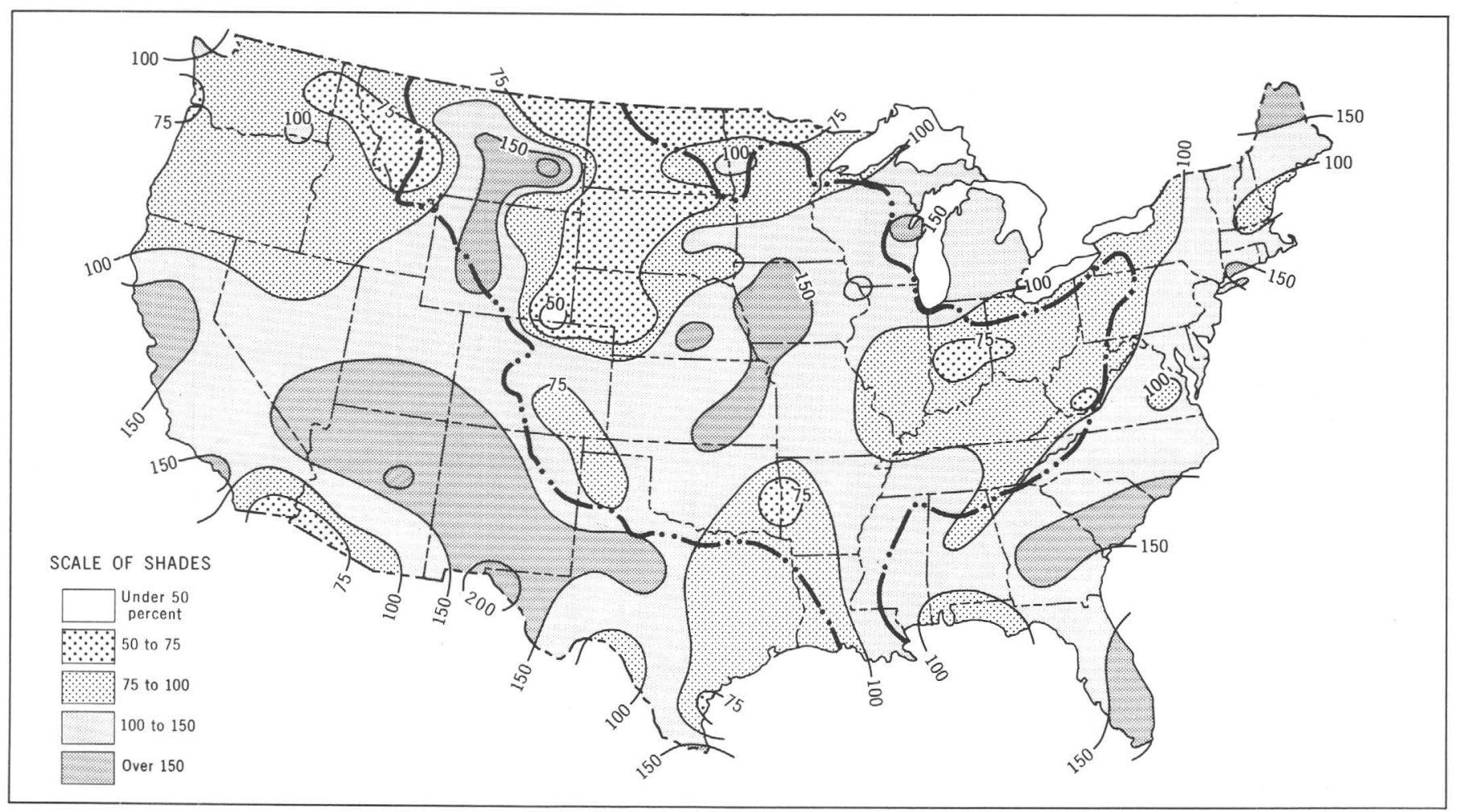

FIGURE 3.-Total winter precipitation in 3-month period prior to March 1973 as a percentage of normal winter precipitation. 


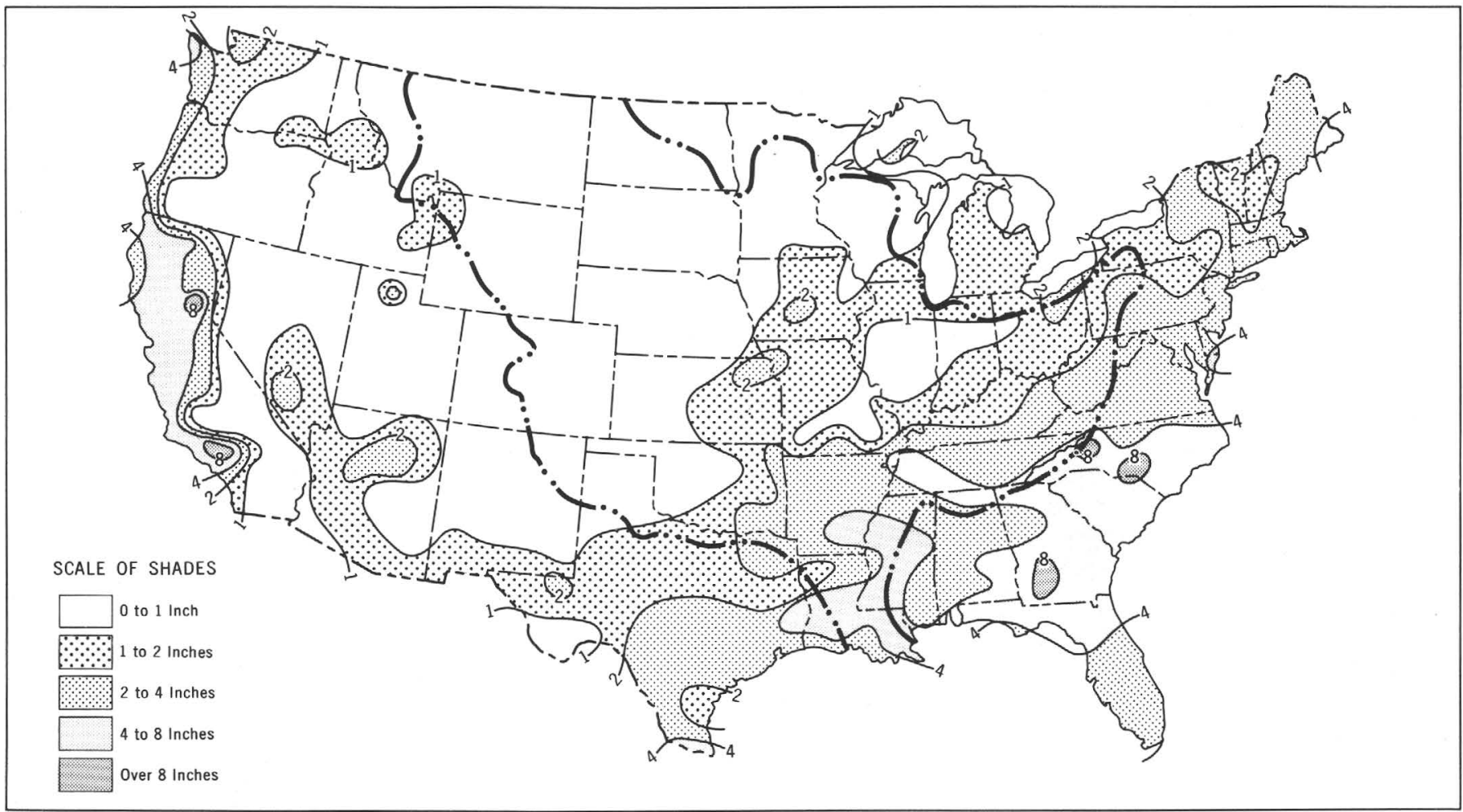

FIGURE 4.-Total precipitation in February 1973.

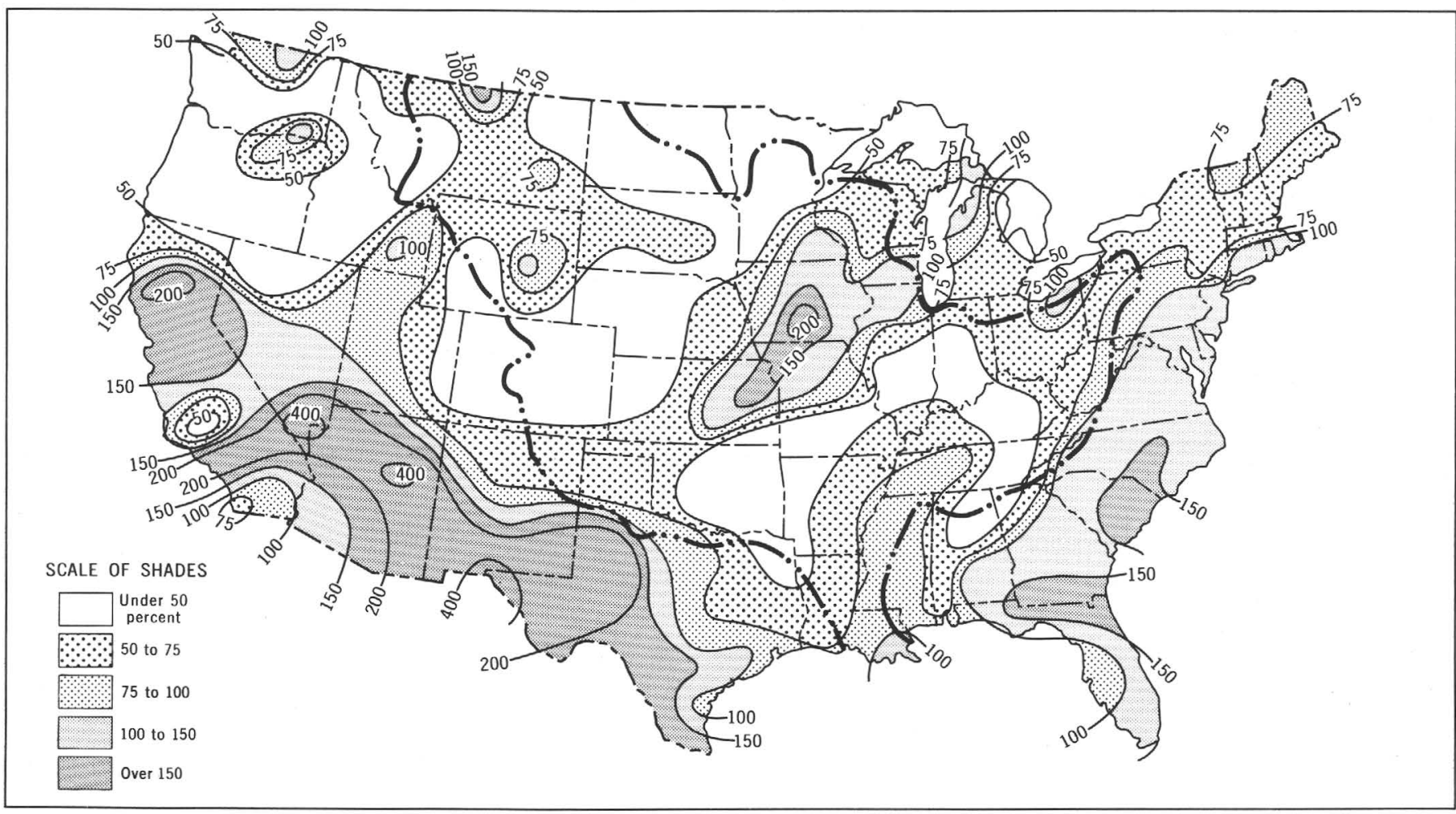

FIGURE 5.-Total precipitation in February 1973 as a percentage of normal February precipitation. 
Missouri Rivers (Environmental Data Service and Statistical Reporting Service, 1973). The snow cover at the beginning of March 1973, which could have provided subsequent snowmelt runoff to the Mississippi River, was both limited in extent and depth (fig. 6). The water equivalent of snow depends on its density, which in turn depends on the "age" of the snow on the ground and the onsite meteorological conditions since its fall. Using the climatological maximum observed water-equivalent data of record in Weather Bureau Technical Paper No. 50 (Miller and Paulhus, 1964), a liberal estimate for the water equivalent for snow cover in the Minnesota-Wisconsin area for March 1-15 seems to be one-fourth of the snow depth. This means that the 1-inch isopleth of snow depth in figure 6 could be considered as an approximate 0.25 -inch isohyetal in case of total melting. In the first weeks of March, the mean temperatures over Minnesota and Wisconsin were more than $12^{\circ} \mathrm{F}\left(6.7^{\circ} \mathrm{C}\right)$ above normal, partially as a result of occasional warm moist air intrusion from the south. The snow cover there receded further northward (fig. 7b), providing limited runoff to the Middle Mississippi River flow. But, when compared with concurrent and subsequent heavy precipitation, such as the 2.8 inches $(71 \mathrm{~mm})$ at LaCrosse, Wis., from March 5 to 11 or the 1.65 inches $(42 \mathrm{~mm})$ in a single day on March 11 at Winona, Minn., the snowmelt factor becomes overshadowed.

The snowmelt contribution to runoff in the Rocky Mountain States can be inferred from the water supply projection for March 1, 1973 (National Weather Service, 1973). It shows that the runoff from the mountainous headwater regions for the Missouri, Platte, and Arkansas Rivers, when averaged, is only slightly above the 1953-67 average. These projections were based on both antecedent precipitation and possible contributions from snowmelt, including normal precipitation subsequent to the date of the outlook. When compared with the very heavy precipitation that fell on the Great Plains in March 1973, snowmelt in the Rockies also could not be a major factor in the initiation of the flood.

From the foregoing discussions, it seems that the antecedent events did contribute towards the initiation of the flood in the sense that higher streamflow conditions prevailing in the Middle Mississippi basin and parts of the Missouri basin at the beginning of March 1973 provided a high flood potential. But such contribution was not a necessary prerequisite in view of the extraordinary precipitation over the basin March and April 1973. Without the antecedent conditions, a major flood would still have occurred. Henceforth, our attention will be directed

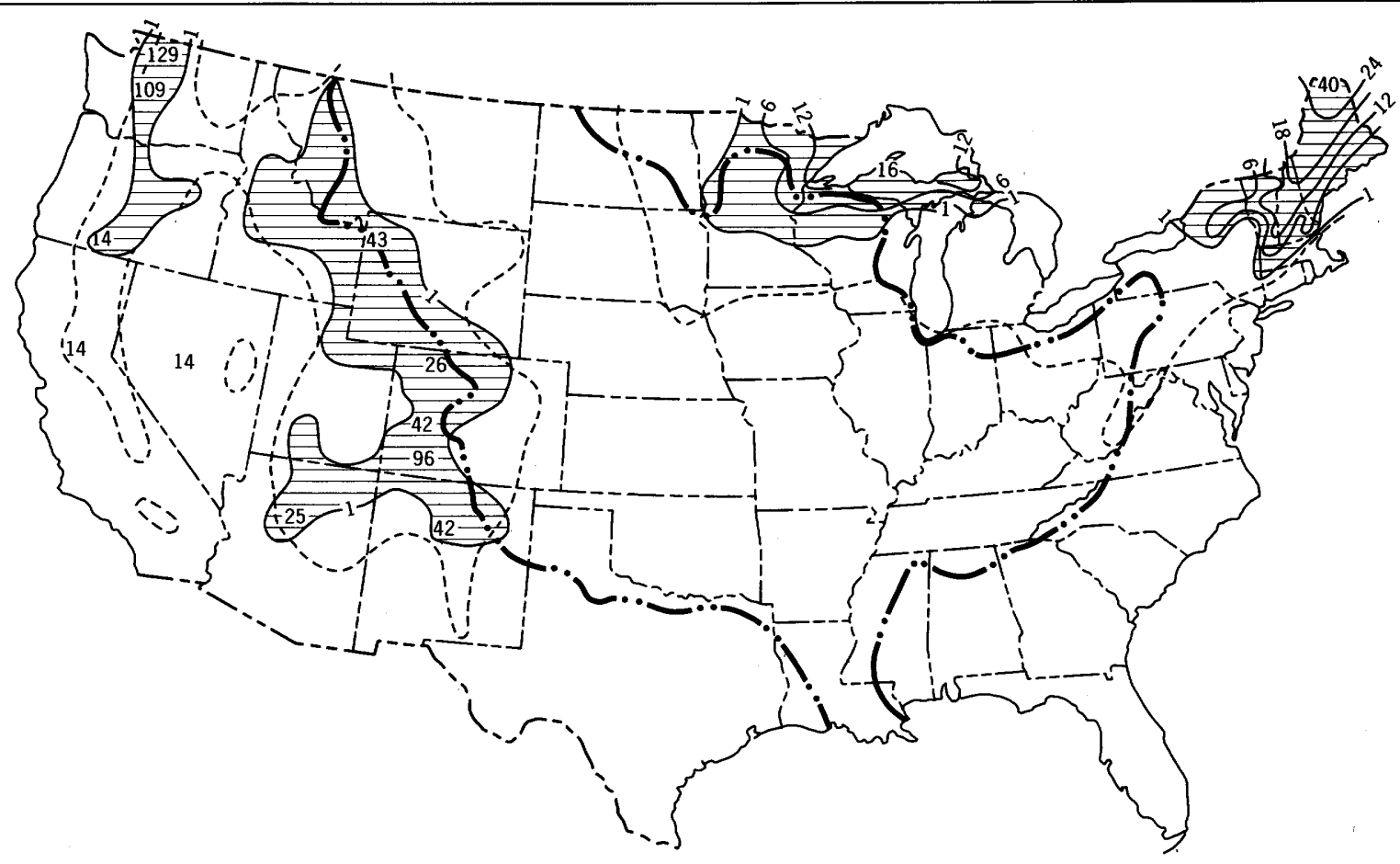

FIGURE 6.-Depth of snow on ground, March 5, 1973. 


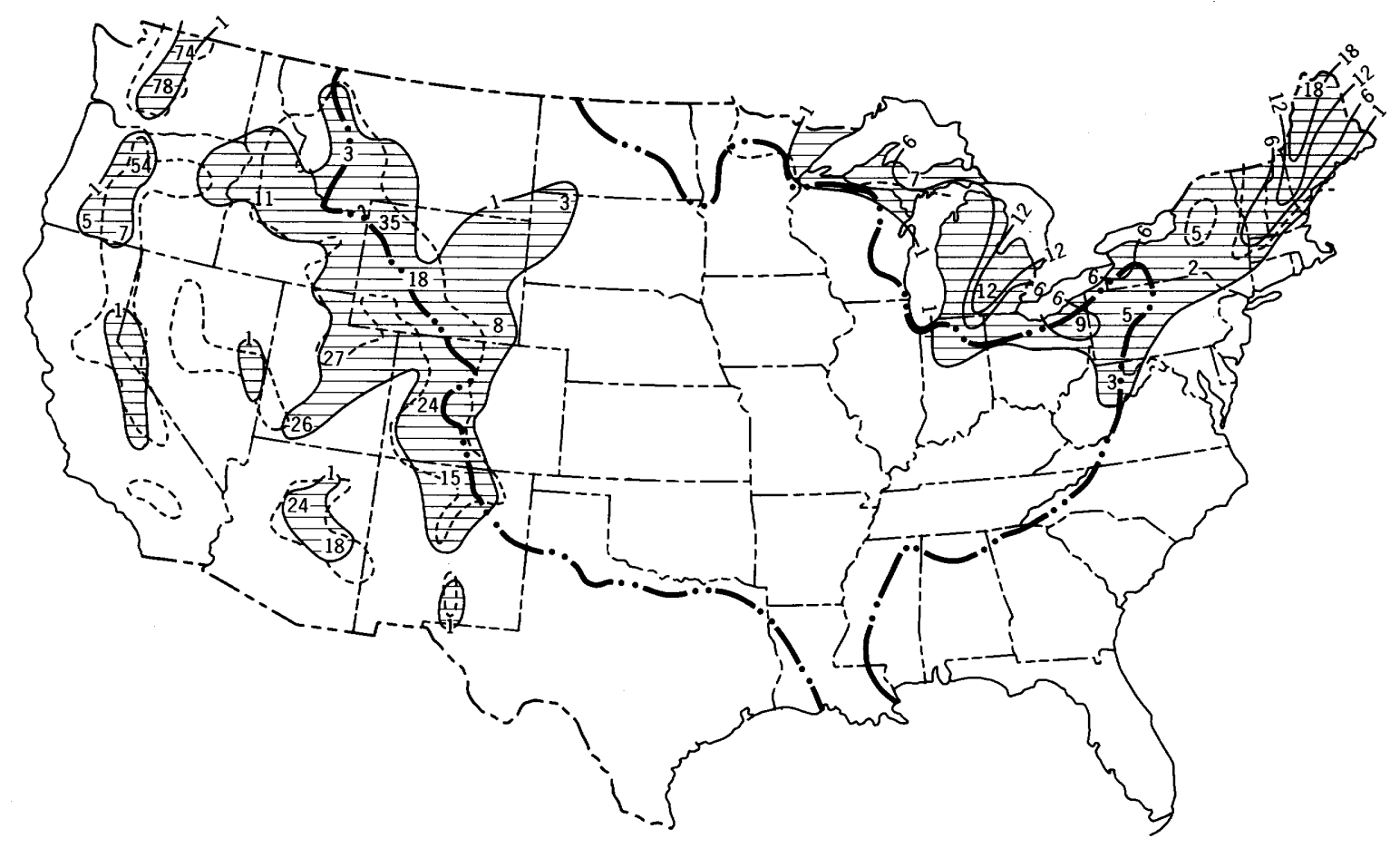

Figure 7.-Depth of snow on the ground, March 19, 1973.

to meteorological events after the beginning of March 1973.

For convenience, the flood episode (from a meteorological standpoint) can be considered to have begun in early March, when, on March 8, flooding was first reported along the Mississippi main stem in the Grafton-Alton area in Illinois, and to have ended in late May, when, on May 25, after establishing a new record of 77 days above flood stage at St. Louis, Mo. (exceeding by 19 days the 1844 record), the Mississippi River fell below flood stage. The choice of dates is motivated by the necessity to set a clearly defined time boundary for our study and admittedly is somewhat arbitrary. Flood events over some tributaries need not coincide with this interval. In view of the timelag involved between precipitation or the lack of it and the response of streamflow for a major river system such as the Mississippi, the proper time interval to consider for the meteorological setting should be from March to mid-May, with emphasis on the months of March and April 1973, since these were the wet months.

\section{METEOROLOGICAL EVENTS ASSOCIATED WITH THE FLOOD}

To portray the mean flow in the lower troposphere during the flood episode, the mean 700-mb contours, their departure from normal, and the mean $700-\mathrm{mb}$ geostrophic windspeed for March and April 1973 are shown in figures 8 and 9 ; surface temperature anomalies are also shown in figures 10 and 11 . The figures are an integral part of this section and should be examined together with the discussion. Specific reference to a figure will generally be omitted unless deemed necessary.

The mean 700-mb contour pattern for March 1973 (fig. $8 A$ ) was characterized by a blocking high north of eastern Siberia, another over the British Isles, a broad double trough over southwestern and central United States, and a ridge over the eastern seaboard. This placed the whole Mississippi basin, except the high headwater region of the Missouri River, under a trough-to-ridge mean contour pattern at $700 \mathrm{mb}$. Synoptic experience has long established that the area east of the upper mean trough is characterized by mean velocity and mass convergence (divergence) below (above) the level of nondivergence. The axis of maximum $700-\mathrm{mb}$ windspeed over North America for March normally extending over the Northern United States was located much farther south along the gulf coast. The attending stronger than normal southerly flow shown in the March contour pattern facilitated the frequent intrusion of warm moist maritime airmass into the basin and caused the surface temperature to rise above normal (fig. 10). 

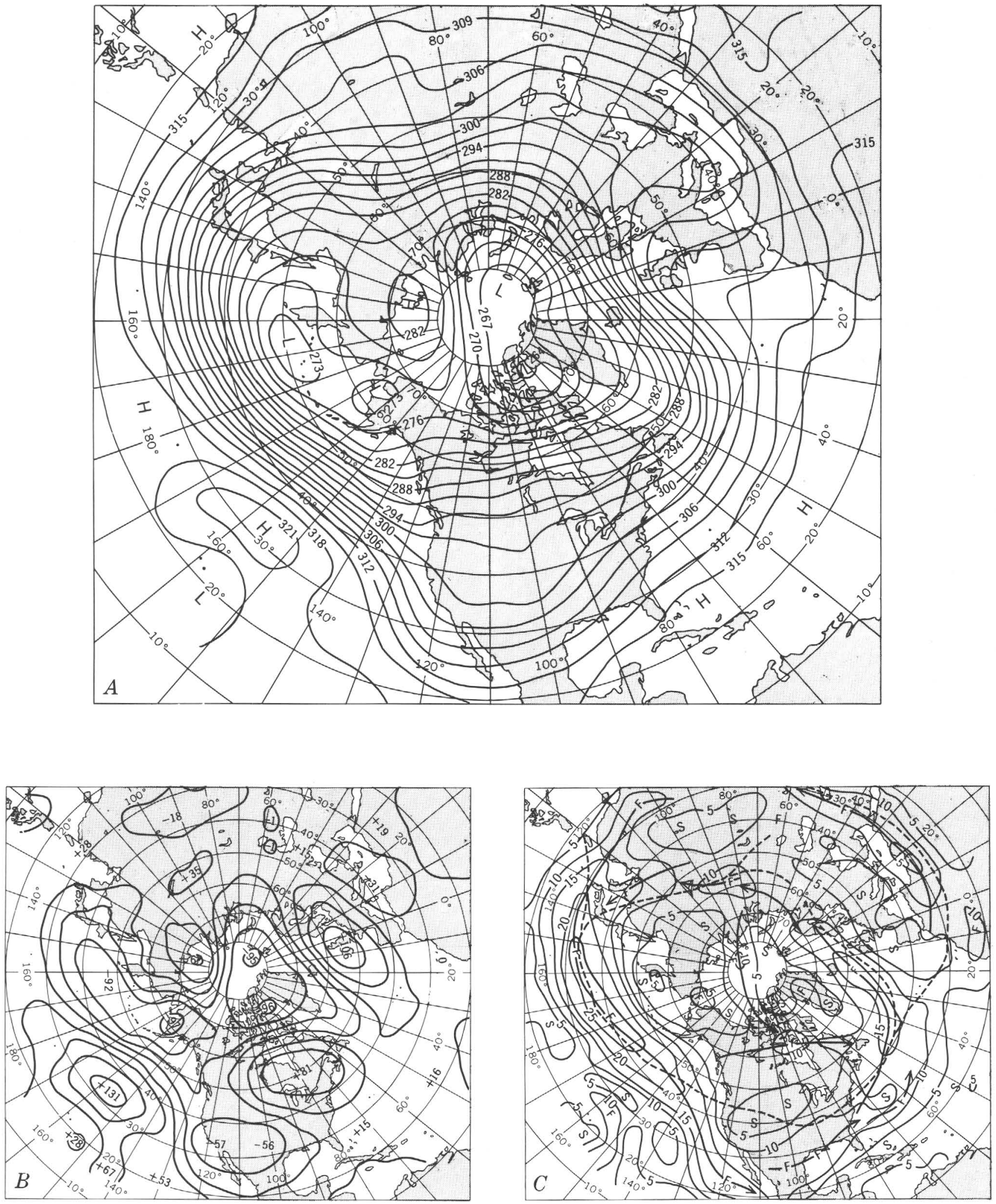

Figure 8.- $A$, Mean 700-mb contours in decametres for March 1973. B, Departure from normal of mean 700-mb height in metres for March 1973. C, Mean 700-mb geostrophic windspeed for March 1973. 

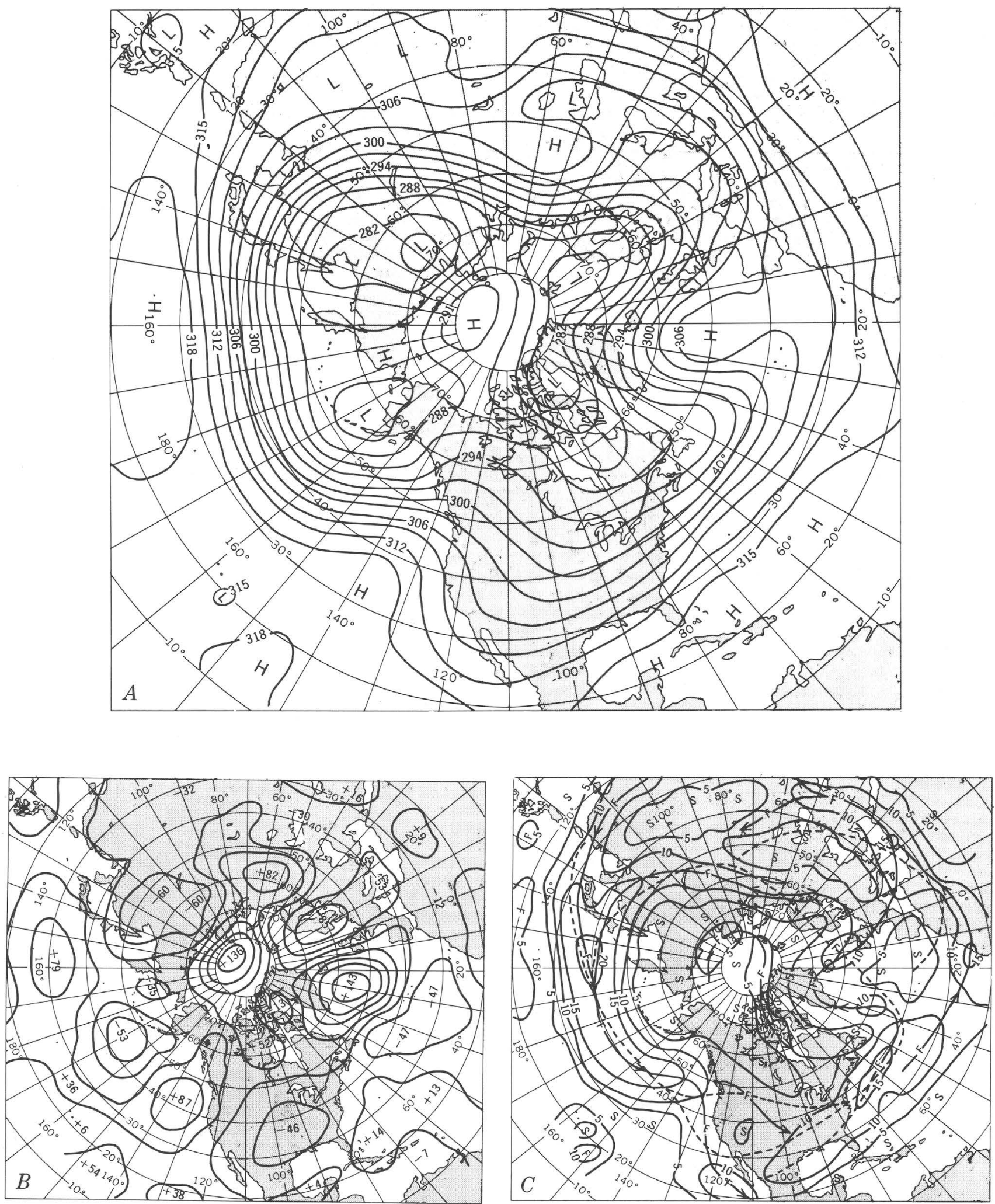

Figure 9.-A, Mean 700-mb contours in decametres for April 1973. B, departure from normal of mean 700 -mb height in metres for April 1973. C, Mean 700-mb geostrophic windspeed for April 1973. 
March 1973 was an extremely wet month (figs. 12 and 13). The entire Mississippi basin, except the mountainous headwater region of the Missouri River, received above normal precipitation. The southern part of the Great Plains, the midsection of the Upper Mississippi River, and the Tennessee-Carolina border region received from two to four times the normal precipitation for March. Southwestern Kansas had at least six times the normal precipitation in March. Dodge City, Kans., received more than seven times its normal rainfall of 1.16 inches $(29 \mathrm{~mm})$; while Topeka, in northeastern Kansas also received more than four times its expected rainfall of 2.01 inches $(51 \mathrm{~mm})$. Persistent heavy rainfall over the midsection of the country in March and to a lesser extent in April set new monthly records for many stations (table 1 ).

The mean 700-mb contours for April 1973 show that the blocking High formerly over the British Isles had retrograded to an area south of Greenland (see fig. 9). Over North America, a broad, deep single trough replaced the double trough of March. It was oriented northeast-southwest, extending from the Hudson Bay to south of Baja California. Compared with March, the April 700-mb mean contour west of the deep trough was more meridional; this was associated with the frequent cold air outbreaks
TABLE 1.-Record and near record monthly precipitation ${ }^{1}$ in the Mississippi River basin in the spring of 1973

\begin{tabular}{|c|c|c|c|}
\hline Station & $\begin{array}{l}\text { Monthly } \\
\text { amount } \\
\text { (in.) }\end{array}$ & $\begin{array}{l}\text { De- } \\
\text { par- } \\
\text { ture } \\
\text { (in.) }\end{array}$ & Remarks \\
\hline Peoria, Ill _-_- & 6.95 & +4.10 & Wettest March. \\
\hline Springfield, Ill _.--- & 7.89 & +5.01 & $\begin{array}{l}\text { Wettest March since } \\
1898 .\end{array}$ \\
\hline Sioux City, Iowa -- & 4.02 & +2.56 & Wettest March. \\
\hline Dodge City, Kans -- & 8.84 & +7.68 & $\begin{array}{l}\text { Wettest March since } \\
1874 .\end{array}$ \\
\hline Topeka, Kans _-.-- & 8.44 & +6.43 & $\begin{array}{l}\text { Wettest March since } \\
1888 .\end{array}$ \\
\hline Columbia, Mo _-.-- & 10.09 & +7.44 & $\begin{array}{l}\text { Wettest March since } \\
1890 .\end{array}$ \\
\hline Grand Island, Nebr & 5.57 & +4.30 & Wettest March. \\
\hline Norfolk, Nebr _._-- & 5.96 & +4.51 & $\begin{array}{l}\text { Wettest March since } \\
1871 .\end{array}$ \\
\hline Tulsa, Okla & 11.94 & +9.51 & $\begin{array}{l}\text { Wettest March since } \\
1888 .\end{array}$ \\
\hline Sioux Falls, S. Dak & 3.52 & +1.98 & $\begin{array}{l}\text { Wettest March since } \\
1917 .\end{array}$ \\
\hline Knoxville, Tenn -.- & 10.24 & +5.51 & Do. \\
\hline Madison, Wis _..-- & $\begin{array}{l}5.04 \\
7.11\end{array}$ & $\begin{array}{l}+3.20 \\
+4.54\end{array}$ & $\begin{array}{l}\text { Wettest March. } \\
\text { Second wettest April } \\
\text { on record. }\end{array}$ \\
\hline Havre, Mont & .03 & -.57 & Driest March. \\
\hline Little Rock, Ark --- & 14.20 & +9.27 & $\begin{array}{l}\text { Wettest April on } \\
\text { record }\end{array}$ \\
\hline Memphis, Tenn -.-- & 9.44 & +4.81 & $\begin{array}{l}\text { Third wettest April } \\
\text { on record. }\end{array}$ \\
\hline Milwaukee, Wis --- & 7.31 & +4.78 & $\begin{array}{l}\text { Wettest April on } \\
\text { record. }\end{array}$ \\
\hline Moline, Ill _-_-_---- & 11.30 & +8.13 & Do. \\
\hline
\end{tabular}

${ }^{1}$ Obtained from Environmental Data Service and Statistical Reporting Service (1973).

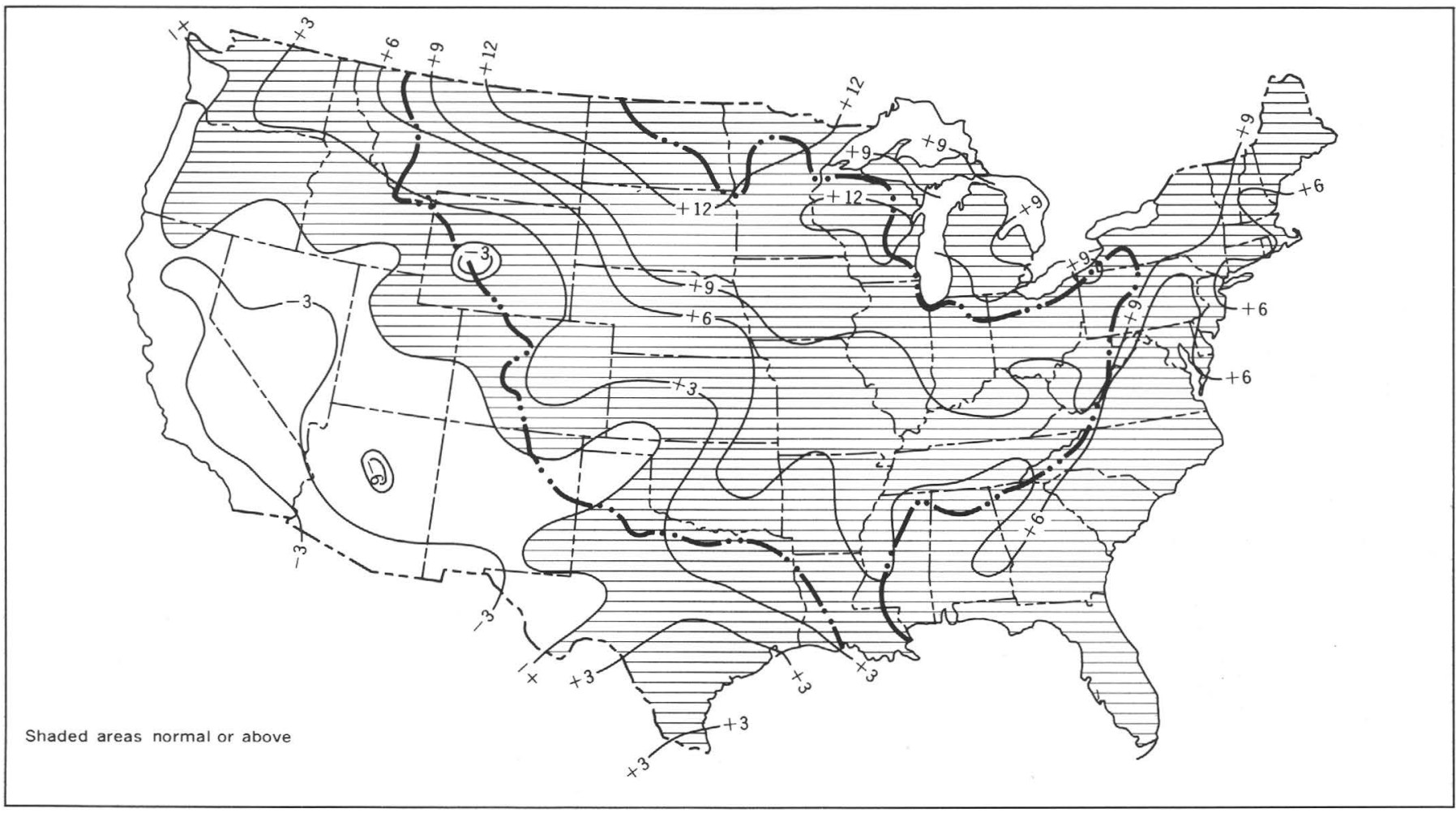

FIGURE 10.-Temperature departure, March 1973, from 30-year mean March temperature. 


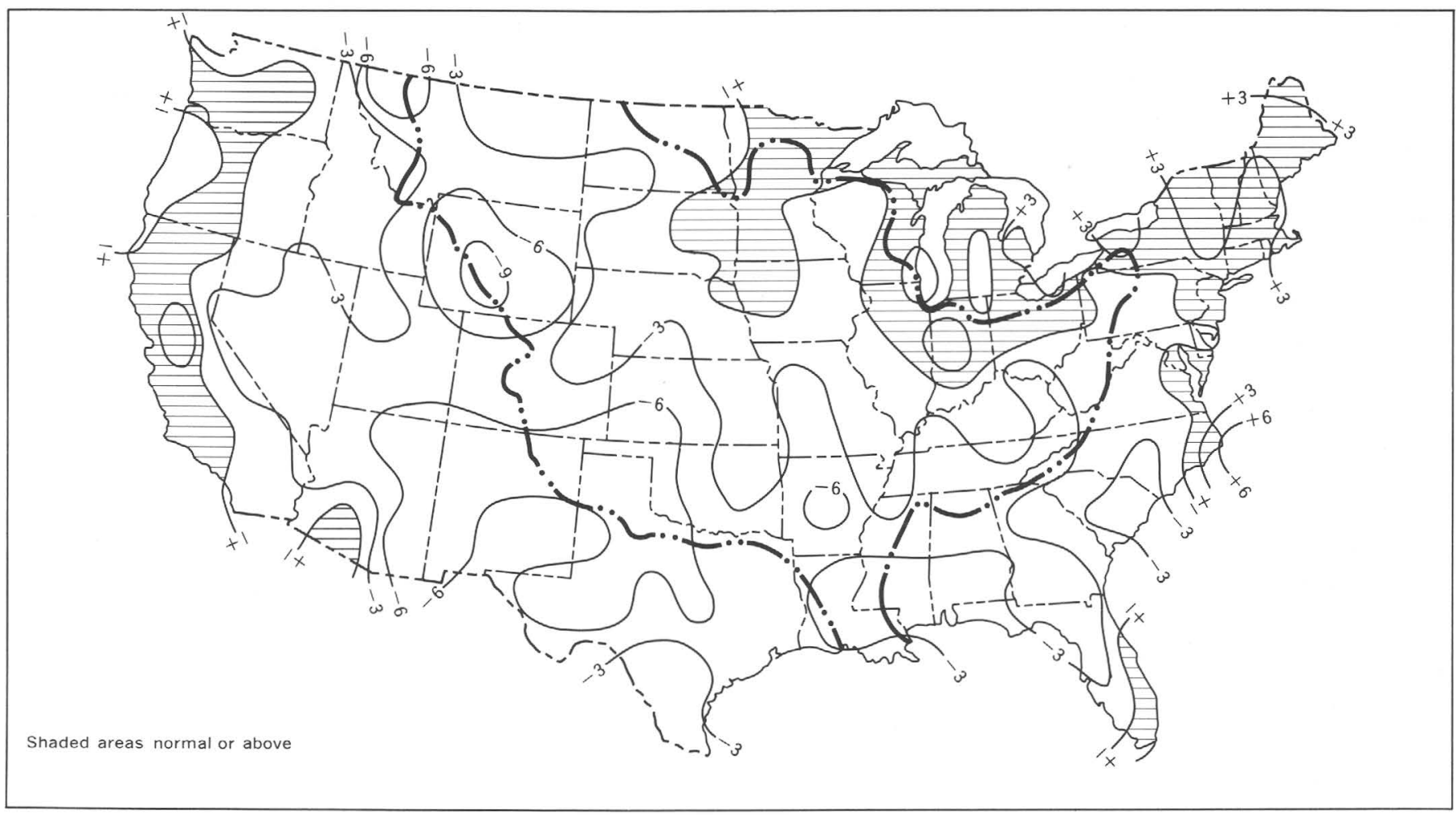

Figure 11.-Temperature departure, April 1973, from 30-year mean April temperature.

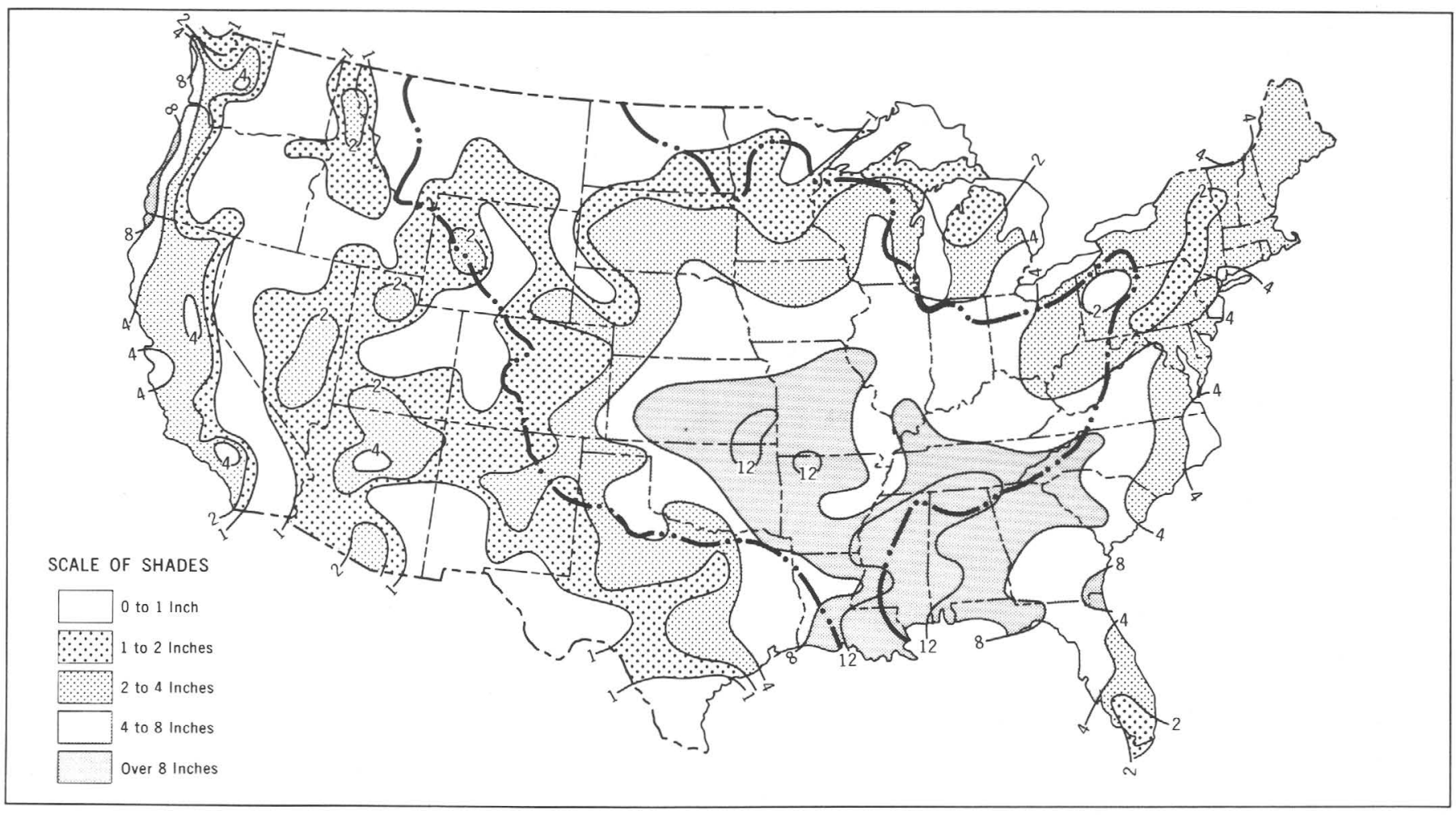

FIGURE 12.-Total precipitation in March 1973. 


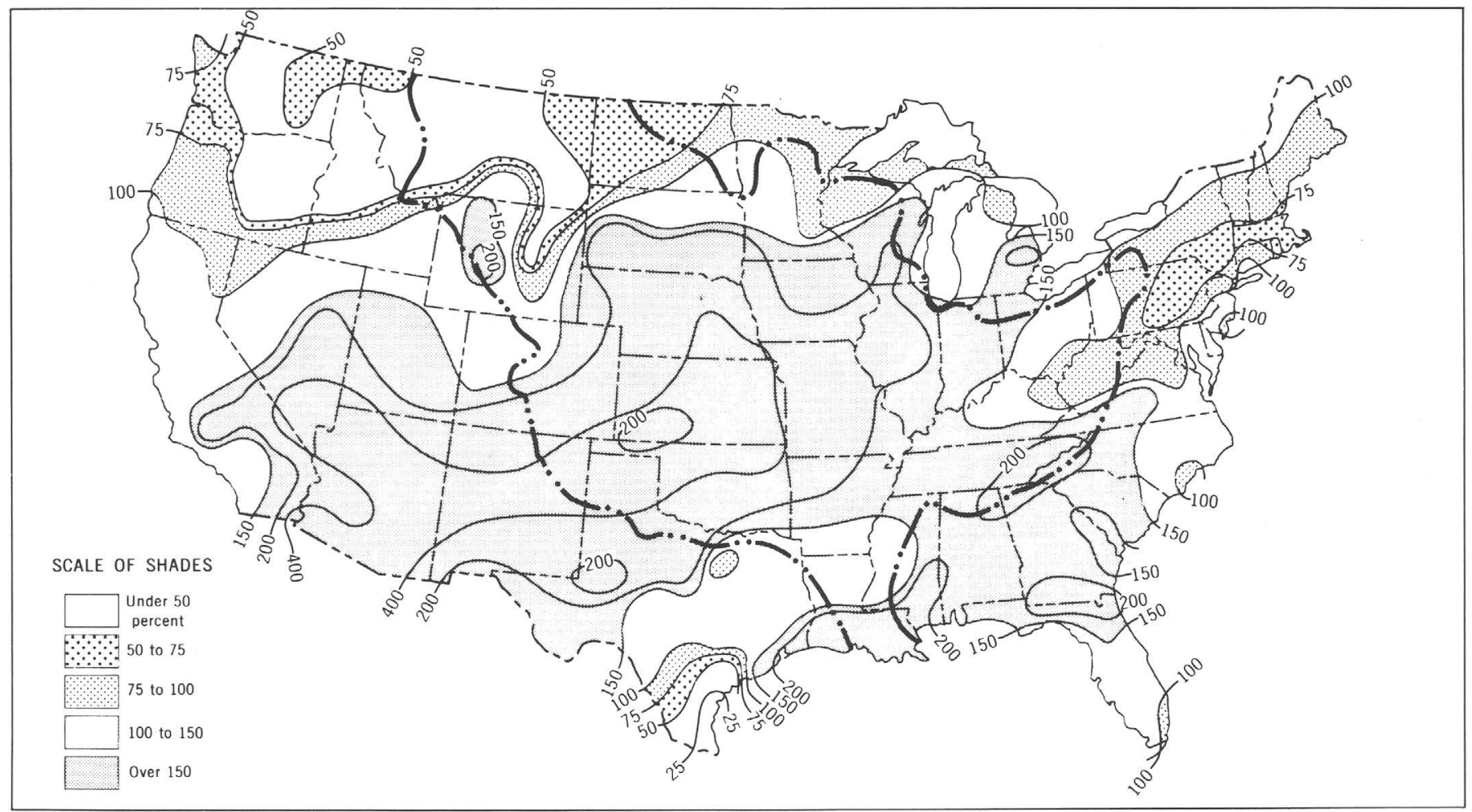

FIGURE 13.-Total precipitation in March 1973 as a percentage of normal March precipitation.

from Canada causing the mean monthly surface temperature to plunge below normal over much of the basin (see fig. 11). However, to the east of the trough the contour pattern became more zonal. The southern axis of maximum 700-mb wind remained in the same position as in March, while the secondary northern axis had moved southward from northern Canada to Central United States.

If March can be described as extremely wet over the whole basin, then April can be described as very wet over part of the basin (figures 14 and 15). Northwest Minnesota, the Dakotas, and Nebraska had well below normal precipitation. But parts of the Middle Mississippi Valley above Canton, Mo., the Lower Mississippi Valley below Memphis, Tenn., and the northern Great Plains had more than twice the normal precipitation. A snowstorm starting on April 19 dumped several feet of snow on Montana and Wyoming. Nearly 20 inches $(508 \mathrm{~mm})$ fell in sections of Iowa between April 8 to 10. Northeast Missouri, southeast Iowa, northern Illinois, Arkansas, Mississippi, and Louisiana all had more than 8 inches $(203 \mathrm{~mm})$ of rain in April. Much of this fell in the stormy week of April 16-22, setting the stage for the record-breaking flood crest to appear on the Mississippi River main stem.
The average sky cover and the percentage of possible sunshine for March and April 1973 are shown in figures 16-19. It should be noted that these two parameters, though negatively correlated, do not follow a simple complementary relationship. Comparisons with climatological normals for a sample of stations are shown in table 2. It is evident that for the Mississippi basin as a whole the average sky cover was larger and the mean percentage of possible sunshine was smaller than normal in the spring of 1973. For example, Des Moines, Iowa, had an average sky cover of 7.9 (6.7) in March (April) 1973, compared to a normal of 6.6 (6.2). Des Moines also had about half the normal percentage of possible sunshine in March 1973. This made that month the second least sunny month of record in 75 years. Topeka, Kans., had less than half its normal hours of sunshine in March. The possible effect of these on the amount of water loss will be discussed in a later section.

A climatological index that gives a measure of the degree to which the weather has been abnormally dry or wet is the Palmer Index, based on the water balance concept (Palmer, 1965). Basically, climatological analysis of the long record for a station is made to determine the roles of evapotranspiration, moisture gain, moisture loss, and runoff. Then, a precipi- 


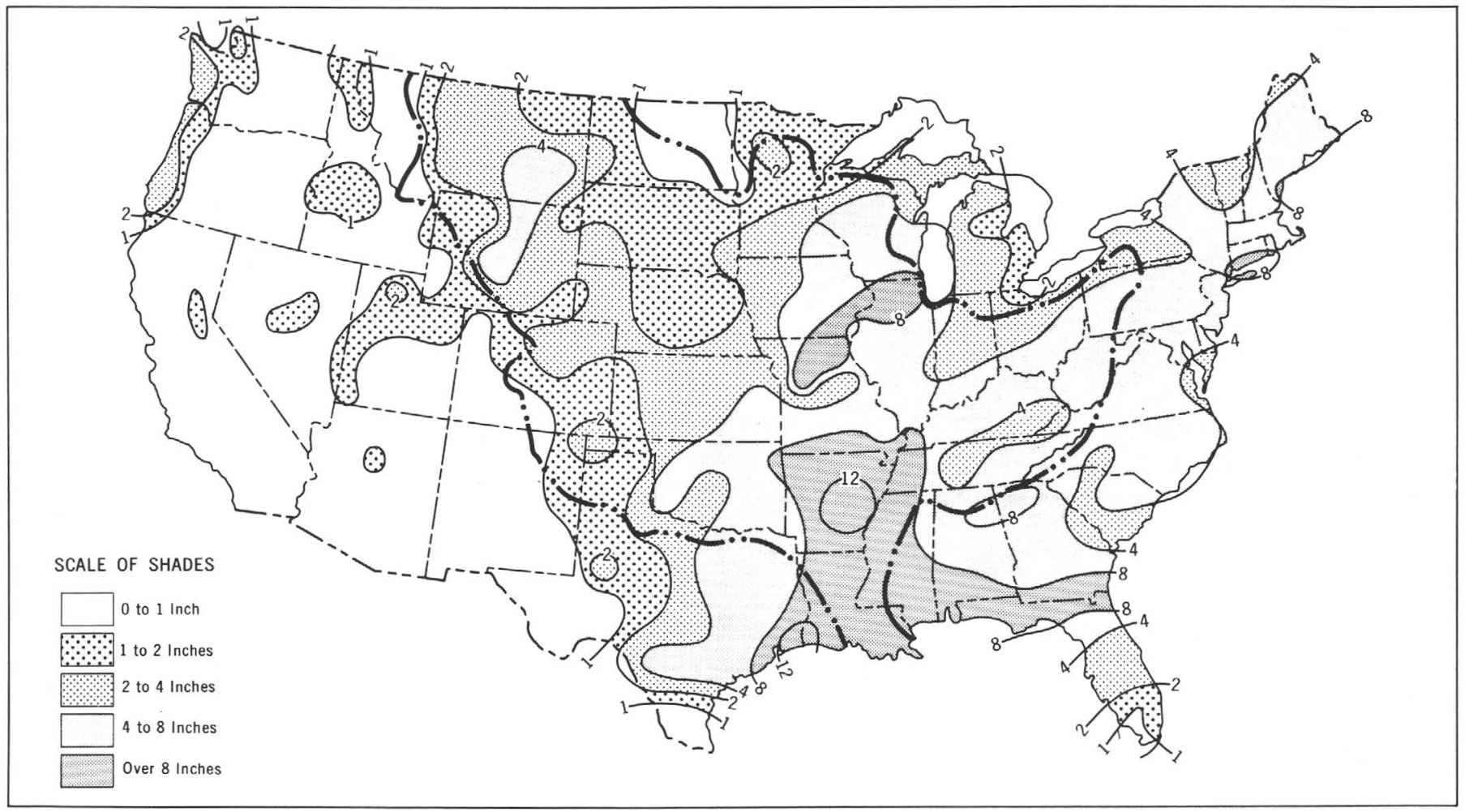

FIGURE 14.-Total precipitation in April 1973.

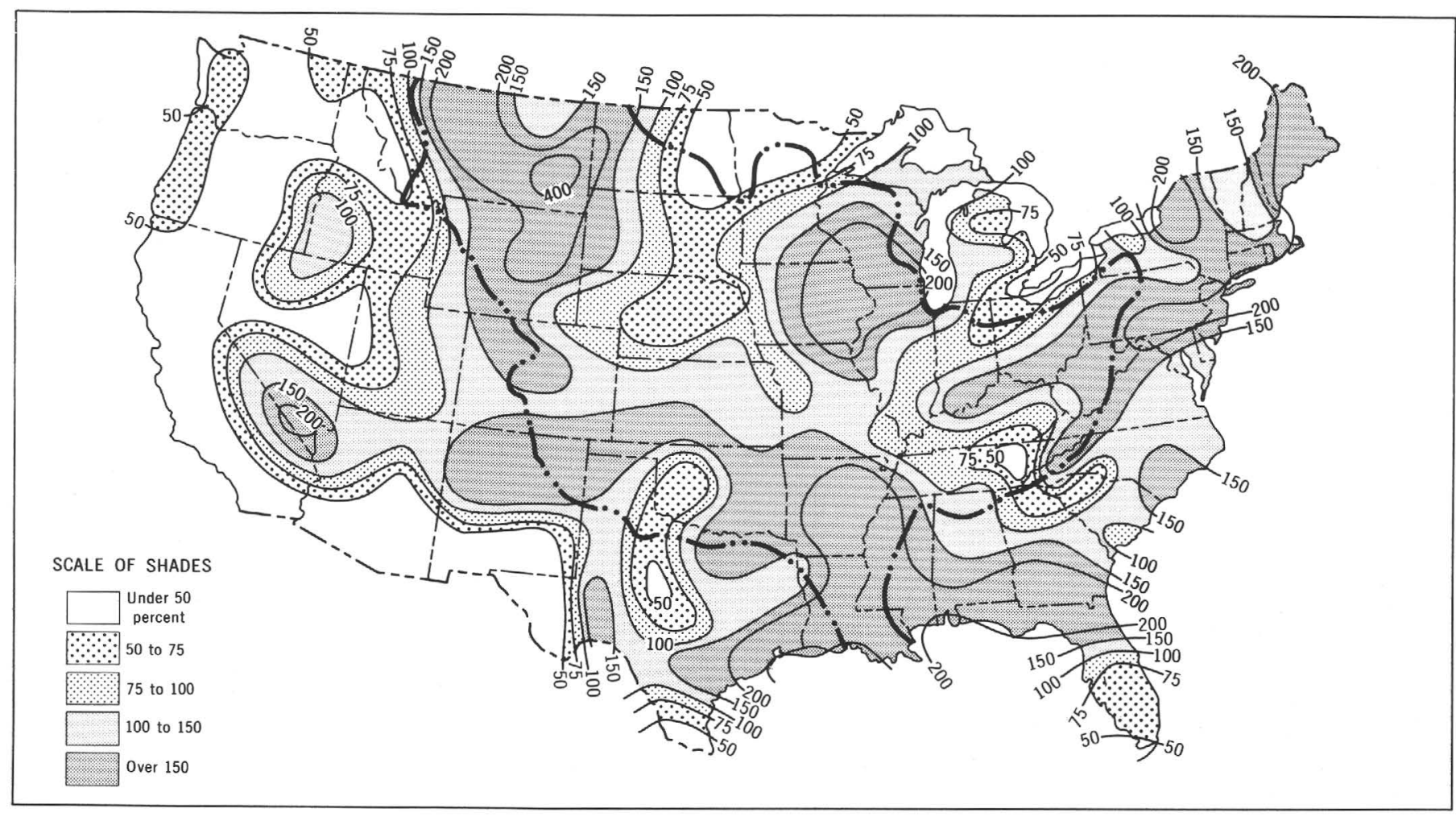

FIGURE 15.-Total precipitation in April 1973 as a percentage of normal April precipitation. 
tation amount is computed that balances the net requirement. The actual precipitation minus this computed precipitation is then converted to the current Palmer Index through weighting with antecedent moisture conditions. Maps of this index over the United States at the end of March and April 1973 are shown in figures 20 and 21 (Environmental Data Service and Statistical Reporting Service, 1973). At the end of March, large areas in the Great Plains and along the Mississippi main stem had Palmer Index greater than four, which indicates that actual rainfall far exceeded balance requirements and abnormally wet conditions existed. Twenty days later, this area was further expanded. However, there was a high degree of similarity in the index patterns between these two times. Due to the considerable weight given to antecedent moisture conditions, the Palmer Index is a relatively conservative quantity. Its variation is slow and devoid of the high frequency fluctuations of the isohyetal patterns.

\section{HIGHLIGHTS FOR SELECTED WEEKS}

In this section, the general weather situations for several selected weeks in which significant precipitation events occurred are presented. Examination of some of these events themselves are done in later sections.

\section{MARCH 5-11}

Much of the basin during this week was under a trough-to-downstream ridge pattern at $500 \mathrm{mb}$. A succession of Lows incipient in Southwestern United States moved across the Midwest to the Great Lakes region and became occluded. At 7:00 a.m. e.s.t.,
March 7, a storm was centered over Wisconsin. A cold front extended from the storm center, through the Ohio Valley and Tennessee Valley, to New Orleans and brought widespread rain to the eastern half of the United States, with local thunderstorms and showers occurring ahead of the front. On March 9, a frontal wave appeared over the Lower Mississippi Valley; by $7: 00$ a.m. e.s.t., March 10, the Low was centered over Oklahoma-northeastern Texas. The associated warm front extended from the Low in the northeast direction up to Lake Ontario. This system brought much rain to the southern Great Plains and the Ohio and Tennessee Valleys. On March 11, the occluded storm center was at the northwest corner of Missouri, with the cold front approximately parallel to the Mississippi stem. Rainfall was heavy over a wide area west of the stem and over the Ohio Basin and the State of Mississippi. Marble Hill, in southeast Missouri, had 4.75 in. (121 $\mathrm{mm}$ ) on March 11. For the whole week, precipitation exceeding 2 in. $(51 \mathrm{~mm}$ ) covered areas along almost the entire stretch of the Mississippi main stem, the Lower Ohio and Lower Tennessee Valleys, and over large parts of the Arkansas River Valley. There was little time delay for runoff to reach the river system. Some low-lying areas along the Mississippi River main stem, like Grafton and Alton, Ill., first reported flood flow on March 8, signifying the beginning of the long Mississippi flood of spring 1973.

\section{MARCH $12-18$}

A $500-\mathrm{mb}$ ridge was over the midsection of the country at the beginning of the week. By 7:00 a.m.

TABLE 2.-Average sky cover and percentage of possible sunshine for selected stations in the Mississippi basin, March and A pril 1978, versus climatological normals ${ }^{1}$

\begin{tabular}{|c|c|c|c|c|c|c|c|c|}
\hline \multirow{3}{*}{ Station } & \multicolumn{4}{|c|}{ Average sky cover } & \multicolumn{4}{|c|}{$\begin{array}{l}\text { Percentage of possible } \\
\text { sunshine }\end{array}$} \\
\hline & \multicolumn{2}{|c|}{ March } & \multicolumn{2}{|c|}{ April } & \multicolumn{2}{|c|}{ March } & \multicolumn{2}{|c|}{ April } \\
\hline & 73 & Normal & 73 & Normal & 73 & Normal & 73 & Normal \\
\hline Little Rock, Ark & 7.0 & 6.5 & 6.9 & 6.2 & 66 & 56 & 69 & 60 \\
\hline Moline, Ill & 7.7 & 6.5 & 7.2 & 6.1 & 40 & 55 & 49 & 57 \\
\hline Indianapolis, Ind & 7.9 & 6.7 & 8.3 & 7.0 & 39 & 51 & 28 & 56 \\
\hline Des Moines, Iowa & $\dddot{7.9}$ & 6.6 & 6.7 & 6.2 & 28 & 55 & 55 & 58 \\
\hline Topeka, Kans & 8.3 & 6.1 & 5.5 & 6.1 & 28 & 59 & 54 & 60 \\
\hline Louisville, Ky & 7.7 & 6.5 & 8.1 & 6.1 & 45 & 51 & 33 & 55 \\
\hline Shreveport, La & 7.2 & 6.2 & 6.8 & 6.1 & 41 & 56 & 42 & 59 \\
\hline Minneapolis, Minn & $7 . \overline{9}$ & 7.0 & 6.7 & 6.5 & 43 & 53 & 53 & 58 \\
\hline St. Louis, Mo & 7.7 & 6.5 & 7.6 & 6.0 & 41 & 55 & 37 & 60 \\
\hline 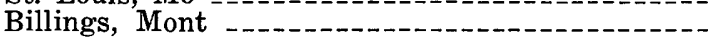 & 6.7 & 7.1 & 8.0 & 6.8 & 78 & 50 & 40 & 60 \\
\hline Omaha, Nebr & 8.4 & 6.4 & 5.8 & 6.2 & 30 & 58 & 57 & 60 \\
\hline Bismarck, N. Dak & 7.1 & 6.8 & 7.3 & 6.4 & 61 & 58 & 63 & 61 \\
\hline Columbus, Ohio & 8.1 & 6.7 & 8.2 & 6.3 & 33 & 49 & 30 & 52 \\
\hline Tulsa, Okla & 7.4 & 5.8 & 6.3 & 6.1 & 45 & 58 & 58 & 62 \\
\hline Pittsburgh, $\mathrm{Pa}$ & 8.1 & 7.1 & 8.0 & 7.0 & 42 & 48 & 32 & $4 \overline{9}$ \\
\hline 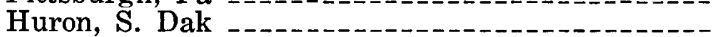 & 7.9 & 7.1 & 6.6 & 6.2 & 39 & 56 & $5 \overline{9}$ & 62 \\
\hline Chattanooga, Tenn & 8.2 & 6.0 & 6.9 & 5.5 & 35 & 53 & 44 & 60 \\
\hline Madison, Wis & 7.9 & 6.5 & 7.4 & 6.2 & 39 & 52 & 41 & 56 \\
\hline
\end{tabular}

1 Normals were interpolated from Environmental Data Service (1968). 


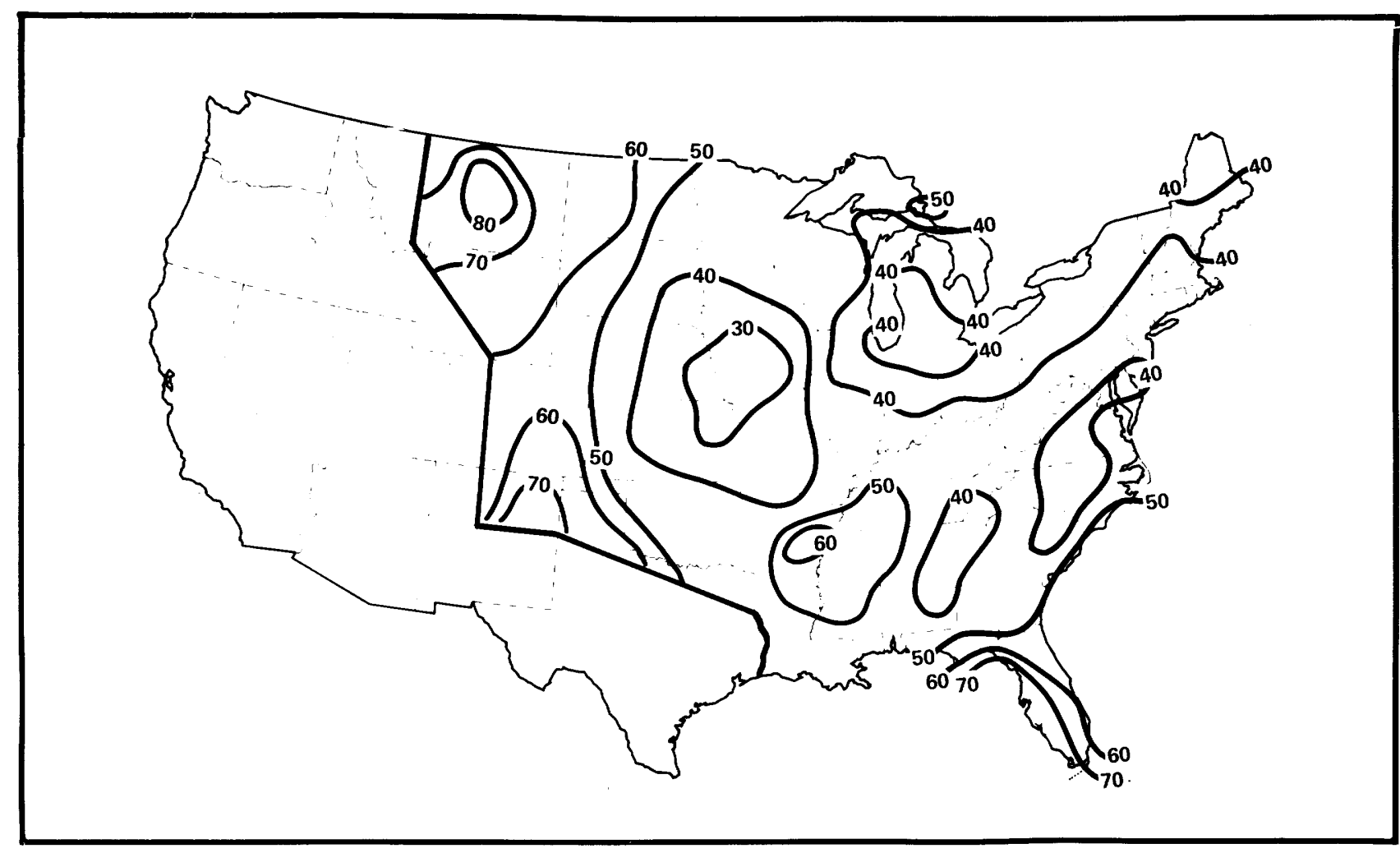

Figure 16.-Mean percentage of possible sunshine, Marci: 1973.

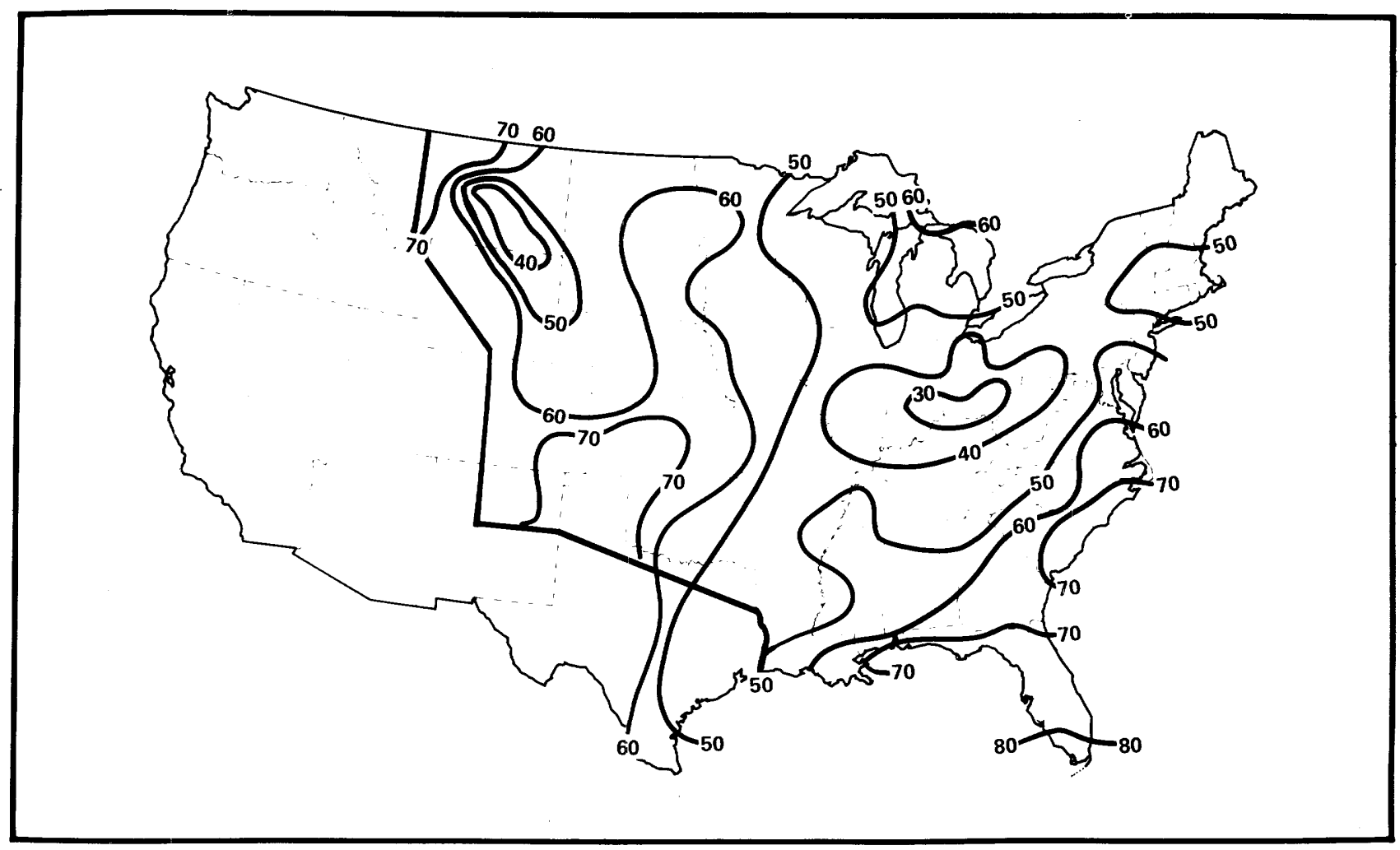

FIgURE 17.-Mean percentage of possible sunshine, April 1973. 


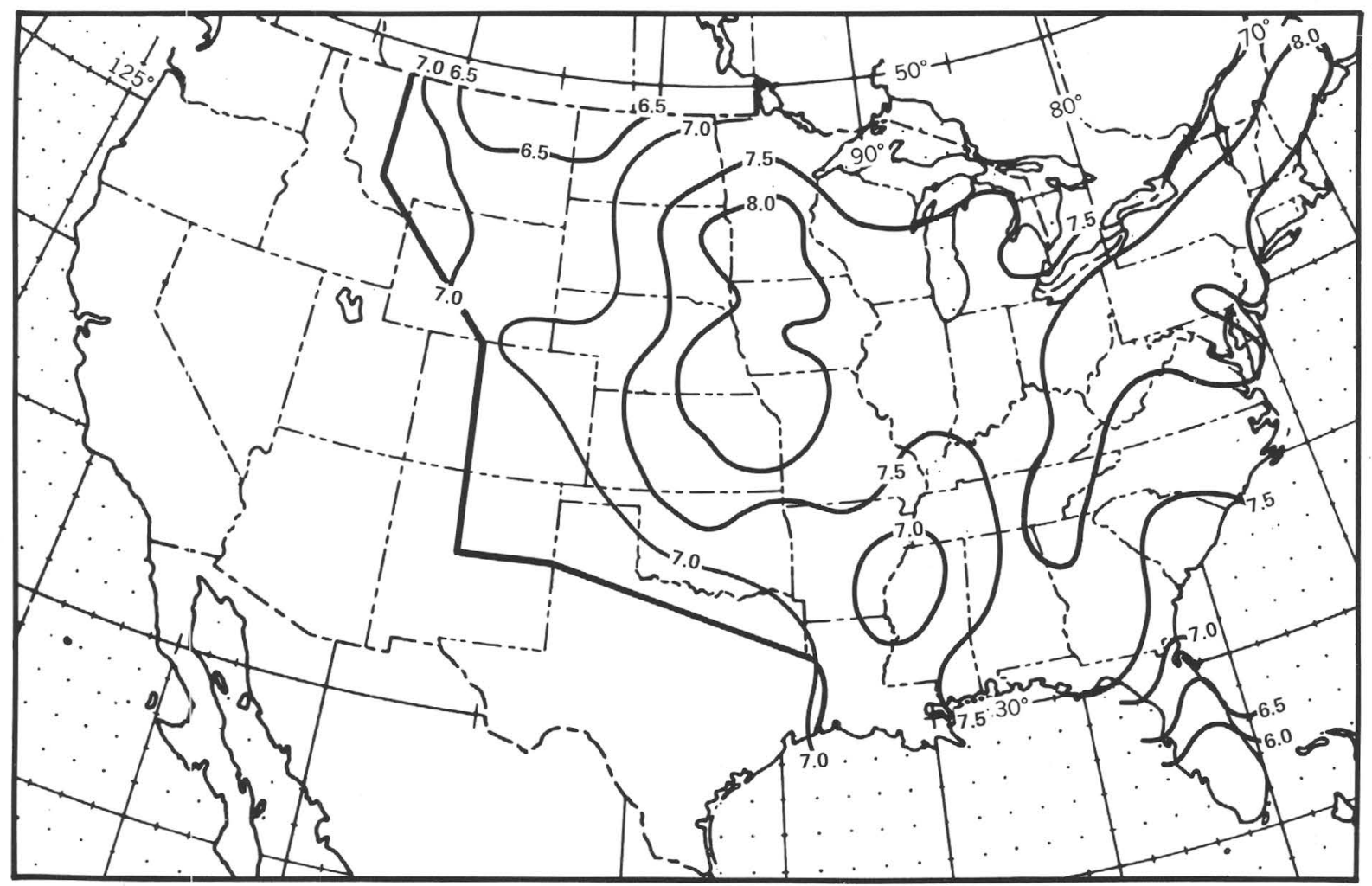

Figure 18.-Mean sky cover, sunrise to sunset, March 1973.

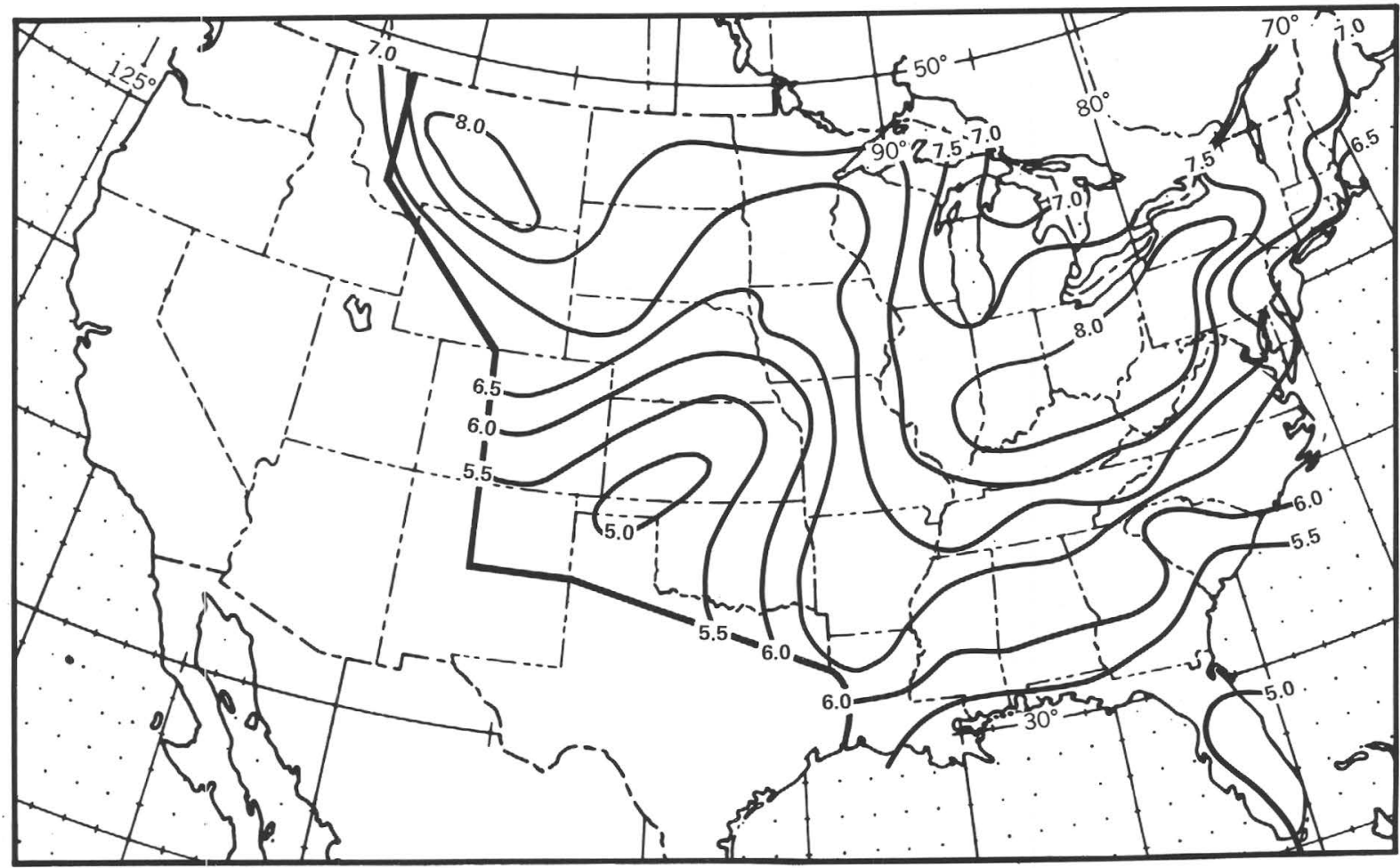

FIGURE 19.-Mean sky cover, sunrise to sunset, April 1973. 


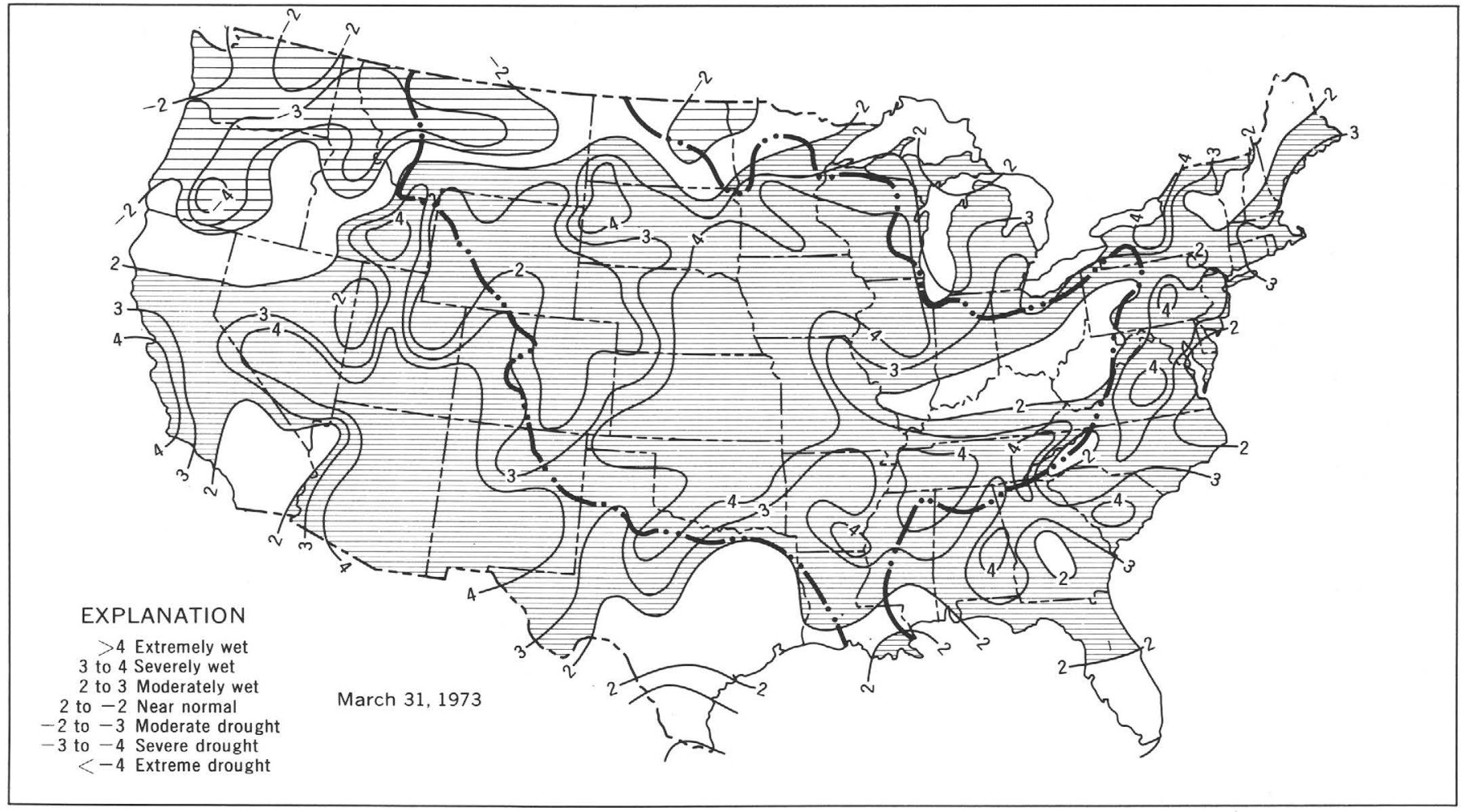

FIGURE 20.-Palmer Index on March 31, 1973.

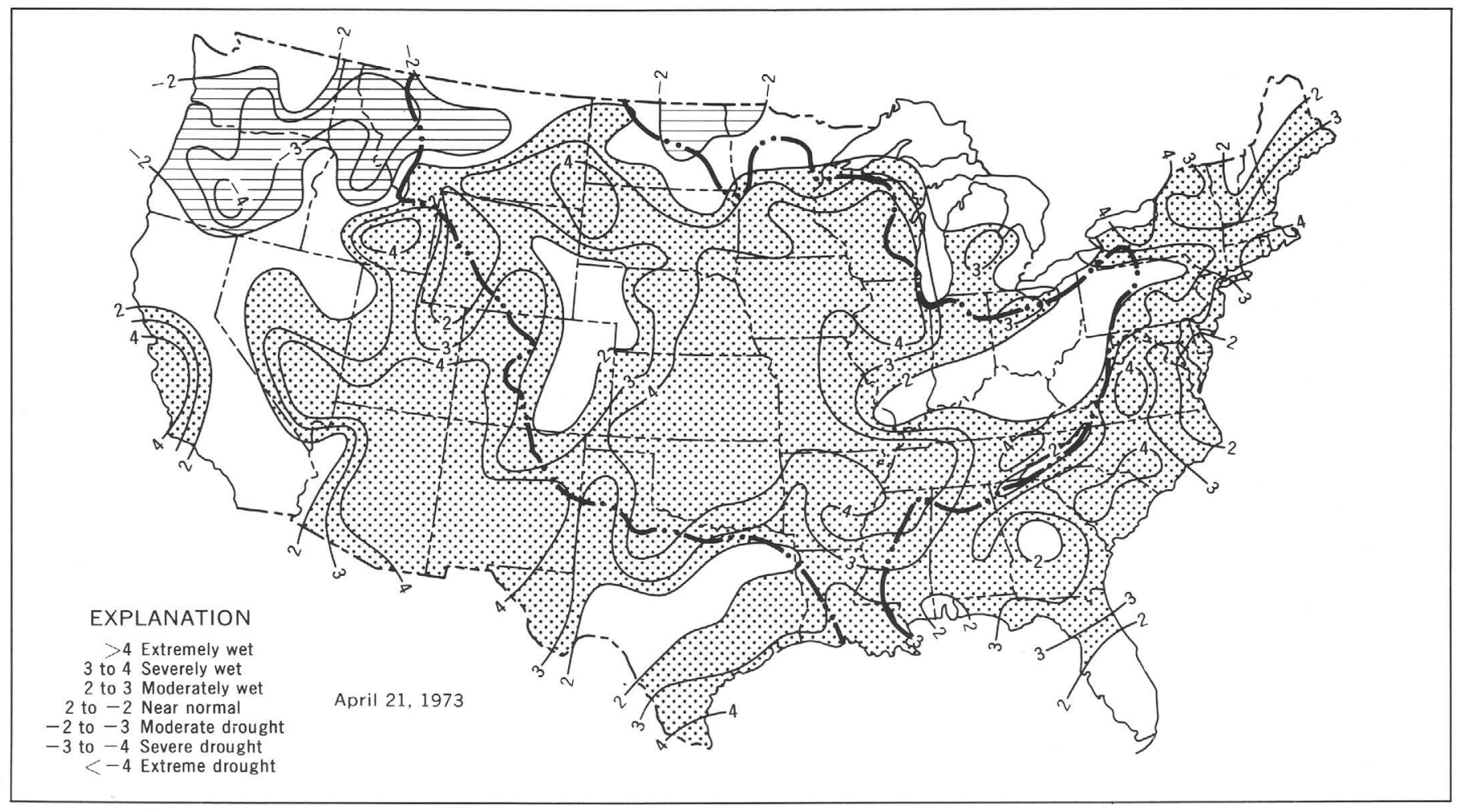

Figure 21.-Palmer Index on April 21, 1973. 
e.s.t., March 14, because of the wave progression, the Southeastern United States was situated under the $500-\mathrm{mb}$ trough to downstream ridge pattern. This condition persisted through the 16th, coinciding approximately in line with the existence of a surface quasi-stationary front oriented from Louisiana through Tennessee and toward the northeast. These synoptic scale features provided a favorable setting for the precipitation events to come.

An incipient Low formed to the lee of the southern Rockies on March 12. By the morning of March 13, the surface Low had a large circulation along the eastern slopes of the Rockies. It deepened rapidly while moving northeastward. Its central pressure was less than $976 \mathrm{mb}$ when located over Nebraska at 7:00 a.m. e.s.t., March 14. This storm dominated the circulation pattern over the Plains. Violent thunderstorms were triggered with the inflow of warm moist tropical air across the Mississippi Valley. Twentyone tornadoes were sighted from Texas to Illinois on March 13-14. A blizzard raged across Wyoming and the Dakotas. Cheyenne, Wyo., had 13 in. $(330 \mathrm{~mm})$ of snow driven by wind gusts up to $60 \mathrm{mph}(96.54$ $\mathrm{km} / \mathrm{hr})$. It dumped $4 \mathrm{ft}(1,219 \mathrm{~mm})$ of snow over the Black Hills and 14 inches $(356 \mathrm{~mm}$ ) on Rapid City, S. Dak. Rain fell over the Plains and the Upper Mississippi Valley. This storm moved to the Great Lakes region and became occluded on March 15.

But, during the evening of March 15, a second Low developed over Louisiana from a wave along the front extending from the occlusion over the Great Lakes, through the Southeastern States, to the Lower Mississippi Valley. This wave developed into a cyclone and moved northeast towards central Tennessee. By the morning of March 16, this Low was over central Kentucky, and another Low developed along the front in Mississippi. The associated frontal system remained quasi-stationary across the Southeastern States. Persistent southwesterly inflow brought warm moist maritime air into the Tennessee and Ohio River basin. Rain was widespread over the whole Eastern United States on March 15 and 16, with heavy rains throughout central Louisiana, northern Mississippi and Alabama, Tennessee, southern Kentucky, and up to the western regions of the Carolinas. Hamilton 3S, Ala., had 9.06 inches $(230 \mathrm{~mm})$; Fulton $3 \mathrm{~W}$, Miss., had 9.15 inches (232 $\mathrm{mm}$ ) ; and Coldwater, Tenn., had 6.70 inches (170 $\mathrm{mm}$ ) on March 16 alone. By the end of this week, major flooding through the Tennessee River and other rivers in the Southeastern States was in progress.
On March 16, the two Lows combined and continued to intensify while moving to the northeast. By 7:00 a.m. e.s.t., March 17, it was located over Lake Erie with a central pressure of $981.3 \mathrm{mb}$ and was occluded. The associated cold front had progressed to the Atlantic coast, bringing moderate rain to the Coastal States. By the morning of March 18, the Low had moved to the New England-Quebec border, and its circulation pattern indicated a much reduced low-level moisture inflow.

\section{APRIL 16-22}

The average $500-\mathrm{mb}$ circulation was characterized by a deep trough over the west fringe of the basin and a strong ridge over the Eastern United States. The persistent Bermuda High was present at the surface over the western Atlantic, reaching the eastern seaboard. This led to a strong southerly wind over the Central Mississippi Valley, which brought in large quantities of moisture-laden tropical air from the Gulf. The intruding warm air and the cold polar air coming down from western Canada met over the Central States. The frontal zone formed by April 19 had a nearly meridional orientation, and its eastward progression was very slow bringing continuous heavy rain to the midsection of the country. Thunderstorms and tornadoes were also frequent over the Midwest in the latter part of the week.

A more detailed account of the storm of April 1922 is presented in a separate section.

\section{PRECIPITATION EVENTS IN THE MISSISSIPPI BASIN DURING THE SPRING OF 1973}

A recurrent feature of the precipitation events during March and April 1973 is the repeated accumulation of precipitation over large areas in the basin, as can be inferred from daily isohyetal maps (pls. 1-3). Weekly precipitation totals and cumulative departures from the normals covering a period from the end of February to late May for 44 stations are shown in table 3. This sample includes a few stations that, strictly speaking, are located outside the Mississippi drainage basin. For example, Meridian, Miss., and Jackson, Miss., are located in the gulf coast drainage of the Pascagoula River and the Pearl River, respectively. But both stations are close to the Mississippi basin proper and are first-order NWS observing stations and, therefore, are included in the table. Total monthly precipitation for March and April 1973 are shown in figures 12-15, respectively. The cumulative percentage departures of pre- 
cipitation amounts from the normals for January to May 1973 for a sample of stations along the Mississippi River and its major tributaries are shown in figures 22 and 23. These departures up to February were generally small. However, almost all stations in major tributary drainages started to show positive precipitation departure trends in March.

Several major precipitation occurrences in this generally wet interval can be distinguished from table 3. For example, the heavy precipitation in the week ending on March 11 over the Midwest and the Corn Belt signifies the initiation of the flood episode.

A wave cyclone with a quasi-stationary front over Southeastern United States brought intense rainfall over a belt stretching from northern Louisiana, through parts of Missisippi, Alabama, Tennessee, and Kentucky, and up to parts of the Carolinas and Virginia on March 14-17. This storm was responsible for the widespread flooding in the Tennessee Valley and other southeast basins. The heavy rain over the eastern Great Plains and the Gulf States in the week ending March 25 aggravated the flooding of the Lower Missouri and Lower Mississippi Valleys. The very heavy rainfall in the week ending April 22 of 4 in. $(102 \mathrm{~mm})$ or more over areas draining into almost the whole Mississippi River main stem up to the Wisconsin border aggravated the major flooding already in progress and was partly responsible for the record-breaking crest passing St. Louis on April 28. The associated weather situations of some of these precipitation events have been presented in a previous section.

Many stations in the basin experienced record or near-record monthly precipitation in March or April 1973 , as shown in table 1 . Some notable precipitation events for selected stations in the basin during the flood episode and their comparisons with climatology are shown in table 4. Precipitation amounts used in the comparison were interpolated from Weather Bureau Technical Paper No. 40 (Hershfield, 1961) and No. 49 (Miller, 1964). Number of days in month with $0.01 \mathrm{in} .(0.25 \mathrm{~mm})$ or more rain was obtained from the Climatic Atlas of the United States (Environmental Data Service, 1968) and Weather Bureau Technical Paper No. 57 (Miller and Frederick, 1966), respectively.

A comparison between tables 1 and 4 will illustrate the characteristics of a majority of precipitation events associated with the flood episode. For example, Springfield, Ill., had the wettest March since 1898 , but as would be expected its greatest 1hour (24-hour) rainfall in March 1973 was consid- erably smaller than the 1-year 1-hour (24-hour) rainfall of $1.3(2.7)$ in. ( $33 \mathrm{~mm}, 69 \mathrm{~mm})$. Topeka, Kans., had the wettest March since 1888, but the observed heaviest 24-hour rainfall was only 1.32 in. (34 mm) compared with the 1-year return period value of $2.8 \mathrm{in} .(71 \mathrm{~mm})$. Both stations had 18 days with rain in March, which is an unusually high number. Tulsa, Okla., also had the wettest March back to 1888 , with an observed rainfall of 11.94 in. (303 $\mathrm{mm}$ ), yet the greatest observed 24-hour rainfall in that month was 2.07 in. $(53 \mathrm{~mm})$, considerably smaller than the 1-year recurrence rainfall of 3.4 in. $(86 \mathrm{~mm})$. However, the number of 19 rainy days is remarkably large when compared with a climatic normal of 8 days. Dodge City, Kans., experienced the wettest March back to 1874, with total monthly rainfall of $8.84 \mathrm{in} .(225 \mathrm{~mm})$ and a positive departure of 7.68 in. $(195 \mathrm{~mm})$. The maximum 24-hour rainfall in March 1973 was 2.54 in. (65 mm), approximately equal to the 2-year rainfall. When one considers that the probability is 0.75 that at least once in the next 2 years a 24-hour rainfall of similar or greater amount could occur, this amount is hardly very unusual. What is again notable is that there were 17 rainy days in the month compared with a climatological normal of less than 7 days. These examples serve to illustrate the phenomenon that, for many stations located in the Great Plains and in the Middle Mississippi basin, the record monthly rainfalls during the flood episode were not necessarily accompanied by record-breaking individual precipitation events. Instead, they manifested the cumulative effects of a succession of cyclone and front passages, each of which might have brought along moderate to heavy precipitation.

However, several notably heavy precipitation events are worth mentioning. Winona 5E, Miss., recorded a 24-hour rainfall of 9.07 in. $(230 \mathrm{~mm}$ ) ending 6:00 a.m. c.s.t., March 16. This was an event with a return period exceeding 100 years. Victory, Tenn., had 10.4 in. $(264 \mathrm{~mm})$ in 48 hours, and Belvidre, Tenn., had $7.36 \mathrm{in}$. (187 mm) in 24 hours on March 15-16. These also exceeded the respective 100year recurrence amounts. Many other significant precipitation events occurring in the Southeastern United States outside of the Mississippi basin in mid-March 1973 were documented in a separate reportin this same series.

Radio Station KWIX, Moberly, Mo., recorded a 6hour rainfall of $7.1 \mathrm{in}$. $(180 \mathrm{~mm})$ and a 24 -hour rainfall of $9.5 \mathrm{in.}(241 \mathrm{~mm})$ ending early morning on April 21, 1973. These amounts exceeded the respec- 
TABLE 3.-Weekly precipitation totals and cumulative departures from normal, in inches, February 26-May 20, 1973

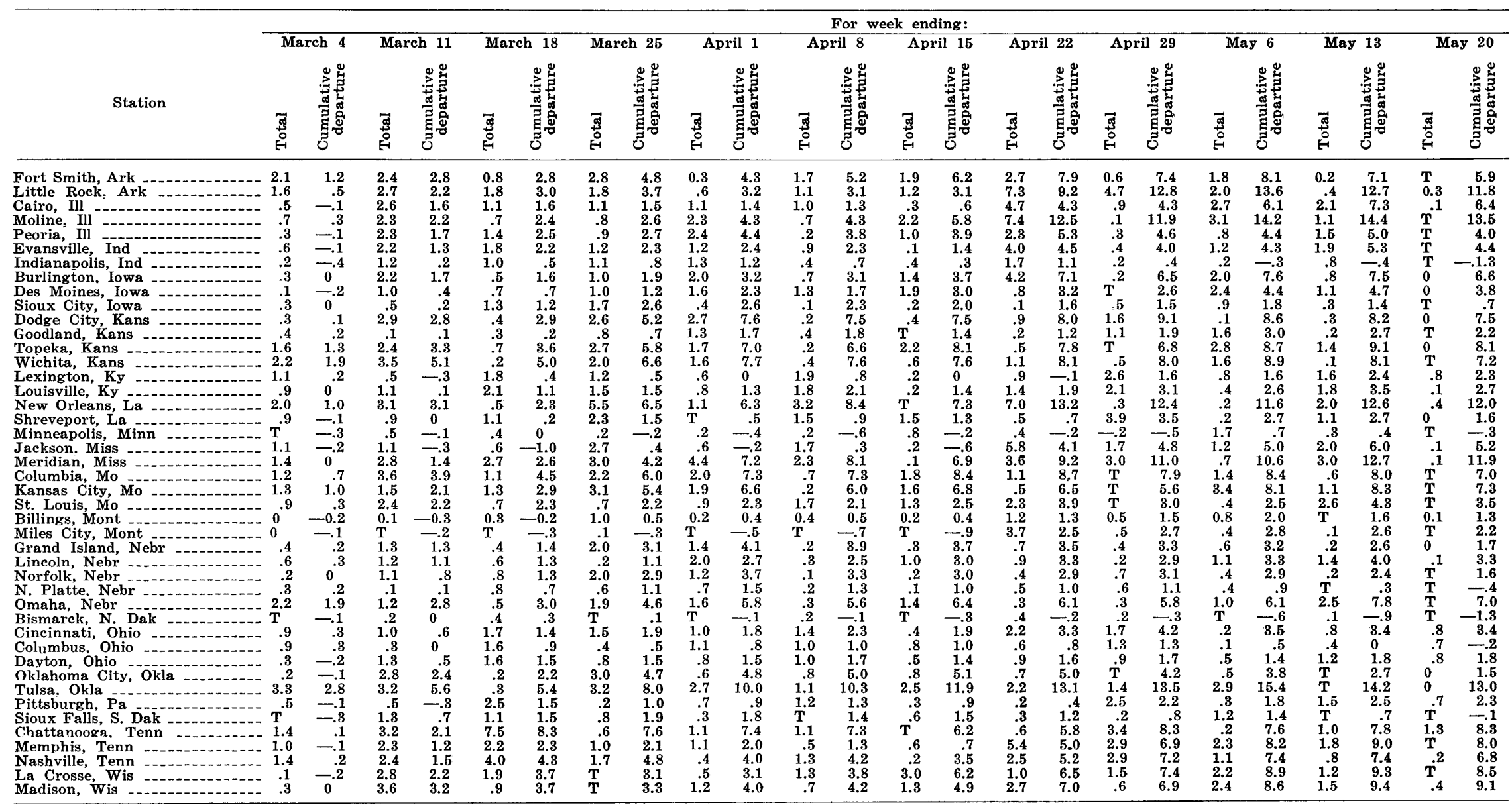




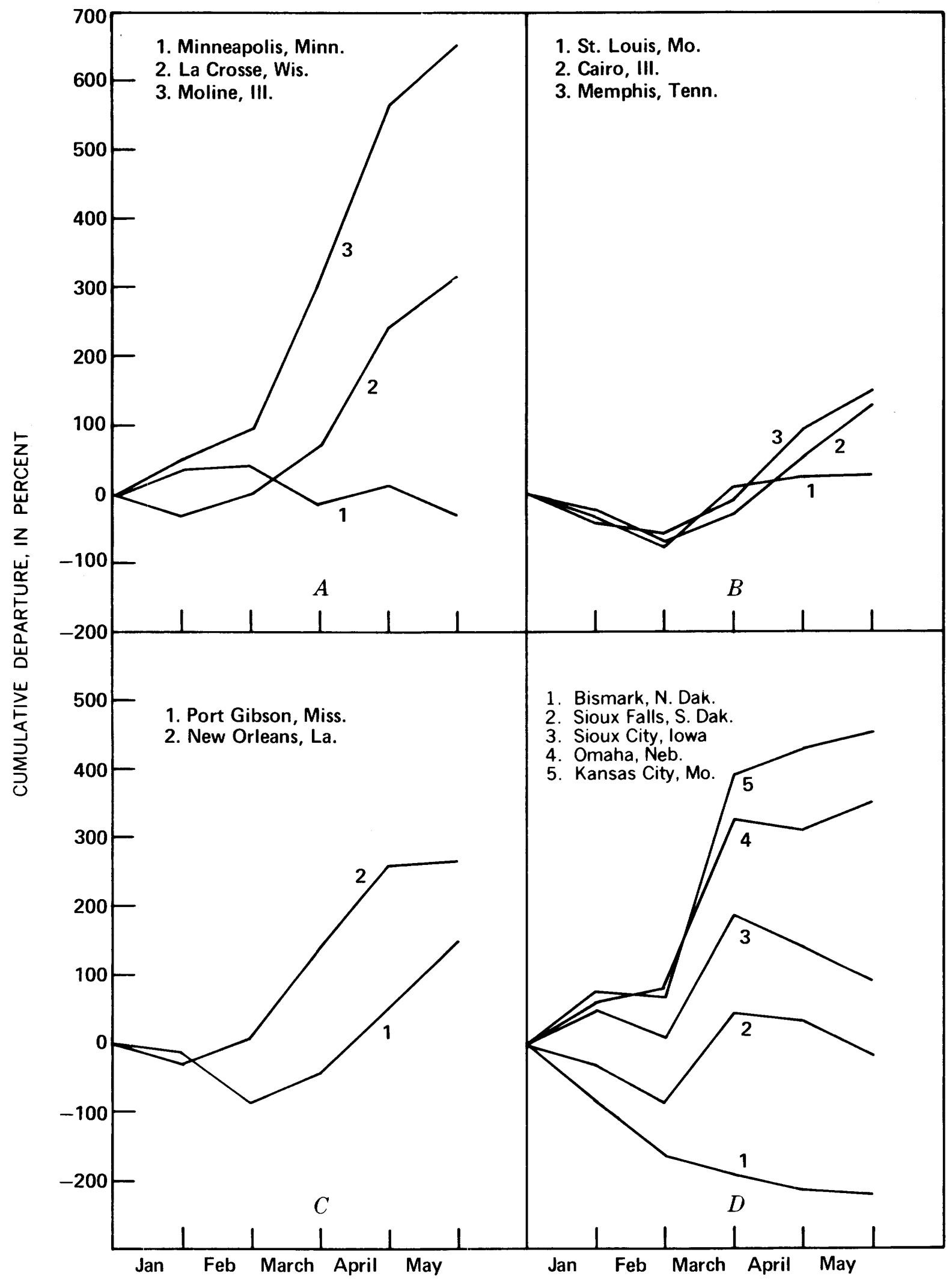

FIGURE 22.-Cumulative percentage departures of precipitation amounts from station normals, January to May 1973. 


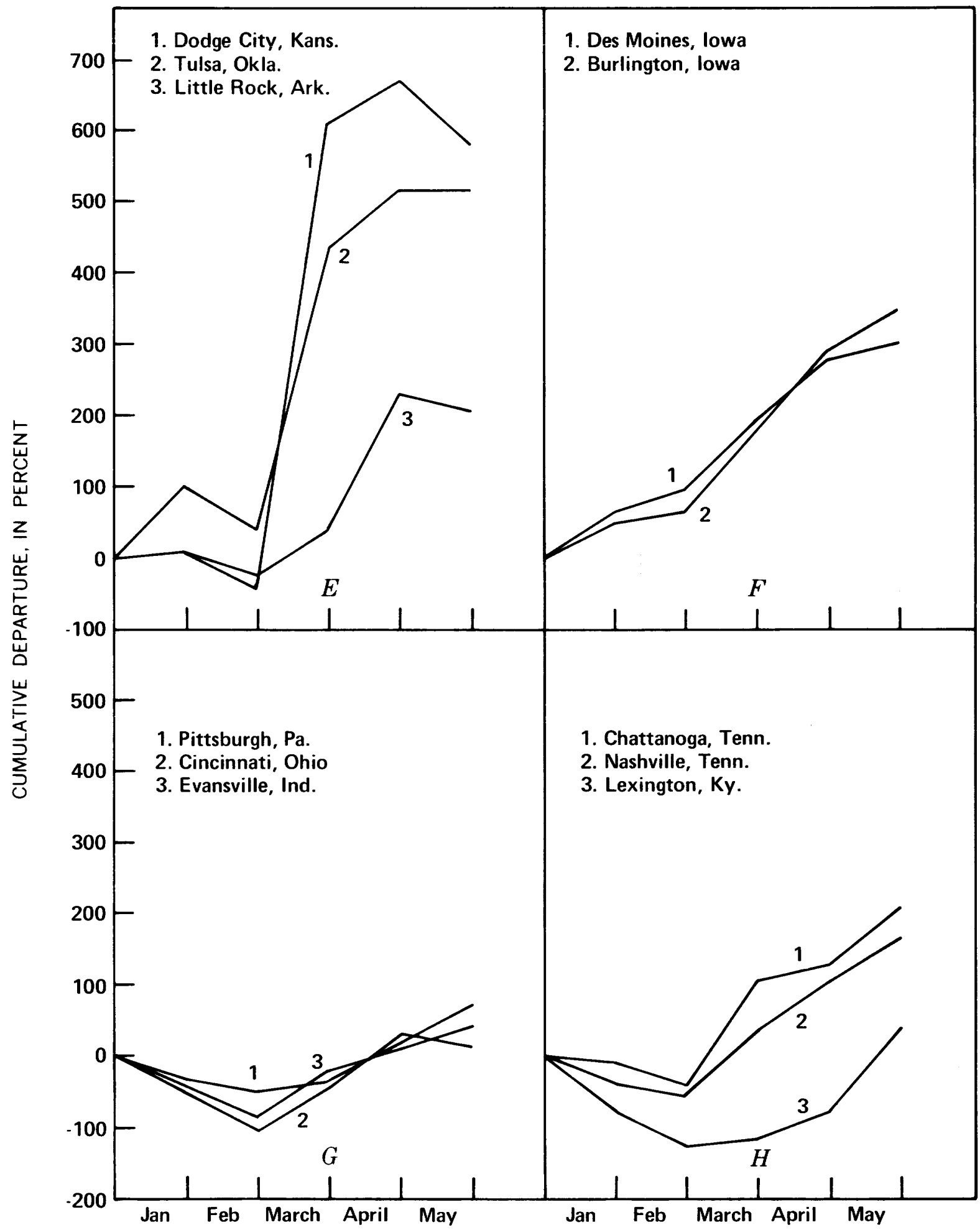

FIGURE 23.-Cumulative percentages departures of precipitation amounts from station normals, January to May 1973.

tive 100-year values and were significant. The corresponding 24-hour probable maximum precipitation for Moberly, Mo., is $20.1 \mathrm{in}$. (511 mm) (Riedel and others, 1956). The observed precipitation reached 47
1. Des Moines, lowa

2. Burlington, lowa

1. Chattanoga, Tenn

2. Nashville, Tenn

3. Lexington, $\mathrm{Ky}$. percent of the probable maximum precipitation.

The maximum 1-hour rain at radio Station KWIX, Moberly, Mo., on April 21 was about equal to the 1year recurrence value (table 4 ) despite the very sig- 
TABLE 4.-A sample of precipitation events in the Mississippi basin in March and April 1973

\begin{tabular}{|c|c|c|c|c|c|c|c|c|c|c|c|c|c|c|}
\hline \multirow{3}{*}{ Station } & \multirow{3}{*}{$\begin{array}{l}\text { Latitude } \\
\text { North }\end{array}$} & \multirow{3}{*}{$\begin{array}{l}\text { Longitude } \\
\text { West }\end{array}$} & \multirow{3}{*}{$\begin{array}{l}\text { Eleva- } \\
\text { tion } \\
(\mathrm{ft})\end{array}$} & \multirow{3}{*}{$\begin{array}{l}\text { Dura- } \\
\text { tion } \\
\text { (hr) }\end{array}$} & \multicolumn{3}{|c|}{ Observed rainfall } & \multirow{2}{*}{\multicolumn{3}{|c|}{$\begin{array}{l}\text { Amount (in.) for } \\
\text { specified return } \\
\text { period (yr.) }\end{array}$}} & \multicolumn{4}{|c|}{$\begin{array}{l}\text { Number of days in month } \\
\text { with rain }\end{array}$} \\
\hline & & & & & \multirow{2}{*}{\multicolumn{2}{|c|}{$\begin{array}{l}\text { Time of ending } \\
\text { (CST) }\end{array}$}} & \multirow{2}{*}{$\underset{\text { (in.) }}{\text { Amount }}$} & & & & \multicolumn{2}{|c|}{$\geqslant 0.01$ inch } & \multicolumn{2}{|c|}{$\supseteq 0.5$ inch } \\
\hline & & & & & & & & 1 & 10 & 100 & $\begin{array}{l}\text { Ob- } \\
\text { served }\end{array}$ & $\begin{array}{l}\text { Nor- } \\
\text { mal }^{2}\end{array}$ & $\begin{array}{l}\text { Ob- } \\
\text { served }\end{array}$ & $\begin{array}{l}\text { Nor- } \\
\text { mal }^{3}\end{array}$ \\
\hline \multicolumn{15}{|c|}{ Arkansas } \\
\hline $\begin{array}{l}\text { Eudora } \\
\text { Little Rock } \\
\text { St. Charles }\end{array}$ & $\begin{array}{l}33^{\circ} 07^{\prime} \\
34^{\circ} 44^{\prime} \\
34^{\circ} 23^{\prime} \\
\end{array}$ & $\begin{array}{l}91^{\circ} 16^{\prime} \\
92^{\circ} 14^{\prime} \\
91^{\circ} 08^{\prime}\end{array}$ & $\begin{array}{l}135 \\
257 \\
200\end{array}$ & $\begin{array}{r}24 \\
1 \\
24\end{array}$ & $\begin{array}{r}\text { 8:00 a.m. } \\
11: 00 \text { p.m. } \\
\text { 8:00 a.m. }\end{array}$ & $\begin{array}{l}\text { Mar. } 16 \\
\text { Apr. } 22 \\
\text { Apr. } 20\end{array}$ & $\begin{array}{l}5.89 \\
1.53 \\
9.18\end{array}$ & $\begin{array}{l}3.6 \\
1.6 \\
3.5\end{array}$ & $\begin{array}{l}6.2 \\
2.6 \\
6.0 \\
\end{array}$ & $\begin{array}{l}8.7 \\
3.7 \\
8.3\end{array}$ & $\begin{array}{r}11 \\
17 \\
9 \\
\end{array}$ & $\begin{array}{r}10.4 \\
10.2 \\
9.7 \\
\end{array}$ & $\begin{array}{l}8 \\
8 \\
6 \\
\end{array}$ & $\begin{array}{l}4.5 \\
4.2 \\
4.1 \\
\end{array}$ \\
\hline \multicolumn{15}{|c|}{ Illinois } \\
\hline Moline & $41^{\circ} 27^{\prime}$ & $90^{\circ} 31^{\prime}$ & 582 & $\begin{array}{r}1 \\
24\end{array}$ & $\begin{array}{l}\text { 7:00 p.m. } \\
\text { 7:00 p.m. }\end{array}$ & $\begin{array}{l}\text { Apr. } 21 \\
\text { Apr. } 21\end{array}$ & $\begin{array}{l}1.38 \\
5.81\end{array}$ & $\begin{array}{l}1.3 \\
2.7\end{array}$ & $\begin{array}{l}2.2 \\
4.8\end{array}$ & $\begin{array}{l}3.1 \\
6.6\end{array}$ & 15 & 11.0 & 5 & 2.5 \\
\hline Springfield - & $39^{\circ} 50^{\prime}$ & $89^{\circ} 40^{\prime}$ & 588 & $\begin{array}{r}24 \\
1 \\
24\end{array}$ & $\begin{array}{l}\text { 8:00 p.m. } \\
\text { 3:00 a.m. }\end{array}$ & $\begin{array}{lr}\text { Mar. } 10 \\
\text { Mar. } 7\end{array}$ & $\begin{array}{r}.01 \\
.48 \\
1.82 \\
\end{array}$ & $\begin{array}{l}2.1 \\
1.3 \\
2.7\end{array}$ & $\begin{array}{l}4.0 \\
2.2 \\
4.7\end{array}$ & $\begin{array}{l}0.0 \\
3.1 \\
6.5\end{array}$ & 18 & 12.0 & 6 & 2.3 \\
\hline \multicolumn{15}{|c|}{ Iowa } \\
\hline Keosauqua - - - & $40^{\circ} 44^{\prime}$ & $91^{\circ} 58^{\prime}$ & 625 & 24 & 6:00 p.m. & Apr. 21 & 4.20 & 2.8 & 4.8 & 6.8 & 12 & 10.5 & 7 & 2.6 \\
\hline \multicolumn{15}{|c|}{ Kansas } \\
\hline $\begin{array}{l}\text { Cimarron } \\
\text { Dodge City } \\
\text { Topeka }\end{array}$ & $\begin{array}{l}37^{\circ} 48^{\prime} \\
37^{\circ} 46^{\prime} \\
39^{\circ} 04^{\prime}\end{array}$ & $\begin{array}{r}100^{\circ} 21^{\prime} \\
99^{\circ} 58^{\prime} \\
95^{\circ} 38^{\prime} \\
\end{array}$ & $\begin{array}{r}2,625 \\
2,582 \\
877 \\
\end{array}$ & $\begin{array}{l}24 \\
24 \\
24\end{array}$ & $\begin{array}{r}7: 00 \text { a.m. } \\
12: 00 \text { p.m. } \\
1: 00 \text { p.m. }\end{array}$ & $\begin{array}{lr}\text { Mar. } 24 \\
\text { Mar. } 10 \\
\text { Mar. } \quad 4\end{array}$ & $\begin{array}{l}3.10 \\
2.54 \\
1.32 \\
\end{array}$ & $\begin{array}{l}1.9 \\
2.1 \\
2.8 \\
\end{array}$ & $\begin{array}{l}4.0 \\
4.1 \\
5.2 \\
\end{array}$ & $\begin{array}{l}3.9 \\
6.0 \\
7.6 \\
\end{array}$ & $\begin{array}{l}13 \\
17 \\
18 \\
\end{array}$ & $\begin{array}{l}6.5 \\
6.5 \\
8.2 \\
\end{array}$ & $\begin{array}{l}\mathbf{5} \\
\mathbf{4} \\
\mathbf{9} \\
\end{array}$ & $\begin{array}{r}0.8 \\
.8 \\
1.6 \\
\end{array}$ \\
\hline \multicolumn{15}{|c|}{ Kentucky } \\
\hline $\begin{array}{l}\text { Hickman 1E } \\
\text { Paducah Sewage Plant.- }\end{array}$ & $\begin{array}{l}36^{\circ} 34^{\prime} \\
37^{\circ} 06^{\prime}\end{array}$ & $\begin{array}{l}89^{\circ} 10^{\prime} \\
88^{\circ} 36^{\prime}\end{array}$ & $\begin{array}{l}375 \\
325\end{array}$ & $\begin{array}{r}24 \\
1 \\
24\end{array}$ & $\begin{array}{l}\text { 5:00 p.m. } \\
\text { 3:00 p.m. } \\
12 \mathrm{M} . \\
\end{array}$ & $\begin{array}{l}\text { Apr. } 19 \\
\text { Apr. } 19 \\
\text { Apr. } 20 \\
\end{array}$ & $\begin{array}{l}5.22 \\
1.6 \\
3.5 \\
\end{array}$ & $\begin{array}{l}3.2 \\
1.3 \\
3.1 \\
\end{array}$ & $\begin{array}{l}5.1 \\
2.2 \\
4.9 \\
\end{array}$ & $\begin{array}{l}6.9 \\
3.1 \\
6.8 \\
\end{array}$ & $\begin{array}{l}15 \\
12\end{array}$ & $\begin{array}{l}12.0 \\
12.1\end{array}$ & $\begin{array}{l}7 \\
6\end{array}$ & $\begin{array}{l}3.4 \\
3.2\end{array}$ \\
\hline \multicolumn{15}{|c|}{ Louisiana } \\
\hline Morgan City & $29^{\circ} 41^{\prime}$ & $91^{\circ} 11^{\prime}$ & 5 & $\begin{array}{r}1 \\
24 \\
\end{array}$ & $\begin{array}{r}\text { 8:00 p.m. } \\
12: 00 \text { p.m. }\end{array}$ & $\begin{array}{l}\text { Apr. } 17 \\
\text { Apr. } 17\end{array}$ & $\begin{array}{l}3.1 \\
8.5 \\
\end{array}$ & $\begin{array}{l}2.2 \\
4.4 \\
\end{array}$ & $\begin{array}{l}3.4 \\
8.9 \\
\end{array}$ & $\begin{array}{r}4.4 \\
13.2 \\
\end{array}$ & 7 & 7.0 & 3 & 3.4 \\
\hline \multicolumn{15}{|c|}{ Mississippi } \\
\hline $\begin{array}{l}\text { Fort Adams } \\
\text { Grenada Dam } \\
\text { Jackson } 5 \mathrm{E} \\
\text { Winona } 5 \mathrm{E}-\end{array}$ & $\begin{array}{l}31^{\circ} 05^{\prime} \\
33^{\circ} 48^{\prime} \\
32^{\circ} 19^{\prime} \\
33^{\circ} 29^{\prime}\end{array}$ & $\begin{array}{l}91^{\circ} 33^{\prime} \\
89^{\circ} 46^{\prime} \\
90^{\circ} 05^{\prime} \\
89^{\circ} 38^{\prime}\end{array}$ & $\begin{array}{r}70 \\
283 \\
330 \\
390 \\
\end{array}$ & $\begin{array}{r}1 \\
24 \\
24 \\
24 \\
24 \\
\end{array}$ & $\begin{array}{l}\text { 10:00 a.m. } \\
\text { 6:00 p.m. } \\
\text { 8:00 a.m. } \\
\text { 3:00 p.m. } \\
\text { 6:00 a.m. }\end{array}$ & $\begin{array}{ll}\text { Apr. } & 16 \\
\text { Mar. } 24 \\
\text { Mar. } 16 \\
\text { Apr. } 16 \\
\text { Mar. } 16 \\
\end{array}$ & $\begin{array}{l}2.55 \\
6.63 \\
7.38 \\
4.98 \\
9.07\end{array}$ & $\begin{array}{l}1.9 \\
4.2 \\
3.6 \\
3.8 \\
3.7 \\
\end{array}$ & $\begin{array}{l}3.1 \\
7.9 \\
6.2 \\
6.8 \\
6.2\end{array}$ & $\begin{array}{r}4.1 \\
11.0 \\
8.5 \\
9.6 \\
8.5\end{array}$ & $\begin{array}{l}10 \\
16 \\
16 \\
10 \\
11 \\
\end{array}$ & $\begin{array}{r}8.5 \\
10.0 \\
11.0 \\
9.0 \\
11.0\end{array}$ & $\begin{array}{l}\mathbf{5} \\
\mathbf{6} \\
8 \\
\mathbf{4} \\
\mathbf{9}\end{array}$ & $\begin{array}{l}4.1 \\
4.3 \\
4.8 \\
4.0 \\
4.8\end{array}$ \\
\hline \multicolumn{15}{|c|}{ Missouri } \\
\hline $\begin{array}{l}\text { Columbia } \\
\text { Madison } \\
\text { Moberly Radio KWIX }\end{array}$ & $\begin{array}{l}38^{\circ} 49^{\prime} \\
39^{\circ} 28^{\prime} \\
39^{\circ} 24^{\prime}\end{array}$ & $\begin{array}{l}92^{\circ} 13^{\prime} \\
92^{\circ} 13^{\prime} \\
92^{\circ} 26^{\prime}\end{array}$ & $\begin{array}{l}887 \\
974 \\
850\end{array}$ & $\begin{array}{r}24 \\
24 \\
1 \\
6 \\
24 \\
24 \\
\end{array}$ & $\begin{array}{r}11: 00 \text { p.m. } \\
\text { 7:00 a.m. } \\
\text { 2:00 a.m. } \\
\text { 2:00 a.m. } \\
\text { 5:00 a.m. } \\
\text { 12:00 } \mathrm{p.m} .\end{array}$ & $\begin{array}{l}\text { Mar. } 10 \\
\text { Apr. } 21 \\
\text { Apr. } 21 \\
\text { Apr. } 21 \\
\text { Apr. } 21 \\
\text { Apr. } 22 \\
\end{array}$ & $\begin{aligned} \mathbf{1 . 7 9} \\
\mathbf{9 . 0 0} \\
1.5 \\
\mathbf{7 . 1} \\
\mathbf{9 . 5} \\
11.7 \\
\end{aligned}$ & $\begin{array}{l}2.9 \\
2.9 \\
1.4 \\
2.1 \\
2.9\end{array}$ & $\begin{array}{l}\mathbf{5 . 1} \\
\mathbf{5 . 0} \\
\mathbf{2 . 4} \\
\mathbf{3 . 7} \\
\mathbf{5 . 1} \\
\mathbf{9 . 2} \\
\end{array}$ & $\begin{array}{r}7.3 \\
7.2 \\
3.4 \\
5.4 \\
7.2 \\
13.0 \\
\end{array}$ & $\begin{array}{r}17 \\
9 \\
11\end{array}$ & $\begin{array}{l}11.0 \\
11.1 \\
11.0\end{array}$ & $\begin{array}{l}7 \\
5 \\
4\end{array}$ & $\begin{array}{l}2.3 \\
2.7 \\
2.8\end{array}$ \\
\hline \multicolumn{15}{|c|}{ Nebraska } \\
\hline Grand Island & $40^{\circ} 58^{\prime}$ & $98^{\circ} 19^{\prime}$ & 1,841 & 24 & 8:00 a.m. & Mar. 24 & 1.31 & 2.0 & 4.0 & 6.0 & 17 & 7.2 & 4 & 0.8 \\
\hline \multicolumn{15}{|c|}{ Oklahoma } \\
\hline $\begin{array}{l}\text { Poteau } \\
\text { Tulsa } \\
\text { Wichita MT WL REF -- }\end{array}$ & $\begin{array}{l}35^{\circ} 04^{\prime} \\
36^{\circ} 11^{\prime} \\
34^{\circ} 44^{\prime}\end{array}$ & $\begin{array}{l}94^{\circ} 38^{\prime} \\
95^{\circ} 54^{\prime} \\
98^{\circ} 43^{\prime} \\
\end{array}$ & $\begin{array}{r}572 \\
668 \\
1,665 \\
\end{array}$ & $\begin{array}{l}24 \\
24 \\
24 \\
\end{array}$ & $\begin{array}{r}\text { 6:00 p.m. } \\
\text { 10:00 p.m. } \\
\text { 9:00 p.m. }\end{array}$ & $\begin{array}{l}\text { Apr. } 23 \\
\text { Mar. } 24 \\
\text { Mar. } 30 \\
\end{array}$ & $\begin{array}{l}4.95 \\
2.07 \\
3.55 \\
\end{array}$ & $\begin{array}{l}3.4 \\
3.4 \\
2.8 \\
\end{array}$ & $\begin{array}{l}6.4 \\
6.1 \\
5.6 \\
\end{array}$ & $\begin{array}{l}9.3 \\
8.9 \\
8.5 \\
\end{array}$ & $\begin{array}{r}14 \\
19 \\
6 \\
\end{array}$ & $\begin{array}{l}9.9 \\
8.0 \\
6.0 \\
\end{array}$ & $\begin{array}{l}\mathbf{5} \\
7 \\
\mathbf{3} \\
\end{array}$ & $\begin{array}{l}4.0 \\
2.1 \\
1.1 \\
\end{array}$ \\
\hline \multicolumn{15}{|c|}{ South Dakota } \\
\hline Sioux Falls - - & $43^{\circ} 34^{\prime}$ & $96^{\circ} 44^{\prime}$ & 1,418 & 24 & 4:00 p.m. & Mar. 14 & 1.08 & 2.1 & 4.0 & 5.9 & 12 & 8.2 & 2 & 0.8 \\
\hline \multicolumn{15}{|c|}{ Tennessee } \\
\hline Belvidere - & $35^{\circ} 08^{\prime}$ & $86^{\circ} 11^{\prime}$ & 985 & $\begin{array}{r}1 \\
24\end{array}$ & $\begin{array}{l}\text { 1:00 a.m. } \\
\text { 11:00 a.m. }\end{array}$ & $\begin{array}{l}\text { Mar. } 16 \\
\text { Mar. } 16\end{array}$ & $\begin{array}{l}1.35 \\
7.36\end{array}$ & $\begin{array}{l}1.37 \\
3.2\end{array}$ & $\begin{array}{l}2.3 \\
5.2\end{array}$ & $\begin{array}{l}3.2 \\
7.1\end{array}$ & 16 & 13.2 & 5 & 4.7 \\
\hline $\begin{array}{l}\text { Chattanooga }-1- \\
\text { Knoxville } \\
\text { Victory }\end{array}$ & $\begin{array}{l}35^{\circ} 02^{\prime} \\
35^{\circ} 49^{\prime} \\
35^{\circ} 06^{\prime}\end{array}$ & $\begin{array}{l}85^{\circ} 12^{\prime} \\
83^{\circ} 59^{\prime} \\
87^{\circ} 51^{\prime}\end{array}$ & $\begin{array}{l}665 \\
980 \\
830\end{array}$ & $\begin{array}{l}24 \\
24 \\
24 \\
48\end{array}$ & $\begin{array}{l}\text { 3:00 p.m. } \\
\text { 6:00 p.m. } \\
\text { 1:00 p.m. } \\
\text { 3:00 p.m. }\end{array}$ & $\begin{array}{l}\text { Mar. } 16 \\
\text { Mar. } 16 \\
\text { Mar. } 15 \\
\text { Mar. } 16\end{array}$ & $\begin{array}{r}6.53 \\
4.85 \\
6.48 \\
10.40 \\
\end{array}$ & $\begin{array}{l}3.2 \\
2.9 \\
3.3\end{array}$ & $\begin{array}{l}\mathbf{5 . 2} \\
\mathbf{5 . 0} \\
\mathbf{5 . 4} \\
\mathbf{6 . 3} \\
\end{array}$ & $\begin{array}{l}7.1 \\
6.9 \\
7.3 \\
8.9 \\
\end{array}$ & $\begin{array}{l}16 \\
16 \\
18\end{array}$ & $\begin{array}{l}13.6 \\
13.0 \\
12.5\end{array}$ & $\begin{array}{r}6 \\
4 \\
10\end{array}$ & $\begin{array}{l}4.9 \\
5.2 \\
4.4\end{array}$ \\
\hline \multicolumn{15}{|c|}{ Wisconsin } \\
\hline $\begin{array}{l}\text { Clinton 2N } \\
\text { Madison } \\
\text { Milwaukee }-\end{array}$ & $\begin{array}{l}42^{\circ} 37^{\prime} \\
43^{\circ} 08^{\prime} \\
42^{\circ} 57^{\prime}\end{array}$ & $\begin{array}{l}88^{\circ} 52^{\prime} \\
89^{\circ} 20^{\prime} \\
87^{\circ} 54^{\prime}\end{array}$ & $\begin{array}{l}920 \\
858 \\
672\end{array}$ & $\begin{array}{l}24 \\
24 \\
24\end{array}$ & $\begin{array}{r}\text { 6:00 p.m. } \\
\text { 4:00 a.m. } \\
\text { 10:00 p.m. }\end{array}$ & $\begin{array}{l}\text { Apr. } 21 \\
\text { Mar. } 7 \\
\text { Apr. } 21\end{array}$ & $\begin{array}{l}4.39 \\
2.52 \\
3.04\end{array}$ & $\begin{array}{l}2.4 \\
2.4 \\
2.3\end{array}$ & $\begin{array}{l}3.9 \\
4.0 \\
3.8\end{array}$ & $\begin{array}{l}5.6 \\
5.9 \\
5.5\end{array}$ & $\begin{array}{l}14 \\
13 \\
17\end{array}$ & $\begin{array}{l}11.9 \\
11.1 \\
11.2\end{array}$ & $\begin{array}{l}\mathbf{5} \\
\mathbf{3} \\
\mathbf{3}\end{array}$ & $\begin{array}{l}1.9 \\
1.3 \\
1.2\end{array}$ \\
\hline
\end{tabular}

${ }^{1}$ Interpolated from Environmental Data Service and Statistical Reporting Service (1973) for durations up to 24 hours and from Mason (1952)

for durations exceeding 24 hours.
2 Interpolated from Environmental Data Service (1968).

3 Interpolated from Miller (1964).

nificant 6- and 24-hour observed rainfall. The accompanying weather situation was a case of thunderstorms imbedded within a quasistationary squall line, which in turn was associated with the cyclone scale weather system. These thunderstorms, fed by the convergent inflow of moist air, regenerated and maintained a precipitation rate exceeding 1 in./hr (inch per hour) for 5 hours within a 6 -hour period ending 2 a.m., April 21.

Dimensionless temporal patterns of four storms 
are shown in figure 24. Each storm duration was bounded at each end by at least 2 hours with no rain. The 6-hour and 24-hour storm rainfall at radio Station KWIX, Moberly, Mo., as well as the 48-hour rainfall at Victory, Tenn., exceeded their respective 100 -year values (table 4 ). The other two storms occurred in Arkansas and Mississippi, respectively, around March 24, 1973. They yielded fair amounts of rain but did not reach significance. It is interesting to note that for storms number 1-3 less than 20 percent of the rain fell in the initial 50 percent of the duration. However, the storm rainfall over Victory, Tenn., in mid-March 1973 had 60 percent of the amount concentrated in the initial 30 percent of the duration. Without the antecedent moderate but continuous rain normally characterizing weather situations in the warm sector, the heavy shower was triggered at Victory, Tenn., by the cold front passage from the west in the early afternoon of March 14, and rainfall continued as the front stagnated. Then the rainfall intensity reduced as the front moved out of western Tennessee on March 16.

\section{AREAL PRECIPITATION}

In addition to the areal precipitation distribution represented graphically by the isohyetal analyses, a few numerical values are illustrative. For example, the Southwest Climatic Division in Kansas, with an area of $12,076 \mathrm{mi}^{2}$ (square miles) $\left(31,277 \mathrm{~km}^{2}\right)$, had an average precipitation depth of $7.06 \mathrm{in} .(179 \mathrm{~mm})$ in March 1973, compared with the 30-year (194170) March normal of 0.96 in. (24 mm). This positive departure was 3.76 times the corresponding standard deviation and amounted to an additional 4.84 billion $\mathrm{m}^{3}$ (cubic metres) of water. The Northwest Prairie Climatic Division in Missouri, which covers an area of $14,310 \mathrm{mi}^{2}\left(37,063 \mathrm{~km}^{2}\right)$ in the confluence region of the Missouri and Mississippi Rivers, had 30-year (1941-70) monthly mean precipitation values of 2.83 and 3.89 in. (72 and $99 \mathrm{~mm}$ ) for March and April respectively. However, the matching observed average precipitation in 1973 was 8.83 and $5.97 \mathrm{in}$. (224 and $152 \mathrm{~mm}$ ). The March positive departure represented 5.65 billion $\mathrm{m}^{3}$ of water over this confluence region. Areal average rainfalls for both divisions in March 1973 were greater than any corresponding amount in their respective 30-year records. The average precipitation depth over the Tennessee River Basin in March and April 1973 was 11.37 and 5.80 in. (289 and $147 \mathrm{~mm}$ ) respectively compared with the 75-year mean values of $5.61(142 \mathrm{~mm})$ for March and $4.48(114 \mathrm{~mm})$ for April. Its positive de- parture in March alone was equivalent to more than 530 billion $\mathrm{ft}^{3}$ ( 15 billion $\mathrm{m}^{3}$ ) of water.

\section{SEASONAL STRATIFICATION OF PRECIPITATION EVENTS}

In the foregoing discussion it was mentioned that the cumulative effect of individually rather insignificant precipitation events closely following one another could lead to a total event of great significance. Here, it should be pointed out that seasonal stratification of precipitation events could substantially affect their recurrence probabilities and, consequently, their associated significance qualifications. Because the same amount of precipitation falling in different seasons could result in very different runoffs for a watershed of moderate or large size, the question of seasonal stratification is a relevant one. For example, the maximum 10-day precipitation over Dodge City, Kans., in March 1973 was 5.2 in. (132 $\mathrm{mm}$ ). Since the 5-year 10-day value is $6.1 \mathrm{in}$. (155 $\mathrm{mm}$ ) derived from annual precipitation data (Miller, 1964), 5.2 in. (132 $\mathrm{mm})$ in 10 days might seem to be not far from normal. However, the precipitation climatology of western Kansas indicates that much of its rainfall usually occurs in the period from May to September. For a 10-day rainfall of such magnitude to fall in March is extremely rare. The record of 61 years (1912-72) at Dodge City shows a highest maximum 10-day rainfall in March of only $3.66 \mathrm{in} .(93 \mathrm{~mm})$, with a mean of $0.98 \mathrm{in}$. $(25 \mathrm{~mm})$ and a standard deviation of $0.78 \mathrm{in.}$ (20 $\mathrm{mm})$.

Even if one extends the time period of consideration into 6 months, from November 1 through April 30 , the maximum observed 10-day precipitation in these 6 -month intervals over the 61 years is only 4.07 in. $(103 \mathrm{~mm})$, and the mean is 1.99 in. $(51 \mathrm{~mm})$. Using Gumbel's method in fitting these data with a Fisher-Tippett type I distribution, it can be shown that the probability of a 10-day precipitation of $\mathbf{5 . 2}$ in. (132 mm) occurring in any of those 6-month periods would be less than 0.01 . As a consequence of this and similar exceptional events in the vicinity, flooding was reported in progress along the Upper Arkansas River near Dodge City, Kans., in March 1973. In this analysis, even though the requirements of large sample size and relative independence of the maxima were still satisfied, the resultant probability should be considered as only an estimate.

\section{STORM COMBINATIONS}

One of the techniques useful in the simulation of possible extreme flood conditions is to produce hypothetical floods by combining two or more past storms 


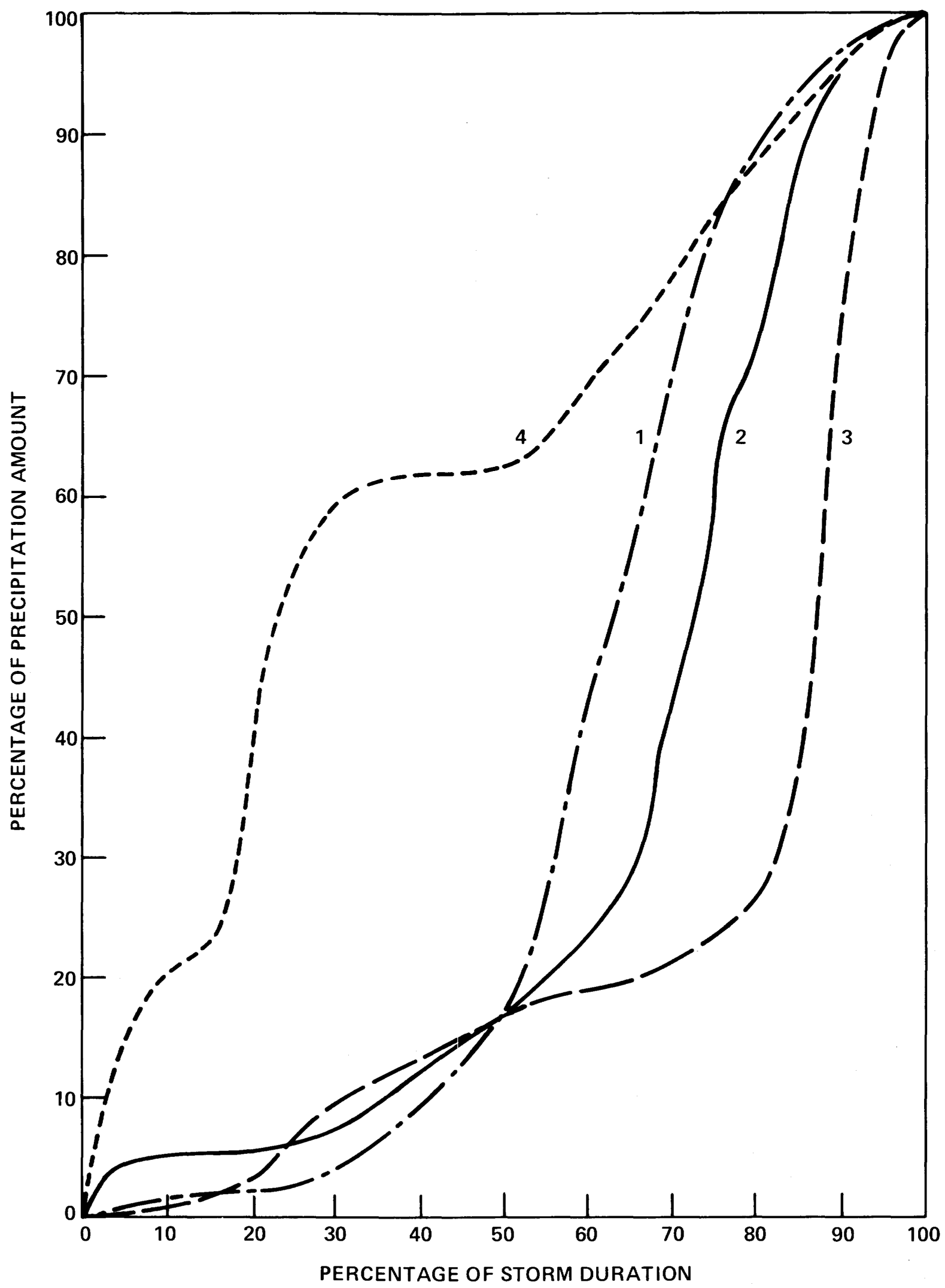

Figure 24.-Dimensionless temporal patterns of four storms over the basin. 
that actually occurred in widely separated time periods into a sequence interrupted by a period of no precipitation to allow for the evolution of synoptic conditions in a meteorologically reasonable manner. Transposition of isohyetal patterns may also be done to achieve a more hydrologically critical placement of the rain.

In the Mississippi basin flood episode, spring 1973, many stations and many large areas experienced prolonged rainy spells. Again, using the Northeast Prairie Climatological Division of Missouri as an example, it had the following rainy periods in March 1973: March 1-7, 9-11, 13-14, 17, 19-21, 24-26, 28-31 (Environmental Data Service 1973a). There was only 1 clear day in each of the periods March 1-11 and March 24-31. For the month as a whole, there were at most 2 clear days following one storm before another storm started to dump rain over the same region. A clear day is defined here as a day with less than 10 percent of the stations in the Division reporting 24 -hour rainfall of $0.01 \mathrm{in}$. $(0.25 \mathrm{~mm})$ or more. It is evident that nature had provided a very efficient storm combination by tightly packing them one after another. This same situation happened over many other areas in the basin. These long sequences of storms can be used fruitfully as building blocks in future simulations of storm combinations for appropriate areas.
THE STORM OF APRIL 19-22, 1973, OVER THE CENTRAL MISSISSIPPI BASIN

The storm of April 19-22, 1973, with its precipitation center in northeastern Missouri, brought heavy rain to wide areas either along or close to the Upper Mississippi and the Lower Missouri Rivers, and contributed materially to the buildup of the recordbreaking high crest passing St. Louis, Mo., and the Lower Mississippi main stem in late April and early May 1973. For this reason, it was chosen for a more detailed study.

\section{STORM HISTORY}

At $6: 00$ a.m. c.s.t., April 18, 1973, an incipient Low was located in east-central Colorado. By 6:00 p.m. c.s.t. the next day, it had become a well organized cyclone with its center over Nebraska. Its central pressure had fallen below $984 \mathrm{mb}$, and frontogenesis also had been in progress. Meanwhile, the eastern half of the United States, because of a strong Bermuda High off the Atlantic coast, had a predominantly southerly wind extending at least to $700 \mathrm{mb}$. The 850- and 700-mb charts for $6: 00$ p.m. c.s.t., April 19, displayed a conspicuous lag of the thermal trough with respect to the contour trough over the Great Plains region (figs. 25-28), indicating cold (warm)

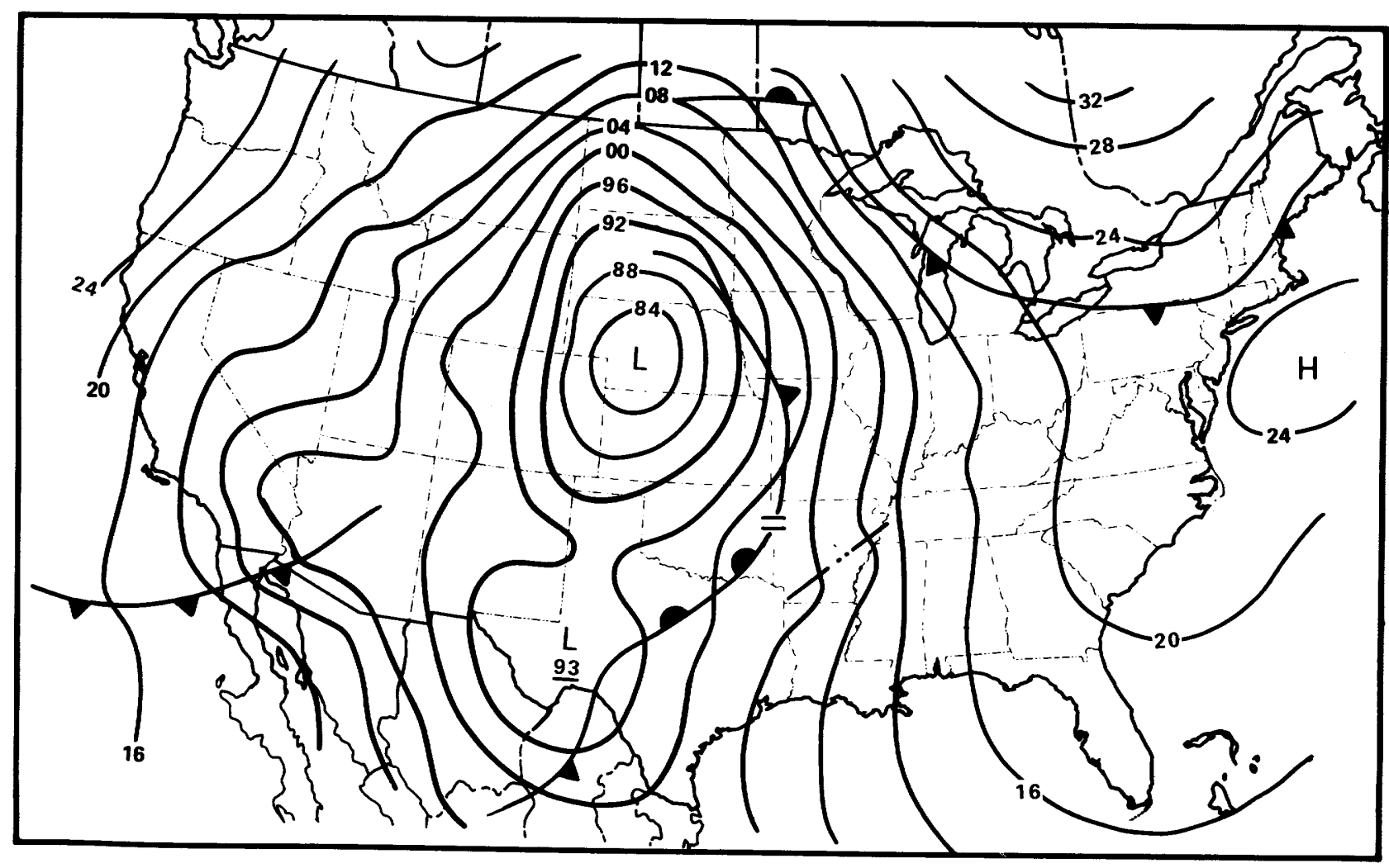

FIGURE 25.—Surface weather chart for 6:00 p.m. c.s.t., April 19, 1973. 


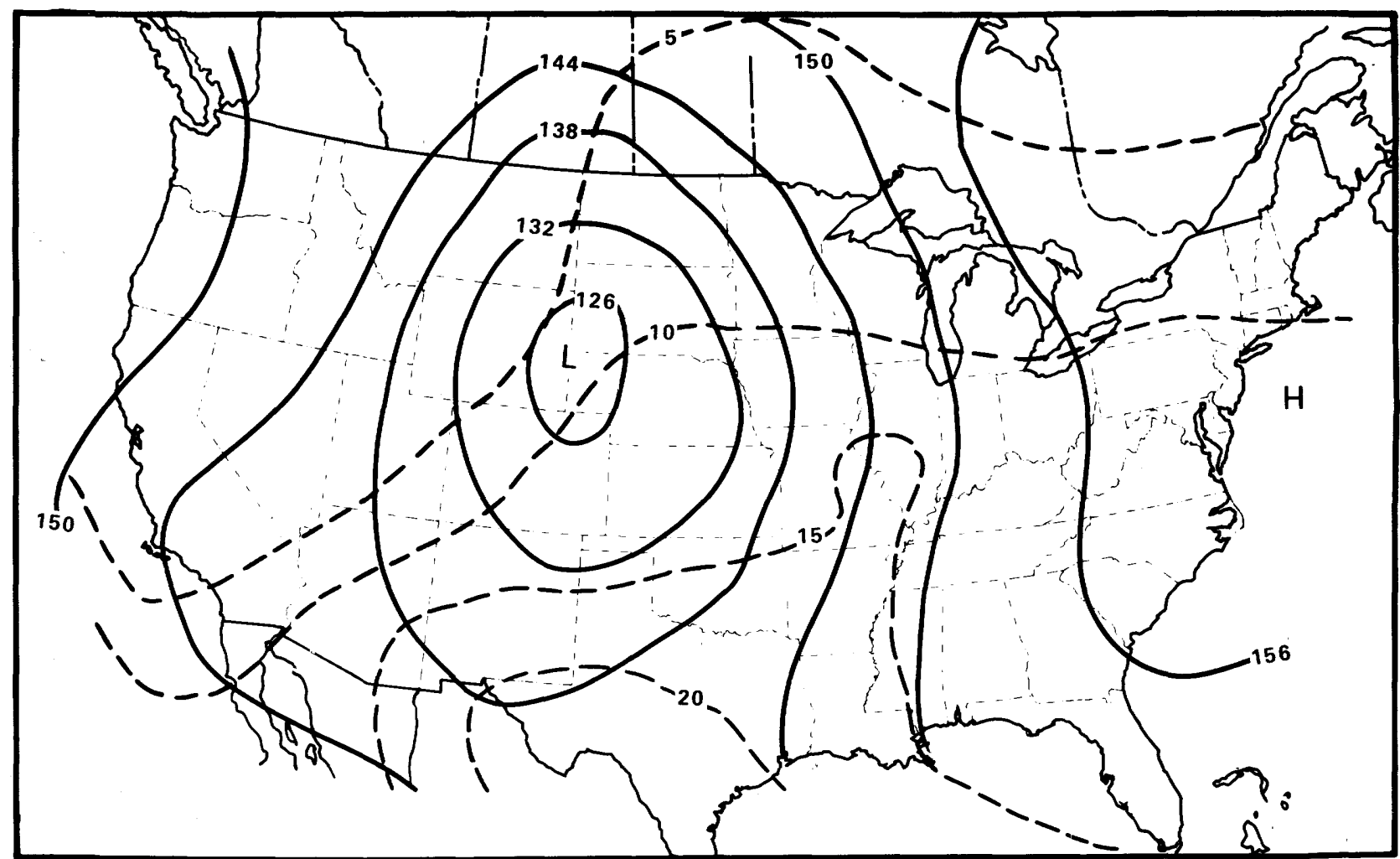

FigURE 26. $-850-\mathrm{mb}$ chart for 6:00 p.m. c.s.t., April 19, 1973.

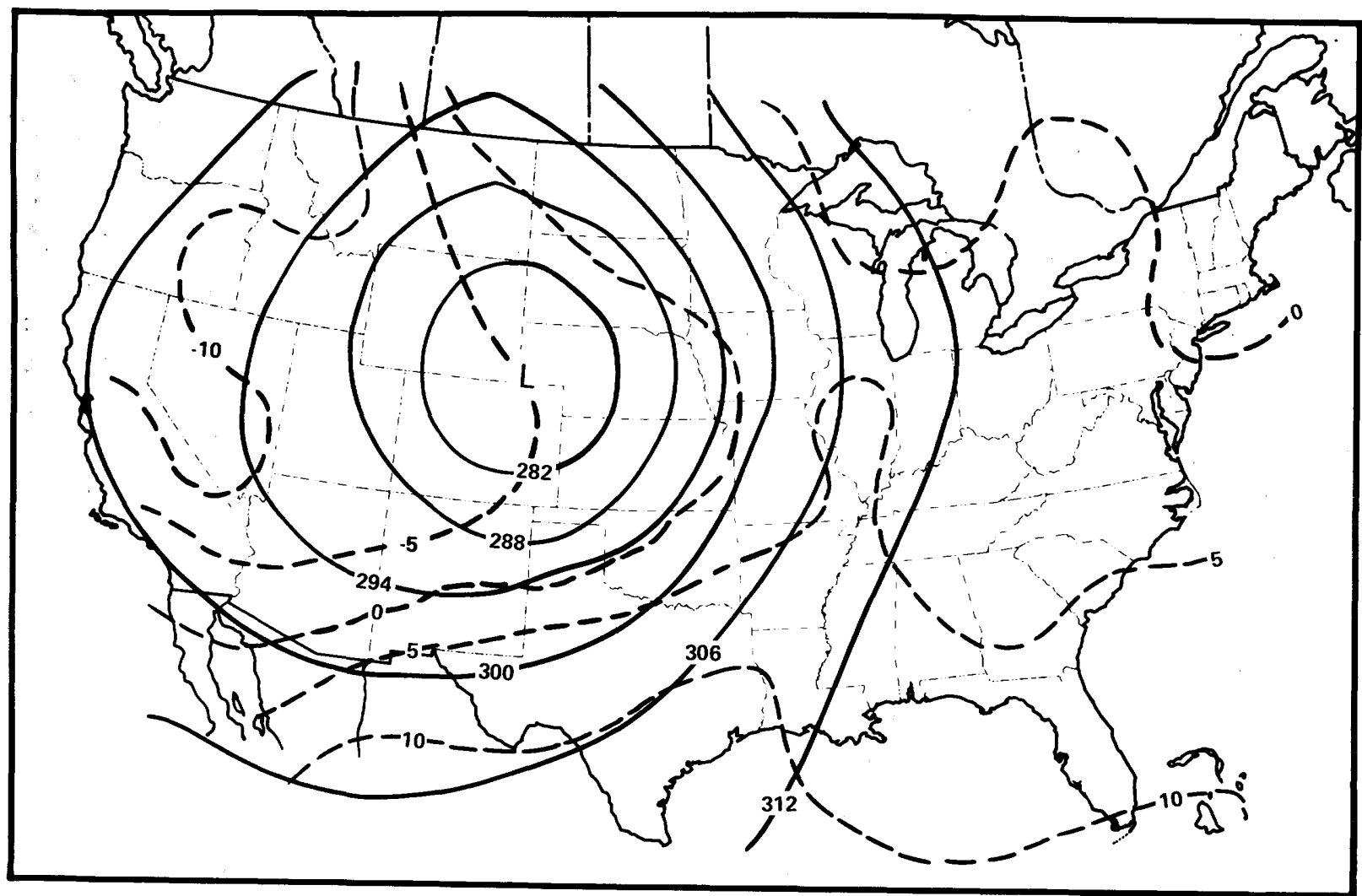

Figure 27.-700-mb chart for 6:00 p.m. c.s.t., April 19, 1973. 


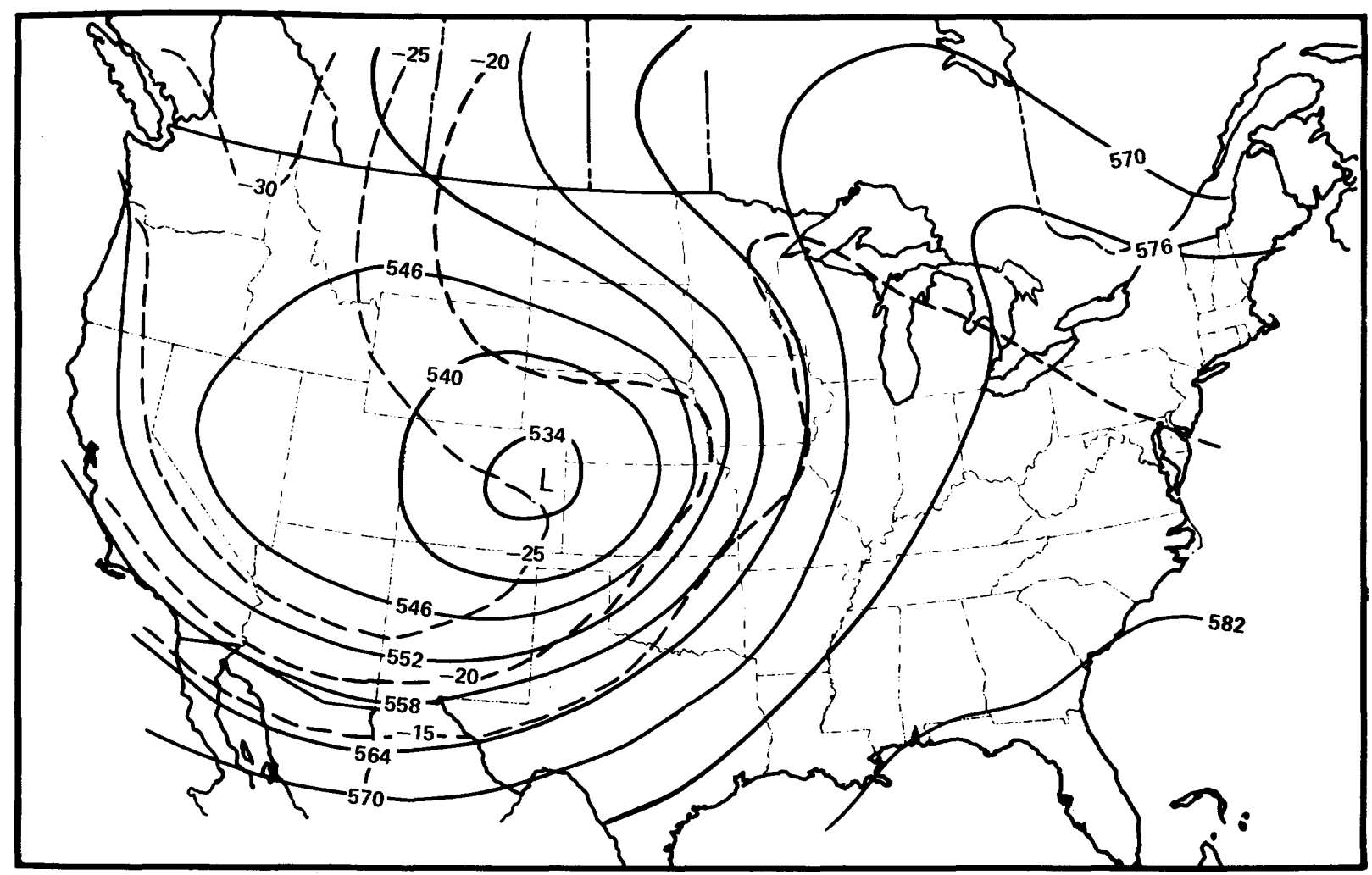

FigURE 28.-500-mb chart for 6:00 p.m. c.s.t., April 19, 1973.

advection behind (ahead of) the contour trough. The whole basin, except the Upper Mississippi Valley and a part of the Ohio Valley, where a shortwave ridge was passing through, was underneath a $500-\mathrm{mb}$ trough-to-ridge flow pattern (fig. 28).

Meanwhile, the weather system rapidly developed. By 3:00 a.m. c.s.t., April 20, a meso-High was in existence just behind the cold front in eastern Iowa. An instability line, possibly associated with weak frontal wave perturbations, began to appear over northern Missouri. By 6:00 a.m. c.s.t., April 20, the Low was over the Dakotas. The frontal zone marking the boundary between the tropical maritime airmass to the east and cold polar airmass to the west became well established throughout the central Basin. The cold front extended from the Low center in the Dakotas through Minnesota, Iowa, and Missouri and then changed into a stationary front through Oklahoma to Texas. In the Central Mississippi Valley, wind was still predominantly from the south or southeast at the surface and veered with height. By 3:00 p.m. c.s.t., the instability line over northern Missouri had developed into a squall line and strong thunderstorm activities began. The front below Iowa was now classified as a warm front, but movement was very minor. This squall line remained quasistationary about $70 \mathrm{mi}(112.6 \mathrm{~km})$ to the east of the front in northeastern Missouri for about 9 hours. The strong temperature gradient, the persistent convergent inflow of warm moist air, and the high instability along the quasistationary front and squall line also provided an environment favorable to the growth of severe storms of much smaller scale. Nine confirmed tornadoes were sighted on April 19, 16 tornadoes on April 20, and 3 on April 21 in Missouri alone. Many funnel clouds and tornadoes were also observed in Illinois and Iowa during this period. Numerous windstorms and hailstorms were also induced by the large-scale cyclone system. Hailstones with diameters reaching 2 in. ( $51 \mathrm{~mm}$ ) fell in Henry County, Iowa, on April 19. A windstorm with gusts up to $85 \mathrm{mph}(137 \mathrm{~km} / \mathrm{hr})$ hit western Iowa the same day, causing property losses and injuring five people.

The surface analysis and 850-, 700-, and 500-mb analyses for 6:00 a.m. and 6:00 p.m. c.s.t., April 20, 1973 , are shown in figures $29-36$. The $850-\mathrm{mb}$ data (not shown in figures) clearly illustrates that the saturated (or nearly saturated) state of the air over the basin was due to the continuous intrusion of the 
warm moist maritime airmass into the Mississippi Valley from the Gulf of Mexico, indicated by the shape of the isotherm pattern. At 6:00 p.m. c.s.t., April 20, southerly winds at $850 \mathrm{mb}$ reached a speed of about 50 knots $(92.6 \mathrm{~km} / \mathrm{hr})$ over Little Rock, Ark., 45 knots $(83.4 \mathrm{~km} / \mathrm{hr})$ over Monett, Mo., and 30 knots $(55.6 \mathrm{~km} / \mathrm{hr})$ over Peoria, Ill., indicating moisture convergence over Missouri and Illinois. The antecedent rising motion in the warm intruding air, plus the apparent moisture convergence factor, led to an $850-\mathrm{mb}$ relative humidity of 95 percent over Little Rock, Ark., and to complete saturation over the latter two stations.

The 700-mb analysis of $6: 00$ p.m. c.s.t., April 20 (fig. 35), shows the same predominantly southerly inflow of warm moist air into the Mississippi basin but with wind direction shifted slightly towards the west. The warm advection over the valley along the main stem Mississippi River extended through a very deep layer, up to $300 \mathrm{mb}$. The associated rising motion within this deep moist layer brought about widespread condensation and formed a cloud lane extending from Louisiana and eastern Texas up to Wisconsin.

\section{PARCEL TRAJECTORIES LEADING INTO THE BASIN}

To facilitate the identification of the airmass source region $(\mathrm{s})$ and the visualization of the ante- cedent three-dimensional air movement, a set of past air parcel trajectories at three levels valid at 6:00 p.m. c.s.t., April 20, are shown in figure 37 . Solid (dashed) lines in figures 37 and 38 denote ascending (descending) trajectory. The three-digit numbers at origin points indicate the initial pressure levels in millibars. The numbers in parentheses specify the $K$ indices.

The $K$ index is a measure of the airmass moisture content and static stability and is given by :

$$
K=\left(T_{850}-T_{500}\right)+T_{d, 850}-\left(T_{700}-T_{\mathrm{d}, 7 \text {; } 0}\right)
$$

Here, $T$ is temperature in degrees Celsius; $T_{d}$, the dew point temperature; and the subscripts denote pressure levels. The larger the $K$ index of the airmass, the more unstable it is. A $K$ index of 25 for Peoria, Ill. (fig. 37), indicates that airmass thunderstorms are possible. For comparison, a $K$ index greater (less) than $35(20)$ is associated with numerous (no) thunderstorms.

For example, the air parcel arriving at Peoria, Ill., at $700 \mathrm{mb}$ at $6: 00$ p.m. c.s.t., April 20 , originated at about lat $28^{\circ} \mathrm{N}$., long $95^{\circ} \mathrm{W}$. in the Gulf of Mexico at pressure level $782 \mathrm{mb} 24$ hours ago. During this period, it traveled northward and slowly rose to 700 $\mathrm{mb}$. The pressure level at which the parcel was located 6 hours ago was $731 \mathrm{mb}$, as labeled on this particular trajectory. The synoptic scale rising motion

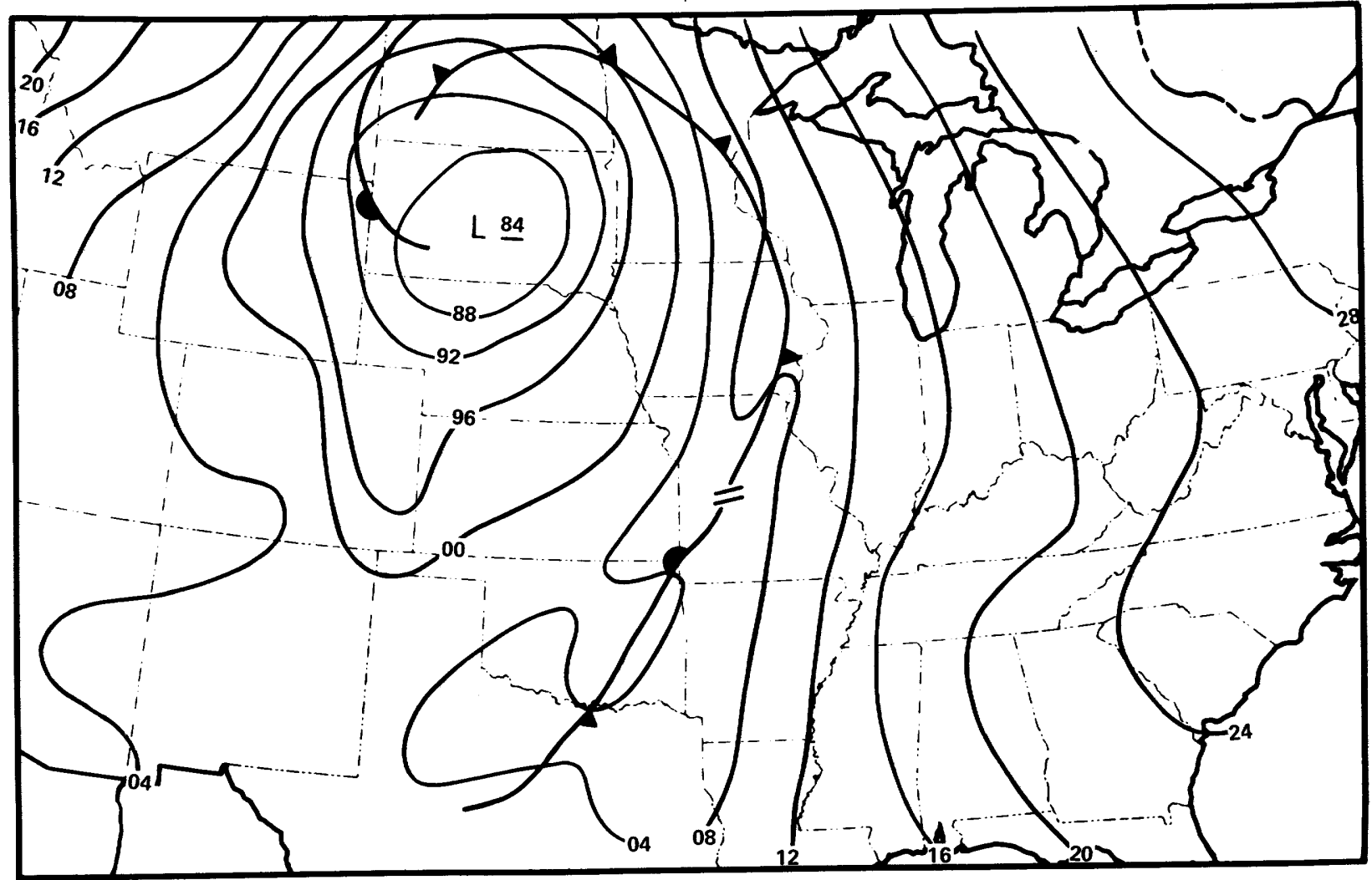

FIGURE 29.-Surface weather chart for 6:00 a.m. c.s.t., April 20, 1973. 


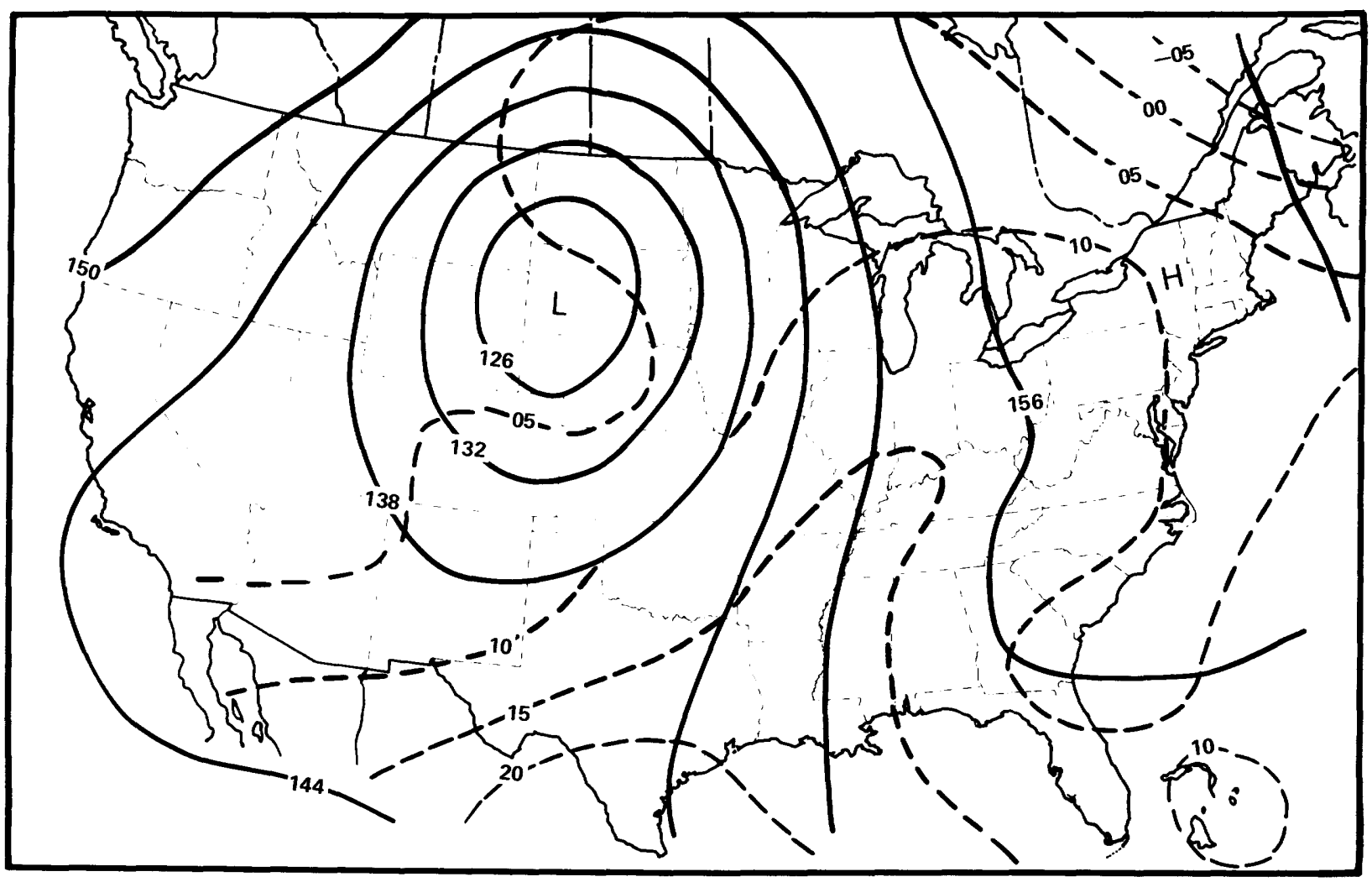

FiguRe 30.-850-mb chart for 6:00 a.m. c.s.t., April 20, 1973.

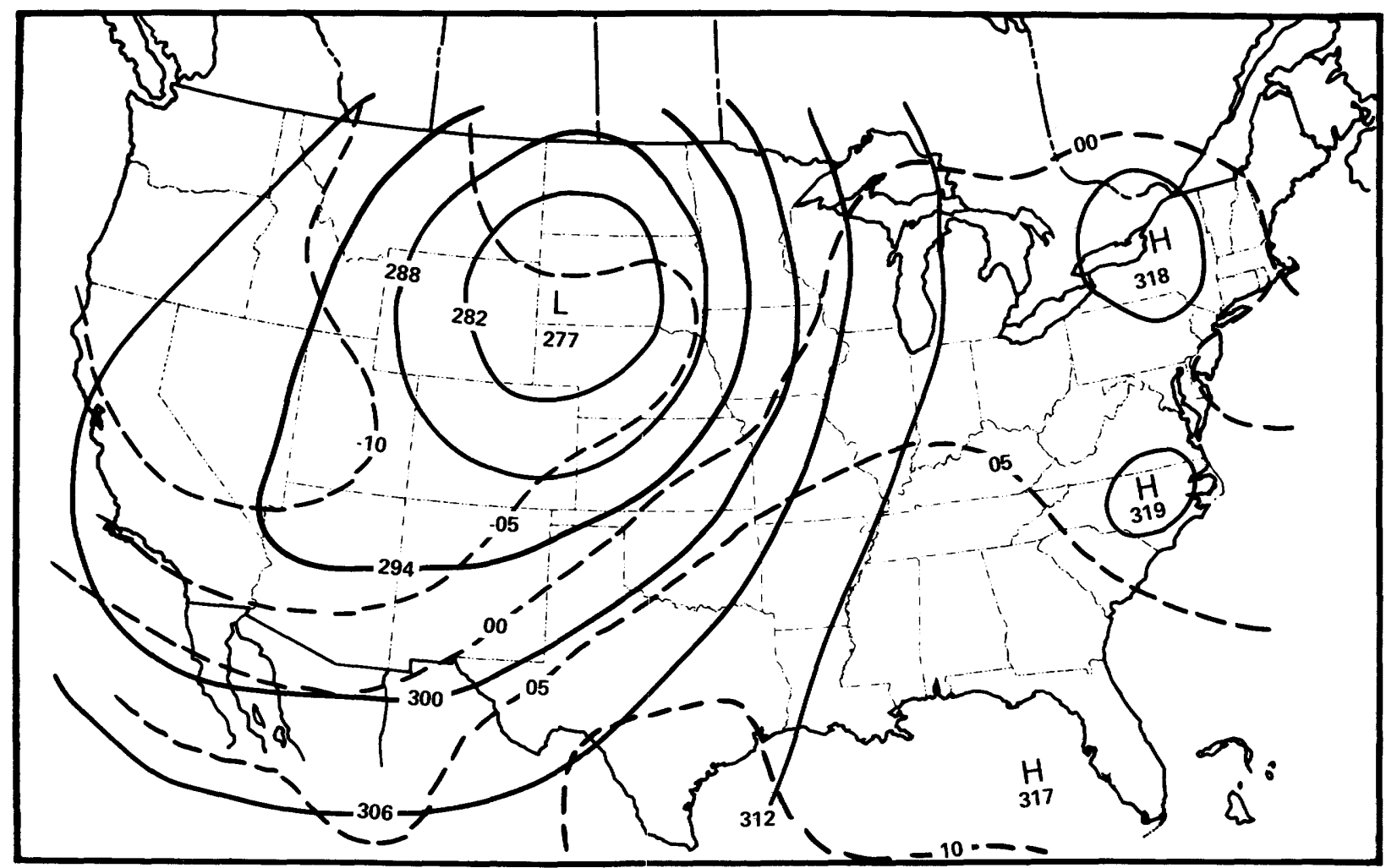

Figure 31.-700-mb chart for 6:00 a.m. c.s.t., April 20, 1973. 


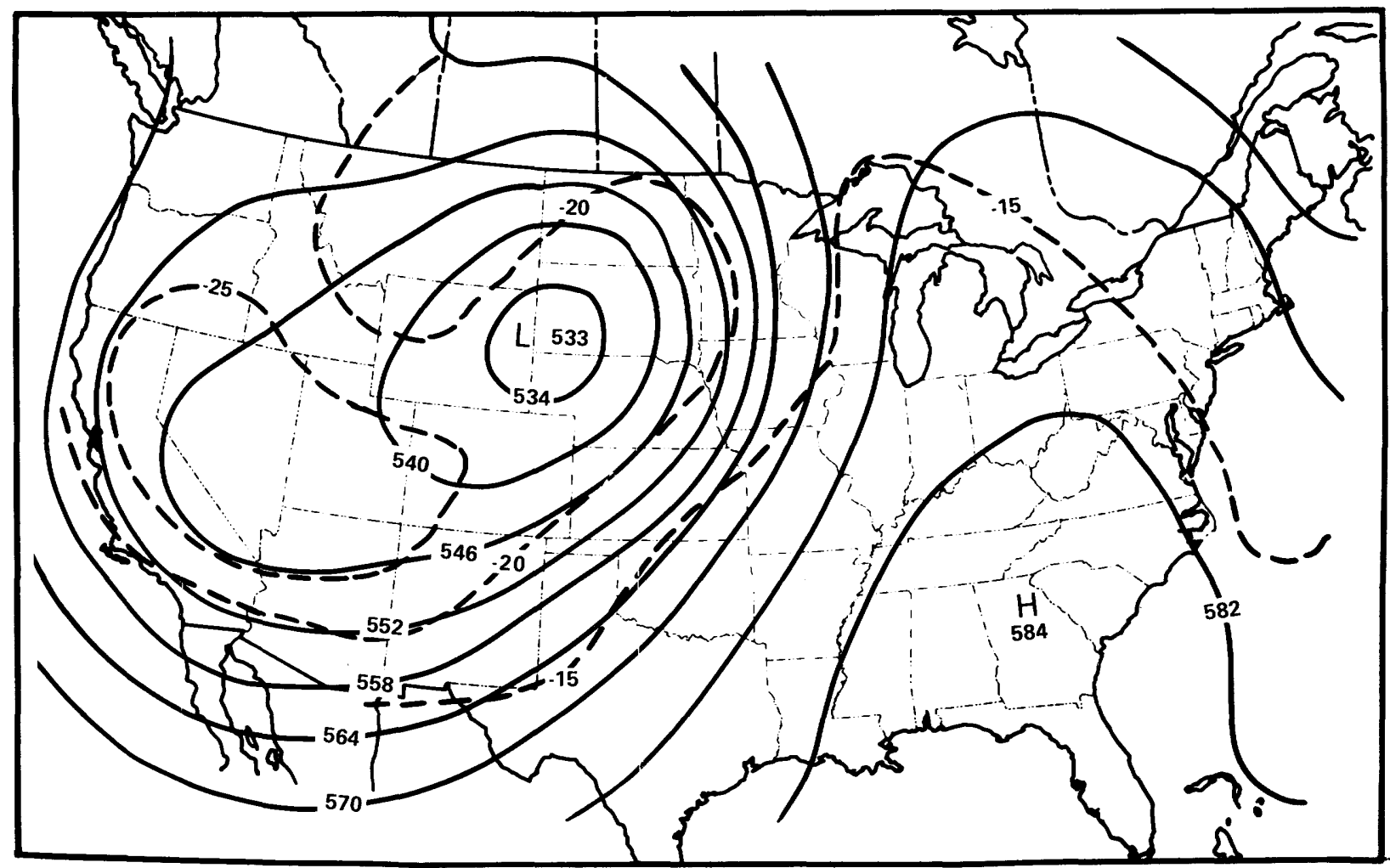

FIGURE 32.-500-mb chart for 6:00 a.m. c.s.t., April 20, 1973.

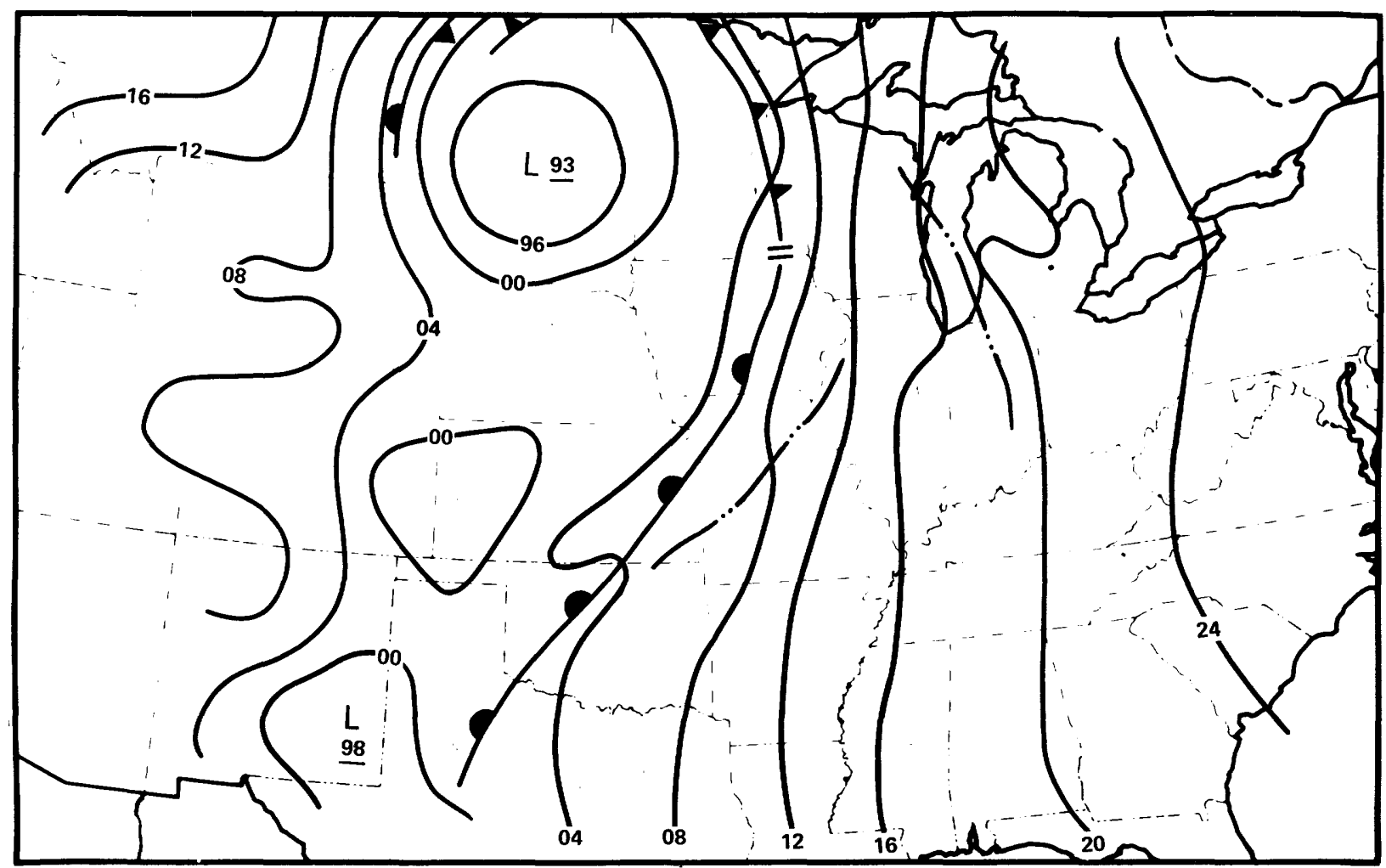

FIGURE 33.-Surface weather chart for 6:00 p.m. c.s.t., April 20, 1973. 


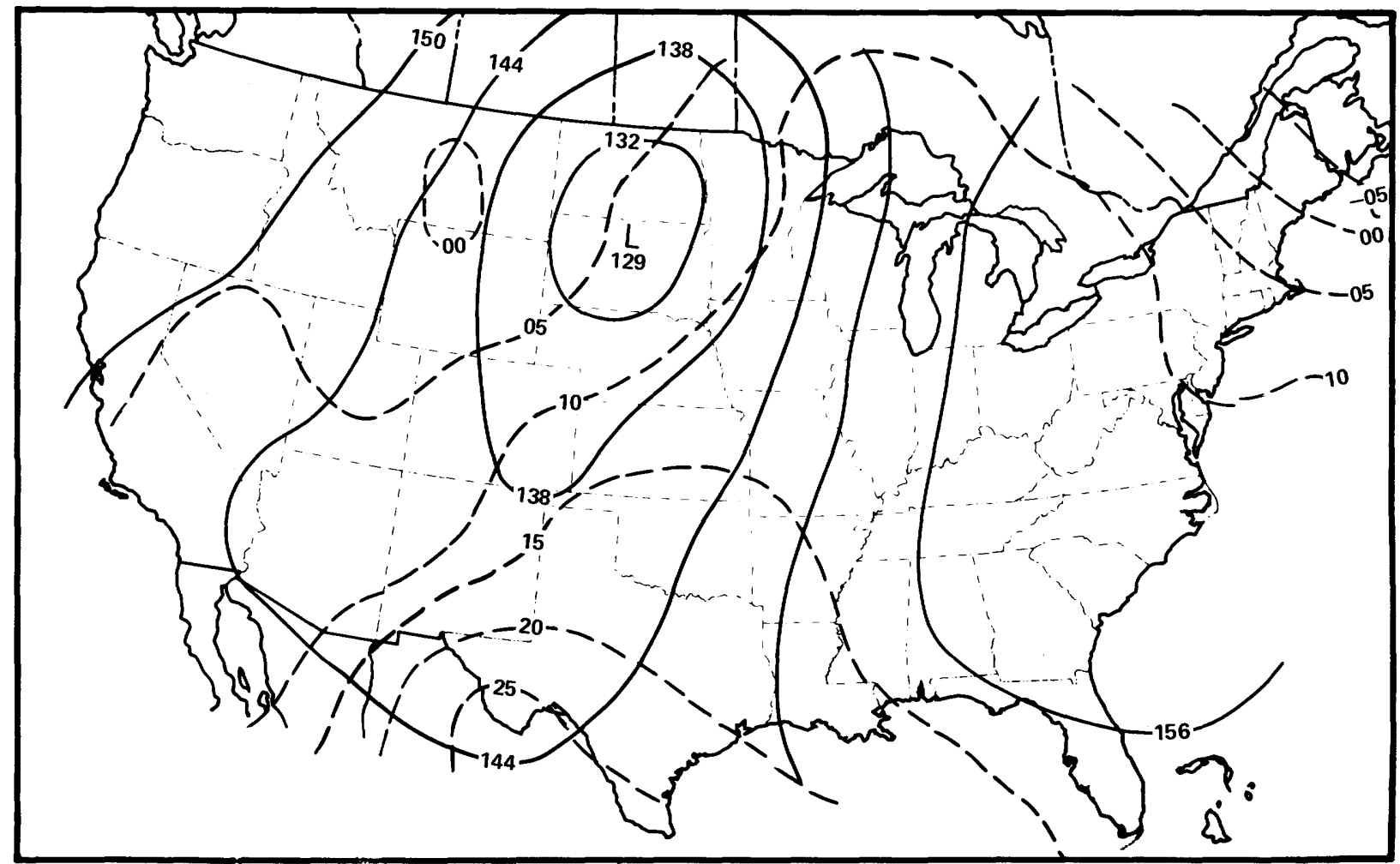

FiguRe 34.-850-mb chart for 6:00 p.m. c.s.t., April 20, 1973.

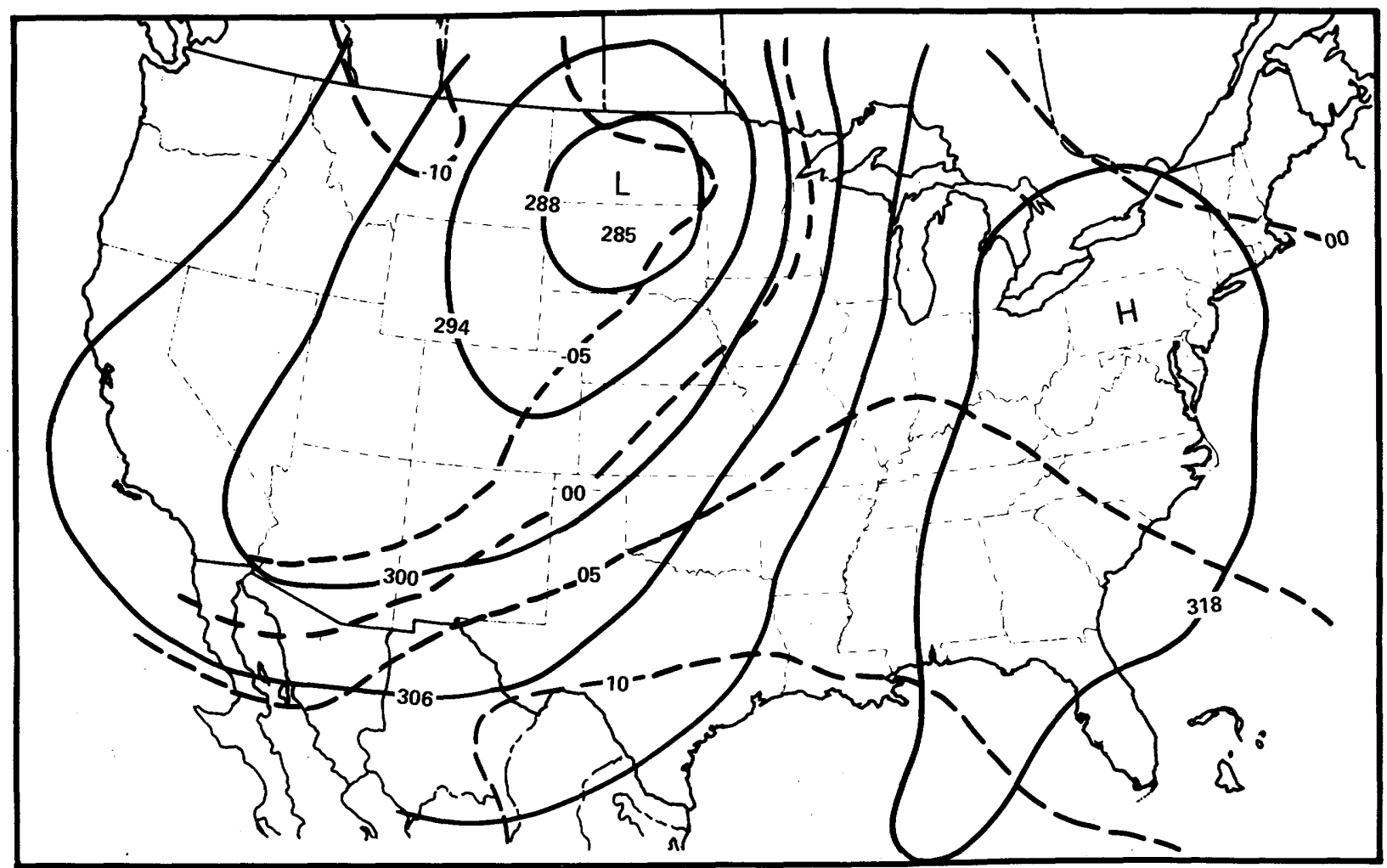

FIGURE 35.-700-mb chart for 6:00 p.m. c.s.t., April 20, 1973. 


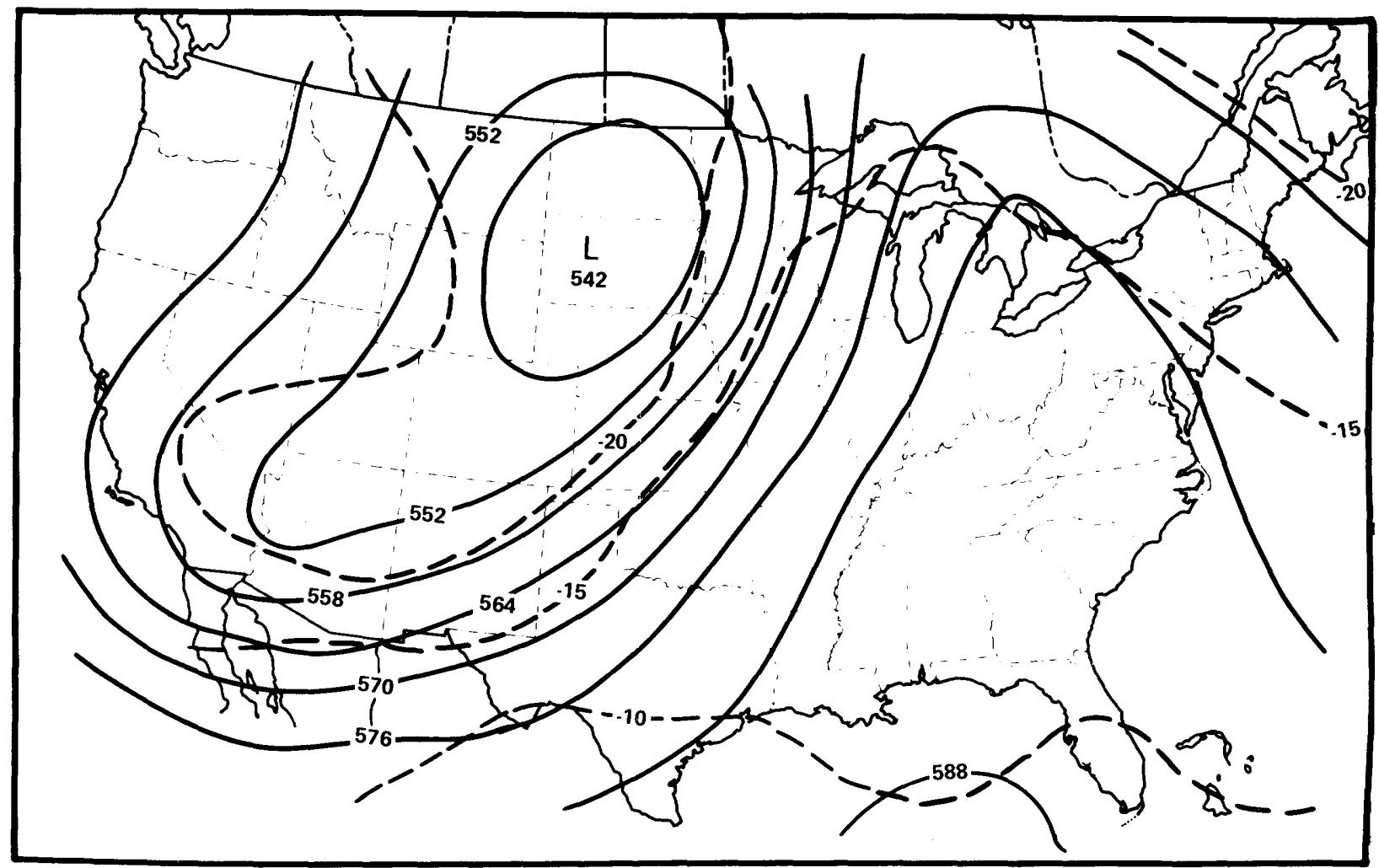

Figure 36.-500-mb chart for 6:00 p.m. c.s.t., April 20, 1973.

was $140 \times 10^{-5} \mathrm{mb} \mathrm{sec}^{-1}$. Figure 38 shows that the 24-hour trajectory of a parcel arriving at $850 \mathrm{mb}$ over Peoria, Ill., can be traced back to just off the Louisiana coast at the $878-\mathrm{mb}$ level. On figure 39, solid lines are used to depict all surface trajectories without regard to vertical displacements; also shown is the position of fronts on the surface. For Peoria, Ill., the surface air parcel originated in the southeastern corner of Alabama 24 hours earlier. It is evident that southerly flow was predominant in the basin through a deep layer prior to $6: 00 \mathrm{p} . \mathrm{m}$. c.s.t., April 20. At the surface, there was convergence along the front, and the flow was southeasterly. This gradually changed to south by west at $700 \mathrm{mb}$. For comparison, the 24-hour trajectories for $700-\mathrm{mb}$ at 6:00 p.m. c.s.t., April 5, are also shown in figure 40 . April 5 was a day of fine weather with no appreciable precipitation over the Mississippi basin. The contrast with figure 37 is illuminating.

It can be estimated from figure 39 and the mean sea surface temperature distribution for April 1973 (not shown) that the surface air parcels arriving in the Central Mississippi Valley in the evening of April 20 were located 2 days before off the east coast of Florida, where the water temperature was in excess of $75^{\circ} \mathrm{F}\left(23.9^{\circ} \mathrm{C}\right)$. Such a warm source region is necessary to support the observed high dew point of $62^{\circ} \mathrm{F}\left(16.7^{\circ} \mathrm{C}\right)$ characterizing the air flowing into northeastern Missouri. Lott and Myers (1956), in their study of the trajectories of a number of floodproducing storms in the Mississippi basin, also found that such storms are associated with an inflow of tropical air originating over a relatively warm sea surface.

The 12-hour net vertical displacements of air parcels reaching $700 \mathrm{mb}$ at 6:00 a.m. c.s.t., April 21, 1973 , are shown in figure 41 . Rising motions associated with the intrusion of the maritime tropical airmass prevailed in the whole Central Mississippi Valley, while sinking motion prevailed in the western Great Plains.

These trajectories were calculated by the operational National Weather Service Three-Dimensional Trajectory Model (Reap, 1972). Briefly, trajectories were traced backwards from a selected terminal point to origin point using the terminal point wind at the verification time, $t$, to arrive at a first-guess upwind position at a previous time, $t-\delta t$, or

$$
X_{2}(t-\delta t)=X_{1}(t)-U_{1}(t) \delta t
$$

$X_{2}(t-\delta t)$ is the first-guess upwind position along the $x$ axis; $U_{1}(t)$, the wind component at the terminal 


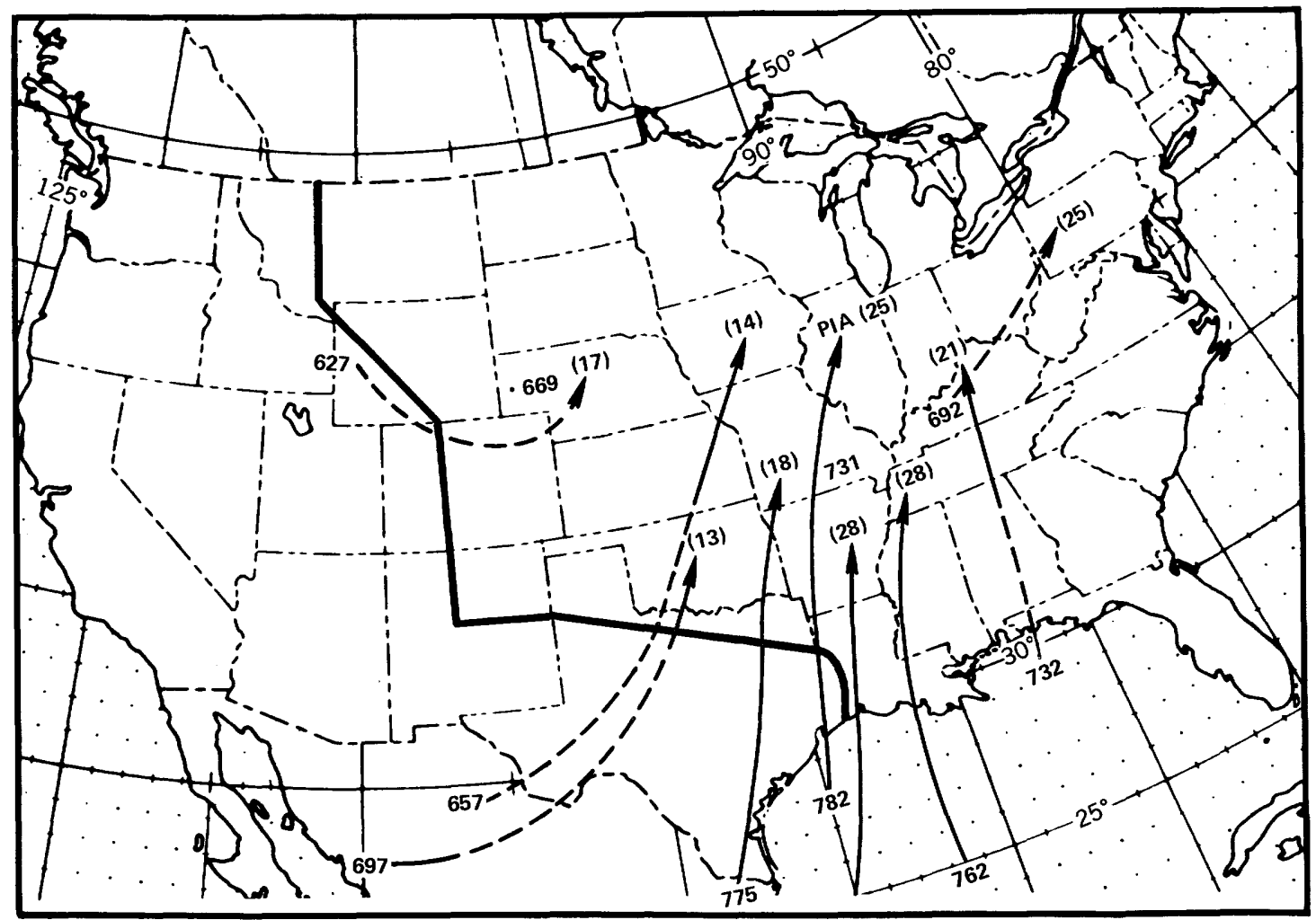

FIGURE 37.-Map showing 24-hour trajectories ending at 700-mb at 6:00 p.m. c.s.t., April 20, 1973.

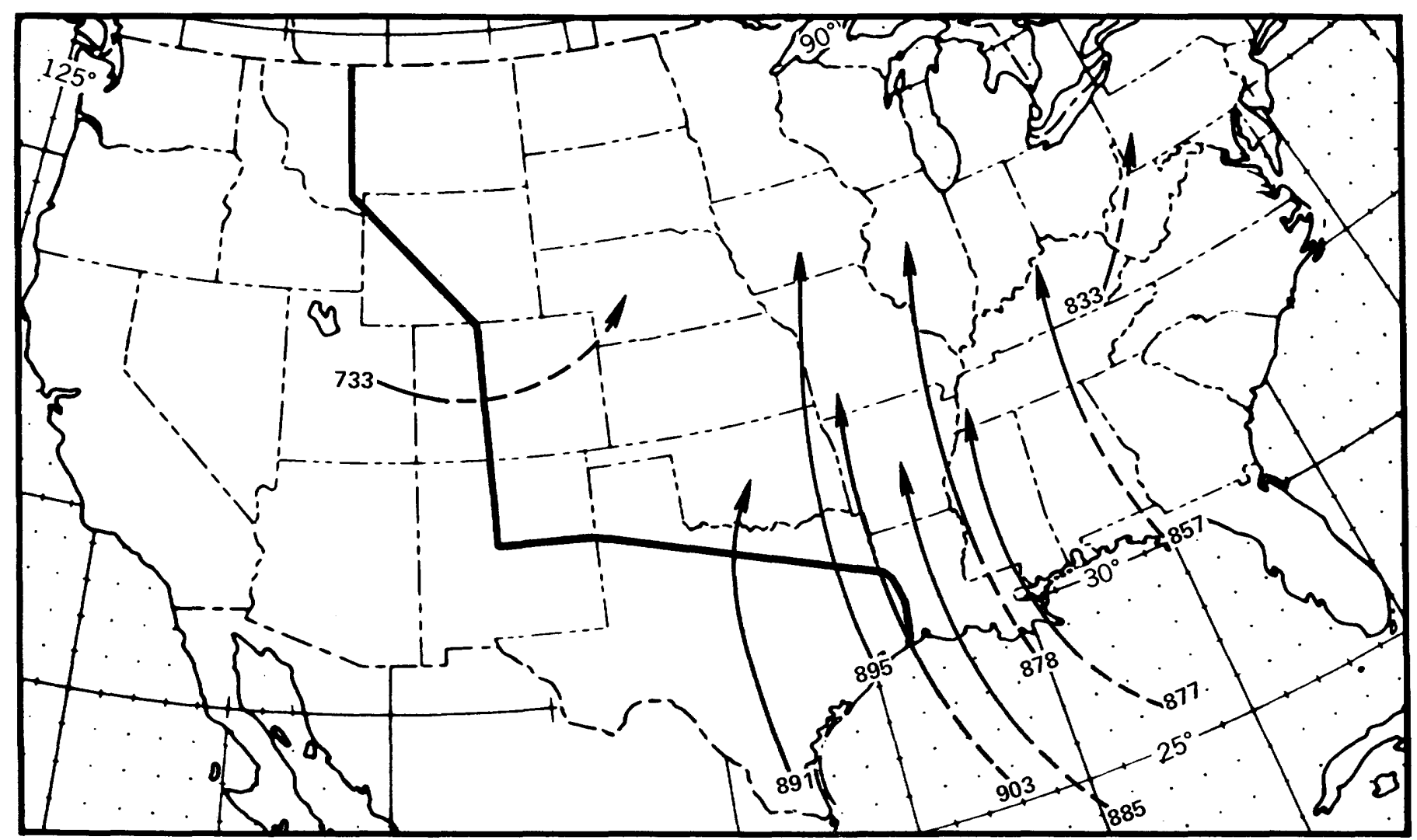

FIGURE 38.-Map showing 24-hour trajectories ending at 850-mb at 6:00 p.m. c.s.t., April 20, 1973. 


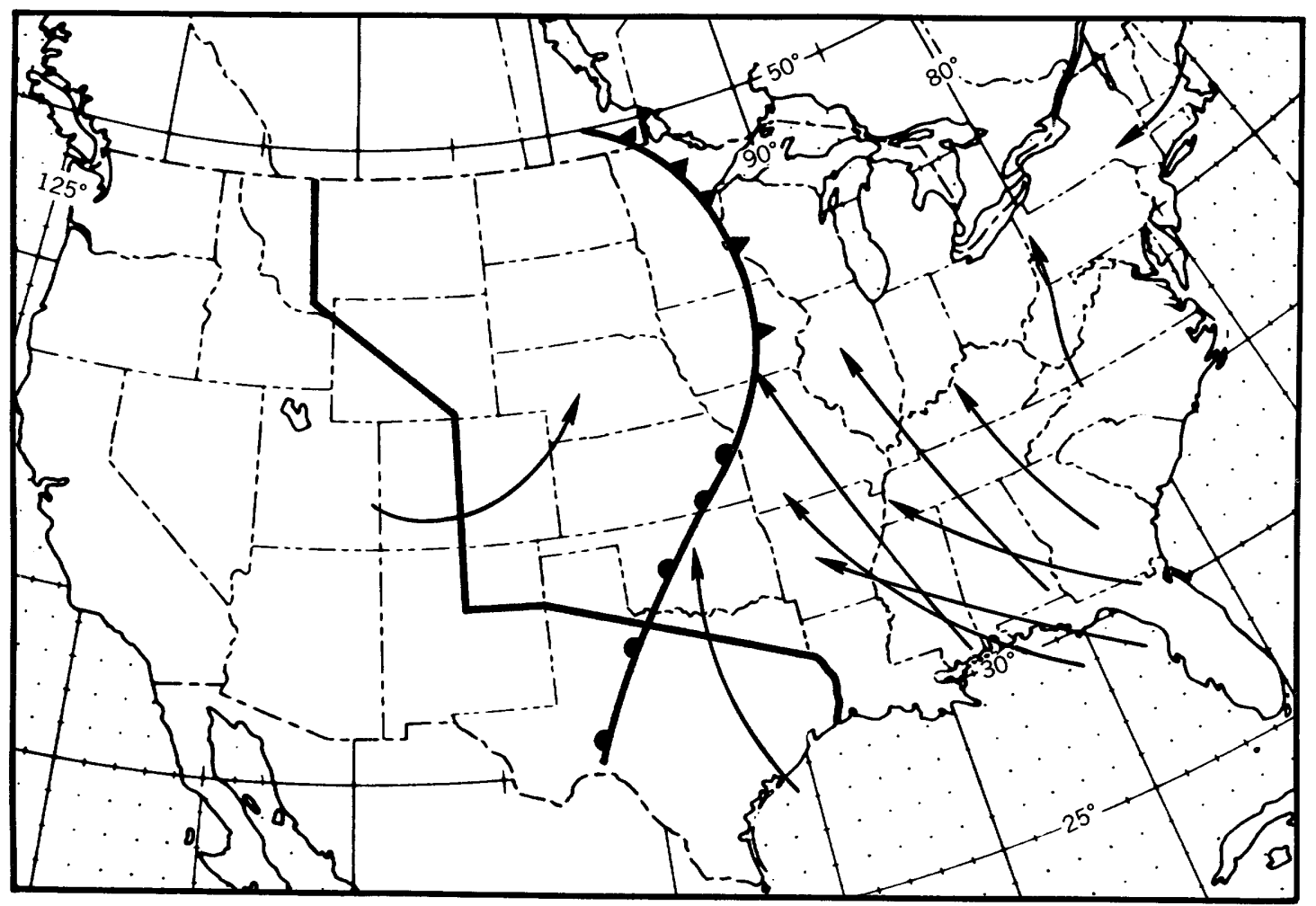

FIGURE 39.-Map showing 24-hour surface trajectories ending at 6:00 p.m. c.s.t., April 20, 1973.

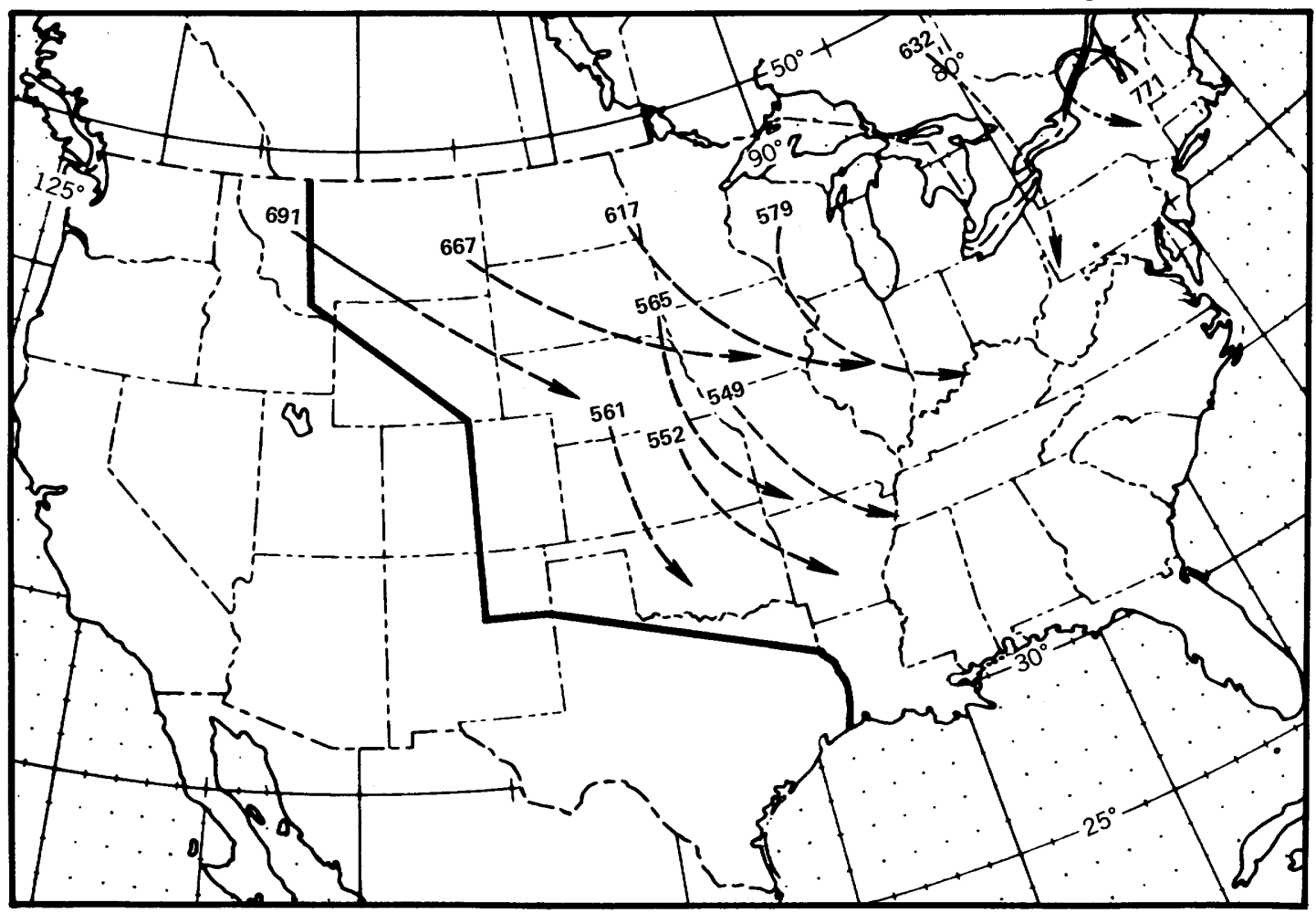

FIGURE 40.-Map showing 24-hour trajectories ending at 700-mb at 6:00 p.m. c.s.t., April 5, 1973. 
point, $X_{1}(t) ; \delta t$ equals 2 hours. An improved secondguess upwind location is given by

$$
X_{3}(t-\delta t)=X_{1}(t)-1 / 2\left[U_{2}(t-\delta t)+U_{1}(t)\right] \delta t
$$

where $U_{2}(t-\delta t)$ is the interpolated value of $U$ at the first guess point. Successive iteration of (3) is performed by replacing $U_{2}(t-\delta t)$ by $U_{3}(t-\delta t)$, and so forth, until the computed positions converge within prescribed limits. The winds used are forecast winds generated by the operational National Meteorological Center Six-Layer Primitive Equation Model. In essence, the trajectories are calculated through a process of "reverse advection."

\section{ASSOCIATED SYNOPTIC CONDITIONS}

A few pertinent synoptic conditions at 6:00 a.m. c.s.t., April 20, are summarized in figure 42 . The polar jet axis $(J)$ and the low-level jet axis $(L J)$ were obtained from $300-\mathrm{mb}$ and $850-\mathrm{mb}$ isotach analyses, respectively. The polar jet (low-level jet) represented windspeeds of 70-110 (35-60) knots at the 300- (850-) mb level. The extent of the moist air tongue was inferred from the surface dew-point temperature and the $850-\mathrm{mb}$ dew-point depression and adjusted by the average relative humidity from surface to $500 \mathrm{mb}$. A dry layer was in the middle troposphere, as shown by the 6:00 a.m. c.s.t., April

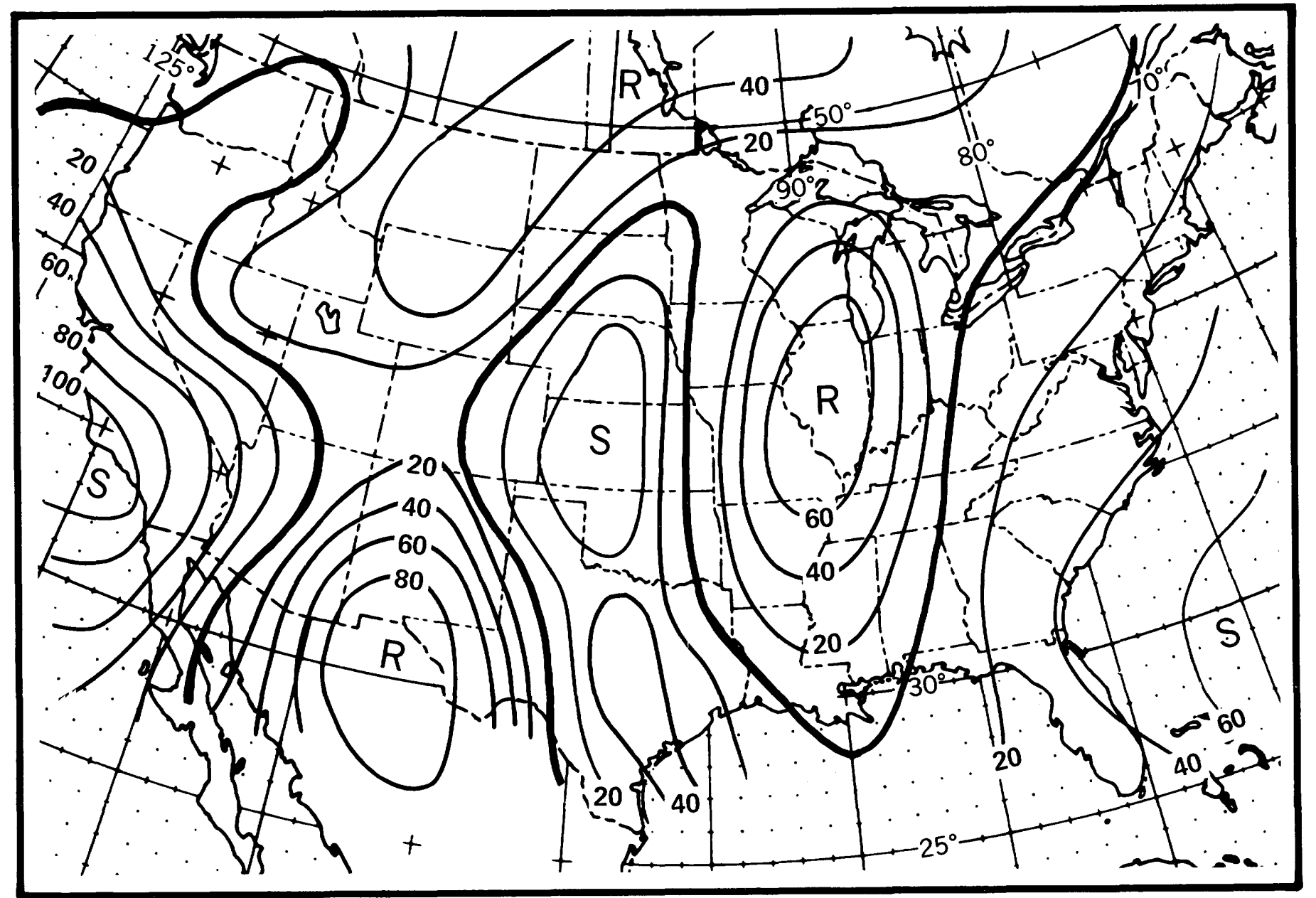

Figure 41.-Map showing 12-hour net vertical displacement of air parcels reaching 700-mb at 6:00 a.m. c.s.t., April 21, 1973. 


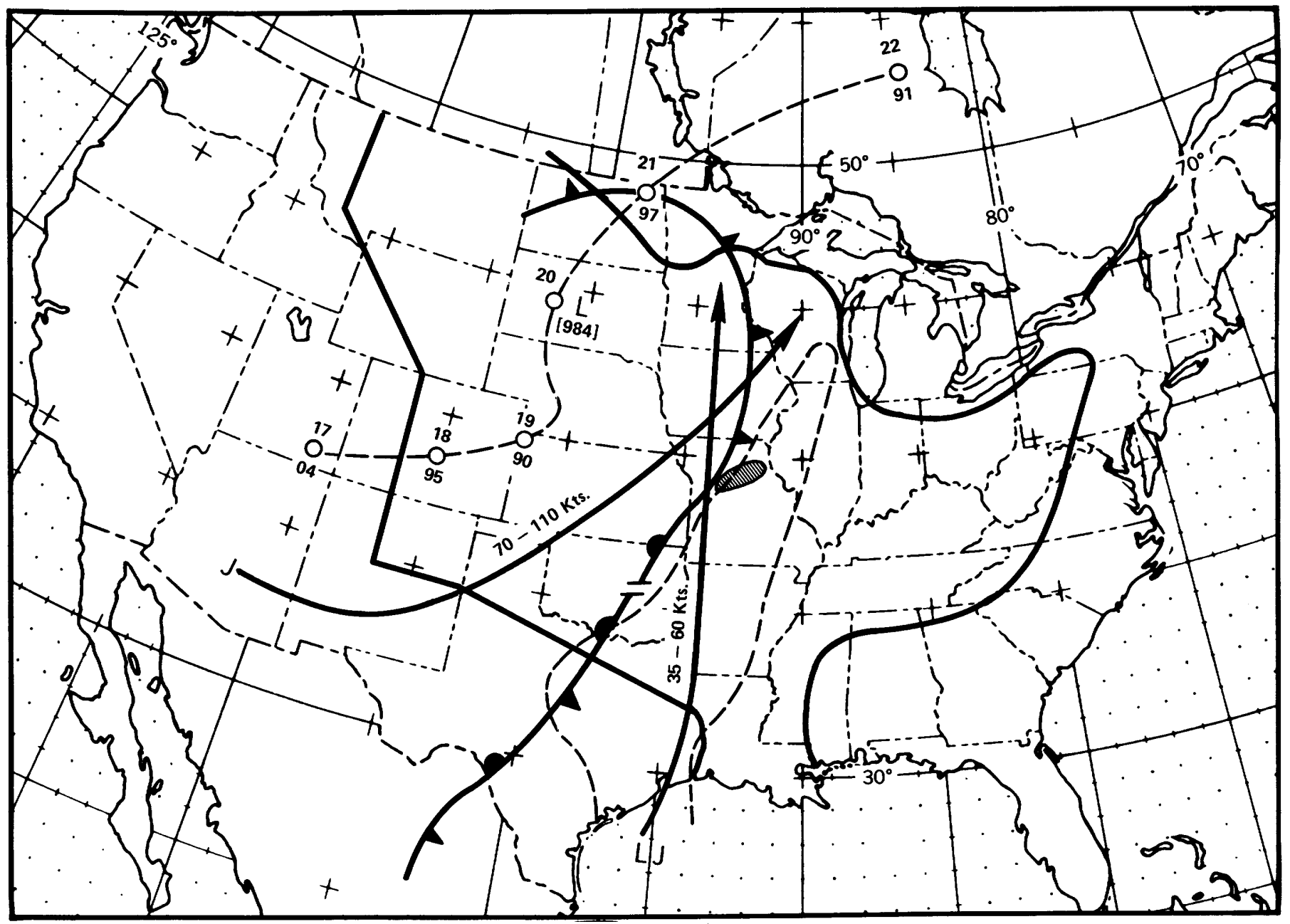

FIGURE 42.-Some synoptic features at 6:00 a.m. c.s.t., April 20, 1973, before the inception of a small line in northern Missouri.

20, sounding at Little Rock, Ark. (fig. 44). The wind there veered with height and reached 53 knots $(98$ $\mathrm{km} / \mathrm{hr}$ ) at $500 \mathrm{mb}$. It is known that severe storms are most likely to break out near the intersection of the projections of the two jet axes and near the west side of the moist air tongue. A squall line developed over northern Missouri 9 hours later. Heavy rainfall around Moberly, Mo., began about $7: 00$ p.m. c.s.t.

Analyses for precipitable water and lifted index valid for 6:00 a.m. c.s.t., April 21, are shown in figure 43 . It can be seen that the basin was covered by relatively moist and unstable air with a lifted index less than four.

The 12-hour persisting dew-point temperature ending 6:00 a.m. c.s.t., April 21, at Columbia, Mo., was $62^{\circ} \mathrm{F}\left(16.6^{\circ} \mathrm{C}\right)$ and should represent to a good measure the low-level moisture inflow into the storm because of the prevailing southerly wind. For comparison, the maximum 12-hour persisting dew-point temperature of record there in April was $69^{\circ} \mathrm{F}$ $\left(18.8^{\circ} \mathrm{C}\right)$ (Environmental Data Service, 1968).

\section{PROXIMITY SOUNDINGS RELATED TO THE STORM}

The sounding for Little Rock, Ark., at 6:00 a.m. c.s.t., April 20, 1973 (fig. 44), showed an almost saturated surface layer extending to $850 \mathrm{mb}$, or about $1.5 \mathrm{~km}$. Above $850 \mathrm{mb}$, the air became slightly less moist; then, it became very dry about $729 \mathrm{mb}$. This sounding had a Showalter Index of -6 , indicating strong local static instability. Little Rock, Ark., was located in the moist tongue at that time (see fig. 42). The presence of an overlying dry layer is quite common during the stage of tropical maritime airmass intrusion into the basin and before widespread precipitation develops.

A station in the rawinsonde network reasonably close to the precipitation center at Moberly, Mo., is Peoria, Ill., 180 miles $(290 \mathrm{~km})$ to the northeast. 


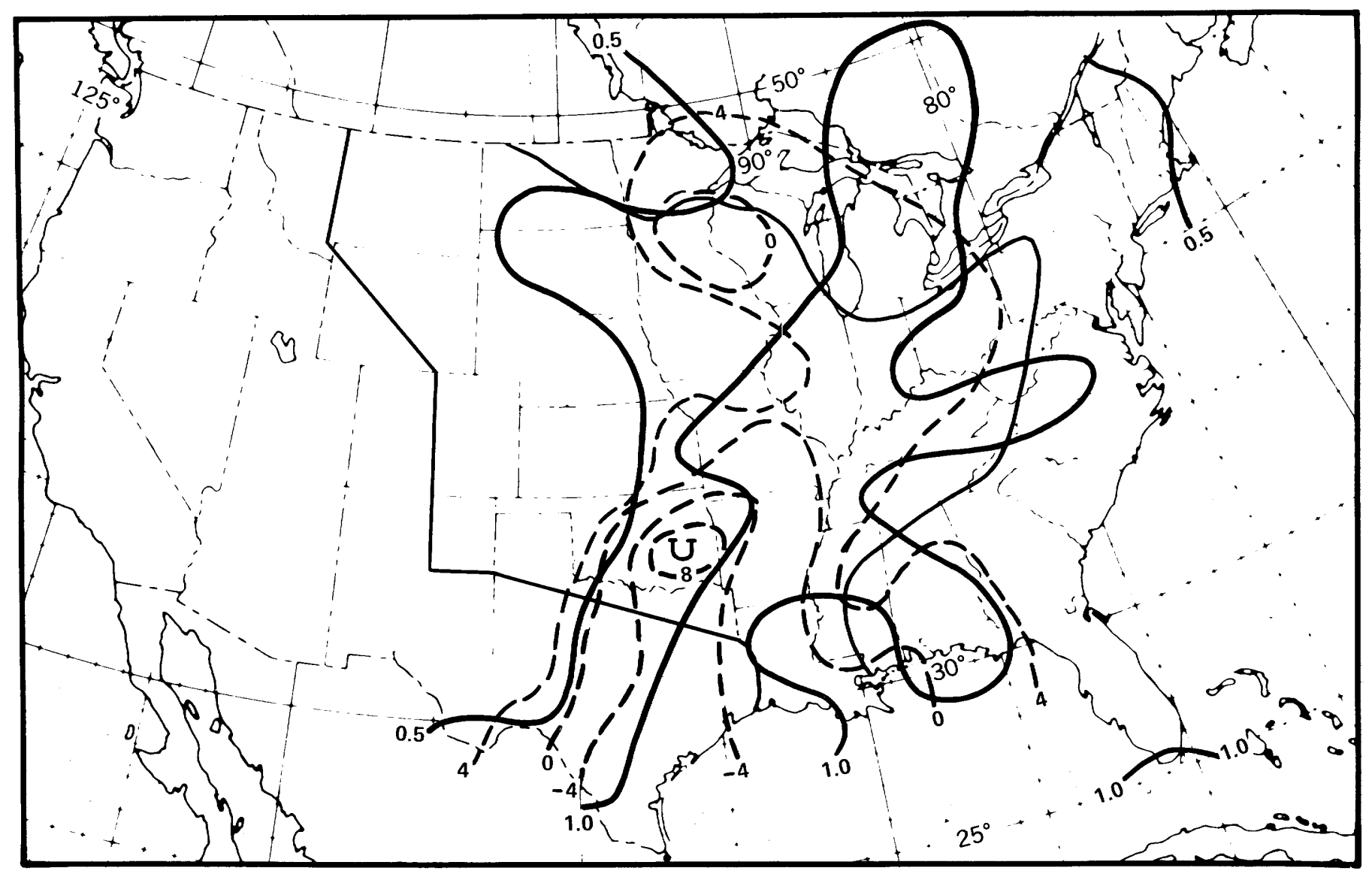

FiguRE 43.-Analysis of precipitable water from surface to $500 \mathrm{mb}$ and lifted index for 6:00 a.m., c.s.t., April 21 , 1973.

The sounding for Peoria at 6:00 p.m., c.s.t., April 20, is shown in figure 45. It shows a potentially unstable and moist surface layer extending to $850 \mathrm{mb}$, with an average relative humidity of 80 percent. This was capped by a relatively shallow stratus deck about 500 -m thick. Above this lay a dry layer about 1,700 $\mathrm{m}$ in depth. Above the dry layer were cumulonimbus storm clouds extending from $650 \mathrm{mb}$ up to $300 \mathrm{mb}$ (the sounding was plotted up to $400 \mathrm{mb}$ ), approximately through a depth of $5.5 \mathrm{~km}$. Total precipitable water was evaluated to be $1.44 \mathrm{in}$. $(37 \mathrm{~mm}$ ) compared to a corresponding climatological mean for April of 0.556 in. $(14 \mathrm{~mm})$ with standard deviation 0.292 in. $(7 \mathrm{~mm})$. In considering the precipitation potential of storm clouds, the relevant parameters are cloud thickness and temperatures at cloud base and top. These factors, as revealed by figure 45 , provide favorable conditions for precipitation to occur if coupled with a convergent motion field at low levels. The cloud-base temperature of $-2^{\circ} \mathrm{C}$ still allows an adequate in-cloud liquid water content. The considerable cloud depth of $5.5 \mathrm{~km}$ furnishes a convenient setting for collection processes to proceed. A cloud top at a temperature of $-40.1^{\circ} \mathrm{C}$ insures the presence of ice crystals there. At 500 (450) $\mathrm{mb}$, where the cloud temperature was $-11^{\circ} \mathrm{C}\left(-18^{\circ} \mathrm{C}\right)$, saturation with respect to water corresponded to a supersaturation of 11 (15) percent over ice.

The number of atmospheric ice nuclei active per unit volume could be expressed as approximately proportional to exp $(\Delta T)$; here, $\Delta T$ is the degree of supercooling. At a temperature of $-18^{\circ} \mathrm{C}$ at the $450-\mathrm{mb}$ level of this sounding, a reasonable estimate was that, on the average, active ice nuclei were present at a concentration of one in several tens of litres of atmosphere. With the existence of an environmental supersaturation of 15 percent, ice crystals would begin to be nucleated through the three-phase process. Once these ice particles reached a threshold size, accretion of supercooled water droplets through riming and aggregation of other ice crystals could proceed.

An actual cloud cover photograph for 12:00 m. (1800 G.m.t.), April 20, obtained by NOAA satellite, is shown in figure 46. The cloud band extending over the whole Mississippi stem generally coincided with 


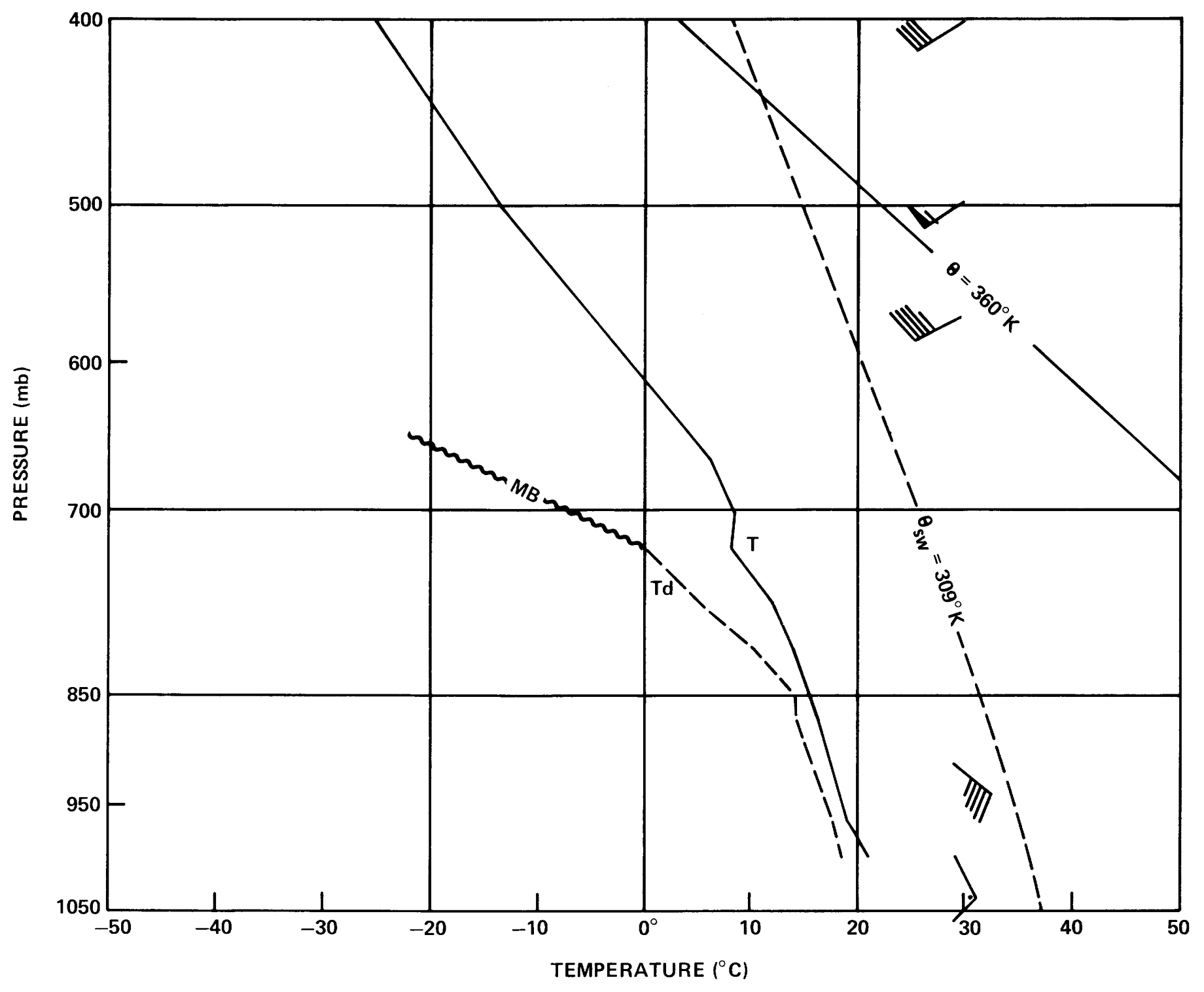

Figure 44.-Sounding for Little Rock, Ark., at 6:00 a.m., c.s.t., April 20, 1973.

regions of frontal activity, while the clear area to the west was associated with subsiding cold air mass.

\section{POLAR JET AXIS AND PRECIPITATION CENTER}

The relationship between polar jet stream and precipitation pattern has long been a topic of interest to many investigators. Smith and Younkin (1972) proposed a composite model relating the progression of the polar jet stream to areas of heavy precipitation in Central United States. They found that a valid model was the "digging" of the jet as it progressed eastward, and the most common area for heaviest rainfall was situated with its western edge about 250 n.mi. (nautical miles) $(463 \mathrm{~km})$ in advance of the jet position at the beginning of the 12-hour rainfall measurement period. In our study of the April 1922 storm, the precipitation center in northern Missouri, together with the jet axes obtained from 300 $\mathrm{mb}$ isotach analysis, is shown in figure 47 . The precipitation was accumulated in a 12-hour period from 6:00 p.m. c.s.t., April 20, to 6:00 a.m. c.s.t., April 21, 1973. The corresponding jet axis at the beginning of this period was marked " $b$ " in figure 47 . The western edge of the 4-in. $(102 \mathrm{~mm})$ isohyetal center was about 280 miles $(450 \mathrm{~km})$ ahead of axis b. The jet axis, instead of progressing as envisioned by Smith and Younkin's model, actually oscillated and stayed within a narrow belt from Texas to Iowa during a 24-hour period. 


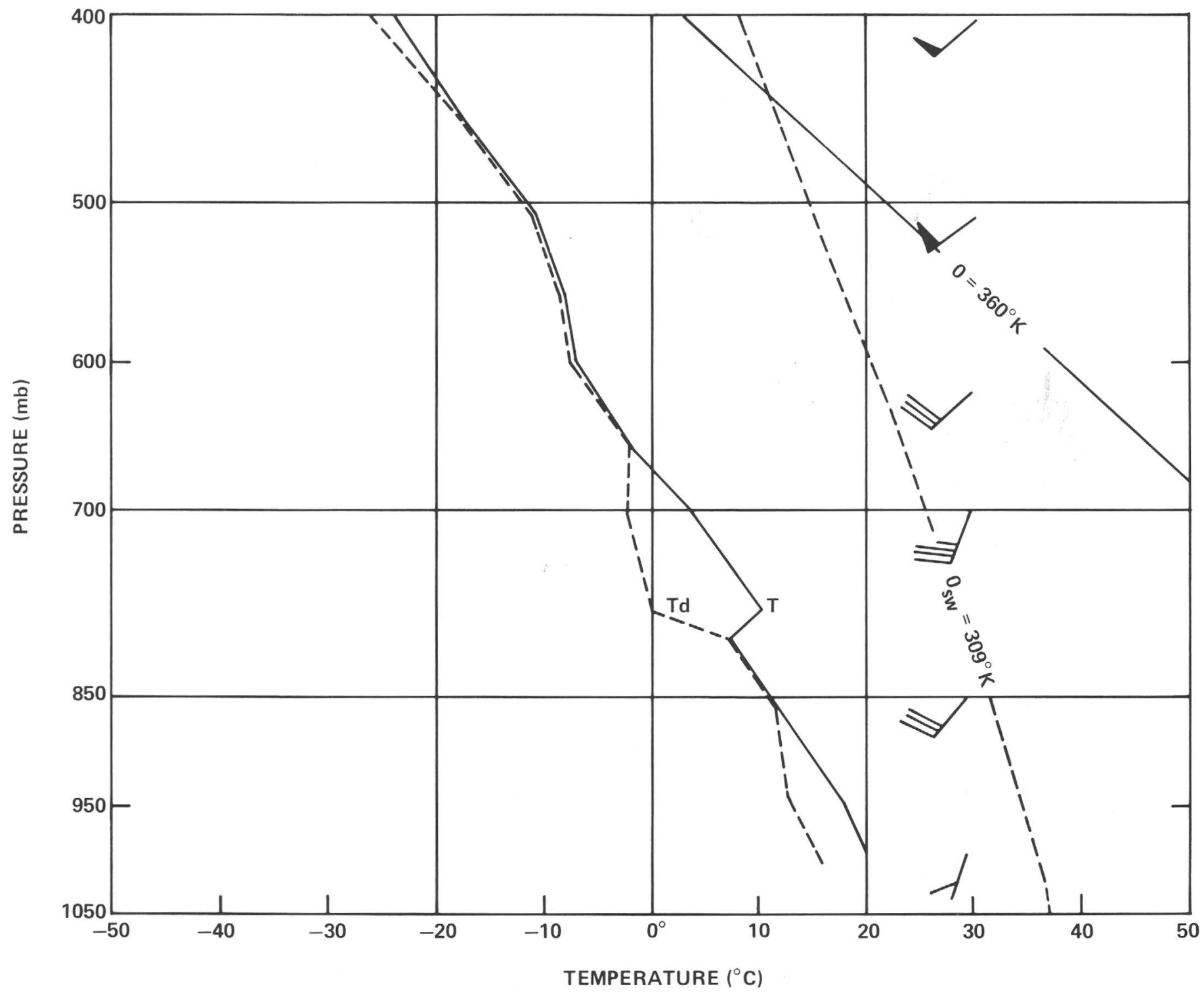

Figure 45.-Sounding for Peoria, Ill., at 6:00 p.m., c.s.t., April 20, 1973.

The presence of the jet axis implies the existence of a region in the vicinity with large vertical wind shear and high baroclinicity. A quasistationary jet, in turn, means that this region is subjected to persistent large upper tropospheric divergence and strong midtropospheric vertical motion and therefore is favorable for cyclone development and consequent precipitation.

\section{PRECIPITATION CENTERED AT MOBERLY, MO., AND IN OTHER LOCATIONS}

Isohyetal analysis for the precipitation center in northern Missouri is shown in figure 48. Mass rainfall curves for Moberly Radio KWIX and three other recording gages are shown in figure 49 . The isohyetal pattern had a northeast-southwest orientation approximately parallel to that of the quasistationary squall line and the front. Recorder traces at Higbee $7 \mathrm{~S}$, which is $15 \mathrm{mi}(24 \mathrm{~km})$ to the southwest of Moberly, shows that the most intense rate there was $1.75 \mathrm{in.}(44 \mathrm{~mm})$ in 30 minutes, between $10: 00$ and $10: 30$ p.m. c.s.t. on April 20. Across the pattern, precipitation amounts dropped off sharply. Columbia, Mo., located $30 \mathrm{mi}(48 \mathrm{~km})$ south of Moberly, received just $0.15 \mathrm{in} .(4 \mathrm{~mm})$ of rain in the 12-hour period ending 6:00 a.m. c.s.t., April 21.

Between 8:00 p.m. c.s.t., April 20, and 2:00 a.m. c.s.t., April 21, Moberly Radio KWIX received 7.1 in. $(180 \mathrm{~mm})$ of rain at an average rate of $1.2 \mathrm{in.}$ (30 $\mathrm{mm}$ ) per hour. Because the lifetime of an individual 


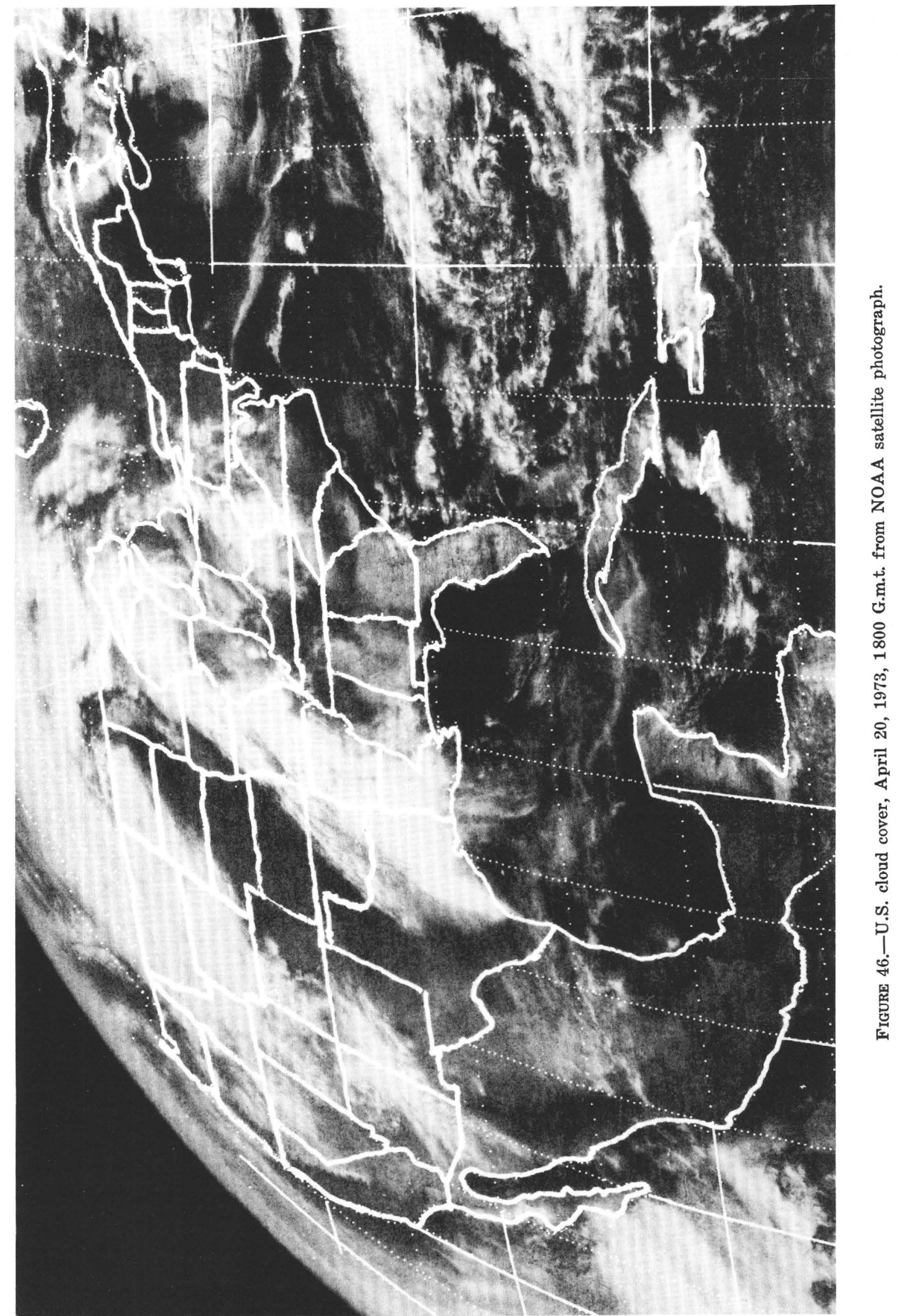




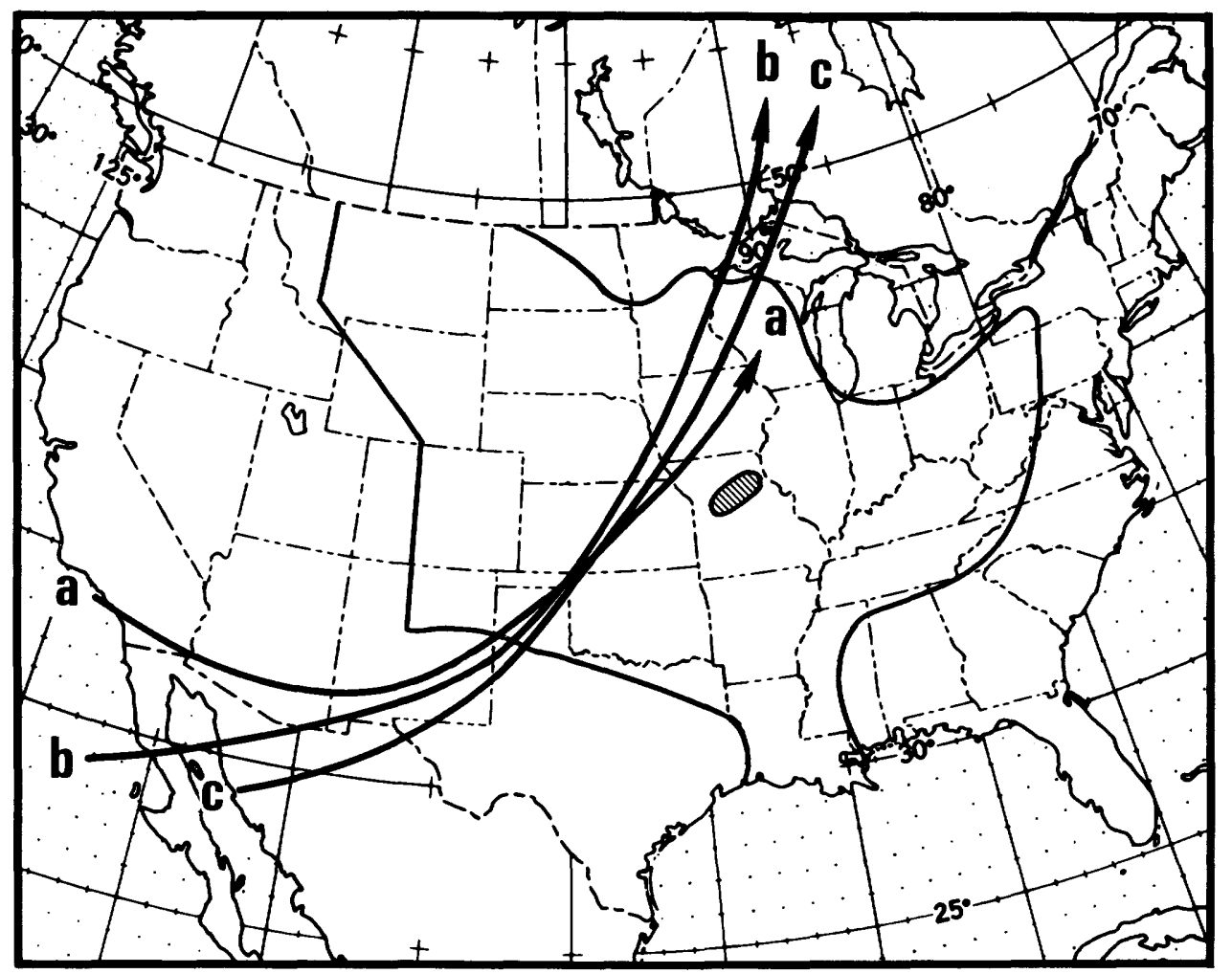

Figure 47.-Position of jet axis at (a) 6:00 a.m. c.s.t., April 20, 1973, (b) 6:00 p.m., April 20, 1973, (c) 6:00 a.m. c.s.t., April 21, 1973. Precipitation center in northern Missouri with more than 4 inches in 12 hours ending 6:00 a.m. c.s.t., April 21, 1973, also shown.

convective cell is on the order of half an hour, to maintain such a persistent rain shower for 6 hours, new cells must be generated as the old ones decay. The spreading out of the cold and gusty downdraft from the raining mature cell had the effect of a local cold front, lifting incoming warm air from the south to condensation and releasing its potential instability to trigger further vertical growth into a full-blown new cell.

A complete depth-area-duration analysis for this storm has not been made at this time. A comparison between the observed point rainfall at Moberly Radio KWIX and the maximum average depths of rainfalls for $10 \mathrm{mi}^{2}\left(26 \mathrm{~km}^{2}\right)$ areas and various durations for past significant storms over an area within $200 \mathrm{mi}$. (322 km) from Moberly, Mo., however, is presented (table 5). A significant storm is defined here as one with the 6-hour maximum average depth of rainfall over $10 \mathrm{mi}^{2}\left(26 \mathrm{~km}^{2}\right)$ exceeding $7 \mathrm{in}$. $(178 \mathrm{~mm})$. These were compiled from historical files of the U.S. Army Corps of Engineers together with National Weather Service update data. All the storms listed were extratropical cyclones not associated with hurricane passage. It is evident that the amount of rainfall of the Moberly storm was frequently exceeded in comparison, but it is most interesting to observe that it is exceptional for a storm to occur there in the spring season with such magnitude.

A comparison of this storm with the Illinois model 12-hour storm is presented in table 6 . This is justified on the grounds that Missouri and Illinois are in the same general climatic regime. The Illinois model storm is a statistical composite for the characteristics of 12-hour periods of maximum rainfall in the 10 most severe rainstorms occurring in Illinois mostly in the summer during a 10-year period (Huff and Changnon, 1964). For the Moberly storm, its 12hour features from 7:00 p.m. c.s.t., April 20, to 7:00 a.m. c.s.t., April 21, 1973, were used in this comparison. The winds aloft associated with the Moberly storm were more southerly and stronger. The higher positive departure of the dew point is a reflection of the greater variability of dew points in the spring season as compared with the predominantly summer season data of the Illinois storm. The synoptic scale dew-point departure and the inflow wind field measure the water vapor convergence into the storm and 
will affect the amount of precipitation. But precipitation amount is also dependent on the temporal and spatial distribution of the mesoscale storm vertical velocities which are not routinely measured. During the life cycle of the Moberly storm, the transient updraft profile could be such that a considerable proportion of the condensed liquid water was carried to the cloud-top divergence field and eventually reevaporated without further participation in the precipitation process. This offers a plausible explanation for its apparent lower precipitation efficiency compared with that of the Illinois model storm. It is interesting to note, however, that for both cases maximum rain occurred around midnight, when diurnal heating effect was completely overshadowed by storm dynamics.

Moberly, Mo., with an elevation of $850 \mathrm{ft}(259 \mathrm{~m})$ above mean sea level, is situated on a gentle ridge that separates the drainage basins between the Mississippi and Missouri Rivers. The surrounding regions are relatively flat. The steepest terrain gradient is towards the southeast, where the elevation changes at an average slope of less than 1/1,000. Hence, it seems unlikely that orography could have had any significant effect in the distribution of storm precipitation in this case.

In addition to the heavy rain in northern Missouri, the storm also brought widespread heavy precipitation over the basin, as can be verified by the isohyetal maps (pls. 1-3). The northern Plains region,

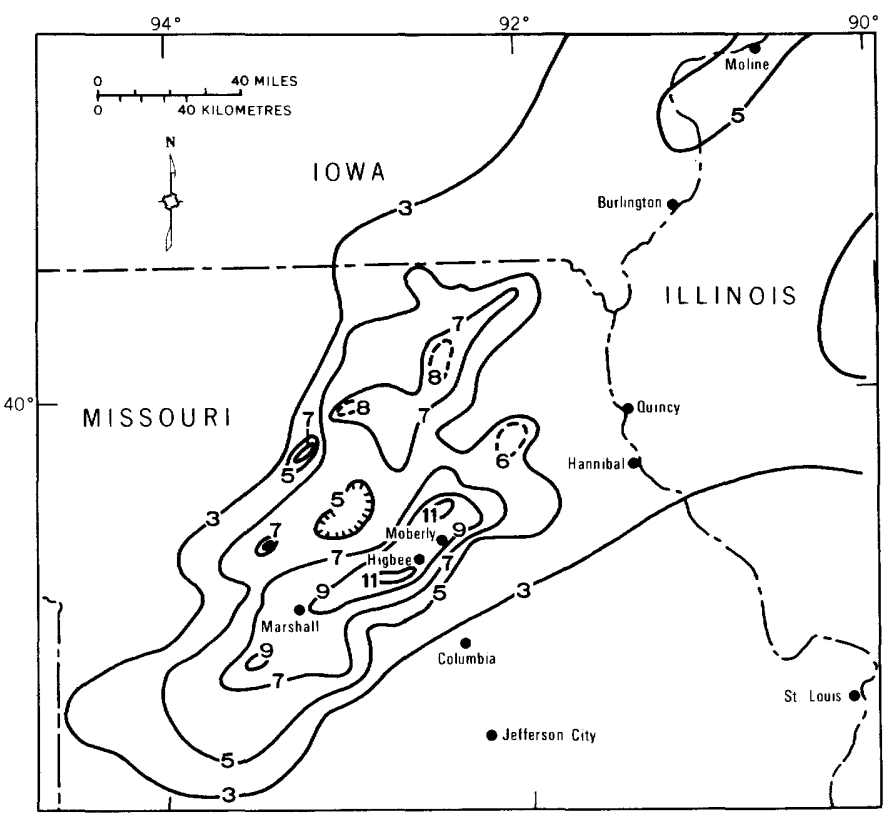

FigURE 48.-Total storm rainfall April 19-22, 1973, near storm center at Moberly, Mo., showing area with 2 inches or more rain.

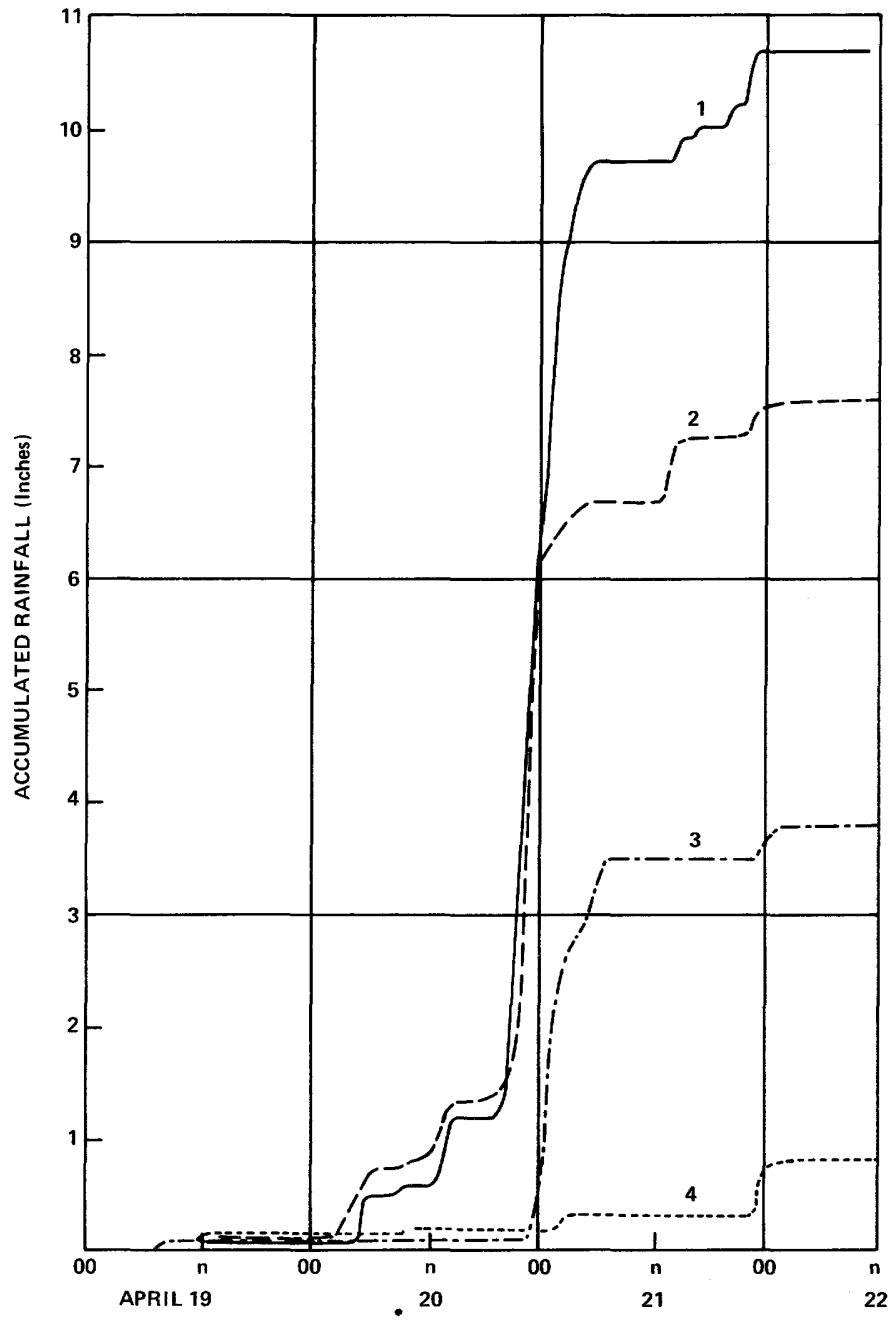

Frgure 49.-Mass curves of rainfall for (1) Moberly Radio KWIX, (2) Higbee 7S, (3) Hannibal Waterworks, and (4) Columbia WSO for April 19-22, 1973.

which was generally under the cold airmass, received heavy rain from April 19 to April 21; Shonkin $7 \mathrm{~S}$, Mont. $\left(47^{\circ} 32^{\prime}\right.$ N., $110^{\circ} 35^{\prime} \mathrm{W}$.), had 3.10 in. $(79 \mathrm{~mm})$ of rain on April 20; Bowman 11SE, N.D. $\left(46^{\circ} 02^{\prime}\right.$ N., $103^{\circ} 18^{\prime}$ W. $)$, had 1.78 in. $(45 \mathrm{~mm})$ on April 19; Faith $2 \mathrm{~W}$, S. Dak. $\left(45^{\circ} 02^{\prime}\right.$ N., $102^{\circ} 05^{\prime}$ W.), had 2.24 in. $(57 \mathrm{~mm}$ ) on April 19. These three amounts represent the greatest 1-day precipitation in April 1973 for Montana, North Dakota, and South Dakota, respectively. However, the heaviest precipitation occurred in the warm sector region under the intruding tropical maritime airmass. For example, Clinton $2 \mathrm{~N}$, Wis. $\left(42^{\circ} 37^{\prime}\right.$ N., $88^{\circ} 52^{\prime}$ W. $)$, recorded 4.39 in. $(112 \mathrm{~mm})$ of rain on April 21. Keosauque, Iowa $\left(40^{\circ} 44^{\prime} \mathrm{N} ., 91^{\circ} 58^{\prime} \mathrm{W}\right.$.), had 4.20 in. (107 mm) on the same day. St. Charles, Ark. (34 $23^{\prime}$ N., $91^{\circ} 08^{\prime}$ W.), had 9.18 in. $(23 \mathrm{~cm})$ on April 20; Hickman 1E, Ky. $\left(36^{\circ} 34^{\prime}\right.$ N., $89^{\circ} 10^{\prime}$ W.), had 5.22 in. (133 mm) 
TABLE 5.-Comparison of past significant storm rainfalls ${ }^{1}$ within a 200 mile radius of Moberly, Mo., ${ }^{2}$ with the observed rainfall at Moberly Radio KWIX in the storm of April 19-22, 1973

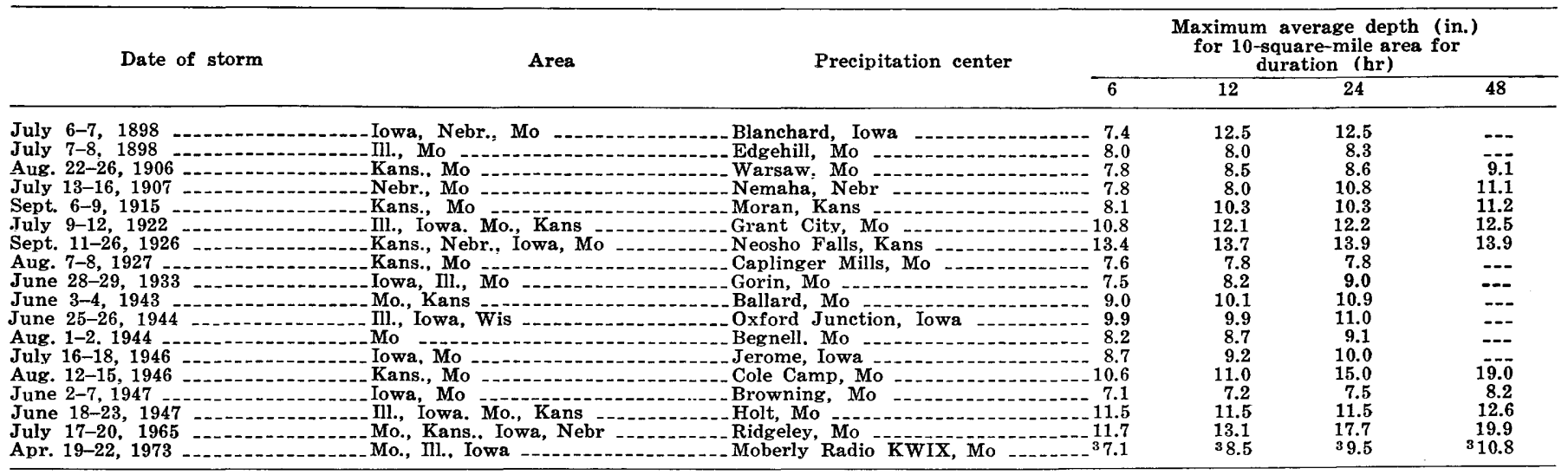

1 Obtained from U.S. Army Corps of Engineers and updated with National Weather Service data.
2 Only major storms with precipitation centers within 200 miles from Moberly, Mo., storm durations longer than 24 hours, and maximum average 2 Only major storms with precipitation centers within 200 miles from Moberly,
precipitation depths for 10 square miles in 6 hours exceeding 7 inches are in cluded.

precipitation depths for 10 square miles in 6 hours
Observed rainfall in inches at maximum station.

TABLE 6.-Comparison of the April 20-21, 1973, storm near Moberly, Mo., with the Illinois model 12-hour severe rainstorm

\begin{tabular}{|c|c|c|}
\hline Parameter & $\begin{array}{l}\text { Moberly } \\
\text { storm }\end{array}$ & $\begin{array}{c}\text { Mlinois } \\
\text { model }\end{array}$ \\
\hline $\begin{array}{l}\text { Squall line orientation, degrees-- } \\
\text { Orientation of surface isohyetal }\end{array}$ & $220-040$ & $255-075$ \\
\hline pattern, degrees & 245-065 & $265-085$ \\
\hline $850-\mathrm{mb}$ wind; degrees, knots & 210,40 & 245,30 \\
\hline 700-mb wind; degrees, knots & 215,50 & $255, \quad 30$ \\
\hline $\begin{array}{l}\text { 500-mb wind; degrees, knots } \\
\text { Surface dew point, departure }\end{array}$ & 220,70 & 270,30 \\
\hline from normal, ${ }^{\circ} \mathrm{F}$ & +18 & +5 \\
\hline Starting time of rain, c.s.t & 7:00 p.m. & $7: 00$ p.m. \\
\hline Time of maximum rain, c.s.t & $\begin{array}{r}\text { 10:00 p.m. } \\
\text { 2:00 a.m. }\end{array}$ & $\begin{array}{l}\text { 9:30 p.m. } \\
3: 30 \text { a.m. }\end{array}$ \\
\hline $\begin{array}{l}\text { Maximum 12-hour point rainfall, } \\
\text { inches }\end{array}$ & 8.5 & 9.4 \\
\hline
\end{tabular}

on April 19: Covington $1 \mathrm{~W}$, Tenn. $\left(35^{\circ} 34^{\prime}\right.$ N., $89^{\circ}$ $40^{\prime}$ W.), had 5.62 in. (143 mm) on April 20; and La Porte, Ind. $\left(41^{\circ} 36^{\prime}\right.$ N., $86^{\circ} 43^{\prime}$ W.), had 2.95 in. (65 $\mathrm{mm}$ ) on April 22. All these represent the greatest 1day precipitation in the month of April 1973 for these States. It is evident that April 19-22 was indeed a very stormy period. Areas receiving 2 in. (51 $\mathrm{mm}$ ) or more precipitation during the 7-day period April 16-22, 1973, are shown in figure 50. The critical placement of heavy precipitation in the Central Mississippi Valley along the main stem contributed materially to the subsequent record flood crests passing down the Mississippi River. The Low finally moved to northeast Canada by $7: 00$ a.m. e.s.t., April 22. But the diffused remains of a foot-dragging frontal zone extending from Texas to New England lingered on, along which frontogenesis was soon to start again.

\section{ESTIMATION OF WATER LOSS IN THE MISSISSIPPI BASIN IN SPRING 1973}

The transformation of liquid water from the surface into water vapor in the atmosphere constitutes a vital link in the hydrologic cycle. Atmospheric water vapor is being replenished continuously either by direct evaporation from soil and free water surface or by transpiration through leaves of vegetation. This return flow is the reverse process of precipitation and will determine to a large extent the part of the total precipitation available for runoff and ground-water recharge over a time and space scale appropriate to the Mississippi basin flood of spring 1973. It is no accident that major floods are not as frequent in the Mississippi Valley in the summer, which is the season of maximum water loss. Therefore, in considering the meteorological setting of this flood, a discussion of the water-loss process is justified.

Evapotranspiration is the term used to describe the combined process of evaporation and transpiration. But the former is a physical process, whereas the latter involves plant biological functions and is very difficult to measure. Accordingly, the integrated effects of these two processes as related to the flood episode will be discussed separately for convenience.

The rate of transpiration depends on many factors. A relatively warm air environment, low relative humidity, breezy winds, bright sunlight, and moist soil are factors favorable to the transpiration process. For most plants, highest transpiration occurs during midday and early afternoon and drops off sharply as incident solar radiation becomes unavailable. In 


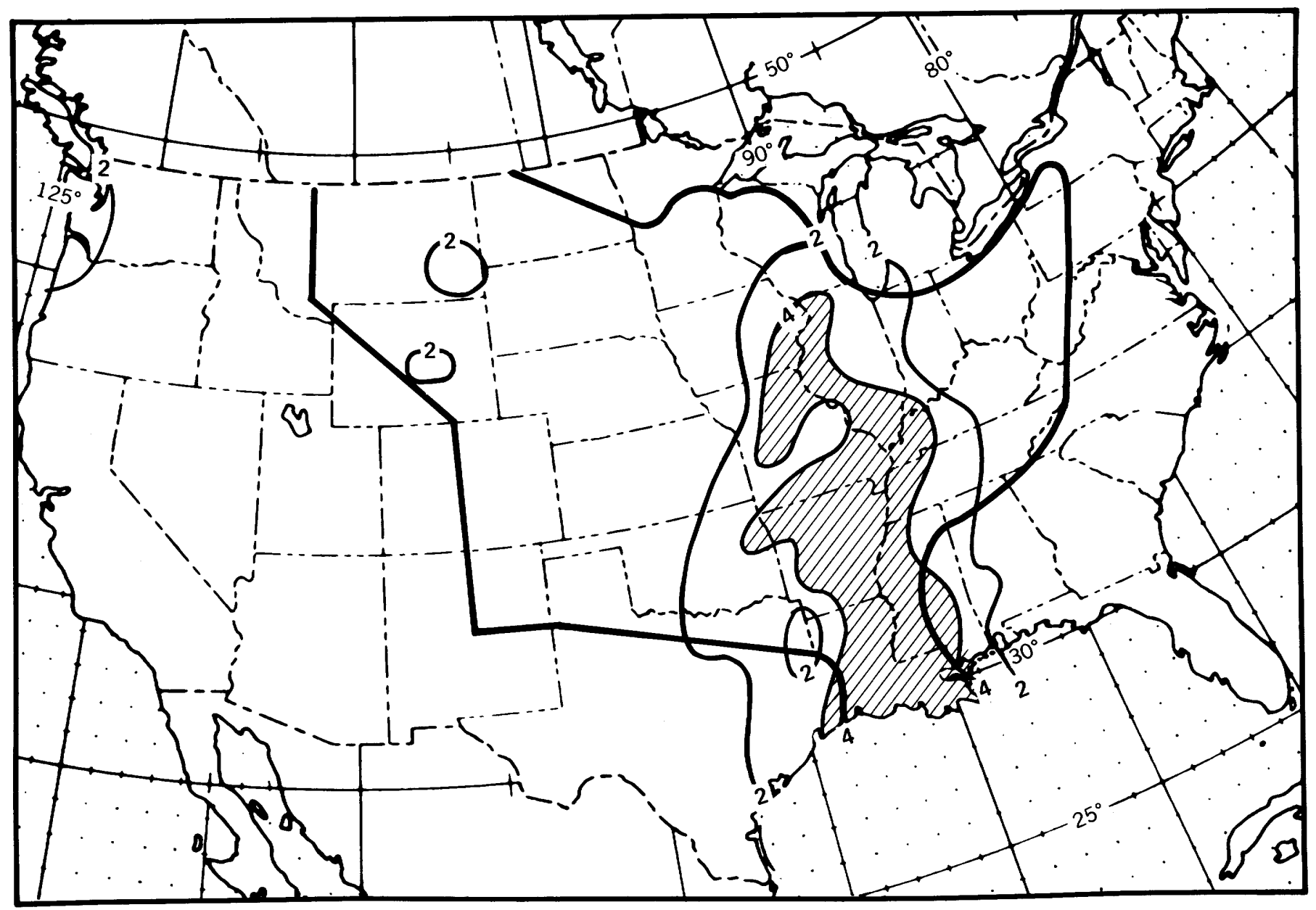

FiguRE 50.-Total rainfall April 16-22, 1973, showing areas with 2 inches or more rain.

March and April 1973, incident solar radiation at the surface over the basin was much less than normal; mean surface temperature over the whole basin averaged above (below) normal in March (April) 1973. There was also excessive soil moisture and higher than normal relative humidity. These conflicting influences on transpiration rate indicated that there was no reason to assume that the transpiration water loss during the flood episode would be very different from other years if vegetation acreage in the basin were essentially the same.

Agricultural land covers a major part of the Mississippi basin; and because of the onset of the flood, spring planting throughout the basin was disrupted and crop acreage was cut sharply below normal (Environmental Data Service and Statistical Reporting Service, 1973). For example, at the end of April 1973, Louisiana had 20 percent corn and 40 percent rice acreage planted compared with 85 percent and 80 percent respectively at the same time the year before. Mississippi had less than 2 percent cot- ton acreage planted compared with $\mathbf{5 5}$ percent the year before. Arkansas had no cotton planted, whereas the normal was 33 percent, and 5 percent rice acreage seeded, whereas the normal was 67 percent. Oklahoma reported 15 percent barley and 9 percent oats headed; in 1972, it was 51 percent and 43 percent respectively. Missouri only had one twentythird of the corn acreage and 8 percent of the oat acreage of 1972 . Kansas had 67 percent oat seeded compared with a normal of 97 percent. Illinois just started corn planting. Indiana had only one-third of the normal acreage of oats seeded. Ohio had oat seeding 30 percent completed compared with a normal of 75 percent. Water was reported standing in many midwestern fields. Farm animals were dying from exhaustion due to not getting adequate rest on the cold wet ground. There were also scattered reports of flood damage to crops already on the ground. A considerable part of low-lying farmland along the Mississippi and its tributaries was still under water toward the end of April. These facts all testified to 
the drastic reduction of crop acreage in the Mississippi basin at that time. It seems likely as a consequence that the integrated transpiration loss during the flood episode over the basin could be less than normal.

The evaporation process derives its basic driving energy from the radiation balance of the evaporating surface; at the same time, it is a mass transfer process with a rate determined by the vapor pressure gradient near the surface and the windspeed just above. This rate can be described by the following equation by Kohler and Parmele (1967) :

$$
E=\frac{\left(Q_{i r}-\epsilon \sigma T_{a}^{4}\right)+E_{a}\left[\gamma+4 \epsilon \sigma T_{a}{ }^{3} / f(u)\right]}{\Delta+\left[\gamma+4 \epsilon \sigma T_{a}^{3} / f(u)\right]}
$$

where:

$$
\begin{array}{ll}
E & =\text { evaporation rate } \\
Q_{i r} & =\text { difference between incident and reflected } \\
& \quad \text { radiation over all wavelength } \\
\epsilon & =\text { emissivity of water surface } \\
\sigma & =\text { Stefan-Boltzmann constant } \\
T_{a} & =\text { air temperature (at screen height) } \\
\gamma & =\text { psychrometric constant } \\
\Delta & =\left(d e_{s} / d T\right)_{T_{a}} \\
E_{a} & =f(u)\left[e_{s}-e_{a}\right] \\
f(u) & =\text { wind function } \\
e_{s} & =\text { saturation vapor pressure at air tempera- } \\
& \quad \text { ture at screen height } \\
e_{a} & =\text { vapor pressure of air at screen height }
\end{array}
$$

The wind function is of the form $\left(a+b u_{z}\right) ; a$ and $b$ are empirical constants; $u$ is total wind movement per day; and $z$ is the anemometer height.

The interpretation of equation (4) is that evaporation has an energy component which is a function of radiation balance and an aerodynamic component which is a function of saturation deficit and wind speed. Data availability does not permit an integration of equation (4) over the time and space domain corresponding to the flood episode. Instead, a general discussion is given.

Average incoming solar radiation received during March and April 1973 for a sample of stations in the basin is shown in table 7 .

This was the radiation measured at the surface after depletion due to reflection, back scattering and absorption in the atmosphere but before surface reflection. The integrated surface albedo over the Basin in the spring of 1973 could be slightly smaller than normal due to the less extensive snow cover and the increased soil wetness. However, since the average daily insolation received at the surface was much less than normal, mainly due to the much higher than normal reflection by the more extensive cloud cover, it seems that a slight decrease in surface albedo would not be sufficient to alter the relative magnitudes between the resulting $1973 Q_{i r}$ 's and climatological $Q_{i r}$ 's. Hence, it is reasonable to infer that the integrated $Q_{i r}$ over the basin would also be considerably less than normal for these 2 months. The average temperature over the 2 -month period in the Mississippi basin (figs. 10 and 11) should have been close to or slightly higher than normal. Therefore, in the spring of 1973 , the contribution to evaporation in the Basin due to the radiation balance as represented by the first term in the numerator of equation (4) should be smaller than normal. Another important process that should be taken into consideration is the evaporation of rain drops. Once a drop falls through the cloud base, it would be subjected to increased evaporation before it reaches the ground. This problem was investigated by Kinzer and Gunn (1951) among others. The evaporation rate of freely falling water drops depends on the drop radius, the water vapor density gradient from a transition layer at drop surface to that of the environment, the density, viscosity, molecular diffusivity of the ambient air, the vertical velocity of the environmental air and the Reynolds number. Mason (1952) integrated one version of the condensational growth equation by assuming a constant updraft of $10 \mathrm{~cm} \mathrm{sec}$ se $^{-1}$ a ground temperature of $15^{\circ} \mathrm{C}$ and a lapse rate of $6.5^{\circ} \mathrm{C} \mathrm{km}^{-1}$. He was able to show that a small drop with an initial radius of $330 \mu$ falling from a cloud base at elevation $1,750 \mathrm{~m}$ through subcloud air with 80 percent relative humidity would have shrunk to a radius of $100 \mu$ when it reached the ground. This represented an evaporation of more than 97 percent of its original mass. However, this result must be regarded as a very favorable case for evaporation because of the larger surface-to-mass ratio of drizzle droplets compared with rain drops and the assumed updraft. Recent numerical simulations of rain drop evaporation with subcloud layer structure represented by the 6:00 p.m. c.s.t., April 20, 1973, sounding at Peoria. Ill. (fig. 45), a down draft of $1.5 \mathrm{~m}$ $\mathrm{sec}^{-1}$ and with ventilation effect taken into account, shows that for a rain drop of $1 \mathrm{~mm}$ radius initially located at the cloud base at a height of $1,300 \mathrm{~m}$ will take about 160 seconds to reach the ground, and the mass loss during descent amounts to 8 percent. The air below the cloud base would also be cooled due to the extraction of its internal energy to provide for a part of the latent heat consumed in drop evapora- 
TABLE 7.-Comparison of daily average solar radiation for March and April 1973 received at the surface with the climatic normal solar radiation ${ }^{1}$

[Units of solar radiation are langleys per day]

\begin{tabular}{|c|c|c|c|c|c|}
\hline Station & $\begin{array}{c}\text { March } \\
1973 \\
\text { average }\end{array}$ & $\begin{array}{l}\text { March } \\
\text { normal }\end{array}$ & $\begin{array}{c}\text { April } \\
1973 \\
\text { average }\end{array}$ & $\begin{array}{c}\text { April } \\
\text { normal }\end{array}$ & $\mathrm{N}^{2}$ \\
\hline Little Rock, Ark _--- & 271 & 364 & 323 & 449 & 19 \\
\hline Indianapolis, Ind & 265 & 315 & 310 & 410 & 19 \\
\hline Omaha, Nebr & 210 & 350 & 458 & 460 & 39 \\
\hline Bismarck, N. Dak & 249 & 359 & 404 & 432 & 18 \\
\hline Oklahoma City, Okla-- & 289 & 397 & 439 & 475 & 20 \\
\hline Rapid City, S. Dak & 336 & 385 & 397 & 466 & 22 \\
\hline Nashville, Tenn & 292 & 328 & 343 & 439 & 28 \\
\hline Oak Ridge, Tenn & 262 & 330 & 328 & 430 & 21 \\
\hline
\end{tabular}

${ }^{1}$ Obtained from Environmental Data Service and Statistical Reporting Service (1973).
2 Number of

tion. With the very large number of drops of various sizes involved in actual rainfall, the subcloud layer would be brought to saturation or near saturation by this process as the ambient vapor pressure, $e_{a}$, increases and approaches a reduced $e_{s}$ corresponding to the wet-bulb temperature distribution of the subcloud layer. Hence, $\left(e_{s}-e_{a}\right)$ and consequently the second term in the numerator of equation (4) would tend toward zero or be very small during rainfall. Since for the Mississippi basin as a whole the weather in March and April 1973 was characterized by a succession of prolonged rainfall, surface evaporation rates would be minimized.

Actual monthly total evaporation for a sample of Mississippi basin stations in March and April 1973, together with comparative climatological values, is shown in table 8. The choice of sample stations is dictated mainly by data availability. These data tend to support the aforementioned analysis. For example, 9 stations out of a total of 11 in March and 13 stations out of a total of 14 in April showed lower monthly evaporations than their respective climatic means. Combined as a single sample, a Wilcox pairsample rank test indicated that if the null hypothesis that there was no substantial difference between the observed and the climatic values were true, then the probability was less than 0.00005 that such a predominantly one-sided departure could have happened by chance.

Some exceptions to the general pattern can be explained by the role of wind. For example, Stuttgart 9 ESE, Ark., which had a slightly higher than normal evaporation in April 1973, experienced a greater monthly total mind movement over the pan than any of the 24 antecedent Aprils in the climatic data set.

Since during the flood episode more than 12 million acres $(485,640 \mathrm{sq} \mathrm{km})$ of mostly cropland in the basin were inundated at one time or another, the effect that this increased free water surface would have on the integrated total evaporation should be examined. It is well known that evaporation from a free water surface may be less rapid than that from a moist soil under similar conditions because the soil with its multitude of irregular grains will present a larger evaporating surface. Since the newly formed free water surface covered mainly what should have been plowed and irrigated crop acreage, it seems that the flooding might lead to a lower evaporation loss than before.

When all these factors are considered, a reasonable conclusion is that integrated evaporation over the Mississippi basin seemed to be less than normal in March and April 1973. This is separate from and in addition to the possible reduction in transpiration loss mentioned earlier. These decreases might seem insignificant when compared with the large precipi-

TABLE 8.-Comparison of evaporation in inches for March and April 1973 with climatic mean monthly evaporation ${ }^{1}$

\begin{tabular}{|c|c|c|c|c|c|c|c|c|}
\hline \multirow[b]{2}{*}{ Station } & \multicolumn{4}{|c|}{ March } & \multicolumn{4}{|c|}{ April } \\
\hline & $\mathbf{E}$ & Departure & $\begin{array}{l}\text { Percent } \\
\text { change }\end{array}$ & $N^{2}$ & $\mathbf{E}$ & Departure & $\begin{array}{l}\text { Percent } \\
\text { change }\end{array}$ & $N$ \\
\hline $\begin{array}{l}\text { Blakely Mountain Dam, Ark } \\
\text { Stuttgart 9 ESE, Ark } \\
\text { Hope } 3 \text { NE, Ark } \\
\text { Carlyle Reservoir, Ill } \\
\text { Evansville, Ind } \\
\text { Fall River Dam, Kans } \\
\text { Torento Dam, Kans } \\
\text { State University, Miss } \\
\text { Lakeside, Mo } \\
\text { Charles Mill Dam, Ohio } \\
\text { Fort Supply Dam, Okla } \\
\text { Great Salt Plains Dam, Okla.-- } \\
\text { Hulah Dam, Okla } \\
\text { Witra Dam, Okla --- } \\
\text { Jefferson City Evaporation } \\
\text { Station, Tenn }\end{array}$ & $\begin{array}{l}2.53 \\
4.64 \\
3.15 \\
--- \\
5 . \overline{5} \\
3.27 \\
4.45 \\
--- \\
\overline{4.45} \\
5.25 \\
3.88 \\
3.55 \\
2.72\end{array}$ & $\begin{array}{r}-1.76 \\
-.96 \\
-1.50 \\
-1.11 \\
-.15\end{array}$ & $\begin{array}{r}-28.3 \\
-15.4 \\
-27.9 \\
-23.8 \\
-5.2\end{array}$ & $\begin{array}{l}17 \\
17 \\
20 \\
22\end{array}$ & $\begin{array}{l}3.61 \\
5.62 \\
3.36 \\
4.48 \\
3.71 \\
6.43 \\
6.28 \\
5.99 \\
3.67 \\
2.45 \\
6.74 \\
5.32 \\
6.31 \\
--- \\
4.22\end{array}$ & $\begin{array}{r}-0.89 \\
+.43 \\
-1.60 \\
-1.13 \\
-1.32 \\
-.97 \\
-.10 \\
-.76 \\
-1.26 \\
-.91 \\
-2.49 \\
-2.50 \\
-1.04\end{array}$ & $\begin{array}{r}-19.8 \\
+8.3 \\
-32.2 \\
-20.1 \\
-26.2 \\
-13.1 \\
-1.6 \\
-12.7 \\
-25.5 \\
-27.1 \\
-27.0 \\
-32.0 \\
-14.1\end{array}$ & $\begin{array}{r}19 \\
24 \\
21 . \\
9 \\
24 \\
24 \\
17 \\
24 \\
23 \\
23 \\
24 \\
24 \\
24\end{array}$ \\
\hline
\end{tabular}

1 Obtained from Environmental Data Service (1973b) and historical Climatological Data.

2 Number of years of data available in arriving at the normals. 
tation amounts over the basin in the same period. However, because the soils were already fully saturated during the flood episode, any reduction in water loss would result in more runoff and contribute to the aggravation and prolongation of the flood. The absence of vegetation over large areas of low land tended to further facilitate runoff. This is one example of the feedback effect of hydrometeorological events.

\section{SOME CONCLUDING REMARKS} (METEOROLOGY)

The higher than normal streamflow over the northern central part of the basin at the beginning of March 1973 provided a setting for relatively high flood potential. However, the predominant cause of the flood was the frequent occurrence of widespread and persistent rain over the basin during the spring of 1973. These rainfalls were mainly associated with extratropical cyclones and frontal activities. The fundamental mechanism of cyclogenesis was the baroclinic instability of the meandering westerlies. These cyclones had as their basic source of energy the large-scale temperature contrasts between the tropical maritime airmasses frequently intruding into the basin from the gulf and the polar airmasses moving southeastward from Canada. Rainfalls from many such storms generally did not appear as unusual when compared with climatological annual extremes. However, their significance may increase appreciably if precipitation data were stratified by season. On occasions, thunderstorms and squall lines imbedded within the cyclone scale weather systems did produce localized significant individual precipitation, such as those over Victory, Tenn., on March 1416 and over Moberly, Mo., on April 20-21.

The cyclone scale weather system represents a major response by the atmospheric circulation to the latitudinal net radiation imbalance that results in a surplus (deficit) of radiative heating equatorward (poleward) of about $37^{\circ}$ latitude on an annual basis. This geophysical fact makes the poleward energy transport imperative, without which the high (low) latitude region would become progressively colder (warmer) year after year.

In the middle latitudes of the Northern Hemisphere, the required northward energy transport is carried out mainly through the agency of eddy fluxes manifested by cyclone scale weather systems and upper airwaves. A typical extratropical cyclone visiting the Central Mississippi basin in the spring can be represented by the storm of April 19-22, 1973.
Associated with this storm was a strong warm tropical airmass intrusion into the basin through a deep layer extending at least above the 850-mb level and a cold polar air outbreak west of the front. At the same time, warm (cold) air was rising (sinking) (fig. 41). This positive correlation between the vertical velocity and temperature represents a conversion of available potential energy into kinetic energy. These storms, in essence, performed at least the functions of northward transport of energy, upward transfer of energy, and the conversion from potential into kinetic energy. Palmen (1961), based on a mean kinetic energy conversion rate of 20 watts $\mathrm{m}^{-2}$ for a typical polar front cyclone, estimated that five such cyclones north of lat $32^{\circ} \mathrm{N}$. at any one time during the winter in the Northern Hemisphere were needed to achieve a reasonable mean rate of kinetic energy generation through the atmosphere. This is generally in agreement with synoptic observations.

Tracks of sea level cyclone centers in March and April 1973 (Environmental Data Service, 1973b) show that these 2 months were very stormy over the basin. This might seem to suggest that the northward energy flux and the kinetic energy generation over the basin could have been greater than normal during this period. A conceivable antecedent scenario, which would necessitate a more vigorous northward energy transport in the spring of 1973, could have been a farther southward than normal snowline over the northern regions of the continents and a higher (lower) than normal sky cover for the high (low) latitude regions in the preceding summer. But it should be emphasized that it is the net poleward energy transport integrated around a complete latitude circle that compensates for the latitudinal radiational imbalance. Because the Mississippi basin only extends over a 6-percent sector of the latitude circle at $37^{\circ} \mathrm{N}$., the question whether the integrated poleward energy transport in spring 1973 was really higher than normal cannot be answered without hemispheric data, including energy transport data by ocean currents in both the Atlantic and the Pacific Oceans.

A recent study by Vonder Harr and Ort (1973) using the net radiation budget of the earth-atmosphere system from satellite measurements and atmospheric energy transport calculated from rawinsonde data indicated that the ocean played a much more important role in poleward energy transport than was formerly realized. For the Northern Hemisphere, the ocean transported 40 percent of the required energy in the region, $0^{\circ}-70^{\circ} \mathrm{N}$. This was 
the mean annual value so storage could be neglected in the calculation and balance relationships could be used. In view of this substantial role, any consideration of hemispheric poleward energy flux in March and April 1973 demands a detailed knowledge of poleward energy transport by oceans in the same period. The ocean storage of energy must also be known. Such information is not yet available.

The precipitation process is primarily controlled by atmospheric dynamics interacting with cloud microphysics. The extensive and persistent precipitation over the Mississippi basin in the spring of 1973 was, as mentioned earlier, associated with the numerous passages of extratropical cyclones and frontal activities. Spar (1973) carried out numerical experiments with the Mintz-Arkawa general circulation model and found that a sea-surface temperature anamoly of several degrees Celsius in the northern Pacific Ocean either persistent through a season or just 1 month would induce marked changes in the monthly and seasonal precipitation over Eastern United States. However, the magnitude of the seasurface temperature anomaly required was much greater than that actually observed in the spring of 1973. Power spectrum analysis of meteorological time series by Sawyer (1970) disclosed the existence of large-scale atmospheric fluctuations with a time scale the order of a month. Such long-duration fluctuations in the motion field, as possibly exemplified by a blocking High over the eastern Pacific or a persistent trough over Western United States, would in turn affect the distribution of precipitation. A prolonged wet spell over a large area, such as that which occurred in March and April 1973 over the Mississippi basin, though very rare, could be expected to return in the future at irregular intervals.

A well-known proverb states that a picture is worth a thousand words. For the purpose of completing the documentation of the main features of the meteorological setting during the flood episode, daily isohyetal maps (pls. 1-3) and daily surface and 500mb charts valid at 7:00 a.m. e.s.t. (1200 G.m.t.) are presented (pls. 4-9). Days on which no significant area in the Mississippi basin received 0.5 in. (13 $\mathrm{mm}$ ) or more were omitted from plates 1-3, though these lesser amounts may also have contributed to the flood runoff.

\section{DATA AT STREAM-GAGING STATIONS}

Gaging station information included in this report was selected on the basis of outstanding peak floods, volumes, stages, or the availability of significant sediment data in drainage basins of all sizes. Figure 51 shows the location of the flood and sediment data collection sites. Detailed discharge data in table 12 (near the end of the report) make it possible to reproduce flood hydrographs for flood-control, sediment, and water-management studies. Some streams had normal discharges during part of the March through May base period; for these streams the periods of normal discharges are omitted and only flood data are presented.

Streamflow data included in table 12 of this report were generally obtained from automatic water-stage recording gages or readings of nonrecording gages by Geological Survey observers. At some gaged sites that are included in this report, the flooding was so severe that the automatic recorders were inundated or destroyed, and it was necessary to obtain floodstage data from non-automatic temporary gages. Also included are data collected at crest-stage partial-record stations, usually located on streams with small drainage areas, where only peak stages and discharges are collected.

Suspended-sediment concentration and discharge data are included with the streamflow data on a daily basis whenever available in sufficient quantity to construct a continuous record, otherwise it was tabulated on a periodic basis. Particle-size data are listed on a periodic basis. The suspended-sediment data were determined from samples collected in depthintegrating samplers using techniques described by Guy and Norman (1970). For days when the published sediment discharge value differs from the value computed as the product of discharge times mean concentration times 0.0027 , the reader can assume that the sediment discharge for that day was computed by the subdivided-day method (Porterfield, 1972). For periods when no samples are collected, daily loads of suspended sediment are estimated on the basis of water discharge and sediment concentrations observed immediately before and after the periods and suspended-sediment loads for other periods of similar discharge.

\section{MAGNITUDE AND FREQUENCY OF FLOOD PEAKS AND VOLUMES}

The estimated recurrence intervals (return periods) of spring 1973 flood peaks and volumes are shown in the gaging-station data tabulations (table 12). Detailed flood-frequency reports containing data for numerous gaged sites and methods for estimating frequency data at ungaged sites are available from district offices of the Geological Survey in each State. 


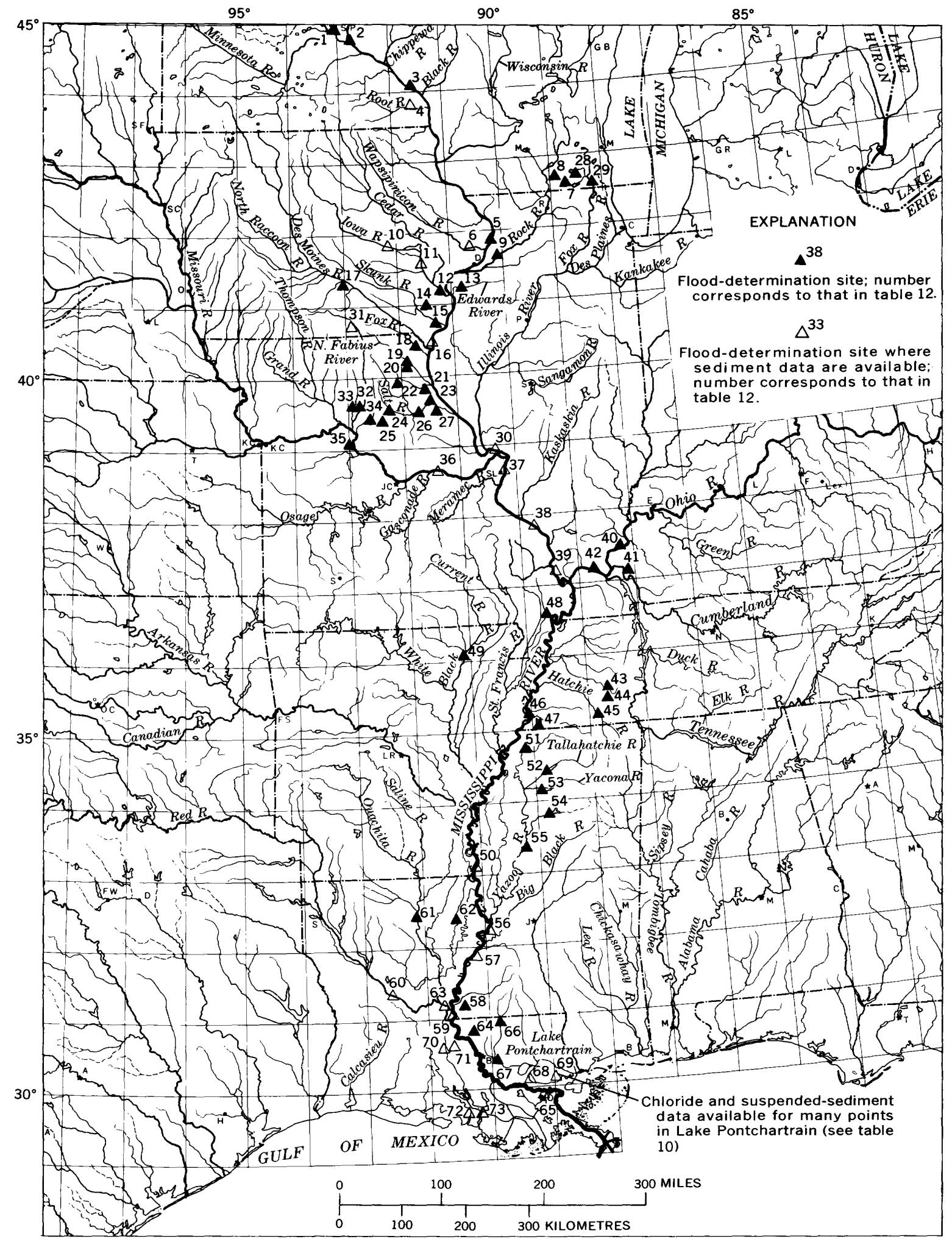

FIGURE 51.-Location of flood determination and sediment data sites in the Mississippi River basin.

For this report, inclusion of peak-flow data for tributary streams was generally limited to those flood peaks having recurrence intervals of 30 years or greater except where new station records for stage or discharge were set or where the data were useful in delineating inflow from major tributaries 
such as the Ohio River. Data were also included for gaging stations where outstanding volumes of flow were recorded or where sediment data were available.

The flood-frequency estimates for most tributary station data were determined by comparison of the magnitude of the peak-flow rate or volume with station-frequency curve data. The frequency curves for gaging stations had already been determined by computer, mathematically fitting a Pearson Type III distribution to the logarithms of the annual flood data as described by the U.S. Water Resources Council (1967). For a few stations where fitting of the Pearson Type III distribution to flood data proved impractical, graphical methods described by Dalrymple (1960) were used.

Flood-frequency relationships for the Mississippi River are presented in figure 52. Floodflows of the Mississippi River have been affected by manmade changes for many years, but an evaluation of the effects of these changes was not attempted for this report. The graphs shown were developed on the basis of actual flow data; these data include the effects of gradual changes caused by storage and levee systems in the basin. The frequency estimates shown for main-stem stations in table 12 are based on the relationships shown in figure 52 .

The recurrence intervals of flood peaks and volumes varied considerably throughout the Mississippi River basin during the 1973 spring floods. In the upper reaches of the basin, especially in Missouri and Iowa, the recurrence intervals of both flood peaks and volumes on many tributary streams were in excess of 100 years. However, in the lower parts of the basin, flood volumes generally had higher recurrence intervals than flood peaks.

Because of considerable regulation and manmade changes on some of the major streams, recurrence intervals are not shown for flood peaks and volumes at all stations listed in table 12 . However, comparisons with past peak-flow events were shown in the station manuscripts to provide some insight into the relative magnitude and return period of the event.

\section{THE FLOODS}

\section{MISSISSIPPI RIVER MAIN STEM}

The 1973 spring flood on the main stem of the Mississippi River had its beginnings in the early fall of 1972. Runoff from many tributaries throughout the basin was above normal from October 1972 through June 1973 producing above average flows on the main stem during the period (figs. 53 and 54). During the winter, flood-control reservoirs filled, fields became saturated, water tables were unusually high, and bankfull stages were common on many major tributary streams in Iowa, Missouri, Wisconsin, and Illinois; thus the stage was set for the devastating main-stem floods in the spring of 1973.

Selected photographs (figs. 55-58) illustrate some of the impacts of main-stem flooding during the spring of 1973. These are representative of thousands of photographs taken during the flooding by State and Federal agencies, newspapers, and private citizens.

\section{FLOOD PEAKS}

Upstream from Winona, Minn., the Mississippi River was not significantly affected by flooding in 1973. However, discharge records for three mainstem stations in this reach are included so that comparisons with past flood events can be made. Although the main-stem flooding was not severe in this part of the basin (recurrence intervals of peaks ranged from 3 to 7 years), it should be noted that the recurrence intervals of the peaks gradually increased in a downstream direction as tributary inflow became increasingly heavy.

The maximum 1973 flood stages were the highest ever observed in the reach of the Mississippi extending approximately $370 \mathrm{mi}(595 \mathrm{~km})$ upstream from Cape Girardeau, Mo. Downstream from Cape Girardeau, the river reached its highest stages since 1937. Flood-crest profiles are shown for the Mississippi River in figures 59-65. Table 9 describes and tabulates the flood elevations used to plot the profiles and provides data on maximum flood elevation prior to 1973. Discharge hydrographs for the 1973 flood are shown for selected Mississippi River gaging stations in figure 66.

The most extensive flooding over the whole Mississippi River basin occurred during April 1973, when more than 12 million acres (30 million ha) of land were flooded and at least 50,000 people were forced from their homes. Flood stages were the highest ever observed at St. Louis, where the river reached its maximum crest of $43.23 \mathrm{ft}(13.177 \mathrm{~m})$ on April 28, exceeding the crest stage of $41.32 \mathrm{ft}(12.594 \mathrm{~m})$ that was observed at St. Louis on June 27, 1844, and the flood peak of April 1785 that may have reached $42 \mathrm{ft}$ $(12.80 \mathrm{~m})$.

It is important to note that the peak stage of April 28, 1973, did not signify the greatest peak discharge of record; the peak discharge of $852,000 \mathrm{ft}^{3} / \mathrm{s}$ 

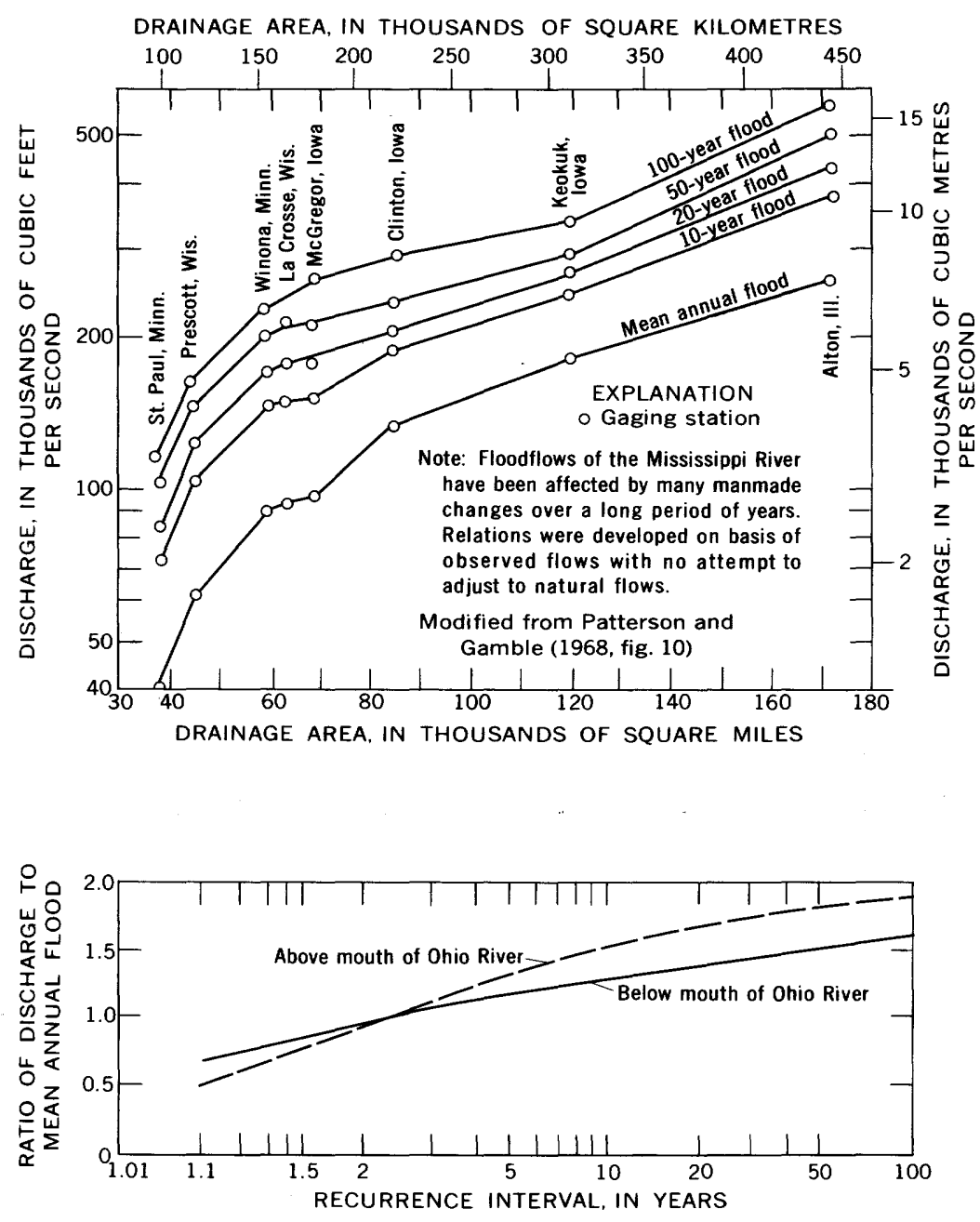

DISTANCE ABOVE HEAD OF PASSES, LA., IN KILOMETRES

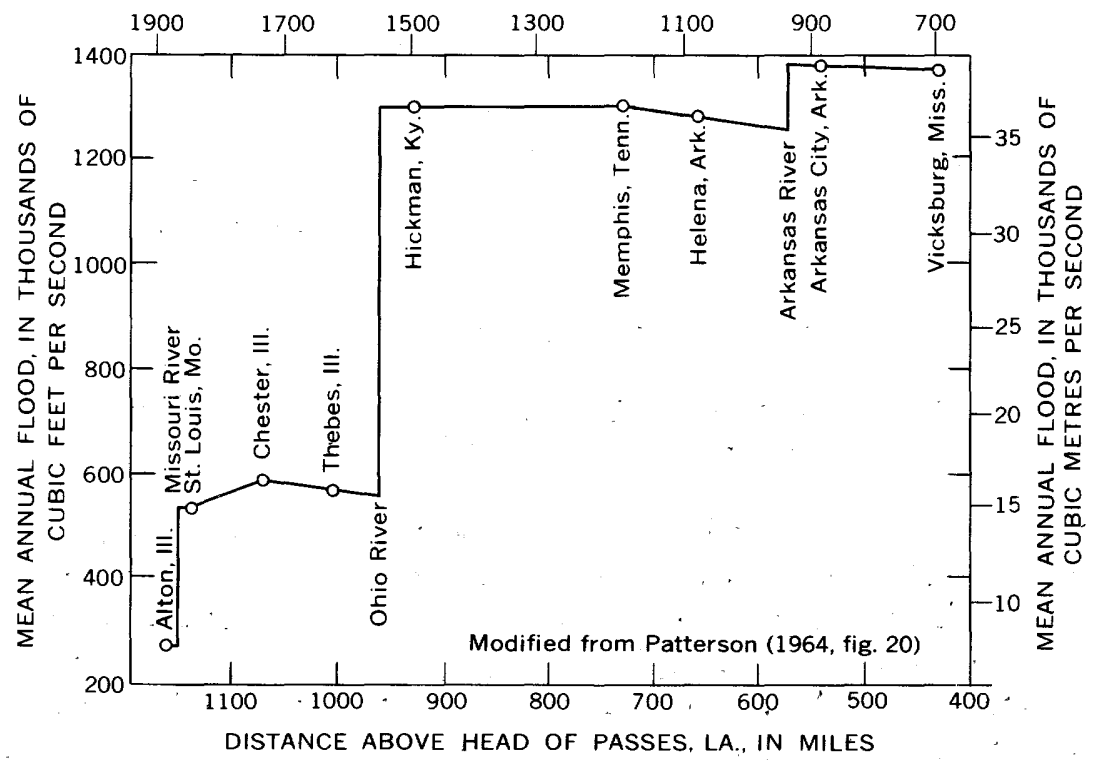

FIGURE 52.-Graphs for determining flood-frequency for the Mississippi River. 


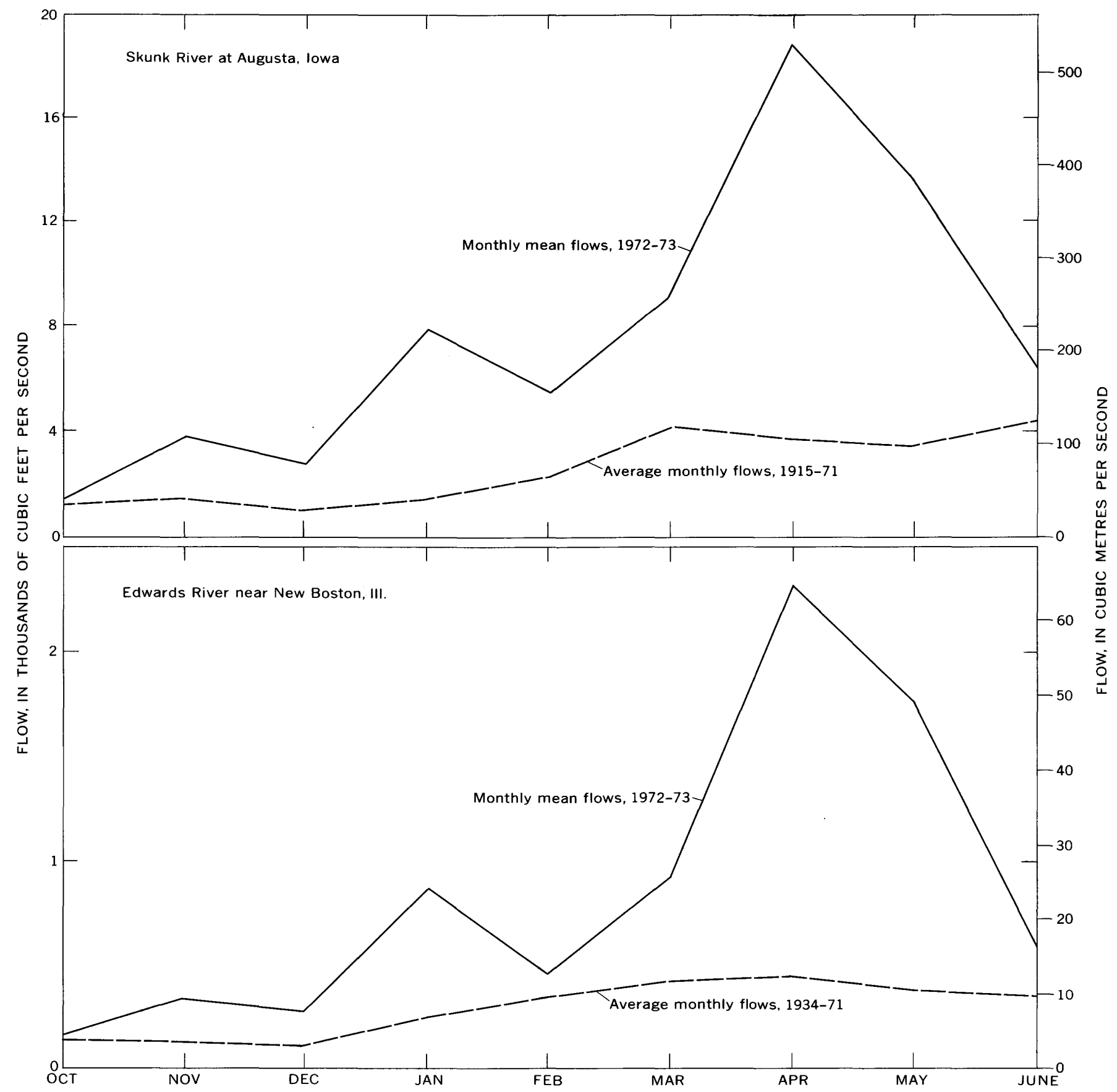

FIGURE 53.-Comparison of monthly mean flows for October 1972-June 1973 with average monthly flows 1917-71; selected stations in the Mississippi River basin.

(cubic feet per second) $\left(24,100 \mathrm{~m}^{3} / \mathrm{s}\right)$ was exceeded during the floods of $1785,1844,1883,1892,1903$, 1909 , and 1927. In fact, the flood of 1844, while reaching a $1.9 \mathrm{ft}(0.58 \mathrm{~m})$ lower peak stage, produced a 50 percent greater peak discharge (about 1.3 million $\left.\mathrm{ft}^{3} / \mathrm{s}\left[36,800 \mathrm{~m}^{3} / \mathrm{s}\right]\right)$. The primary reason for this apparent inconsistency is the extensive modern levee-floodwall system that has caused an in- crease in stage of a given discharge at St. Louis. This alteration of the stage-discharge relation has also occurred in many other reaches of the river and is generally caused by man's activity on the flood plain.

Another interesting facet of the 1973 main-stem flood was the number of outstanding flood crests on the river during March through May. Three to four distinct crests were recorded at stations in the upper 


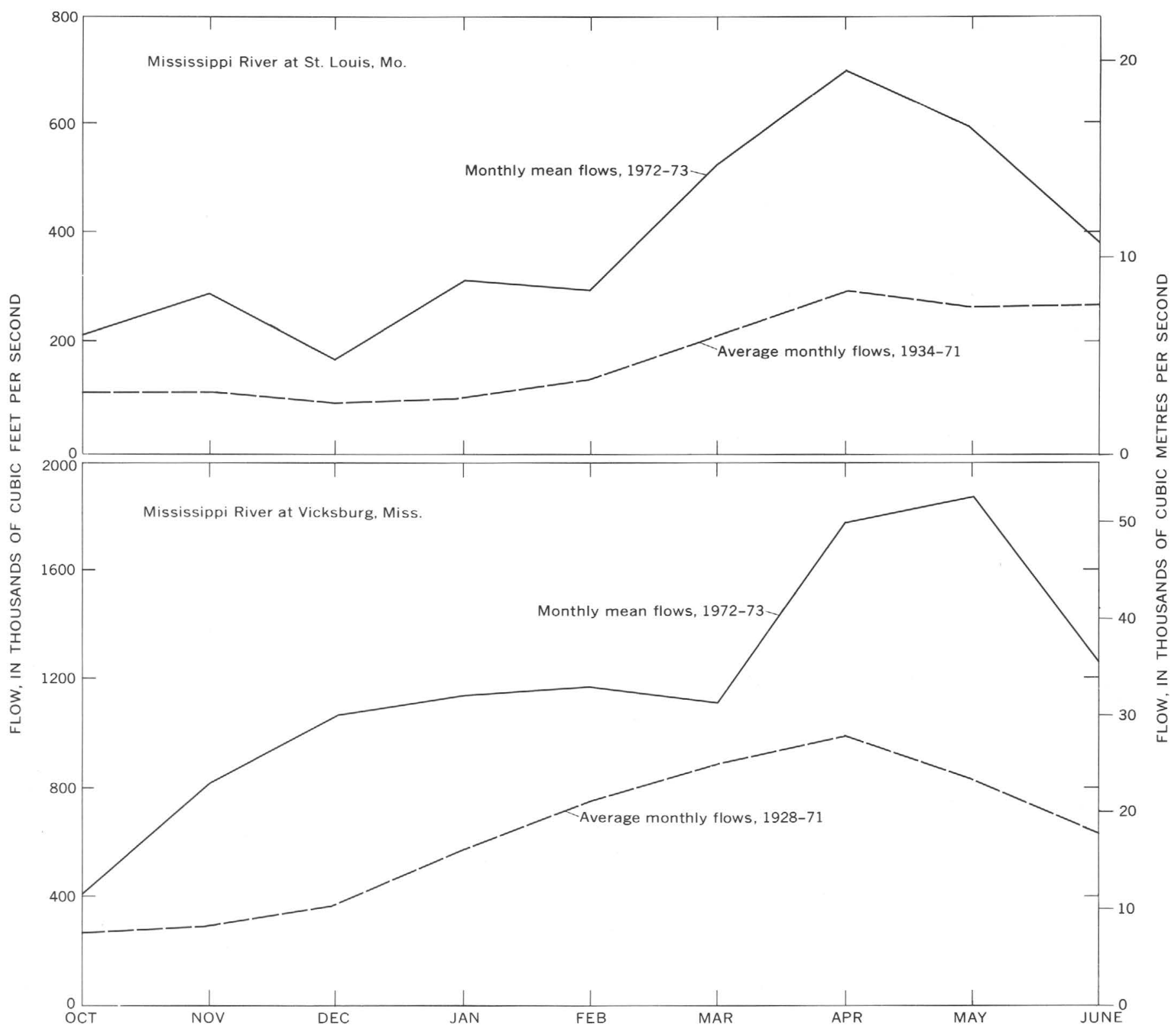

FIGURE 54.-Comparison of monthly mean flows for October 1972-June 1973 with average monthly flows 1917-71; selected stations in the Mississippi River basin.

Mississippi basin, and two were recorded at stations downstream from the Ohio River (see figure 66). The discharge hydrograph for the Mississippi River at St. Louis, for example, shows four distinct crests during this period. All of these peaks were well above flood stage and the last three peaks all ranked sixth or higher when compared to peak-stage data collected since 1861. Thus, three of the six highest peaks of record occurred at St. Louis during a 5week period. However, these peaks should not be considered as independent events because all of them were the result of a series of storms that occurred in a relatively short period of time.

\section{FLOOD DURATION AND VOLUME}

A very important feature of the 1973 Mississippi River flood was the duration of the event on the main stem and the resulting volumes of runoff involved. New records for consecutive days above flood stage were set for most main-stem gaging stations from southern Iowa to Louisiana. The real significance of the new records can be shown at stations where long periods of record are available for comparison. At St. Louis, Mo., for example, the Mississippi remained above flood stage for 77 consecutive days, exceeding. by 14 days the record established in 1844. At Chester, Ill., where collection of hydrologic records began in 


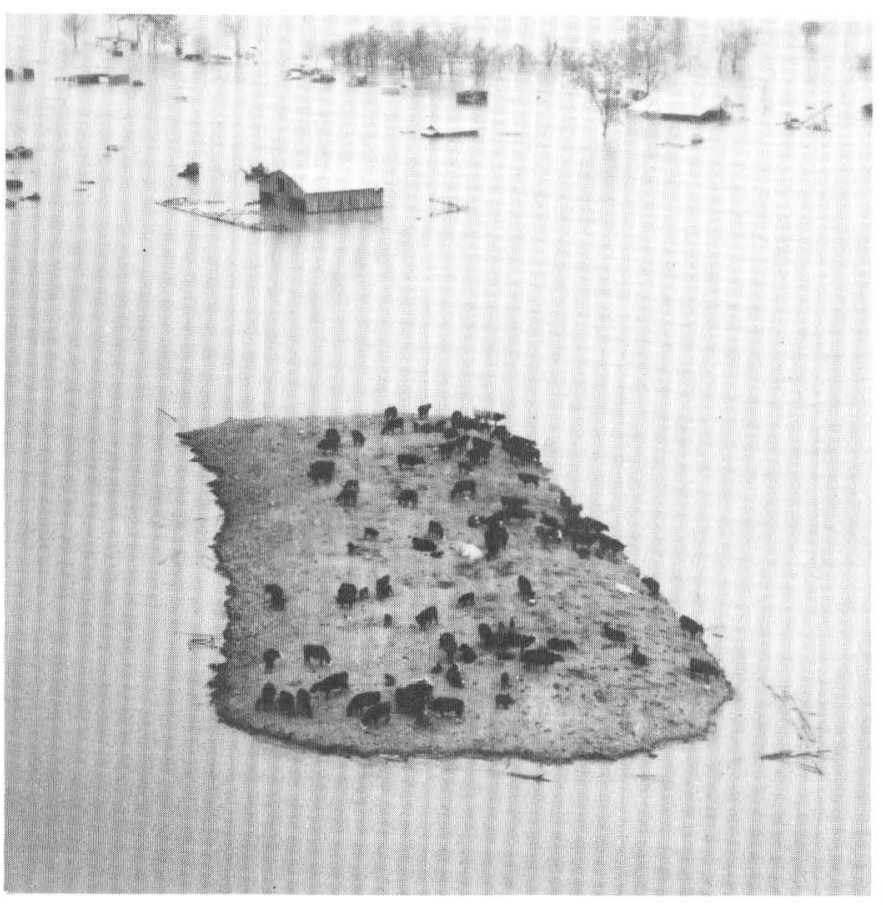

FIGURE 55.-Effects of Mississippi River flooding, spring 1973.

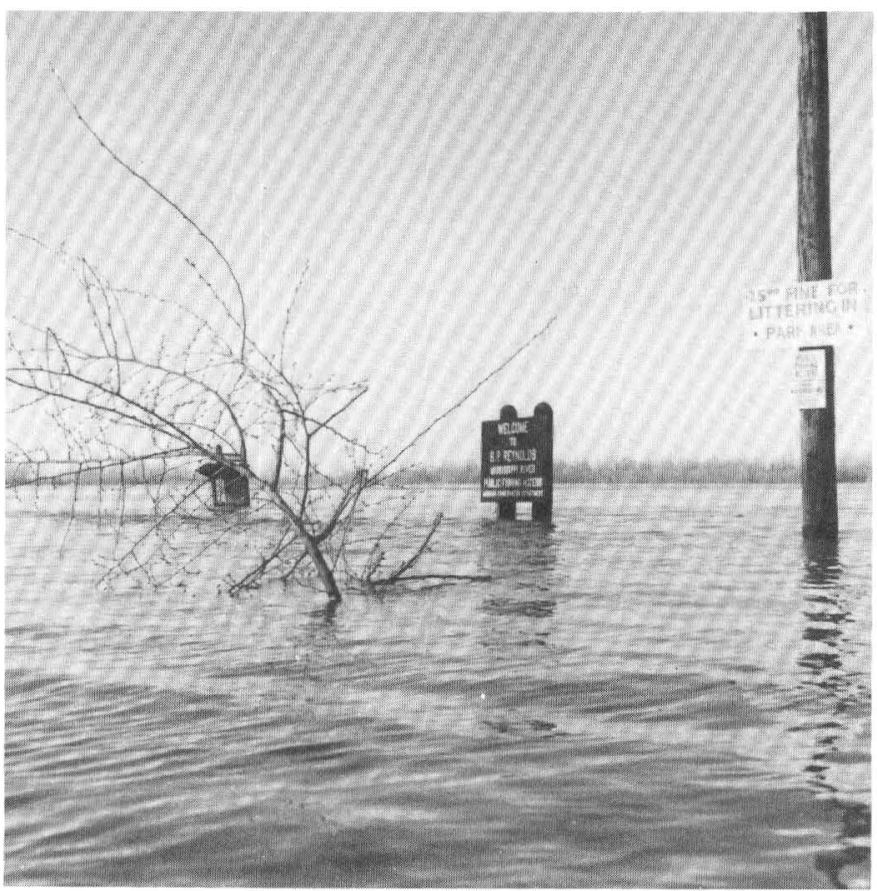

FIgURE 56.-Effects of Mississippi River flooding, spring 1973.

1927, the river remained above flood stage for an extraordinary 97 consecutive days. At Memphis the river was above flood stage for 63 consecutive days, the longest sustained flood since at least 1872, and at Vicksburg, a new record of 88 consecutive days above flood stage was established. The cumulative

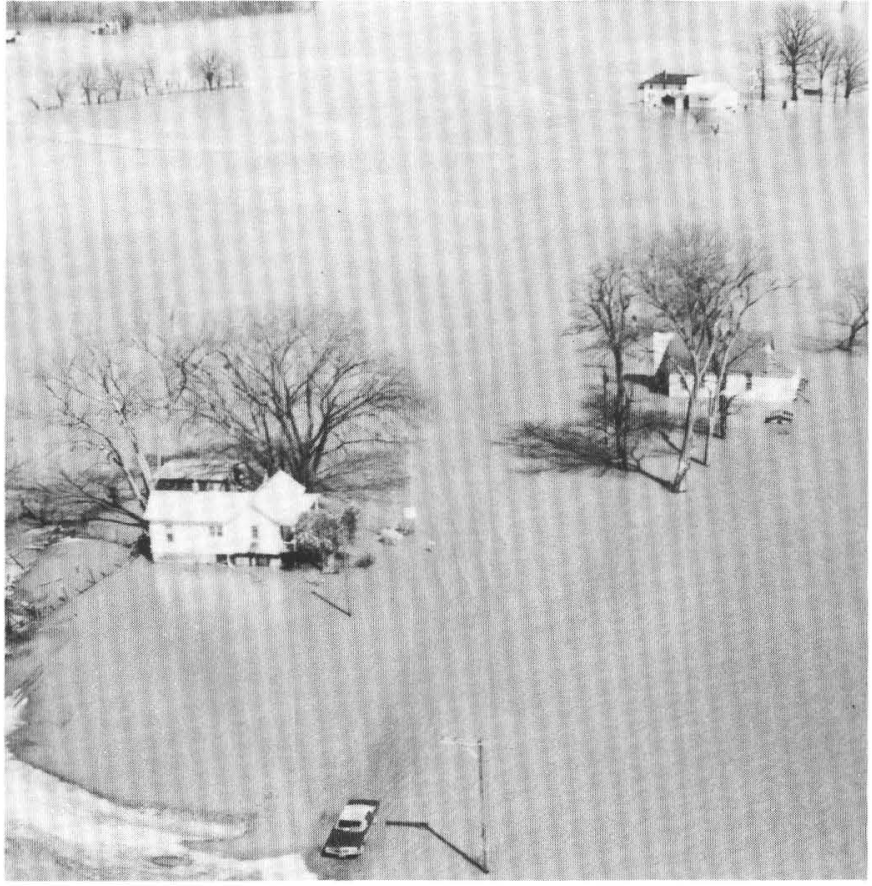

FIGURE 57._Effects of Mississippi River flooding, spring 1973.

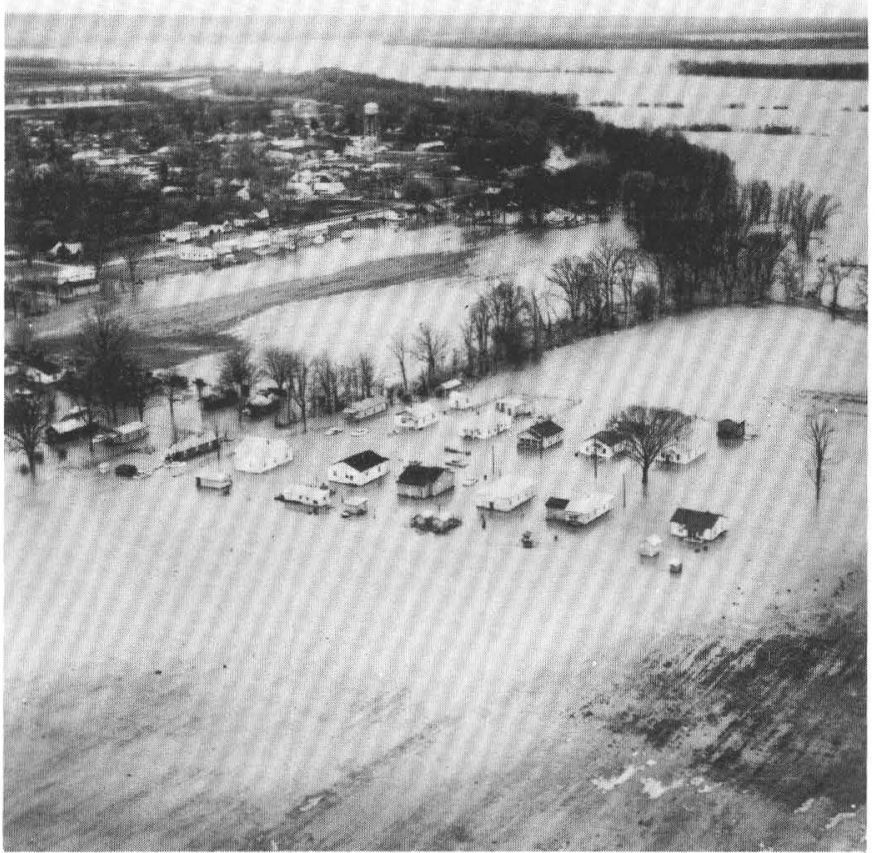

FIGURE 58.-Effects of Mississippi River flooding, spring 1973.

runoff for the Mississippi River at Vicksburg during the first 9 months of the 1973 water year (October 1972-June 1973) was 632 million acre-feet (779 $\left.\mathrm{km}^{3}\right)$; this exceeds the total flows for the first 9 months of previous flood years; 1927, 561 million acre-feet $\left(691 \mathrm{~km}^{3}\right) ; 1950,499$ million acre-feet 


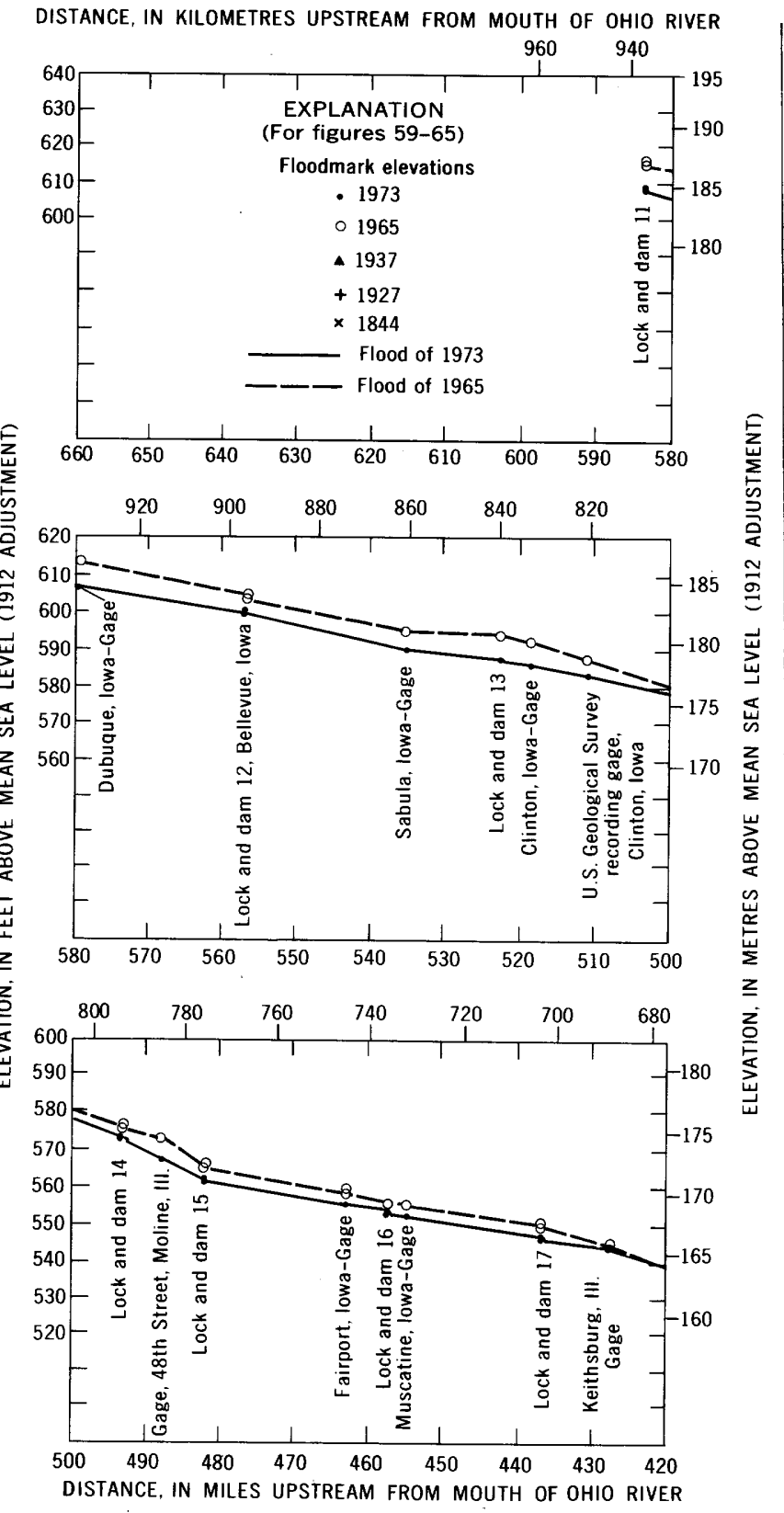

FIGURE 59.-Flood-crest profiles of Mississippi River.

$\left(616 \mathrm{~km}^{3}\right) ; 1945,463$ million acre-feet $\left(571 \mathrm{~km}^{3}\right)$; and 1937,410 million acre-feet $\left(506 \mathrm{~km}^{3}\right)$. The volumes of flood runoff associated with these events along the main stem have been computed for selected Mississippi River stations and are shown in table 12.

The tremendous volumes of runoff and duration of the flood event caused unusual emergency measures to be taken in the lower reaches of the Mississippi River system. On April 8, 1973, the Bonnet Carre Spillway, about $30 \mathrm{mi}(48 \mathrm{~km})$ upstream from New Orleans, was opened for the first time since 1950 to lower the river stage at New Orleans by diverting
DISTANCE, IN KILOMETRES UPSTREAM FROM MOUTH OF THE OHIO RIVER

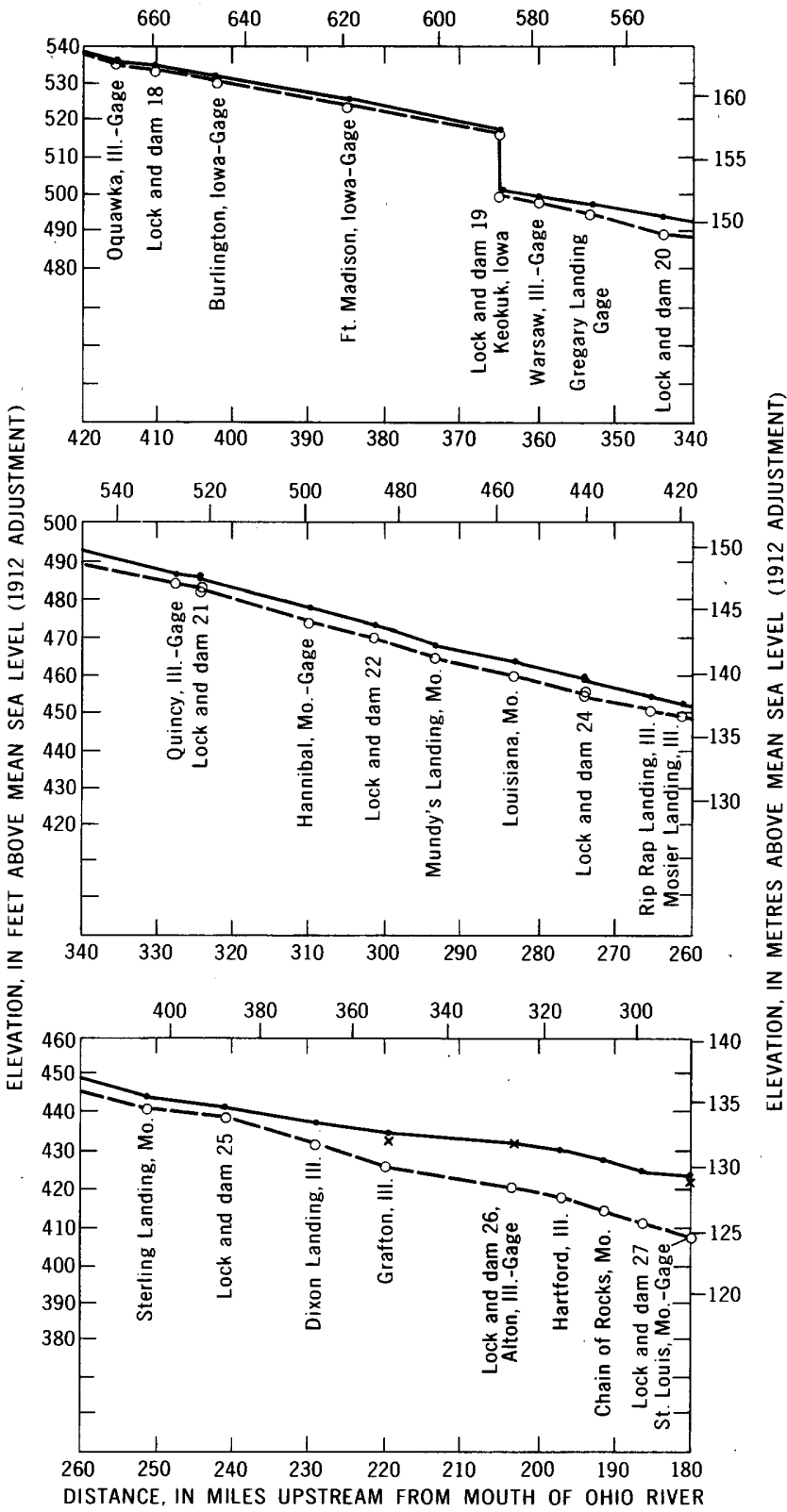

Figure 60.-Flood-crest profiles of Mississippi River.

floodwater from the river through Lake Pontchartrain to the Gulf of Mexico. Late in the month the Morganza Floodway, upstream from Baton Rouge, was opened for the first time since its construction (1953) in order to divert floodwater through the Atchafalaya River to the Gulf of Mexico. These diversions plus those through the Old River Control Structure amounted to about 40 percent of the flow at Vicksburg and relieved pressure on the levees downstream. Hydrologic information collected during the operation of these diversions is shown in table 12. 


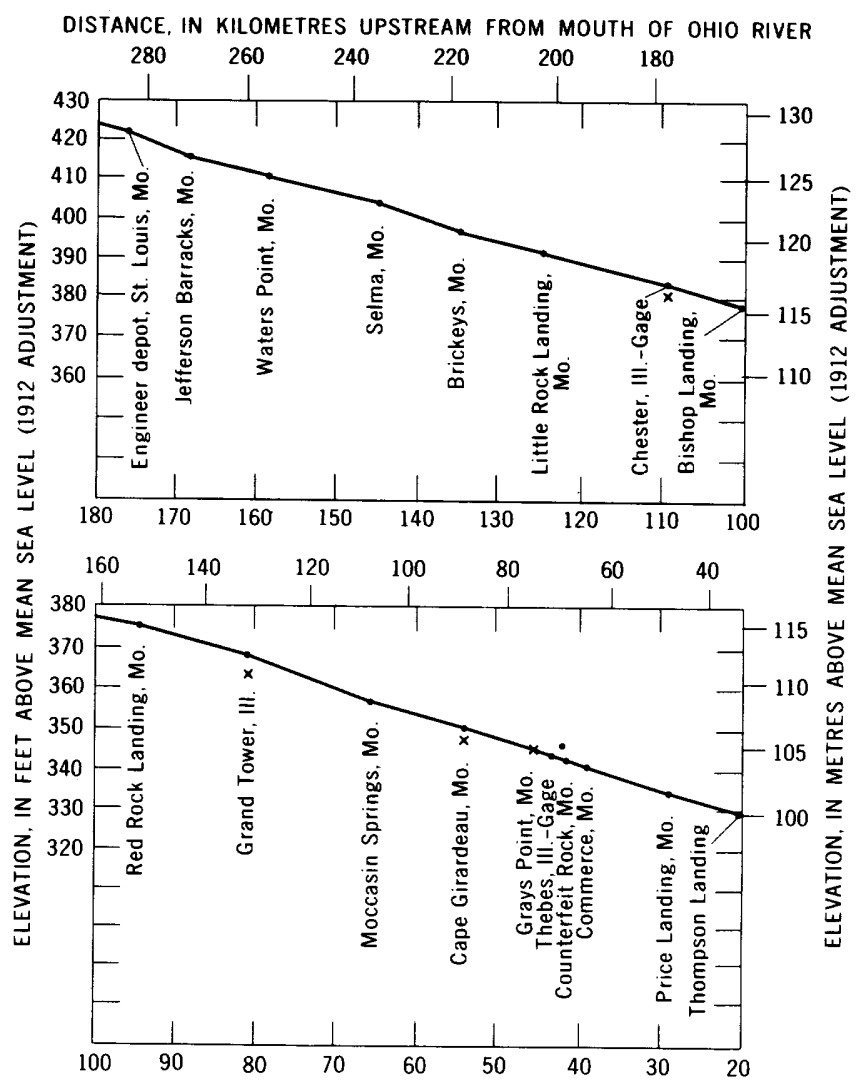

DISTANCE, IN MILES UPSTREAM FROM MOUTH OF OHIO RIVER

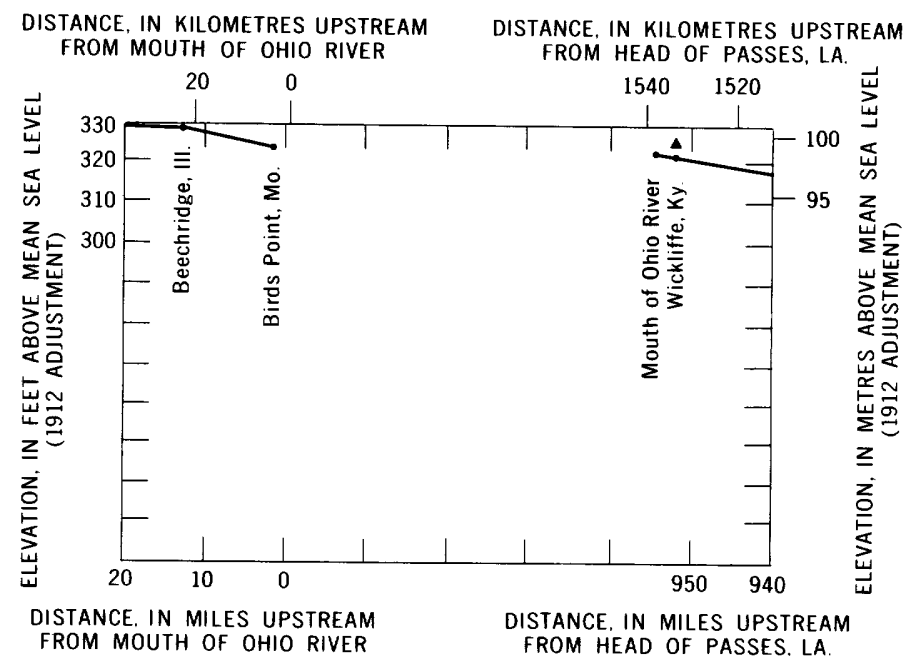

FiguRE 61.-Flood-crest profiles Mississippi River.

\section{SUSPENDED SEDIMENT}

The uppermost main-stem suspended-sediment data were collected at Keokuk, Iowa, where daily single-bottle samples were obtained downstream of Lock and Dam 19. Sediment transported at this site was nearly 24 million tons for the period March 1 to June 30 , or an average of 196,000 tons per day. The discharge-weighted mean concentration was 342
DISTANCE, IN KILOMETRES UPSTREAM FROM HEAD OF PASSES, LA.

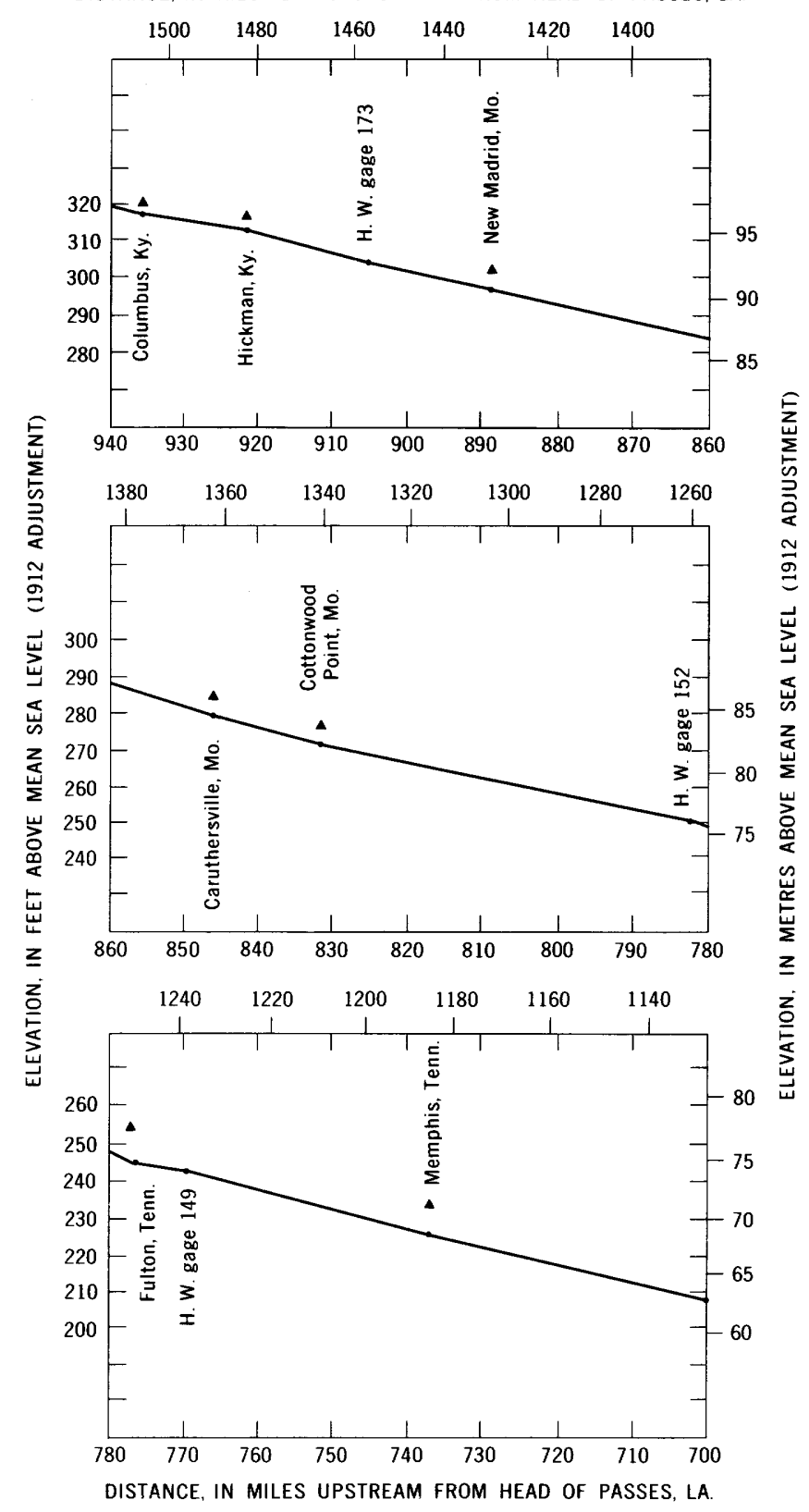

FIgURE 62.-Flood-crest profiles of Mississippi River.

$\mathrm{mg} / \mathrm{l}$ (milligrams per litre). The maximum daily load was $1,787,000$ tons with a mean concentration of $1,930 \mathrm{mg} / \mathrm{l}$ on April 24 .

At Alton, Ill., the data available (April 5-11) show an average daily load of 145,600 tons and a discharge-weighted mean concentration of $139 \mathrm{mg} / \mathrm{l}$, compared with a mean of approximately $260 \mathrm{mg} / \mathrm{l}$ for the same period at Keokuk. The samples on these 7 days averaged 9 percent sand.

At St. Louis, some of the data obtained March 26 to May 9 (daily from April 4-13) show the difference in concentration across the river caused by the 


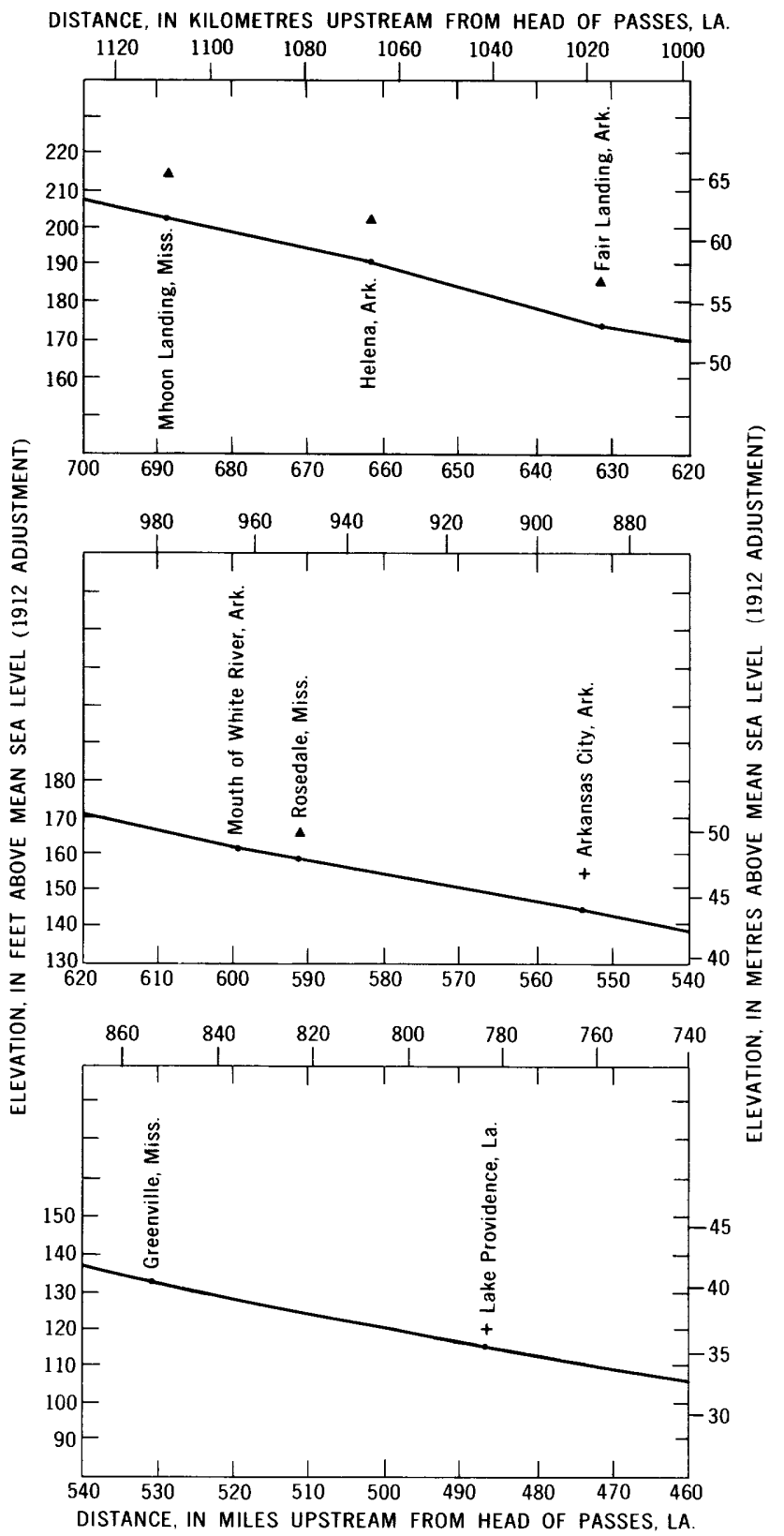

FIgURE 63.-Flood-crest profiles of Mississippi River.

relatively heavier loads discharged upstream by the Missouri River. See table 12. Concentrations for the "Missouri River water" were about double those for the "Mississippi River water." Size analysis of 12 of the 16 observations showed an average of 24 percent sand.

Observations of suspended-sediment on April 5, 7-11 at Chester, Ill., showed a discharge-weighted mean concentration of $501 \mathrm{mg} / \mathrm{l}$ and an average of 20 percent sand. At Thebes, Ill., observations April 711,13 , showed a discharge-weighted mean concentration of $584 \mathrm{mg} / \mathrm{l}$ and an average of 31 percent

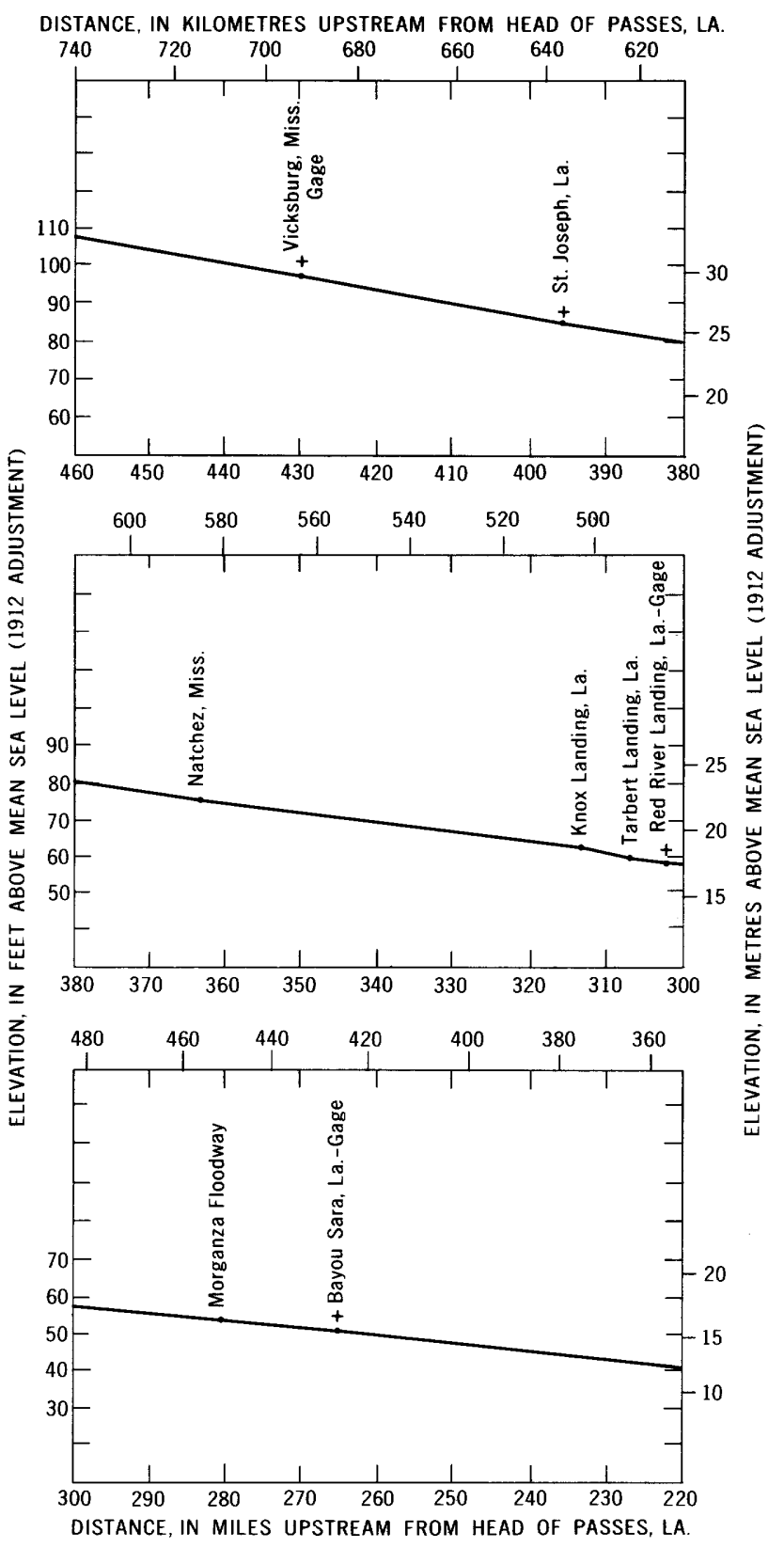

FIGURE 64.-Flood-crest profiles of Mississippi River.

sand. Thus the concentration of fines is the same $(403 \mathrm{mg} / \mathrm{l})$ at each station for this period of time.

Comprehensive water-discharge, suspended-sediment, and bed-material data were obtained MarchJune at Arkansas City, Ark., Vicksburg, Miss., and Natchez, Miss., by the Corps of Engineers, Vicksburg District. Suspended-sediment samples were generally obtained at four points at each of six verticals across the stream for each measurement. The verticals were positioned near the centroid of each of the six segments of the flow in the cross section and the points were at $11,32,54$, and 84 percent of 


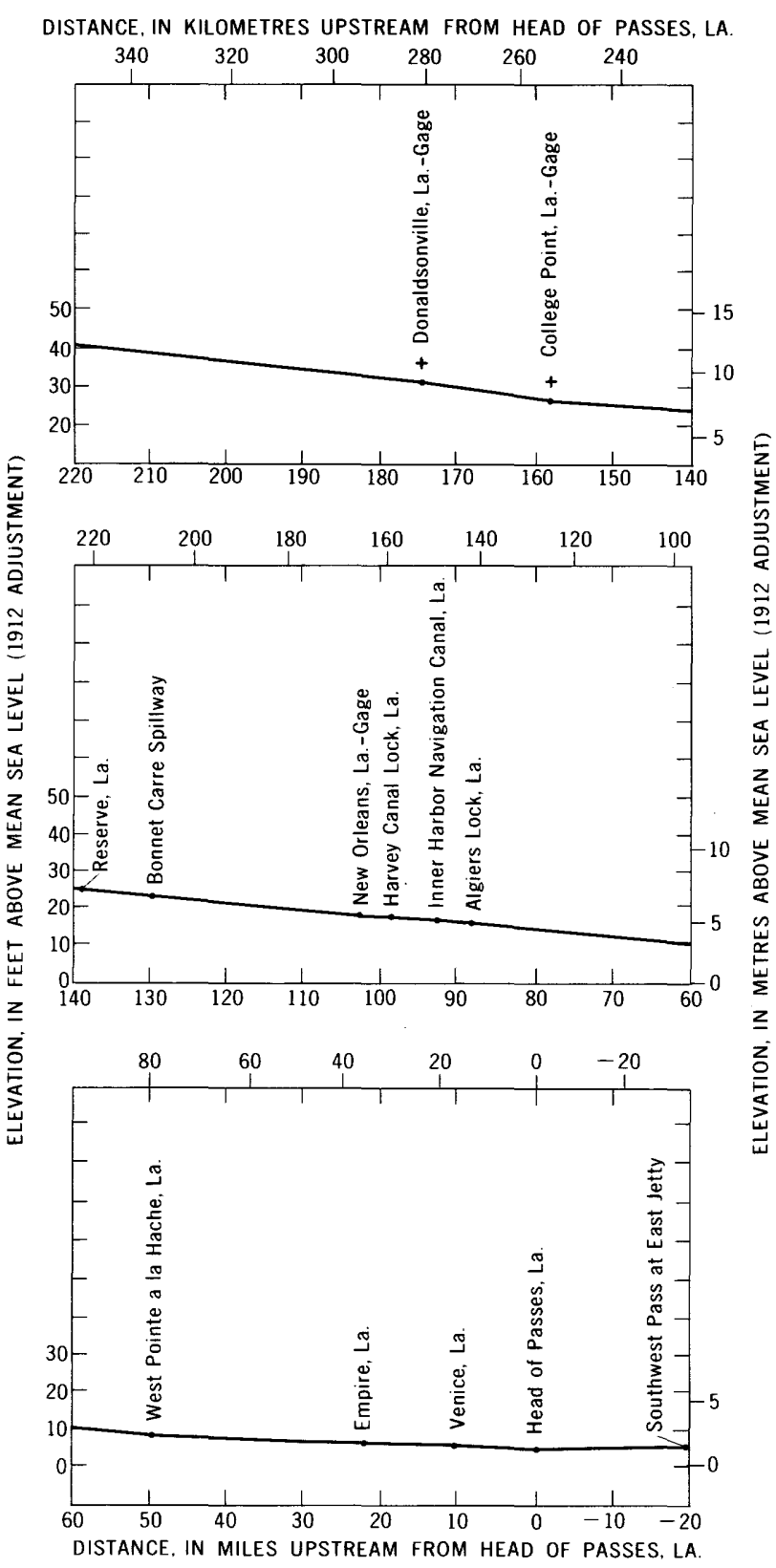

Figure 65.-Flood-crest profiles of Mississippi River.

the depth of the respective verticals. Bed-material samples were obtained at each vertical. A summary of these data (table 12) shows the average suspended sediment concentration of the point samples for the right, middle, and left two verticals and the average $D_{16}, D_{50}$, and $D_{84}$ size of bed material for all verticals for each observation.

At Arkansas City, 17 observations at about 1-week intervals indicate an average suspended-sediment concentration of $241 \mathrm{mg} / \mathrm{l}(237 \mathrm{mg} / \mathrm{l}$ dischargeweighted) which averaged 39 percent sand. The median size of bed material for these observations ranged from $0.012 \mathrm{in}$. to $0.168 \mathrm{in}$. (0.31 to $4.28 \mathrm{~mm}$ ).

At Vicksburg, 28 observations were obtained, 3 of which contain a laboratory error for the sand-sized suspended sediment. The average suspended-sediment concentration for the 25 observations was 272 $\mathrm{mg} / 1$ (288 $\mathrm{mg} / \mathrm{l}$ discharge-weighted) which averaged 47 percent sand. The median size of bed material for the 28 observations ranged from 0.019 in. to 0.129 in. $(0.48$ to $3.27 \mathrm{~mm})$.

At Natchez, 24 observations were obtained, 2 in March, 6 in April, 9 in May, and 7 in June. The average suspended-sediment concentration was $255 \mathrm{mg} / \mathrm{l}$ (253 $\mathrm{mg} / \mathrm{l}$ discharge-weighted) which averaged 49 percent sand. The median size of bed material for the 24 observations ranged from 0.014 in. to $0.019 \mathrm{in}$. ( 0.36 to $0.47 \mathrm{~mm}$ ).

These comprehensive data for Arkansas City, Vicksburg, and Natchez, together with water discharge at stations upstream from Arkansas City and downstream from Natchez, were used to estimate the total suspended-sediment transported past these stations during the March-June flood period. The totals were 122, 146, and 137 million tons for Arkansas City, Vicksburg, and Natchez, respectively. The total at Arkansas City happens to be nearly equal the sum of the Missouri River at Hermann (103 million tons) and the Mississippi River at Keokuk (24 million tons).

Daily suspended-sediment data at Tarbert Landing shows a total transport of 99 million tons in 135 million $\mathrm{ft}^{3} / \mathrm{s}$-days $\left(330\right.$ thousand $\mathrm{hm}^{3}$ ) of water discharge and thus a discharge-weighted concentration of $272 \mathrm{mg} / \mathrm{l}$ for the March-June period.

Because of the water-quality interest pertaining to Lake Pontchartrain, intensive water and suspended-sediment discharge data were obtained for flows of Bonnet Carre Floodway near Norco, La., from April 9 to June 21, the entire flow period. See map of Lake Pontchartrain area, figure 67. These data showed $\mathbf{1 5 . 4}$ million tons moving into the lake in 10.3 million $\mathrm{ft}^{3} / \mathrm{s}$-days ( 25 thousand $\mathrm{hm}^{3}$ ) of flow for a suspended-sediment discharge-weighted mean concentration of $556 \mathrm{mg} /$ l. Particle-size information is not available. Chloride and suspended-sediment concentration data for several dates, generally between April 14 and May 9, and for October 20 and November 1 are given for specific locations in Lake Pontchartrain as indicated in figure 67 and table 10. These data show a general movement and mixing of the water from Bonnet Carre Floodway as chloride concentrations drop and suspended-sediment concentration rises during the spring series of measure- 


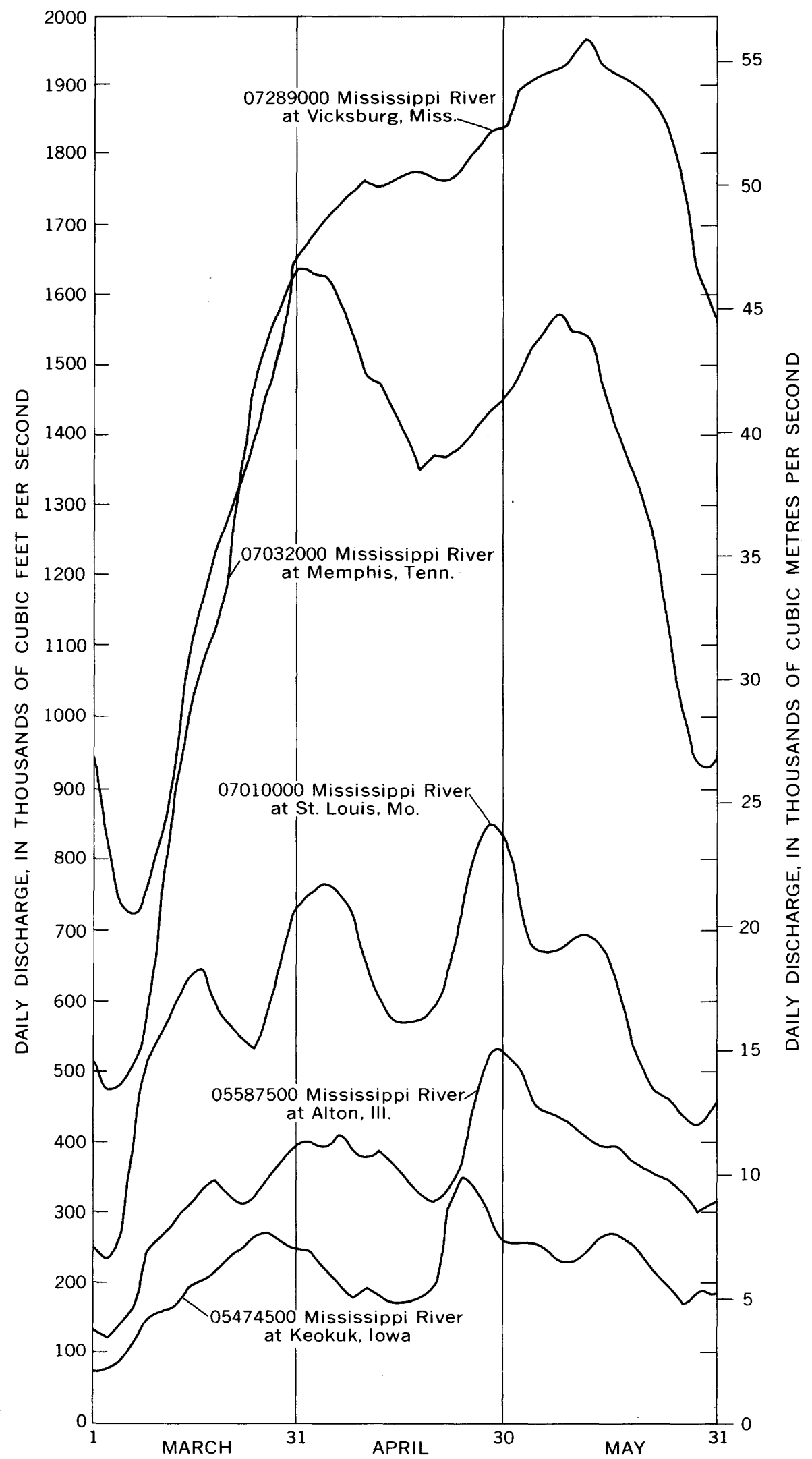

FIGURE 66.-Discharge hydrographs at selected gaging stations on the Mississippi River, March-May 1973. 
TABLE 9.-Flood-crest elevations on the Mississippi River

[Based on data furnished by U.S. Army Corps of Engineers except at U.S. Geological Survey gaging stations]

\begin{tabular}{llcc} 
Location & $\begin{array}{c}\text { Miles above } \\
\text { mouth of } \\
\text { Ohio River }\end{array}$ & Date & $\begin{array}{c}\text { Elevation } \\
\text { in feet } \\
(1912 \\
\text { adjustment) }\end{array}$ \\
\hline
\end{tabular}

Dubuque, Iowa:

Lock and dam 11, pool _-_-_._._._. 583.1

Lock and dam 11, tailwater

Gage 30 at Dubuque, Iowa -

Bellevue, Iowa:

Lock and dam 12, pool

Lock and dam 12, tailwater

Gage at Sabula, Iowa _........

Lock and dam 13, pool

Lock and dam 13, tailwater

Gage at Clinton, Iowa -...................

U.S. Geological Survey recording gage at Clinton Iowa

Lock and dam 14, pool

Lock and dam 14, tailwater

Gage at 48th St., Moline, Ill -

Lock and dam 15, pool _....................

Lock and dam 15, tailwater -.............

Gage at Fairport, Iowa -

Lock and dam 16, pool

Lock and dam 16, tailwater -..................

Gage at Muscatine, Iowa -

Lock and dam 17, pool

Lock and dam 17, tailwater -...............

Gage at Keithburg, Ill _...

Gage at Oquawka, Ill -

Lock and dam 18, pool _.............-

Lock and dam 18, tailwater _...............

Gage at Burlington, Iowa

Gage at Ft. Madison, Iowa

Keokuk, Iowa:

Lock and dam 19, pool

Lock and dam 19, tailwater and U.S.

Geological Survey recording gage

Gage at Warsaw, Ill recording gage -...-.--

Gage at Gregory Landing, M M

Lock and dam 20, pool

Lock and dam 20, tailwater

Gage at Quincy, Ill _...............

Lock and dam 21, pool

Lock and dam 21, tailwater -

Gage at Hannibal. Mo

Saverton, Mo.

Lock and dam 22, pool -...............

Lock and dam 22, tailwater

Mundy's Landing, Mo

Louisiana, Mo and dam 24 , pool

Lock and dam 24, pool

Rip Rap Landing, Ill

Mozier Landing, Ill

Sterling Landing, Mo

Lock and dam 25, pool

Lock and dam 25, tailwater

Dixon Landing, Ill

Grafton, Ill _...

Alton, Ill.:

Lock and dam 26, pool

Lock and dam 26, tailwater and U.S.

Geological Survey recording gage

Hartford, Ill

Chain of Rocks, Mo

Lock and dam 27, pool

Lock and dam 27, tailwater

ing gage - depot, St. Louis, Mo

Engineer depot, St. Louis, Mo

Jefferson Barrarks, Mo

Selma, Mo

Brickeys, Mo

Little Rock, Landing, Mo

\section{3}

Mar. 23

Mar. 23

Mar. 23

608.95

556.7

556.7

535.0

522.5

522.5

518.0

Mar. 24

Mar. 24

Mar. 24-25

Mar. 25

Mar. 25

511.8

493.3

493.3

487.9

482.9

482.9

463.5

457.2

457.2

455.2

437.2

437.0

428.0

415.9

410.5

410.5

403.1

383.9

364.3

364.2

359.9

352.9

434.2

343.2

327.9

324.9

324.9

309.9

301.2

301.1

293.0

282.9

273.5

273.2

265.0

260.3

250.8

241.5

241.2

228.3

218.0

203.0

202.7

196.8

190.4

185.3

185.1

180.0

176.8

168.7

158.5

145.8

136.0

125.5
Mar. 25

Mar. 25-26

Mar. 26

Mar. 25-26

Mar. 26-27

Mar. 25

Apr. 26

Apr. 26

Apr. 25

Apr. 25

Apr. 25

Apr. 25

Apr. 25

Apr. 25

Apr. 25

Apr. 25

Apr. 25-26

Apr. 25

Apr 25-26

Apr. 25

Apr. 26

Apr. 24

Apr. 23

Apr. 25

Apr. 23

Apr. 23

Apr. 26

Apr. 26

Apr. 24

Apr. 24

Apr. 24

Apr. 24

Apr. 24

Apr. 24

Apr. 25

Apr. 27

Apr. 27

Apr. 28

Apr. 28

Apr. 28

Apr. 28

Apr. 28

Apr. 28

Apr. 28

Apr. 28

Apr. 28

Apr. 28

Apr. 29

Apr. 29

Apr. 29

Anr. 29

Apr. 29
608.52

607.30

599.93

599.30

590.97

589.00

588.63

586.34

583.33

574.58

570.63

568.04

562.10

561.33

555.27

554.07

553.64

553.34

548.62

548.44

542.49

537.84

536.42

535.92

532.75

525.74

518.69

500.71

499.75

497.23

$\overline{493.00}$

486.99

486.40

485.80

477.57

$\overline{472.90}$

468.85

464.38

459.10

458.58

453.63

451.80

447.08

444.50

444.02

439.82

436.99

433.15

432.15

431.20

429.31

426.30

423.17

420.78

416.39

410.84

404.12

398.23

391.29

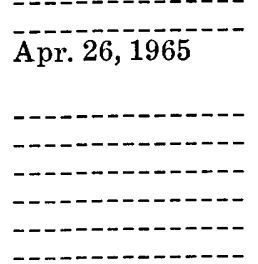

Apr. 28, 1965

- Apr.--o--o-

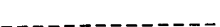

Apr. 28, 1965

-

Apr. 29, 1965

- Apr. 27,1965

Apr. 27, 1965

Apr. 30,1965

-.---.--.-..-

Apr. 30,

May 1, 1965

May 1, 1965

Mav 1, 1965

May 1, 1965

May 1,1965

-..---_-.--

(1)

May 1,1965

$\overline{11.66}$

----

-

- - -

---

587.33

-.---

--.--

564.98

(1) 
THE FLOODS

TABLE 9.-Flood-crest elevations on the Mississippi River-Continued

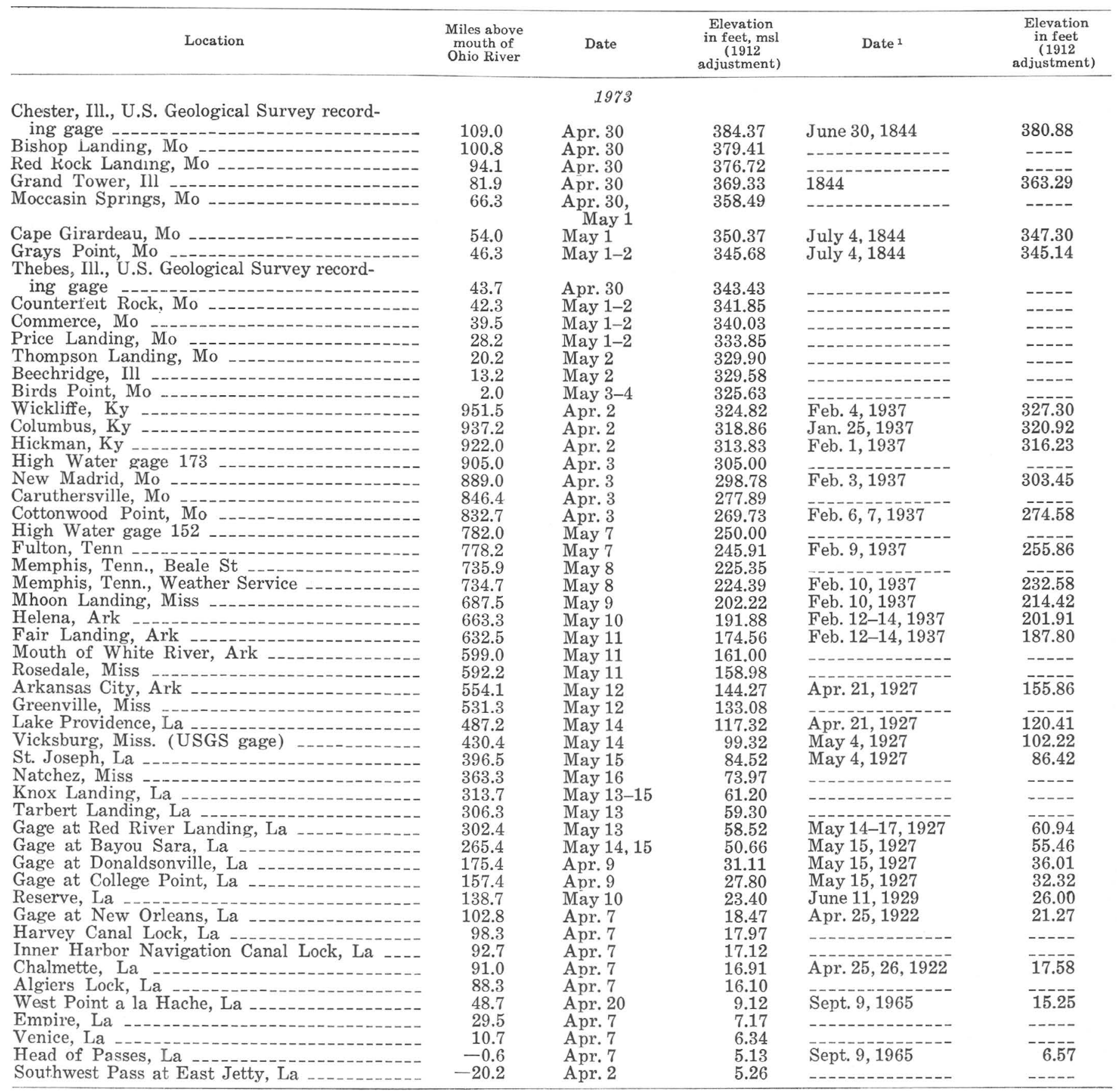

1 Prior to 1973 at selected sites.

ments. Wave action is considered responsible for suspending notable quantities of fine sand from the bed of the lake. The finest sand (0.0024 in. [0.062 $\mathrm{mm}$ ) ) usually settles from 4.72 to 7.48 in. (12 to 19 $\mathrm{cm}$ [centimetres]) per minute in still water depending on temperature (U.S. Inter-Agency Report No. 12, 1957, fig. 2).

Daily suspended-sediment loads were computed for New Orleans from April 1 to June 30 on the basis of measurements generally obtained each 2 to 7 days. If the March-April load ratio is the same as at Tarbert Landing, then the March load at New Orleans would be 39 million tons and the total for March to June would be 137 million tons. This load together with the average concentration of the available suspended-sediment samples (about $400 \mathrm{mg} / \mathrm{l}$ ) suggests that the river may have picked up considerable sediment from the channel between Natchez 


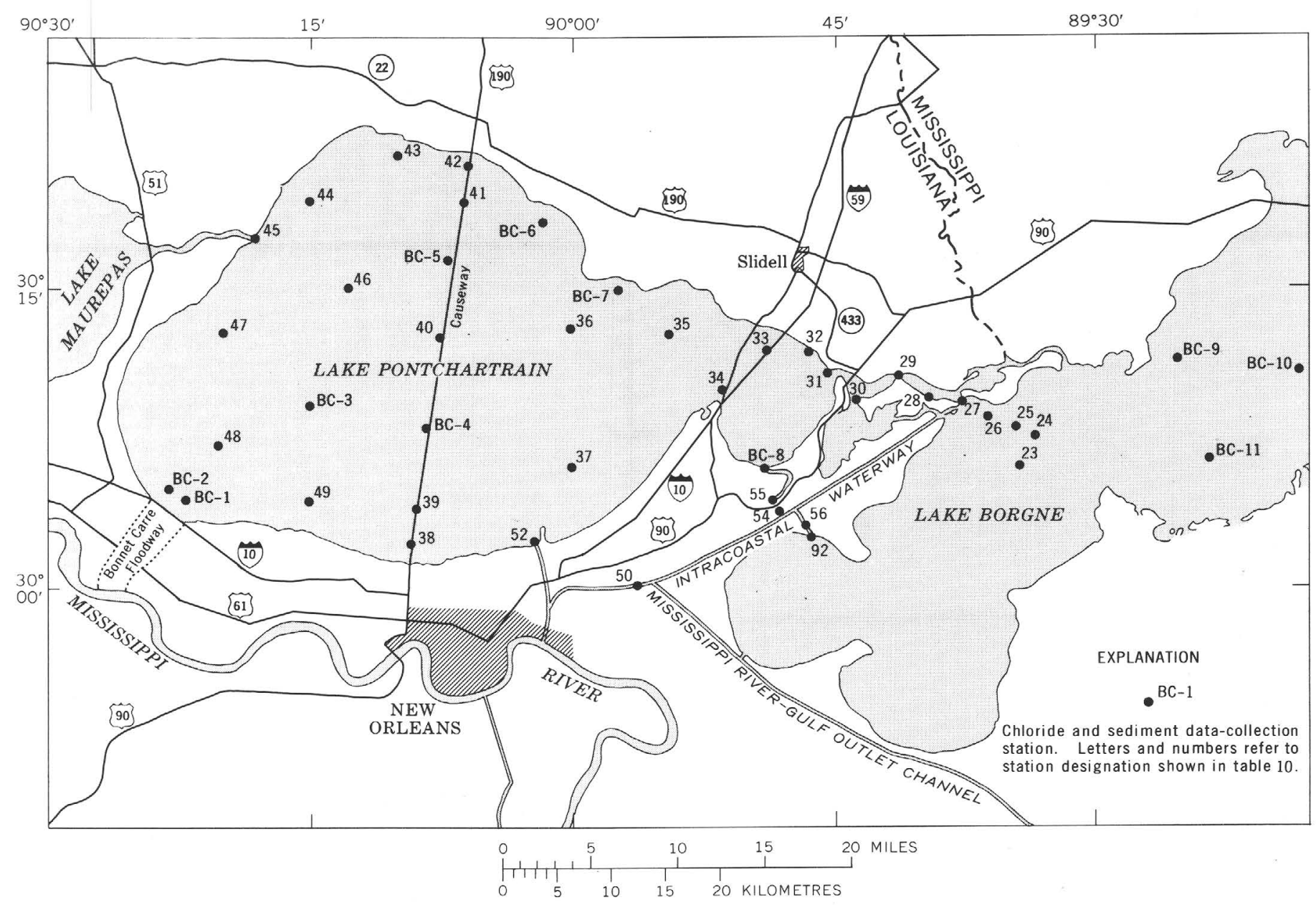

FIgURE 67.-Data collection points in Lakes Ponchartrain and Borgne, La.

and New Orleans considering, as noted previously, that approximately 40 percent of the flow at Vicksburg (and Natchez) was diverted away from the main channel on its way to New Orleans. See data for Old River Outflow Channel, Morganza Floodway, and Bonnet Carre Floodway (table 12).

At Old River Outflow Channel, 16 measurements of flow and suspended sediment between March 5 and June 26 show an average suspended-sediment concentration of $274 \mathrm{mg} / \mathrm{l}$ which is nearly identical with the $272 \mathrm{mg} / \mathrm{l}$ discharge-weighted mean for March-June at Tarbert Landing. The suspendedsediment averaged 32 percent sand. Based on the average transport rate of 259,000 tons per day for these 16 measurements, the transport in Old River Outflow Channel is estimated at 32 million tons for the March-June period.

Daily flow and suspended-sediment concentration and load data for Morganza Floodway near Krotz Springs, La., are given for April 19 to June 15. The maximum suspended-sediment concentration was
$72 \mathrm{mg} / \mathrm{l}$ and the average is approximately one-tenth of the probable concentration of the Mississippi at this diversion.

In considering the total flow and sediment movement to the Gulf of Mexico during the flood; it is also necessary to show data for the Atchafalaya River. (Data for the Red River at Alexandria are discussed in the section, "Tributary Streams in Louisiana.") Daily flow and suspended-sediment concentration and load data are given in table 12 for the Atchafalaya River at Krotz Springs, La., which is downstream from the Old River Outflow Channel. This record shows a total transport of 68 million tons for the March-June period and a discharge-weighted mean concentration of $353 \mathrm{mg} / \mathrm{l}$ of suspended sediment. Particle-size data are not available. Measurements at 3- to 5-day intervals were made on the Lower Atchafayala River at Morgan City, La.; April 18 to June 29 and on Wax Lake Outlet at Calumet, La., April 20 to June 29. These data are inadequate to estimate loads for the entire March-June period. 
TABLE 10.-Chloride and suspended-sediment data, Lake Pontchartrain, La.

[Data obtained at numerous points (fig. 35) to monitor changes in chloride and suspended sediment as a result of flow through Bonnet Carre Floodway ]

\begin{tabular}{|c|c|c|c|c|}
\hline \multirow[b]{2}{*}{ Station } & \multirow[b]{2}{*}{ Date } & \multirow[b]{2}{*}{$\begin{array}{c}\text { Chloride } \\
(\mathrm{mg} / \mathrm{l})\end{array}$} & \multicolumn{2}{|c|}{ Suspended sediment } \\
\hline & & & $\begin{array}{l}\text { Concen- } \\
\text { tration } \\
(\mathrm{mg} / \mathrm{l})\end{array}$ & $\begin{array}{l}\text { Percent } \\
\text { finer than } \\
0.062 \mathrm{~mm}\end{array}$ \\
\hline BC-1 _ & $\begin{array}{r}4-14-73 \\
4-15-73 \\
4-16-73 \\
4-23-73 \\
4-27-73 \\
4-30-73 \\
5-03-73 \\
5-06-73 \\
11-01-73\end{array}$ & $\begin{array}{r}18 \\
18 \\
10 \\
21 \\
19 \\
45 \\
16 \\
16 \\
880\end{array}$ & $\begin{array}{r}377 \\
613 \\
441 \\
330 \\
305 \\
283 \\
-\overline{262} \\
88\end{array}$ & $\begin{array}{r}91 \\
82 \\
87 \\
94 \\
92 \\
96 \\
--\overline{8} \\
100\end{array}$ \\
\hline
\end{tabular}

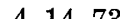

$4-15-73$

$4-16-73$

4-23-73

$4-27-73$

4-30-73

5-03-73

$5-06-73$

11-01-73

BC-3

$$
\begin{aligned}
& 4-14-73 \\
& 4-15-73 \\
& 4-16-73 \\
& 4-19-73 \\
& 4-23-73 \\
& 4-27-73 \\
& 4-30-73 \\
& 5-03-73 \\
& 5-06-73 \\
& 5-09-73
\end{aligned}
$$

11-01-73

BC-4 _..--

\section{4-14-73}

4-15-73

4-17-73

$4-21-73$

5-03-73

5-06-73

11-01-73

16
16
16
20
21
22
18
16
780

339

475

287

105

228

186

150

780

$$
\begin{aligned}
& 96 \\
& 98 \\
& 93 \\
& 96 \\
& 98 \\
& 95 \\
& 96 \\
& 96 \\
& 99
\end{aligned}
$$

$48 \quad 89$

$\begin{array}{rr}48 & 89 \\ 220 & 233\end{array}$

$20 \quad 210$

$510 \quad 173$

$730 \quad 212$

$220 \quad 209$

$24 \quad 138$

$\begin{array}{rr}18 & 112 \\ 20 & 111 \\ 44 & 93\end{array}$

1,300

93
168

1,100

1,100

300
36

18
24

24
1,800

$$
\begin{array}{r}
81 \\
104 \\
112 \\
142 \\
210 \\
109
\end{array}
$$

BC-5

$4-14-73$
$4-15-73$

$4-17-73$

$4-17-73$
$4-21-73$

$4-27-73$

5-03-73

5-06-73

11-01-73

$\begin{array}{rr}380 & 91 \\ 560 & 105 \\ 1,540 & 276 \\ 1,480 & 514 \\ 600 & 203 \\ 460 & 147 \\ 380 & 171 \\ 1,600 & 137\end{array}$

$\mathrm{BC}-6$

\begin{tabular}{|c|c|c|c|c|}
\hline \multirow[b]{2}{*}{ Station } & \multirow[b]{2}{*}{ Date } & \multirow[b]{2}{*}{$\begin{array}{l}\text { Chloride } \\
(\mathrm{mg} / \mathrm{l})\end{array}$} & \multicolumn{2}{|c|}{ Suspended sediment } \\
\hline & & & $\begin{array}{l}\text { Concen- } \\
\text { tration } \\
(\mathrm{mg} / \mathrm{I})\end{array}$ & $\begin{array}{c}\text { Percent } \\
\text { finer than } \\
0.062 \mathrm{~mm}\end{array}$ \\
\hline $\mathrm{BC}-8$ & $\begin{array}{r}4-15-73 \\
4-23-73 \\
5-03-73 \\
10-30-73\end{array}$ & $\begin{array}{r}1,700 \\
84 \\
220 \\
2,400\end{array}$ & $\begin{array}{r}308 \\
82 \\
98 \\
169\end{array}$ & $\begin{array}{r}98 \\
98 \\
94 \\
100\end{array}$ \\
\hline $\mathrm{BC}-9----$ & $\begin{array}{l}4-14-73 \\
4-19-73 \\
4-21-73 \\
4-25-73 \\
4-28-73 \\
4-30-73 \\
5-02-73 \\
5-08-73\end{array}$ & $\begin{array}{r}960 \\
910 \\
490 \\
400 \\
560 \\
480 \\
540 \\
62\end{array}$ & $\begin{array}{r}91 \\
94 \\
67 \\
83 \\
74 \\
610 \\
1,653 \\
178\end{array}$ & $\begin{array}{l}72 \\
92 \\
83 \\
77 \\
91 \\
87 \\
90 \\
94\end{array}$ \\
\hline
\end{tabular}

$$
\begin{aligned}
& 4-15-73 \\
& 4-16-73 \\
& 4-17-73 \\
& 4-23-73 \\
& 4-28-73 \\
& 4-30-73 \\
& 5-03-73 \\
& 5-07-73
\end{aligned}
$$

10-30-73

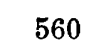

1,200

1,670
960

960
380

360

920
130

1,600

$$
251
$$

$$
\begin{array}{r}
99 \\
64 \\
98 \\
97 \\
94 \\
99 \\
98 \\
93 \\
95 \\
99 \\
100
\end{array}
$$

$$
\begin{array}{r}
95 \\
97 \\
94 \\
95 \\
98 \\
98 \\
100
\end{array}
$$

82
90
99
91
98
99
99
100

TABLE 10.-Chloride and suspended-sediment data, Lake Pontchartrain, La.-Continued

BC-10

5-08-73

$4-14-73$
$4-19-73$
$4-21-73$
$4-25-73$
$4-28-73$
$4-30-73$
$5-02-73$
$5-08-73$

1,500

2,700

2,000

380

720

1,200

660

178

4-14-73

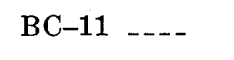

4-19-73

4-21-73

4-25-73

4-28-73

5-02-73

5-08-73

1,700

1,300

1,900

560
760

770

920

$\begin{array}{rr}114 & 96 \\ 83 & 86 \\ 96 & 95 \\ 48 & 95 \\ 46 & 94 \\ 76 & 89 \\ 85 & 94 \\ 163 & 95\end{array}$

23

4-14-73

4-19-73

4-21-73

4-23-73

4-25-73

4-28-73

4-30-73

5-02-73

5-08-73

520

1,800

1.700

480

330
680

620

900

650

122

122

142
91
69

69
50

50
81

56

1,800

4-14-73

4-21-73

4-23-73

4-25-73

4-28-73

4-30-73

5-02-73

5-08-73

1,200

360
560

1.600

910
720

340

140

\section{4}

101

128
75

160

66
70

70
86

77

97

94

69
69

48
136

136
46

137

25

4-14-73

4-19-73

4-21-73

4-23-73

4-25-73

4-28-73

4-30-73

5-02-73

5-08-73

1,800

920

360

630

860
700

460

120

1,750

760

4-19-73

4-21-73

4-23-73

4-25-73

4-28-73

4-30-73

5-02-73

5-08-73

27

$4-15-73$
$4-23-73$

540
1,900
5-07-73

10-30-73
820

700

510
78

$82 \quad 80$

$82 \quad 98$

63
$312 \quad 97$
125

$$
125
$$

$60 \quad 97$

$256 \quad 98$

71
274

$173 \quad 95$

$342 \quad 97$

$133 \quad 9$

$78 \quad 96$

$\begin{array}{ll}75 & 93 \\ 90 & 94\end{array}$

$131 \quad 92$

$\begin{array}{ll}48 & 88 \\ 56 & 89\end{array}$

$\begin{array}{ll}56 & 89 \\ 56 & 93\end{array}$

1,660

216

97
92 
TABLE 10.-Chloride and suspended-sediment data, Lake Pontchartrain, La.-Continued

\begin{tabular}{|c|c|c|c|c|}
\hline \multirow[b]{2}{*}{ Station } & \multirow[b]{2}{*}{ Date } & \multirow[b]{2}{*}{$\begin{array}{l}\text { Chloride } \\
(\mathrm{mg} / \mathrm{l})\end{array}$} & \multicolumn{2}{|c|}{ Suspended sediment } \\
\hline & & & $\begin{array}{l}\text { Concen- } \\
\text { tration } \\
(\mathrm{mg} / \mathrm{l})\end{array}$ & $\begin{array}{l}\text { Percent } \\
\text { finer than } \\
0.062 \mathrm{~mm}\end{array}$ \\
\hline & $\begin{array}{r}4-30-73 \\
5-07-73 \\
10-30-73\end{array}$ & $\begin{array}{r}660 \\
240 \\
2,500\end{array}$ & $\begin{array}{r}136 \\
65 \\
327\end{array}$ & $\begin{array}{r}87 \\
92 \\
100\end{array}$ \\
\hline $28 \ldots$ & $\begin{array}{r}4-15-73 \\
4-19-73 \\
4-23-73 \\
4-30-73 \\
5-07-73 \\
10-30-73\end{array}$ & $\begin{array}{r}1,200 \\
700 \\
680 \\
320 \\
260 \\
2,800\end{array}$ & $\begin{array}{r}120 \\
81 \\
93 \\
69 \\
90 \\
191\end{array}$ & $\begin{array}{l}92 \\
93 \\
89 \\
93 \\
96 \\
97\end{array}$ \\
\hline $29---$ & $\begin{array}{r}4-15-73 \\
4-19-73 \\
4-23-73 \\
4-30-73 \\
5-07-73 \\
10-30-73\end{array}$ & $\begin{array}{r}1,520 \\
580 \\
680 \\
840 \\
100 \\
2,400\end{array}$ & $\begin{array}{r}212 \\
128 \\
96 \\
90 \\
68 \\
254\end{array}$ & $\begin{array}{r}95 \\
97 \\
94 \\
95 \\
95 \\
100\end{array}$ \\
\hline 30 & $\begin{array}{r}4-15-73 \\
4-19-73 \\
4-23-73 \\
4-28-73 \\
4-30-73 \\
5-03-73 \\
5-07-73 \\
10-30-73\end{array}$ & $\begin{array}{r}1,940 \\
760 \\
740 \\
910 \\
850 \\
320 \\
42 \\
2,600\end{array}$ & $\begin{array}{r}147 \\
131 \\
164 \\
158 \\
86 \\
96 \\
85 \\
167\end{array}$ & $\begin{array}{l}93 \\
96 \\
97 \\
97 \\
93 \\
94 \\
99 \\
99\end{array}$ \\
\hline $31_{-}$ & $\begin{array}{r}4-15-73 \\
4-19-73 \\
4-23-73 \\
4-28-73 \\
4-30-73 \\
5-07-73 \\
10-30-73\end{array}$ & $\begin{array}{r}1,920 \\
690 \\
810 \\
730 \\
630 \\
310 \\
2,600\end{array}$ & $\begin{array}{r}229 \\
98 \\
103 \\
87 \\
65 \\
81 \\
189\end{array}$ & $\begin{array}{l}97 \\
95 \\
91 \\
79 \\
80 \\
90 \\
98\end{array}$ \\
\hline 32 & $10-30-73$ & 2,600 & 211 & 99 \\
\hline $33---$ & $10-30-73$ & 2,600 & 203 & 98 \\
\hline $34 \ldots$ & $10-30-73$ & 2,400 & 243 & 99 \\
\hline 35 & $10-30-73$ & 2,100 & 230 & 99 \\
\hline $36 \ldots$ & $10-30-73$ & 2,200 & 266 & 91 \\
\hline $37 \ldots$ & $10-30-73$ & 2,300 & 144 & 90 \\
\hline $38 \ldots$ & $\begin{array}{r}4-14-73 \\
4-15-73 \\
4-17-73 \\
4-21-73 \\
4-27-73 \\
5-03-73 \\
5-06-73 \\
5-09-73 \\
11-01-73\end{array}$ & $\begin{array}{r}520 \\
420 \\
80 \\
62 \\
80 \\
41 \\
31 \\
38 \\
1,400\end{array}$ & $\begin{array}{r}1,010 \\
764 \\
16 \\
65 \\
173 \\
58 \\
70 \\
100 \\
113\end{array}$ & $\begin{array}{l}81 \\
99 \\
76 \\
97 \\
96 \\
92 \\
92 \\
95 \\
97\end{array}$ \\
\hline $39 \ldots$ & $\begin{array}{r}4-14-73 \\
4-17-73 \\
4-21-73 \\
4-27-73 \\
5-03-73 \\
5-06-73 \\
5-09-73 \\
11-01-73\end{array}$ & $\begin{array}{r}260 \\
200 \\
170 \\
78 \\
22 \\
18 \\
22 \\
1,800\end{array}$ & $\begin{array}{r}84 \\
102 \\
154 \\
248 \\
156 \\
82 \\
68 \\
99\end{array}$ & $\begin{array}{l}96 \\
95 \\
97 \\
97 \\
96 \\
96 \\
91 \\
98\end{array}$ \\
\hline $40 \ldots$ & $\begin{array}{r}4-14-73 \\
-4-17-73 \\
4-21-73 \\
5-03-73 \\
5-06-73 \\
11-01-73\end{array}$ & $\begin{array}{r}780 \\
860 \\
100 \\
270 \\
270 \\
190 \\
1,900\end{array}$ & $\begin{array}{l}172 \\
206 \\
184 \\
241 \\
164 \\
155 \\
233\end{array}$ & $\begin{array}{l}94 \\
93 \\
98 \\
96 \\
97 \\
91 \\
99\end{array}$ \\
\hline $41 \ldots$ & $11-01-73$ & 1,100 & 47 & 91 \\
\hline
\end{tabular}

TABLE 10.-Chloride and suspended-sediment data, Lake Pontchartrain, La.-Continued

\begin{tabular}{|c|c|c|c|c|}
\hline \multirow[b]{2}{*}{ Station } & \multirow[b]{2}{*}{ Date } & \multirow[b]{2}{*}{$\underset{(\mathrm{mg} / \mathrm{l})}{\text { Chloride }}$} & \multicolumn{2}{|c|}{ Suspended sediment } \\
\hline & & & $\begin{array}{l}\text { Concen- } \\
\text { tration } \\
(\mathrm{mg} / \mathrm{l})\end{array}$ & $\begin{array}{l}\text { Percent } \\
\text { finer than } \\
0.062 \mathrm{~mm}\end{array}$ \\
\hline 42 & $11-01-73$ & 1,300 & 116 & 97 \\
\hline $43 \ldots$ & $\begin{array}{r}4-14-73 \\
4-15-73 \\
4-21-73 \\
4-23-73 \\
4-27-73 \\
4-30-73 \\
5-03-73 \\
5-06-73 \\
11-01-73\end{array}$ & $\begin{array}{r}180 \\
280 \\
720 \\
720 \\
96 \\
340 \\
500 \\
660 \\
840\end{array}$ & $\begin{array}{r}67 \\
167 \\
179 \\
114 \\
28 \\
83 \\
128 \\
221 \\
99\end{array}$ & $\begin{array}{l}89 \\
65 \\
92 \\
95 \\
82 \\
74 \\
93 \\
87 \\
95\end{array}$ \\
\hline $44----$ & $\begin{array}{r}4-14-73 \\
4-15-73 \\
4-21-73 \\
4-23-73 \\
4-27-73 \\
4-30-73 \\
5-03-73 \\
5-06-73 \\
11-01-73\end{array}$ & $\begin{array}{l}18 \\
60 \\
18 \\
12 \\
11 \\
12 \\
240 \\
130 \\
220\end{array}$ & $\begin{array}{r}33 \\
178 \\
106 \\
51 \\
45 \\
42 \\
104 \\
150 \\
73\end{array}$ & $\begin{array}{l}76 \\
62 \\
85 \\
86 \\
86 \\
82 \\
88 \\
78 \\
93\end{array}$ \\
\hline $45 \ldots$ & $\begin{array}{r}4-14-73 \\
4-15-73 \\
4-16-73 \\
4-21-73 \\
4-23-73 \\
4-27-73 \\
4-30-73 \\
5-03-73 \\
5-06-73 \\
11-01-73\end{array}$ & $\begin{array}{r}160 \\
180 \\
320 \\
200 \\
120 \\
78 \\
60 \\
270 \\
200 \\
760\end{array}$ & $\begin{array}{r}64 \\
281 \\
344 \\
118 \\
76 \\
79 \\
31 \\
149 \\
111 \\
83\end{array}$ & $\begin{array}{l}72 \\
60 \\
76 \\
71 \\
79 \\
73 \\
68 \\
91 \\
90 \\
96\end{array}$ \\
\hline $46 \ldots$ & $11-01-73$ & 970 & 79 & 97 \\
\hline $47 \ldots$ & $\begin{array}{r}4-14-73 \\
4-15-73 \\
4-16-73 \\
4-21-73 \\
4-23-73 \\
4-27-73 \\
4-30-73 \\
5-03-73 \\
5-06-73 \\
11-01-73\end{array}$ & $\begin{array}{r}460 \\
220 \\
460 \\
180 \\
340 \\
340 \\
50 \\
58 \\
130 \\
860\end{array}$ & $\begin{array}{r}66 \\
79 \\
---- \\
---- \\
---- \\
---- \\
--\overline{113} \\
115 \\
107\end{array}$ & $\begin{array}{r}96 \\
99 \\
--- \\
--- \\
--- \\
-- \\
94 \\
86 \\
98\end{array}$ \\
\hline 48 & $\begin{array}{r}4-14-73 \\
4-15-73 \\
4-16-73 \\
4-23-73 \\
4-27-73 \\
4-30-73 \\
5-03-73 \\
5-06-73 \\
5-09-73 \\
11-01-73\end{array}$ & $\begin{array}{r}20 \\
18 \\
18 \\
740 \\
21 \\
24 \\
19 \\
20 \\
16 \\
1,200\end{array}$ & $\begin{array}{l}142 \\
159 \\
336 \\
117 \\
248 \\
105 \\
120 \\
137 \\
137 \\
184\end{array}$ & $\begin{array}{r}\mathbf{1 0 0} \\
\mathbf{9 4} \\
72 \\
83 \\
98 \\
98 \\
95 \\
97 \\
99 \\
99\end{array}$ \\
\hline 49 & $\begin{array}{r}4-14-73 \\
4-15-73 \\
4-16-73 \\
4-19-73 \\
4-23-73 \\
4-27-73 \\
4-30-73 \\
5-03-73 \\
5-06-73 \\
5-09-73 \\
11-01-73\end{array}$ & $\begin{array}{r}42 \\
75 \\
85 \\
22 \\
100 \\
28 \\
36 \\
30 \\
34 \\
16 \\
1,100\end{array}$ & $\begin{array}{r}54 \\
63 \\
256 \\
230 \\
166 \\
96 \\
182 \\
63 \\
148 \\
124 \\
222\end{array}$ & $\begin{array}{r}99 \\
100 \\
98 \\
99 \\
97 \\
97 \\
97 \\
92 \\
96 \\
98 \\
99\end{array}$ \\
\hline $50 \ldots$ & $\begin{array}{l}4-15-73 \\
4-16-73 \\
4-19-73 \\
4-23-73\end{array}$ & $\begin{array}{r}1,100 \\
1,400 \\
260 \\
200\end{array}$ & $\begin{array}{r}152 \\
98 \\
52 \\
180\end{array}$ & $\begin{array}{l}97 \\
89 \\
98 \\
97\end{array}$ \\
\hline
\end{tabular}


TABLE 10.-Chloride and suspended-sediment data, Lake Pontchartrain, La.-Continued

\begin{tabular}{|c|c|c|c|c|}
\hline \multirow[b]{2}{*}{ Station } & \multirow[b]{2}{*}{ Date } & \multirow[b]{2}{*}{$\underset{(\mathrm{mg} / \mathrm{l})}{\text { Chloride }}$} & \multicolumn{2}{|c|}{ Suspended sediment } \\
\hline & & & $\begin{array}{l}\text { concen- } \\
\text { tration } \\
(\mathrm{mg} / \mathrm{l})\end{array}$ & $\begin{array}{l}\text { Percent } \\
\text { finer than } \\
0.062 \mathrm{~mm}\end{array}$ \\
\hline & $\begin{array}{l}4-30-73 \\
5-03-73 \\
5-07-73\end{array}$ & $\begin{array}{l}82 \\
36 \\
58\end{array}$ & $\begin{array}{r}306 \\
66 \\
108\end{array}$ & $\begin{array}{l}92 \\
95 \\
95\end{array}$ \\
\hline $52 \ldots$ & $\begin{array}{r}4-17-73 \\
10-30-73\end{array}$ & $\begin{array}{r}310 \\
2,200\end{array}$ & $\begin{array}{r}65 \\
364\end{array}$ & $\begin{array}{l}97 \\
99\end{array}$ \\
\hline 54 & $\begin{array}{l}4-15-73 \\
4-19-73 \\
4-23-73 \\
4-30-73 \\
5-03-73 \\
5-07-73\end{array}$ & $\begin{array}{r}1,800 \\
680 \\
100 \\
530 \\
140 \\
28\end{array}$ & $\begin{array}{r}333 \\
139 \\
89 \\
131 \\
95 \\
86\end{array}$ & $\begin{array}{r}98 \\
98 \\
100 \\
95 \\
95 \\
78\end{array}$ \\
\hline 55 & $\begin{array}{r}4-15-73 \\
4-23-73 \\
10-30-73\end{array}$ & $\begin{array}{r}1,800 \\
260 \\
2,600\end{array}$ & $\begin{array}{r}322 \\
91 \\
274\end{array}$ & $\begin{array}{l}99 \\
99 \\
99\end{array}$ \\
\hline 56 & $\begin{array}{r}4-15-73 \\
4-19-73 \\
4-23-73 \\
4-30-73 \\
5-07-73 \\
10-30-73\end{array}$ & $\begin{array}{r}1,800 \\
750 \\
290 \\
680 \\
78 \\
2,700\end{array}$ & $\begin{array}{r}185 \\
--- \\
-8 \overline{1} \\
95 \\
274\end{array}$ & $\begin{array}{r}96 \\
--- \\
-\overline{91} \\
95 \\
99\end{array}$ \\
\hline $92 \ldots$ & $10-30-73$ & 2,700 & 367 & 87 \\
\hline
\end{tabular}

Even though the concentrations of the available data are somewhat less than at Krotz Springs, the sum of the sediment discharge for Morgan City and Calumet appears to be roughly equal that of the river at Krotz Springs.

\section{TRIBUTARY STREAMS-FLOODING AND SUSPENDED SEDIMENT}

The following brief descriptions of tributary flooding are presented on a state-by-state basis, beginning with the State of Minnesota and proceeding in a downstream direction. The authors believe that this type of text presentation will be more convenient for the reader than a basin approach. However, the gaging-station data for streamflow and sediment are shown in the traditional manner in all tabulations; that is, the stations are arranged in downstream order within the basins.

\section{TRIBUTARY STREAMS IN MINNESOTA}

Tributary inflow from Minnesota streams was not significant during the 1973 Mississippi River basin floods. Recurrence intervals of recorded flood peaks on these streams ranged from about 2 to 9 years, but most streams experienced only minor rises during the period. The data from these streams are useful in delineating those areas of the Mississippi River basin where tributary inflow did not contribute to the major main-stem flooding downstream but these data are not included in this report.
The only gaging-station data included for this State, in addition to that for main-stem stations on the Mississippi, are for the Root River near Houston where daily suspended-sediment data are available from April 13 to June 30, 1973. The Root River data are typical of many tributaries draining to the Mississippi from Minnesota and Wisconsin. Rapid changes in suspended-sediment transport rate can be noted for many storms-the transport on April 14 was 356 tons $(128 \mathrm{mg} / \mathrm{l})$ and on April 16 it was 30,600 tons $(1,660 \mathrm{mg} / \mathrm{l})$.

\section{TRIBUTARY STREAMS IN WISGONSIN}

Outstanding peak discharges with recurrence intervals exceeding 100 years were recorded on the Fox River and its tributary, Sugar Creek, in the Illinois River basin in extreme southern Wisconsin and on Turtle and Little Turtle Creeks in the Rock River basin. The 1973 flood-crest profiles are shown for Little Turtle Creek and the 100-year flood profile is shown for Turtle Creek in figure 68.

The major impact of this flooding was felt in the Beloit area where the record-breaking flood on Turtle Creek inundated a 40-square block area of Beloit and South Beloit (fig. 69). Factories, stores, homes, and a motel were hard hit. Hundreds of residents were temporarily left homeless, and production was halted or curtailed in several plants.

Elsewhere in the State, 5- to 10-year recurrence interval floods were recorded on Mississippi River tributaries, and effects of the flooding were much less severe.

\section{TRIBUTARY STREAMS IN IOWA}

Numerous outstanding tributary floods occurred during March-May 1973 in Iowa. The largest of these floods occurred in late April in the Wapsipinicon, Iowa, Skunk, and Des Moines River basins of southeastern Iowa, at a time when the Mississippi River was approaching its second spring crest. This synchronization of flood events not only caused record stages on the Mississippi River but helped to keep the Mississippi above flood stage in excess of 2 months from Keithsburg, Ill., to the mouth.

A heavy snowstorm during April 8-10 caused an accumulation of 15 to $20 \mathrm{in}$. ( 381 to $508 \mathrm{~mm}$ ) of wet snow in the lower part of the Wapsipinicon River basin and was a primary reason for record flooding 10 days later. Heavy rains accompanied by rapid snowmelt during April 20-22 produced a record flood at the gaging station near DeWitt on April 22; flood stage was exceeded at the DeWitt station for 


\section{DISTANCE, IN KILOMETRES UPSTREAM FROM MOUTH}

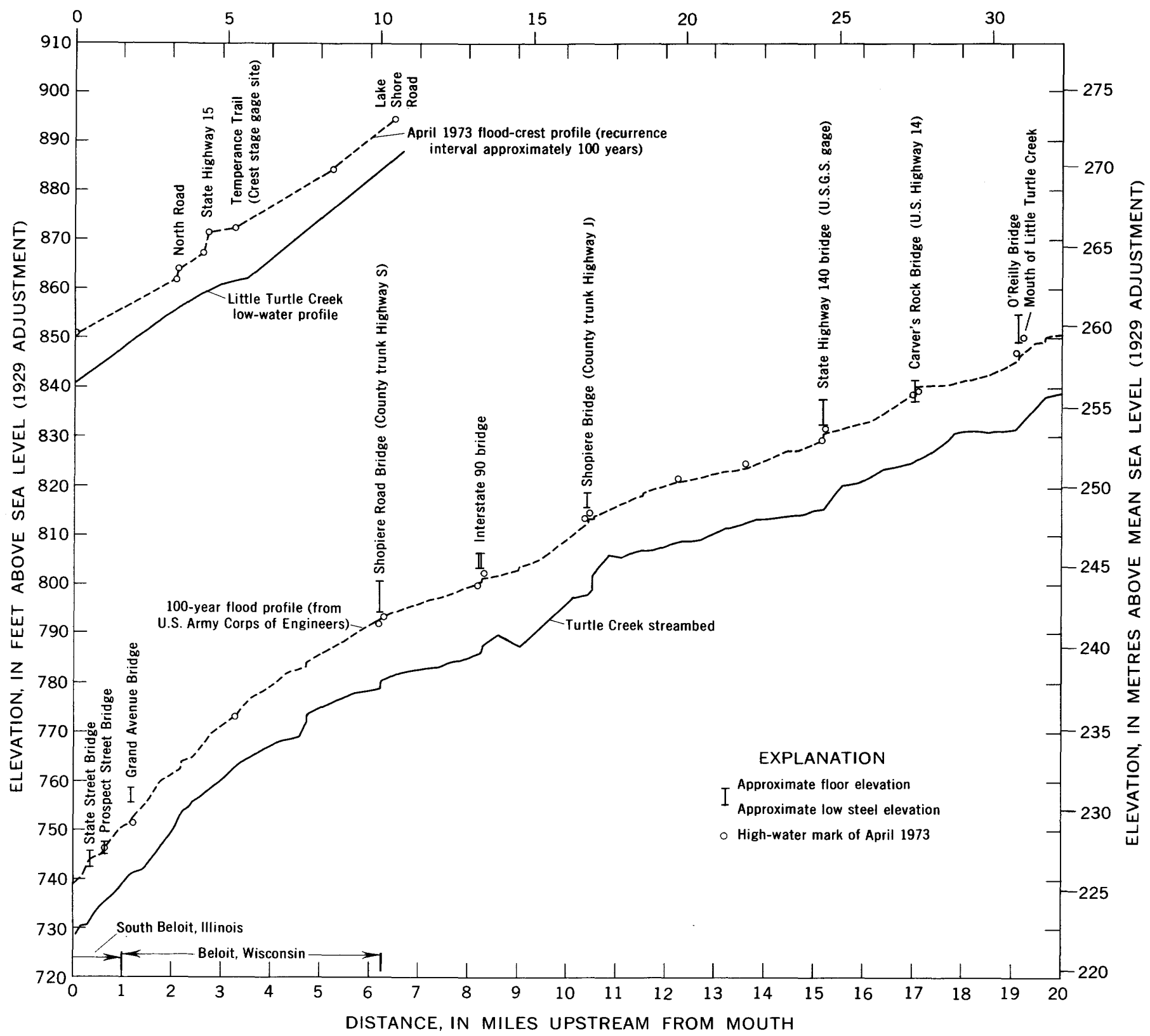

Figure 68.-Flood-crest profiles of Turtle and Little Turtle Creeks, Rock and Walworth Counties, Wis.

34 consecutive days (April 16 to May 19), a new record.

The suspended-sediment data for the Wapsipinicon River at DeWitt shows the variability of sediment movement reflecting the availability of sediment for the river to carry. The breakup of ice caused the concentration to reach a mean value of $2,180 \mathrm{mg} / \mathrm{l}$ for March 7 at a mean flow of $4,500 \mathrm{ft}^{3} / \mathrm{s}$ $\left(127 \mathrm{~m}^{3} / \mathrm{s}\right.$ ) for the day. The peak flood day (April 22) had a mean flow of $25,400 \mathrm{ft}^{3} / \mathrm{s}\left(719 \mathrm{~m}^{3} / \mathrm{s}\right)$ and $415 \mathrm{mg} / \mathrm{l}$. The maximum daily sediment transport rate of 52,000 tons was reached on May 28 when the mean flow was $5,700 \mathrm{ft}^{3} / \mathrm{s}\left(161 \mathrm{~m}^{3} / \mathrm{s}\right)$ at 3,390 $\mathrm{mg} / \mathrm{l}$, which occurred after many of the farmers had planted their crops.

Excessive runoff from the Iowa River basin began in July 1972. Numerous storms moved across the region during the period July 1972 to February 1973 , saturating the basin, causing very high base flows in the streams, and setting the stage for the 1973 spring floods. Flooding occurred at most gaging stations in the basin during March through May 


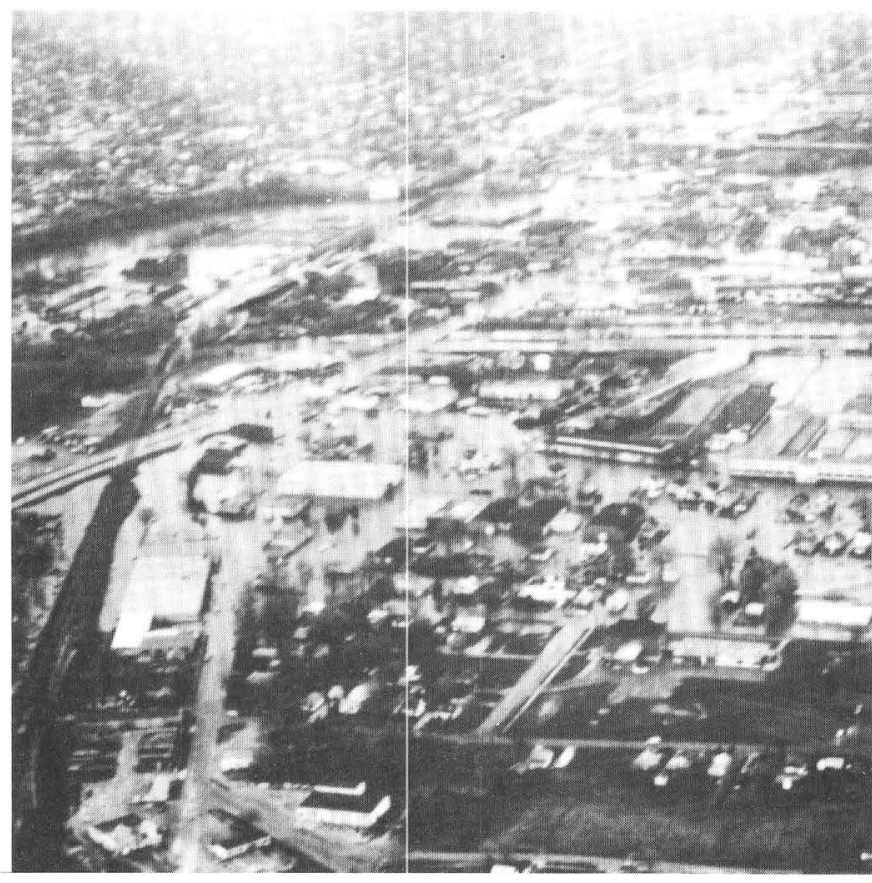

FIGURE 69.-Effects of Turtle Creek flooding at Beloit, Wis., April 21, 1973.

1973 , but the only station where an outstanding flood event occurred was near the mouth of the Iowa River at Wapello. Even though the peak discharge at Wapello was reduced approximately $20,000 \mathrm{ft}^{3} / \mathrm{s}$ $\left(566 \mathrm{~m}^{3} / \mathrm{s}\right)$ by the operation of Coralville Reservoir, the peak stage of April 22 exceeded the previously known peak by $1.2 \mathrm{ft}(0.37 \mathrm{~m})$.

Daily suspended-sediment data are shown in table 12 for the Iowa River at Marengo and the Iowa River at Iowa City, a few miles upstream and a few miles downstream from Coralville Reservoir, respectively. The data at Marengo are probably typical of rural basins in Iowa for this event, and the data at Iowa City show the effect of the reservoir in trapping sediment. Until April 20 the suspended-sediment concentration was notably lower at Iowa City than at Marengo. Though much of the flow on that day of 15,100 $\mathrm{ft}^{3} / \mathrm{s}\left(428 \mathrm{~m}^{3} / \mathrm{s}\right)$ was stored in the reservoir $[2,700$ $\mathrm{ft}^{3} / \mathrm{s}\left(76.5 \mathrm{~m}^{3} / \mathrm{s}\right)$ at Iowa City] the concentration at Iowa City was $780 \mathrm{mg} / \mathrm{l}$ compared to $145 \mathrm{mg} / \mathrm{l}$ at Marengo. On the 21st the concentration at Iowa City was $1,580 \mathrm{mg} / 1$ versus $160 \mathrm{mg} / \mathrm{l}$ at Marengo. Small tributary inflow between the dam and Iowa City may have contributed substantially to these concentrations. As occurred on the Wapsipinicon, a heavy sediment load was moved by the Iowa River on May 28 after a period of relatively dry weather when crops could be planted.
During the period April 20-22, intense rains of more than $6.5 \mathrm{in} .(165 \mathrm{~mm})$ fell in the lower part of the Skunk River basin. Because the basin had already been saturated by preceding rain storms and snowstorms, flash floods occurred, forcing many families from their homes and causing extensive property damage. Record stages occurred at gaging stations on Big Creek near Mt. Pleasant and Skunk River at Augusta. Flood profiles for Big Creek and Skunk River are shown in figure 70. The peak discharges at the Big Creek and Skunk River stations had recurrence intervals of 90 years and greater than 100 years, respectively. At the Skunk River station, the stage and discharge are believed to be the greatest since at least 1851 .

Only the lower part of the Skunk River basin downstream from the confluence of the North and South Skunk Rivers experienced outstanding floods. This was because most of the intense rainfall occurred in the lower reaches of the basin. The time lag between precipitation and peak discharge at the Augusta gaging station was shortened tremendously by the rainfall distribution pattern: during previous floods the peak discharge followed the initial rise by 7 or more days, but the April peak occurred within $21 / 2$ days.

In the Des Moines River basin, runoff became excessive in July 1972 and continued through the fall and winter. During March-May 1973, snowmelt and heavy rainfall produced several medium to high floodflow conditions. However, significant flooding was limited to the upper Des Moines River, primarily because of storage in Lake Red Rock. The lake retained a record storage of $1,608,000$ acre-feet $\left(1,980 \mathrm{hm}^{3}\right)$ of water, nearly 88 percent of capacity and within $2 \mathrm{ft}(0.61 \mathrm{~m})$ of full flood-control level. Peak discharges and stages of record were not exceeded, but the volume of floodflow from the basin over an extended period aggravated the flood situation on the Mississippi River.

The suspended-sediment record of the Chariton River near Chariton, Iowa, is probably typical of many tributary streams in south-central Iowa. The maximum daily mean concentration was $2,790 \mathrm{mg} / \mathrm{l}$ on May 27 when 10,300 tons were transported in a mean flow of $1,220 \mathrm{ft}^{3} / \mathrm{s}\left(34.6 \mathrm{~m}^{3} / \mathrm{s}\right)$ for the day. At the Marengo and DeWitt stations the peak load occurred on May 28.

\section{TRIBUTARY STREAMS IN ILLINOIS}

In Illinois, significant flood peaks and volumes were recorded only on the Rock and Edwards Riv- 


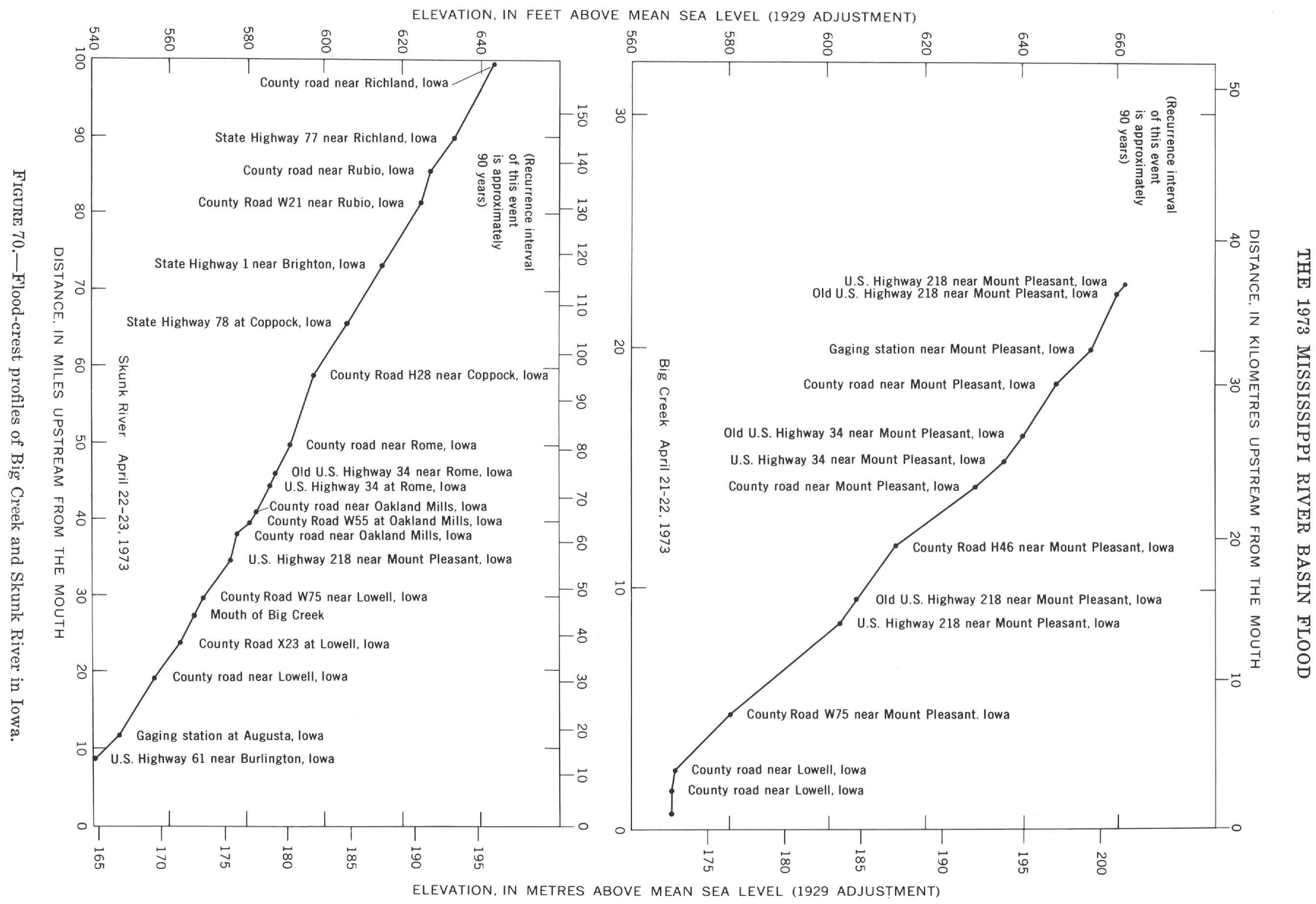


ers in the northwestern part of the State. At the gaging station on Rock River near Joslin, the recurrence interval of the peak discharge was only 17 years; however, flood volumes for 7-, 15-, and 30-day periods were the greatest in 34 years of record. For Edwards River near New Boston, the recurrence interval of the peak discharge exceeded 100 years; the recurrence intervals of the 1- to 30-day flood volumes also exceeded 100 years and were the largest recorded in 39 years of data collection. Flood-crest profiles for the Rock River are shown in figure 71 .

Minor flooding occurred on many tributary streams in northern and central Illinois, especially during April, and contributed to the exceptionally high stages on the Mississippi River main stem.

The major tributaries in the southern part of the State, Kaskaskia River and Big Muddy River, are partly controlled by reservoirs and did not contribute significantly to the Mississippi River flooding.

\section{TRIBUTARY STREAMS IN MISSOURI}

In addition to serious backwater flooding from the Mississippi River, severe headwater floods occurred on Mississippi River tributary streams in Missouri during the latter part of April 1973. Streams had been above normal for a considerable period of time prior to the intense April rains that saturated the area, consequently most of the rain that fell was discharged from the area as storm runoff.

During April 21-22, 1973, an unusually severe spring storm moved across central and northeastern Missouri. The resulting headwater flood peaks and volumes were extraordinary in the Fox, North and Middle Fabius, North, Salt, Lower Chariton, and East Fork Chariton River basins of northeastern Missouri. In addition, a record-breaking flood peak was observed during this period on Little River ditch 251 near Lilbourn in southeastern Missouri. Available flood-profile data for the downstream reaches of North Fabius and North Rivers are shown in figure 72.

As shown in table 12, the volumes of flood runoff from these basins for 1-, 3-, 7-, 15-, and 30-day periods have estimated recurrence intervals that are greater than 100 years in many instances; some of the flood volumes were nearly two times greater than the 100-year event. Thus the volume of flood runoff in these basins was just as significant as the extraordinarily high peak flows.

The gaging-station record on South Fork Salt River at Santa Fe was not included in table 12, be- cause this tributary experienced only a moderate rise even though nearby streams reached record stages. This indicates that intense precipitation was not evenly distributed over all parts of the area. In general, though, the entire northeastern parts of the State plus a small area in the southeast were hard hit by flooding during April 20-22.

When compared to historic records at long-time gaging stations, peak discharges and flood volumes were not exceptional on the Missouri River as a whole during March-May 1973. However, the lower reaches of the river received substantial amounts of storm runoff from uncontrolled tributary streams in Missouri, resulting in a peak stage of $33.7 \mathrm{ft}$ $(10.3 \mathrm{~m})$ on the gage at Hermann, Mo. This was the second highest stage ever observed, surpassed only by the record stage of $35.5 \mathrm{ft}(10.8 \mathrm{~m})$ in 1844 , but the peak discharge of $500,000 \mathrm{ft}^{3} / \mathrm{s}\left(14,200 \mathrm{~m}^{3} / \mathrm{s}\right)$ was only the sixth highest; the stage-discharge relationship has been altered by Federal and agricultural levees and by other activities of man on the flood plain. The duration of the flood in the lower reaches of the Missouri River (Hermann, Mo., to the mouth) was significant, as the river remained above flood stage for a record 73 consecutive days during March-May at Hermann and set new records for monthly mean discharges during January through April 1973.

Suspended-sediment data at Hermann show a total of 103 million tons transported past the station from March 1 to June 30. The discharge-weighted mean concentration was $1,376 \mathrm{mg} / \mathrm{l}$ for this period. The percentage of sand-sized material in 17 observations during this period ranged from 20 to 78 . The 100 million tons transported during this 4month period is considerably below that measured for several previous floods, partly because of upstream reservoir control and partly because of less runoff from the Missouri basin. The 4 "wet" years of 1949-52 had sediment loads at Hermann for this March-June period of $218,173,249$, and 170 million tons, respectively.

\section{TRIBUTARY STREAMS IN KENTUGKY}

Recurrence intervals of floods peaks in Kentucky ranged from 2 to 5 years, and flood problems were not severe. However, daily discharge data are presented in table 9 for gaging stations on the Ohio and Cumberland Rivers so that the contribution from these extensive river systems can be evaluated and comparisons can be made with flood events of the past. 

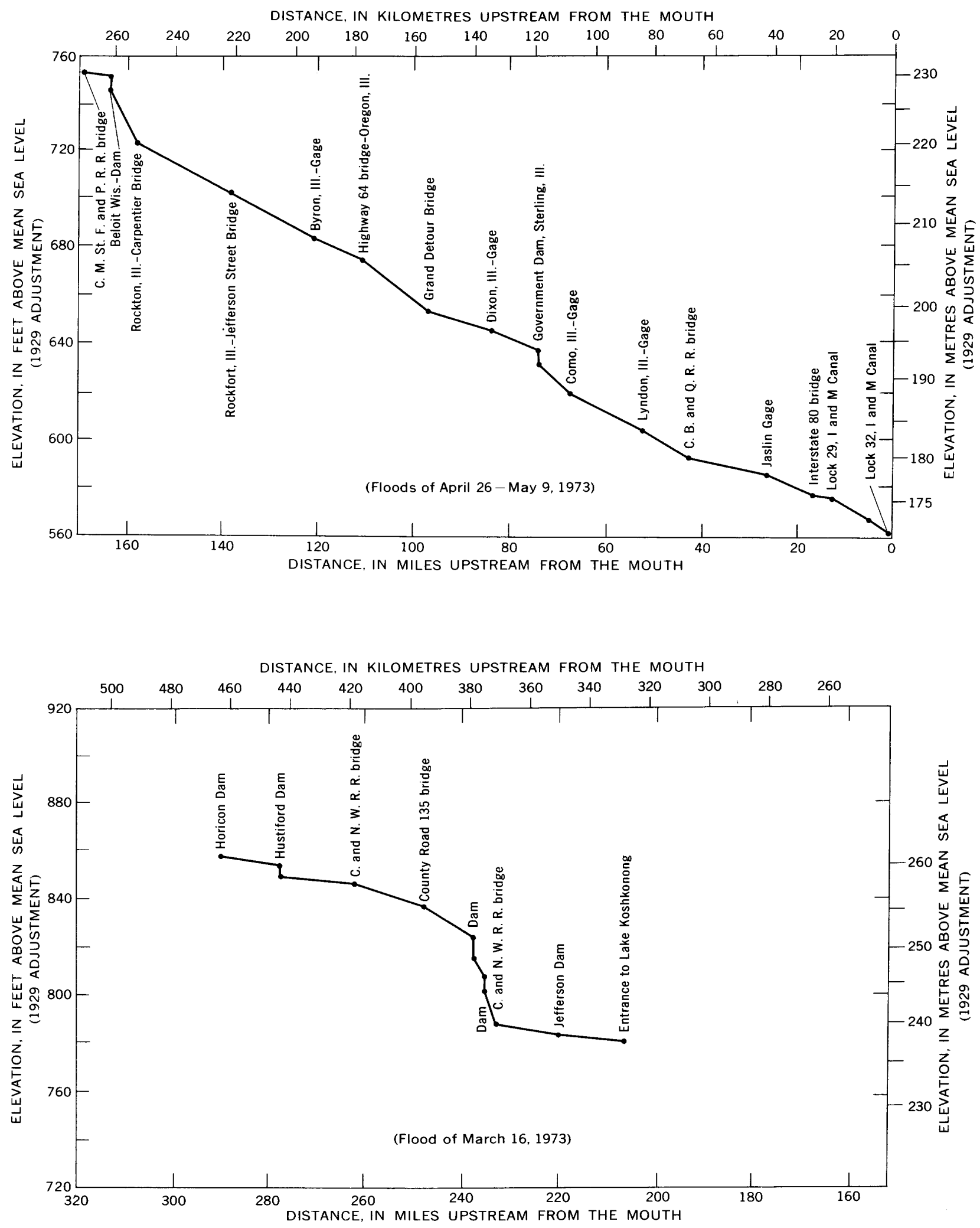

FIGURE 71.-Flood-crest profiles of Rock River, Illinois and Wisconsin. 

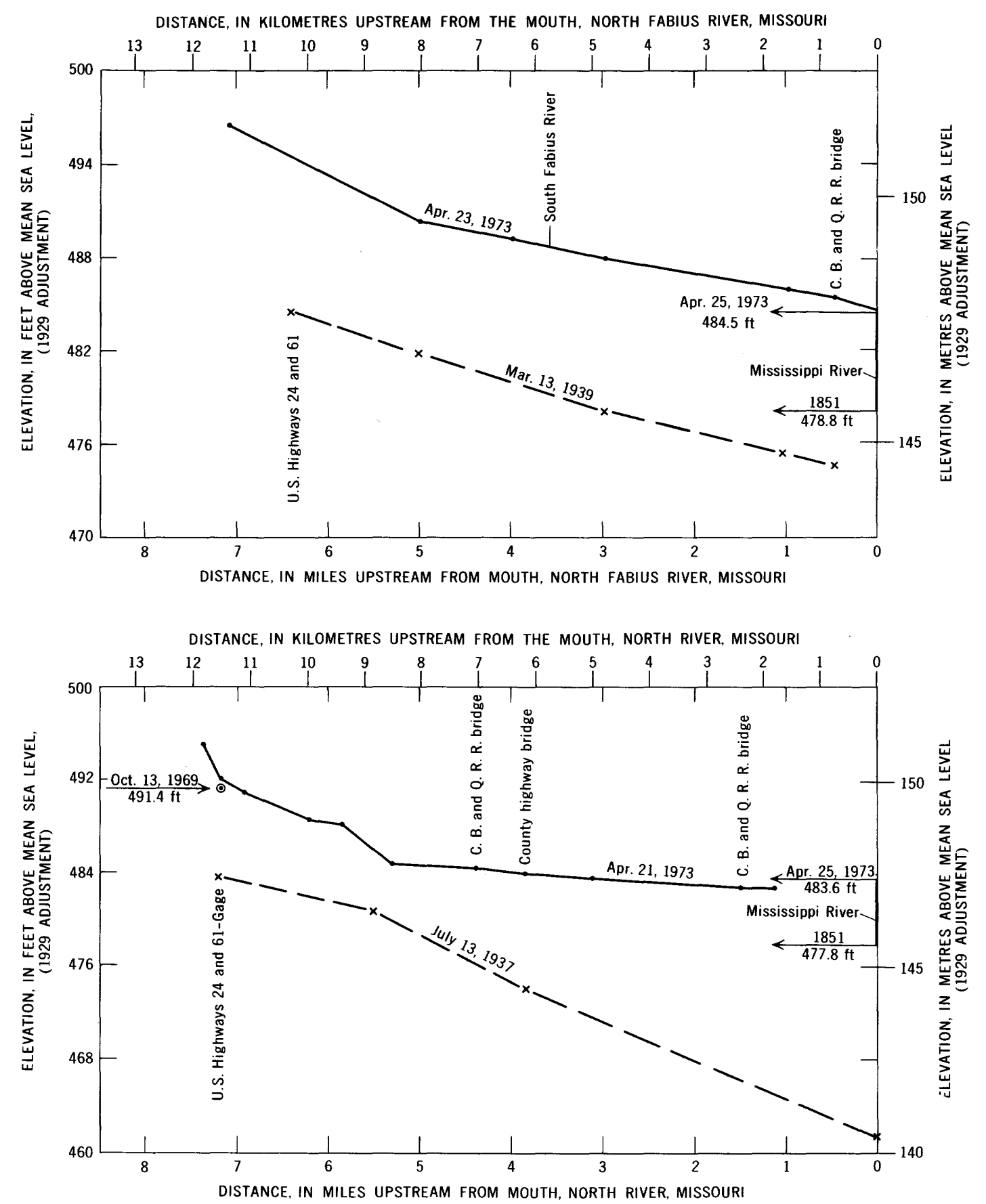

FiguRE 72.-Flood-crest profiles of North Fabius and North Rivers, Missouri.

TRIBUTARY STREAMS IN TENNESSEE

Above-normal rainfall throughout the fall and winter set the stage for excessive runoff in many tributary basins in Tennessee during March and April 1973.

In mid-March a flood peak with recurrence interval of 70 years occurred on the Hatchie River at Bolivar, Tenn. Most of the record peak flow of 61,600 $\mathrm{ft}^{3} / \mathrm{s}\left(1,740 \mathrm{~m}^{3} / \mathrm{s}\right)$ originated in northern Mississippi in the headwaters of the drainage basin, where 6 to 8 in. (152 to $203 \mathrm{~mm}$ ) of rainfall was reported in a 24-hour period.

Flooding occurred along almost all streams tributary to the Mississippi River in western Tennessee during the period, April 19-22, 1973. The most significant peak of this period, $31,200 \mathrm{ft}^{3} / \mathrm{s}\left(884 \mathrm{~m}^{3} / \mathrm{s}\right)$, was recorded on the South Fork Forked Deer River 
at Jackson on April 21, and it was the second highest since records began in 1930 .

Most of the problems caused by the 1973 spring floods in western Tennessee were associated with high stages along the main stem of the Mississippi that caused high stages from backwater in the lower reaches of tributary streams. The principal economic impact was caused by extensive crop damage behind private levees and inside the Mississippi River levee system.

\section{TRIBUTARY STREAMS IN ARKANSAS}

During March-June 1973, floodwaters in Arkansas covered thousands of acres and caused millions of dollars in property damage. One of the major causes of damage was backwater in the tributaries near their confluence with the Mississippi River. For instance, the St. Francis River backed up rather than draining normally into the Mississippi, flooding additional thousands of acres of farmland because of the simultaneous main-stem and tributary flooding. Flooding was also extensive along the White River and lower reaches of the Arkansas River.

Even though damage and hardship occurred, the recurrence intervals of peak flows and stages on Mississippi River tributaries in Arkansas were not generally outstanding. The most significant flood crest was recorded on Black River at Black Rock, where the highest peak in 37 years of record (recurrence interval of 20 years) was observed. Most other eastern Arkansas streams experienced peaks with recurrence intervals of 2 to 12 years, and the data are not presented in this report.

\section{TRIBUTARY STREAMS IN MISSISSIPPI}

As shown by the station data, the most outstanding flood peaks on tributary streams in Mississippi occurred in late March. However, the long-term effects of the flooding lasted well into June because of the tremendous amounts of backwater in the lower reaches of many of the tributary streams.

One of the primary reasons for the late March flooding was a 10 -in. $(0.25 \mathrm{~m})$ rainfall that occurred in the upper Yazoo River basin on March 15. Extensive flooding occurred along the Yazoo River, and the excessive runoff filled four large reservoirs in the upper basin, resulting in discharges over the emergency spillways.

Approximately 25 percent of the total agricultural damages that were sustained during the 1973 flood occurred in Mississippi, according to Kassner and Miller (1973). In the Yazoo basin alone, more than $3,590 \mathrm{mi}^{2}\left(9,310 \mathrm{~km}^{2}\right)$ were inundated (fig. $73)$, including an area of over $900 \mathrm{mi}^{2}\left(2,331 \mathrm{~km}^{2}\right)$ north of Vicksburg that was inundated by Mississippi River backwater. Eighty percent of some of the counties in the region were flooded, and the Yazoo River at Yazoo City did not fall below flood stage until June 26, 1973.

\section{TRIBUTARY STREAMS IN LOUISIANA}

The 1973 Mississippi River basin flood became significant in April in Louisiana. Streamflow was above normal at all gaging stations; at the Amite River gaging station near Denham Springs the mean discharge was the highest for April in $\mathbf{3 5}$ years of record. Flooding occurred along the Red and Ouachita Rivers for the entire months of April and May. On the Ouachita River at Monroe the peak discharge of $88,900 \mathrm{ft}^{3} / \mathrm{s}\left(2,520 \mathrm{~m}^{3} / \mathrm{s}\right)$ on May 6 was the fourth highest since 1932. In June, tributary flooding subsided, but the Mississippi River remained above flood stage until late in the month.

The most outstanding facet of the tributary flooding in Louisiana was the tremendous volume of flood runoff that was recorded during, and for several months prior to, the March-May base flood period. Accordingly, flood-volume-frequency data for 1-, 3-, 7-, 15-, 30-, 60-, 90-, 120-, and 183-day periods were computed for selected gaging stations in Louisiana.

The results of discharge and sediment measurements are presented in table 12 for four Louisiana floodway sites where floodwater was diverted from the Mississippi during March through June. The diversions were made through these floodways to protect levee systems in the New Orleans area. (See discussion on main-stem flooding.)

Suspended-sediment data for the Red River at Alexandria are available for March 1 to June 30 . The discharge-weighted mean concentration was $1,230 \mathrm{mg} / \mathrm{l}$ and the transport was $36,200,000$ tons for the period. Particle-size data are not available.

\section{WATER AND SEDIMENT DISCHARGE TO LAKE PONTCHARTRAIN AND THE GULF OF MEXICO}

Suspended-sediment data were obtained at 24 locations pertinent to the flood area, 18 of which were adequate to report daily values for at least one continuous month in the March-June period, and 6 of which are adequate to indicate only instantaneous conditions. Overall the data are sufficient to give a qualitative indication of the tributary sources 


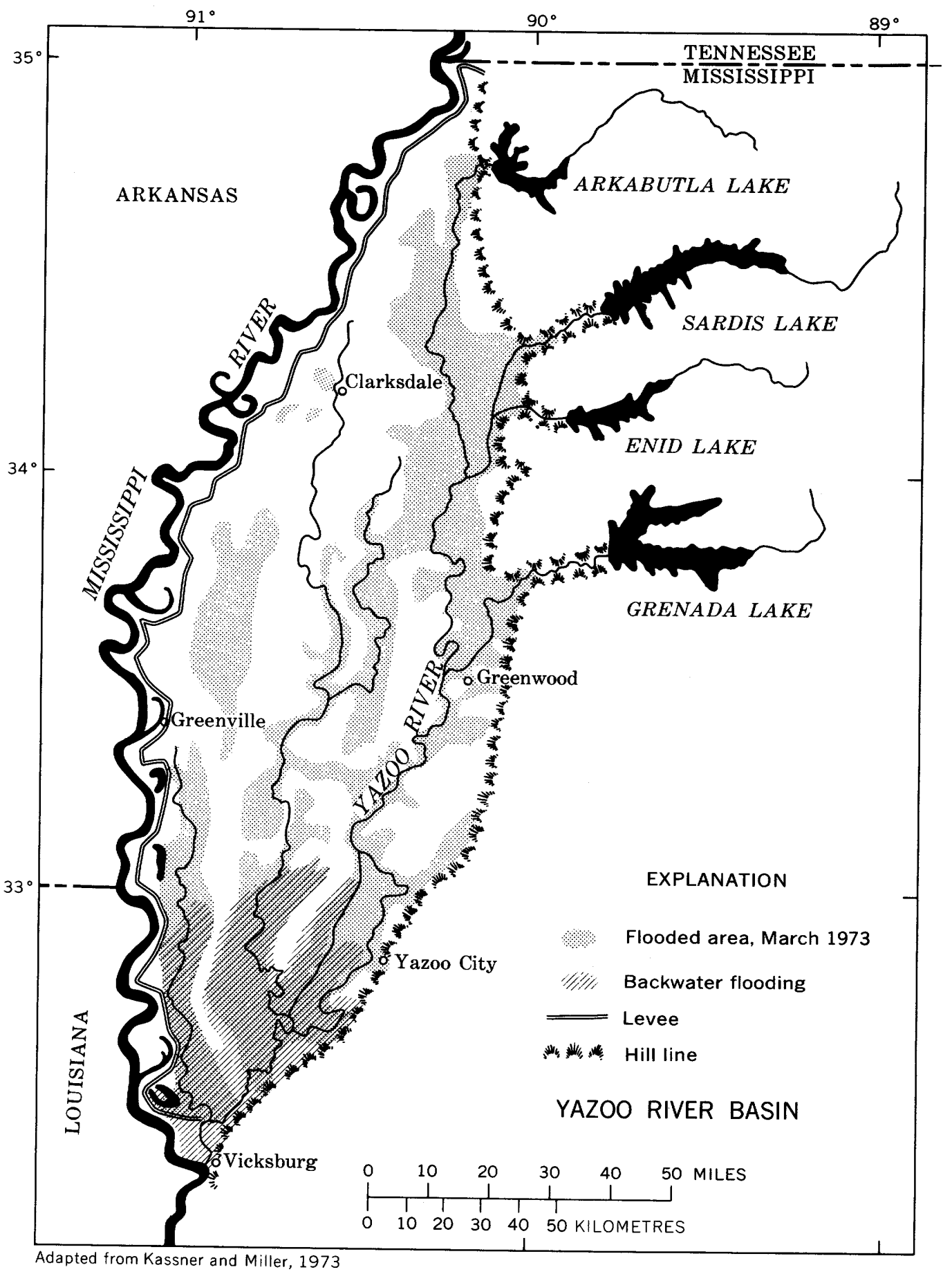

Figure 73.-Extent of flooding during March 1973 in the Mississippi River Delta region of northwest Mississippi.

of sediment and its movement to the Gulf. Water discharge, suspended-sediment discharge, and discharge-weighted mean concentration are summarized on a monthly basis in table 11.

Though the sediment loads given in table 11 may seem prodigious at first glance, they are really relatively low for most of the streams when compared to previous flood events. The long duration of the flooding and the large amount of water generally resulted in low concentrations. For example, the average annual sediment yield (Hydrology-Sedimentation Advisory Committee, 1966), for the Wapsipinicon River near DeWitt is about $220 \mathrm{t} / \mathrm{mi}^{2}\left(84.9 \mathrm{t} / \mathrm{km}^{2}\right)$ in $227\left(\mathrm{ft}^{3} / \mathrm{s}\right.$-days $) / \mathrm{mi}^{2}\left[0.21 \mathrm{hm}^{3} / \mathrm{km}^{2}\right]$ of water 
TABLE 11.-Summary of sediment and related streamflow data for 1973 Mississippi River flood

[Blank spaces indicate insufficient data for monthly totals (see table 12)]

\begin{tabular}{|c|c|c|c|c|c|c|c|c|c|c|c|c|c|c|c|c|}
\hline \multirow{2}{*}{$\begin{array}{l}\text { Map } \\
\text { No. } \\
\text { (fig. } \\
\text { 51) }\end{array}$} & \multirow{2}{*}{ Station name } & \multicolumn{5}{|c|}{$\begin{array}{l}\text { Water discharge, } \\
\text { in } 1,000 \mathrm{ft} 3 / \mathrm{s} \text { days }\end{array}$} & \multicolumn{5}{|c|}{$\begin{array}{l}\text { Sediment discharge, } \\
\text { in 1,000 tons }\end{array}$} & \multicolumn{5}{|c|}{$\begin{array}{l}\text { Discharge-weighted sediment } \\
\text { concentration, in } \mathrm{mg} / \mathrm{l}\end{array}$} \\
\hline & & March & April & May & June & Total & March & April & May & June & Total & March & April & May & June & Event \\
\hline 4 & $\begin{array}{l}\text { Root River } \\
\text { near } \\
\text { Houston, } \\
\text { Minn }\end{array}$ & $-\ldots$ & 65 & 76 & 38 & -- - & ----- & 127 & 127 & 26 & -..-- & ---- & 724 & 619 & 253 & ---- \\
\hline 6 & $\begin{array}{l}\text { Wapsipinicon } \\
\text { River near } \\
\text { Dewitt, } \\
\text { Iowa }\end{array}$ & 177 & 219 & 188 & ----- & ${ }^{1} 584$ & 120 & 136 & 175 & ----- & ${ }^{1} 431$ & 775 & 230 & 345 & $-\cdots--$ & ${ }^{1} 273$ \\
\hline 10 & $\begin{array}{l}\text { Iowa River at } \\
\text { Marengo, }\end{array}$ & & & & the & & & & & & & & & & & \\
\hline 11 & Iowa - & 193 & 244 & 181 & $-\cdots$ & ${ }^{1} 618$ & 226 & 260 & 134 & ---- & ${ }^{1} 620$ & 434 & 395 & 274 & ---- & ${ }^{1} 372$ \\
\hline 16 & $\begin{array}{l}\text { Iowa } \\
\text { Mississippi } \\
\text { River at }\end{array}$ & 132 & 200 & 268 & ---- & ${ }^{1} 600$ & 76 & 116 & 67 & ---- & ${ }^{1} 259$ & 213 & 215 & 93 & ---- & ${ }^{1} 160$ \\
\hline & Keokuk, & 5,746 & 6,889 & 6,992 & 4,456 & 25,883 & 5,571 & 9,516 & 5,731 & 3,056 & 23,874 & 359 & 512 & 304 & 254 & 342 \\
\hline 30 & $\begin{array}{l}\text { Mississippi } \\
\text { River at } \\
\text { Alton, Ill }\end{array}$ & 8,572 & 11,766 & 12,021 & 7,896 & 40,255 & $\ldots \ldots$ & $\ldots$ & ----- & & ---- & -...- & $\ldots-$ & --.-- & ---- & \\
\hline 31 & $\begin{array}{l}\text { Chariton River } \\
\text { near Chari- }\end{array}$ & & & & & 更 & $-\ldots$ & -- & $\cdots$ & $---\infty$ & ---- & & 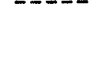 & 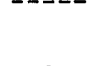 & $-x_{-}$ & \\
\hline 36 & $\begin{array}{l}\text { ton, Iowa -- } \\
\text { Missouri River }\end{array}$ & 15 & 19 & 15 & ----- & ${ }^{1} 49$ & 21 & 23 & 32 & ---- & ${ }^{1} 76$ & 533 & 434 & 800 & ---- & ${ }^{1} 574$ \\
\hline 37 & $\begin{array}{l}\text { at Hermann, } \\
\text { Mo } \\
\text { Mississippi }\end{array}$ & 8,293 & 10,003 & 5,954 & 3,403 & 27,653 & 45,730 & 35,230 & 14,530 & 7,206 & 102,696 & 2,040 & 1,300 & 904 & 784 & 1,376 \\
\hline 38 & $\begin{array}{l}\text { River at St. } \\
\text { Louis, Mo -- } \\
\text { Mississippi } \\
\text { River at }\end{array}$ & 16,176 & 20,775 & 18,120 & 11,148 & 66,219 & ----- & ---- & ---- & ---- & ---- & $-\cdots$ & ---- & ---- & ---- & $-\cdots$ \\
\hline 39 & $\begin{array}{l}\text { Chester, Ill - } \\
\text { Mississippi } \\
\text { River at }\end{array}$ & 16,380 & 21,591 & 19,375 & 11,955 & 69,301 & ----- & ---- & ---- & ---- & ---- & -..- & $\ldots$ & ---- & $-\cdots$ & ---- \\
\hline 50 & $\begin{array}{l}\text { River at } \\
\text { Thebes, Ill -- } \\
\text { Mississippi } \\
\text { River near } \\
\text { Arkansas }\end{array}$ & 16,709 & 21,930 & 20,330 & 12,846 & 71,815 & $\cdots$ & $-\cdots-$ & ---- & ---- & ---- & ---- & $\cdots-$ & $-\cdots$ & $-\cdots$ & ---- \\
\hline 56 & $\begin{array}{l}\text { City, Ark -- } \\
\text { Mississippi } \\
\text { River at } \\
\text { Vicksburg, }\end{array}$ & --- & ---- & $-\cdots$ & $-\cdots$ & $----^{2}$ & ${ }^{2} 29,000$ & 40,000 & 33,000 & 20,400 & 122,400 & ---- & -...- & $-\cdots--$ & ---- & 237 \\
\hline 57 & $\begin{array}{l}\text { Miss } \\
\text { Mississippi } \\
\text { River at } \\
\text { Natchez, }\end{array}$ & 34,400 & 52,890 & 57,443 & 37,320 & $182,053^{2}$ & ${ }^{2} 39,000$ & 54,000 & 35,000 & 18,000 & 146,000 & 429 & 373 & 230 & 172 & 297 \\
\hline \multirow[t]{2}{*}{59} & $\begin{array}{l}\text { Miss } \\
\text { Mississippi } \\
\text { River at } \\
\text { Tarbert } \\
\text { Landing, }\end{array}$ & ---- & $-\cdots-$ & ---- & ---- & $----^{2}$ & 39,000 & 43,000 & 38,000 & 17,000 & 137,000 & $--\cdots$ &.-- & -..-- & ---- & 253 \\
\hline & Miss & 24,162 & 38,502 & 42,570 & 29,298 & 134,532 & 28,071 & 31,110 & 23,310 & 16,559 & 99,050 & 430 & 299 & 203 & 209 & 272 \\
\hline
\end{tabular}


TABLE 11.-Summary of sediment and related streamflow data for 1973 Mississippi River flood-Continued

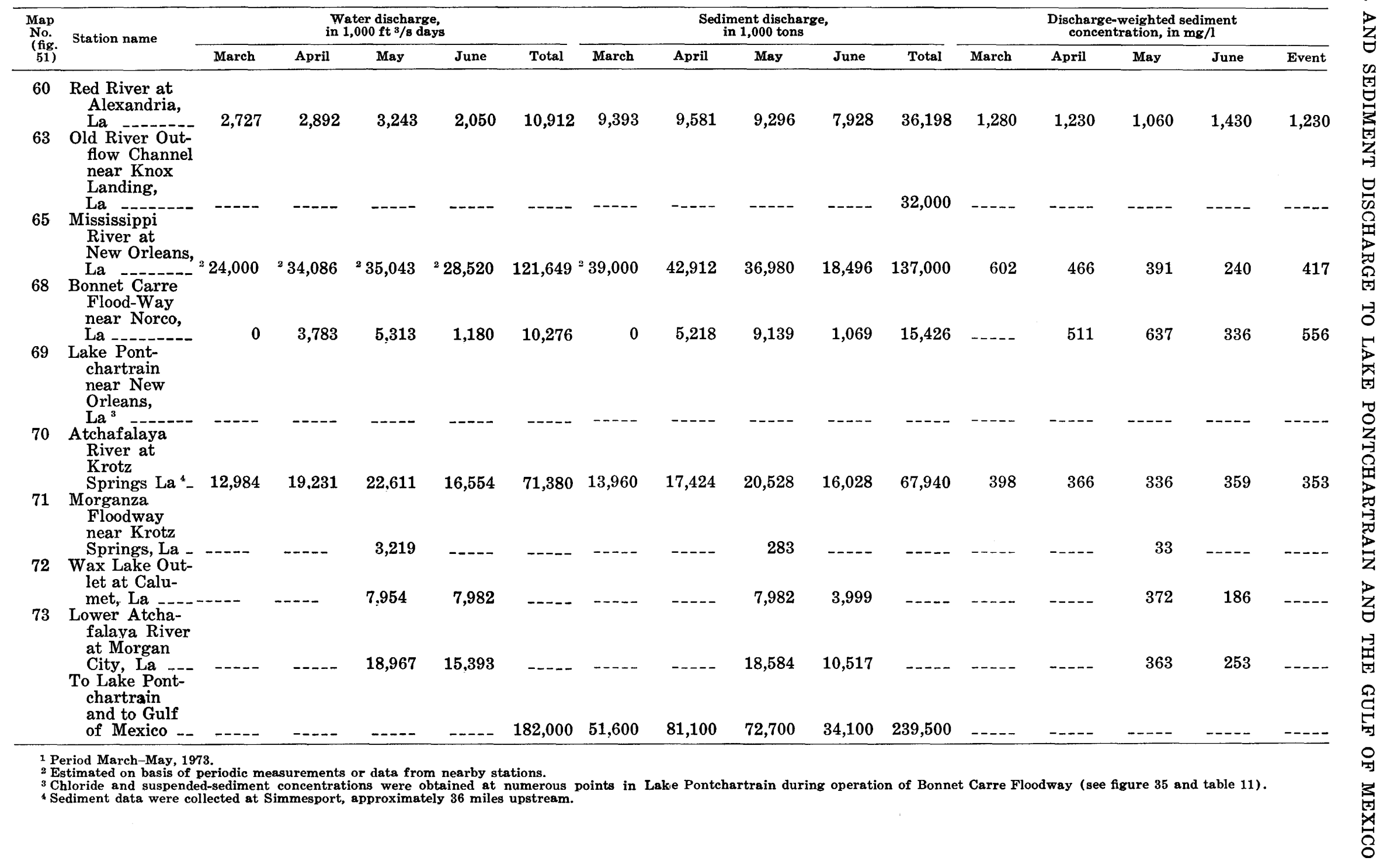


discharge for a mean concentration of $359 \mathrm{mg} / 1$; whereas, the March-May yield was $185 \mathrm{t} / \mathrm{mi}^{2}(71.4$ $\left.\mathrm{t} / \mathrm{km}^{2}\right)$ in $251\left(\mathrm{ft}^{3} / \mathrm{s}\right.$-days $) / \mathrm{mi}^{2}\left[0.237 \mathrm{hm}^{3} / \mathrm{km}^{2}\right]$ for a mean concentration of $273 \mathrm{mg} / \mathrm{l}$. The mean concentration of the Iowa River at Iowa City from 1945 to 1957, prior to Coralville Reservoir, was 649 $\mathrm{mg} / \mathrm{l}$ (Hydrology-Sedimentation Advisory Committee, 1966), but the flow of the 1973 flood into the reservoir at Marengo had a mean concentration of only $372 \mathrm{mg} / \mathrm{l}$ for this event. From March through June 1973 the Missouri River at Hermann, Mo., moved 103 million tons of sediment $(1,376 \mathrm{mg} / \mathrm{l})$ toward the Mississippi River. This is considerably less than the March through June average load of 202 million tons for the 4 "wet" years 1949-52.

At scattered points in the Mississippi River basin, the sediment loads were relatively high during the 1973 flood. At Vicksburg, Miss., the mean MarchJune concentration was $297 \mathrm{mg} / \mathrm{l}$ for a total of 146 million tons in 182 million $\mathrm{ft}^{3} / \mathrm{s}$-days $\left(445,000 \mathrm{hm}^{3}\right)$ of water discharge. At New Orleans the 4-month mean concentration was $417 \mathrm{mg} / \mathrm{l}$; and even though nearly 40 percent of the flow was diverted from the river by various floodways upstream, the load was about 137 million tons, which indicates considerable sediment inflow from tributaries between the stations, or enlargement of the channel. The nearly 24 million tons measured for the Mississippi River at Keokuk, Iowa (March-June) was considerably more than the computed average annual load of $9.4 \mathrm{mil}-$ lion. The mean concentration of $342 \mathrm{mg} / \mathrm{l}$ for the flood period is also considerably more than the com-

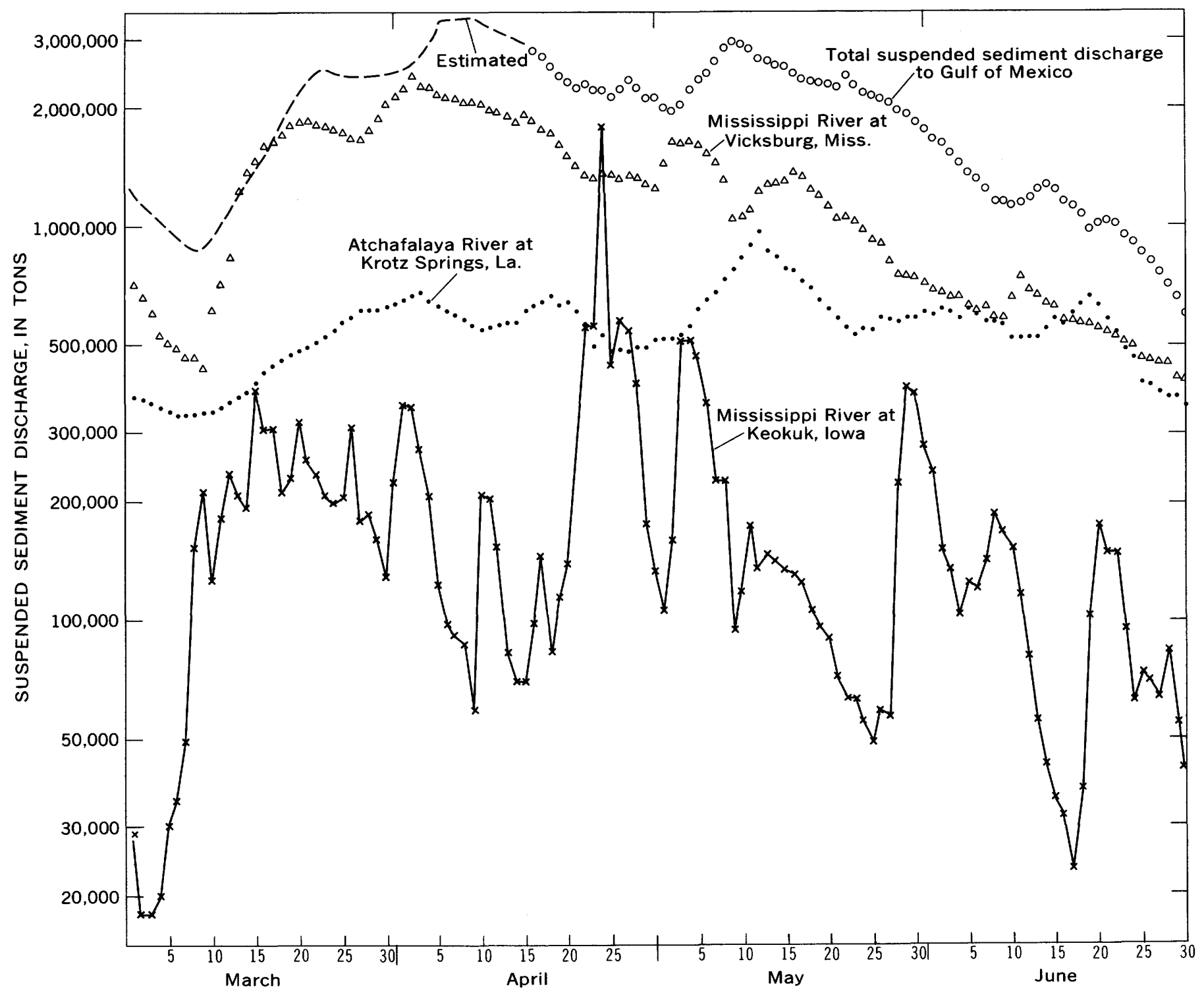

FIGURE 74.-March-June 1973 suspended sediment discharge at selected points in the Mississippi River basin. 
puted long-term average of $154 \mathrm{mg} / \mathrm{l}$. The MarchJune temporal distribution of the sediment load for Keokuk and other selected points in the basin is shown in figure 74 on a daily basis.

The sediment discharge to the Gulf during the flood can be estimated using data collected at the stations Bonnet Carre Floodway near Norco, La. (via Lake Pontchartrain), Wax Lake Outlet at Calumet, La., Lower Atchafalaya River at Morgan City, La., and Mississippi River at New Orleans, La. See figure 74 and tables 11 and 12. Data prior to about April 15 were not obtained at the Calumet and Morgan City stations and therefore estimates of the sediment discharge of the flood March 1 to April 15 were based on data at Vicksburg and the Atchafalaya at Krotz Springs.

The total March through June water discharge of the flood to the Gulf of Mexico was approximately 182 million $\mathrm{ft}^{3} / \mathrm{s}$-days $\left(445,000 \mathrm{hm}^{3}\right)$ including 10 million $\left(24,500 \mathrm{hm}^{3}\right)$ into and through Lake Pontchartrain. The total sediment discharge during this period was approximately 240 million tons including 15 million into Lake Pontchartrain.

\section{SELECTED REFERENCES}

Anderson, D. B., and Burmeister, I. L., 1970, Floods of March-May 1965 in the Upper Mississippi River basin: U.S. Geol. Survey Water-Supply Paper 1850-A, 448 p.

Dalrymple, Tate, 1960, Flood frequency analyses: U.S. Geol. Survey Water-Supply Paper 1543-A, 80 p.

Environmental Data Service, 1968, Climatic atlas of the United States: Washington, U.S. Govt. Priting Office, 80 p.

1973a, Hourly presipitation data: v. 23, no. 3-5, Asheville, N.C., National Climatic Center.

1973b, Climatological data: v. 79, no. 3-5, Asheville, N.C., National Climatic Center.

Environmental Data Service and Statistical Reporting Service, 1973, Weekly weather and crop bulletin: v. 60 , no. 1-23, Washington, Agricultural Climatology Service Office.

Guy, H. P., and Norman, V. W., 1970, Field methods for measurement of fluvial sediment: U.S. Geol. Survey Techniques of Water Resources Inv., book 3, chap. C2, 59 p.

Hershfield, D. M., 1961, Rainfall frequency atlas of the United States for durations from 30 minutes to 24 hours and return periods from 1 to 100 years: U.S. Weather Bur. Tech. Paper no. 40, 115 p.

Huff, F. A., and Changnon, S. A., Jr., 1964, A model 10-inch rainstorm: Jour. of Applied Meteorology, v. 3, no. 5, 587-599.

Hydrology-Sedimentation Advisiory Committee, 1966, Fluvial sediment in the Upper Mississippi River basin: App. G. Upper Mississippi River comprehensive basin study, F. J. Mack, Corps of Engineers, Rock Island, Ill., Chairman, $116 \mathrm{p}$.

Kassner, H. A., and Miller, R. P., 1973, Flood of '73: Water Spectrum, Dept. of the Army, Corps of Engineers, v. 5, no. 2 , p. $30-36$.
Kinzer, G. D., and Gunn, R., 1951, The evaporation, temperature and thermal relaxation time of freely falling water drops: Jour. of Meterology, v. 8, no. 2, p. 71-83.

Kohler, M. A., and Parmele, L. H., 1967, Generalized estimate of freewater evaporation: Water Resource Research, v. 3 , no. 4, fourth quarter, p. 997-1005.

Lott, G. A., and Myers, V. A., 1956, Meterology of flood-producing storms in the Mississippi River basin: Hydrometeorological Rept. no. 34, 226 p.

Mason, J. B., 1952, The production of rain and drizzle by coalescence in stratiform clouds: Quarterly Jour. of Royal Meteorol. Soc., v. 78, no. 337, p. 377-386.

Miller, J. F., 1964, Two- to ten-day precipitation for return periods of 2 to 100 years in the contiguous United States: U.S. Weather Bur. Tech. Paper no. 49, 29 p.

Miller, J. F., and Frederick, R. H., 1966, Normal monthly number of days with precipitation of $0.5,1.0,2.0$, and 4.0 inches or more in the conterminous United States: U.S. Weather Bur. Tech. Paper no. 57, 52 p.

Miller, J. F., and Pauhus, J. L. H., 1964, Frequency of maximum water equivalent of March snowcover in northern central United States: U.S. Weather Bur. Tech. Paper no. $50,24 \mathrm{p}$.

National Weather Service, 1973, Water supply outlook for the western United States: v. 25, no. 3, 16 p.

Palmen, E., 1961, On the mechanism of the vertical heat flux and generation of kinetic energy in the atmosphere: Tellus, v. 18 , no. 4 , fourth quarter, p. 838-845.

Palmer, W. C., 1965, Meteorological drought: U.S. Weather Bur. Research Paper no. 45, 58 p.

Patterson, J. L., 1964, Magnitude and frequency of floods in the United States, Part 7, Lower Mississippi River basin: U.S. Geol. Survey Water-Supply Paper 1681, 636 p.

Patterson, J. L., and Gamble, C. R., 1968, Magnitude and frequency of floods in the United States, Part 5, Hudson Bay and Upper Mississippi River basins: U.S. Geol. Survey Water-Supply Paper 1678, 546 p.

Porterfield, George, 1972, Computation of fluvial-sediment discharge: U.S. Geol. Survey Techniques of Water Resources Inv., book 3, chap. C3, $66 \mathrm{p}$.

Reap, R. M., 1972, An operational three-dimensional trajectory model: Jour. of Applied Meteorology, v. 11, no. 8, p. 1193-1202.

Riedel, J. T., Appleby, J. F., and Schloemer, R. W., 1956, Seasonal variation of the probable maximum precipitation east of the 105th meridian for areas from 10 to 1,000 square miles and durations of $6,12,24$, and 48 hours: Hydrometeorological Rept. no. 33, 58 p.

Sawyer, J. S., 1970, Observational characteristics of atmospheric fluctuation with a time scale of a month: Quarterly Jour. of Royal Meteorol. Soc., v. 96 , no. 410, p. 610 625.

Smith, W., and Younkin, R. J., 1972, An operationally useful relationship between the polar jet stream and heavy precipitation: Monthly Weather Review, v. 100, no. 6, p. 434-440.

Spar, J., 1973, Supplementary notes on sea-surface temperature anomalies and model-generated meteorological histories: Monthly Weather Review, v. 101, no. 10, p. 767773.

U.S. Inter-Agency Committee on Water Resources, Subcommittee on Sedimentation, 1957, Some fundamentals of particle-size analysis, report 12 of a study of methods used in measurement and analysis of sediment loads in streams: $55 \mathrm{p}$. 
U.S. Water Resources Council, 1967, A uniform technique for determining floodflow frequencies: U.S. Water Resources Council, Bull. 15, 15 p.
Vonder Harr, T. H., and Ort, A. H., 1973, New estimate of annual poleward energy transport by northern hemisphere oceans: Jour. of Physical Oceanography, v. 3, no. 2, p. 169-172. 
TABLE 12 
TABLE 12.-Station descriptions and discharge and suspended-sediment data

This table presents information for gaging stations where outstanding flood events were experienced and where sediment data are available during the spring 1973 flood.

The map numbers (in parenthesis at top of each manuscript) are the same as the numbers on the station location map (fig. 51) for each station and will aid in identifying the site.

The station numbers immediately follow the map numbers and are nationwide identification numbers used by the U.S. Geological Survey to locate the stations in downstream order. Stations in this table are arranged in downstream order; however, an alphabetical listing with station numbers is provided in the station index.

Location provides an exact geographical reference to the gaged site.

Under drainage area is the most recently determined area of the basin based on the most accurate maps available at the time of the determination.

Gage provides a description of the type of gage used to collect the data and gives the datum of the gage.

this stage was exceeded during the spring 1973 floods is included along with a comparison to previous floods. (1) Also included for many stations are suspended-sediment data and recurrence intervals in years for flood peaks smaller than the estimated 100-year peak. Whenever 1973 peaks exceeded the estimated 100-year peak,

Remarks includes statements about regulation in the basin, diversions, cooperation, or other pertinent information.

\section{MISSISSIPPI RIVER MAIN STEM}

\section{(1) 05331000 Mississippi River at St. Paul, Minn.}

Location.-Lat $44^{\circ} 56^{\prime} 40^{\prime \prime}$, long $93^{\circ} 05^{\prime} 20^{\prime \prime}$, in SE1/4 NE1/4 sec. 6, T. 28 N., R. 22 W., Ramsey County, on left bank in St. Paul, $300 \mathrm{ft}(91 \mathrm{~m})$ upstream from Robert Street Bridge, $6 \mathrm{mi}(10 \mathrm{~km})$ downstream from Minnesota River, and at mile 839.3 $(1,350.4 \mathrm{~km})$ upstream from Ohio River. Auxiliary water-stage recorder $5.6 \mathrm{mi}(9.0 \mathrm{~km})$ downstream from base gage.

Drainage area.- $36,800 \mathrm{mi}^{2}\left(95,300 \mathrm{~km}^{2}\right)$, approximately.

Gage.-Base gage: Water-stage recorder. Datum of gage is $683.62 \mathrm{ft}(208.367 \mathrm{~m})$ above mean sea level, datum of 1929 .

Auxiliary gage: Water-stage recorder. Datum of gage is $684.16 \mathrm{ft}(208.532 \mathrm{~m})$ above mean sea level, datum of 1912 . Flood stage.- $-14.00 \mathrm{ft}(4.27 \mathrm{~m})$.

Maxima.-March-May 1973: Discharge, 51,800 ft $\mathrm{ft}^{3} / \mathrm{s}\left(1,470 \mathrm{~m}^{3} / \mathrm{s}\right)$ 4:00 p.m., Mar. 20 [gage height, $11.19 \mathrm{ft}(3.41 \mathrm{~m})$ ]. Recurrence interval of discharge is 3 years (based on figure 52 ).

Period of record: $1851-70,1872$ to current year. Maximum discharge, $171,000 \mathrm{ft}^{3} / \mathrm{s} \quad\left(4,840 \mathrm{~m}^{3} / \mathrm{s}\right)$ Apr. 16,1965 [gage height $26.01 \mathrm{ft}(7.928 \mathrm{~m})$ from floodmark) ].

Remarks.-Floodflow not materially affected by artificial storage.

Mean discharge, in cubic feet per second, 1973

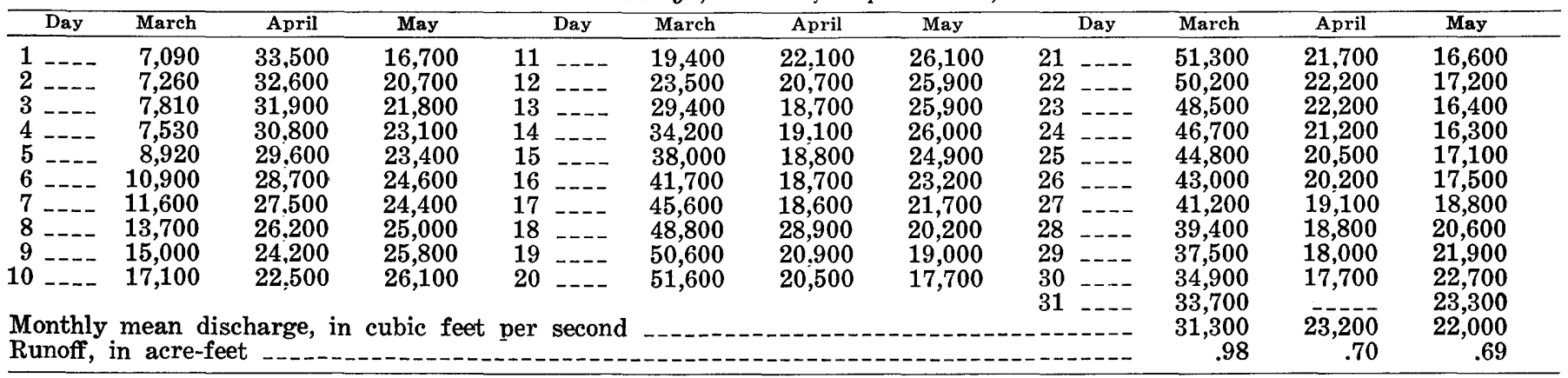

\section{MISSISSIPPI RIVER MAIN STEM}

(2) 05344500 Mississippi River at Prescott, Wis.

Location.-Lat $44^{\circ} 44^{\prime} 45^{\prime \prime}$, long $92^{\circ} 48^{\prime} 00^{\prime \prime}$, in sec. 9, T. 26 N., R. 20 W., Pierce County, on left bank at Prescott, $200 \mathrm{ft}(61$ $\mathrm{m})$ downstream from St. Croix River, $300 \mathrm{ft}(91 \mathrm{~m})$ south of Chicago, Burlington \& Quincy Railroad bridge, $800 \mathrm{ft}(244 \mathrm{~m})$ south of bridge on U.S. Highway 10, and at mile $811.4(1,305.5 \mathrm{~km})$ upstream from Ohio River. Auxiliary water-stage recorder 10.7 mile $(17.2 \mathrm{~km})$ downstream from base gage.

Drainage area.-44,800 $\mathrm{mi}^{2}\left(116,000 \mathrm{~km}^{2}\right)$, approximately.

Gage.-Base gage: Water-stage recorder. Datum of gage is $619.50 \mathrm{ft}(197.968 \mathrm{~m})$ above mean sea level, datum of 1929 .

Auxiliary gage: Water-gage recorder. Datum of gage is $650.00 \mathrm{ft}(198.120 \mathrm{~m})$ above mean sea level, datum of 1929 .

Bankfull stage. $-39.00 \mathrm{ft}(11.887 \mathrm{~m})$.

Maxima.-March-May 1973: Discharge, 78,300 ft ${ }^{3} \mathrm{~s}\left(2,220 \mathrm{~m} /{ }^{3} \mathrm{~s}\right)$ 2:00 p.m. Mar. 20 [gage height, $33.83 \mathrm{ft}(10.311 \mathrm{~m})$ ]. Recurrence interval of discharge is 4 years (based on figure 30 ).

Period of record: June 1928 to current year. Maximum discharge, $228,000 \mathrm{ft}^{3} / \mathrm{s}\left(6,460 \mathrm{~m}^{3} / \mathrm{s}\right)$ Apr. 18,1965 [gage height, $43.11 \mathrm{ft}(13.140 \mathrm{~m})$ from graph based on gage readings)].

Remarks.-Floodflow not materially affected by artificial storage.

Mean discharge, in cubic feet per second, 1973

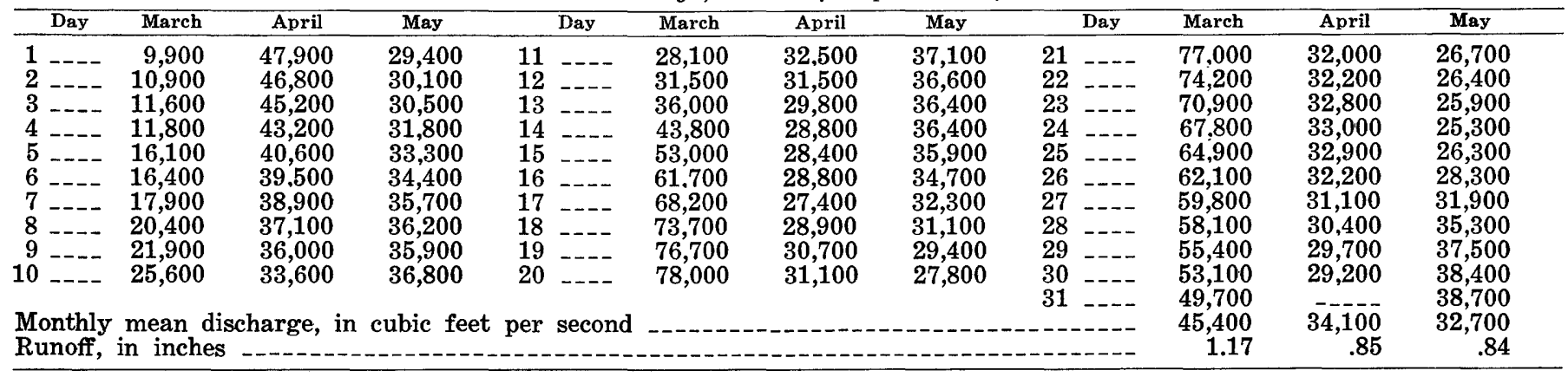


TABLE 12.-Station descriptions and discharge and suspended-sediment data-Continued

\section{MISSISSIPPI RIVER MAIN STEM}

(3) 05378500 Mississippi River at Winona, Minn.

Location.-Lat $44^{\circ} 03^{\prime} 20^{\prime \prime}$, long $91^{\circ} 38^{\prime} 15^{\prime \prime}$, in sec. 23 , T. 107 N., R. 7 W., Winona County, on right bank at Winona pumping station in Winona, $91 / 2$ miles $(15.3 \mathrm{~km})$ upstream from Trempealeau River and at mile $725.7(1,167.7 \mathrm{~km})$ upstream from the Ohio River. Auxiliary digital water-stage recorder at navigation dam 5A in sec. 9, T. 107 N., R. 7 W., 2.7 miles $(4.3 \mathrm{~km})$ upstream.

Drainage area.- $59,200 \mathrm{mi}^{2}\left(153,300 \mathrm{~km}^{2}\right)$, approximately.

Gage.-Base gage: Water-stage recorder. Datum of gage is $639.64 \mathrm{ft}(194.962 \mathrm{~m})$ above mean sea level, datum of 1929 . Auxiliary gage: Water-stage recorder. Datum of gage is $640.00 \mathrm{ft}(195.072 \mathrm{~m})$ above mean sea level, datum of 1912 .

Flood stage. $-13 \mathrm{ft}(3.97 \mathrm{~m})$.

Maxima.-March-May 1973: Discharge, $136,000 \mathrm{ft}^{3} / \mathrm{s}\left(3,850 \mathrm{~m}^{3} / \mathrm{s}\right) 0100$ hours Mar. 20 [gage height, $14.58 \mathrm{ft}$ (4.444 m) ]. Recurience interval of discharge is 7 years (based on figure 52).

Period of record: June 1928 to current year. Maximum discharge, 268,000 ft $\mathrm{ft}^{3} / \mathrm{s}\left(7,590 \mathrm{~m}^{3} / \mathrm{s}\right)$ Apr. 19, 1965 [gage height, $20.77 \mathrm{ft}(6.331 \mathrm{~m})$ from floodmark $)]$

Remarks.-Floodflow not materially affected by artificial storage.

Mean discharge, in cubic feet per second, 1973

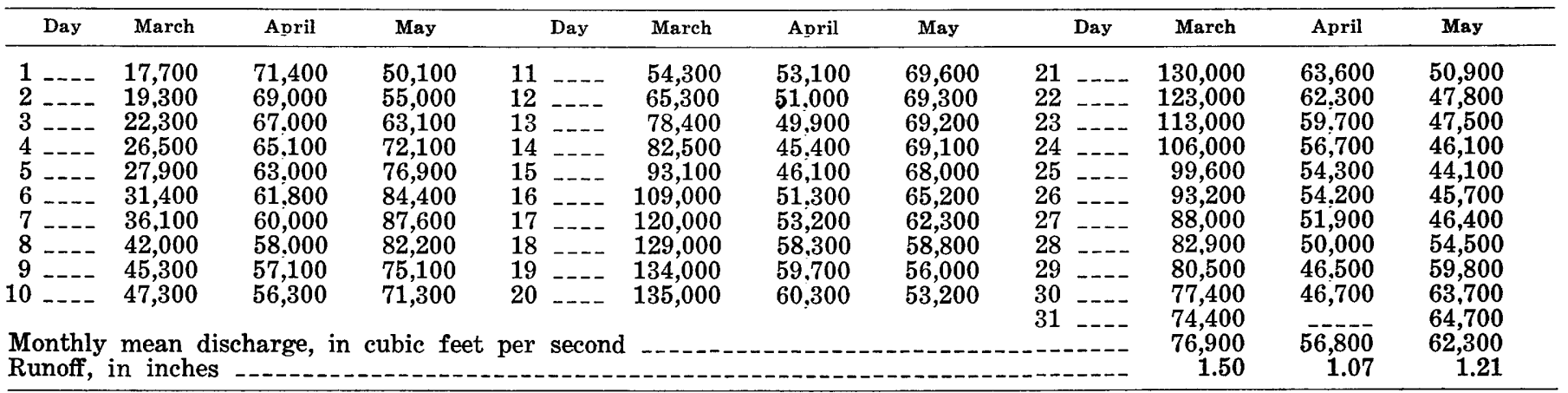

\section{ROOT RIVER BASIN}

\section{(4) 05385000 Root River near Houston, Minn.}

Location.-Lat $43^{\circ} 46^{\prime} 05^{\prime \prime}$, long $91^{\circ} 35^{\prime} 11^{\prime \prime}$, in sec. 32, T. 104 N.. R. 6 W., Houston County, on right bank 1 mile (1.6 km) west of Houston, and 2.5 miles $(4.0 \mathrm{~km})$ upstream from South Fork.

Drainage area.- $1,270 \mathrm{mi}^{2}\left(3,290 \mathrm{~km}^{2}\right)$, approximately.

Gage.-Water-stage recorder. Datum of gage is $671.86 \mathrm{ft}(204.783 \mathrm{~m})$ above mean sea level, datum of 1929 .

Bankfull stage. $-12 \mathrm{ft}(3.7 \mathrm{~m})$, approximately.

Maxima.-March-May 1973: Discharge, 11,700 ft ${ }^{3} / \mathrm{s}\left(331 \mathrm{~m}^{3} / \mathrm{s}\right), 4: 00$ p.m., Apr. 17 [gage height, $10.48 \mathrm{ft}$ (3.194 m)]. Recurrence interval of discharge, 2 years.

Period of record: May 1909 to Sept. 1917, May to November 1929, March 1930 to current year. Maximum discharge, 37,000 $\mathrm{ft}^{3} / \mathrm{s}\left(1,050 \mathrm{~m}^{3} / \mathrm{s}\right)$ Apr. 1, 1952 [gage height, $13.90 \mathrm{ft}(4.237 \mathrm{~m})$ ]; maximum gage height, $18.32 \mathrm{ft}(5.584 \mathrm{~m}) \mathrm{Mar} .2,1965$ (backwater from ice).

Remarks.-Floodflow not affected by artificial storage. Station data included in this report primarily for sediment analysis.

Mean water discharge and suspended-sediment concentration and discharge

\begin{tabular}{|c|c|c|c|c|c|c|c|c|c|c|c|c|c|c|c|c|c|c|c|}
\hline \multicolumn{5}{|c|}{ March } & \multicolumn{5}{|c|}{ April } & \multicolumn{5}{|c|}{ May } & \multicolumn{5}{|c|}{ June } \\
\hline \multirow[b]{2}{*}{ Day } & & \multicolumn{3}{|c|}{$\begin{array}{c}\text { sediment } \\
\text { Suspended }\end{array}$} & \multirow{2}{*}{\multicolumn{2}{|c|}{ Day }} & \multicolumn{3}{|c|}{$\begin{array}{l}\text { Suspended } \\
\text { sediment }\end{array}$} & \multicolumn{5}{|c|}{$\begin{array}{l}\text { Susvended } \\
\text { sediment }\end{array}$} & \multicolumn{5}{|c|}{$\begin{array}{l}\text { Suspended } \\
\text { sediment }\end{array}$} \\
\hline & & $\begin{array}{c}\text { Mean } \\
\text { dis- } \\
\text { charge } \\
\left(\mathrm{ft}^{3} / \mathrm{s}\right)\end{array}$ & $\begin{array}{l}\text { Mean } \\
\text { concen- } \\
\text { tration } \\
(\mathrm{mg} / \mathrm{l})\end{array}$ & $\begin{array}{l}\text { Dis- } \\
\text { charge } \\
\text { (tons/ } \\
\text { day) }\end{array}$ & & & $\begin{array}{c}\text { Mean } \\
\text { dis- } \\
\text { charge } \\
\left(\text { ft }^{3} / \mathrm{s}\right)\end{array}$ & $\begin{array}{l}\text { Mean } \\
\text { concen- } \\
\text { tration } \\
(\mathrm{mg} / \mathrm{l})\end{array}$ & $\begin{array}{l}\text { Dis- } \\
\text { charge } \\
\text { (tons/ } \\
\text { day) }\end{array}$ & Day & & $\begin{array}{c}\text { Mean } \\
\text { dis- } \\
\text { charge } \\
\left(\mathrm{ft}^{3} / \mathrm{s}\right)\end{array}$ & $\begin{array}{l}\text { Mean } \\
\text { concen- } \\
\text { tration } \\
(\mathrm{mg} / \mathrm{l})\end{array}$ & $\begin{array}{c}\text { Dis- } \\
\text { charge } \\
\text { (tons/ } \\
\text { day) }\end{array}$ & Day & & $\begin{array}{c}\text { Mean } \\
\text { dis- } \\
\text { charge } \\
\left(\mathrm{ft}^{3} / \mathrm{s}\right)\end{array}$ & $\begin{array}{l}\text { Mean } \\
\text { concen- } \\
\text { tration } \\
(\mathrm{mg} / \mathrm{I})\end{array}$ & $\begin{array}{c}\text { Dis- } \\
\text { charge } \\
\text { (tons/ } \\
\text { day) }\end{array}$ \\
\hline 1 & & 660 & $\ldots$ & $\ldots$ & 1 & & 1.130 & 150 & 458 & 1 & & 2.210 & 1,280 & 8,010 & 1 & & 1,560 & 184 & $\mathbf{7 7 5}$ \\
\hline 2 & & 1,610 & -- & $-\cdots$ & $\begin{array}{l}1 \\
2\end{array}$ & & $\begin{array}{l}1,150 \\
1,170\end{array}$ & $\begin{array}{l}100 \\
187\end{array}$ & $\begin{array}{l}400 \\
591\end{array}$ & $\begin{array}{l}1 \\
2\end{array}$ & & $\begin{array}{l}2,210 \\
6,350\end{array}$ & $\begin{array}{l}1,280 \\
2,120\end{array}$ & $\begin{array}{r}8,010 \\
36,300\end{array}$ & $\begin{array}{l}1 \\
2\end{array}$ & & 1,460 & $\begin{array}{l}164 \\
167\end{array}$ & 658 \\
\hline 3 & & 2,600 & $\cdots$ & - & 3 & - & 1,370 & 245 & $\begin{array}{l}906 \\
906\end{array}$ & 3 & $\cdots$ & 6,620 & 1.200 & 21,400 & 3 & & 1,390 & 170 & 638 \\
\hline 4 & & 3,930 & -1 & $-1-$ & 4 & & 1,390 & 205 & 769 & 4 & & $\mathbf{4 , 4 8 0}$ & 800 & 9,680 & 4 & & 1,410 & 176 & 670 \\
\hline 5 & & $\begin{array}{l}8,930 \\
3,430\end{array}$ & $\cdots$ & $-\cdots$ & $\begin{array}{l}4 \\
5\end{array}$ & & $\begin{array}{l}1,390 \\
1,230\end{array}$ & 220 & 731 & $\frac{4}{5}$ & & $\begin{array}{l}4,480 \\
3,250\end{array}$ & $\begin{array}{l}800 \\
485\end{array}$ & $\begin{array}{l}9,000 \\
4,260\end{array}$ & $\mathbf{5}$ & & 1,830 & 228 & 1,130 \\
\hline 6 & -- & 2,430 & -1 & 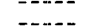 & 6 & $\ldots$ & 1,140 & 178 & 548 & 6 & & 2,770 & 345 & 2,580 & 6 & $\ldots$ & $\begin{array}{l}1,630 \\
1,630\end{array}$ & 538 & 2,370 \\
\hline 7 & & 3,980 & $\cdots$ & 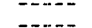 & 7 & n. & $\begin{array}{l}1,140 \\
1,070\end{array}$ & 135 & $\begin{array}{l}390 \\
390\end{array}$ & $\begin{array}{l}0 \\
7\end{array}$ & & 2,570 & 290 & 2,010 & 7 & & 1.500 & 295 & 1,190 \\
\hline 8 & & 4,000 & $\cdots$ & 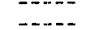 & 8 & 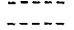 & 1,040 & 141 & 396 & 8 & $---\overline{-}$ & 3.530 & $\begin{array}{l}290 \\
495\end{array}$ & 4,720 & 8 & & 1,380 & 217 & 809 \\
\hline 9 & $\cdots$ & 2,500 & -1 & $\ldots$ & 9 & 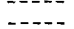 & 1,060 & 160 & 458 & $\stackrel{\circ}{9}$ & & 5,250 & 778 & 11,000 & 9 & --- & 1,300 & 193 & 677 \\
\hline 10 & & 1,950 & $-\ldots$ & -1 & 10 & $\cdots$ & 1,030 & $\begin{array}{l}100 \\
175\end{array}$ & $\begin{array}{l}480 \\
487\end{array}$ & 10 & & $\mathbf{3 , 4 1 0}$ & $\begin{array}{l}538 \\
538\end{array}$ & $\begin{array}{r}11,900 \\
4,950\end{array}$ & 10 & & $\begin{array}{l}1,000 \\
1,230\end{array}$ & $\begin{array}{l}178 \\
178\end{array}$ & 591 \\
\hline 11 & $-\cdots$ & 7,360 & $\cdots$ & $-\cdots$ & 11 & - & $\begin{array}{r}1,000 \\
935\end{array}$ & 154 & 389 & 11 & -- & $\begin{array}{l}5.410 \\
2,700\end{array}$ & $\begin{array}{l}540 \\
345\end{array}$ & 2,520 & 11 & & 1.180 & 179 & 570 \\
\hline 12 & $-\cdots$ & $\mathbf{9 , 4 3 0}$ & & -1 & 12 & $\cdots$ & 982 & 112 & 297 & 12 & & 2.330 & 258 & 1,620 & 12 & $-\ldots$ & 1,160 & 230 & 720 \\
\hline 13 & & 4,260 & 985 & 11,400 & 13 & $\cdots$ & 988 & 88 & 235 & 13 & & 2,080 & 175 & 983 & 13 & & 1,120 & 222 & 671 \\
\hline $\begin{array}{l}13 \\
14\end{array}$ & -- & $\begin{array}{l}4,200 \\
3,810\end{array}$ & 1.260 & 13.000 & $\begin{array}{l}10 \\
14\end{array}$ & -- & $\begin{array}{r}900 \\
1,030\end{array}$ & 128 & 356 & $\begin{array}{l}13 \\
14\end{array}$ & $-\cdots$ & $\begin{array}{l}2,080 \\
1,920\end{array}$ & 210 & 1,090 & 14 & -- & 1.090 & 170 & 500 \\
\hline $\begin{array}{l}14 \\
15\end{array}$ & & 5.250 & $\begin{array}{l}1.200 \\
1.640\end{array}$ & 23,200 & 15 & $\cdots$ & $\begin{array}{l}1,370 \\
2,370\end{array}$ & 433 & 3,170 & 15 & --1 & 1,790 & 240 & 1,160 & 15 & & 1,050 & 143 & 405 \\
\hline 16 & $\ldots$ & 3.900 & 1,010 & 10,600 & 16 & $\cdots$ & 6.860 & 1,660 & 30.700 & 16 & $\ldots$ & 1.670 & 195 & 879 & 16 & - & 1.070 & 140 & 404 \\
\hline 17 & $-\cdots$ & 2.880 & 610 & $\begin{array}{r}1,740 \\
0.740\end{array}$ & 17 & $\cdots$ & $\begin{array}{r}0,600 \\
10.600\end{array}$ & 1,560 & 44,600 & 17 & $\cdots$ & 1.570 & $\begin{array}{l}158 \\
158\end{array}$ & 670 & 17 & - & 1,060 & 149 & 426 \\
\hline 18 & & 2.300 & 400 & 2,480 & 18 & 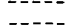 & 5,700 & 1.030 & 15.900 & 18 & - & 1.500 & 168 & 680 & 18 & & 1,330 & 329 & $1, \cap 20$ \\
\hline 19 & $-\cdots$ & 1,920 & 350 & 1,810 & $\begin{array}{l}10 \\
19\end{array}$ & $-\cdots$ & 3,670 & 700 & $\begin{array}{r}6.940 \\
0\end{array}$ & $\begin{array}{l}10 \\
19\end{array}$ & $\ldots$ & 1.430 & 200 & 772 & 19 & 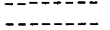 & 1.640 & 662 & 2,930 \\
\hline 20 & $\ldots$ & 1,660 & 330 & 1,480 & 20 & $\cdots$ & 2.960 & 465 & 5,720 & 20 & - n-n & 1,370 & 198 & 732 & 20 & & 1.720 & 532 & 2,470 \\
\hline 21 & & $\begin{array}{l}1,510 \\
1,510\end{array}$ & 245 & $\begin{array}{r}9,400 \\
999\end{array}$ & 21 & $\cdots$ & 2.530 & 440 & $\begin{array}{l}0,120 \\
3,010\end{array}$ & 21 & $-\cdots$ & $\begin{array}{l}1,010 \\
1,330\end{array}$ & $\begin{array}{l}180 \\
180\end{array}$ & 646 & 21 & & 1,390 & 372 & 1,400 \\
\hline 22 & $\cdots$ & 1,430 & 220 & 849 & 22 & $\cdots$ & 2,240 & 345 & 2,090 & $\begin{array}{l}21 \\
22\end{array}$ & $---\overline{-}$ & $\begin{array}{l}1,530 \\
1,350\end{array}$ & $\begin{array}{l}100 \\
171\end{array}$ & $\begin{array}{l}040 \\
623\end{array}$ & 22 & & 1,210 & 237 & 774 \\
\hline 23 & & 1,340 & 221 & 800 & 23 & $\cdots$ & 1,990 & 320 & 1,720 & 23 & & 1,340 & 147 & 532 & 23 & & 1.120 & 177 & 535 \\
\hline
\end{tabular}


TABLE 12.-Station descriptions and discharge and suspended-sediment data-Continued

Mean water discharge and suspended-sediment concentration and discharge-Continued

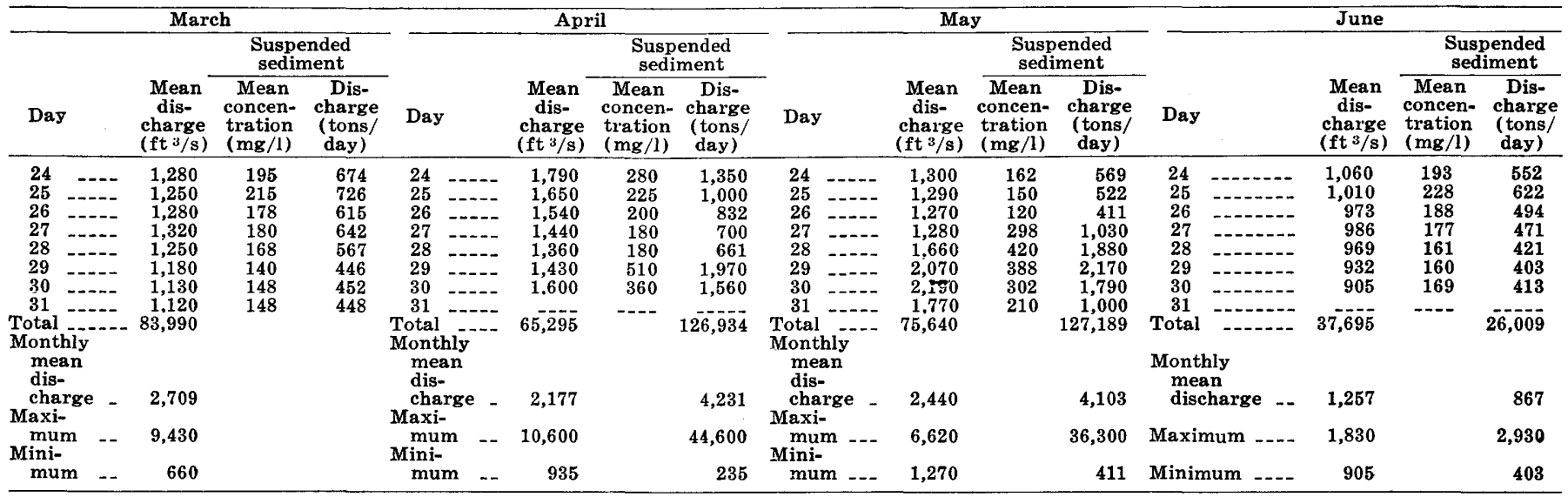

MISSISSIPPI RIVER MAIN STEM

(5) 05420500 Mississippi River at Clinton, Iowa

Location.-Lat $41^{\circ} 46^{\prime} 53^{\prime \prime}$, long $90^{\circ} 15^{\prime} 04^{\prime \prime}$, in NW1/4 sec. 34 , T. 81 N., R. 6 E., Clinton County, on right bank at foot of Seventh Avenue in Camanche, 5.0 miles $(8.0 \mathrm{~km})$ upstream from Wapsipinicon River, 6.4 miles $(10.3 \mathrm{~km})$ downstream from Clinton, 10.6 miles $(17.1 \mathrm{~km})$ downstream from dam 13 , and at mile $511.8(823.5 \mathrm{~km})$ upstream from Ohio River. Prior to June 6,1969 , at site $400 \mathrm{ft}(122 \mathrm{~m})$ downstream.

Drainage area.- $85,600 \mathrm{mi}^{2}\left(222,000 \mathrm{~km}^{2}\right)$, approximately, at Fulton-Lyons Bridge where discharge measurements are made.

Gage.-Water-stage recorder. Datum of gage is $562.68 \mathrm{ft}(171.505 \mathrm{~m})$ above mean sea level, datum of 1929 . June 1873 to May 31,1934 , staff gage in stone well and June 1, 1934, to Sept. 30, 1939, water-stage recorder 14.8 miles (23.8 km) downstream at Le Claire, at datum $0.07 \mathrm{ft}(0.021 \mathrm{~m})$ lower. Oct. 1,1939 , to Sept. 30,1955 , water-stage recorder $10.6 \mathrm{miles}(17.1 \mathrm{~km})$ upstream at dam 13, at datum $5.48 \mathrm{ft}(1.670 \mathrm{~m})$ higher. Auxiliary water-stage recorder at dam 13 since Oct. 1 , 1958. Present gage used as auxiliary gage Oct. 1,1939 , to Sept. $30,1955$.

Flood stage. $-16 \mathrm{ft}(4.9 \mathrm{~m})$.

Maxima.-March-May 1973: Daily discharge, 207,000 ft $3 / \mathrm{s}\left(5,860 \mathrm{~m}^{3} / \mathrm{s}\right)$ Mar. 25; gage height, $20.65 \mathrm{ft}(6.294 \mathrm{~m}), 11: 00 \mathrm{a.m}$, Mar. 25. Recurrence interval of discharge is 20 years (based on figure 52 ).

June 1873 to February 1973: Daily discharge, $307,000 \mathrm{ft}^{3} / \mathrm{s}\left(8,690 \mathrm{~m}^{3} / \mathrm{s}\right)$.

Apr. 28, 1965; gage height, $24.65 \mathrm{ft}(7.513 \mathrm{~m})$ Apr. 28, 1965. Maximum stage known since at least 1828 that of Apr. 28, 1965 .

Mean stage, in feet and discharge in cubic feet per second in 1973

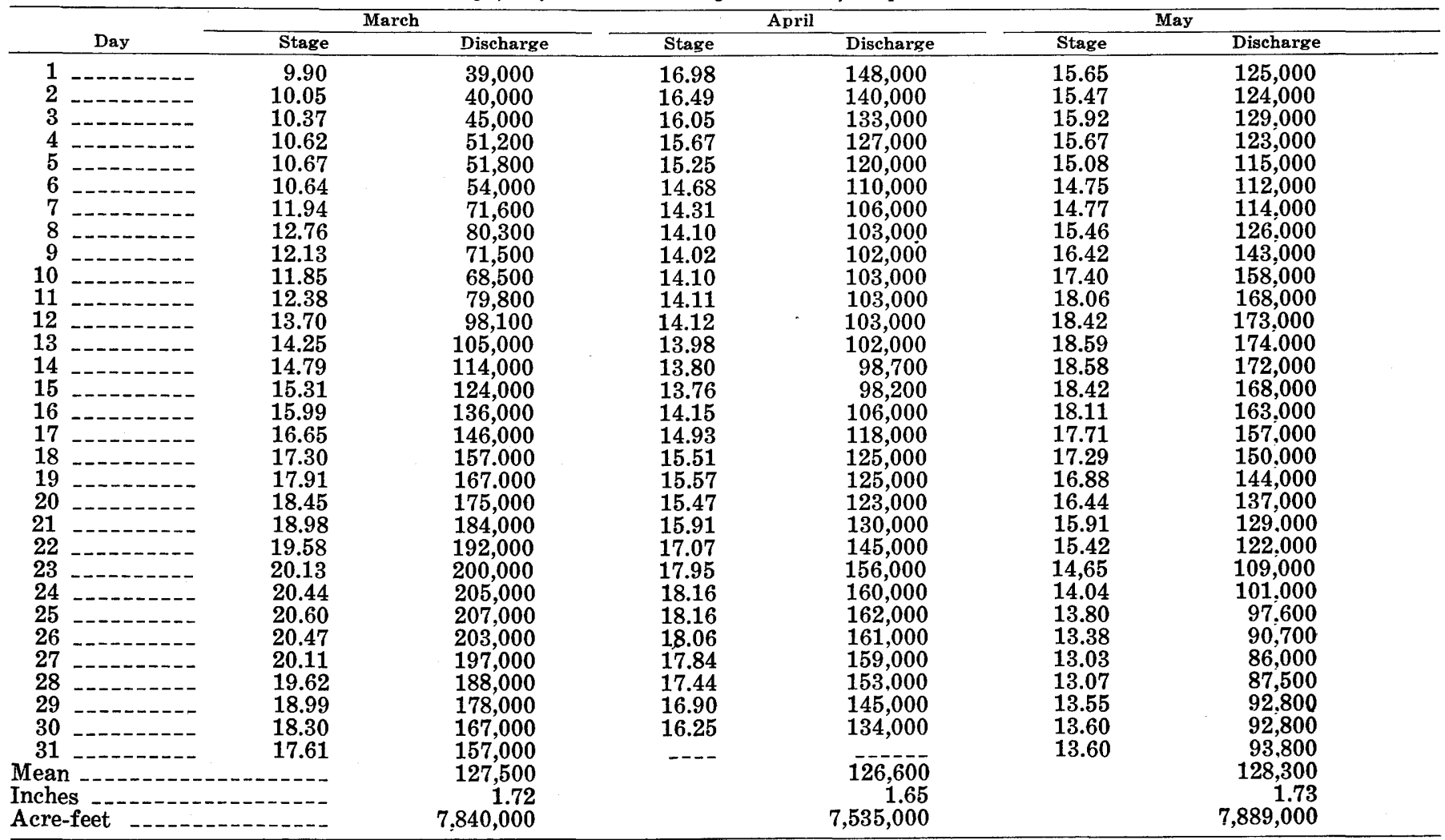


TABLE 12.-Station descriptions and discharge and suspended-sediment data-Continued

\begin{tabular}{|c|c|c|c|c|c|}
\hline Period & \multicolumn{5}{|c|}{ Highest mean discharge, in cubic feet per second, for the indicated number of consecutive days } \\
\hline March-May 1973 & 207,000 & 205,000 & 199,000 & 182,000 & 150,000 \\
\hline 1874-1972 - & 307,000 & 304,000 & 296,000 & 271,000 & 224,000 \\
\hline Recurrence interval, in years, for & & & & & \\
\hline 1973 flood volumes & 20 & 10 & 10 & 10 & 7 \\
\hline
\end{tabular}

WAPSIPINICON RIVER BASIN

(6) 05422000 Wapsipinicon River near DeWitt, Iowa

Location.-Lat $41^{\circ} 46^{\prime} 01^{\prime \prime}$, long $90^{\circ} 32^{\prime} 05^{\prime \prime}$, in SW1/4 NE1/4 sec. 6, T. 80 N., R. 4 E., Clinton County, on left bank $5 \mathrm{ft}(1.5 \mathrm{~m})$ upstream from bridge on U.S. Highway $61,0.9$ mile $(1.4 \mathrm{~km})$ downstream from Silver Creek, $4.0 \mathrm{miles}(6.4 \mathrm{~km})$ south of water tower in DeWitt, 6.2 miles $(10.0 \mathrm{~km})$ upstream from Brophy Creek, and 18.2 miles $(29.3 \mathrm{~km})$ upstream from mouth.

Drainage area. $-2,330 \mathrm{mi}^{2}\left(6,030 \mathrm{~km}^{2}\right)$.

Gage.-Water-stage recorder. Datum of gage is $598.81 \mathrm{ft}(182.517 \mathrm{~m})$ above mean sea level.

Flood stage.-10 ft $(3.0 \mathrm{~m})$. Flood stage was exceeded continuously from Apr. 16 to May 19, 1973.

Maxima.-March-May 1973: Discharge, 27,000 ft $/ \mathrm{s}\left(765 \mathrm{~m}^{3} / \mathrm{s}\right)$ 11:45 a.m. Apr. 22 [gage height, $12.76 \mathrm{ft}(3.889 \mathrm{~m})$ ]. Recurrence interval of discharge is 12 years.

June 1934 to February 1973: Discharge, 26,000 $\mathrm{ft}^{3} / \mathrm{s}\left(736 \mathrm{~m}^{3} / \mathrm{s}\right)$ June 27, 1944 [gage height, $12.07 \mathrm{ft}(3.679 \mathrm{~m})$ ]; maximum gage height, $12.30 \mathrm{ft}(3.749 \mathrm{~m})$ July $9,1969$.

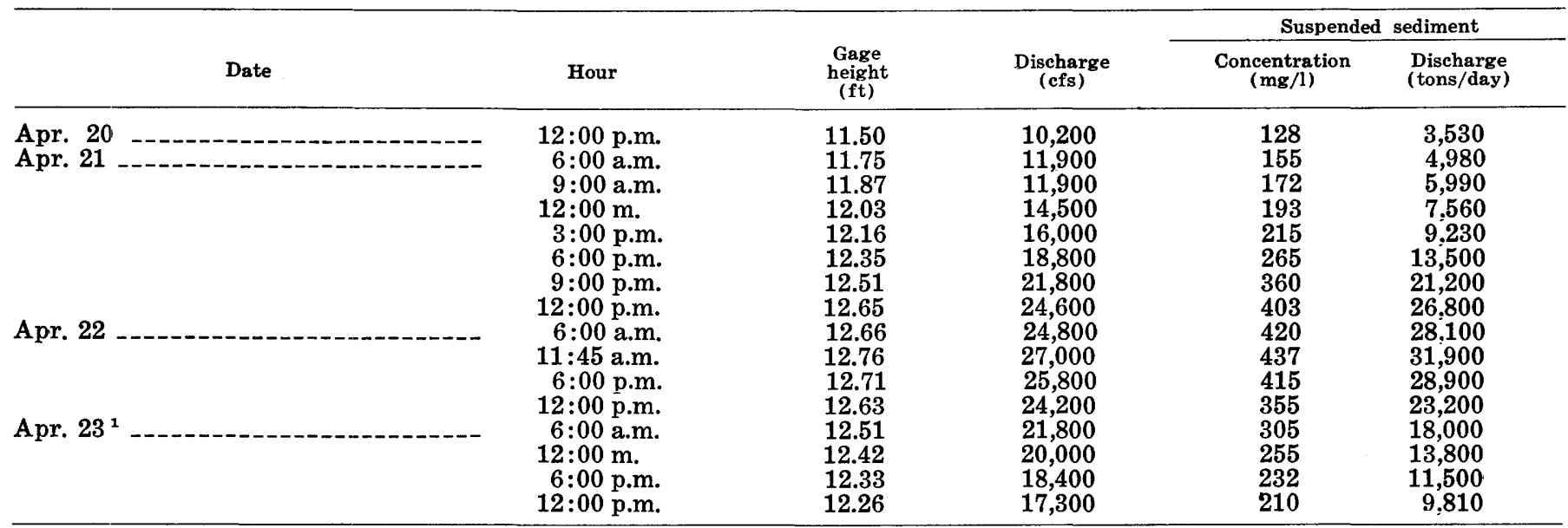

${ }^{1}$ A seven-vertical suspended-sediment sample at 11:40 a.m. contained 76 percent clay, 12 percent silt, and 12 percent sand.

Mean water discharge and suspended-sediment concentration and discharge

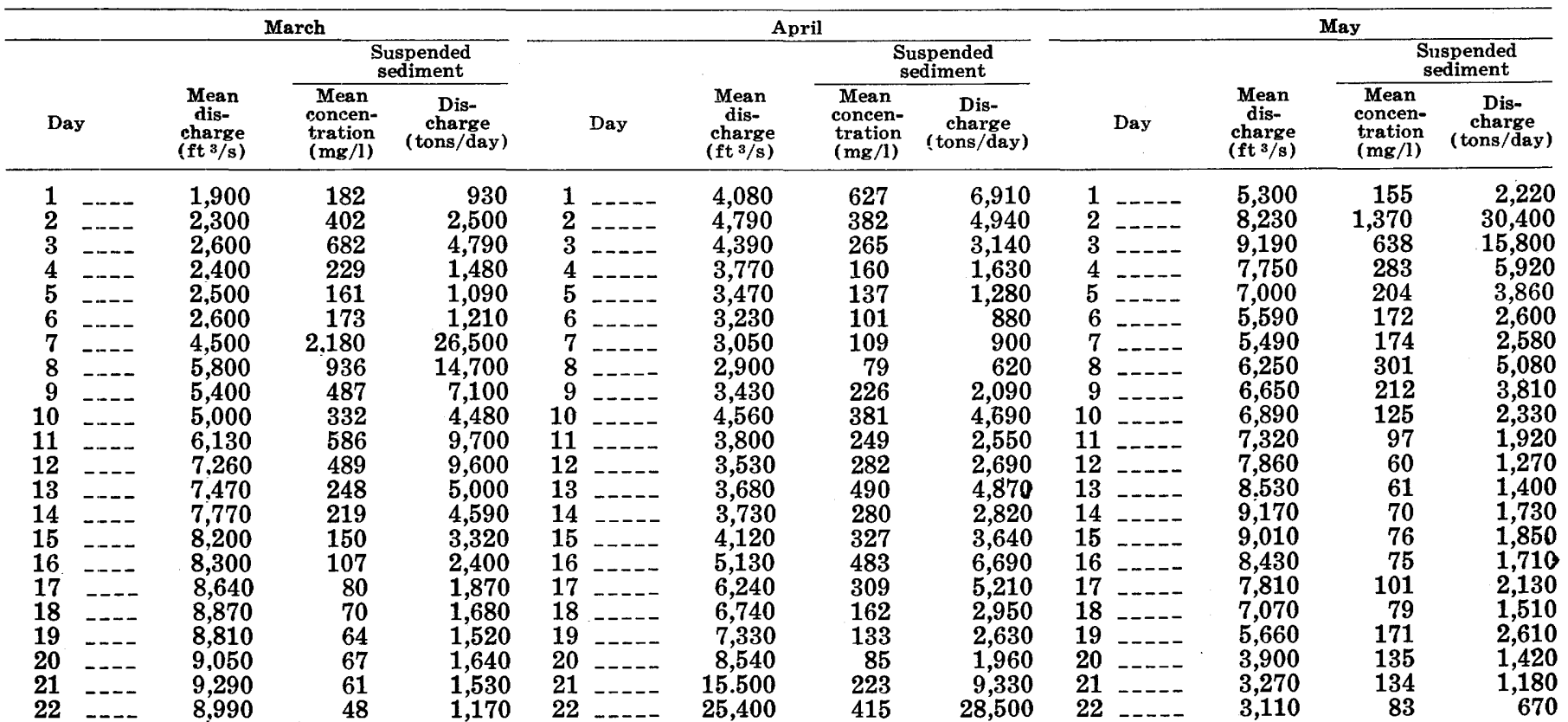


TABLE 12.-Station descriptions and discharge and suspended-sediment data-Continued

Mean water discharge and suspended-sediment concentration and discharge-Continued

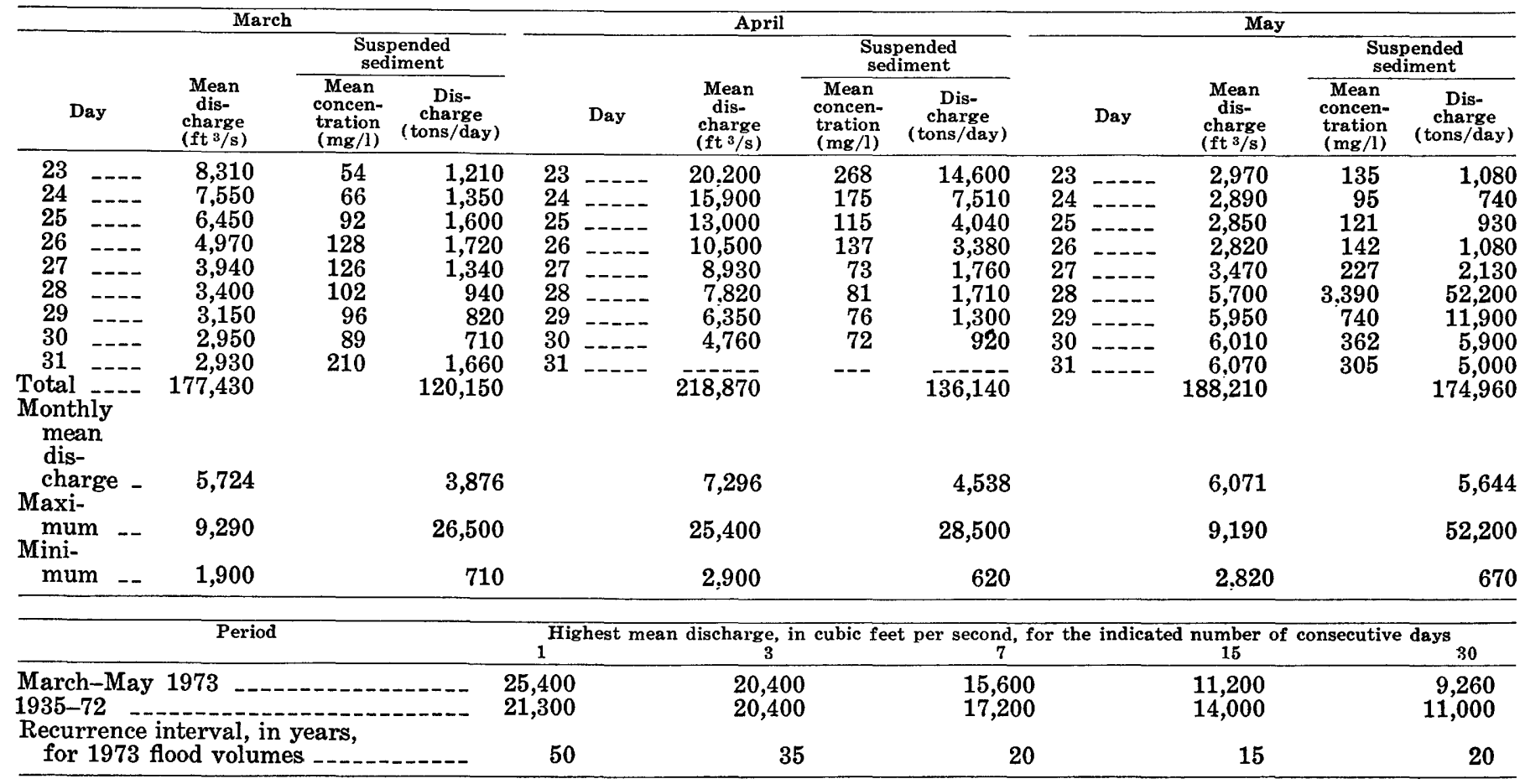

ROCK RIVER BASIN

(7) 05431400 Little Turtle Creek at Allens Grove, Wis.

Location.- Lat $42^{\circ} 34^{\prime} 46^{\prime \prime}$, long $88^{\circ} 45^{\prime} 33^{\prime \prime}$, in NE1/4 sec. 6, T. 1 N., R. 15 E., Walworth County, at bridge on country road, $0.2 \mathrm{mi}(0.3 \mathrm{~km})$ south of Allens Grove.

Drainage area.- $41.8 \mathrm{mi}^{2}\left(108.3 \mathrm{~km}^{2}\right)$.

Gage.-Crest stage only.

Bankfull stage. $-12.5 \mathrm{ft}(3.81 \mathrm{~m})$.

Maxima._March-May 1973: Discharge, 8,400 ft $\mathrm{ft}^{3} / \mathrm{s}\left(238 \mathrm{~m}^{3} / \mathrm{s}\right)$ Apr. 21 [gage height, $18.28 \mathrm{ft}$ (5.572 $\left.\mathrm{m}\right)$ ]. Discharge exceeded the 100-year flood. 1962 to February 1973: Discharge, $2,440 \mathrm{ft}^{3} / \mathrm{s}\left(69.1 \mathrm{~m}^{3} / \mathrm{s}\right)$ Feb. 19, 1971 [gage height, $15.55 \mathrm{ft}(4.740 \mathrm{~m})$ ].

\section{ROCK RIVER BASIN}

(8) 05431500 Turtle Creek near Clinton, Wis.

Location.-Lat $42^{\circ} 35^{\prime} 47^{\prime \prime}$, long $88^{\circ} 51^{\prime} 50^{\prime \prime}$, in SE1/4 sec. 29 , T. 2 N., R. 14 E., Rock County, on left bank $15 \mathrm{ft}(5 \mathrm{~m})$ downstream from bridge on State Highway 140, $2.7 \mathrm{mi}(4.3 \mathrm{~km})$ north of Clinton, $11 \mathrm{mi}(18 \mathrm{~km})$ northeast of Beloit, and 16 mi $(26 \mathrm{~km})$ upstream from mouth.

Drainage area.- $202 \mathrm{mi}^{2}\left(523 \mathrm{~km}^{2}\right)$.

Gage.-Digital recorder tape punched at 60-minute intervals. Datum of gage is $817.00 \mathrm{ft}(249.022 \mathrm{~m})$ above mean sea level (levels by Corps of Engineers).

Bankfull stage. $-8.0 \mathrm{ft}(2.44 \mathrm{~m})$.

Maxima.-March-May 1973: Discharge, 16,500 ft $\mathrm{ft}^{3} / \mathrm{s}\left(467 \mathrm{~m}^{3} / \mathrm{s}\right)$ 8:00 a.m., Apr. 21 [gage height, $12.85 \mathrm{ft}$ (3.917 m)]. Discharge exceeded the 100-year flood. 1938 to February 1973: Discharge, $10,700 \mathrm{ft}^{3} / \mathrm{s}\left(303 \mathrm{~m}^{3} / \mathrm{s}\right)$ in February 1938 [gage height, $12.09 \mathrm{ft}(3.685 \mathrm{~m}) \mathrm{from} \mathrm{flood-}$ marks) ]

Mean discharge, in cubic feet per second, 1973

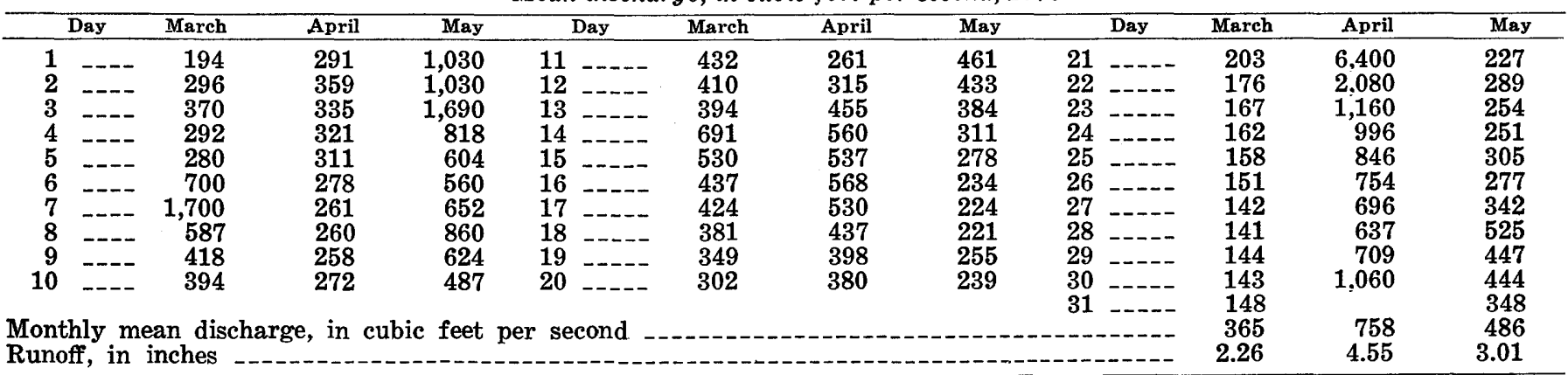


TABLE 12.-Station descriptions and discharge and suspended-sediment data-Continued

Gage height, in feet, and discharge, in cubic feet per second, at indicated time, 1973

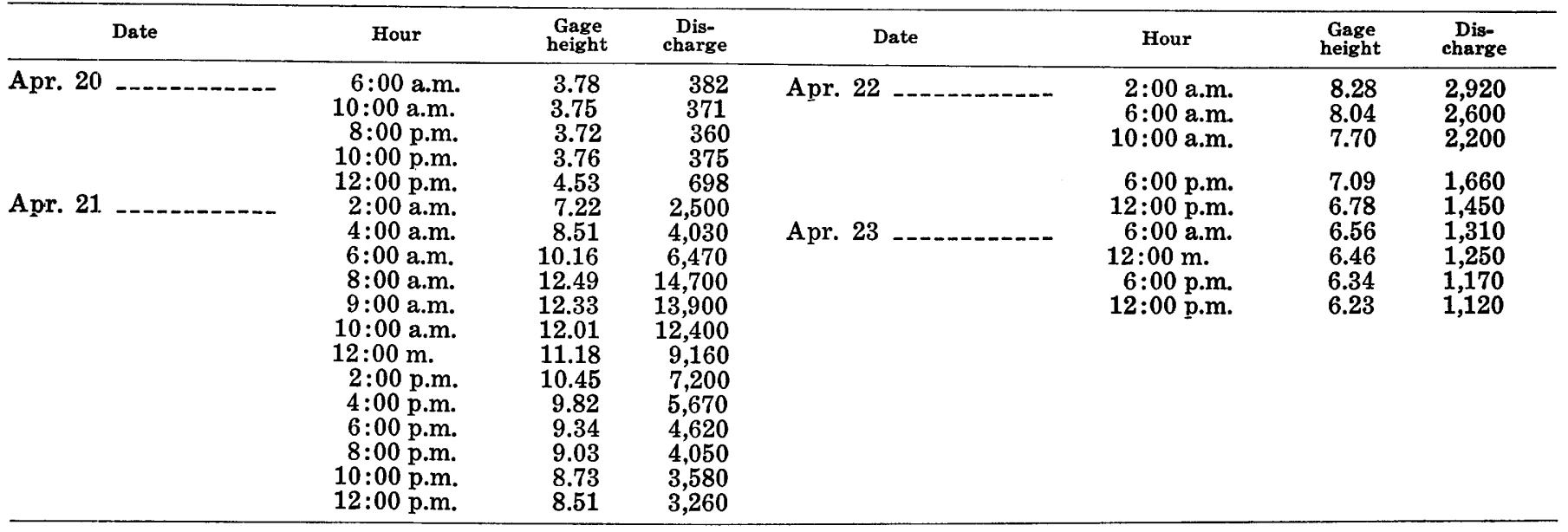

\begin{tabular}{|c|c|c|c|c|c|}
\hline Period & \multicolumn{5}{|c|}{ Highest mean discharge, in cubic feet per second, for the indicated number of consecutive days } \\
\hline $\begin{array}{l}\text { March-May } 1973 \\
1940-71\end{array}$ & $\begin{array}{l}6,400 \\
4,130\end{array}$ & $\begin{array}{l}3,210 \\
3,330\end{array}$ & $\begin{array}{l}1,850 \\
2,160\end{array}$ & $\begin{array}{l}1,370 \\
1,360\end{array}$ & $\begin{array}{l}938 \\
744\end{array}$ \\
\hline $\begin{array}{l}\text { Recurrence interval, in years, for } \\
1973 \text { flood volumes }\end{array}$ & $>100$ & $>100$ & 50 & 80 & $>100$ \\
\hline
\end{tabular}

\section{ROCK RIVER BASIN}

(9) 05446500 Rock River near Joslin, 111.

Location.-Lat $41^{\circ} 33^{\prime} 35^{\prime \prime}$, long $90^{\circ} 10^{\prime} 55^{\prime \prime}$, in NE1/4 sec. 18 , T. 18 N., R. 3 E., Rock Island County, on right bank at downstream side of bridge on State Highway $92,1.8$ miles $(2.9 \mathrm{~km})$ east of Joslin, 12 miles (19 km) downstream from Rock Creek, and 27 miles $(43 \mathrm{~km})$ upstream from mouth.

Drainage area.-9,551 $\mathrm{mi}^{2}\left(24,737 \mathrm{~km}^{2}\right)$, revised.

Gage.-Water-stage recorder. Datum of gage is $564.06 \mathrm{ft}(171.925 \mathrm{~m})$ above mean sea level (levels by Corps of Engineers). Maxima.-March-May 1973: Discharge, 41,500 ft $/ \mathrm{s}\left(1,180 \mathrm{~m}^{3} / \mathrm{s}\right)$ 11:00 a.m. Apr. 23 [gage height, $17.74 \mathrm{ft}(5.407 \mathrm{~m})$ ]. Recurrence interval of discharge is 17 years.

1939 to February 1973: Discharge, 46,200 ft $3 / \mathrm{s}\left(1,310 \mathrm{~m}^{3} / \mathrm{s}\right)$ Mar. 22, 1948 [gage height, $14.46 \mathrm{ft}(4.407 \mathrm{~m})$ ]; gage height, 17.69 (5.392 m) Feb. 23, 1971 (backwater from ice).

Maximum stage known since 1892, that of Apr. 23, 1973.

Mean discharge, in cubic feet per second, 1973

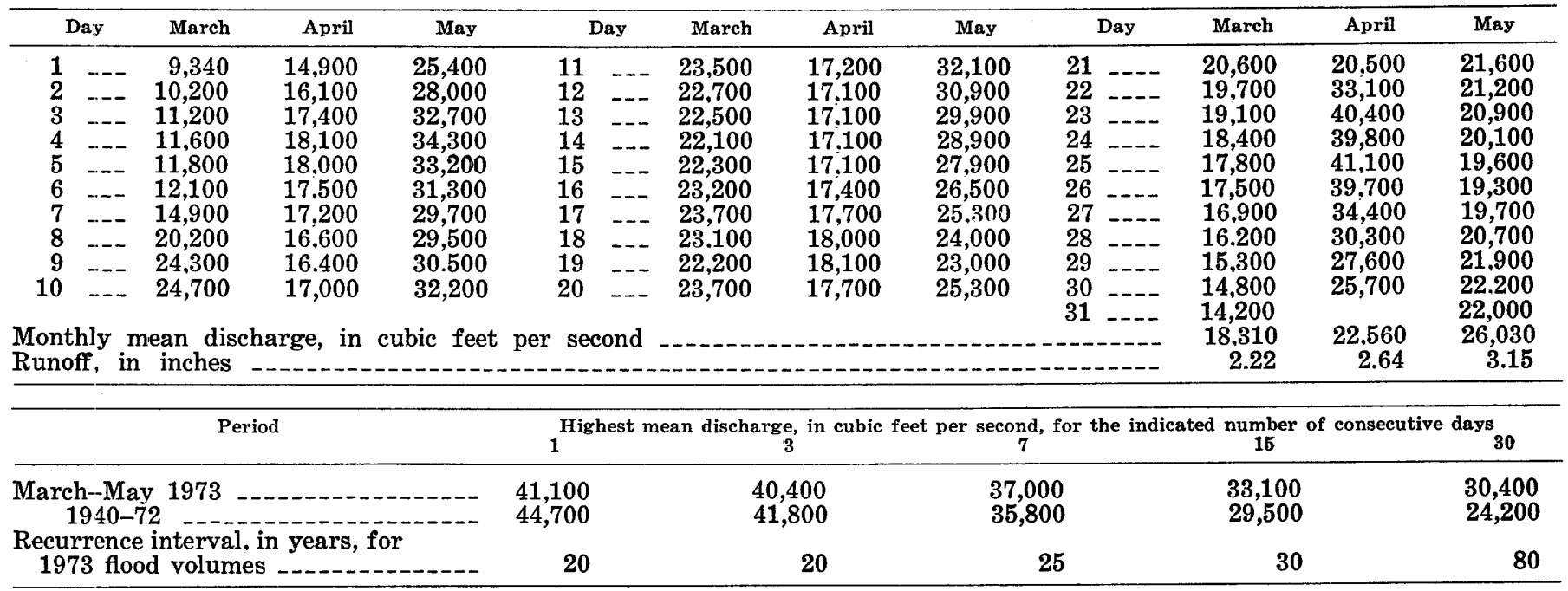

IOWA RIVER BASIN

(10) 05453100 Iowa River at Marengo, Iowa

Location.-Lat $41^{\circ} 48^{\prime} 41^{\prime \prime}$, long $92^{\circ} 03^{\prime} 42^{\prime \prime}$, in SW1/4 NE1/4 sec. 24, T. 81 N., R. 11 W., Iowa County, on right bank 10 ft (3 m) downstream from abandoned highway bridge, 0.7 mile $(1.1 \mathrm{~km})$ downstream from Big Bear Creek, $0.8 \mathrm{mile}(1.3 \mathrm{~km}) \mathrm{north}$ of Marengo, 4.9 miles $(7.9 \mathrm{~km})$ upstream from Hilton Creak, and at mile $139.4(224.3 \mathrm{~km})$. 
TABLE 12.-Station descriptions and discharge and suspended-sediment data-Continued

Drainage area.-2,794 $\mathrm{mi}^{2}\left(7,236 \mathrm{~km}^{2}\right)$.

Gage.-Water-stage recorder. Datum of gage is $720.52 \mathrm{ft}(219.614 \mathrm{~m})$ above mean sea level.

Flood stage.-14 ft $(4.3 \mathrm{~m})$.

Maxima.-March-May 1973: Discharge, 16,600 ft's $/ \mathrm{s}\left(470 \mathrm{~m}^{3} / \mathrm{s}\right)$ 6:15 p.m., Apr. 16 [gage height, $17.73 \mathrm{ft}$ (5.404 m)]. Recurrence interval of discharge is 3 years.

October 1956 to February 1973: Discharge, 30,800 $\mathrm{ft}^{3} / \mathrm{s}\left(8.72 \mathrm{~m}^{3} / \mathrm{s}\right)$ Mar. 31, 1960 [gage height, $19.21 \mathrm{ft}(5.855 \mathrm{~m})$ ] Maximum gage height, $19.79 \mathrm{ft}(6.032 \mathrm{~m})$ July $12,1969$.

Remarks.-Station data included in this report primarily for sediment analysis.

Mean water discharge and suspended-sediment concentration and discharge

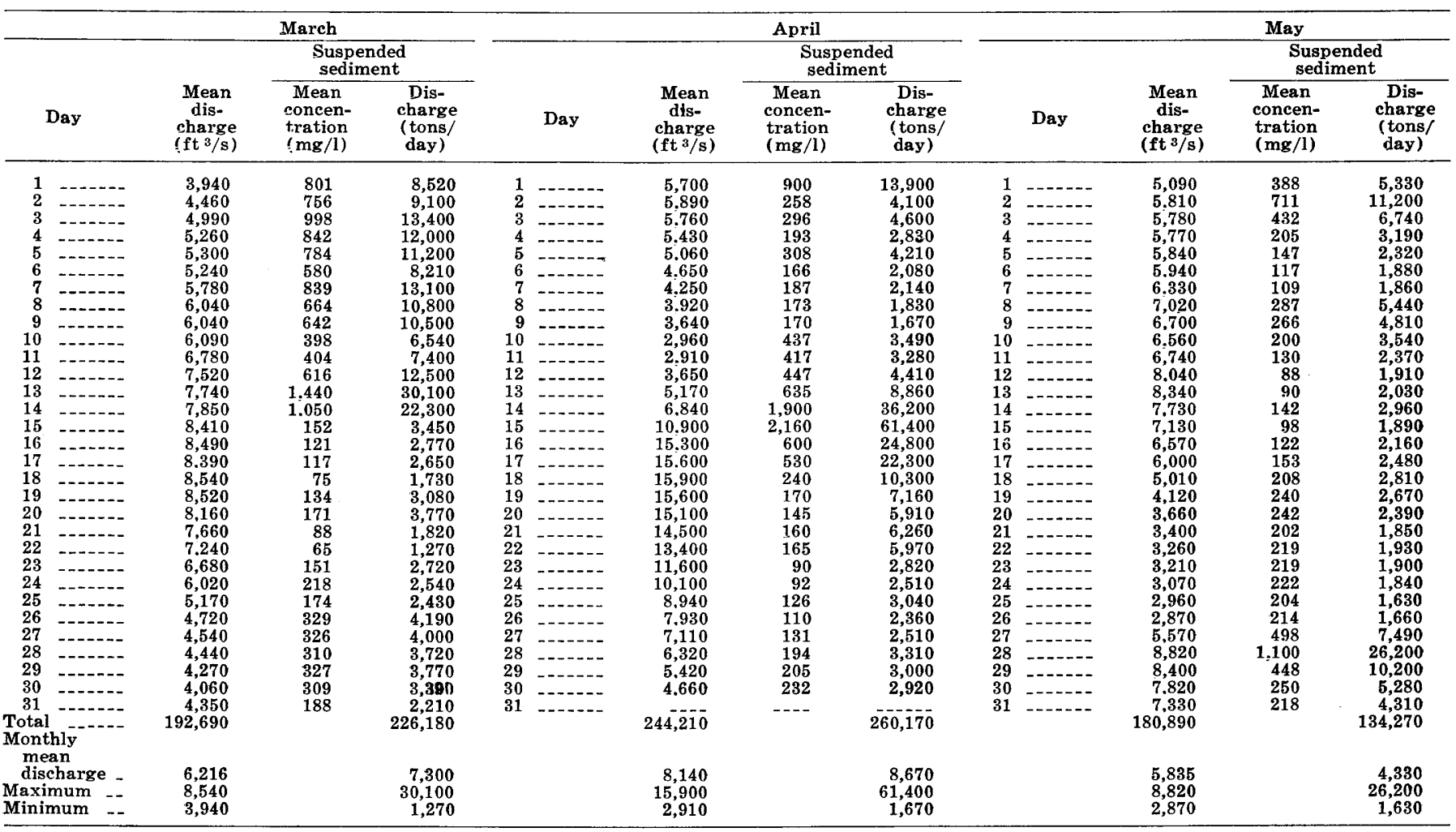

Gage height, water discharge, and suspended-sediment concentration and discharge

\begin{tabular}{|c|c|c|c|c|c|c|c|c|c|c|c|}
\hline \multirow[b]{2}{*}{ Date } & \multirow[b]{2}{*}{ Time } & \multirow[b]{2}{*}{$\underset{\substack{\text { Gage } \\
\text { height } \\
(\mathrm{ft})}}{ }$} & \multirow[b]{2}{*}{$\begin{array}{c}\text { Dis- } \\
\text { charge } \\
\text { (cfs) }\end{array}$} & \multirow{2}{*}{\multicolumn{2}{|c|}{$\begin{array}{cc}\text { Suspended } & \text { sediment } \\
\text { Concen- } & \text { Dis- } \\
\text { tration } & \text { charge } \\
(\mathrm{mg} / \mathrm{l}) & \text { tons } / \\
& \text { day } \\
\end{array}$}} & \multirow[b]{2}{*}{ Date } & \multirow[b]{2}{*}{ Time } & \multirow[b]{2}{*}{$\begin{array}{c}\text { Gage } \\
\text { height } \\
(\mathrm{ft})\end{array}$} & \multirow[b]{2}{*}{$\begin{array}{c}\text { Dis- } \\
\text { charge } \\
\text { (cfs) }\end{array}$} & \multicolumn{2}{|c|}{ Suspended sediment } \\
\hline & & & & & & & & & & $\begin{array}{c}\text { Concen- } \\
\text { tration } \\
(\mathrm{mg} / \mathrm{l})\end{array}$ & $\begin{array}{c}\text { Dis- } \\
\text { charge } \\
\text { tons/ } \\
\text { day }\end{array}$ \\
\hline
\end{tabular}

\footnotetext{
${ }^{1}$ One-vertical suspended-sediment sample at 7:00 a.m. contained 29 percent clay, 63 percent silt, and 8 percent sand.
} 
TABLE 12.-Station descriptions and discharge and suspended-sediment data-Continued

IOWA RIVER BASIN

(11) 05454500 Iowa River at Iowa City, Iowa

Location.-Lat $41^{\circ} 39^{\prime} 24^{\prime \prime}$, long $91^{\circ} 32^{\prime} 27^{\prime \prime}$, in SE1/4 SE1/4 sec. 9, T. 79 N., R. 6 W., Johnson County, on right bank $25 \mathrm{ft}(7.6 \mathrm{~m})$ downstream from Hydraulics Laboratory of University of Iowa in Iowa City, $175 \mathrm{ft}(53 \mathrm{~m})$ downstream from University Dam, 0.8 mile $(1.3 \mathrm{~km})$ upstream from Ralston Creek, 3.6 miles $(5.8 \mathrm{~km})$ downstream from Clear Creek, and at mile 74.2 $(119.4 \mathrm{~km})$.

Drainage area.- $-3,271 \mathrm{~m}^{2}\left(8,472 \mathrm{~km}^{2}\right)$

Gage.-Water-stage recorder. Datum of gage is $29.0 \mathrm{ft}(8.8 \mathrm{~m})$ above Iowa City datum, and $617.27 \mathrm{ft}(188.14 \mathrm{~m})$ above mean sea level, datum of 1929 . June 1, 1903, to July 21, 1906, chain gage $1,200 \mathrm{ft}(366 \mathrm{~m})$ upstream at datum $13.05 \mathrm{ft}(3.98 \mathrm{~m})$ higher. Nov. 29, 1907, to Oct. 29, 1913, staff gage $200 \mathrm{ft}(61 \mathrm{~m})$ upstream at different datum. Oct. 30, 1913, to Nov. 18, 1921, chain gage $2,600 \mathrm{ft}(792 \mathrm{~m})$ downstream at datum $10.2 \mathrm{ft}(3.11 \mathrm{~m})$ higher. Nov. 19, 1921, to Sept. 30, 1922, water-stage recorder at present site at datum $11.0 \mathrm{ft}(3.35 \mathrm{~m})$ higher. Oct. 1, 1930, to Sept. 30, 1934, at present site at Iowa City datum Oct. 1, 1934 to Sept. 30, 1972, at datum $10.00 \mathrm{ft}(3.05 \mathrm{~m})$ higher.

Maxima.-March-May 1973: Discharge, 11,300 ft's $\left(320 \mathrm{~m}^{3} / \mathrm{s}\right) 10: 45 \mathrm{a} . \mathrm{m}$., hours May 1, [gage height, $22.04 \mathrm{ft}(6.718 \mathrm{~m})$ ].

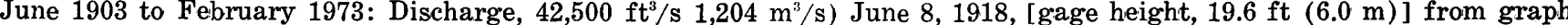
based on gage readings, site and datum then in use.

Maximum stage known since 1850 , about $34 \mathrm{ft}(10.4 \mathrm{~m})$ June 1851 [discharge, about $70,000 \mathrm{ft}^{3} / \mathrm{s}\left(1,980 \mathrm{~m}^{3} / \mathrm{s}\right)$ ].

March-May 1973: Sediment concentration, maximum daily, 1,580 mg/1 April 21 .

Sediment discharge, maximum daily, 20,300 tons (18,400 t) April 21.

October 1943 to February 1973: Sediment concentration, maximum daily, 7,800 mg/l June 13, 1953.

Sediment discharge, maximum daily, 177,000 tons (161,000t) May 23, 1944

Remarks.-Flow regulated by Coralville Lake [capacity 476,000 ac-ft $\left(587 \mathrm{hm}^{3}\right)$ ] since Sept. 7 , 1958. Station data included in this report primarily for sediment analysis.

Mean water discharge and suspended-sediment concentration and discharge

\begin{tabular}{|c|c|c|c|c|c|c|c|c|c|c|c|c|c|c|}
\hline \multirow{3}{*}{\multicolumn{2}{|c|}{ Day }} & \multicolumn{3}{|c|}{ March } & \multicolumn{5}{|c|}{ April } & \multicolumn{5}{|c|}{ May } \\
\hline & & \multirow[b]{2}{*}{$\begin{array}{c}\text { Mean } \\
\text { dis- } \\
\text { charge } \\
\left(\mathrm{ft}^{3} / \mathrm{s}\right)\end{array}$} & \multicolumn{2}{|c|}{$\begin{array}{l}\text { Suspended } \\
\text { sediment }\end{array}$} & \multirow{2}{*}{\multicolumn{2}{|c|}{ Day }} & \multirow[b]{2}{*}{$\begin{array}{c}\text { Mean } \\
\text { dis- } \\
\text { charge } \\
\left(\mathrm{ft}^{3} / \mathrm{s}\right)\end{array}$} & \multicolumn{2}{|c|}{$\begin{array}{c}\text { Suspended } \\
\text { sediment }\end{array}$} & \multirow{2}{*}{\multicolumn{2}{|c|}{ Day }} & \multirow[b]{2}{*}{$\begin{array}{c}\text { Mean } \\
\text { dis- } \\
\text { charge } \\
\left(\mathrm{ft}^{3} / \mathrm{s}\right)\end{array}$} & \multicolumn{2}{|c|}{$\begin{array}{c}\text { Suspended } \\
\text { sediment }\end{array}$} \\
\hline & & & $\begin{array}{c}\text { Mean } \\
\text { concen- } \\
\text { tration } \\
(\mathrm{mg} / \mathrm{l})\end{array}$ & $\begin{array}{c}\text { Dis- } \\
\text { charge } \\
\text { (tons/ } \\
\text { day) }\end{array}$ & & & & $\begin{array}{l}\text { Mean } \\
\text { concen- } \\
\text { tration } \\
(\mathrm{mg} / \mathrm{l})\end{array}$ & $\begin{array}{c}\text { Dis- } \\
\text { charge } \\
\text { (tons/ } \\
\text { day) }\end{array}$ & & & & $\begin{array}{l}\text { Mean } \\
\text { concen- } \\
\text { tration } \\
(\mathrm{mg} / 1)\end{array}$ & $\begin{array}{l}\text { Dis- } \\
\text { charge } \\
\text { (tons/ } \\
\text { day) }\end{array}$ \\
\hline 1 & .- & 5,650 & 241 & 3,680 & 1 & & 4,830 & 139 & 1,810 & 1 & & 10.800 & 103 & 3,000 \\
\hline 2 & $\ldots$ & 6,050 & 216 & 3,530 & 2 & & 3,920 & 92 & 974 & 2 & & 9,690 & 143 & 3,740 \\
\hline$\overline{3}$ & ------. & 6,000 & 191 & 3,090 & 3 & & 5,960 & 78 & 1,260 & 3 & & 8,080 & 177 & 3,860 \\
\hline 4 & 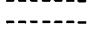 & 5,600 & 164 & 2,480 & 4 & - & 7,570 & 65 & 1,330 & 4 & & 8,080 & 86 & 1,880 \\
\hline 5 & - & 5,510 & 139 & 2,070 & 5 & - & 8.530 & 56 & 1,290 & 5 & & 8,980 & 72 & 1,750 \\
\hline 6 & 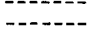 & 5.610 & 270 & 4,090 & 6 & $\ldots$ & 8,780 & 48 & 1,140 & 6 & & 10,200 & 73 & 2,010 \\
\hline 7 & -..... & 6,250 & 504 & 8,510 & 7 & & 9,180 & 51 & 1,260 & 7 & & 10,700 & 105 & 3,030 \\
\hline 8 & $-1-1$ & 6.000 & $\begin{array}{l}0.04 \\
187\end{array}$ & $\begin{array}{l}0,010 \\
3,030\end{array}$ & 8 & & 9,130 & 57 & 1,410 & 8 & & 9,640 & 163 & 4,240 \\
\hline 9 & - & 6,030 & 130 & 2,120 & 9 & - & 9.180 & 63 & 1,560 & 9 & - & 9,580 & 155 & 4,010 \\
\hline 10 & - - & 6,170 & 165 & 2,750 & 10 & & 9,040 & 68 & 1,660 & 10 & & 9,460 & 139 & 3,550 \\
\hline 11 & $-\cdots$ & 6,790 & 363 & 6,650 & 11 &.- & 9,050 & 73 & 1,780 & 11 & & 9,690 & 134 & 3,510 \\
\hline 12 & ------- & 6,680 & 244 & 4,400 & 12 &.- & 9.080 & 81 & 1,990 & 12 & & 10,200 & 129 & 3,550 \\
\hline 13 & - - - & 5,980 & 145 & 2,340 & 13 & $\cdots$ & 8.220 & 110 & 2,440 & 13 & & 10,200 & 123 & 3,390 \\
\hline 14 & -- & 5,080 & 526 & 7,210 & 14 & - & 7,350 & 175 & 3,470 & 14 & $\ldots$ & 10,100 & 117 & 3,190 \\
\hline 15 & ------ & 5,160 & 158 & 2,200 & 15 & & 5,440 & 295 & 4,330 & 15 & & 10,100 & 100 & 2,730 \\
\hline 16 & 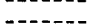 & 4,150 & 102 & 1,140 & 16 & -- & 4,090 & 276 & 3,050 & 16 & --1 & 10,000 & 83 & 2,240 \\
\hline 17 & ---.... & 1,650 & 90 & 401 & 17 & $--1-1$ & 3.390 & 198 & 1,810 & 17 & - & 6,230 & 202 & 3,400 \\
\hline 18 & - & 1,350 & 81 & 295 & 18 & - & $\begin{array}{l}2.990 \\
2.990\end{array}$ & 164 & 1,320 & 18 & & 8,510 & 47 & 1,080 \\
\hline 19 & - & 1,350 & 72 & 262 & 19 & -- & 2,320 & 138 & 864 & 19 & - & 9,910 & 38 & 1,020 \\
\hline 20 & $-\ldots$ & 1,340 & 63 & 228 & 20 & 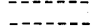 & 2,700 & 780 & 5,690 & 20 & 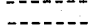 & 9,850 & 37 & 984 \\
\hline 21 & ---.- & 1,330 & 52 & 187 & 21 & 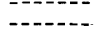 & 4,750 & 1,580 & 20,300 & 21 & & 9.920 & 36 & 964 \\
\hline 22 & - & 1,340 & 48 & 174 & 22 & $-\cdots$ & 3,350 & 1,120 & 10,100 & 22 & & 9,890 & 36 & 961 \\
\hline 23 & -...-- & 1,330 & 46 & 165 & 23 & $\ldots$ & 1,920 & 490 & 2,540 & 23 & $\ldots$ & 8,990 & 41 & 995 \\
\hline 24 & - & 1,330 & 44 & 158 & 24 & - & 4,090 & 465 & 5,120 & 24 & $\ldots$ & 8,130 & 42 & 922 \\
\hline 25 & -.....-. & 1,400 & 53 & 200 & 25 & $--1-1$ & 5,940 & 705 & 11,300 & 25 & $-1-1$ & 6,410 & 40 & 692 \\
\hline 26 & - & 1,430 & 53 & 205 & 26 & & 7,830 & 450 & 9,510 & 26 & & 6,340 & 40 & 685 \\
\hline 27 & 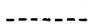 & 1,730 & 41 & 192 & 27 & - & 9,720 & 228 & 5,980 & 27 & $\ldots$ & 7,610 & 41 & 842 \\
\hline 28 & -...... & 3,430 & 62 & 574 & 28 & -..... & 10,500 & 157 & 4,450 & 28 & 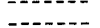 & 6,120 & 113 & 1,870 \\
\hline 29 & $\ldots$ & 5,060 & 219 & 2,990 & 29 & - & 10.400 & 116 & 3,260 & 29 & 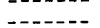 & 4,010 & 85 & 920 \\
\hline 30 & - & 7,340 & 281 & 5,570 & $\mathbf{3} 0$ & - & 10,500 & 94 & 2,660 & 30 & - & 4,930 & 69 & 918 \\
\hline 31 & $-\cdots--$ & 7.820 & 257 & 5,430 & 31 & ----- & & & & 31 & & 5,610 & 111 & 1,680 \\
\hline \multirow{2}{*}{\multicolumn{2}{|c|}{$\begin{array}{l}\text { Monthly } \\
\text { mean } \\
\text { dis- }\end{array}$}} & 131,940 & & 76,321 & & & 199,750 & & 115,668 & & & 267,960 & & 67,613 \\
\hline & & & & & & & & & & & & & & \\
\hline \multirow{2}{*}{\multicolumn{2}{|c|}{$\begin{array}{c}\text { charge } \\
\text { Maximum }\end{array}$}} & 4,260 & & 2,460 & & & 6,660 & & 3,860 & & & 8,640 & & 2,180 \\
\hline & & 7,820 & & 8,510 & & & 10,500 & & 20,300 & & & 10,800 & & 4,240 \\
\hline \multicolumn{2}{|c|}{ Minimum -- } & 1,330 & & 158 & & & $\begin{array}{r}1,920 \\
1,900\end{array}$ & & 864 & & & 4,010 & & 685 \\
\hline
\end{tabular}

IOWA RIVER BASIN

(12) 05465500 Iowa River at Wapello, Iowa

Location.-Lat $41^{\circ} 10^{\prime} 48^{\prime \prime}$, long $91^{\circ} 10^{\prime} 57^{\prime \prime}$, in NW1/4 SE1/4 sec. 27, T. 74 N., R. 3 W., Louisa County, on right bank $30 \mathrm{ft}(9 \mathrm{~m})$ downstream from bridge on State Highway 99 at east edge of Wapello, 13.0 miles $(20.9 \mathrm{~km})$ downstream from Cedar River, and at mile $16.0(25.7 \mathrm{~km})$

Drainage area.-12,499 $\mathrm{mi}^{2}\left(32.372 \mathrm{~km}^{2}\right)$.

Gage.--Water-stage recorder. Datum of gage is $538.98 \mathrm{ft}(164.281 \mathrm{~m})$ above mean sea level, adjustment of $1912.0 \mathrm{ct} .1$, 1914 to Apr. 15, 1934, nonrecording gage and Apr. 16, 1934 to Sept. 30, 1972, water-stage recorder at datum $10 \mathrm{ft}$ (3.05 m) higher. Flood stage. $-20 \mathrm{ft}(6.1 \mathrm{~m})$. Flood stage was exceeded for 47 days during the 3 -month report period.

Maxima.-March-Mav 1973: Discharge, 92,000 $\mathrm{ft}^{3} / \mathrm{s}\left(2.600 \mathrm{~m}^{3} / \mathrm{s}\right) 12: 00 \mathrm{p} . \mathrm{m}$., Apr. 22 [gage height, $28.63 \mathrm{ft}(8.726 \mathrm{~m})$ ].

October 1914 to February 1973: Discharge, $94,000 \mathrm{ft}^{3} / \mathrm{s}\left(2,660 \mathrm{~m}^{3} / \mathrm{s}\right)$ June 18, 1947. [gage height, $16.14 \mathrm{ft}(4.919 \mathrm{~m})$, datum then in use]; maximum gage height, $17.40 \mathrm{ft}(5.304 \mathrm{~m})$ July 151969 , datum then in use.

Remarks. - High flows regulated by Coralville Lake [capacity 476.000 acre-ft $\left(587 \mathrm{hm}^{3}\right)$ ] since Sept. 17, 1958 . Recurrence intervals of flood peaks and volumes are not shown because of reservoir effect. 
TABLE 12.-Station descriptions and discharge and suspended-sediment data-Continued

Mean discharge, in cubic feet per second, 1973

\begin{tabular}{|c|c|c|c|c|c|c|c|c|c|c|c|c|}
\hline \multicolumn{2}{|c|}{ Day } & \multirow{2}{*}{$\frac{\text { March }}{13,400}$} & \multirow{2}{*}{ April } & \multirow{2}{*}{$\frac{\text { May }}{29,900}$} & Day & March & April & \multirow{2}{*}{$\frac{\text { May }}{42,200}$} & Day & \multirow{2}{*}{$\frac{\text { March }}{33,500}$} & \multirow{2}{*}{$\frac{\text { April }}{53,600}$} & \multirow{2}{*}{$\frac{\text { May }}{22,100}$} \\
\hline 1 & & & & & 11 & 28,900 & 24,000 & & 21 & & & \\
\hline 2 & --- & 13,600 & 25,200 & 37,500 & 12 & 31,400 & 22,500 & 38,500 & 22 & 30,900 & 81,300 & 21,600 \\
\hline 3 & --- & 15,600 & 23,200 & 41,100 & 13 & 33,500 & 22,800 & 37,500 & $23 \ldots$ & 28,200 & 84,200 & 21,100 \\
\hline 4 & --- & 15,300 & 21,700 & 41,500 & 14 & 34,600 & 23,800 & 38,500 & 24 & 24,300 & 69,800 & 20,200 \\
\hline 5 & & 15,600 & 21,000 & 34,200 & 15 & 34,700 & 24,600 & 39,500 & 25 & 21,200 & 53,000 & 19,300 \\
\hline 6 & $\ldots$ & 17,000 & 21,400 & 29,000 & 16 & 33,800 & 25,700 & 39,000 & 26 & 19,400 & 40,600 & 17,200 \\
\hline 7 & $\ldots$ & 22,000 & 21,200 & 29,000 & 17 & 32,100 & 27,400 & 35,700 & 27 & 18,200 & 34,100 & 19,500 \\
\hline 8 & - & 25,800 & 20.900 & 33,200 & 18 & 32,400 & 30,800 & 30,200 & 28 & 16,700 & 30,500 & 27,900 \\
\hline 9 & & 27,000 & 23,100 & 38,100 & 19 & 35.900 & 35,500 & 24,300 & 29 & 16,900 & 28.100 & 31,900 \\
\hline 10 & - & 26,600 & 26,300 & 42,700 & $20---$ & 36,200 & 36,400 & 22,700 & $30 \ldots$ & 18,000 & 27,000 & 33,700 \\
\hline \multicolumn{9}{|c|}{ Monthly mean discharge, in cubic $\mathrm{ft} p$} & & $\begin{array}{l}20,500 \\
24,940\end{array}$ & 33.480 & 360 \\
\hline & & 1 uin & ge, in & 政 10 & & & & & & $1,534,000$ & $1,992,000$ & $1,928,000$ \\
\hline
\end{tabular}

Gage height, in feet, and discharge in cubic feet per second, at indicated time, 1973

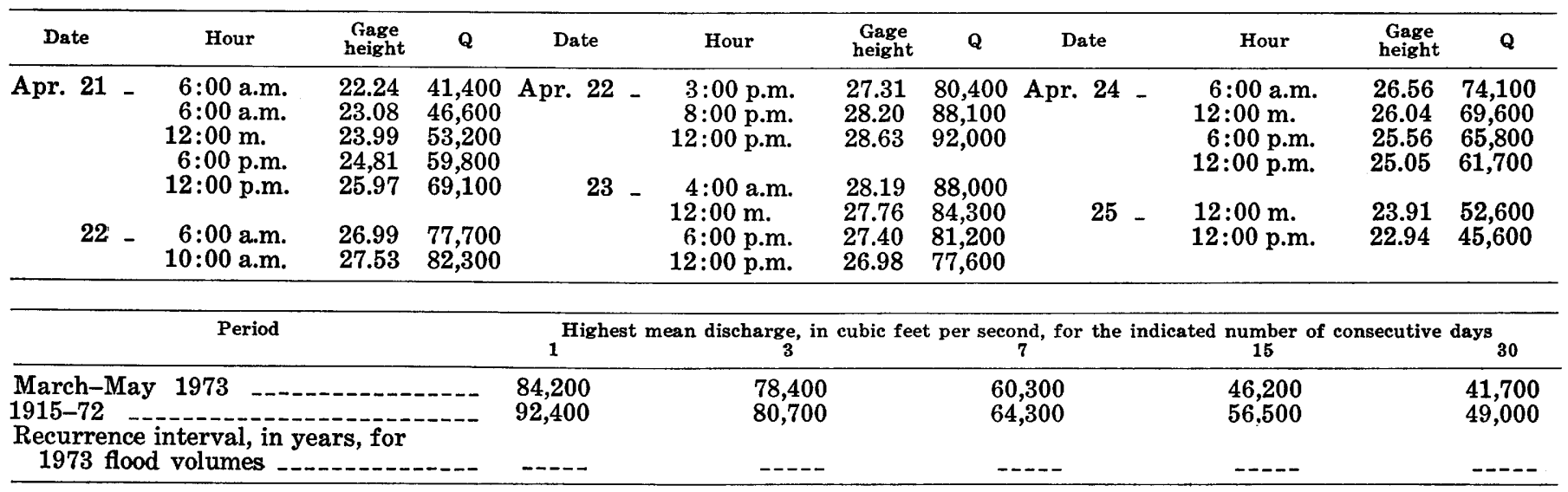

EDWARDS RIVER BASIN

(13) 05466500 Ewards River near New Boston, Ill.

Location.-Lat $41^{\circ} 11^{\prime} 15^{\prime \prime}$, long $90^{\circ} 58^{\prime} 05^{\prime \prime}$, at quarter corner between secs. 21 and 28 , T. 14 N., R. 5 W., Mercer County, on left bank at downstream side of bridge on State Highway 17, 1.5 miles $(2.4 \mathrm{~km})$ northeast of New Boston and 5 miles $(8$ $\mathrm{km}$ ) upstream from mouth.

Drainage area.- $445 \mathrm{mi}^{2}\left(1,153 \mathrm{~km}^{2}\right)$.

Gage.-Water-stage recorder. Datum of gage is $529.92 \mathrm{ft}(161.520 \mathrm{~m})$ above mean sea level (levels by Corps of Engineers)

Maxima.-March-May 1973: Discharge, 18,000 ft's $\left(510 \mathrm{~m}^{3} / \mathrm{s}\right)$ 8:45 a.m., Apr. 22 [gage height, $23.33 \mathrm{ft}$ (7.111 m)]. Discharge exceeded the 100-year flood.

1934 to February 1973: Discharge, 7,280 $\mathrm{ft}^{3} / \mathrm{s}\left(206 \mathrm{~m}^{3} / \mathrm{s}\right)$ Apr. 26, 1950, May 12, 1951; gage height, $21.53 \mathrm{ft}(6.562 \mathrm{~m})$ Feb. 21, 1971 (backwater from ice).

Mean discharge, in cubic feet per second, 1973

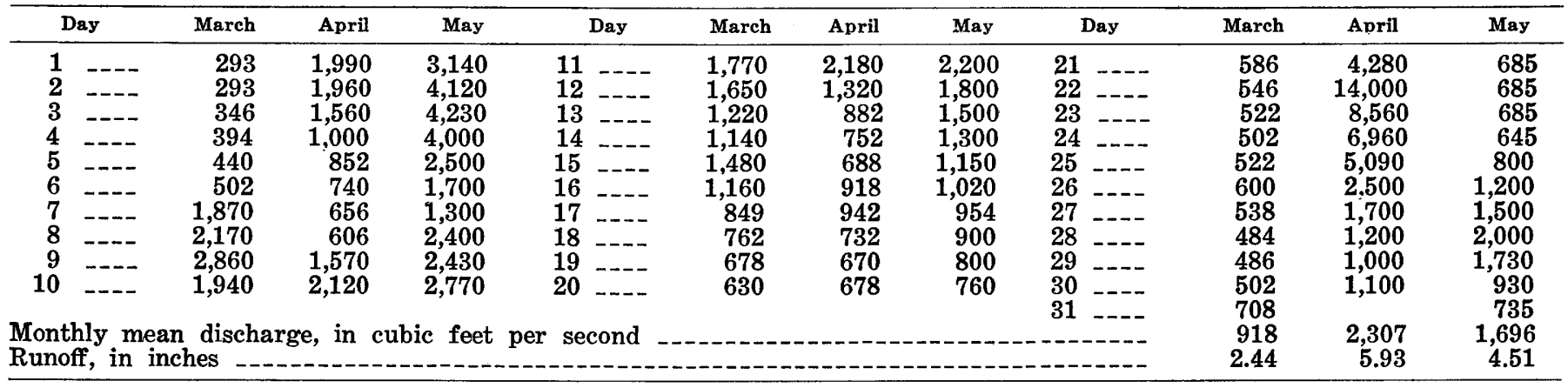

\begin{tabular}{|c|c|c|c|c|c|}
\hline Period & \multicolumn{5}{|c|}{${ }_{1}^{\text {Highest mean discharge, in cubic feet per second, for the indicated number of consecutive days }}{ }_{30}$} \\
\hline March-May 1973 _. & $\begin{array}{r}14,000 \\
7,280\end{array}$ & $\begin{array}{l}9,840 \\
6,210\end{array}$ & $\begin{array}{l}6,160 \\
4,000\end{array}$ & $\begin{array}{l}4,290 \\
2,310\end{array}$ & $\begin{array}{l}2,910 \\
1,780\end{array}$ \\
\hline
\end{tabular}


TABLE 12.-Station descriptions and discharge and suspended-sediment data-Continued

\section{SKUNK RIVER BASIN}

(14) 05473500 Big Creek near Mount Pleasant, Iowa

Location.-Lat $41^{\circ} 00^{\prime} 52^{\prime \prime}$, long $91^{\circ} 34^{\prime} 49^{\prime \prime}$, in NW1/4 NW1/4 sec. 29 , T. 72 N., R. 6 W., Henry County, on left bank $12 \mathrm{ft}$ (4 m) downstream from bridge on county highway, $100 \mathrm{ft}(30 \mathrm{~m})$ downstream from Lynn Creek, 0.7 mile (1.1 km) downstream from Brandywine Creek, and 3.7 miles $(6.0 \mathrm{~km})$ northwest of courthouse at Mount Pleasant.

Drainage area.-106 $\mathrm{mi}^{2}\left(275 \mathrm{~km}^{2}\right)$.

Gage.-Waterstage recorder and concrete control. Datum of gage is $630.53 \mathrm{ft}(192.186 \mathrm{~m})$ above mean sea level.

Bankfull stage. $-17 \mathrm{ft}(5.2 \mathrm{~m})$.

Maxima.-March-May 1973: Discharge, 10,500 ft3 $/ \mathrm{s}\left(297 \mathrm{~m}^{3} / \mathrm{s}\right) \quad 3: 00$ a.m., Apr. 22 [gage height, 25.58 (7.797 m)], from rating curve extended above $6,200 \mathrm{ft}^{3} / \mathrm{s}\left(176 \mathrm{~m}^{3} / \mathrm{s}\right)$ on basis of contracted-opening measurement at gage height 18.51 ft $(5.642 \mathrm{~m})$ and contracted-opening measurements of 1973 peak flow at sites 2 miles $(3 \mathrm{~km})$ upstream [63 mi $\left.\left.{ }^{2}(163 \mathrm{~km})^{2}\right)\right]$ and 6 miles $(10 \mathrm{~km})$ downstream $\left[115 \mathrm{mi}^{2}\left(298 \mathrm{~km}^{2}\right)\right]$. Recurrence interval of discharge is 90 years.

October 1955 to February 1973: Discharge $\left(6,150 \mathrm{ft}^{3} / \mathrm{s}\left(174 \mathrm{~m}^{3} / \mathrm{s}\right)\right.$ Sept. 21,1965 [gage height, $18.51 \mathrm{ft}(5.642 \mathrm{~m}), \mathrm{from}$ floodmarks)], from rating curve extended as explained above. Flood of Aug. 3, 1948 reached a stage of $27 \mathrm{ft}$ [ (8.2 $\mathrm{m}$ ) (discharge not determined) ].

Remarks.-Flood-profile data available elsewhere in this report.

Mean discharge, in cubic feet per second, 1973

\begin{tabular}{|c|c|c|c|c|c|c|c|c|c|c|c|c|}
\hline \multicolumn{2}{|c|}{ Day } & March & April & May & Day & March & April & May & Day & March & April & May \\
\hline 1 & $\ldots$ & 65 & 1,510 & 650 & $11 \ldots$ & 751 & 400 & 170 & 21 & 70 & 4,720 & 39 \\
\hline 2 & -.-- & 144 & 602 & 2,500 & $12 \ldots$ & 402 & 288 & 125 & 22 & 62 & 7,680 & 41 \\
\hline 3 & $\ldots$ & 184 & 332 & 488 & 13 & 281 & 197 & 101 & 23 & 57 & 815 & 39 \\
\hline 4 & $\ldots$ & 166 & 258 & 267 & $14 \ldots$ & 805 & 152 & 85 & 24 & 57 & 354 & 37 \\
\hline 5 & -..- & 169 & 207 & 191 & 15 & 395 & 123 & 72 & $25 \ldots$ & 162 & 260 & 42 \\
\hline 6 & -... & 259 & 162 & 193 & 16 & 206 & 254 & 61 & 26 & 245 & 196 & 39 \\
\hline 7 & -.-- & 937 & 123 & 441 & 17 & 154 & 194 & 53 & $27 \ldots$ & 155 & 152 & 2,710 \\
\hline 8 & -..- & 448 & 97 & 730 & 18 & 115 & 143 & 48 & $28 \ldots$ & 119 & 121 & 1,690 \\
\hline 9 & $\ldots$ & 316 & 1,500 & 344 & 19 & 95 & 11 & 47 & 29 & 132 & 105 & 424 \\
\hline 10 & --- & 458 & 867 & 234 & 20 & 83 & 982 & 41 & $30 \ldots$ & 162 & 94 & 271 \\
\hline Mon & $\mathrm{v}$ & isol & in & fe & & & & & 31 ---- & $\begin{array}{l}858 \\
275\end{array}$ & 767 & $\begin{array}{l}193 \\
399\end{array}$ \\
\hline Run & $\begin{array}{l}\text { iny } \\
\text { ffe, in }\end{array}$ & & & & & & & & --- & $\begin{array}{l}270 \\
2.99\end{array}$ & 8.07 & $\begin{array}{r}39 y \\
4.34\end{array}$ \\
\hline Runc & ffe, in & eet & & & & & & & & 16,880 & 45,630 & 24,530 \\
\hline
\end{tabular}

Gage height, in feet, and discharge in cubic feet per second, at indicated time, 1973

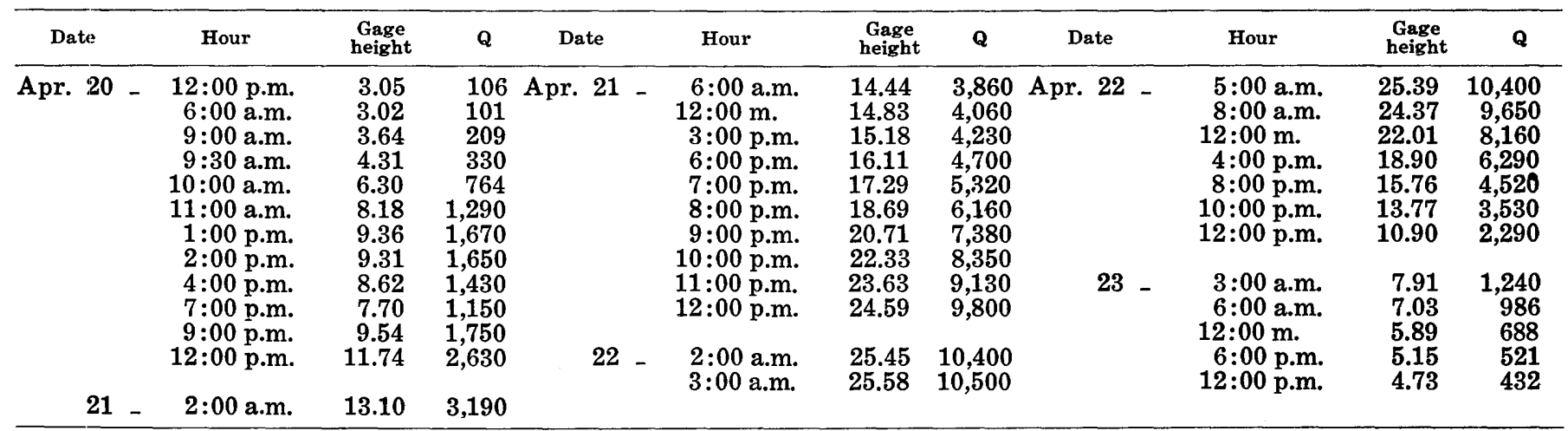

\begin{tabular}{|c|c|c|c|c|c|}
\hline Period & \multicolumn{5}{|c|}{$\underset{1}{\text { Highest mean discharge, in cubic feet per second, for the indicated number of consecutive days }}{ }_{3}$} \\
\hline $\begin{array}{l}\text { March-May } 1973 \\
1956-72\end{array}$ & $\begin{array}{l}7,680 \\
5,460\end{array}$ & $\begin{array}{l}4,460 \\
3,810\end{array}$ & $\begin{array}{l}2,140 \\
2,100\end{array}$ & $\begin{array}{l}1,230 \\
1,410\end{array}$ & $\begin{array}{r}839 \\
1,040\end{array}$ \\
\hline $\begin{array}{l}\text { Recurrence interval, in years, for } \\
1973 \text { flood volumes }\end{array}$ & 100 & 50 & 30 & 30 & 25 \\
\hline
\end{tabular}

SKUNK RIVER BASIN

(15) 05474000 Skunk River at Augusta, Iowa

Location.-Lat $40^{\circ} 45^{\prime} 13^{\prime \prime}$, long $91^{\circ} 16^{\prime} 40^{\prime \prime}$, in NE1/4 NE1/4 sec. 26, T. 69 N., R. 4 W., Des Moines County, on left bank 300 ft (91 m) upstream from bridge on State Highway 394 at Augusta, 2.0 miles $(3.2 \mathrm{~km})$ upstream from Long Creek and at mile $12.5(20.1 \mathrm{~km})$.

Drainage area. $-4,303 \mathrm{mi}^{2}\left(11,144 \mathrm{~km}^{2}\right)$.

Gage.-Water-stage recorder. Datum of gage is $521.24 \mathrm{ft}$. $(158.874 \mathrm{~m})$ above mean sea level. Prior to Nov. 15, 1913, nonrecording gage at site $400 \mathrm{ft}(122 \mathrm{~m})$ upstream at datum about $0.7 \mathrm{ft}(0.2 \mathrm{~m})$ higher. May 27,1915 , to Jan. 14, 1935, nonrecording gage at site $400 \mathrm{ft}(122 \mathrm{~m})$ upstream at present datum.

Flood stage. $-15 \mathrm{ft}(4.6 \mathrm{~m})$.

Maxima.-March-May 1973: Discharge, 66,800 ft $/ \mathrm{s}\left(1,890 \mathrm{~m}^{3} / \mathrm{s}\right)$ 1:30 a.m., Apr. 23 [gage height, $27.05 \mathrm{ft}(8.245 \mathrm{~m})$ ]. Discharge exceeded the 100-year flood. 
TABLE 12.-Station descriptions and discharge and suspended-sediment data-Continued

September to November 1913, October 1914 to February 1973: Discharge, 51,000 $\mathrm{ft}^{3} / \mathrm{s}\left(1,440 \mathrm{~m}^{3} / \mathrm{s}\right)$ Apr. 3, 1960, [gage height, $25.00 \mathrm{ft}(7.620 \mathrm{~m})]$.

Remarks.-Peak stage or April 1973 flood occurred within 60 hours after torrential rains in the lower part of the basin. That for the April 1960 flood occurred 7 days after the initial rise in stage. Flood-profile data available elsewhere in this report. Stage and discharge for April 1973 flood are believed to be the greatest since 1851 .

Mean discharge, in cubic feet per second, 1973

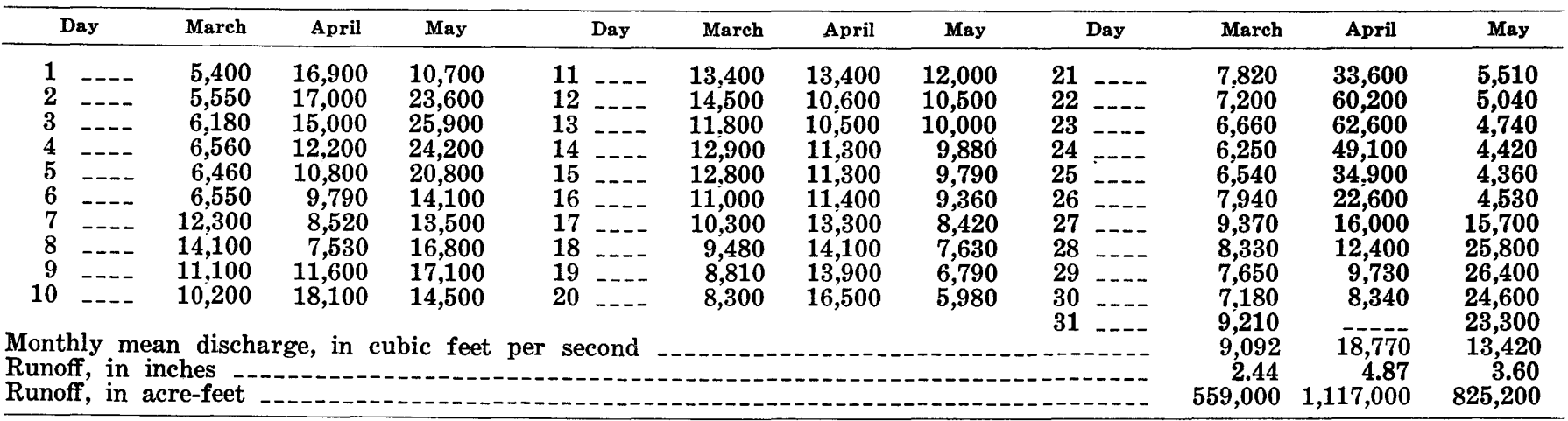

Gage height, in feet, and discharge in cubic feet per second, at indicated time, 1973

\begin{tabular}{|c|c|c|c|c|c|c|c|c|c|c|c|}
\hline Date & Hour & $\begin{array}{c}\text { Gage } \\
\text { height }\end{array}$ & $\mathbf{Q}$ & Date & Hour & $\begin{array}{c}\text { Gage } \\
\text { height }\end{array}$ & $\mathbf{Q}$ & Date & Hour & $\begin{array}{c}\text { Gage } \\
\text { height }\end{array}$ & $\mathbf{Q}$ \\
\hline Apr. 21 & $\begin{array}{r}\text { 6:00 a.m. } \\
\text { 6:00 a.m. } \\
\text { 12:00 m. } \\
\text { 6:00 p.m. } \\
12: 00 \text { p.m. }\end{array}$ & $\begin{array}{l}17.45 \\
19.17 \\
20.48 \\
21.88 \\
23.65\end{array}$ & $\begin{array}{l}23,300 \\
28,200 \\
33,000 \\
38,800 \\
47,300\end{array}$ & $\begin{array}{r}\text { Apr. } 22- \\
23-\end{array}$ & $\begin{array}{r}9: 00 \text { p.m. } \\
12: 00 \text { p.m. } \\
1: 30 \text { a.m. } \\
4: 00 \text { a.m. }\end{array}$ & $\begin{array}{l}26.95 \\
27.03 \\
\\
27.05 \\
27.03\end{array}$ & $\begin{array}{l}66,100 \\
66,600 \\
\\
66,800 \\
66,600\end{array}$ & Apr. 24 & $\begin{array}{c}\text { 6:00 a.m. } \\
\text { 12:00 m. } \\
\text { 6:00 p.m. } \\
12: 00 \text { p.m. }\end{array}$ & $\begin{array}{l}24.63 \\
24.01 \\
23.40 \\
22.66\end{array}$ & $\begin{array}{l}52,200 \\
49,100 \\
46,000 \\
42,400\end{array}$ \\
\hline $22-$ & $\begin{array}{c}\text { 6:00 a.m. } \\
\text { 12:00 m. } \\
\text { 6:00 p.m. }\end{array}$ & $\begin{array}{l}25.40 \\
26.15 \\
26.78\end{array}$ & $\begin{array}{l}56,800 \\
61,300 \\
65,100\end{array}$ & & $\begin{array}{c}\text { 8:00 a.m. } \\
12: 00 \text { m. } \\
\text { 6:00 p.m. } \\
12: 00 \text { p.m. }\end{array}$ & $\begin{array}{l}26.82 \\
26.46 \\
25.85 \\
25.24\end{array}$ & $\begin{array}{l}\mathbf{6 5 , 3 0 0} \\
63,200 \\
\mathbf{5 9 , 5 0 0} \\
\mathbf{5 5 , 8 0 0}\end{array}$ & $25-$ & $\begin{array}{l}12: 00 \mathrm{~m} . \\
\text { 12:00 p.m. }\end{array}$ & $\begin{array}{l}20.95 \\
19.02\end{array}$ & $\begin{array}{l}34,900 \\
27,700\end{array}$ \\
\hline
\end{tabular}

\begin{tabular}{|c|c|c|c|c|c|}
\hline Period & \multicolumn{5}{|c|}{${ }_{1}$ Highest mean discharge, in cubic feet per second, for the indicated number of consecutive days ${ }_{30}$} \\
\hline March-May 1973 & $\begin{array}{l}62,600 \\
50,100\end{array}$ & $\begin{array}{l}57,300 \\
45,700\end{array}$ & $\begin{array}{l}39,900 \\
37,000\end{array}$ & $\begin{array}{l}25,500 \\
25,500\end{array}$ & $\begin{array}{l}20,700 \\
21,000\end{array}$ \\
\hline $\begin{array}{l}\text { Recurrence interval, in years, for } \\
1973 \text { flood volumes }\end{array}$ & $>100$ & $>100$ & $>100$ & $>100$ & $>100$ \\
\hline
\end{tabular}

\section{MISSISSIPPI RIVER MAIN STEM}

(16) 05474500 Mississippi River at Keokuk, Iowa

Location.-Lat $41^{\circ} 23^{\prime} 37^{\prime \prime}$, long $91^{\circ} 22^{\prime} 27^{\prime \prime}$, in SE1/4 SW1/4 sec. 30 , T. 65 N., R. 4 W., Lee County, near right bank in tailwater of dam and powerplant of Union Electric Co. at Keokuk, 0.2 mile $(0.3 \mathrm{~km})$ upstream from bridge on U.S. Highway $136,2.7$ miles $(4.3 \mathrm{~km})$ upstream from Des Moines River, and at mile $364.2(586.0 \mathrm{~km})$ upstream from Ohio River.

Drainage area.- $119,000 \mathrm{mi}^{2}\left(308,000 \mathrm{~km}^{2}\right)$, approximately.

Gage.-Water-stage recorder. Datum of gage is $477.41 \mathrm{ft}(145.515 \mathrm{~m}$ ) above mean sea level (levels by Corps of Engineers; $477.83 \mathrm{ft}(145.643 \mathrm{~m})$ above mean sea level, adjustment of $1912 ; 477.34 \mathrm{ft}(145.493 \mathrm{~m})$ above mean gulf level; and 484.65 ft $(147.721 \mathrm{~m})$ above Memphis datum. Jan. 1, 1878, to May 1913, nonrecording gage at Galland (formerly Nashville), 8 miles $(13 \mathrm{~km})$ upstream; zero of gage was set to low-water mark of 1864, or $496.94 \mathrm{ft}(151.467 \mathrm{~m})$ above mean sea level, adjustment of 1912 .

Flood stage. $-16 \mathrm{ft}(4.9 \mathrm{~m})$.

Maxima.-March-May 1973: Daily discharge, 344,000 $\mathrm{ft}^{3} / \mathrm{s}\left(9,740 \mathrm{~m}^{3} / \mathrm{s}\right)$ Apr. 24. gage height, $23.35 \mathrm{ft}$ (71.17 m), Apr. 24. Recurrence interval of discharge is 100 years (based on figure 52).

January 1878 to February 1973: Daily discharge, 327,000 $\mathrm{ft}^{3} / \mathrm{s}\left(9,260 \mathrm{~m}^{3} / \mathrm{s}\right)$ May 1, 1965; gage height, $22.14 \mathrm{ft}(6.748 \mathrm{~m})$ May 1, 1965.

Flood of June 6,1851 , reached a stage of $21.0 \mathrm{ft}(6.40 \mathrm{~m})$, present site and datum; estimated as $13.5 \mathrm{ft}(4.11 \mathrm{~m})$ at Galland [discharge, $\left.360,000 \mathrm{ft}^{3} / \mathrm{s}\left(10,200 \mathrm{~m}^{3} / \mathrm{s}\right)\right]$.

Remarks.-Minor flow regulation by powerplant above station, since 1913, and reservoirs and navigation dams above station since about 1935. Discharge computed from records of operation of turbines in powerplant and spillway gates in dam. Flood-volume data are not available for this station. 
TABLE 12.-Station descriptions and discharge and suspended-sediment data-Continued

Mean water discharge and suspended-sediment concentration and discharge

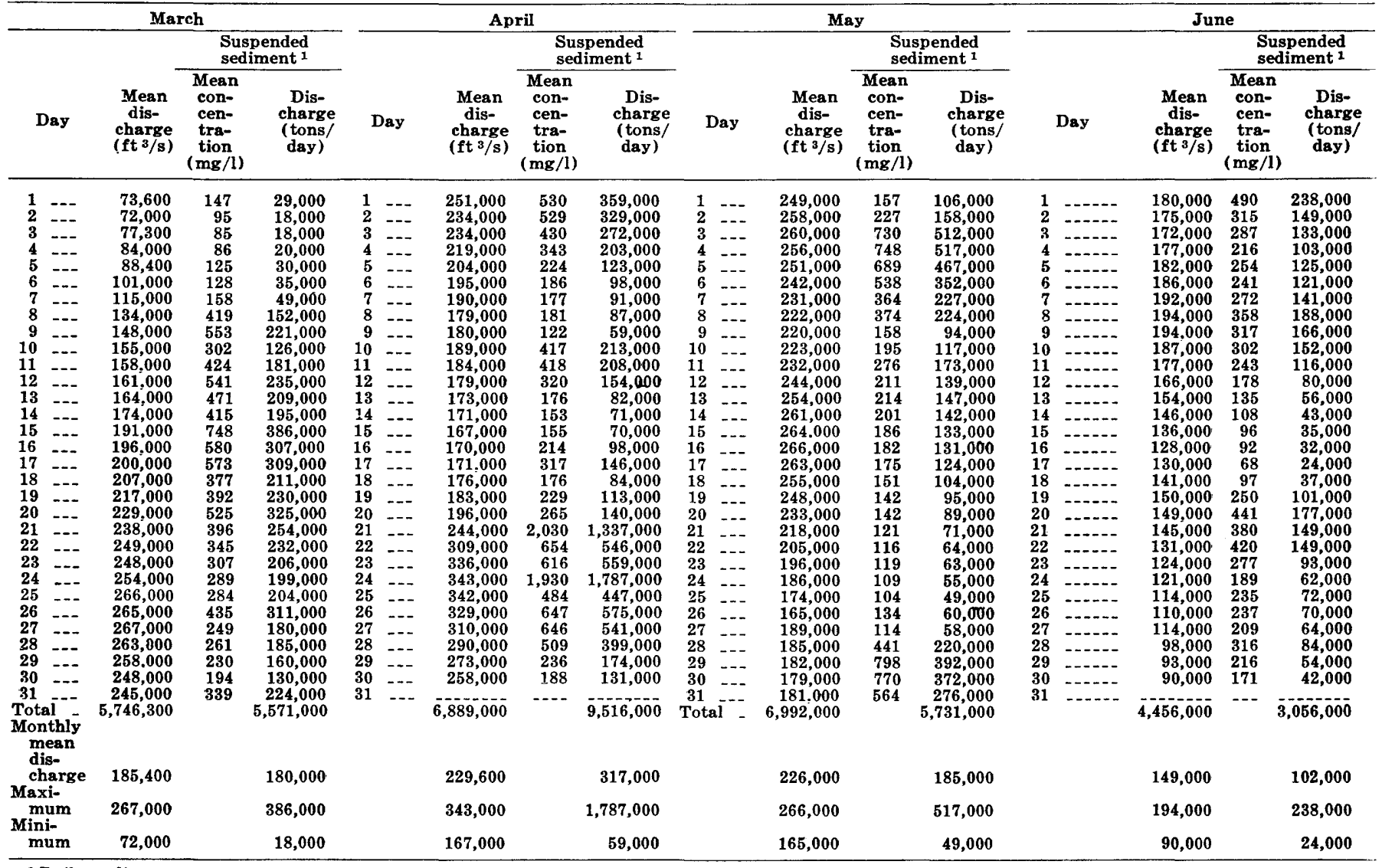

${ }^{1}$ Daily sediment concentrations are values determined from a single-bottle sample taken near midstream.

\section{DES MOINES RIVER BASIN}

(17) 05488100 Lake Red Rock near Pella, Iowa

Location.-Lat $41^{\circ} 22^{\prime} 11^{\prime \prime}$, long $92^{\circ} 58^{\prime} 48^{\prime \prime}$, in NE1/4 NW1/4 sec. 19 , T. 76 , N., R. 18 W., Marion County, at outlet works near right end of Red Rock Dam on Des Moines River, 1.4 miles $(2.3 \mathrm{~km})$ upstream from Lake Creek, $4.5 \mathrm{miles}(7.2 \mathrm{~km})$ southwest of Pella and at mile $142.3(229.0 \mathrm{~km})$.

Drainage area.-12,323 $\mathrm{mi}^{2}\left(31,917 \mathrm{~km}^{2}\right)$.

Gage.-Water-stage recorder. Datum of gage is at mean sea level (levels by Corps of Engineers).

Maxima.-March-May 1973: Contents, 1,700,000 acre-ft (2.10 $\left.\mathrm{km}^{3}\right)$ 10:00 a.m., May 14 [elevation, $777.95 \mathrm{ft}(237.119 \mathrm{~m})$ ]. March 1969 to February 1973: Contents, 1,010,000 acre-ft $\left(1.25 \mathrm{~km}^{3}\right)$ Aug. 2, 1969, [elevation, $764.83 \mathrm{ft}(233.120 \mathrm{~m})$ ].

Remarks.-Reservoir storage began in March 1969. The storage capacity of the reservoir at full flood-control pool level [780 ft $(238 \mathrm{~m})]$ is $1,830,000$ acre-ft $\left(2.26 \mathrm{~km}^{3}\right)$ that of conservation pool level $[725 \mathrm{ft}(221 \mathrm{~m})]$ is $90,000 \mathrm{acre}-\mathrm{ft}(111 \mathrm{hm})$.

Elevation, in feet, and contents in acre-feet, 1973

\begin{tabular}{|c|c|c|c|c|c|c|c|}
\hline Date & Time & Elevation & Contents & Date & Time & Elevation & Contents \\
\hline $\begin{array}{l}\text { Jan. } 31 \ldots \\
\text { Feb. } 28 \ldots \\
\text { Mar. } 31\end{array}$ & $\begin{array}{l}\text { 12:00 p.m. } \\
\text { 12:00 p.m. } \\
\text { 12:00 p.m. }\end{array}$ & $\begin{array}{l}731.54 \\
728.09 \\
764.62\end{array}$ & $\begin{array}{r}160,000 \\
121,000 \\
1,996,000\end{array}$ & $\begin{array}{l}\text { Apr. } 30 \\
\text { May } 14 \\
\text { May } 31\end{array}$ & $\begin{array}{l}12: 00 \text { p.m. } \\
10: 00 \text { a.m. } \\
12: 00 \text { p.m. }\end{array}$ & $\begin{array}{l}774.33 \\
777.95 \\
775.23\end{array}$ & $\begin{array}{l}\mathbf{1}, 470,000 \\
\mathbf{1}, \mathbf{7 0 0 , 0 0 0} \\
\mathbf{1 , 5 2 0 , 0 0 0}\end{array}$ \\
\hline
\end{tabular}

\section{FOX RIVER BASIN}

(18) 05495000 Fox River at Wayland, Mo.

Location.-Lat $40^{\circ} 23^{\prime} 33^{\prime \prime}$, long $91^{\circ} 35^{\prime} 50^{\prime \prime}$, in NW1/4 sec. 31 , T. 65 N., R. 6 W., Clark County, on left bank $90 \mathrm{ft}(27 \mathrm{~m})$ downstream from bridge on U.S. Highway $136,0.8$ mile $(1.3 \mathrm{~km})$ west of Wayland, and 5 miles $(8.0 \mathrm{~km})$ downstream from Brush Creek.

Drainage area. $-400 \mathrm{mi}^{2}\left(1,036 \mathrm{~km}^{2}\right)$, approximately.

Gage.-Digital water-stage recorder. Datum of gage is $501.52 \mathrm{ft}(152.863 \mathrm{~m})$ above mean sea level, datum of 1929 .

Flood stage. $-15 \mathrm{ft}(4.6 \mathrm{~m})$.

Maxima.-March-May 1973: Discharge, 26,400 ft $3 \mathrm{ft}^{3} \mathrm{~s}\left(748 \mathrm{~m}^{3} / \mathrm{s}\right)$ 6:00 p.m., Apr. 22 [gage height, $21.71 \mathrm{ft}(6.617 \mathrm{~m})$ ]. Discharge exceded the 100-year flood.

February 1922 to February 1973: Discharge, 25,000 ft $/ \mathrm{s}\left(708 \mathrm{~m}^{3} / \mathrm{s}\right) \mathrm{June} 29,1933$ [gage height, $21.53 \mathrm{ft}(6.562 \mathrm{~m}) \mathrm{from}$ floodmarks]. 
TABLE 12.-Station descriptions and discharge and suspended-sediment data-Continued

Mean discharge, in cubic feet per second, 1973

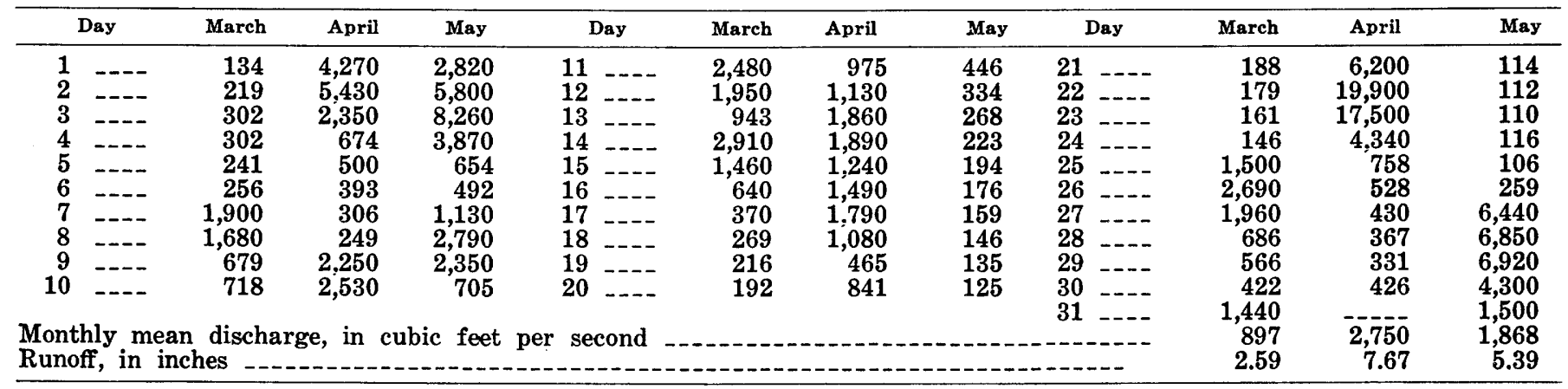

Gage height, in feet, and discharge, in cubic feet per second, at indicated time, 1973

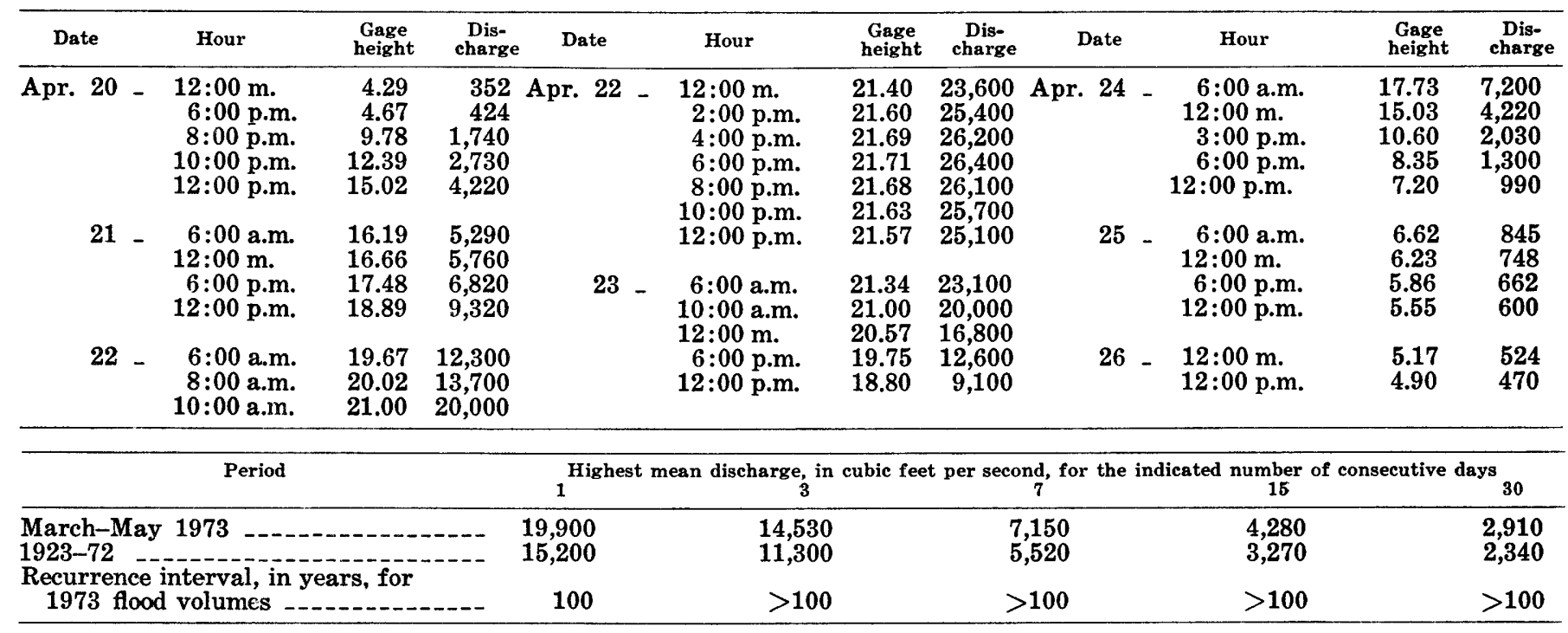

FABIUS RIVER BASIN

(19) 05497000 North Fabius River at Monticello, Mo.

Location.-Lat $40^{\circ} 06^{\prime} 30^{\prime \prime}$, long $91^{\circ} 42^{\prime} 51^{\prime \prime}$, in SW1/4 SE1/4 sec. 6 , T. 61 N., R. 7 W., Lewis County, on right bank upstream from bridge on State Highway 16, 1 mile $(1.6 \mathrm{~km})$ south of Monticello, and 19 miles $(30.6 \mathrm{~km})$ upstream from Middle Fabius River.

Drainage area.-452 $\mathrm{mi}^{2}\left(1,171 \mathrm{~km}^{2}\right)$.

Gage.-Digital water-stage recorder. Datum of gage is $540.73 \mathrm{ft}(164.815 \mathrm{~m})$ above mean sea level, datum of 1929 .

Flood stage.-22 ft $(6.7 \mathrm{~m})$.

Maxima.-March-May 1973: Discharge, 20,700 ft's $/ \mathrm{s}\left(586 \mathrm{~m}^{3} / \mathrm{s}\right)$ 12:00 p.m. Apr. 22 [gage height, $33.03 \mathrm{ft}(10.068 \mathrm{~m})$ ] Discharge exceeded the 100-year flood.

February 1922 to February 1973: Discharge, $17,400 \mathrm{ft}^{3} / \mathrm{s}\left(493 \mathrm{~m}^{3} / \mathrm{s}\right)$ June 30,1933 [gage height, $30.8 \mathrm{ft}(9.39 \mathrm{~m})$, from floodmarks ].

Maximum stage since at least 1874, that of June $30,1933$.

Mean discharge, in cubic feet per second, 1973

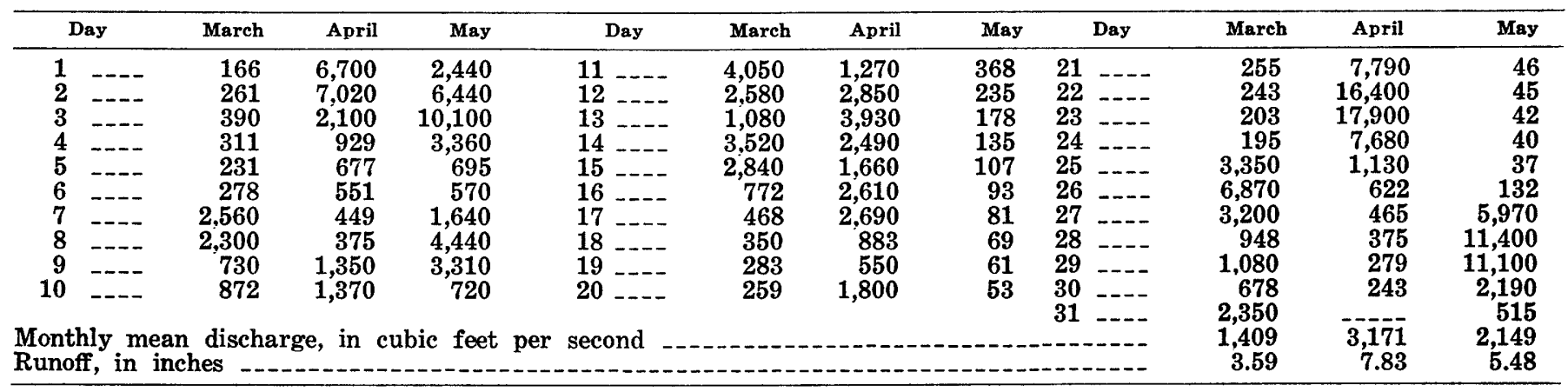


TABLE 12.-Station descriptions and discharge and suspended-sediment data-Continued

Gage height, in feet, and discharge, in cubic feet per second, at indicated time, 1973

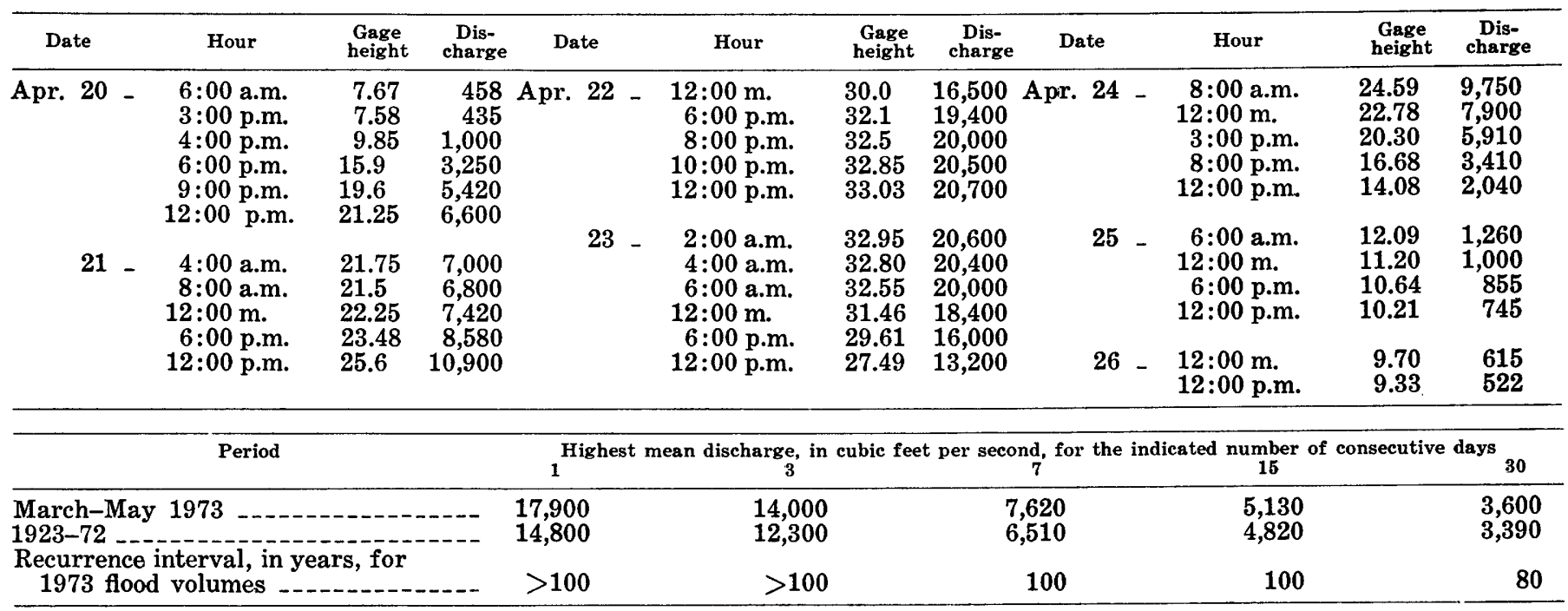

\section{FABIUS RIVER BASIN}

(20) 05498000 Middle Fabius River near Monticello, Mo.

Location.-Lat $40^{\circ} 05^{\prime} 37^{\prime \prime}$, long $91^{\circ} 44^{\prime} 08^{\prime \prime}$, in SE1/4 sec. 12, T. 61 N., R. 8 W., Lewis County, on left bank on downstream end of bridge pier on State Highway $16,2.5$ miles $(4.0 \mathrm{~km})$ south west of Monticello, 8 miles (12.9 km) downstream from Radish Branch, and 17 miles $(27.4 \mathrm{~km})$ upstream from mouth.

Drainage area.- $393 \mathrm{mi}^{2}\left(1,018 \mathrm{~km}^{2}\right)$.

Gage.-Digital water-stage recorder. Datum of gage is $540.46 \mathrm{ft}(164.732 \mathrm{~m})$ above mean sea level.

Flood stage. $-13 \mathrm{ft} .(4.0 \mathrm{~m})$

Maxima.-March-May 1973: Discharge 17,700 ft $\mathrm{ft}^{3} / \mathrm{s} \quad\left(501 \mathrm{~m}^{3} / \mathrm{s}\right) \quad 12: 30$ a.m. Apr. 23 [gage height, $27.14 \mathrm{ft}(8.272 \mathrm{~m})$ ].

Discharge exceeded the 100-year fiood.

July 1945 to February 1973: Discharge, 16,200 $\mathrm{ft}^{3} / \mathrm{s}\left(459 \mathrm{~m}^{3} / \mathrm{s}\right)$ June 7, 1947 [gage height, $26.28 \mathrm{ft}(8.010 \mathrm{~m})$ ].

Maximum stage since $1930,26.6 \mathrm{ft}(8.11 \mathrm{~m})$, from floodmark, date unknown [discharge, $16,800 \mathrm{ft}^{3} / \mathrm{s}^{\left(476 \mathrm{~m}^{3} / \mathrm{s}\right)}$ ]. Flood of June 17, 1945, reached a stage of $23.3 \mathrm{ft}(7.10 \mathrm{~m})$, from floodmarks.

Mean discharge, in cubic feet per second, 1973

\begin{tabular}{|c|c|c|c|c|c|c|c|c|c|c|c|c|}
\hline \multicolumn{2}{|c|}{ Day } & March & April & May & Day & March & April & May & Day & March & April & May \\
\hline 1 & ---- & 214 & 4,180 & 232 & 11 & 2,250 & 1,030 & 485 & 21 & 174 & 6,580 & 87 \\
\hline 2 & --- & 298 & 4,340 & 1,970 & 12 & 2,480 & 1,770 & 312 & 22 & 167 & 12,200 & 85 \\
\hline 3 & $\ldots$ & 277 & 4,930 & $\mathbf{2 , 9 9 0}$ & 13 & 2,060 & 2,280 & 228 & 23 & 150 & 15,100 & 82 \\
\hline 4 & -- & 238 & 1.940 & 4,920 & 14 & 3,230 & $\mathbf{2 , 4 3 0}$ & 180 & 24 & 165 & 8,970 & 79 \\
\hline 5 & -1 & 226 & 623 & 1,720 & 15 & 2,300 & 1,980 & 150 & 25 & 3,070 & 2,190 & 79 \\
\hline 6 & $\ldots$ & 310 & 432 & 502 & 16 & 1,130 & 1,910 & 132 & 26 & 4,080 & 484 & 145 \\
\hline 7 & $\ldots$ & 1,650 & 315 & 1,520 & 17 & 440 & 2,100 & 11 & 27 & 4,1 & 329 & 5,480 \\
\hline 8 & -- & 1,960 & 247 & 3,070 & 18 & 285 & 1,170 & 10 & 28 & 3,980 & 242 & 6,040 \\
\hline 9 & -- & 1,120 & 1,040 & 2,800 & 19 & 224 & 500 & 101 & 29 & 1,160 & 193 & 9,040 \\
\hline 10 & $\ldots$ & 902 & 1,140 & 1,190 & 20 & 194 & 761 & 93 & 30 & 639 & 156 & 7,230 \\
\hline & & & & & & & & & & $\begin{array}{l}2,750 \\
1,369\end{array}$ & 7719 & $\begin{array}{r}873 \\
\end{array}$ \\
\hline \multicolumn{10}{|c|}{$\begin{array}{l}\text { Monthly mean discharge, in cubic feet per second } \\
\text { Runoff, in inches }\end{array}$} & $\begin{array}{r}1,000 \\
4.00\end{array}$ & $\begin{array}{r}2,119 \\
7.72\end{array}$ & $\begin{array}{r}1,0.93 \\
4.93\end{array}$ \\
\hline
\end{tabular}

Gage height, in feet, and discharge, in cubic feet per second, at indicated time, 1973

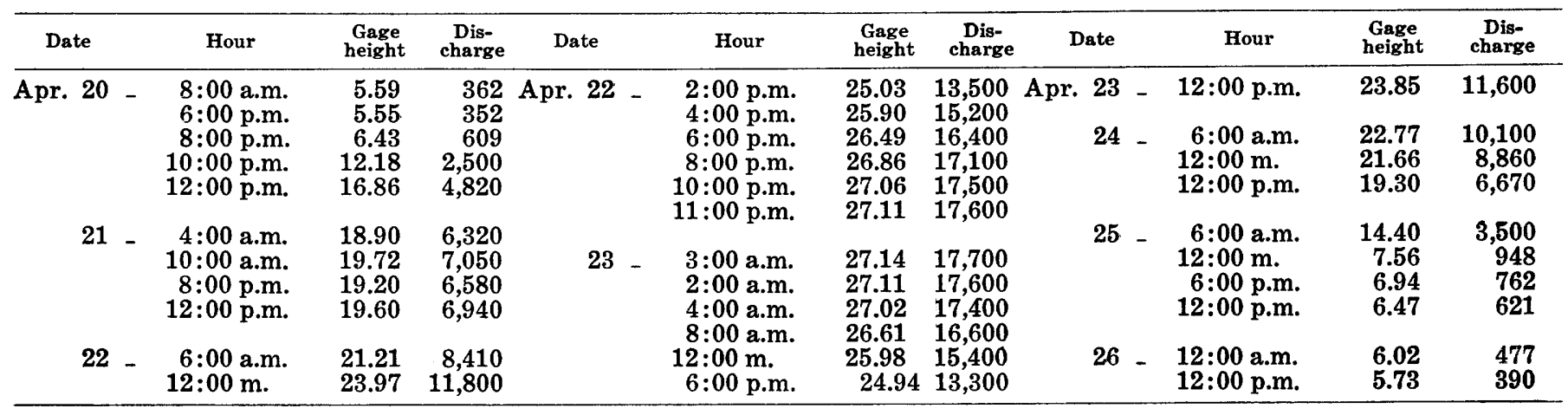


TABLE 12.-Station descriptions and discharge and suspended-sediment data-Continued

\begin{tabular}{|c|c|c|c|c|c|}
\hline Period & \multicolumn{5}{|c|}{ Highest mean discharge, in cubic feet per second, for the indicated number of consecutive days } \\
\hline $\begin{array}{l}\text { March-May } 1973 \\
1946-72 \\
\text { Recurrence interval, in years, for }\end{array}$ & $\begin{array}{l}15,100 \\
14,300\end{array}$ & $\begin{array}{l}12,100 \\
11,000\end{array}$ & $\begin{array}{l}6,610 \\
6,200\end{array}$ & $\begin{array}{l}4,060 \\
4,060\end{array}$ & $\begin{array}{l}3,160 \\
2,920\end{array}$ \\
\hline 1973 flood volumes & $>100$ & $>100$ & $>100$ & $>100$ & $>100$ \\
\hline
\end{tabular}

FABIUS RIVER BASIN

(21) 05500000 South Fabius River near Taylor, Mo.

Location.-Lat $39^{\circ} 53^{\prime} 49^{\prime \prime}$, long $91^{\circ} 34^{\prime} 49^{\prime \prime}$, in SW1/4 NW1/4 sec. 21 , T. 59 N., R. 6 W., Marion County, on right bank at downstream side of highway bridge, 4.5 miles $(7.2 \mathrm{~km})$ southwest of Taylor, 5 miles $(8.0 \mathrm{~km})$ downstream from Grassy Creek, and 5.3 miles $(8.5 \mathrm{~km})$ upstream from confluence with North Fabius River.

Drainage area.-620 $\mathrm{mi}^{2}\left(1,606 \mathrm{~km}^{2}\right)$.

Gage.-Digital water-stage recorder. Datum of gage is $482.91 \mathrm{ft}(147.190 \mathrm{~m})$ above mean sea level, datum of 1929 .

Flood stage.-11 ft (3.4 m).

Maxima.-March-May 1973: Discharge, $16,900 \mathrm{ft} / \mathrm{s} \quad\left(479 \mathrm{~m}^{3} / \mathrm{s}\right) \quad 3: 00$ a.m. Apr. 24 [gage height, $18.33 \mathrm{ft}$ (5.587 m)]. Recurrence interval of discharge is 25 years.

October 1934 to February 1973: Discharge, 19,700 $\mathrm{ft}^{3} / \mathrm{s}\left(558 \mathrm{~m}^{3} / \mathrm{s}\right)$ June 8, 1947 [gage height, $19.5 \mathrm{ft}(5.94 \mathrm{~m})$ ], from rating curve extended above $11,000 \mathrm{ft}^{3} / \mathrm{s}\left(312 \mathrm{~m}^{3} / \mathrm{s}\right)$. Flood in 1928 reached a stage of $18.49 \mathrm{ft}(5.636 \mathrm{~m})$, from floodmark, present site and datum.

Mean discharge, in cubic feet per second, 1973

\begin{tabular}{|c|c|c|c|c|c|c|c|c|c|c|c|c|}
\hline \multicolumn{2}{|c|}{ Day } & \multirow{2}{*}{$\begin{array}{c}\text { March } \\
177\end{array}$} & \multirow{2}{*}{$\begin{array}{c}\text { April } \\
7,280\end{array}$} & \multirow{2}{*}{$\begin{array}{c}\text { May } \\
595\end{array}$} & Day & \multirow{2}{*}{$\frac{\text { March }}{4,400}$} & \multirow{2}{*}{$\begin{array}{l}\text { April } \\
2,770\end{array}$} & \multirow{2}{*}{$\begin{array}{l}\text { May } \\
740\end{array}$} & Day & \multirow{2}{*}{$\begin{array}{r}\text { March } \\
315\end{array}$} & \multirow{2}{*}{$\begin{array}{c}\text { April } \\
12,000\end{array}$} & \multirow{3}{*}{$\begin{array}{r}\text { May } \\
\begin{array}{l}82 \\
81\end{array}\end{array}$} \\
\hline 1 & $-\ldots-$ & & & & 11 & & & & $21 \ldots$ & & & \\
\hline 2 & ---- & 310 & 6,830 & 3,730 & 12 & 3,910 & 2.990 & 413 & 22 & 269 & 13.600 & \\
\hline 3 & $\begin{array}{l}---- \\
----\end{array}$ & 612 & 5,130 & 2,740 & 13 & 3,580 & 3,220 & 293 & 23 & 233 & 14,000 & 81 \\
\hline 4 & ---- & 618 & 3,020 & 1,820 & 14 & 6.170 & 2,440 & 225 & 24 & 315 & 15,000 & 74 \\
\hline 5 & $-\ldots$ & 504 & 1,040 & 1,100 & 15 & 5,160 & 1,680 & 184 & 25 & 5,650 & 9,110 & 74 \\
\hline 6 & --- & 1,410 & 706 & 672 & 16 & 3,520 & 2,360 & 155 & $26 \ldots$ & 7,060 & 2,680 & 84 \\
\hline 7 & $\ldots-$ & 4,220 & 563 & 2,850 & 17 & 890 & 2,980 & 132 & 27 & 7,260 & 773 & 8,600 \\
\hline 8 & $\ldots-$ & 3,580 & 449 & 4,750 & 18 & 471 & 1,970 & 116 & $28 \ldots$ & 5,400 & 522 & 7,100 \\
\hline 9 & - . - & 1,980 & 1,690 & 4,370 & 19 & 349 & 778 & 103 & 29 & 4,570 & 361 & 6,440 \\
\hline 10 & $-\ldots$ & 2,100 & 2,970 & 2,460 & 20 & 317 & 483 & 93 & 30 & 2,620 & 269 & 5,940 \\
\hline & & & & & & & & & $31 \ldots$ & 4,460 & & 3,790 \\
\hline Mon & hly $n$ & isc & Nat & Es & con & & & & 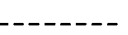 & 2,659 & 3,989 & 1,932 \\
\hline Runo & & & & & & & & & & 4.94 & 7.18 & 3.59 \\
\hline
\end{tabular}

Gage height, in feet, and discharge in cubic feet per second, at indicated time, 1973

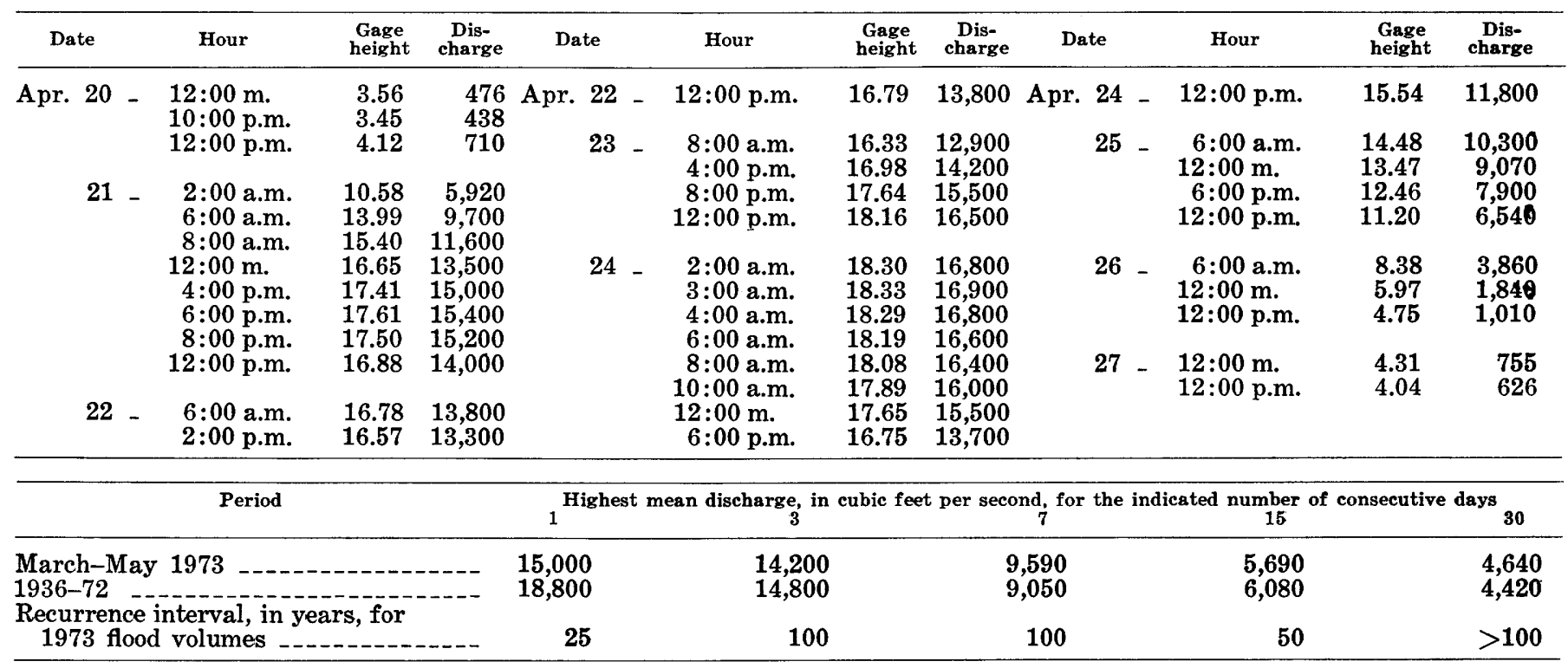

NORTH RIVER BASIN

(22) 05500500 North River at Bethel, Mo.

Location.-Lat $39^{\circ} 52^{\prime} 29^{\prime \prime}$, long $92^{\circ} 01^{\prime} 26^{\prime \prime}$, in NE1/4 NW1/4 sec. 33 , T. 59 N., R. 10 W., Shelby County, at left abutment on downstream side of bridge on State Highway 15 at Bethel, 2.5 miles $(4.0 \mathrm{~km})$ upstream from Messner Branch.

Drainage area.- $58 \mathrm{mi}^{2}\left(150 \mathrm{~km}^{2}\right)$, approximately. 
TABLE 12.-Station descriptions and discharge and suspended-sediment data-Continued

Gage.-Digital water-stage recorder. Datum of gage is $683.37 \mathrm{ft}(208.291 \mathrm{~m})$ above mean sea level.

Flood stage. $-14 \mathrm{ft}(4.3 \mathrm{~m})$.

Maxima.-March-May 1973: Discharge, 4,820 ft $/ \mathrm{s}\left(136 \mathrm{~m}^{3} / \mathrm{s}\right)$ 5:15 a.m., Apr. 21 [gage height, $19.53 \mathrm{ft}$ (5.953 m)]. Recurrence interval of discharge is 10 years.

April 1930 to July 1936 (fragmentary), August 1936 to February 1973: Discharge, 6,930 ft ${ }^{3} / \mathrm{s}^{\left(196 \mathrm{~m}^{3} / \mathrm{s}\right)}$ Apr. 5, 1947 ; gage height, $20.9 \mathrm{ft}(6.37 \mathrm{~m})$ Apr. 5, 1947, and Oct. 24, 1957.

Maximum stage since at least 1875, that of Apr. 5, 1947 and Oct. 24, 1957.

Mean discharge, in cubic feet per second, 1973

\begin{tabular}{|c|c|c|c|c|c|c|c|c|c|c|c|c|}
\hline \multicolumn{2}{|c|}{ Day } & \multirow{2}{*}{$\frac{\text { March }}{31}$} & \multirow{2}{*}{\begin{tabular}{|c|} 
April \\
1,380
\end{tabular}} & \multirow{2}{*}{$\begin{array}{c}\text { May } \\
40\end{array}$} & Day & \multirow{2}{*}{$\begin{array}{r}\text { March } \\
818\end{array}$} & \multirow{2}{*}{$\begin{array}{l}\text { April } \\
349\end{array}$} & \multirow{2}{*}{$\begin{array}{l}\text { May } \\
28\end{array}$} & Day & \multirow{2}{*}{$\frac{\text { March }}{60}$} & \multirow{2}{*}{$\begin{array}{r}\text { April } \\
3,160\end{array}$} & \multirow{2}{*}{$\frac{\text { May }}{4.0}$} \\
\hline 1 & --- & & & & $11 \ldots$ & & & & $21 \ldots \ldots$ & & & \\
\hline$\overline{\mathbf{2}}$ & --- & 196 & 509 & 598 & 12 & 420 & 590 & 17 & 22 & 43 & 1,700 & 5.0 \\
\hline 3 & --- & 152 & 73 & 199 & 13 & 241 & 309 & 12 & 23 & 32 & 552 & 16 \\
\hline 4 & $-\ldots$ & 78 & 42 & 50 & 14 & 1,150 & 94 & 9.8 & 24 & 266 & 93 & 23 \\
\hline 5 & ---- & 62 & 33 & 30 & 15 & 728 & 67 & 8.6 & 25 & 1,960 & 53 & 26 \\
\hline 6 & ---- & 128 & 26 & 57 & 16 & 89 & 352 & 7.6 & 26 & 1,580 & 35 & 12 \\
\hline 7 & $\begin{array}{l}---- \\
--\infty-\end{array}$ & 544 & 20 & 412 & 17 & 52 & 368 & 6.8 & $27 \ldots$ & $\begin{array}{r}1,000 \\
279\end{array}$ & 26 & 749 \\
\hline 8 & --- & 372 & 16 & 664 & 18 & 38 & 44 & 6.0 & 28 & 125 & 22 & 1,520 \\
\hline 9 & --- & 79 & 293 & 141 & 19 & 32 & 25 & 5.0 & 29 & 363 & 20 & 214 \\
\hline 10 & ---- & 230 & 298 & 49 & 20 & 58 & 207 & 4.3 & $30 \ldots$ & 435 & 17 & 55 \\
\hline \multirow{2}{*}{\multicolumn{10}{|c|}{ Monthly mean discharge, in cubic feet per second }} & 538 & ーーテテ & \\
\hline & & & & & & & & & & 361 & 359 & 161 \\
\hline \multicolumn{10}{|c|}{ Runoff, in inches } & 7.17 & 6.91 & 3.20 \\
\hline
\end{tabular}

Gage height, in feet, and discharge, in cubic feet per second, at indicated time, 1973

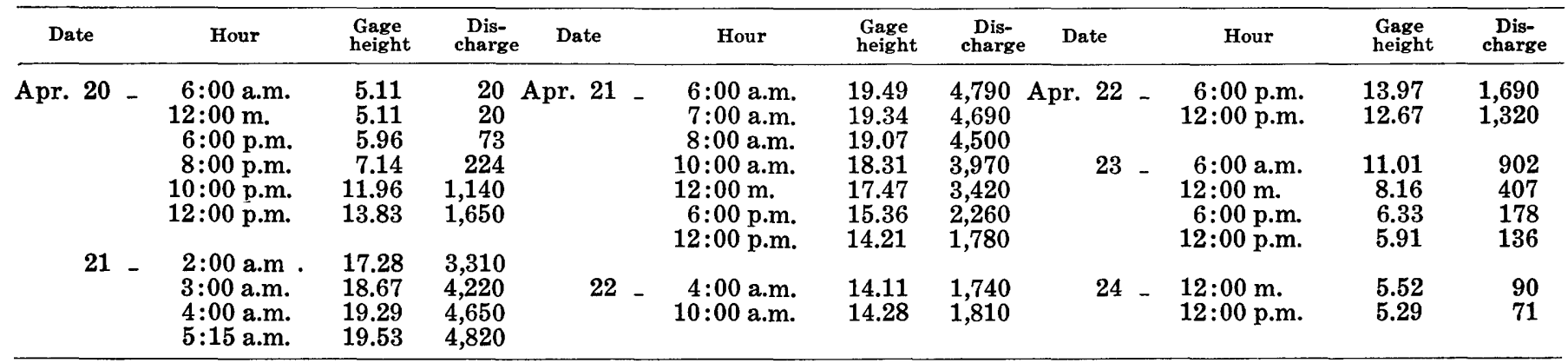

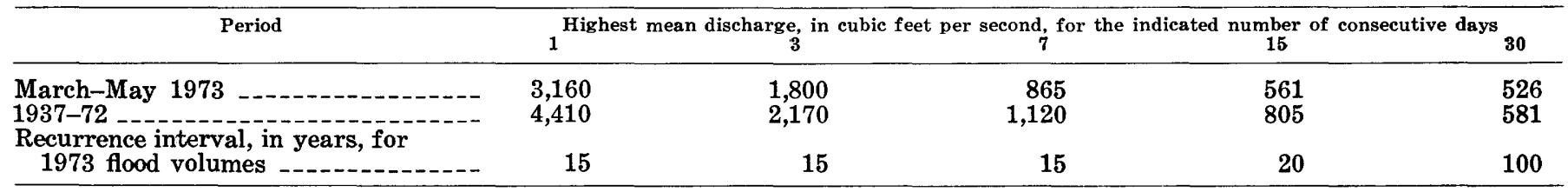

\section{NORTH RIVER BASIN}

(23) 05501000 North River at Palmyra, Mo.

Location.-Lat $39^{\circ} 49^{\prime} 06^{\prime \prime}$, long $91^{\circ} 31^{\prime} 13^{\prime \prime}$, in SE1/4 SW1/4 sec. 13, T. 58 N., R. 6 W., Marion County, on right bank $100 \mathrm{ft}$ (30 m) upstream from city waterworks dam, $1,000 \mathrm{ft}(305 \mathrm{~m})$ upstream from upstream bridge on dual U.S. Highways 24 and $61,0.5$ mile $(0.8 \mathrm{~km})$ north of Palmyra, and 7 miles $(11.3 \mathrm{~km})$ upstream from mouth.

Drainage area. $-373 \mathrm{mi}^{2}\left(966 \mathrm{~km}^{2}\right)$.

Gage.-Digital water-stage recorder. Datum of gage is $464.81 \mathrm{ft}$ (141.674 m) above mean sea level (levels by Corps of Engineers).

Flood stage. $-19 \mathrm{ft}(5.8 \mathrm{~m})$.

Maxima.-March-May 1973: Discharge, 57,500 ft $\mathrm{ft}^{3} / \mathrm{s}\left(1,628 \mathrm{~m}^{3} / \mathrm{s}\right)$ 11:00 a.m., Apr. 21 [gage height, $29.70 \mathrm{ft}(9.053 \mathrm{~m})$ ]. Discharge exceeded the 100-year flood.

December 1934 to February 1973: Discharge, 27,400 ft3 $/ \mathrm{s}\left(776 \mathrm{~m}^{3} / \mathrm{s}\right)$ Apr. 11, 1944 [gage height, 22.96 ft (6.998 m), site then in use], from rating curve extended above $15,000 \mathrm{ft}^{3} / \mathrm{s}\left(425 \mathrm{~m}^{3} / \mathrm{s}\right.$, gage height, $26.57 \mathrm{ft}(8.099 \mathrm{~m}) 0 \mathrm{ct} .13,1969$.

Maximum stage prior to 1934 , about $28.0 \mathrm{ft}(8.5 \mathrm{~m})$ from floodmarks, date unknown, at site $1,000 \mathrm{ft}(305 \mathrm{~m}) \mathrm{downstream}$, present datum.

Remarks.-Water diverted from river above dam by city of Palmyra. Backwater from Mississippi River Apr. 1-5, Apr. 22 to May 23. Discharge for period of backwater from Mississippi River estimated on basis of 8 discharge measurements, elevation of Mississippi River at Hannibal, and records for nearby stations. 
TABLE 12.-Station descriptions and discharge and suspended-sediment data-Continued

Mean discharge, in cubic feet per second, 1973

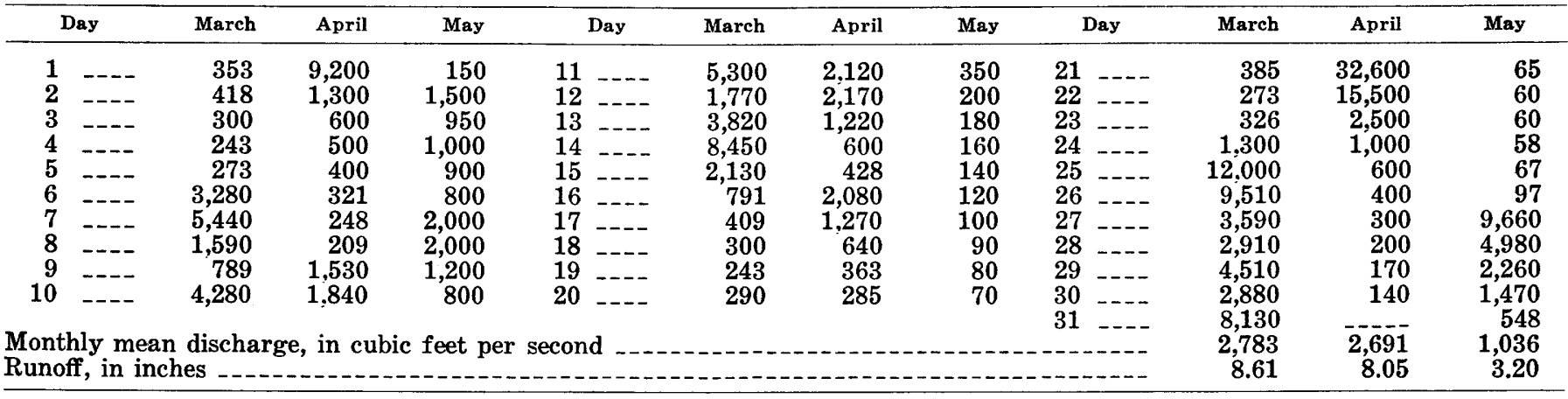

Gage height, in feet, and discharge, in cubic feet per second, at indicated time, 1973

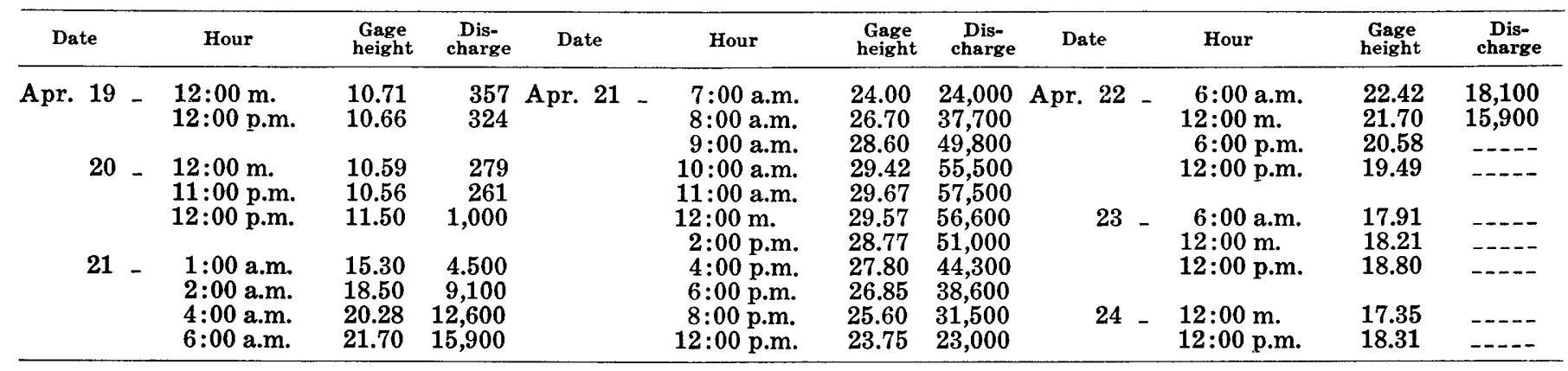

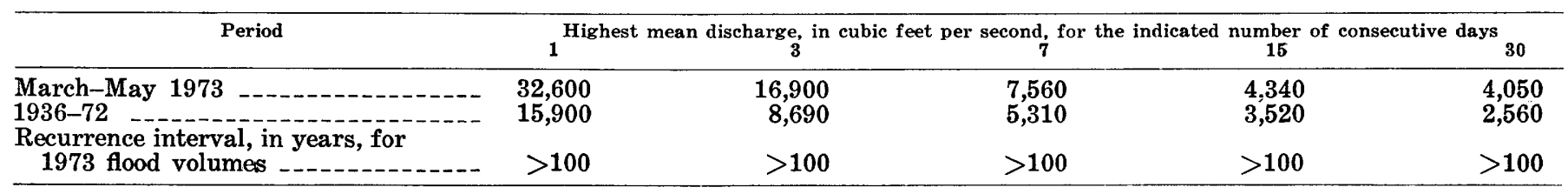

\section{SALT RIVER BASIN}

(24) 05506500 Middle Fork Salt River at Paris, Mo.

Location.-Lat $39^{\circ} 29^{\prime} 05^{\prime \prime}$, long $91^{\circ} 59^{\prime} 50^{\prime \prime}$, in NE1/4 NW1/4 NW1/4 sec. 11, T. 54 N., R. 10 W., Monroe County, on right bank near upstream side of bridge on East Madison Street in Paris, about $600 \mathrm{ft}(183 \mathrm{~m})$ downstream from Wabash Railroad bridge, 12.5 miles $(20.1 \mathrm{~km})$ upstream from Elk Fork Salt River, and at mile $104.5(168.1 \mathrm{~km})$ above mouth of Salt River.

Drainage area.- $356 \mathrm{mi}^{2}\left(922 \mathrm{~km}^{2}\right)$.

Gage.-Digital water-stage recorder until Apr. 21 (2:00 p.m.) when gage was washed out by high water. Wire-weight gage therafter. Datum of gage is $621.71 \mathrm{ft}(189.497 \mathrm{~m})$ above mean sea level.

Flood stage. $-12 \mathrm{ft}(3.7 \mathrm{~m})$.

Maxima.-March-May 1973: Discharge, 45,000 ft $\mathrm{ft}^{3} / \mathrm{s}\left(1,274 \mathrm{~m}^{3} / \mathrm{s}\right)$ 10:00 p.m., Apr. 21 [gage height, $33.5 \mathrm{ft}$ (10.21 m), from high-water marks]. Discharge exceeded the 100-year flood.

October 1939 to February 1973: Irischarge, 23,100 $\mathrm{ft}^{3} / \mathrm{s}\left(654 \mathrm{~m}^{3} / \mathrm{s}\right)$ Aug. 1, 1958 [gage height, $29.94 \mathrm{ft}(9.126 \mathrm{~m})$ ]

Remarks.-Water diverted from river upstream from gage by city of Paris.

Mean discharge, in cubic feet per second, 1973

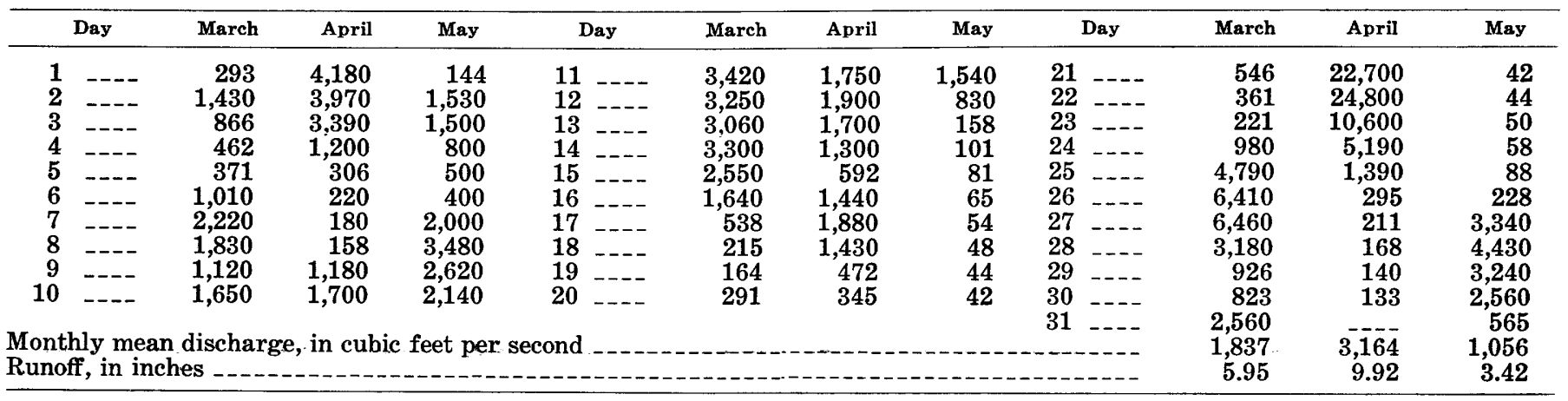


TABLE 12.-Station descriptions and discharge and suspended-sediment data-Continued

Gage height, in feet, and discharge, in cubic feet per second, at indicated time; 1973

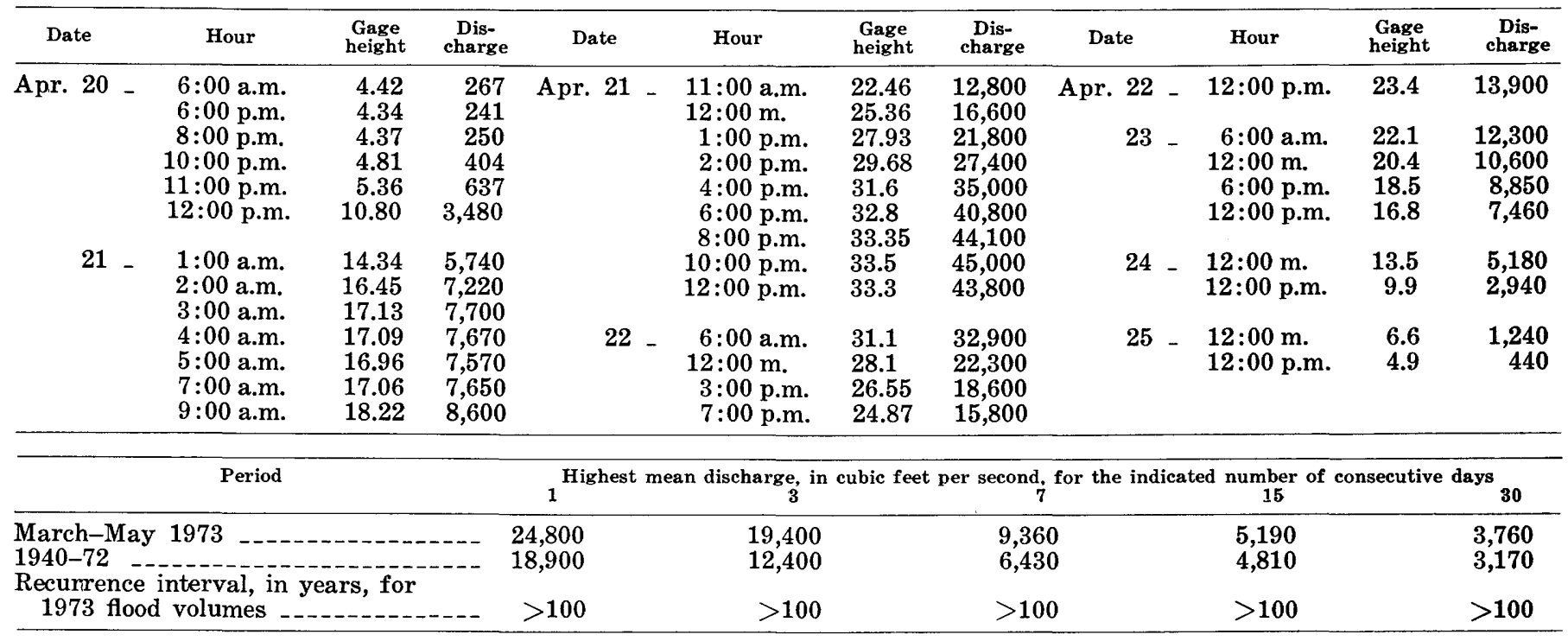

SALT RIVER BASIN

(25) 05506800 Elk Fork Salt River near Madison, Mo.

Location.-Lat $39^{\circ} 26^{\prime} 05^{\prime \prime}$, long $92^{\circ} 10^{\prime} 04^{\prime \prime}$, in SW1/4 NE1/4 SW1/4, sec. 29 , T. 54 N., R. 11 W., Monroe County, on left bank $25 \mathrm{ft}$ $(8 \mathrm{~m})$ downstream from bridge on County Highway AA, $500 \mathrm{ft}(152 \mathrm{~m})$ downstream from Allen Creek, $3.5 \mathrm{miles}(5.6 \mathrm{~km})$ southeast of Madison, and at mile $29.8(47.9 \mathrm{~km})$.

Drainage area. $-200 \mathrm{mi}^{2}\left(518 \mathrm{~km}^{2}\right)$.

Gage.-Digital water-stage recorder. Datum of gage is $690.16 \mathrm{ft}$ (210.361 m) above mean sea level (Missouri State Highway Commission bench mark).

Maxima.-March-May 1973: Discharge, 42,300 ft $\mathrm{ft}^{3} / \mathrm{s}\left(1,198 \mathrm{~m}^{3} / \mathrm{s}\right)$ 1:30 p.m., Apr. 21 [gage height, $33.4 \mathrm{ft}$ (10.18 m), from highwater mark in gage house]. Discharge exceeded the 100-year flood.

October 1968 to February 1973: Discharge, 13,900 $\mathrm{ft}^{3} / \mathrm{s}\left(394 \mathrm{~m}^{3} / \mathrm{s}\right)$ Oct. 13, 1969 [gage height, $29.19 \mathrm{ft}(8.897 \mathrm{~m})$ ].

Flood of July 9, 1967, reached a stage of $31.25 \mathrm{ft}(9.525 \mathrm{~m})$ from floodmark [discharge, $31,200 \mathrm{ft}^{3} / \mathrm{s}\left(884 \mathrm{~m}^{3} / \mathrm{s}\right), \mathrm{revised}$, by contracted-opening method]. Flood of 1871 reached nearly the same stage, from information by local resident.

Mean discharge, in cubic feet per second, 1973

\begin{tabular}{|c|c|c|c|c|c|c|c|c|c|c|c|c|c|}
\hline \multicolumn{2}{|c|}{ Day } & March & April & May & & Day & March & April & May & Day & March & April & May \\
\hline 1 & $\ldots$ & 557 & 4,590 & 67 & 11 & --- & 3.740 & 1.270 & 130 & 21 & 228 & 24,100 & 15 \\
\hline 3 & -..- & 448 & 245 & 224 & 13 & $\ldots$ & 744 & 261 & 56 & 23 & 77 & 1,050 & 35 \\
\hline 4 & -.-- & 228 & 146 & 104 & 14 & $-\ldots$ & 2,000 & 150 & 40 & 24 & 1,260 & 230 & 45 \\
\hline 6 & -- & 1,570 & 77 & 282 & 16 & -- & 157 & 1,790 & 30 & 26 & 4,580 & 132 & 90 \\
\hline 7 & $\ldots$ & 2,940 & 60 & 2,720 & 17 & --- & 100 & 1,070 & 25 & 27 & 398 & 92 & 500 \\
\hline 8 & -..- & 660 & 70 & 2,730 & 18 & -... & 75 & 215 & 20 & $28 \ldots$ & 192 & 65 & 1,000 \\
\hline 9 & --.- & 203 & 1,570 & 299 & 19 & $\ldots$ & 62 & 137 & 17 & 29 & 1,060 & 44 & 500 \\
\hline \multicolumn{11}{|c|}{ Monthly mean discharge, in cubic feet per second } & $\begin{array}{l}2,470 \\
1154\end{array}$ & 1651 & $\begin{array}{r}85 \\
329\end{array}$ \\
\hline \multicolumn{11}{|c|}{ Runoff, in inches } & $\begin{array}{r}1,104 \\
6.66\end{array}$ & $\begin{array}{r}1,001 \\
9.21\end{array}$ & 1.90 \\
\hline
\end{tabular}

Gage height, in feet, and discharge, in cubic feet per second, at indicated time, 1973

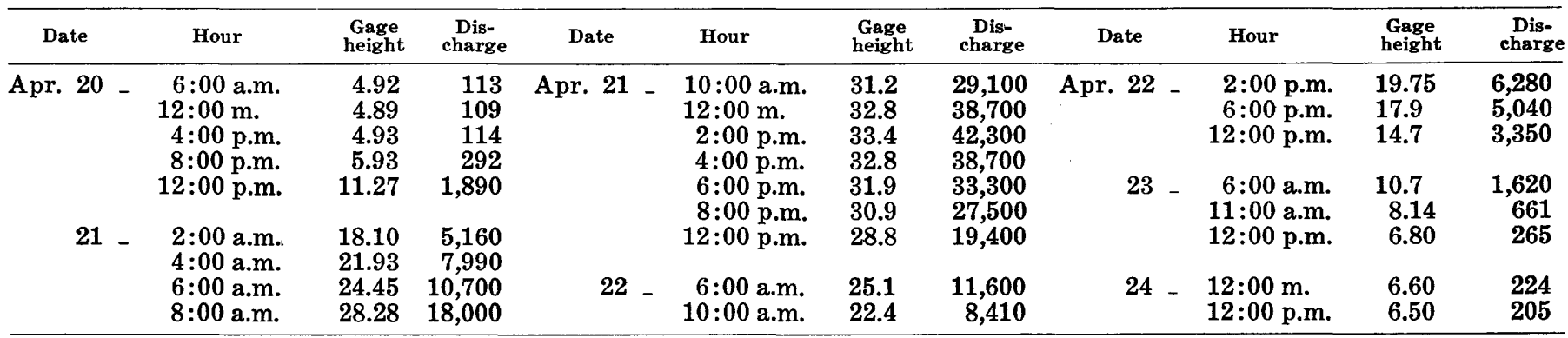


TABLE 12.-Station descriptions and discharge and suspended-sediment data-Continued

\section{SALT RIVER BASIN}

(26) 05507500 Salt River near Monroe City, Mo.

Location.-Lat $39^{\circ} 32^{\prime} 25^{\prime \prime}$, long $91^{\circ} 40^{\prime} 20^{\prime \prime}$, in NE1/4 NW1/4 sec. 22 , T. 55 N., R. 7 W., Ralls County, on left bank on downstream side of old bridge pier, $135 \mathrm{ft}(41 \mathrm{~m})$ upstream from highway bridge at Joanna, 2,500 ft (762 m) downstream from Indian Creek, 2 miles $(3.2 \mathrm{~km})$ upstream from Lick Creek, 8 miles $(12.9 \mathrm{~km})$ southeast of Monroe City, and at mile $63.5(102.2$ $\mathrm{km}$ ).

Drainage area. $-2,230 \mathrm{mi}^{2}\left(5,780 \mathrm{~km}^{2}\right)$, approximately.

Gage.-Digital water-stage recorder. Datum of gage is $520.04 \mathrm{ft}(158.508 \mathrm{~m})$ above sea level, datum of 1929.

Flood stage.-26 ft $(7.9 \mathrm{~m})$.

Maxima.-March-May 1973: Discharge, 102,000 ft' 1 s $\left(2,889 \mathrm{~m}^{3} / \mathrm{s}\right)$ at approximately 1:00 p.m. on Apr. 22 [gage height, 39.1

ft $(11.92 \mathrm{~m})$ from high-water marks obtained by levels]. Discharge exceeded the 100 -year flood. October 1939 to February 1973: Discharge, 89,500 $\mathrm{ft}^{3} / \mathrm{s}\left(2,535 \mathrm{~m}^{3} / \mathrm{s}\right)$ Oct. 14, 1969 [gage height, $37.40 \mathrm{ft}(11.400 \mathrm{~m})$, from floodmarks].

Flood in June 1928 reached a stage of about $36 \mathrm{ft}(11 \mathrm{~m})$, from information by local residents.

Mean discharge, in cubic feet per second, 1973

\begin{tabular}{|c|c|c|c|c|c|c|c|c|c|c|c|c|c|}
\hline \multicolumn{2}{|c|}{ Day } & \multirow{2}{*}{$\begin{array}{r}\text { March } \\
694\end{array}$} & \multirow{2}{*}{$\begin{array}{c}\text { April } \\
31,500\end{array}$} & \multirow{2}{*}{$\begin{array}{c}\text { May } \\
1,440\end{array}$} & \multicolumn{2}{|r|}{ Day } & \multirow{2}{*}{$\begin{array}{c}\text { March } \\
28,400\end{array}$} & \multirow{2}{*}{$\frac{\text { April }}{11,400}$} & \multirow{2}{*}{$\begin{array}{c}\text { May } \\
4,110\end{array}$} & Day & \multirow{2}{*}{$\frac{\text { March }}{2,750}$} & \multirow{2}{*}{$\begin{array}{c}\text { April } \\
35,500\end{array}$} & \multirow{2}{*}{$\frac{\text { May }}{324}$} \\
\hline 1 & $\ldots-\ldots$ & & & & 11 & & & & & 21 & & & \\
\hline 2 & ---- & 6,090 & 30,300 & 4,710 & 12 & ----- & 24,500 & 10,200 & 2,050 & 22 & 2,290 & 94,000 & 358 \\
\hline 3 & --- & 6,470 & 16,700 & 7,560 & 13 & --- & 13,400 & 8,610 & 1,390 & 23 & 1,530 & 67,000 & 364 \\
\hline 4 & ---- & 3,440 & 9,860 & 6,620 & 14 & $\ldots$ & 18,200 & 7,120 & 1,030 & $24 \ldots$ & 3,040 & 42,000 & 528 \\
\hline 5 & $\ldots$ & 3,810 & 2,930 & 2,500 & 15 & -.- & 15,200 & 5,090 & 852 & $25 \ldots$ & 26,600 & 25,000 & 497 \\
\hline 6 & $-\ldots$ & 13,300 & 2,070 & 2,150 & 16 & ---- & 9,660 & 8,400 & 723 & 26 & 37,700 & 8,000 & 1,050 \\
\hline 7 & $\ldots$ & 30,000 & 1,720 & 10,900 & 17 & $-\ldots$ & 3,900 & 12,000 & 620 & 27 & 34,500 & 3,000 & 9,330 \\
\hline 8 & --- & 23,700 & 1,460 & 21,700 & 18 & ---- & 1,780 & 7,770 & 524 & $28 \ldots$ & 20,200 & 2,000 & 15,900 \\
\hline 9 & --- & 8,850 & 6,300 & 14,500 & 19 & $\ldots$ & 1,300 & 3,530 & 449 & $29 \ldots$ & 13,000 & 1,500 & 12,500 \\
\hline 10 & --- & 10,300 & 11,900 & 9,040 & 20 & --- & 1,650 & 2,590 & 374 & $30 \ldots$ & 8,910 & 1,240 & 13,300 \\
\hline 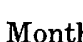 & & & & & & & & & & 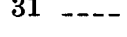 & $\begin{array}{l}14,500 \\
10,570\end{array}$ & $n$ & 12,400 \\
\hline Run & in & es & & & & & & & & & $\begin{array}{r}12,0 \\
6.50\end{array}$ & $\begin{array}{r}10,000 \\
7.85\end{array}$ & $\begin{array}{r}0,100 \\
2.67\end{array}$ \\
\hline
\end{tabular}

Gage height, in feet, and discharge, in cubic feet per second, at indicated time, 1973

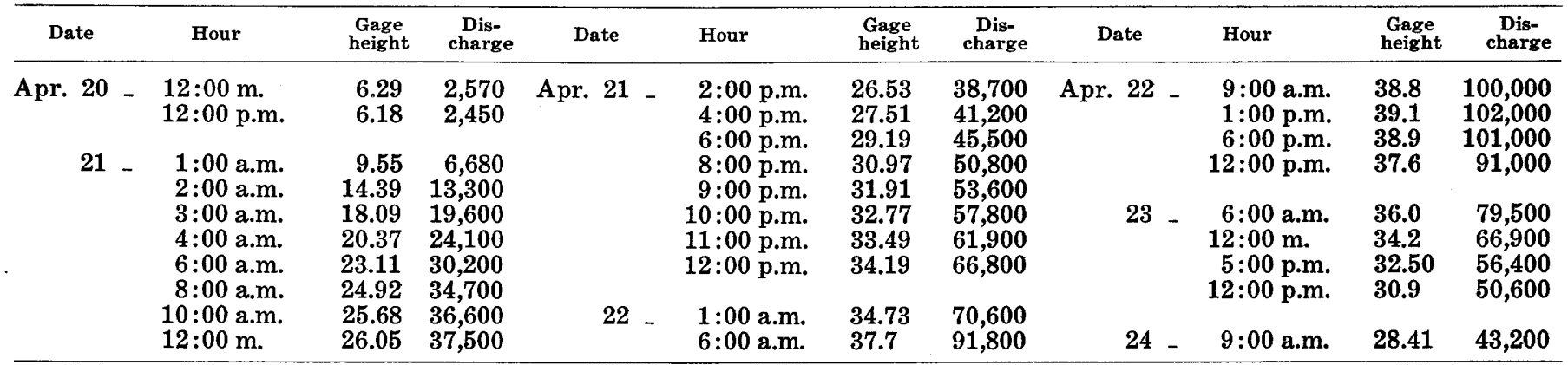

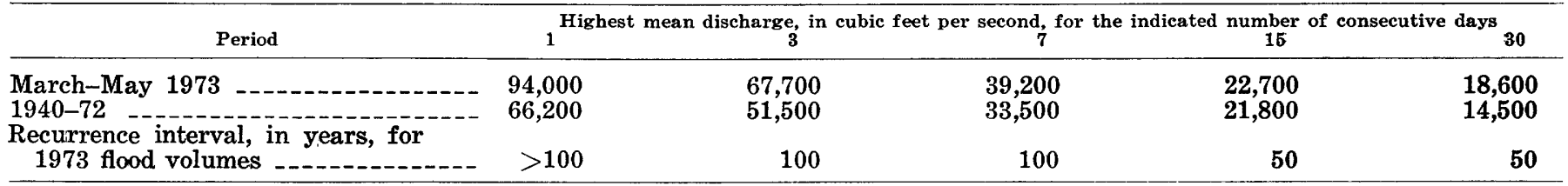

\section{SALT RIVER BASIN}

(27) 05508000 Salt River near New London, Mo.

Location.-Lat $39^{\circ} 36^{\prime} 44^{\prime}$, long $91^{\circ} 24^{\prime} 30^{\prime \prime}$, in NE $1 / 4 \mathrm{NW}^{1 / 4}$ sec. 36 , T. 56 N., R. 5 W., Ralls County, on left bank $180 \mathrm{ft}(55 \mathrm{~m})$ upstream from upstream bridge on dual U.S. Highway 61,2 miles $(3.2 \mathrm{~km})$ north of New London, $8 \mathrm{miles}(12.9 \mathrm{~km})$ upstream from Spencer Creek and at mile $35.5(57.1 \mathrm{~km})$.

Drainage area.-2,480 $\mathrm{mi}^{2}\left(6,420 \mathrm{~km}^{2}\right)$, approximately.

Gage.-Digital water-stage recorder. Datum of gage is $477.03 \mathrm{ft}(145.399 \mathrm{~m})$ above mean sea level, datum of 1929 .

Flood stage. $-19 \mathrm{ft}(5.8 \mathrm{~m})$.

Maxima.-March-May 1973: Discharge, 107,000 ft's $/ \mathrm{s}\left(3,030 \mathrm{~m}^{3} / \mathrm{s}\right)$ at approximately 11:00 p.m. on Apr. 22 [gage height, 31.8 $\mathrm{ft}(9.69 \mathrm{~m})$, from high-water mark in gage house]. Discharge exceeded the 100-year flood.

February 1922 to February 1973: Discharge, 79,500 $\mathrm{ft}^{3} / \mathrm{s}\left(2,251 \mathrm{~m}^{3} / \mathrm{s}\right)$ Oct. 14, 1969 [gage height, $30.62 \mathrm{ft}(9.333 \mathrm{~m})$ ]

Flood of July 14, 1858, reached a stage of $27.6 \mathrm{ft}(8.41 \mathrm{~m})$, present site and datum, based on comparison of June 1928 flood crest at stone marker 1 mile $(1.6 \mathrm{~km})$ downstream from gage. 
THE FLOODS

TABLE 12.-Station descriptions and discharge and suspended-sediment data-Continued

Mean discharge, in cubic feet per second, 1973

\begin{tabular}{|c|c|c|c|c|c|c|c|c|c|c|c|c|c|c|}
\hline \multicolumn{2}{|c|}{ Day } & \multirow{2}{*}{$\begin{array}{r}\text { March } \\
742\end{array}$} & \multirow{2}{*}{$\begin{array}{c}\text { April } \\
26,800\end{array}$} & \multirow{2}{*}{$\frac{\text { May }}{1,960}$} & \multicolumn{2}{|c|}{ Day } & \multirow{2}{*}{$\begin{array}{l}\text { March } \\
25,300\end{array}$} & \multirow{2}{*}{$\frac{\text { April }}{13,200}$} & \multirow{2}{*}{$\frac{\text { May }}{8,210}$} & \multicolumn{2}{|c|}{ Day } & \multirow{2}{*}{$\frac{\text { March }}{2,600}$} & \multirow{2}{*}{$\begin{array}{c}\text { April } \\
40,000\end{array}$} & \multirow{2}{*}{$\begin{array}{r}\text { May } \\
634\end{array}$} \\
\hline 1 & ---- & & & & 11 & & & & & 21 & & & & \\
\hline 2 & ---- & 3,680 & 32,800 & 5,370 & 12 & ---- & 21,800 & 11,700 & 3,380 & 22 & & 1,720 & 98,200 & 718 \\
\hline 3 & ---- & 7,440 & 26,400 & 7,770 & 13 & --- & 15,000 & 9,600 & 2,140 & 23 & ---- & 1,500 & 91,000 & 834 \\
\hline 4 & ---- & 4,640 & 13,900 & 8,420 & 14 & ---- & 17,200 & 8,070 & 1,610 & 24 & ---- & 9,940 & 58,700 & 571 \\
\hline 5 & $-\cdots$ & 3,840 & 4,970 & 4,580 & 15 & ---- & 16,500 & 6,080 & 1,330 & 25 & --- & 27,400 & 39,700 & 731 \\
\hline 6 & ---- & 9,880 & 2,510 & 2,780 & 16 & ---- & 9,390 & 7,050 & 1,150 & 26 & --- & 36,200 & 20,200 & 625 \\
\hline 7 & ---- & 26,800 & 1,890 & 7,710 & 17 & $-\ldots$ & 3,040 & 12,500 & 1,030 & 27 & $\ldots$ & 35,400 & 4,000 & 8,060 \\
\hline 8 & ---- & 30,400 & 1,540 & 20,500 & 18 & ---- & 1,680 & 9,900 & 912 & 28 & --- & 21,300 & 2,600 & 16,100 \\
\hline 9 & ---- & 17,500 & 5,580 & 19,000 & 19 & ---- & 1,580 & 4,920 & 813 & 29 & $\ldots$ & 13,900 & 1,950 & 14,600 \\
\hline 10 & --- & 10,200 & 13,000 & 12,300 & 20 & ---- & 2,910 & 2,720 & 708 & 30 & ---- & 9,540 & 1,730 & 13,600 \\
\hline & & & & & & & & & & 31 & $\ldots$ & 15,200 & & 14,100 \\
\hline & & 6) & 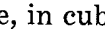 & 20 & & & & & & & --- & 13,040 & 19,110 & 5,879 \\
\hline Runo & in & hes _- & & & & & & & & & & 6.06 & 8.60 & 2.73 \\
\hline
\end{tabular}

Gage height, in feet, and discharge, in cubic feet per second, at indicated time, 1973

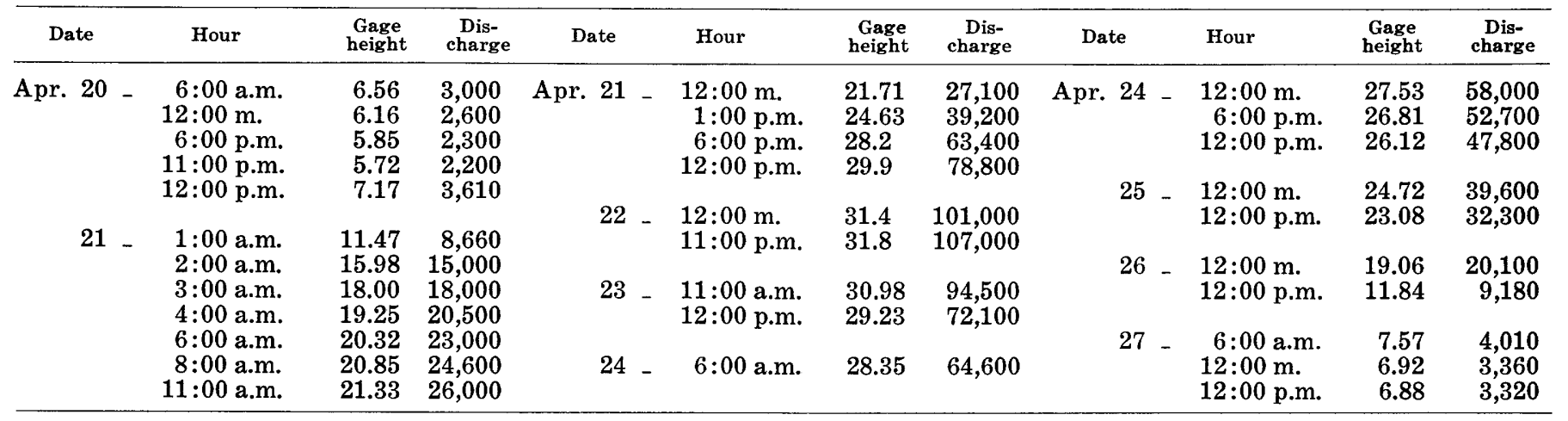

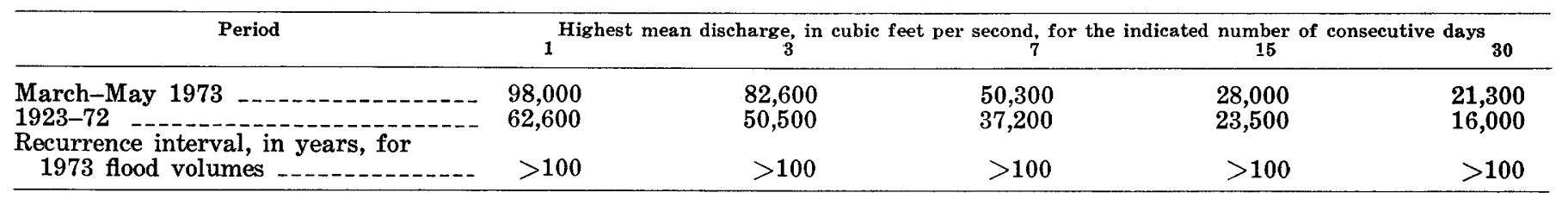

\section{ILLINOIS RIVER BASIN}

(28) 05545100 Sugar Creek at Elkhorn, Wis.

Location.-Lat $42^{\circ} 41^{\prime} 05^{\prime \prime}$, long $88^{\circ} 30^{\prime} 50^{\prime \prime}$, in SW1/4 sec. 29 , T. 3 N., R. 17 E., Walworth County, at culvert on State Highway 11,2 miles $(3 \mathrm{~km})$ northeast of Elkhorn.

Drainage area. $-6.68 \mathrm{mi}^{2}\left(17.30 \mathrm{~km}^{2}\right)$.

Gage.-Crest stage only.

Bankfull stage.-12.0 ft $(3.66 \mathrm{~m})$.

Maxima.-March-May 1973: Discharge, $900 \mathrm{ft}^{3} / \mathrm{s}\left(25.5 \mathrm{~m}^{3} / \mathrm{s}\right)$ Apr. 21 [gage height, $17.47 \mathrm{ft}$ (5.325 m)]. Discharge exceeded the 100-year flood. 1962 to February 1973: Discharge, $225 \mathrm{ft}^{3} / \mathrm{s}\left(6.37 \mathrm{~m}^{3} / \mathrm{s}\right)$ Apr. 16, 1972 [gage height, $12.57 \mathrm{ft}(3.832 \mathrm{~m})$ ].

\section{ILLINOIS RIVER BASIN}

(29) 05546500 Fox River at Wilmot, Wis.

Location.-Lat $42^{\circ} 30^{\prime} 40^{\prime \prime}$, long $88^{\circ} 10^{\prime} 45^{\prime \prime}$, in SW1/4 sec. 30, T. 1 N., R. 20 E., Kenosha County, on right bank $100 \mathrm{ft}(30 \mathrm{~m})$ downstream from bridge on County Trunk C, $300 \mathrm{ft}(91 \mathrm{~m})$ upstream from Wilmont Dam, $1.0 \mathrm{mi}(1.6 \mathrm{~km}) \mathrm{north}$ of Wisconsin-Illinois State lines, and $6.0 \mathrm{mi}(9.6 \mathrm{~km})$ upstream from Fox chain of lakes.

Drainage area. $-868 \mathrm{mi}^{2}\left(2,248 \mathrm{~km}^{2}\right)$.

Gage.-Water-stage recorder and concrete dam. Datum of gage is $735.22 \mathrm{ft}(224.095 \mathrm{~m})$ above mean sea level. Prior to Sept. 1,1956 , nonrecording gage and concrete dam.

Bankfull stage. $-8.00 \mathrm{ft}(2.438 \mathrm{~m})$.

Maxima.-March-May 1973: Discharge, 6,560 ft's $/ \mathrm{s}\left(185 \mathrm{~m}^{3} / \mathrm{s}\right)$ 3:00 p.m., Apr. 23 [gage height, $7.65 \mathrm{ft}(2.332 \mathrm{~m})$ ]. Recurrence interval of discharge is 35 years.

1940 to February 1973: Discharge, $7,520 \mathrm{ft}^{3} / \mathrm{s}\left(213 \mathrm{~m}^{3} / \mathrm{s}\right)$ Mar. 31, 1960 [gage height, $9.25 \mathrm{ft}(2.819 \mathrm{~m})$ ]. 
TABLE 12.-Station descriptions and discharge and suspended-sediment data-Continued

Mean discharge, in cubic feet per second, 1973

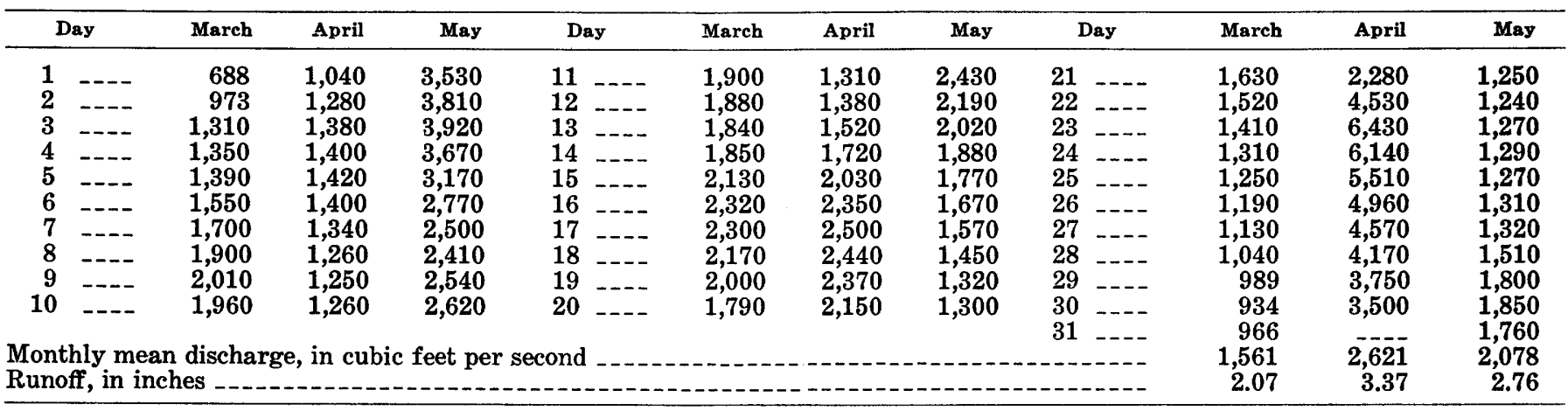

\begin{tabular}{|c|c|c|c|c|c|}
\hline Period & \multicolumn{5}{|c|}{ Highest mean discharge, in cubic feet per second, for the indicated number of consecutive days } \\
\hline $\begin{array}{l}\text { March-May } 1973 \\
1940-71 \\
\text { Recurrence interval, in years, for }\end{array}$ & $\begin{array}{l}6,430 \\
7,100\end{array}$ & $\begin{array}{l}6,030 \\
6,790\end{array}$ & $\begin{array}{l}5,190 \\
6,100\end{array}$ & $\begin{array}{l}4,290 \\
4,420\end{array}$ & $\begin{array}{l}3,300 \\
3,100\end{array}$ \\
\hline 1973 flood volumes & 35 & 50 & 35 & 40 & 50 \\
\hline
\end{tabular}

MISSISSIPPI RIVER MAIN STEM

(30) 05587500 Mississippi River at Alton, Ill.

Location.-Lat $38^{\circ} 53^{\prime} 06^{\prime \prime}$, long $90^{\circ} 10^{\prime} 51^{\prime \prime}$, in NE $1 / 4$ sec. 14 , T. 5 N., R. 10 W., Madison County, near left bank in downstream end of intermediate lock wall of lock and dam 26 at Aiton, $300 \mathrm{ft}(91 \mathrm{~m})$ downstream from Misisouri \& Illinois Bridge \& Belt Railroad bridge, 7.7 miles $(12.4 \mathrm{~km})$ upstream from Missouri River, and at mile $202.7(326.1 \mathrm{~km})$ upstream from Ohio River.

Drainage area.-171,500 $\mathrm{mi}^{2}\left(444,200 \mathrm{~km}^{2}\right)$, approximately.

Gage.-Digital water-stage recorder. Digital water-stage recorder at auxiliary gage (Hartford), $5.9 \mathrm{miles}(9.5 \mathrm{~km})$ downstream. Datum of both gages is at mean sea level (levels by Corps of Engineers).

Flood stage.-421.0 ft $(128.3 \mathrm{~m})$. Flood stage was exceeded for 79 consecutive days (Mar. 12 to May 21). Previous record was 32 days (June 9 to July 11, 1947).

Maxima.-March-June 1973: Discharge, 535,000 $\mathrm{ft}^{3} / \mathrm{s} \quad\left(15,150 \mathrm{~m}^{3} / \mathrm{s}\right) 3: 00 \mathrm{p.m}$. , Apr. 29, including undetermined amount of overflow from Missouri River; gage height, $432.15 \mathrm{ft}(131.719 \mathrm{~m})$ 12:00 m., Apr. 28. Recurrence interval of discharge is 100 years (based on figure 52 ).

October 1927 to February 1973: Discharge, 437,000 $\mathrm{ft}^{3} / \mathrm{s}\left(12,380 \mathrm{~m}^{3} / \mathrm{s}\right)$ May 24, 1943 [gage height, $429.91 \mathrm{ft}(131.037$

$\mathrm{m})$ ], includes $90,000 \mathrm{ft}^{3} / \mathrm{s}\left(2,549 \mathrm{~m}^{3} / \mathrm{s}\right)$ floodwater overflow from Missouri River.

Flood in June 1844 reached a stage of $432.10 \mathrm{ft}(131.704 \mathrm{~m})$, present datum.

Remarks.- Natural flow of stream affected by many reservoirs and navigation dams in upper Mississippi River basin.

Water temperature, stage, water discharge, and suspended-sediment data for given time

\begin{tabular}{|c|c|c|c|c|c|c|c|c|}
\hline \multirow{2}{*}{\multicolumn{2}{|c|}{ Date }} & \multirow[b]{2}{*}{ Hour ${ }^{1}$} & \multirow{2}{*}{$\begin{array}{c}\text { Water } \\
\text { temperature } \\
\left({ }^{\circ} \mathrm{C}\right)\end{array}$} & \multirow[b]{2}{*}{$\begin{array}{c}\text { Stage } \\
(\mathrm{ft})\end{array}$} & \multirow[b]{2}{*}{$\begin{array}{c}\text { Discharge } \\
\left(1,000 \mathrm{ft}^{3} / \mathrm{s}\right)\end{array}$} & \multicolumn{3}{|c|}{ Suspended sediment } \\
\hline & & & & & & $\begin{array}{c}\text { Concentration } \\
(\mathrm{mg} / \mathrm{l})\end{array}$ & $\begin{array}{c}\text { Discharge } \\
(1,000 \text { t/day })\end{array}$ & $\begin{array}{c}\text { Percent } \\
\text { sand }\end{array}$ \\
\hline April & $\begin{array}{r}5 \\
6 \\
6\end{array}$ & $\begin{array}{l}\text { 4:45 p.m. } \\
7: 10 \text { p.m. } \\
\text { 9:10 a.m. } \\
\text { 9:30 a.m. } \\
\text { 2:30 p.m. } \\
\text { 10:00 a.m. } \\
\text { 11:20 a.m. }\end{array}$ & $\begin{array}{r}11.5 \\
11.0 \\
10.0 \\
9.4 \\
7.5 \\
5.0 \\
8.5\end{array}$ & $\begin{array}{l}429.2 \\
429.0 \\
428.6 \\
428.0 \\
427.4 \\
426.6 \\
425.7\end{array}$ & $\begin{array}{l}400 \\
409 \\
399 \\
384 \\
385 \\
376 \\
382\end{array}$ & $\begin{array}{r}213 \\
156 \\
133 \\
95 \\
97 \\
154 \\
115\end{array}$ & $\begin{array}{r}230 \\
172 \\
143 \\
98 \\
101 \\
156 \\
119\end{array}$ & $\begin{array}{r}6 \\
8 \\
8 \\
10 \\
13 \\
13 \\
9 \\
11\end{array}$ \\
\hline
\end{tabular}

1 Time shown is for temperature and suspended-sediment sample. 
THE FLOODS

TABLE 12.-Station descriptions and discharge and suspended-sediment data-Continued

Mean gage height, in feet, and discharge, in cubic feet per second, 1973

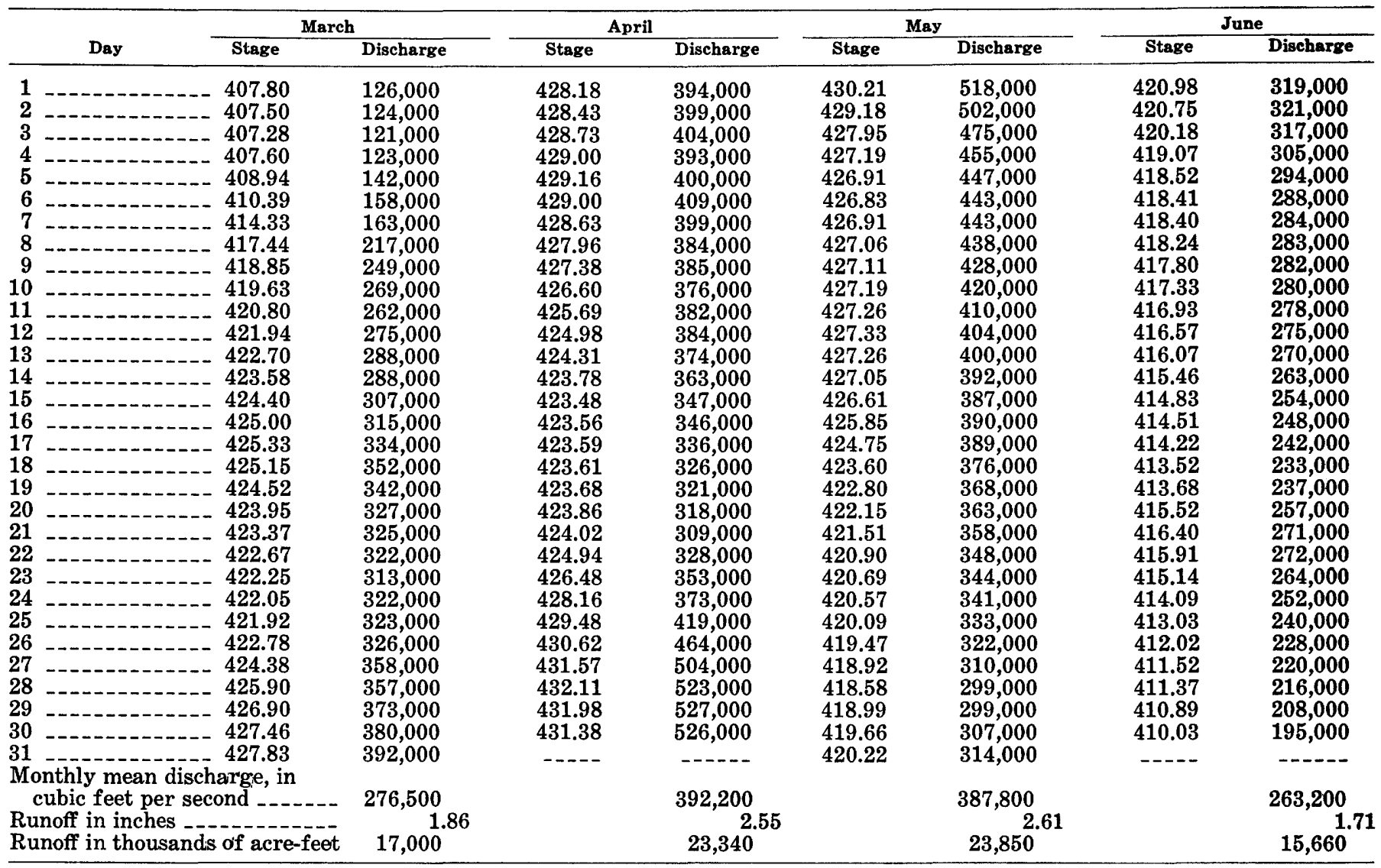

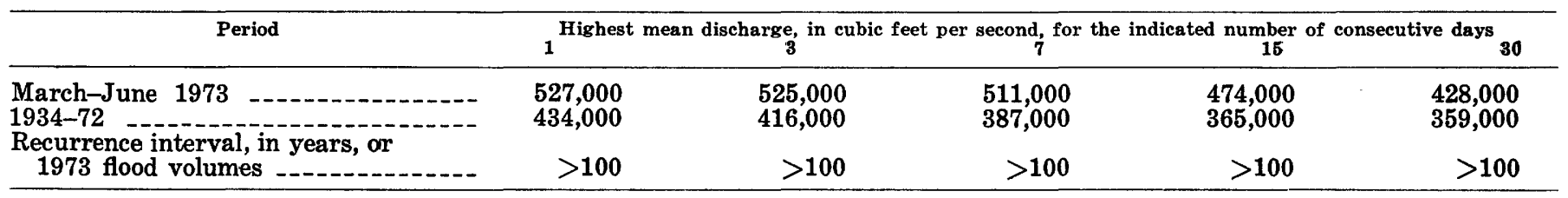

CHARITON RIVER BASIN

(31) 06903400 Chariton River near Chariton, Iowa

Location.-Lat $40^{\circ} 57^{\prime} 12^{\prime \prime}$, long $93^{\circ} 15^{\prime} 37^{\prime \prime}$, in SW1/4 NE $1 / 4$ sec. 15 , T. 71 N., R. 21 W., Lucas County, on right bank 15 ft (4.6 $\mathrm{m})$ downstream from bridge on County Highway S43, 0.4 mile $(0.6 \mathrm{~km})$ downstream from Wolf Creek, and $5.0 \mathrm{miles}(8.0$ $\mathrm{km}$ ) southeast of Chariton.

Drainage area. $-182 \mathrm{mi}^{2}\left(471 \mathrm{~km}^{2}\right)$.

Gage.-Water-stage recorder. Datum of gage is $917.96 \mathrm{ft}(279.79 \mathrm{~m})$ above mean sea level (levels by U.S. Weather Bureau from a Corp of Engineers bench mark).

Flood stage. $-18 \mathrm{ft}(5.5 \mathrm{~m})$.

Maxima.-March-May 1973: Discharge, 2,740 ft $\mathrm{ft}^{3} / \mathrm{s}\left(78 \mathrm{~m}^{3} / \mathrm{s}\right)$ 6:00 p.m., Apr 16 [gage height, $18.02 \mathrm{ft}$ (5.49 m)]. Recurrence interval of discharge is 2 years.

October 1965 to February 1973: Discharge, 6,320 ft $\mathrm{ft}^{3} / \mathrm{s}\left(179 \mathrm{~m}^{3} / \mathrm{s}\right)$ Aug. 8, 1970 [gage height, $20.15 \mathrm{ft}(6.14 \mathrm{~m})$ ].

Flood in March 1960 reached a stage of about $23 \mathrm{ft}(7.0 \mathrm{~m})$ [discharge, about $\left.15,000 \mathrm{ft}^{3} / \mathrm{s}^{2}\left(425 \mathrm{~m}^{3} / \mathrm{s}\right)\right]$.

March-May 1973: Sediment concentration, maximum daily, 2,800 mg/ May 27.

Sediment discharge, maximum daily, 10,400 tons $(9,430 \mathrm{t})$ May 27.

October 1969 to February 1973: Sediment concentration, maximum daily, 3,780 mg/1 May $19,1971$.

Sediment discharge, maximum daily, 21,600 tons $(19,600 \mathrm{t})$ Aug. 8, 1970 .

Remarks.-Station data included in this report primarily for sediment analysis. 
TABLE 12.-Station descriptions and discharge and suspended-sediment data-Continued

Mean water discharge and suspended-sediment concentration and discharge

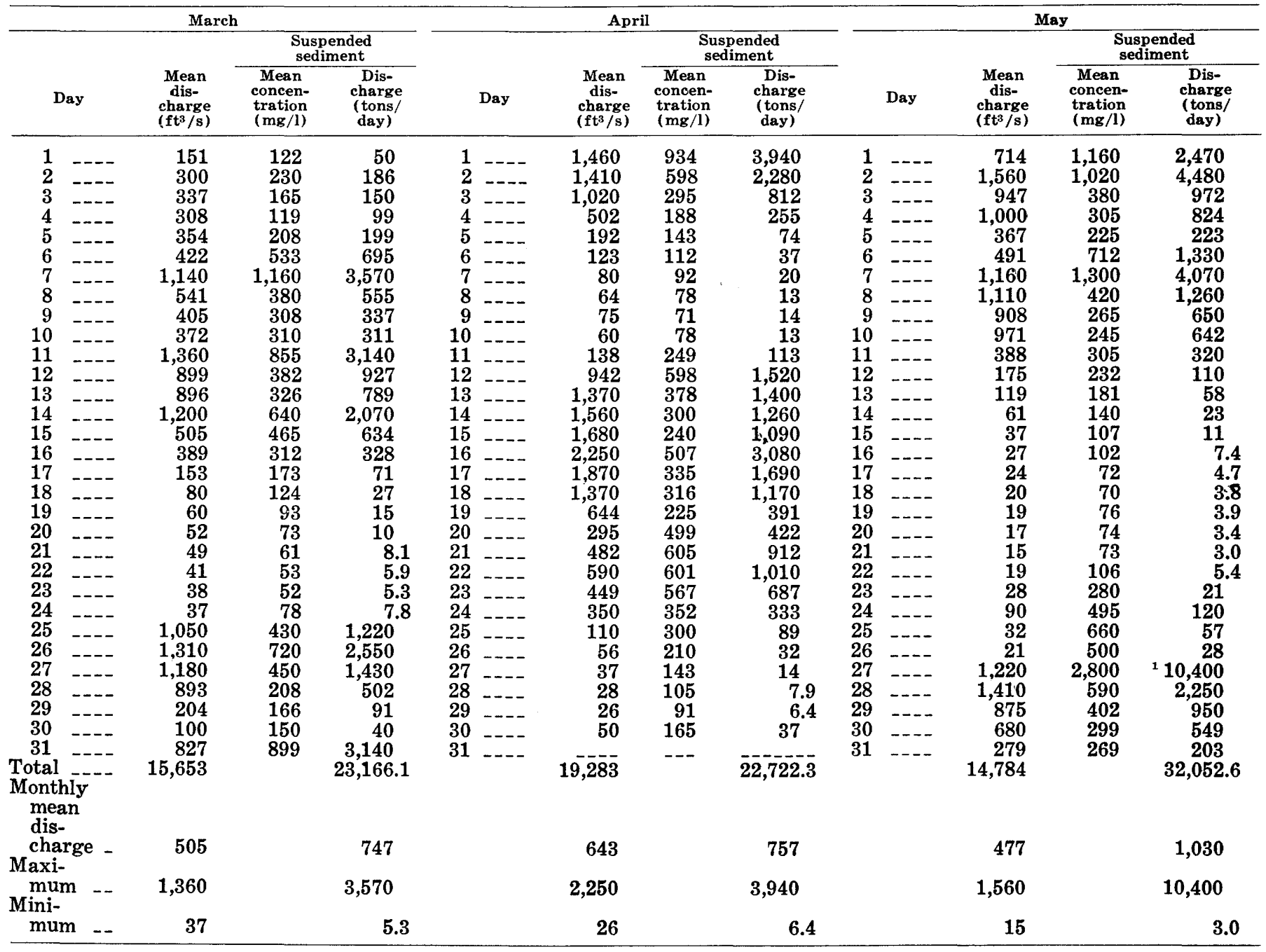

1 A suspended-sediment sample on May 27 at 0810 contained 39 percent clay; 52 percent silt, and 9 percent sand.

CHARITON RIVER BASIN

(32) 06905500 Chariton River near Prairie Hill, Mo.

(Published as "near Keytesville" prior to Oct. 1, 1953)

Location.-Lat $39^{\circ} 32^{\prime} 25^{\prime \prime}$, long $92^{\circ} 47^{\prime} 23^{\prime \prime}$, in NW1/4 NW $1 / 4$ sec. 26 , T. 55 N., R. 17 W., Chariton County, on right bank on downstream side of road at bridge on State Highway 129, 3.2 miles $(5.1 \mathrm{~km})$ northwest of Prairie Hill, $13.5 \mathrm{miles}(21.7 \mathrm{~km})$ upstream from Puzzle Creek and at mile $19.6(31.5 \mathrm{~km})$.

Drainage area.- $1,870 \mathrm{mi}^{2}\left(4,840 \mathrm{~km}^{2}\right)$, approximately.

Gage.-Digital water-stage recorder. Datum of gage is $632.05 \mathrm{ft}(192.649 \mathrm{~m})$ above mean sea level (levels by Corps of Engineers). Prior to Oct. 1, 1953, nonrecording gage at site 8.2 miles $(13.2 \mathrm{~km})$ downstream at datum $13.68 \mathrm{ft}(4.170 \mathrm{~m})$ lower. Oct. 1, 1953, to July 2,1958 , nonrecording gage at present site and datum.

Flood Stage.-15 ft $(4.6 \mathrm{~m})$

Maxima.-March-May 1973: Discharge, 31,900 ft's/s (903 m³ $/ \mathrm{s})$ 4:00 a.m., Apr. 23 [gage height, $21.96 \mathrm{ft}(6.693 \mathrm{~m})$ ]. Discharge exceeded the 100-year flood.

October 1928 to February 1973: Discharge, 25,600 ft $3 / \mathrm{s}\left(725 \mathrm{~m}^{3} / \mathrm{s}\right)$ June 8, 9, 1947 [gage height $25.3 \mathrm{ft}(7.71 \mathrm{~m})$ ], from floodmark, at site and datum then in use.

Remarks.-During 1906 a channel 33.5 miles $(53.9 \mathrm{~km})$ long was dug from the Missouri River at the Chariton-Macon County line to replace 290 miles $(466.6 \mathrm{~km})$ of natural channel. Channel improvement was extended upstream after 1909. 
TABLE 12.-Station descriptions and discharge and suspended-sediment data-Continued

Mean discharge, in cubic feet per second, 1973

\begin{tabular}{|c|c|c|c|c|c|c|c|c|c|c|c|c|}
\hline \multicolumn{2}{|c|}{ Day } & March & April & May & Day & March & April & May & Day & March & April & May \\
\hline 1 & -... & 2,130 & 15,100 & 3,870 & 11 & 10,800 & 4,160 & 4,320 & 21 & 2,440 & 23,700 & 1,890 \\
\hline 3 & -- & 2,830 & 7,060 & 18,500 & 13 & 6,100 & 10.700 & 2,740 & 23 & 2,210 & 30.000 & 1,840 \\
\hline 6 & -..- & 3,510 & 1,540 & 5,700 & $16 \ldots$ & 4,100 & 11.400 & $\mathbf{2 , 1 3 0}$ & 26 & 20,100 & 5,800 & 1,910 \\
\hline 7 & -..- & 9,550 & 1,190 & 9,560 & 17 & 3,080 & 10,200 & 2,050 & 27 & 12,200 & 2,780 & 16,000 \\
\hline 8 & -.-- & 6,600 & 1,040 & 15,500 & 18 & 2,620 & 7,370 & 1,980 & $28 \ldots$ & 7,540 & 1,890 & 21,900 \\
\hline 9 & -.-- & 4,880 & 2,720 & 9,400 & 19 & 2,340 & 5,780 & 1,930 & 29 & 5,700 & 1,490 & 23,500 \\
\hline \multirow{2}{*}{\multicolumn{10}{|c|}{$\begin{array}{l}\text { Monthly mean discharge, in cubic feet per second } \\
\text { Runoff, in inches }\end{array}$}} & 5,720 & 8,980 & 7,800 \\
\hline & & & & & & & & & & 3.53 & 5.36 & 4.81 \\
\hline
\end{tabular}

Gage height, in feet, and discharge, in cubic feet per second, at indicated time, 1973

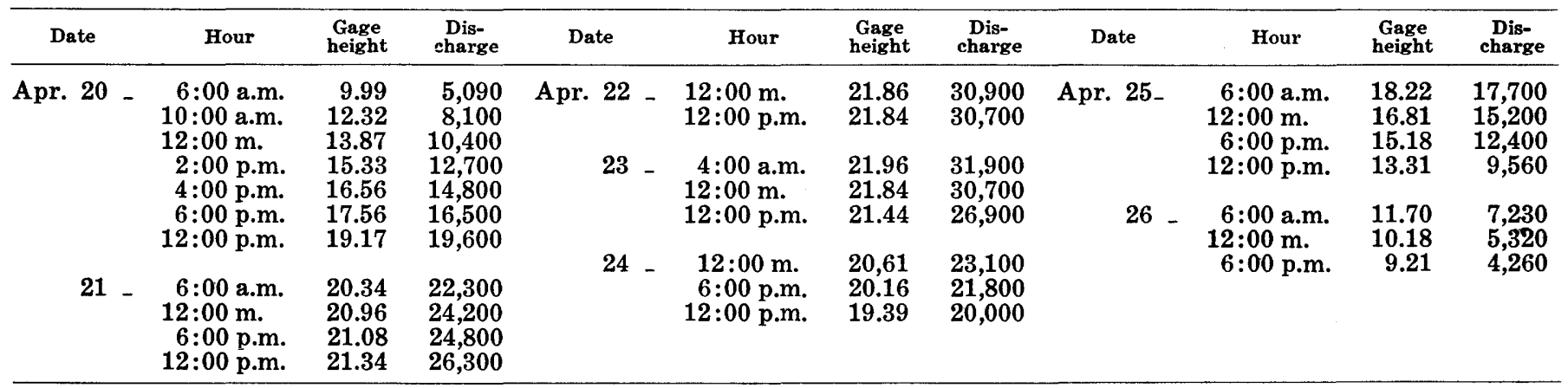

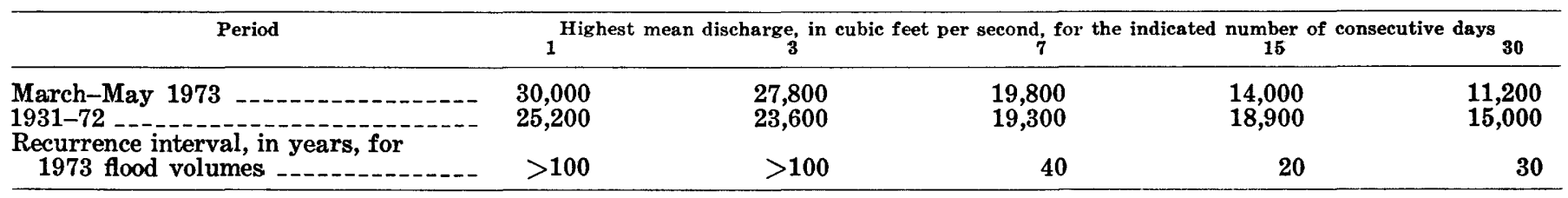

\section{CHARITON RIVER BASIN}

(33) 06906000 Mussel Fork near Musselfork, Mo.

Location.-Lat $39^{\circ} 31^{\prime} 26^{\prime \prime}$, long $92^{\circ} 56^{\prime} 59^{\prime \prime}$, in SW1/4 SW $1 / 4 \mathrm{SE}^{1 / 4}$ sec. 32, T. 55 N., R. 18 W., Chariton County, on left bank at downstream side of pier of bridge on State Highway $5,4.5$ miles $(7.2 \mathrm{~km})$ southwest of Musselfork, and $1.5 \mathrm{miles}(2.4 \mathrm{~km})$ upstream from Long Branch.

Drainage area. $-267 \mathrm{mi}^{2}\left(692 \mathrm{~km}^{2}\right)$.

Gage.-Digital water-stage recorder. Datum of gage is $639.25 \mathrm{ft}(194.843 \mathrm{~m})$ above mean sea level, datum of 1929 .

Maxima.-March-May 1973: Discharge, 23,100 $\mathrm{ft}^{3} / \mathrm{s}\left(654 \mathrm{~m}^{3} / \mathrm{s}\right)$ 6:45 a.m., Apr. 22 [gage height, 22.11 ft (6.739)]. Discharge exceeded the 100-year flood.

October 1948 to December 1951, October 1962 to February 1973: Discharge, $9,500 \mathrm{ft}^{3} / \mathrm{s}\left(269 \mathrm{~m}^{3} / \mathrm{s}\right) \mathrm{July} 11,1969 \mathrm{from} \mathrm{loop}$ rating, levee break [gage height, $21.0 \mathrm{ft}(6.40 \mathrm{~m})$ ]; gage height, $21.58 \mathrm{ft}(6.578 \mathrm{~m})$ July 10,1969 .

Mean discharge, in cubic feet per second, 1973

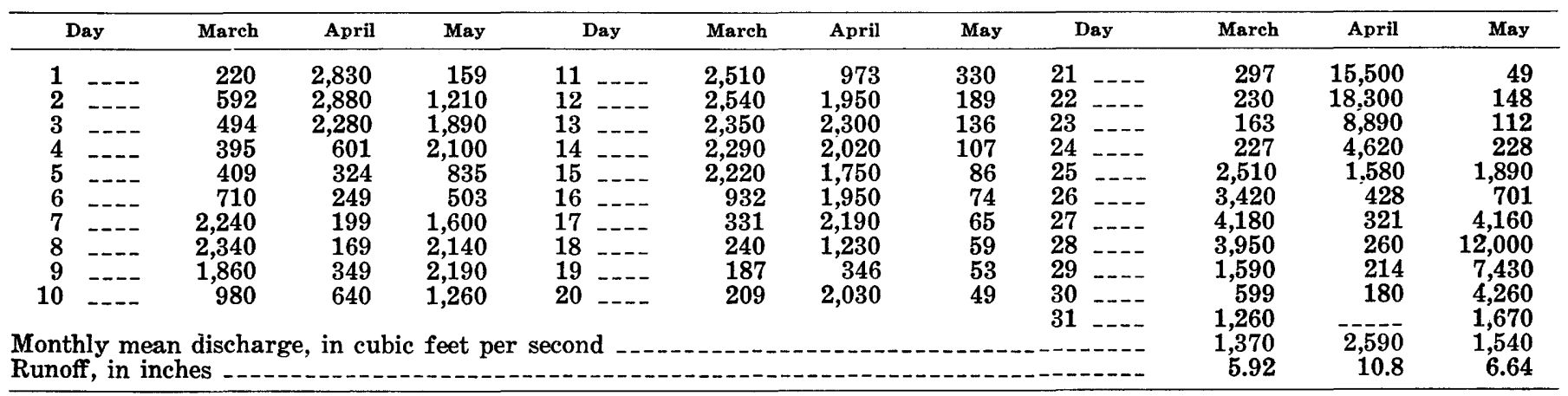


TABLE 12.-Station descriptions and discharge and suspended-sediment data-Continued

Gage height, in feet, and discharge, in cubic feet per second, at indicated time, 1973

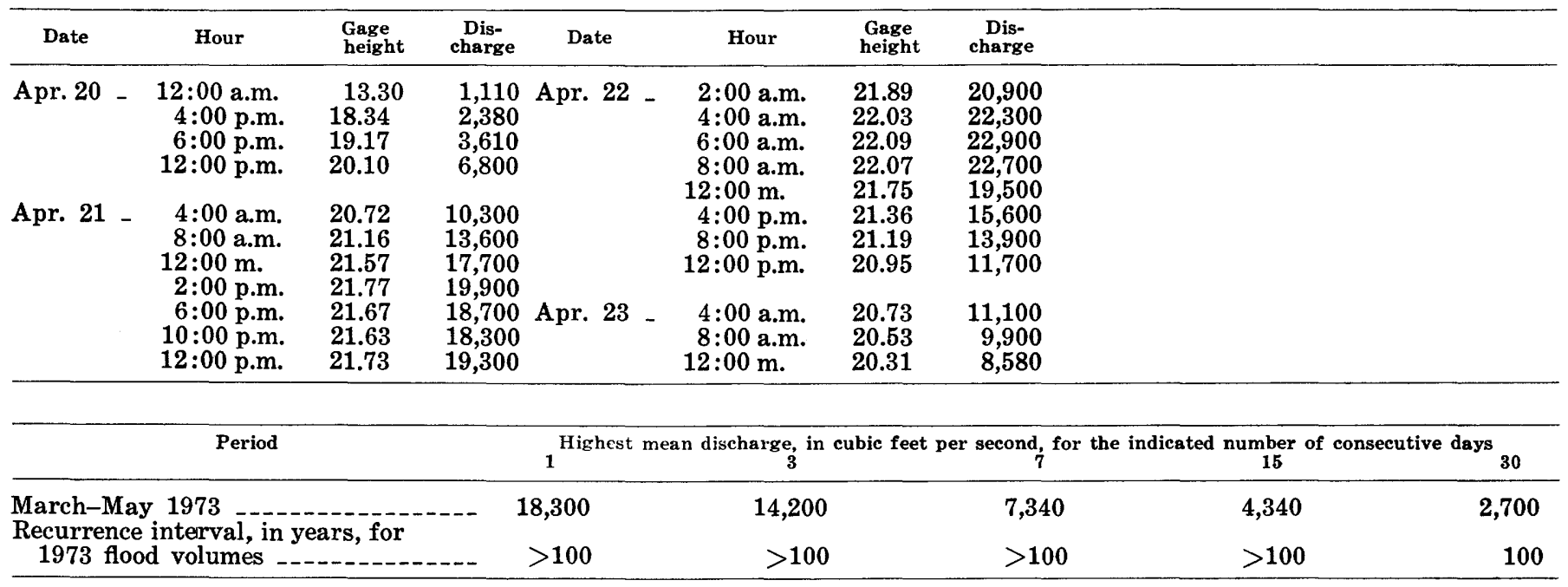

LITTLE CHARITON RIVER BASIN

(34) 06906300 East Fork Chariton River near Huntsville, Mo.

Location.-Lat $39^{\circ} 27^{\prime} 19^{\prime \prime}$, long $92^{\circ} 34^{\prime} 09^{\prime \prime}$, in NE1/4 NW1/4 sec. 26 , T. 54 N., R. 15 W., Randolph County, at downstream side of left pile bent of bridge on County Highway C, 1 mile $(1.6 \mathrm{~km})$ downstream from Sugar Creek and $1.5 \mathrm{miles}(2.4 \mathrm{~km})$ northwest of Huntsville.

Drainage area. $-220 \mathrm{mi}^{2}\left(570 \mathrm{~km}^{2}\right)$.

Gage.-Graphic water-stage recorder. Datum of gage is $656.43 \mathrm{ft}(200.080 \mathrm{~m})$ above mean sea level (datum of 1929$)$.

Maxima.-March-May 1973: Discharge, 30,000 ft' $/ \mathrm{s}\left(850 \mathrm{~m}^{3} / \mathrm{s}\right)$ 3:00 a.m., Apr. 21 [gage height, $20.78 \mathrm{ft}(6.334 \mathrm{~m})$ ]. Discharge exceeded the 100-year flood.

October 1962 to February 1973: Discharge, 19,200 $\mathrm{ft}^{3} / \mathrm{s}\left(544 \mathrm{~m}^{3} / \mathrm{s}\right)$ July 9, 1967 [gage height, $19.76 \mathrm{ft}(6.023 \mathrm{~m})$ ].

Mean discharge, in cubic feet per second, 1973

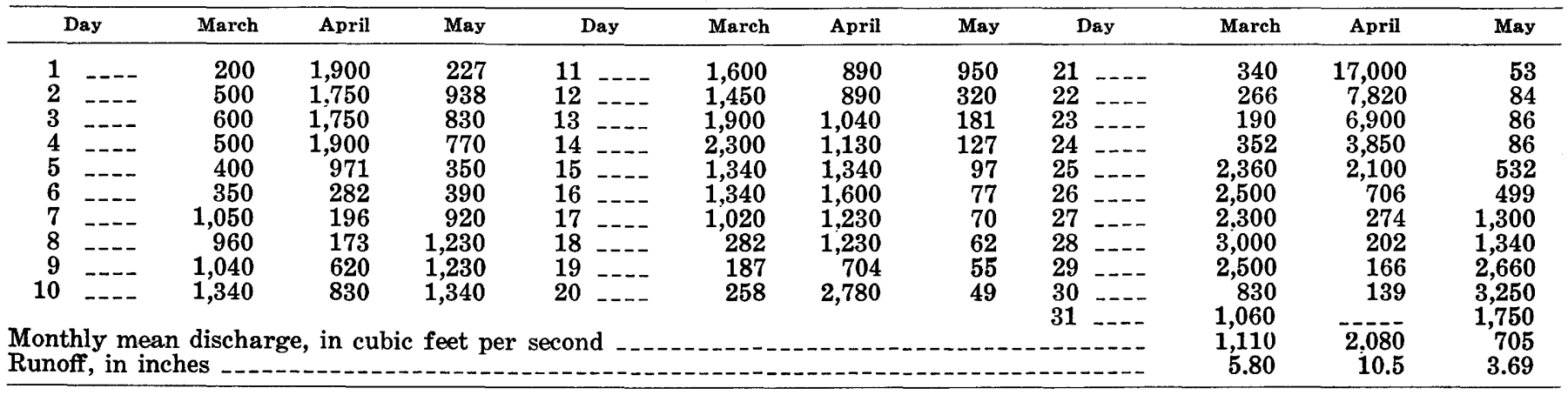

Gage height, in feet, and discharge, in cubic feet per second, at indicated time, 1973

\begin{tabular}{|c|c|c|c|c|c|c|c|}
\hline Date & Hour & $\begin{array}{l}\text { Gage } \\
\text { height }\end{array}$ & $\begin{array}{r}\text { Dis- } \\
\text { charge }\end{array}$ & Date & Hour & $\begin{array}{c}\text { Gage } \\
\text { height }\end{array}$ & $\begin{array}{r}\text { Dis- } \\
\text { charge }\end{array}$ \\
\hline Apr. 20 & $\begin{array}{r}\text { 12:00 m. } \\
\text { 4:00 p.m. } \\
\text { 8:00 p.m. } \\
\text { 10:00 p.m. } \\
\text { 11:00 p.m. } \\
\text { 12:00 p.m. }\end{array}$ & $\begin{array}{l}16.64 \\
17.35 \\
17.68 \\
18.85 \\
19.80 \\
20.50\end{array}$ & $\begin{array}{r}1.380 \\
2,620 \\
3,490 \\
8,350 \\
17,600 \\
26,100\end{array}$ & $\begin{array}{l}\text { Apr. } 21 \text { - } \\
\text { Apr. } 22 \text { - }\end{array}$ & $\begin{array}{r}\text { 2:00 p.m. } \\
\text { 9:00 p.m. } \\
\text { 12:00 p.m. } \\
\text { 2:00 a.m. } \\
\text { 6:00 a.m. }\end{array}$ & $\begin{array}{c}19.15 \\
18.53 \\
18.74 \\
\\
18.90 \\
18.51\end{array}$ & $\begin{array}{r}10,900 \\
6,550 \\
7,640 \\
8,700 \\
6,450\end{array}$ \\
\hline Apr. 21 - & $\begin{array}{r}\text { 2:00 a.m. } \\
\text { 3:00 a.m. } \\
\text { 6:00 a.m. } \\
\text { 8:00 a.m. } \\
\text { 10:00 a.m. }\end{array}$ & $\begin{array}{l}20.75 \\
20.78 \\
20.55 \\
20.20 \\
19.75\end{array}$ & $\begin{array}{l}29,400 \\
30,000 \\
26,800 \\
22,600 \\
17,100\end{array}$ & & & & \\
\hline
\end{tabular}


TABLE 12.-Station descriptions and discharge and suspended-sediment data-Continued

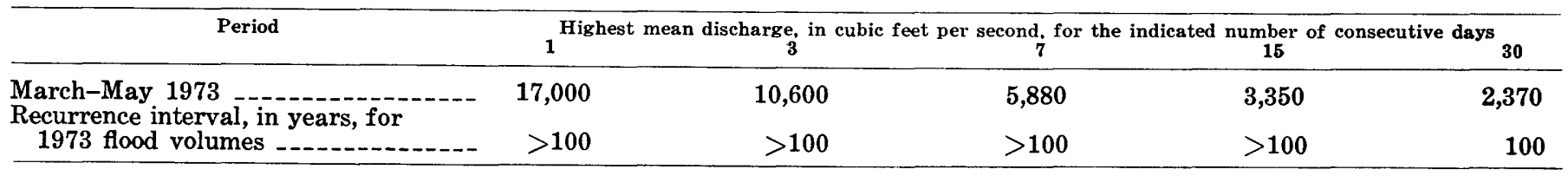

\section{SLOUGH CREEK BASIN}

(35) 06906600 Burge Branch near Arrow Rock, Mo.

Location.-Lat $39^{\circ} 02^{\prime} 43^{\prime \prime}$, long $92^{\circ} 56^{\prime} 35^{\prime \prime}$, in SW1/4 NE1/4 sec. 1 , T. 49 N., R. 19 W., Cooper County, on right bank $30 \mathrm{ft}$ (9 m) upstream from culvert on county road, 1.5 miles $(2.4 \mathrm{~km})$ south of Arrow Rock.

Drainage area.- $0.33 \mathrm{mi}^{2}\left(0.855 \mathrm{~km}^{2}\right)$.

Gage.-Graphic water-stage recorder. Altitude of gage is $610 \mathrm{ft}(186 \mathrm{~m})$, from topographic map.

Maxima.-March-May 1973: Discharge, $276 \mathrm{ft}^{3} / \mathrm{s}$ (7.82 $\left.\mathrm{m}^{3} / \mathrm{s}\right)$ 11:00 p.m., Apr. 20 [gage height, $9.27 \mathrm{ft}(2.825 \mathrm{~m})$, from floodmark]. Discharge exceeded the 100-year flood.

October 1959 to February 1973: Discharge, $134 \mathrm{ft}^{3} / \mathrm{s}\left(3.79 \mathrm{~m}^{*} / \mathrm{s}\right)$ Sept. 13, 1961 [gage height $4.38 \mathrm{ft}(1.335 \mathrm{~m})$ ]; gage height, $7.31 \mathrm{ft}(2.228 \mathrm{~m})$ June 8,1966 .

Gage height, in feet, and discharge, in cubic feet per second, at indicated time, 1973

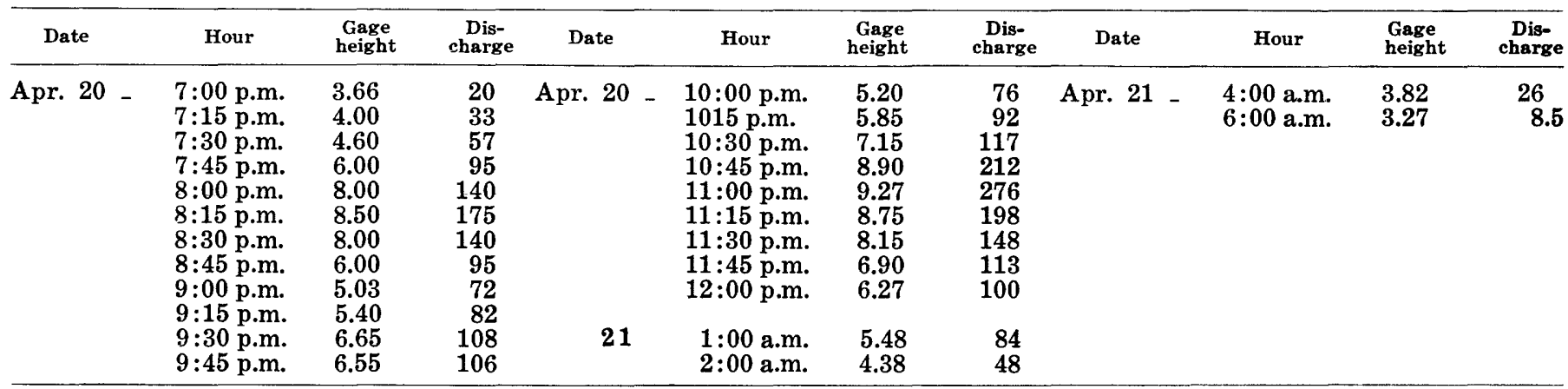

\section{MISSOURI RIVER BASIN}

(36) 06934500 Missouri River at Hermann, Mo.

Location.-Lat $38^{\circ} 42^{\prime} 36^{\prime \prime}$, long $91^{\circ} 26^{\prime} 91^{\prime \prime}$, in SW1/4 sec. 25 , T. 46 N., R. 5 W., Montgomery County, on downstream side of third pier from right abutment of bridge on State Highway 19 at Hermann. River mile, $97.9(157.5 \mathrm{~km})$.

Drainage area.- $528,200 \mathrm{mi}^{2}\left(1,368,000 \mathrm{~km}^{2}\right)$, approximately.

Gage.-Water-stage recorder. Datum of gage is $481.56 \mathrm{ft}(146.779 \mathrm{~m})$ above mean sea level. Prior to Sept. 26, 1930, nonrecording gage at site $480 \mathrm{ft}(146 \mathrm{~m})$ downstream at datum $0.07 \mathrm{ft}(.02 \mathrm{~m})$ lower. Sept. 26, 1930, to Mar. 27, 1932, nonrecording gage; Mar. 28, 1932, to June 12, 1945, water-stage recorder; June 13, 1945, to Apr. 2, 1946, nonrecording gage; at present site and datum.

Flood stage. $-21 \mathrm{ft}(6.4 \mathrm{~m})$. Flood stage was exceeded for 73 consecutive days (Mar. 6-May 17). Previous record was 37 days (June 23 to July 29,1951 ).

Maxima.-March-May 1973; Discharge, $500,000 \mathrm{ft}^{3} / \mathrm{s}\left(14,160 \mathrm{~m}^{3} / \mathrm{s}\right) 3: 15$ a.m. Apr. 25 [gage-height, $33.70 \mathrm{ft}(10.272 \mathrm{~m})$ ] October 1897 to Feb. 1973: Maximum discharge $676,000 \mathrm{ft}^{3} / \mathrm{s}\left(19,140 \mathrm{~m}^{3} / \mathrm{s}\right)$ June 6,7, 1903 [gage height $29.5 \mathrm{ft}(8.99$ $\mathrm{m})$ ], discharge computed by Corps of Engineers; maximum gage height, $33.33 \mathrm{ft}(10.159 \mathrm{~m}) \mathrm{July} 19,1951$.

Maximum stage known, $35.5 \mathrm{ft}(10.82 \mathrm{~m})$ in June 1844 [discharge about $892,000 \mathrm{ft}^{3} / \mathrm{s}\left(25,260 \mathrm{~m}^{3} / \mathrm{s}\right)$, computed by Corps of Engineers].

Remarks.- Natural flow of stream is affected by many reservoirs and diversions. Recurrence intervals of peaks and flood volumes have not been computed.

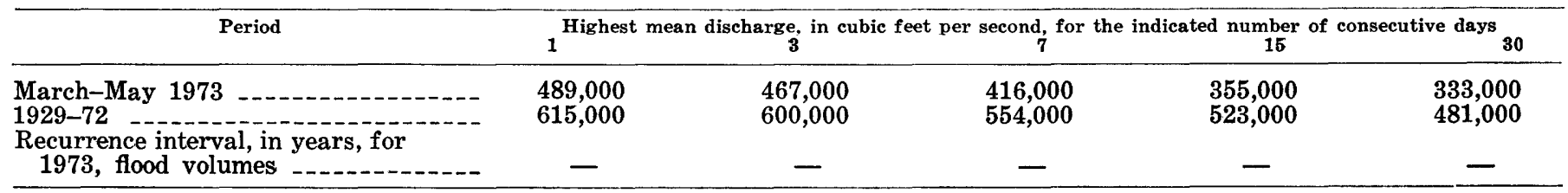


TABLE 12,-Station descriptions and discharge and suspended-sediment data-Continued

Mean water discharge and suspended-sediment concentration, discharge, and percent sand

\begin{tabular}{|c|c|c|c|c|c|c|c|c|c|c|c|c|c|c|c|c|c|c|c|c|c|}
\hline \multirow{3}{*}{\multicolumn{2}{|c|}{ Date }} & \multicolumn{5}{|c|}{ March } & \multicolumn{5}{|c|}{ April } & \multicolumn{5}{|c|}{ May } & \multicolumn{5}{|c|}{ June } \\
\hline & & \multirow[b]{2}{*}{ Stage } & & \multicolumn{3}{|c|}{ Suspended sediment ${ }^{1}$} & \multirow[b]{2}{*}{ Stage } & \multirow[b]{2}{*}{$\begin{array}{c}\text { Dis- } \\
\text { charge } \\
(1,000 \\
\left.\mathbf{f t}^{3} / \mathbf{s}\right)\end{array}$} & \multicolumn{3}{|c|}{ Suspended sediment $^{1}$} & \multicolumn{5}{|c|}{ Suspended sediment ${ }^{1}$} & \multirow[b]{2}{*}{ Stage } & \multirow[b]{2}{*}{$\begin{array}{c}\text { Dis- } \\
\text { charge } \\
(1,000 \\
\left.\mathrm{ft}^{3} / \mathrm{s}\right)\end{array}$} & \multicolumn{3}{|c|}{ Suspended sediment ${ }^{1}$} \\
\hline & & & $\begin{array}{c}\text { Dis- } \\
\text { charge } \\
(1,000 \\
\left.\mathbf{f t}^{3} / \mathbf{s}\right)\end{array}$ & $\begin{array}{c}\text { Concen- } \\
\text { tration } \\
(\mathrm{mg} / \mathrm{l})\end{array}$ & $\begin{array}{c}\text { Dis- } \\
\text { charge } \\
(1,000 \\
\text { tons/ } \\
\text { day) } \\
\end{array}$ & $\begin{array}{l}\text { Per- } \\
\text { cent } \\
\text { sand }\end{array}$ & & & $\begin{array}{l}\text { Concen- } \\
\text { tration } \\
(\mathrm{mg} / \mathrm{l})\end{array}$ & $\begin{array}{c}\text { Dis- } \\
\text { charge } \\
\text { (1,000 } \\
\text { tons/ } \\
\text { day) } \\
\end{array}$ & $\begin{array}{l}\text { Per- } \\
\text { cent } \\
\text { sand }\end{array}$ & Stage & $\begin{array}{c}\text { Dis- } \\
\text { charge } \\
(1,000 \\
\left.\mathrm{ft}^{3} / \mathrm{s}\right)\end{array}$ & $\begin{array}{l}\text { Concen- } \\
\text { tration } \\
(\mathrm{mg} / \mathrm{l})\end{array}$ & $\begin{array}{c}\text { Dis- } \\
\text { charge } \\
(1,000 / \\
\text { tons/ } \\
\text { day }) \\
\end{array}$ & $\begin{array}{l}\text { Per- } \\
\text { cent } \\
\text { sand }\end{array}$ & & & $\begin{array}{l}\text { Concen- } \\
\text { tration } \\
(\mathrm{mg} / \mathrm{l})\end{array}$ & $\begin{array}{c}\text { Dis- } \\
\text { charge } \\
(1,000 \\
\text { tons/ } \\
\text { day) }\end{array}$ & $\begin{array}{l}\text { Per- } \\
\text { cent } \\
\text { sand }\end{array}$ \\
\hline 1 & --- & $\begin{array}{l}15.10 \\
14.47\end{array}$ & 115 & 1,000 & 310 & -- & 31.33 & 386 & 1,800 & 1,900 & -- & 24.55 & 203 & 740 & 410 & -- & 22.68 & 194 & 1,400 & 730 & -- \\
\hline 3 & - & $\begin{array}{l}14.47 \\
14.61\end{array}$ & $\begin{array}{l}109 \\
110\end{array}$ & $\begin{array}{l}990 \\
980\end{array}$ & $\begin{array}{l}291 \\
290\end{array}$ & -- & $\begin{array}{l}31.39 \\
31.59\end{array}$ & $\begin{array}{l}389 \\
397\end{array}$ & $\begin{array}{l}1,800 \\
1,800\end{array}$ & $\begin{array}{l}1,900 \\
1,900\end{array}$ & -- & $\begin{array}{l}23.05 \\
23.89\end{array}$ & $\begin{array}{l}181 \\
194\end{array}$ & $\begin{array}{l}750 \\
850\end{array}$ & $\begin{array}{l}360 \\
450\end{array}$ & $=$ & $\begin{array}{l}21.10 \\
18.95\end{array}$ & $\begin{array}{l}170 \\
140\end{array}$ & 1,300 & $\begin{array}{l}600 \\
450\end{array}$ & -- \\
\hline 4 & - & $\begin{array}{l}15.17 \\
15.01\end{array}$ & 117 & 1,050 & 330 & -- & 31.71 & 402 & $\begin{array}{l}1,760 \\
1,00\end{array}$ & 1,910 & $\overline{41}$ & 25.07 & 214 & 990 & 570 & -- & 18.05 & 129 & 1,200 & 420 & $\overline{22}$ \\
\hline 5 & - n & 17.19 & 142 & 1,600 & 610 & -- & 31.85 & 403 & 1,700 & 1,800 & $\ldots$ & 25.27 & 218 & 1,000 & 590 & $=$ & 19.25 & 143 & 1,200 & 460 & -- \\
\hline 6 & - & 20.70 & 192 & 2,900 & 1,500 & $=$ & 31.59 & 394 & 1,600 & 1,700 & $=$ & 25.39 & 221 & 1,100 & 660 & $=$ & 20.45 & 158 & 1,200 & 510 & -- \\
\hline 7 & - n- n- & $\begin{array}{r}26.49 \\
-18\end{array}$ & 289 & 3,640 & 2,840 & 42 & 30.62 & 346 & 1,400 & 1,300 & -- & 25.97 & 231 & 1,000 & 620 & -- & 20.65 & 161 & 1,200 & 520 & -- \\
\hline $\begin{array}{l}8 \\
9\end{array}$ & --------- & $\begin{array}{l}27.48 \\
27.10\end{array}$ & $\begin{array}{l}307 \\
299\end{array}$ & 3,600 & $\begin{array}{l}3,000 \\
, 300\end{array}$ & -- & $\begin{array}{l}29.15 \\
2777\end{array}$ & $\begin{array}{l}300 \\
260\end{array}$ & 1,300 & 1,100 & 5 & $\begin{array}{l}27.03 \\
27.54\end{array}$ & $\begin{array}{l}249 \\
259\end{array}$ & 1,100 & $\begin{array}{l}740 \\
780\end{array}$ & $\overline{4 \pi}$ & $\begin{array}{l}19.80 \\
1890\end{array}$ & $\begin{array}{l}149 \\
138\end{array}$ & $\begin{array}{l}1,100 \\
990\end{array}$ & $\begin{array}{l}440 \\
370\end{array}$ & -- \\
\hline 10 & - & 27.00 & $\begin{array}{l}299 \\
296\end{array}$ & $\mathbf{2 , 3 0 0}$ & $\begin{array}{l}2,500 \\
1,900\end{array}$ & -- & 26.64 & 245 & $\begin{array}{l}1,700 \\
1,000\end{array}$ & $\begin{array}{l}820 \\
660\end{array}$ & 69 & $\begin{array}{l}27.54 \\
27.86\end{array}$ & $\begin{array}{l}259 \\
266\end{array}$ & $\begin{array}{l}1,110 \\
1,100\end{array}$ & $\begin{array}{l}780 \\
790\end{array}$ & 44 & $\begin{array}{l}18.90 \\
18.16\end{array}$ & $\begin{array}{l}138 \\
129\end{array}$ & $\begin{array}{l}990 \\
870\end{array}$ & $\begin{array}{l}370 \\
300\end{array}$ & -- \\
\hline 11 & 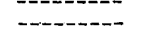 & 29.38 & 343 & 2,300 & 2,100 & $\because-$ & 25.72 & 234 & 920 & 590 & - & 28.26 & 275 & $\begin{array}{l}1,100 \\
1,100\end{array}$ & 820 & $\ldots$ & 17.70 & 123 & 730 & 240 & -- \\
\hline 12 & - & 29.75 & 350 & 2,300 & $\mathbf{2 , 2 0 0}$ & $=$ & 25.06 & 228 & 830 & 510 & -- & 28.45 & 280 & 1,100 & 830 & $\cdots$ & 16.58 & 110 & 585 & 170 & $\overline{20}$ \\
\hline 13 & $-\cdots$ & 29.46 & 333 & $\mathbf{2 , 1 0 0}$ & 1,900 & 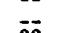 & 24.74 & 228 & 820 & 510 & - & 28.06 & 274 & 1,100 & 820 & $=-$ & 15.48 & 99 & 520 & 140 & $-\pi$ \\
\hline 14 & $-\ldots+n$ & 29.99 & 333 & 1,950 & 1,750 & 33 & 24.74 & 233 & 900 & 570 & - & 26.95 & 255 & 1,000 & 690 & $\overline{2}$ & 14.80 & 93 & 433 & 110 & 24 \\
\hline $\begin{array}{l}15 \\
16 \\
\end{array}$ & -------- & 30.13 & 萠3 & 1,900 & 1,700 & & $\begin{array}{l}25.50 \\
-6602\end{array}$ & 251 & 1,000 & 680 & -- & 25.09 & 225 & 880 & $\begin{array}{l}530 \\
200\end{array}$ & 33 & $\begin{array}{l}15.50 \\
16.60\end{array}$ & 99 & $\begin{array}{l}430 \\
500\end{array}$ & 110 & -- \\
\hline $\begin{array}{l}16 \\
17\end{array}$ & - & $\begin{array}{l}30.01 \\
28.84\end{array}$ & $\begin{array}{l}337 \\
315\end{array}$ & $\begin{array}{l}2,100 \\
2,100\end{array}$ & $\begin{array}{l}1,900 \\
1,800\end{array}$ & -- & $\begin{array}{l}26.22 \\
27.30\end{array}$ & $\begin{array}{l}270 \\
297\end{array}$ & 1,200 & 870 & -- & $\begin{array}{l}22.63 \\
21.10\end{array}$ & $\begin{array}{l}187 \\
166\end{array}$ & 770 & $\begin{array}{l}390 \\
310\end{array}$ & -- & 16.26 & $\begin{array}{l}106 \\
100\end{array}$ & $\begin{array}{l}500 \\
460\end{array}$ & 140 & -- \\
\hline 18 & - & $\begin{array}{l}28.84 \\
27.90\end{array}$ & $\begin{array}{l}399 \\
299\end{array}$ & $\begin{array}{l}2,000 \\
2,000\end{array}$ & $\begin{array}{l}1,800 \\
1,600\end{array}$ & $\overline{-}$ & $\begin{array}{l}27.30 \\
27.81\end{array}$ & $\begin{array}{l}297 \\
313\end{array}$ & $\begin{array}{l}1,300 \\
1,300\end{array}$ & $\begin{array}{l}1,000 \\
1,050\end{array}$ & $\overline{6} \overline{5}$ & $\begin{array}{l}21.10 \\
20.09\end{array}$ & $\begin{array}{l}166 \\
153\end{array}$ & $\begin{array}{l}700 \\
620\end{array}$ & $\begin{array}{l}310 \\
\mathbf{2 5 0}\end{array}$ & $\overline{-}$ & $\begin{array}{l}15.64 \\
15.00\end{array}$ & $\begin{array}{r}100 \\
94\end{array}$ & $\begin{array}{l}460 \\
440\end{array}$ & 110 & $=$ \\
\hline 19 & ------- & 26.67 & 277 & 1,830 & 1,370 & $\overline{33}$ & 28.34 & 323 & 1,300 & 1,100 & -. & 19.29 & 143 & 540 & 210 & 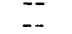 & 18.54 & 133 & 570 & 200 & -. \\
\hline 20 & - & 25.58 & 253 & 1,700 & 1,200 & $\ldots$ & 28.78 & 333 & 1,300 & 1,200 & - & 18.21 & 130 & 480 & 170 & -- & 18.86 & 136 & 680 & 250 & -- \\
\hline 21 & --_-_- & 24.51 & 230 & 1,600 & 1,000 & -- & 29.02 & 338 & 1,400 & 1,300 & -. & 17.04 & 117 & 421 & 130 & 32 & 16.11 & 104 & 600 & 170 & $\cdots$ \\
\hline 22 & ----- & 24.22 & 221 & 1,400 & 840 & $\bar{a}$ & 30.75 & 381 & 1,600 & 1,600 & -. & 17.98 & 126 & 360 & 120 & -- & $\begin{array}{l}14.72 \\
1394\end{array}$ & 92 & $\begin{array}{l}480 \\
420\end{array}$ & 120 & $\cdots$ \\
\hline $\begin{array}{l}23 \\
24\end{array}$ & -......-- & $\begin{array}{l}23.62 \\
22.49\end{array}$ & 207 & $\begin{array}{l}1,320 \\
1,300\end{array}$ & $\begin{array}{l}740 \\
680\end{array}$ & 36 & $\begin{array}{l}32.61 \\
33321\end{array}$ & $\begin{array}{l}463 \\
489\end{array}$ & 1,900 & 2,400 & -- & $\begin{array}{l}18.94 \\
18.69\end{array}$ & $\begin{array}{l}135 \\
130\end{array}$ & $\begin{array}{l}360 \\
395\end{array}$ & 130 & تד & 13.94 & $\begin{array}{l}86 \\
83\end{array}$ & $\begin{array}{l}420 \\
370\end{array}$ & $\begin{array}{l}98 \\
83\end{array}$ & -- \\
\hline 25 & - & $\begin{array}{l}22.49 \\
23.61\end{array}$ & $\begin{array}{l}194 \\
227\end{array}$ & $\begin{array}{l}1,300 \\
1,800\end{array}$ & $\begin{array}{r}680 \\
1,100\end{array}$ & -- & $\begin{array}{l}33.21 \\
33.06\end{array}$ & $\begin{array}{l}489 \\
449\end{array}$ & $\begin{array}{l}1,580 \\
1,090\end{array}$ & $\begin{array}{l}2,090 \\
1,330\end{array}$ & -- & $\begin{array}{l}18.69 \\
18.65\end{array}$ & $\begin{array}{l}130 \\
131\end{array}$ & $\begin{array}{l}395 \\
420\end{array}$ & $\begin{array}{l}140 \\
150\end{array}$ & 42 & $\begin{array}{l}13.55 \\
12.70\end{array}$ & $\begin{array}{l}83 \\
77\end{array}$ & $\begin{array}{l}\begin{array}{l}370 \\
340\end{array} \\
-\end{array}$ & 701 & - \\
\hline 26 & - & $\begin{array}{l}27.94 \\
28.01\end{array}$ & 288 & $\begin{array}{l}2,100 \\
2,100\end{array}$ & $\begin{array}{l}1,100 \\
1,600\end{array}$ & $=$ & 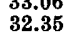 & $\begin{array}{l}449 \\
407\end{array}$ & $\begin{array}{l}1,090 \\
870\end{array}$ & $\begin{array}{l}1,380 \\
960\end{array}$ & $\overline{-}$ & $\begin{array}{l}18.00 \\
18.66\end{array}$ & $\begin{array}{l}131 \\
132\end{array}$ & $\begin{array}{l}420 \\
450\end{array}$ & $\begin{array}{l}160 \\
160\end{array}$ & $=$ & 12.17 & 73 & 320 & $\begin{array}{r}63 \\
63\end{array}$ & -- \\
\hline 27 & - - & 29.05 & 323 & 2,000 & 1,700 & $\ldots$ & 31.61 & 376 & 770 & 780 & $=$ & 19.06 & 138 & 530 & 200 & - & 12.43 & 76 & 300 & 62 & -. \\
\hline & ----- & 29.95 & 349 & 1,890 & 1,780 & 47 & 30.41 & 345 & 700 & 660 & 73 & 20.79 & 163 & 770 & 340 & -- & 11.59 & 70 & 280 & 53 & -- \\
\hline & -------- & 30.66 & 368 & 1,800 & 1,800 & -- & 28.59 & 289 & 720 & 560 & & 21.72 & 177 & 1,200 & 570 & -- & 11.37 & 69 & 270 & 50 & -- \\
\hline & - & $\begin{array}{l}30.66 \\
30.60\end{array}$ & $\begin{array}{l}368 \\
364\end{array}$ & $\begin{array}{l}1,800 \\
1,800\end{array}$ & $\begin{array}{l}1,800 \\
1,800\end{array}$ & -- & 26.53 & 234 & 760 & 480 & 78 & $\begin{array}{l}22.31 \\
22.68\end{array}$ & $\begin{array}{l}187 \\
194\end{array}$ & $\begin{array}{l}1,600 \\
1,500\end{array}$ & $\begin{array}{l}810 \\
790\end{array}$ & - & 11.16 & 68 & & 46 & \\
\hline & tal - & & 8,293 & & $\begin{array}{r}1,000 \\
\mathbf{4 5 , 7 3 1}\end{array}$ & & & 10,003 & $\cdots$ & $35, \overline{230}$ & - & & 5,954 & & 14,530 & & & 3,403 & & 7,206 & \\
\hline \multicolumn{3}{|c|}{$\begin{array}{l}\text { Monthly mean } \\
\text { discharge -.. }\end{array}$} & 268 & & 1,477 & & & 333 & & 1,174 & & & 192 & & 469 & & & 113 & & 240 & \\
\hline \multirow{2}{*}{\multicolumn{3}{|c|}{$\begin{array}{l}\text { Maximum } \\
\text { Minimum }=-\end{array}$}} & 368 & & 3,000 & & & 489 & & 2,400 & & & 280 & & 83 & & & 194 & & 730 & \\
\hline & & & 109 & & 290 & & & 228 & & 480 & & & 117 & & 120 & & & 68 & & 46 & \\
\hline
\end{tabular}

${ }^{1}$ Suspended-sediment data based on observations at 2- to 10-day intervals. 
TABLE 12.-Station descriptions and discharge and suspended-sediment data-Continued

\section{MISSISSIPPI RIVER MAIN STEM}

(37) 07010000 Mississippi River at St. Louis, Mo.

Location.-Lat $38^{\circ} 37^{\prime} 44^{\prime \prime}$, long $90^{\circ} 10^{\prime} 47^{\prime \prime}$, on downstream side of west pier of Eads Bridge at St. Louis, $15 \mathrm{miles}(24.1 \mathrm{~km})$ downstream from Missouri River, 19.2 miles $(30.9 \mathrm{~km})$ upstream from Meramec River, and at mile $180.0(289.6 \mathrm{~km})$ above Ohio River.

Drainage area.- $701,000 \mathrm{mi}^{2}\left(1,820,000 \mathrm{~km}^{2}\right)$.

Gage.-Continuous water-stage recorder. Datum of gage is $379.94 \mathrm{ft}(115.806 \mathrm{~m})$ above mean sea level.

Flood stage.-30.0 ft $(9.1 \mathrm{~m})$. Flood stage was exceeded for 77 consecutive days (Mar. 10 to May 25). Previous record was 63 consecutive days (May 17 to July 18, 1844).

Maxima.-March-June 1973: Discharge, 852,000 ft's $/ \mathrm{s}\left(24,130 \mathrm{~m}^{3} / \mathrm{s}\right)$ 3:00 p.m., Apr. 28 [gage height, $43.23 \mathrm{ft}(13.177 \mathrm{~m})$ ]. Recurrence interval of discharge is 30 years (based on figure 52 ).

January 1861 to February 1973: Daily discharge, 1,019,000 ft"s $/ \mathrm{s}(28,860 \mathrm{~m} / \mathrm{s})$ June 10, 11, 1903 [gage height, $38.00 \mathrm{ft}$ $(11.582 \mathrm{~m})$ ]; gage height, $40.28 \mathrm{ft}(12.277 \mathrm{~m})$ July 21,1951

Flood of June 27, 1844 reached a stage of $41.32 \mathrm{ft}(12.594 \mathrm{~m})$, from floodmarks (discharge, 1,300,000 $\mathrm{ft}^{3} / \mathrm{s} \quad(36,820$ $\left.\mathrm{m}^{3} / \mathrm{s}\right)$, computed by Corps of Engineers). Flood in April 1785 may have reached a stage of $42.0 \mathrm{ft}(12.80 \mathrm{~m})$.

Remarks.- Natural flow of stream affected by many reservoirs and navigation dams in upper Mississippi River basin an by many reservoirs and diversions for irrigation in Missouri River basin.

Mean gage height, in feet, and discharge, in cubic feet per second, 1973

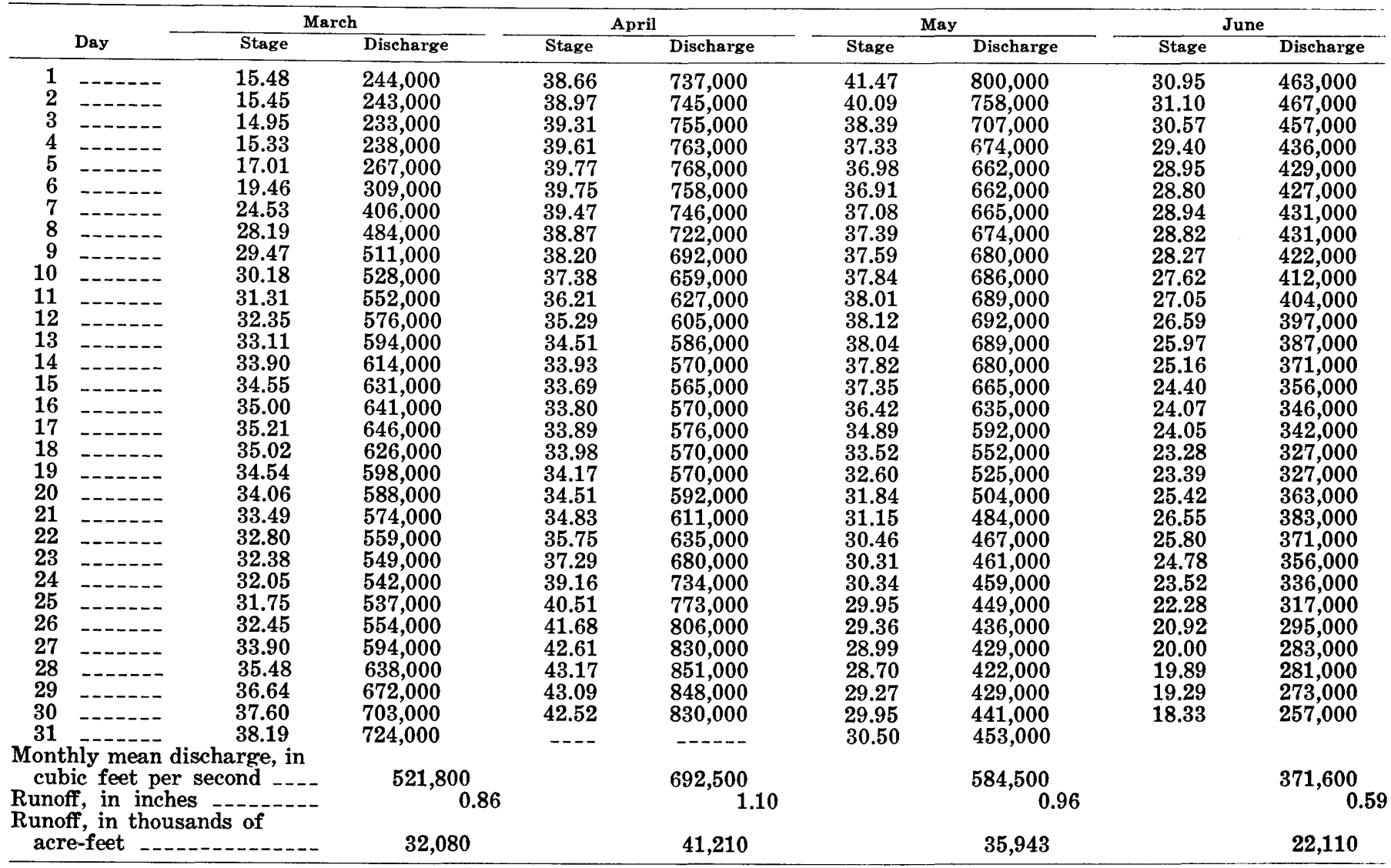

Water temperature, stage, water discharge, and suspended-sediment data at given time

\begin{tabular}{|c|c|c|c|c|c|c|c|c|c|c|c|}
\hline & \multirow{3}{*}{ Date } & \multirow{3}{*}{ Hour } & \multirow{3}{*}{$\begin{array}{c}\text { Water } \\
\text { tempera- } \\
\text { ture } \\
\left({ }^{\circ} \mathrm{C}\right)\end{array}$} & \multirow{3}{*}{$\begin{array}{l}\text { Stage } \\
\text { (ft) }\end{array}$} & \multirow{3}{*}{$\begin{array}{c}\text { Discharge } \\
\left(1,000 \mathrm{ft}^{3} / \mathrm{s}\right)\end{array}$} & \multicolumn{6}{|c|}{ Suspended sediment } \\
\hline & & & & & & \multicolumn{4}{|c|}{ Concentration, $\mathrm{mg} / \mathrm{l}$} & \multirow{2}{*}{$\begin{array}{c}\text { Discharge } \\
(1,000 \\
\text { tons/day) }\end{array}$} & \multirow{2}{*}{$\begin{array}{l}\text { Percent } \\
\text { sand }\end{array}$} \\
\hline & & & & & & Right & Middle & Left & Average & & \\
\hline March & 26 & 12:45 p.m. & 8.3 & 32.2 & 549 & 410 & -- & 340 & 425 & 630 & 36 \\
\hline & 31 - & $11: 57 \mathrm{a.m}$. & 10.5 & 38.1 & 722 & 674 & $\cdots$ & 363 & 519 & 1.012 & 33 \\
\hline \multirow[t]{14}{*}{ April } & 4 & 1:10 p.m. & $\begin{array}{r}10.0 \\
9.0\end{array}$ & $\begin{array}{l}30.1 \\
39.6\end{array}$ & 763 & $\begin{array}{l}674 \\
627\end{array}$ & $\overline{53} \overline{8}$ & $\begin{array}{l}000 \\
356\end{array}$ & 507 & 1,045 & $\begin{array}{l}80 \\
28\end{array}$ \\
\hline & 5 & 12:55 p.m. & 9.4 & & 768 & 862 & 616 & 351 & 610 & 1,265 & 16 \\
\hline & 6 - 6 & $3: 10$ p.m. & 11.0 & $39 . \overline{8}$ & 761 & $\ldots$ & 540 & $\ldots$ & 540 & 1,109 & 10 \\
\hline & 7 & 11:20 a.m. & 10.5 & & 746 & -- & 508 & $\ldots$ & 508 & 1,023 & 11 \\
\hline & 8 & 1:55 p.m. & 10.5 & $\overline{38 . \overline{8}}$ & 719 & $\cdots$ & 398 & $\ldots$ & 398 & 772 & 12 \\
\hline & 9 & 11:15 a.m. & 9.5 & & 692 & --- & 373 & -- & 373 & 697 & $\mathbf{2 3}$ \\
\hline & 10 & 2:00 p.m. & 8.0 & $37 . \overline{5}$ & 665 & -- & 432 & -1 & 432 & 776 & 28 \\
\hline & 11 & $11: 30$ a.m. & 7.5 & -.- & 627 & $\ldots$ & 467 & -- & 467 & 791 & 27 \\
\hline & 12 & $12: 00 \mathrm{~m}$ & 8.0 & $35 . \overline{4}$ & 608 & $\overline{501}$ & 410 & 173 & 361 & $\mathbf{5 9 3}$ & 29 \\
\hline & 13 - & $11: 30$ a.m. & 8.0 & 34.4 & 581 & 472 & 471 & 187 & 376 & 590 & 35 \\
\hline & 17 & 1:05 p.m. & 10.5 & 33.9 & 576 & 590 & $\ldots$ & 260 & 425 & 661 & -. \\
\hline & 27 & $12: 25$ p.m. & 16 & 42.6 & 830 & 895 & --- & 682 & 788 & 1,766 & - \\
\hline & 29 & 1:30 p.m. & 17 & 43.1 & 848 & 557 & $\ldots$ & 420 & 488 & 1,117 & -- \\
\hline & 9 & 3:30 p.m. & 15 & 37.6 & 680 & 512 & -- & 252 & 382 & 701 & - \\
\hline
\end{tabular}


TABLE 12.-Station descriptions and discharge and suspended-sediment data-Continued

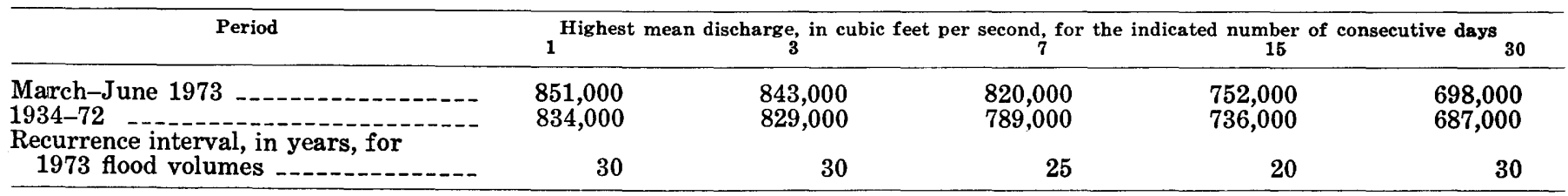

\section{MISSISSIPPI RIVER MAIN STEM}

(38) 07020500 Mississippi River at Chester, Ill.

Location.-Lat $37^{\circ} 54^{\prime} 10^{\prime \prime}$, long $89^{\circ} 51^{\prime} 10^{\prime \prime}$, in SW $1 / 4$ sec. 24 , T. 7 S., R. 7 W., third principal meridian, Randolph County, on downstream side of left pier of main truss of highway bridge at Chester, 8.1 miles (13.0 km) downstream from Kaskaskia River, and at mile $109.9(176.8 \mathrm{~km})$ above Ohio River.

Drainage area.- $712,600 \mathrm{mi}^{2}\left(1,846,000 \mathrm{~km}^{2}\right)$, approximately.

Gage.-Continuous water-stage recorder. Datum of gage is $341.05 \mathrm{ft}(103.952 \mathrm{~m})$ above mean sea level.

Flood stage. $-27.0 \mathrm{ft}(8.2 \mathrm{~m})$. Flood stage was exceeded for 97 consecutive days (Mar. 8 to June 13). Previous record was 36 consecutive days (June 27 to Aug. 1,1951 ).

Maxima.-March-June 1973: Discharge, 886,000 ft $\mathrm{ft}^{3} / \mathrm{s} \quad\left(25,090 \mathrm{~m}^{*} / \mathrm{s}\right)$ 12:00 m., Apr. 30 [gage height, $43.32 \mathrm{ft}(13.204 \mathrm{~m})$ ]. Recurrence interval of discharge is 20 years (based on figure 52 ).

October 1927 to February 1973: Discharge determined, 886,000 ft": $/ \mathrm{s}(25,090 \mathrm{~m}$ ": $/ \mathrm{s})$ July 3,1947 (discharge, including unmeasured overflow, was greater May 24, 1943; gage height, $39.3 \mathrm{ft}(11.98 \mathrm{~m})$ July $23,1951$.

Flood of June 30,1844 , reached a stage of $39.8 \mathrm{ft}\left[(12.13 \mathrm{~m}),\left(\right.\right.$ discharge $1,350,000 \mathrm{ft}^{3} / \mathrm{s}\left(38,230 \mathrm{~m} / \mathrm{s}^{\prime \prime}\right)$, computed by Corps of Engineers)].

Remarks. - Natural flow of stream affected by many reservoirs and navigation dams in upper Mississippi River basin and by many reservoirs and diversions for irrigation in Missouri River basin. Flood-volume-frequency data are not available for this station.

Mean gage height, in feet, and discharge, in cubic feet per second, 1973

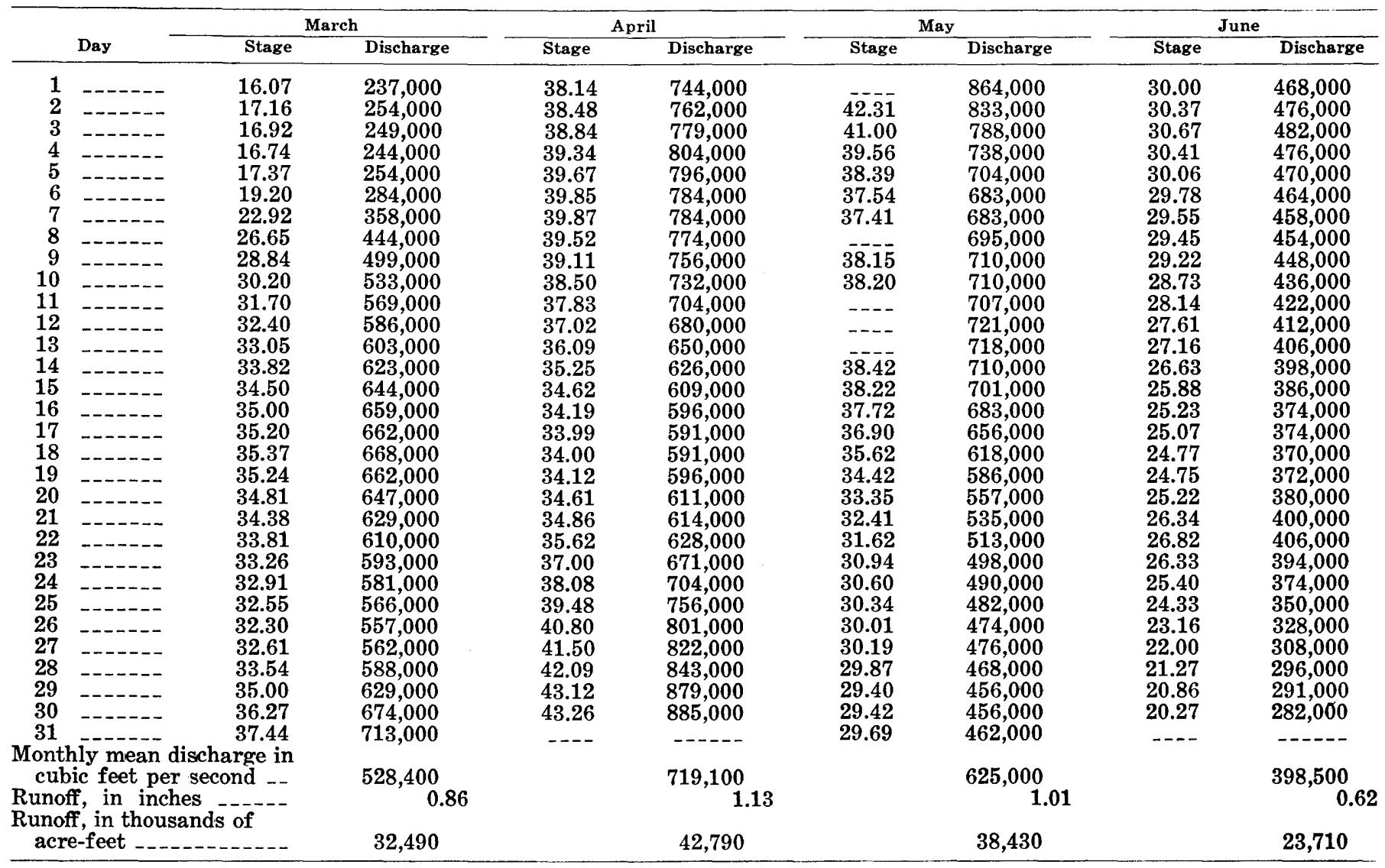


TABLE 12.-Station descriptions and discharge and suspended-sediment data-Continued

Water temperature, stage, water discharge, and suspended-sediment data at given time

\begin{tabular}{|c|c|c|c|c|c|c|c|c|c|}
\hline \multirow[b]{2}{*}{ Date } & & & \multirow[b]{2}{*}{ Hour ${ }^{1}$} & \multirow{2}{*}{$\begin{array}{c}\text { Water } \\
\text { tempera- } \\
\text { ture } \\
\left({ }^{\circ} \mathrm{C}\right)\end{array}$} & \multirow[b]{2}{*}{$\underset{(\mathrm{ft})}{\text { Stage }}$} & \multirow[b]{2}{*}{$\begin{array}{c}\text { Discharge } \\
(1,000 \mathrm{ft} / \mathrm{s})\end{array}$} & \multicolumn{3}{|c|}{ Suspended sediment } \\
\hline & & & & & & & $\begin{array}{l}\text { Concen- } \\
\text { tration } \\
(\mathrm{mg} / 1)\end{array}$ & $\begin{array}{c}\text { Discharge } \\
(1,000 \text { t/day })\end{array}$ & $\begin{array}{l}\text { Percent } \\
\text { sand }\end{array}$ \\
\hline April & $\begin{array}{r}5 \\
7 \\
8 \\
9 \\
10 \\
11\end{array}$ & 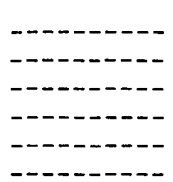 & $\begin{array}{c}5: 00 \text { p.m. } \\
\overline{4}: \overline{45} \text { p.m. } \\
12: 00 \text { m. } \\
5: 30 \text { p.m. } \\
12: 20 \text { p.m. }\end{array}$ & $\begin{array}{r}12.5 \\
11.0 \\
10.5 \\
9.0 \\
8.5 \\
9.5\end{array}$ & $\begin{array}{l}39.9 \\
39.8 \\
39.5 \\
39.2 \\
38.4 \\
38.0\end{array}$ & $\begin{array}{l}804 \\
784 \\
774 \\
760 \\
728 \\
710\end{array}$ & $\begin{array}{l}588 \\
601 \\
564 \\
459 \\
405 \\
369\end{array}$ & $\begin{array}{r}1,276 \\
1,272 \\
1,179 \\
942 \\
796 \\
707\end{array}$ & $\begin{array}{l}13 \\
16 \\
23 \\
19 \\
23 \\
23\end{array}$ \\
\hline
\end{tabular}

${ }^{1}$ Time shown is for temperature and suspended-sediment samples.

Period
1

Highest mean disch

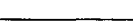

March-June 1973

885,000
in cubic

ic feet per second

, for the indicated number

15 of consecutive days

Recurrence interval, in years, for

1973 flood volumes

876,000

847,000

779,000

26,000

ood volumes ---.----.---.--

MISSISSIPPI RIVER MAIN STEM

(39) 07022000 Mississippi River at Thebes, Ill.

Location.-Lat $37^{\circ} 13^{\prime} 00^{\prime \prime}$, long $89^{\circ} 27^{\prime} 50^{\prime \prime}$, in NW1/4 sec. 17, T. 15 S., R. 3 W., Alexander County, near center span on downstream side of railroad bridge at Thebes, 5 miles $(8.0 \mathrm{~km})$ downstream from Headwater Division Channel, and at mile $43.7(70.3 \mathrm{~km})$ above Ohio River.

Drainage area.- $717,200 \mathrm{mi}^{2}\left(1,858,000 \mathrm{~km}^{2}\right)$, approximately.

Gage.-Continuous water-stage recorder at base gage (Thebes). Continuous water-stage recorder at auxiliary gage (Cape Girardeau $), 8.2$ miles $(13.2 \mathrm{~km})$ upstream. Datum of base gage is at mean sea level.

Flood stage. $-333.0 \mathrm{ft}(101.5 \mathrm{~m})$. Flood stage was exceeded for 95 consecutive days (Mar. 11 to June 13). Previous record was 38 days (Mar. 24 to Apr. 30, 1945).

Maxima.-March-June 1973: Discharge, $886,000 \mathrm{ft}^{3} / \mathrm{s} \quad\left(25,090 \mathrm{~m}^{3} / \mathrm{s}\right) \quad 3: 00 \mathrm{p.m} .$, Apr. $30 ;$ maximum elevation, $343.43 \mathrm{ft}$ $(104.677 \mathrm{~m})$ 11:00 a.m. Apr. 30. Recurrence interval of discharge is 20 years (based on figure 30).

October 1932 to February 1973: Discharge, 893,000 $\mathrm{ft}^{3} / \mathrm{s}\left(25,290 \mathrm{~m}^{3} / \mathrm{s}\right)$ May 27, 1943 [(elevation, $340.33 \mathrm{ft}(103.733$ $\mathrm{m})$, present datum) ].

Flood of July 4, 1844, reached an elevation of $354.14 \mathrm{ft}(105.199 \mathrm{~m})$, present datum, at Grays Point, from floodmarks [discharge, 1,375,000 $\mathrm{ft}^{3} / \mathrm{s}\left(38,940 \mathrm{~m}^{3} / \mathrm{s}\right)$, computed by Corps of Engineers].

Remarks. - Natural flow of stream affected by many reservoirs and navigation dams in upper Mississippi River basin and by many reservoirs and diversions for irrigation in Misssouri River basin.

Mean gage height, in feet, and discharge, in cubic feet per second, 1973

\begin{tabular}{|c|c|c|c|c|c|c|c|c|c|}
\hline & \multirow[b]{2}{*}{ Day } & \multicolumn{2}{|c|}{ March } & \multicolumn{2}{|c|}{ April } & \multicolumn{2}{|c|}{ May } & \multicolumn{2}{|c|}{ June } \\
\hline & & Stage & Discharge & Stage & Discharge & Stage & Discharge & Stage & Discharge \\
\hline 1 & ------ & 19.57 & 230,000 & 40.96 & 750,000 & 43.25 & 876,000 & 34.56 & 492,000 \\
\hline 2 & ------ & 20.70 & 251,000 & 41.15 & 765,000 & 43.28 & 838,000 & 34.75 & 502,000 \\
\hline 3 & ----- & 21.14 & 259,000 & 41.04 & 768,000 & 42.71 & 829,000 & 35.06 & 514,000 \\
\hline 4 & ------ & 20.84 & 255,000 & 41.29 & 777,000 & 41.97 & 798,000 & 35.32 & 520,000 \\
\hline 5 & ------ & 20.98 & 260,000 & 41.50 & 801,000 & 41.20 & 753,000 & 35.29 & 518,000 \\
\hline 6 & $\ldots \ldots$ & 22.06 & 283,000 & 41.50 & 813,000 & 40.58 & 720,000 & 35.08 & 508,000 \\
\hline 7 & ---- & 24.67 & 339,000 & 41.52 & 799,000 & 40.33 & 708,000 & 34.71 & 495,000 \\
\hline 8 & ------ & 28.18 & 416,000 & 41.40 & 807,000 & 40.57 & 724,000 & 34.45 & 487,000 \\
\hline 9 & $\ldots \ldots$ & 30.75 & 471,000 & 41.14 & 765,000 & 40.61 & 726,000 & 34.30 & 481,000 \\
\hline 10 & $--n---$ & 32.69 & 513,000 & 40.88 & 765,000 & 40.50 & 724,000 & 34.05 & 473,000 \\
\hline 11 & ------ & 35.22 & 572,000 & 40.51 & 739,000 & 40.51 & 725,000 & 33.66 & 461,000 \\
\hline 12 & ---- & 36.65 & 600,000 & 40.10 & 707,000 & 40.49 & 728,000 & 33.21 & 448,000 \\
\hline 13 & $--\ldots---$ & 37.25 & 608,000 & 39.58 & 679,000 & 40.38 & 729,000 & 32.77 & 441,000 \\
\hline 14 &.--1 & 37.88 & 630,000 & 38.90 & 655,000 & 40.28 & 725,000 & 32.35 & 435,000 \\
\hline 15 & ----- & 38.55 & 649,000 & 38.43 & 632,000 & 40.10 & 717,000 & 31.62 & 424,000 \\
\hline 16 & ------ & 38.93 & 674,000 & 38.03 & 619,000 & 39.91 & 708,000 & 30.80 & 412,000 \\
\hline 17 & $--\cdots--$ & 39.17 & 681,000 & 37.89 & 610,000 & 39.52 & 694,000 & 30.18 & 405,000 \\
\hline 18 & ----- & 39.45 & 675,000 & 37.83 & 606,000 & 38.90 & 663,000 & 29.91 & 401,000 \\
\hline 19 & $---\cdots$ & 39.58 & 669,000 & 37.94 & 615,000 & 38.15 & 635,000 & 29.55 & 396,000 \\
\hline 20 & 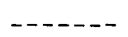 & 39.58 & 668,000 & 38.44 & 631,000 & 37.37 & 603,000 & 29.61 & 399,000 \\
\hline 21 & ---- & 39.57 & 654,000 & 38.56 & 639,000 & 36.70 & 573,000 & 30.06 & 408,000 \\
\hline 22 & ----- & 39.30 & 642,000 & 38.87 & 653,000 & 36.07 & 550,000 & 30.82 & 420,000 \\
\hline 23 & ---- & 38.90 & 630,000 & 39.69 & 693,000 & 35.48 & 535,000 & 30.97 & 419,000 \\
\hline 24 & ----- & 38.64 & 616,000 & 40.32 & 718,000 & 34.94 & 521,000 & 30.51 & 402,000 \\
\hline 25 & 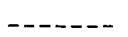 & 38.53 & 604,000 & 40.85 & 752,000 & 34.53 & 509,000 & 29.65 & 378,000 \\
\hline 26 & ----- & 38.29 & 596,000 & 41.70 & 788,000 & 34.16 & 499,000 & 28.60 & 355,000 \\
\hline 27 & $----\ldots$ & 38.18 & 598,000 & 42.39 & 800,000 & 35.25 & 526,000 & 27.36 & 334,000 \\
\hline 28 & $-\cdots--\ldots$ & 38.38 & 614,000 & 42.55 & 856,000 & 35.19 & 519,000 & 26.34 & 315,000 \\
\hline 29 & ------ & 39.10 & 641,000 & 42.95 & 851,000 & 34.65 & 501,000 & 25.70 & 305,000 \\
\hline
\end{tabular}


TABLE 12.-Station descriptions and discharge and suspended-sediment data-Continued

Mean gage height, in feet, and discharge, in cubic feet per second, 1973 -Continued

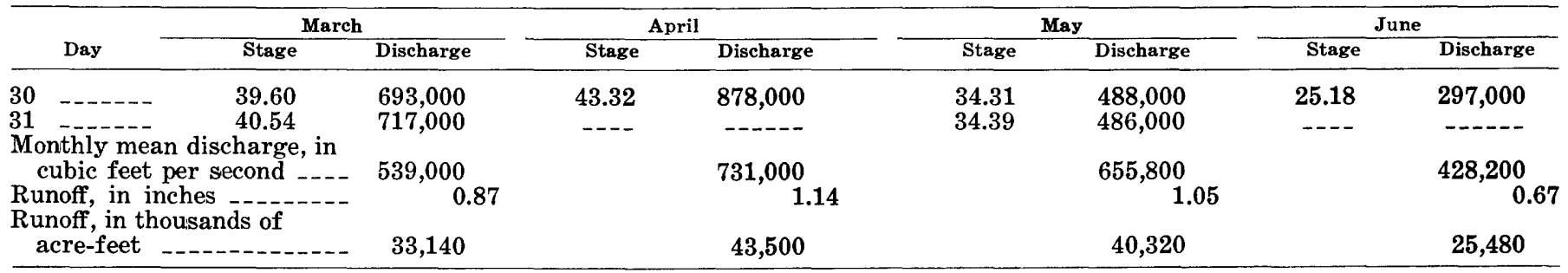

Water temperature, stage, discharge, and suspended-sediment data at given time

\begin{tabular}{|c|c|c|c|c|c|c|c|c|c|}
\hline & \multirow{2}{*}{\multicolumn{2}{|c|}{ Date }} & \multirow[b]{2}{*}{ Hour ${ }^{1}$} & \multirow{2}{*}{$\begin{array}{l}\text { Water } \\
\text { temperature } \\
\left({ }^{\circ} \mathbf{C}\right)\end{array}$} & \multirow[b]{2}{*}{$\underset{(\mathrm{ft})}{\text { Stage }}$} & \multirow[b]{2}{*}{$\begin{array}{c}\text { Discharge } \\
\left(1,000 \mathrm{ft}^{3} / \mathrm{s}\right)\end{array}$} & \multicolumn{3}{|c|}{ Suspended sediment } \\
\hline & & & & & & & $\begin{array}{c}\text { Concentration } \\
(\mathrm{mg} / \mathrm{l})\end{array}$ & $\begin{array}{c}\text { Discharge } \\
(1,000 \text { t } / \text { day })\end{array}$ & $\begin{array}{c}\text { Percent } \\
\text { sand }\end{array}$ \\
\hline April & $\begin{array}{r}7 \\
8 \\
9 \\
10 \\
11 \\
13\end{array}$ & $\begin{array}{l}---------- \\
---------- \\
---------- \\
---------- \\
---------- \\
----------\end{array}$ & $\begin{array}{l}\text { 6:45 p.m. } \\
\text { 8:00 a.m. } \\
\text { 6:00 p.m. } \\
\text { 9:00 a.m. } \\
\text { 8:15 a.m. } \\
\text { 12:40 p.m. }\end{array}$ & $\begin{array}{r}10.5 \\
9.5 \\
9.0 \\
8.0 \\
8.5 \\
9.0\end{array}$ & $\begin{array}{l}41.5 \\
41.4 \\
41.1 \\
40.9 \\
40.5 \\
39.6\end{array}$ & $\begin{array}{l}799 \\
807 \\
765 \\
765 \\
739 \\
679\end{array}$ & $\begin{array}{l}704 \\
720 \\
591 \\
623 \\
425 \\
400\end{array}$ & $\begin{array}{r}1,519 \\
1,569 \\
1,221 \\
1,287 \\
848 \\
733\end{array}$ & $\begin{array}{l}14 \\
28 \\
30 \\
36 \\
38 \\
42\end{array}$ \\
\hline
\end{tabular}

1 Time shown is for temperature and suspended-sediment samples.

\begin{tabular}{|c|c|c|c|c|c|}
\hline & \multicolumn{5}{|c|}{$\begin{array}{l}\text { Highest mean discharge, in cubic feet per second, for the indicated number of consecutive days } \\
1\end{array}$} \\
\hline $\begin{array}{l}\text { March-June } 1973 \\
1934-72 \\
\text { Recurrence interval, in years, for }\end{array}$ & $\begin{array}{l}878,000 \\
886,000\end{array}$ & $\begin{array}{l}868,000 \\
863,000\end{array}$ & $\begin{array}{l}847,000 \\
813,000\end{array}$ & $\begin{array}{l}793,000 \\
767,000\end{array}$ & $\begin{array}{l}743,000 \\
713,000\end{array}$ \\
\hline 1973 flood volumes & 20 & 20 & 20 & 20 & 30 \\
\hline
\end{tabular}

OHIO RIVER BASIN

(40) 03384500 Ohio River at Golconda, Ill.

Location.-Lat $37^{\circ} 21^{\prime} 28^{\prime \prime}$, long $88^{\circ} 28^{\prime} 27^{\prime \prime}$, Pope County, on right bank at lock and dam 51, at Golconda, $0.5 \mathrm{mile}(0.8 \mathrm{~km})$ upstream from McGilligan Creek, 0.7 mile $(1.1 \mathrm{~km})$ down stream from Lusk Creek, and at mile 903.1 (1,453.1 km).

Drainage area.-143,900 $\mathrm{mi}^{2}\left(372,700 \mathrm{~km}^{2}\right)$, approximately.

Gage.-Nonrecording gage read hourly. Datum of gage is $294.6 \mathrm{ft}(89.79 \mathrm{~m}$ ) above mean sea level, Ohio River datum. Auxiliary nonrecording gage read hourly at lock and dam $50,26.3$ miles $(42.3 \mathrm{~km})$ upstream.

Flood stage.-Periods when river exceeded flood stage of $40 \mathrm{ft}(12.2 \mathrm{~m})$ for selected floods, are shown in the following tabulation:

1937: Jan. 13 to Feb. 15

1945: Feb. 28 to Apr. 6

1950: Jan. 8 to Mar. 4

1964: Mar. 10 to 31

1973: Mar. 20 to Apr. 5

May 2 to 10

(34 days)

(38 days)

(56 days)

(22 days)

(17 days)

(9 days)

Maxima.-March-May 1973: Discharge, 601,000 ft $/ \mathrm{s}\left(17,000 \mathrm{~m}^{3} / \mathrm{s}\right)$ Mar. 26, 4:00 p.m., gage height, $45.7 \mathrm{ft}$ (13.93 m) Mar. $26,27$.

1937 to February 1973: Discharge 1,470,000 $\mathrm{ft}^{3} / \mathrm{s}\left(41,600 \mathrm{~m}^{3} / \mathrm{s}\right)$. Feb. 2, 3, 1937; gage height, 62.6 ft (19.08 $\left.\mathrm{m}\right)$ Feb. 1-3, 1937.

Remarks.-Flow partly regulated by many dams and reservoirs.

Mean gage height, in feet, and discharge, in cubic feet per second, 1973

\begin{tabular}{|c|c|c|c|c|c|c|c|}
\hline & \multirow[b]{2}{*}{ Day } & \multicolumn{2}{|c|}{ March } & \multicolumn{2}{|c|}{ April } & \multicolumn{2}{|c|}{ May } \\
\hline & & Stage & Discharge & Stage & Discharge & Stage & Discharge \\
\hline 1 & -.- & 16.30 & 121,000 & 43.26 & 509,000 & 39.13 & 472,000 \\
\hline 2 & - & 16.08 & 117,000 & 42.61 & 493,000 & 40.18 & 490,000 \\
\hline 3 & - & 15.80 & 115,000 & 41.85 & 474,000 & 41.07 & 506,000 \\
\hline 4 & --- & 15.86 & 110,000 & 40.94 & 447,000 & 41.81 & 538,000 \\
\hline 5 & --_- & 15.67 & 109,000 & 39.92 & 420,000 & 42.34 & 546,000 \\
\hline 6 & -...-- & 16.34 & 120,000 & 38.92 & 401,000 & 42.65 & 549,000 \\
\hline 7 & --- - - & 18.22 & 148,000 & 38.47 & 403,000 & 42.58 & 547,000 \\
\hline 8 & ----- & 21.30 & 198,000 & 38.54 & 414,000 & 42.31 & 533,000 \\
\hline 9 & -....- & 24.00 & 242,000 & 38.70 & 427,000 & 41.45 & 499,000 \\
\hline 10 & - - - - - & 26.14 & 262,000 & 39.01 & 434,000 & 40.14 & 452,000 \\
\hline 11 & - - - & 28.89 & 290,000 & 39.00 & 444,000 & 38.51 & 404,000 \\
\hline
\end{tabular}


TABLE 12.-Station descriptions and discharge and suspended-sediment data-Continued

Mean gage height, in feet, and discharge, in cubic feet per second, 1973-Continued

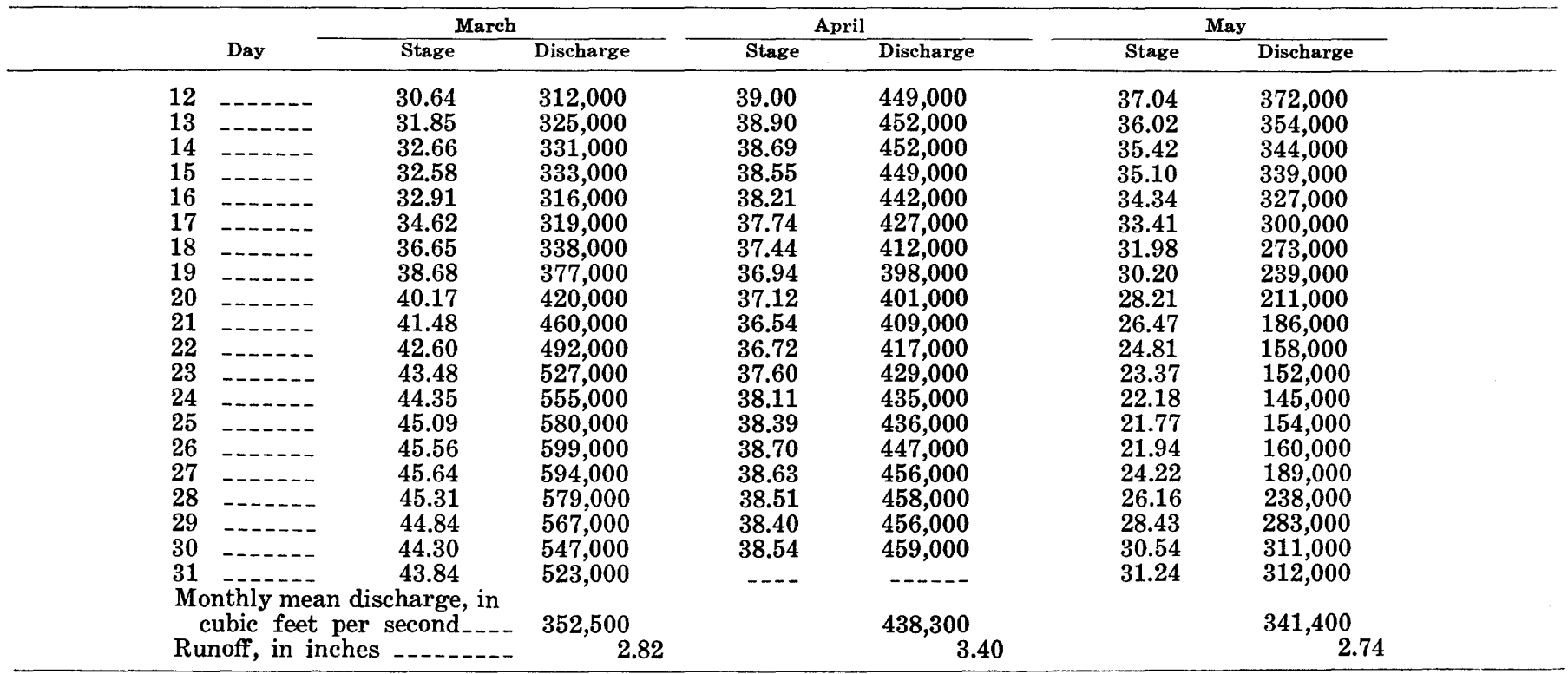

CUMBERLAND RIVER BASIN

(41) 03438220 Cumberland River near Grand Rivers, Ky.

Location.-Lat $37^{\circ} 01^{\prime} 18^{\prime \prime}$, long $88^{\circ} 13^{\prime} 16^{\prime \prime}$, Lyon County, on right bank in powerhouse at Barkley Dam, $1.5 \mathrm{miles}(2.4 \mathrm{~km})$ northeast of Grand Rivers, and at mile $30.6(49.2 \mathrm{~km})$.

Drainage area.-17,598 $\mathrm{mi}^{2}\left(45,579 \mathrm{~km}^{2}\right)$.

Gage.-Water-stage recorder. Datum of gage is $300.00 \mathrm{ft}(91.440 \mathrm{~m})$ above mean sea level. Auxiliary water-stage recorder 11.0 miles $(17.7 \mathrm{~km})$ downstream, and at mile $19.6(31.5 \mathrm{~km})$. Prior to June 27,1964 base gage $27.8 \mathrm{miles}(44.7 \mathrm{~km})$ downstream at mile $2.8(4.5 \mathrm{~km})$, at datum $0.44 \mathrm{ft}(0.134 \mathrm{~m})$ lower.

Maxima.-March-May 1973: Discharge, 126,000 $\mathrm{ft}^{3} / \mathrm{s}\left(3,570 \mathrm{~m}^{3} / \mathrm{s}\right)$ Mar. 17, 12:00 p.m., gage height, $39.72 \mathrm{ft}(12.107 \mathrm{~m}) \mathrm{Mar}$. 25,0615 hours.

1939 to February 1973: Discharge, 201,000 ft" $/ \mathrm{s}\left(5,690 \mathrm{~m}^{*} / \mathrm{s}\right)$ Feb. 18, 1950; gage height, $43.10 \mathrm{ft}(13.137 \mathrm{~m}) \mathrm{Feb} .13$, 1950 (former site and datum).

Flood of January to February 1937 reached a stage of $51.1 \mathrm{ft}[(15.58 \mathrm{~m})$ (former site and datum)];60.3 ft (18.38 m) present site and datum (from river profile)

Remarks.- Regulation by hydroelectric and navigation dams in the Cumberland River basin. Barkley-Kentucky canal diverts water from or to Kentucky Lake in Tennessee River basin.

Mean discharge, in cubic feet per second, 1979

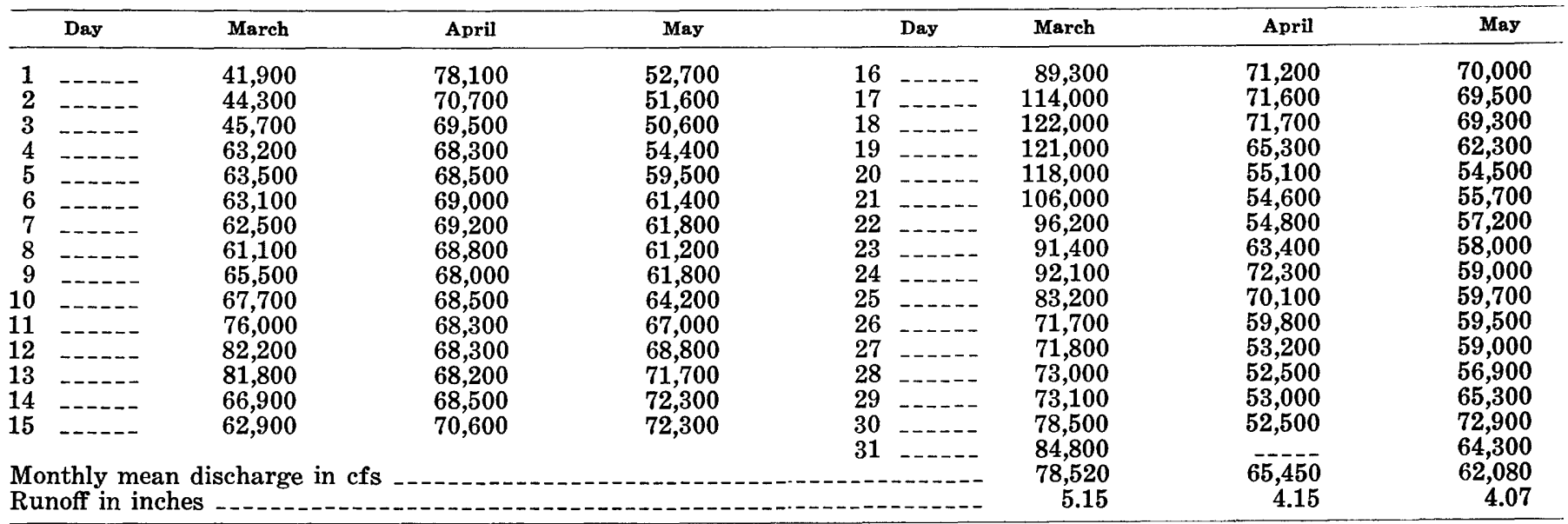


TABLE 12.-Station descriptions and discharge and suspended-sediment data-Continued

OHIO RIVER BASIN

(42) 03611500 Ohio River at Metropolis, Ill.

Location.-Lat $37^{\circ} 08^{\prime} 51^{\prime \prime}$, long $88^{\circ} 44^{\prime} 27^{\prime \prime}$, McCraken County, near center of span on downstream side of pier of Paducah \& Illinois Railroad bridge at Metropolis, 9.5 miles $(15.3 \mathrm{~km})$ downstream from Tennessee River, $37 \mathrm{miles}(59.5 \mathrm{~km})$ upstream from mouth, and at mile $944.1(1,520 \mathrm{~km})$.

Drainage area.-203,000 $\mathrm{mi}^{2}\left(526,000 \mathrm{~km}^{2}\right)$, approximately.

Gage.-Water-stage recorder. Datum of gage $276.27 \mathrm{ft}(84.207 \mathrm{~m})$ above mean sea level. Auxiliary water-stage recorder, 18 miles $(29 \mathrm{~km})$ downstream.

Flood stage.-Periods when river exceeded flood stage of $43 \mathrm{ft}(13.1 \mathrm{~m})$ for selected floods, are shown in the following tabulation:

1937: Jan. 9 to Feb. 23

1945: Feb. 23 to Apr. 17

1950: Jan. 6 to Mar 6

1964: Mar. 9 to Apr. 1

1973: Mar. 13 to May 20

(46 days)

(54 days)

(60 days)

(24 days)

(69 days)

Maxima.-March-May 1973: Discharge, $990,000 \mathrm{ft}^{3} / \mathrm{s}\left(28,000 \mathrm{~m}^{3} / \mathrm{s}\right)$ Mar. 26, 2:00 p.m., [gage height, $50.22 \mathrm{ft}(15.307 \mathrm{~m})$ ]. 1928 to February 1973: Discharge, 1,780,000 ft: $/ \mathrm{s}\left(50,400 \mathrm{~m}^{3} / \mathrm{s}\right)$ Feb. 1, 1937 [total discharge, including overflow through Bay Creek and Cache River Valleys, 1,850,000 ft:3 $\left./ \mathrm{s}\left(52,400 \mathrm{~m}^{3} / \mathrm{s}\right)\right]$; maximum gage height, $66.60 \mathrm{ft}(20.300 \mathrm{~m})$

Feb. 2, 1937.

Remarks.-Flow regulated by many dams and reservoirs.

Mean gage height, in feet, and discharge, in cubic feet per second, 1973

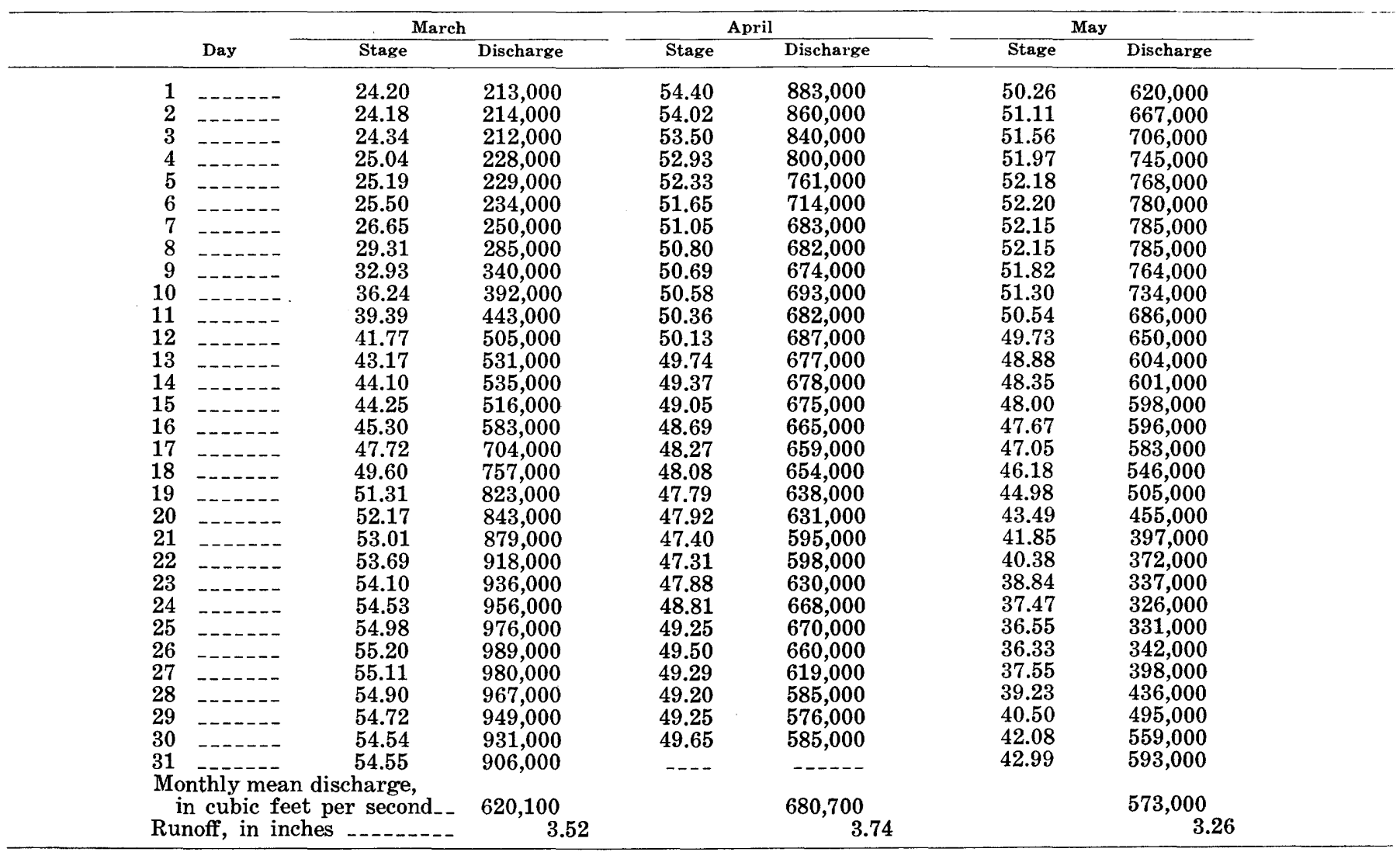

OBION RIVER BASIN

(43) 07027500 South Fork Forked Deer River at Jackson, Tenn.

Location.-Lat $35^{\circ} 35^{\prime} 38^{\prime \prime}$, long $88^{\circ} 48^{\prime} 52^{\prime \prime}$, Madison County, on right bank $20 \mathrm{ft}(6.1 \mathrm{~m})$ downstream from bridge on U.S. Highway 45, 0.6 mile $(1.0 \mathrm{~km})$ downstream from Meridian Creek, and 1.4 miles $(2.3 \mathrm{~km})$ south of the post office in Jackson.

Drainage area.-495 $\mathrm{mi}^{2}\left(1,282 \mathrm{~km}^{2}\right)$.

Gage.-Water-stage recorder. Datum of gage is $330.76 \mathrm{ft}(100.816 \mathrm{~m})$ above mean sea level, datum of 1929 , supplementary adjustment of 1955 .

Flood stage.-17 ft $(5.2 \mathrm{~m})$. Flood stage was exceeded for 2 days in March and for 8 days in April

Maxima.-March-May 1973: Discharge, 31,200 $\mathrm{ft}^{3} / \mathrm{s}\left(884 \mathrm{~m}^{3} / \mathrm{s}\right)$ 7:00 a.m., April 21 [gage height, $22.28 \mathrm{ft}(6.791 \mathrm{~m})$ ]. Recurrence interval of discharge is 35 years.

1929 to February 1973: Discharge $43,600 \mathrm{ft}^{3} / \mathrm{s}\left(1,230 \mathrm{~m}^{3} / \mathrm{s}\right)$ Jan. 21, 1935 [gage height $24.0 \mathrm{ft}(7.32 \mathrm{~m})$ ]. 
TABLE 12.-Station descriptions and discharge and suspended-sediment data-Continued

Mean discharge, in cubic feet per second, 1973

\begin{tabular}{|c|c|c|c|c|c|c|c|c|c|c|c|c|}
\hline \multicolumn{2}{|c|}{ Day } & \multirow{2}{*}{$\frac{\text { March }}{468}$} & \multirow{2}{*}{$\frac{\text { April }}{2,140}$} & \multirow{2}{*}{$\frac{\text { May }}{1,010}$} & Day & \multirow{2}{*}{$\begin{array}{l}\text { March } \\
2,930\end{array}$} & \multirow{2}{*}{$\begin{array}{c}\text { April } \\
1,100\end{array}$} & \multirow{2}{*}{$\frac{\text { May }}{1,160}$} & Day & \multirow{2}{*}{$\frac{\text { March }}{2,210}$} & \multirow{2}{*}{$\begin{array}{c}\text { April } \\
29,300\end{array}$} & \multirow{2}{*}{$\begin{array}{c}\text { May } \\
535\end{array}$} \\
\hline 1 & --- & & & & 11 & & & & 21 & & & \\
\hline 2 & ---- & 510 & 1,800 & 3,010 & 12 & 3,250 & 853 & 1,080 & 22 & 1,260 & 16,100 & 402 \\
\hline 3 & ---- & 1,140 & 1,560 & 3,620 & 13 & 2,820 & 700 & 772 & 23 & 1,060 & 8,640 & 629 \\
\hline 4 & ---- & 892 & 1,120 & 3,610 & 14 & 2,440 & 610 & 610 & 24 & 924 & 7,530 & 667 \\
\hline 5 & --- & 940 & 899 & 2,970 & 15 & 3,110 & 568 & 523 & $25 \ldots$ & 1,280 & 6,180 & 655 \\
\hline 6 & --- & 820 & 721 & 2,160 & 16 & 4,070 & 646 & 473 & $26 \ldots$ & 1,510 & 4,460 & 465 \\
\hline 7 & 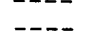 & 3,060 & 1,350 & 2,150 & 17 & 5,280 & 856 & 479 & $27 \ldots$ & 1,300 & 3,640 & 1,970 \\
\hline 8 & --- & 3,150 & 2,060 & 3,220 & 18 & 5,830 & 1,230 & 431 & $28 \ldots$ & 1,100 & 2,760 & 2,740 \\
\hline 9 & ---- & 2,300 & 1,740 & 2,700 & 19 & 4,380 & 2,910 & 413 & 29 & 1,030 & $\mathbf{1 , 5 3 0}$ & 2,070 \\
\hline 10 & --- & 1,620 & 1,510 & 1,590 & 20 & 3,470 & 16,700 & 727 & 30 & 1,180 & 1,100 & 2,160 \\
\hline & & & & & & & & & $31 \ldots$ & 2,520 & & \\
\hline \multicolumn{10}{|c|}{ Monthly mean discharge, in cubic feet per second } & 2,189 & 4,077 & 1,503 \\
\hline \multicolumn{13}{|c|}{ Runoff, in inches } \\
\hline
\end{tabular}

Gage height, in feet, and discharge, in cubic feet per second, at indicated time; 1973

\begin{tabular}{|c|c|c|c|c|c|c|c|c|c|c|c|}
\hline Date & Hour & $\begin{array}{c}\text { Gage } \\
\text { height }\end{array}$ & $\begin{array}{c}\text { Dis- } \\
\text { charge }\end{array}$ & Date & Hour & $\begin{array}{c}\text { Gage } \\
\text { height }\end{array}$ & $\begin{array}{c}\text { Dis- } \\
\text { charge }\end{array}$ & Date & Hour & $\begin{array}{c}\text { Gage } \\
\text { height }\end{array}$ & $\begin{array}{c}\text { Dis- } \\
\text { charge }\end{array}$ \\
\hline Apr. 18 & $\begin{array}{r}\text { 2:00 a.m. } \\
\text { 12:00 m. } \\
\text { 6:00 p.m. } \\
\text { 8:00 p.m. } \\
\text { 10:00 p.m. } \\
\text { 12:00 p.m. } \\
\text { 2:00 a.m. } \\
\text { 4:00 a.m. } \\
\text { 6:00 a.m. } \\
\text { 8:00 a.m. } \\
\text { 10:00 a.m. } \\
\text { 12:00 m. } \\
\text { 2:00 p.m. } \\
\text { 4:00 p.m. } \\
\text { 6:00 p.m. } \\
\text { 8:00 p.m. } \\
10: 00 \text { p.m. } \\
12: 00 \text { p.m. } \\
2: 00 \text { a.m. } \\
\text { 4:00 a.m. } \\
6: 00 \text { a.m. }\end{array}$ & $\begin{array}{r}7.35 \\
7.72 \\
8.72 \\
10.45 \\
12.30 \\
12.98 \\
13.35 \\
13.50 \\
13.49 \\
13.44 \\
12.99 \\
12.26 \\
11.54 \\
10.89 \\
13.33 \\
16.13 \\
16.93 \\
17.78 \\
18.31 \\
18.62 \\
18.96\end{array}$ & $\begin{array}{r}865 \\
976 \\
1,280 \\
1,800 \\
2,350 \\
2,550 \\
2,660 \\
2,710 \\
2,710 \\
2,690 \\
2,560 \\
2,340 \\
2,120 \\
1,930 \\
2,660 \\
3,680 \\
4,420 \\
5,900 \\
7,380 \\
8,480 \\
9,900\end{array}$ & Apr. 20 & $\begin{array}{r}\text { 8:00 a.m. } \\
\text { 10:00 a.m. } \\
\text { 12:00 m. } \\
2: 00 \text { p.m. } \\
\text { 4:00 p.m. } \\
\text { 6:00 p.m. } \\
\text { 8:00 p.m. } \\
\text { 10:00 p.m. } \\
\text { 12:00 p.m. } \\
2: 00 \text { a.m. } \\
\text { 4:00 a.m. } \\
6: 00 \text { a.m. } \\
\text { 7:00 a.m. } \\
\text { 8:00 a.m. } \\
\text { 10:00 a.m. } \\
2: 00 \text { p.m. } \\
6: 00 \text { p.m. } \\
\text { 12:00 p.m. } \\
2: 00 \text { a.m. } \\
6: 00 \text { a.m. } \\
10: 00 \text { a.m. }\end{array}$ & $\begin{array}{l}19.35 \\
19.74 \\
20.11 \\
20.53 \\
20.95 \\
21.30 \\
21.61 \\
21.87 \\
22.05 \\
22.17 \\
22.24 \\
22.27 \\
22.28 \\
22.27 \\
22.25 \\
22.14 \\
21.90 \\
21.36 \\
21.14 \\
20.68 \\
20.20\end{array}$ & $\begin{array}{l}12,100 \\
14,400 \\
16,700 \\
19,200 \\
21.700 \\
24,100 \\
26,300 \\
28,100 \\
29,400 \\
30,400 \\
30,900 \\
31,200 \\
31,200 \\
31,200 \\
31,000 \\
30,100 \\
28,300 \\
25,500 \\
23,000 \\
20,100 \\
17,200\end{array}$ & $\begin{array}{l}24- \\
25- \\
26- \\
27- \\
28- \\
29-\end{array}$ & $\begin{array}{r}\text { 2:00 p.m. } \\
\text { 6:00 p.m. } \\
\text { 12:00 p.m. } \\
2: 00 \text { a.m. } \\
\text { 6:00 a.m. } \\
\text { 10:00 a.m. } \\
\text { 4:00 p.m. } \\
\text { 12:00 p.m. } \\
\text { 2:00 a.m. } \\
\text { 12:00 m. } \\
\text { 12:00 p.m. } \\
\text { 2:00 a.m. } \\
\text { 12:00 m. } \\
12: 00 \text { p.m. } \\
12: 00 \text { m. } \\
12: 00 \text { p.m. } \\
\text { 12:00 a.m. } \\
\text { 12:00 p.m. } \\
\text { 12:00 m. } \\
\text { 12:00 p.m. } \\
\text { 12:00 m. } \\
12: 00 \text { p.m. }\end{array}$ & $\begin{array}{r}19.75 \\
19.32 \\
18.78 \\
18.63 \\
18.72 \\
18.85 \\
18.63 \\
18.42 \\
18.40 \\
18.36 \\
18.21 \\
18.16 \\
17.90 \\
17.46 \\
16.91 \\
16.51 \\
16.07 \\
15.34 \\
13.80 \\
11.11 \\
9.45 \\
8.59\end{array}$ & $\begin{array}{r}14,500 \\
11,900 \\
\mathbf{9 , 1 2 0} \\
\mathbf{8 , 5 2 0} \\
8,880 \\
9,400 \\
\mathbf{8 , 5 2 0} \\
7,770 \\
7,700 \\
7,560 \\
7,080 \\
6,930 \\
6,200 \\
\mathbf{5 , 2 2 0} \\
\mathbf{4 , 4 0 0} \\
3,970 \\
3,640 \\
3,290 \\
2,800 \\
1,990 \\
\mathbf{1 , 5 0 0} \\
\mathbf{1 , 2 4 0}\end{array}$ \\
\hline
\end{tabular}

\section{OBION RIVER BASIN}

(44) 07028950 Turkey Creek at Fairview, Tenn.

Location.-Lat $35^{\circ} 46^{\prime} 07^{\prime \prime}$, long $88^{\circ} 49^{\prime} 59^{\prime \prime}$, Madison County, at bridge on U.S. Highway $45 \mathrm{E}, 0.6$ mile (1.0 km) northeast of Fairview.

Drainage area.-13.3 $\mathrm{mi}^{2}\left(34.4 \mathrm{~km}^{2}\right)$.

Gage.-Water-stage and rainfall recorders. Gage set to arbitrary datum.

Flood stage. $-13 \mathrm{ft}(4.0 \mathrm{~m})$.

Maxima.-March-May 1973: Discharge, 5,400 ft'/s $\left(153 \mathrm{~m}^{3} / \mathrm{s}\right)$ April 19 [gage height $15.10 \mathrm{ft}$ (4.602 m)]. Recurrence interval of discharge is 25 years. 1967 to February 1973: Discharge, 6,360 $\mathrm{ft}^{3} / \mathrm{s}\left(180 \mathrm{~m}^{3} / \mathrm{s}\right)$ July 16, 1972 [gage height, $15.42 \mathrm{ft}(4.700 \mathrm{~m})$ ].

\section{HATCHIE RIVER BASIN}

(45) 07029500 Hatchie River at Bolivar, Tenn.

Location.-Lat $35^{\circ} 16^{\prime} 31^{\prime \prime}$, long $88^{\circ} 58^{\prime} 36^{\prime \prime}$, Hardeman Count'y, on left bank on upstream end of bridge pier on Sitate Highway $18,250 \mathrm{ft}(76 \mathrm{~m})$ upstream from Illinois Central Gulf Railroad bridge, 0.6 mile $(1.0 \mathrm{~km})$ downstream from Spring Creek, and 1.5 miles $(2.4 \mathrm{~km})$ northeast of Bolivar.

Drainage area.- $1,480 \mathrm{mi}^{2}\left(3,833 \mathrm{~km}^{2}\right)$.

Gage.-Water-stage recorder. Datum of gage is $323.49 \mathrm{ft}(98.600 \mathrm{~m})$ above mean sea level, datum of 1929 , supplementary adjustment of 1955 .

Flood stage. $-15 \mathrm{ft}(4.6 \mathrm{~m})$. Flood stage was exceeded for 10 consecutive days in March and for 14 consecutive days in April and May.

Maxima.-March-May 1973: Discharge, $61,600 \mathrm{ft}^{3} / \mathrm{s}\left(1,740 \mathrm{~m}^{3} / \mathrm{s}\right)$. March 18 [gage height, $21.66 \mathrm{ft}(6.602 \mathrm{~m})$ ]. Recurrence interval of discharge is 70 years. 1929 to February 1973: Discharge $56,300 \mathrm{ft}^{3} / \mathrm{s}\left(1,590 \mathrm{~m}^{3} / \mathrm{s}\right)$ Feb. 15, 1948 [gage height $21.53 \mathrm{ft}(6.562 \mathrm{~m})$ ]. 
TABLE 12.-Station descriptions and discharge and suspended-sediment data-Continued

Mean discharge, in cubic feet per second, 1973

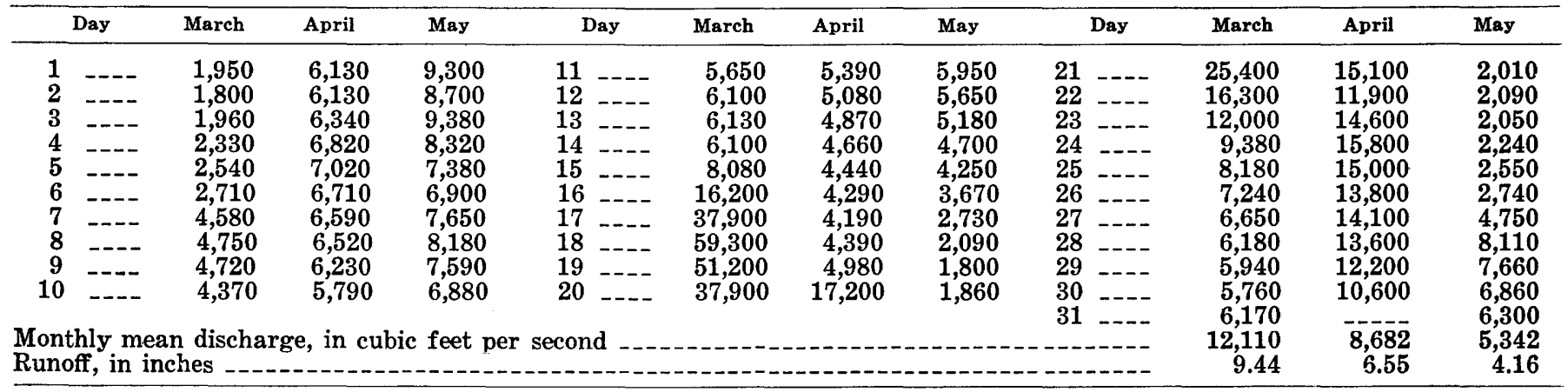

Gage height, in feet, and discharge, in cubic feet per second, at indicated time, 1973

\begin{tabular}{|c|c|c|c|c|c|c|c|c|c|c|c|}
\hline Date & Hour & $\begin{array}{c}\text { Gage } \\
\text { Height }\end{array}$ & $\begin{array}{c}\text { Dis- } \\
\text { charge }\end{array}$ & Date & Hour & $\begin{array}{c}\text { Gage } \\
\text { Height }\end{array}$ & $\begin{array}{c}\text { Dis- } \\
\text { charge }\end{array}$ & Date & Hour & $\begin{array}{c}\text { Gage } \\
\text { Height }\end{array}$ & $\begin{array}{c}\text { Dis- } \\
\text { charge }\end{array}$ \\
\hline
\end{tabular}

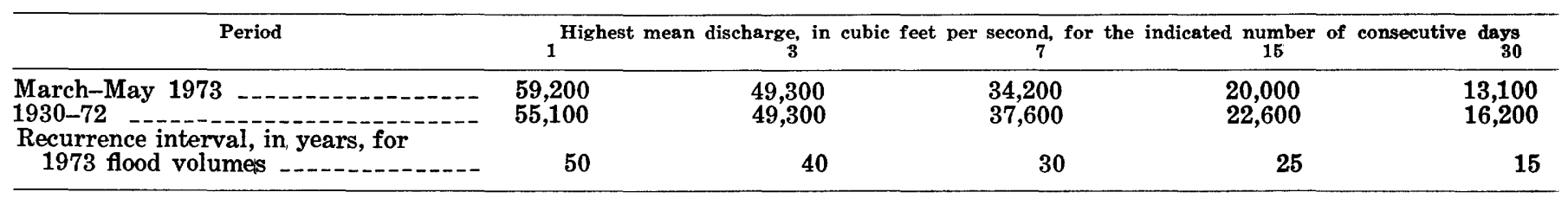

\section{MISSISSIPPI RIVER MAIN STEM}

(46) 07032000 Mississippi River at Memphis, Tenn.

Location.-Lat $35^{\circ} 07^{\prime} 37^{\prime \prime}$, long $90^{\circ} 04^{\prime} 25^{\prime \prime}$, on left bank 50 feet $(15 \mathrm{~m})$ downstream from Harahan Bridge at Memphis, Shelby County, 1.3 miles $(2.1 \mathrm{~km})$ downstream from Beale Street gage, 3.5 miles $(5.6 \mathrm{~km})$ downstream from Wolf River, 70 miles $(113 \mathrm{~km})$ upstream from St. Francis River and at mile $734.8(1,182.3 \mathrm{~km})$.

Drainage area.-932,800 $\mathrm{mi}^{2}\left(2,416,000 \mathrm{~km}^{2}\right)$, approximately.

Gage.-Water-stage recorder. Datum of gage is $183.91 \mathrm{ft}(56.056 \mathrm{~m})$ above mean sea level, datum of $1929,184.21 \mathrm{ft}(56.147$ $\mathrm{m}$ ) above mean Gulf level (1912 Mississippi River Commissi on), and $190.86 \mathrm{ft}$ (58.174 m) on. Memphis datum (1881 Mississippi River Commission). Prior to April 16, 1934, Beale Street staff gage 1.3 miles (2.1 km) upstream at same datum. April 16 to December 21, 1934, staff gage $1,000 \mathrm{ft}(305 \mathrm{~m})$ downstream at same datum.

Flood stage.-34.0 ft $(10.4 \mathrm{~m})$. 1973 flood exceeded flood stage for 63 consecutive days (March 24 to May 25 ).

Maxima.-March-June 1973: Discharge, 1,633,000 $\mathrm{ft}^{3} / \mathrm{s}\left(46,200 \mathrm{~m}^{3} / \mathrm{s}\right)$ April 1-2 [gage height, $40.03 \mathrm{ft}(12.201 \mathrm{~m})$ ]. Maximum stage was $40.48 \mathrm{ft}(12.338 \mathrm{~m})$ May 8. Recurrence interval of discharge is 20 years (based on figure 30 ).

January 1933 to February 1973: Discharge, 1,980,000 $\mathrm{ft}^{3} / \mathrm{s}\left(56,100 \mathrm{~m}^{3} / \mathrm{s}\right)$ Feb. 8, 1937; maximum gage height, $48.69 \mathrm{ft}$

$(14.841 \mathrm{~m})$, Feb. 10, 1937 .

Maximum stage known prior to 1937, about $45.2 \mathrm{ft}(13.78 \mathrm{~m})$ on Apr. 9, 1913.

Remarks.- Streamflow is affected by many reservoirs, navigation dams, and diversions. 
TABLE 12.-Station descriptions and discharge and suspended-sediment data-Continued

Stage, in feet, and discharge in cubic feet per second

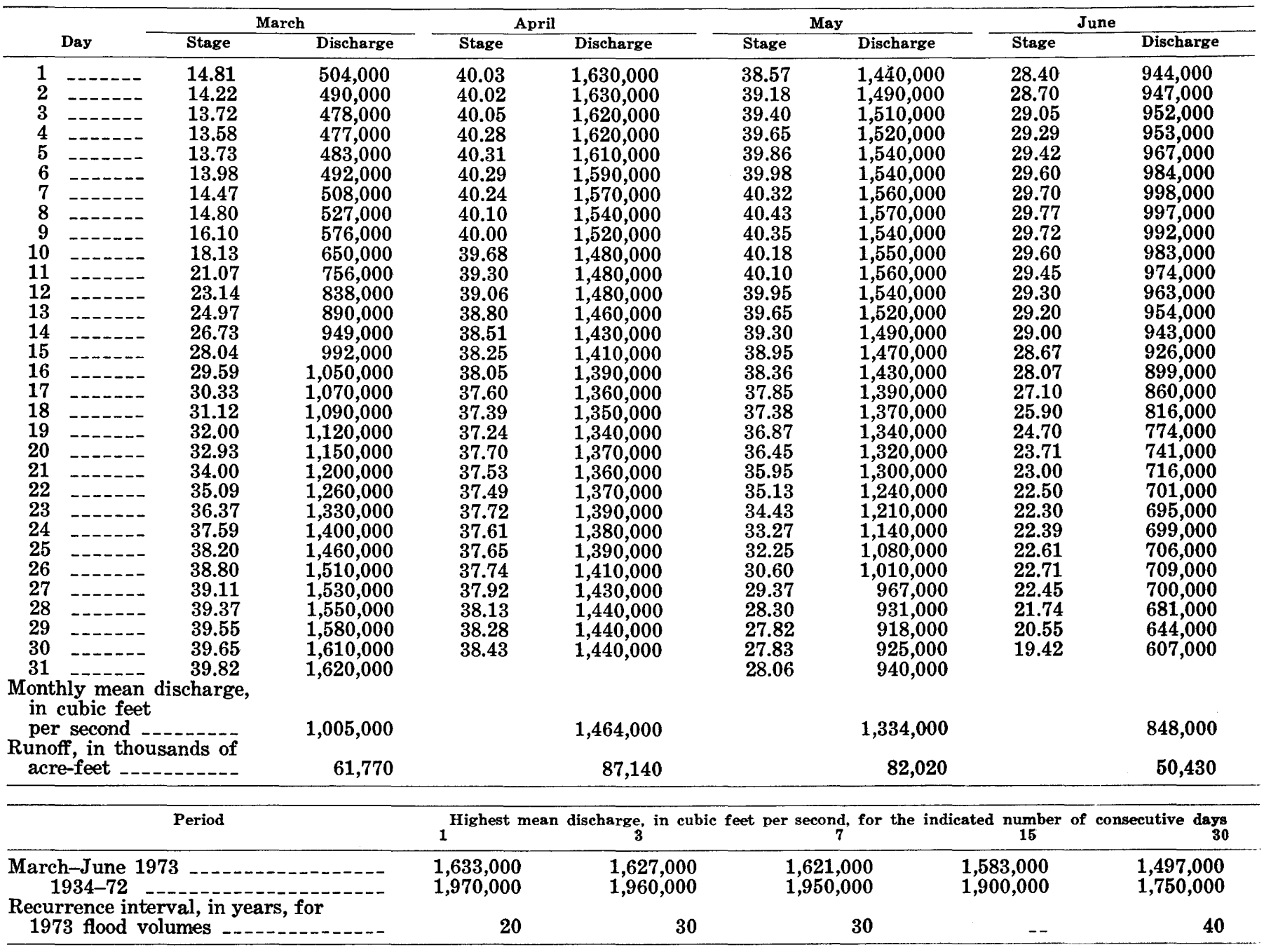

\section{NONCONNAH CREEK BASIN}

(47) 07032200 Nonconnah Creek near Germantown, Tenn.

Location.-Lat $35^{\circ} 02^{\prime} 59^{\prime \prime}$, long $89^{\circ} 49^{\prime} 08^{\prime \prime}$, Shelby County, on left bank at downstream side of bridge on Winchester Road, 2.6 miles $(4.2 \mathrm{~km})$ south of Germantown and 17.3 miles $(27.8 \mathrm{~km})$ upstream from mouth.

Drainage area.-68.2 $\mathrm{mi}^{2}\left(176.6 \mathrm{~km}^{2}\right)$.

Gage.-Water-stage recorder. Datum of gage is $262.92 \mathrm{ft}(80.138 \mathrm{~m})$ above mean sea level, datum of 1929 , supplementary adjustment of 1955 .

Bankfull stage.-Approximately $25 \mathrm{ft}(7.6 \mathrm{~m})$

Maxima.-March-May 1973: Discharge, 8,260 ft"s $\left(234 \mathrm{~m}^{3} / \mathrm{s}\right)$ 1:15 a.m., Apr. 20 [gage height 25.08 (7.644 m)]. Recurrence interval of discharge is 25 years. 1969 to February 1973: Discharge 7,260 ft"/s $\left(206 \mathrm{~m}^{*} / \mathrm{s}\right)$ Dec. 10, 1972 [gage height $\left.23.43 \mathrm{ft}(7.141 \mathrm{~m})\right]$.

Mean discharge, in cubic feet per second, 1973

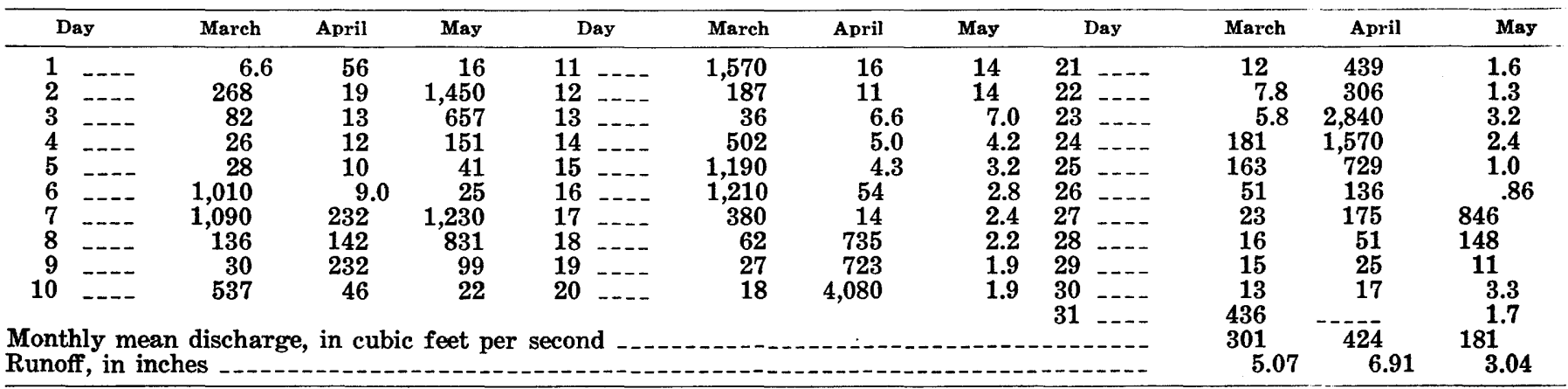


TABLE 12.-Station descriptions and discharge and suspended-sediment data-Continued

Gage height, in feet, and discharge, in cubic feet per second, at indicated time, 1973

\begin{tabular}{|c|c|c|c|c|c|c|c|c|c|c|c|}
\hline Date & Hour & $\begin{array}{l}\text { Gage } \\
\text { height }\end{array}$ & $\begin{array}{c}\text { Dis- } \\
\text { charge }\end{array}$ & Date & Hour & $\begin{array}{c}\text { Gage } \\
\text { height }\end{array}$ & $\begin{array}{c}\text { Dis- } \\
\text { charge }\end{array}$ & Date & Hour & $\begin{array}{c}\text { Gage } \\
\text { height }\end{array}$ & $\begin{array}{c}\text { Dis- } \\
\text { charge }\end{array}$ \\
\hline pr. 19 & $\begin{array}{r}\text { 2:00 a.m. } \\
\text { 12:00 m. } \\
\text { 6:00 p.m. } \\
\text { 8:00 p.m. } \\
\text { 10:00 p.m. } \\
\text { 12:00 p.m. } \\
\text { 3:00 a.m. } \\
\text { 2:00 a.m. } \\
\text { 4:00 a.m. } \\
\text { 6:00 a.m. } \\
\text { 8:00 a.m. } \\
\text { 10:00 a.m. } \\
\text { 12:00 m. } \\
\text { 2:00 p.m. } \\
\text { 4:00 p.m. } \\
\text { 6:00 p.m. } \\
\text { 8:00 p.m. }\end{array}$ & $\begin{array}{r}7.18 \\
6.30 \\
6.08 \\
7.87 \\
14.64 \\
21.57 \\
25.08 \\
24.82 \\
23.63 \\
22.52 \\
21.70 \\
20.19 \\
16.82 \\
12.61 \\
10.73 \\
9.90 \\
9.18\end{array}$ & $\begin{array}{r}488 \\
190 \\
125 \\
711 \\
2,860 \\
6,160 \\
8,260 \\
8,090 \\
7,380 \\
6,710 \\
6,240 \\
5,400 \\
3,770 \\
2,130 \\
1,570 \\
1,320 \\
1,100\end{array}$ & $\begin{array}{r}\text { Apr. } 20 \\
21\end{array}$ & $\begin{array}{c}\text { 10:00 p.m. } \\
\text { 12:00 p.m. } \\
\text { 1 2:00 a.m. } \\
\text { 4:00 a.m. } \\
\text { 12:00 m. } \\
\text { 12:00 p.m. } \\
\text { 2:00 a.m. } \\
\text { 12:00 m. } \\
\text { 4:00 p.m. } \\
\text { 12:00 p.m. } \\
\text { 2:00 a.m. } \\
\text { 4:00 a.m. } \\
\text { 6:00 a.m. } \\
\text { 8:00 a.m. } \\
\text { 10:00 a.m. } \\
\text { 12:00 m. } \\
\text { 2:00 p.m. }\end{array}$ & $\begin{array}{r}9.09 \\
8.96 \\
8.65 \\
8.32 \\
6.72 \\
6.07 \\
6.02 \\
5.92 \\
7.21 \\
8.22 \\
8.14 \\
7.90 \\
13.52 \\
18.94 \\
20.05 \\
19.60 \\
18.72\end{array}$ & $\begin{array}{r}1,080 \\
1,040 \\
945 \\
846 \\
327 \\
122 \\
110 \\
90 \\
498 \\
816 \\
792 \\
720 \\
2,430 \\
4,770 \\
5,330 \\
5,100 \\
4,660\end{array}$ & Apr. 23 & $\begin{array}{r}\text { 4:00 p.m. } \\
\text { 6:00 p.m. } \\
\text { 8:00 p.m. } \\
\text { 10:00 p.m. } \\
\text { 12:00 p.m. } \\
\text { 2:00 a.m. } \\
\text { 12:00 m. } \\
\text { 2:00 p.m. } \\
\text { 4:00 p.m. } \\
\text { 5:45 p.m. } \\
\text { 6:00 p.m. } \\
\text { 8:00 p.m. } \\
\text { 10:00 p.m. } \\
12: 00 \text { p.m. } \\
\text { 2:00 a.m. } \\
12: 00 \text { m. } \\
12: 00 \text { p.m. }\end{array}$ & $\begin{array}{r}16.85 \\
13.68 \\
11.20 \\
9.87 \\
9.06 \\
8.72 \\
7.86 \\
9.51 \\
14.41 \\
15.20 \\
15.20 \\
14.87 \\
13.17 \\
10.61 \\
9.30 \\
7.95 \\
6.51\end{array}$ & $\begin{array}{r}3,780 \\
2,490 \\
1,710 \\
1,310 \\
1,070 \\
966 \\
708 \\
1,200 \\
2,760 \\
3,080 \\
3,080 \\
2,950 \\
2,310 \\
1,530 \\
1,140 \\
735 \\
\mathbf{2 5 4}\end{array}$ \\
\hline
\end{tabular}

ST. FRANCIS RIVER BASIN

(48) 07042500 Little River ditch 251 near Lilbourn, Mo.

Location.-Lat $36^{\circ} 33^{\prime} 19^{\prime \prime}$, long $89^{\circ} 40^{\prime} 10^{\prime \prime}$, on line between secs. 8 and 17, T. 22 N., R. 13 E., New Madrid County, on right bank $150 \mathrm{ft}(46 \mathrm{~m})$ upstream from bridge on U.S. Highway $62,3.7$ miles $(6.0 \mathrm{~km})$ southwest of Lilbourn, and 4 miles $(6.4$ $\mathrm{km})$ northwest of Marston.

Drainage area.-235 $\mathrm{mi}^{2}\left(609 \mathrm{~km}^{2}\right)$.

Gage.-Digital water-stage recorder. Datum of gage is $263.46 \mathrm{ft}(80.303 \mathrm{~m}$ ) above mean sea level (levels by Missouri State Highway Commission). Prior to Oct. 27, 1967, nonrecording gage at present site and datum.

Flood stage. $-14 \mathrm{ft}(4.3 \mathrm{~m})$.

Maxima.-March-May 1973: Discharge, 5,200 ft's $\left(147 \mathrm{~m}^{3} / \mathrm{s}\right)$ 3:15 a.m., Apr. 20 [gage height $13.00 \mathrm{ft}(3.962 \mathrm{~m})$ ]. Maximum gage height, $13.07 \mathrm{ft}(3.984 \mathrm{~m}) 0600$ hours Apr. 23. D ischarge exceeded the 100-year flood.

October 1945 to February 1973: Discharge, 3,530 ft $/ \mathrm{s}\left(100 \mathrm{~m}^{3} / \mathrm{s}\right)$ March 10,1964 [gage height, $\left.15.00 \mathrm{ft}(4.572 \mathrm{~m})\right]$. Maximum gage height, $15.16 \mathrm{ft}(4.621 \mathrm{~m})$ Feb. $15,1950$.

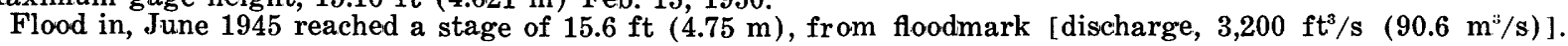

Mean discharge, in cubic feet per second, 1973

\begin{tabular}{|c|c|c|c|c|c|c|c|c|c|c|c|c|}
\hline & Day & March & April & May & Day & March & April & May & Day & March & April & May \\
\hline 1 & ---- & 280 & 963 & 1,080 & 11 & 3,000 & 563 & 1,280 & 21 & 817 & 3,150 & 455 \\
\hline 2 & --- & 270 & 889 & 3,760 & 12 & 2,500 & 509 & 955 & $22-$ & 703 & $\mathbf{2 , 9 3 0}$ & 450 \\
\hline 3 & $-\ldots$ & 260 & 743 & 2,670 & 13 & 2,040 & 464 & 703 & 23 & 603 & 3,980 & 582 \\
\hline 4 & $\ldots$ & 260 & 786 & 1,710 & 14 & 1,260 & 433 & 618 & 24 & 556 & 3,110 & 1,020 \\
\hline 5 & $\ldots$ & 250 & 605 & 1,050 & 15 & 1,180 & 422 & 574 & 25 & 575 & 2,080 & 639 \\
\hline 6 & -- & 250 & 535 & 856 & 16 & 942 & 426 & 560 & 26 & 564 & 1,290 & 499 \\
\hline 7 & --- & 500 & 605 & 1,270 & 17 & 887 & 425 & 528 & 27 & 507 & 1,070 & 1,080 \\
\hline 8 & $\ldots$ & 374 & 723 & 1,370 & 18 & 795 & 1,090 & 510 & 28 & 482 & 906 & 1,010 \\
\hline 9 & $-\ldots$ & 300 & 740 & 964 & 19 & 680 & 2,100 & 499 & 29 & 475 & 820 & 1,010 \\
\hline 10 & -- & 400 & 696 & 814 & 20 & 719 & 4,410 & 480 & 30 & 483 & 736 & 1,020 \\
\hline \multirow{2}{*}{\multicolumn{10}{|c|}{ Monthly mean discharge, in cubic feet per second }} & 1,810 & & 918 \\
\hline & \multicolumn{3}{|c|}{ ( } & & & & & & & $\begin{array}{r}797 \\
391\end{array}$ & $\begin{array}{r}1,270 \\
6,05\end{array}$ & $\begin{array}{r}998 \\
490\end{array}$ \\
\hline
\end{tabular}

Gage height, in feet, and discharge, in cubic feet per second, at indicated time, 1973

\begin{tabular}{|c|c|c|c|c|c|c|c|c|c|c|c|}
\hline Date & Hour & $\begin{array}{l}\text { Gage } \\
\text { height }\end{array}$ & $\begin{array}{r}\text { Dis- } \\
\text { charge }\end{array}$ & Date & Hour & $\begin{array}{c}\text { Gage } \\
\text { height }\end{array}$ & $\begin{array}{c}\text { Dis- } \\
\text { charge }\end{array}$ & Date & Hour & $\begin{array}{c}\text { Gage } \\
\text { height }\end{array}$ & $\begin{array}{c}\text { Dis- } \\
\text { charge }\end{array}$ \\
\hline Apr. 18 & $\begin{array}{r}\text { 2:00 a.m. } \\
\text { 8:00 a.m. } \\
\text { 12:00 m. } \\
\text { 2:00 p.m. } \\
\text { 6:00 p.m. } \\
\text { 12:00 p.m. }\end{array}$ & $\begin{array}{l}3.54 \\
4.55 \\
6.14 \\
6.63 \\
7.09 \\
6.84\end{array}$ & $\begin{array}{r}462 \\
765 \\
1,240 \\
1.390 \\
1,530 \\
1,450\end{array}$ & \multirow[t]{2}{*}{ Apr. } & $\begin{array}{r}\text { 6:00 p.m. } \\
\text { 8:00 p.m. } \\
\text { 10:00 p.m. } \\
12: 00 \text { p.m. }\end{array}$ & $\begin{array}{l}12.38 \\
12.72 \\
12.89 \\
12.94\end{array}$ & $\begin{array}{l}4,580 \\
4,920 \\
\mathbf{5 , 0 9 0} \\
\mathbf{5 , 1 4 0}\end{array}$ & Apr. 21 & $\begin{array}{r}\text { 2:00 a.m. } \\
\text { 8:00 a.m. } \\
\text { 2:00 p.m. } \\
\text { 8:00 p.m. } \\
\text { 10:00 p.m. } \\
\text { 12:00 p.m. }\end{array}$ & $\begin{array}{l}12.40 \\
12.11 \\
11.98 \\
11.61 \\
11.40 \\
11.18\end{array}$ & $\begin{array}{l}3,510 \\
3,240 \\
3,130 \\
2,840 \\
2,690 \\
2,560\end{array}$ \\
\hline 19 & $\begin{array}{l}\text { 2:00 a.m. } \\
\text { 10:00 a.m. } \\
\text { 12:00 m. } \\
\text { 2:00 p.m. } \\
\text { 4:00 p.m. }\end{array}$ & $\begin{array}{r}6.63 \\
5.72 \\
6.68 \\
9.46 \\
11.36\end{array}$ & $\begin{array}{l}1,390 \\
1,120 \\
1,000 \\
2,360 \\
3,620\end{array}$ & & $\begin{array}{r}\text { 6:00 a.m. } \\
\text { 12:00 m. } \\
6: 00 \text { p.m. } \\
\text { 10:00 a.m. } \\
\text { 12:00 p.m. }\end{array}$ & $\begin{array}{l}13.00 \\
12.90 \\
12.78 \\
12,65 \\
12.57\end{array}$ & $\begin{array}{l}4,540 \\
4,440 \\
4,320 \\
4,190 \\
4,120\end{array}$ & 22 & $\begin{array}{r}\text { 4:00 a.m. } \\
\text { 6:00 a.m. } \\
10: 00 \text { a.m. } \\
\text { 6:00 p.m. } \\
12: 00 \text { p.m. }\end{array}$ & $\begin{array}{l}10.60 \\
10.32 \\
11.75 \\
12.19 \\
12.68\end{array}$ & $\begin{array}{l}2,340 \\
2,240 \\
2,920 \\
3,290 \\
3,730\end{array}$ \\
\hline
\end{tabular}


TABLE 12.-Station descriptions and discharge and suspended-sediment data-Continued

Gage height, in feet, and discharge, in cubic feet per second, at indicated time, 1973

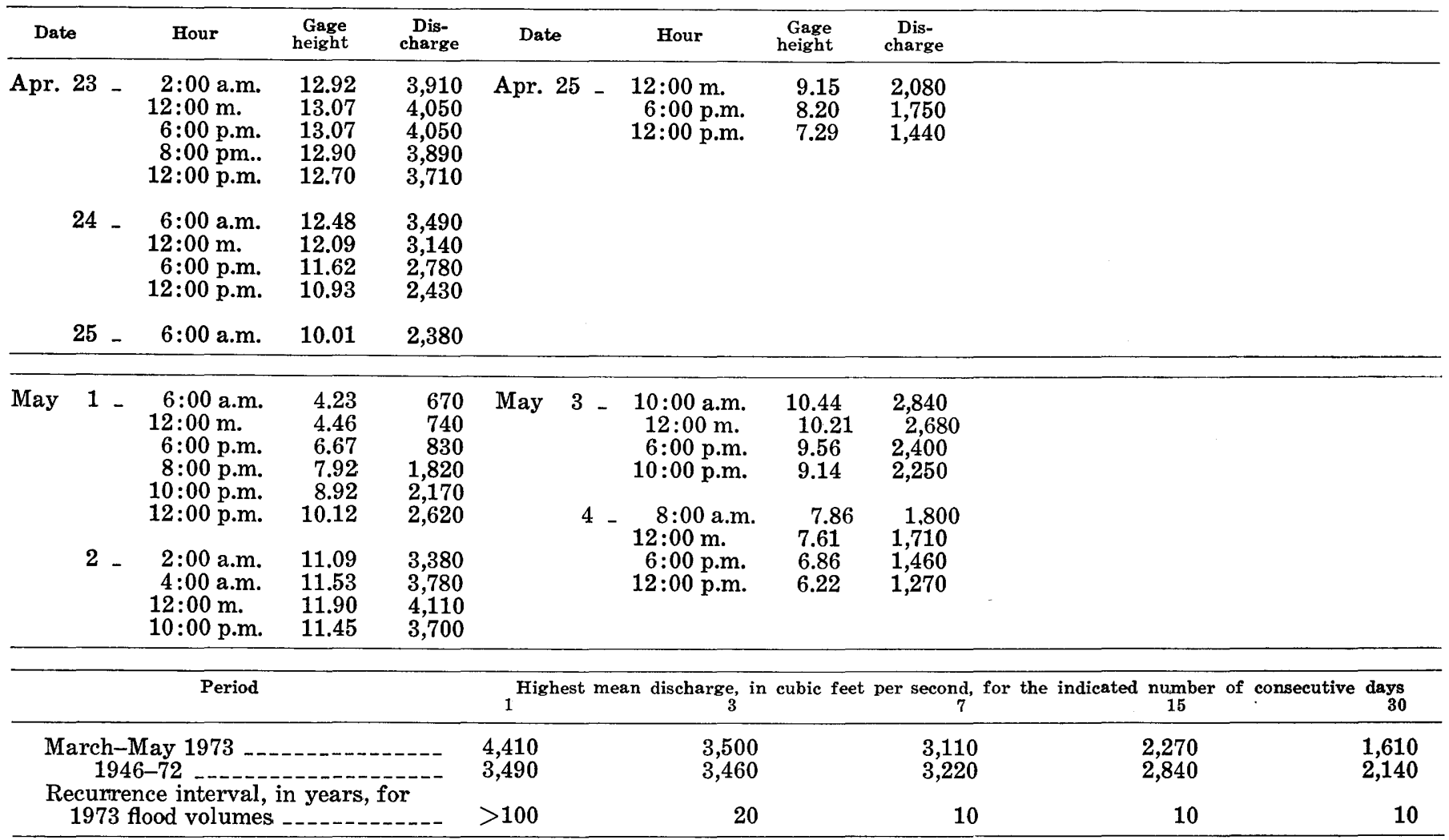

\section{WHITE RIVER BASIN}

(49) 07072500 Black River at Black Rock, Ark.

Lacation.-Lat $36^{\circ} 06^{\prime} 15^{\prime \prime}$, long $91^{\circ} 05^{\prime} 50^{\prime \prime}$, in $\mathrm{NW}^{1 / 4}$ sec. 21 , T. 17 N., R. 1 W., Lawrence County, on right bank $900 \mathrm{ft}(274$ m) downstream from St. Louis-San Francisco Railway bridge at Black Rock, 3.7 miles $(6.0 \mathrm{~km})$ downstream from Spring River, and at mile $68.3(109.9 \mathrm{~km})$

Drainage area.-7,369 $\mathrm{mi}^{2}\left(19,090 \mathrm{~km}^{2}\right)$.

Gage.-Nonrecording gage read twice daily, more often during rises. Datum of gage is $229.56 \mathrm{ft}(69.970 \mathrm{~m})$ above mean sea level. Prior to Aug. 1, 1946, at site $900 \mathrm{ft}(274 \mathrm{~m})$ upstream at same datum.

Flood stage. - $20 \mathrm{ft}(6.1 \mathrm{~m})$.

Maxima.-March-May 1973: Discharge, $105,000 \mathrm{ft}^{3} / \mathrm{s}\left(2,970 \mathrm{~m}^{3} / \mathrm{s}\right) \quad 2: 00$ a.m. April 24 [gage height, $29.94 \mathrm{ft}(8.912 \mathrm{~m})$ ].

Recurrence interval of discharge is 20 years.

1929 to 1931; 1940 to Feb. 1973: Discharge, 103,000 $\mathrm{ft}^{3} / \mathrm{s}\left(2,920 \mathrm{~m}^{3} / \mathrm{s}\right)$ Jan. 25, 1949 [gage height, $28.5 \mathrm{ft}(8.69 \mathrm{~m})$ ].

Remarks.-Flow slightly regulated by Clearwater Lake (Missouri), 189 miles (304 km) upstream, since June 3, 1948 [capacity, 413,700 acre-ft $\left.\left(510 \mathrm{hm}^{3}\right)\right]$.

Mean discharge, in cubic feet per second, 1973

\begin{tabular}{|c|c|c|c|c|c|c|c|c|c|c|c|c|}
\hline & Day & March & April & May & Day & March & April & May & Day & March & April & May \\
\hline 1 & ---- & 8,850 & 33,800 & 46,600 & 11 & 40,200 & 26,400 & 37,000 & 21 & 33,000 & 50,200 & 19,700 \\
\hline 2 & --- & 8,530 & 29,400 & 52,800 & $\begin{array}{ll}11 & ----\end{array}$ & 43,900 & 24,600 & 38,000 & $22-\cdots$ & 29,500 & 51,500 & 18,600 \\
\hline 2 & - & 8,380 & 26,800 & 49,900 & 13 & 34,400 & 23,900 & 37,400 & $23 \ldots$ & 27,200 & 84,700 & 19,500 \\
\hline 6 & -- & 8,410 & 24,000 & 37,200 & 16 & 43,500 & 23,800 & 29,600 & 26 & 28,000 & 86,800 & 17,600 \\
\hline 7 & $\ldots$ & 15,000 & 23,400 & 42,900 & 17 & 43,500 & 23,800 & 26,800 & $27 \ldots$ & 26,000 & 83,300 & 22,500 \\
\hline 8 & $-\ldots$ & 15,500 & 23,300 & 45,400 & 18 & 41,000 & 24,900 & 24,600 & $28 \ldots$ & 24,300 & 73,500 & 34,600 \\
\hline \multirow{2}{*}{\multicolumn{10}{|c|}{$\begin{array}{l}\text { Monthly mean discharge, in cubic feet per second } \\
\text { Runoff, in inches }\end{array}$}} & $\begin{array}{l}32,100 \\
26,210\end{array}$ & 42,280 & $\begin{array}{l}22,200 \\
31,910\end{array}$ \\
\hline & & & & & & & & & & 4.13 & 6.44 & 5.02 \\
\hline
\end{tabular}


TABLE 12.-Station descriptions and discharge and suspended-sediment data-Continued

MISSISSIPPI RIVER MAIN STEM

(50) 07265450 Mississippi River near Arkansas City, Ark.

Location.-Lat $33^{\circ} 33^{\prime} 55^{\prime \prime}$, long $91^{\circ} 14^{\prime} 35^{\prime \prime}$, sec. 18 , T. 13 S., R.1 W., on right bank 3 miles (4.8 km) southwest of Arkansas City, and at mile $554.1(891.5 \mathrm{~km})$ above Head of Passes.

Drainage area.-1,130,600 $\mathrm{mi}^{2}\left(2,928,300 \mathrm{~km}^{2}\right) 22,240 \mathrm{mi}^{2}\left(57,600 \mathrm{~km}^{2}\right)$ non-contributing.

Gage.-Staff gage. Datum of gage is $96.66 \mathrm{ft}(29.462 \mathrm{~m})$ above mean sea level, datum of 1929, supplementary adjustment of 1941.

Flood stage. $-44 \mathrm{ft}(13.4 \mathrm{~m})$.

Maxima.-March-June 1973: Discharge, 1,880,000 $\mathrm{ft}^{3} /\left(53,200 \mathrm{~m}^{3} / \mathrm{s}\right)$ May 12 [gage height $47.62 \mathrm{ft}(14.515 \mathrm{~m})$ ].

November 1879 to February 1973: iDscharge, 2,159,000 ft $\mathrm{ft}^{3} / \mathrm{s}\left(61,100 \mathrm{~m}^{3} / \mathrm{s}\right)$ Feb. 16, 1937 [maximum gage height, 53.86

ft $(16.417 \mathrm{~m})$ on Felb. 17, 1937, a discharge of about $2,472,000 \mathrm{ft}^{3} / \mathrm{s}\left(70,000 \mathrm{~m}^{3} / \mathrm{s}\right)$ accurred in early May, 1927$]$.

Remarks. - Station was included for use in sediment analysis.

Average velocity, water temperature, stage, water discharge, suspended sediment, and bed material

\begin{tabular}{|c|c|c|c|c|c|c|c|c|c|c|c|c|c|c|c|}
\hline & & \multirow{3}{*}{ Date } & \multirow{3}{*}{$\begin{array}{c}\text { Average } \\
\text { veloctiy } \\
\text { (fps) }\end{array}$} & \multirow{3}{*}{$\begin{array}{c}\text { Water } \\
\text { tempera- } \\
\text { ture } \\
\left({ }^{\circ} \mathbf{C}\right)\end{array}$} & \multirow{3}{*}{$\begin{array}{c}\text { Stage } \\
(\mathrm{ft})\end{array}$} & \multirow{3}{*}{$\begin{array}{c}\text { Discharge } \\
\left(1,000 \mathrm{ft}^{3} / \mathrm{s}\right)\end{array}$} & \multicolumn{6}{|c|}{ Suspended sediment } & \multirow{2}{*}{\multicolumn{3}{|c|}{$\underset{(\mathrm{mm})}{\text { Bed material }}$}} \\
\hline & & & & & & & \multicolumn{4}{|c|}{ Concentration, $\mathrm{mg} / 1$} & \multirow{2}{*}{$\begin{array}{l}\text { Discharge } \\
(1,000 \\
\text { tons/day })\end{array}$} & \multirow{2}{*}{$\begin{array}{l}\text { Percent } \\
\text { sand }\end{array}$} & & & \\
\hline & & & & & & & Right & Middle & Left & Average & & & $D_{18}$ & D50 & $\mathrm{D}_{84}$ \\
\hline \multirow[t]{3}{*}{ March } & & -- & $-\quad 4.53$ & 6.5 & 23.82 & 662 & 191 & 258 & 172 & 207 & 388 & 36 & 0.26 & 0.34 & 2.42 \\
\hline & $\begin{array}{r}5 \\
12\end{array}$ & --- & $\begin{array}{r}4.10 \\
-\quad 5.50\end{array}$ & $\begin{array}{r}8.0 \\
10.5\end{array}$ & 22.24 & 597 & 194 & 276 & 143 & 204 & 328 & 43 & .26 & .34 & .45 \\
\hline & $\begin{array}{l}12 \\
30\end{array}$ & 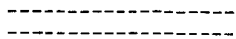 & $\begin{array}{l}5.50 \\
-\quad 7.88\end{array}$ & $\begin{array}{l}10.5 \\
12.0\end{array}$ & $\begin{array}{l}27.47 \\
42.01\end{array}$ & $\begin{array}{r}870 \\
1,680\end{array}$ & $\begin{array}{l}524 \\
263\end{array}$ & $\begin{array}{l}551 \\
273\end{array}$ & $\begin{array}{l}454 \\
252\end{array}$ & $\begin{array}{l}510 \\
262\end{array}$ & $\begin{array}{l}1,272 \\
1,229\end{array}$ & 25 & .29 & .41 & .67 \\
\hline \multirow[t]{5}{*}{ April } & 2 & 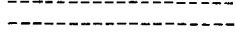 & -8.04 & 13.0 & $\begin{array}{l}42.01 \\
42.98\end{array}$ & $\begin{array}{l}1,080 \\
1,730\end{array}$ & 230 & 240 & 263 & 244 & 1,241 & $\begin{array}{l}00 \\
42\end{array}$ &.$\overline{27}$ & $\overline{.36}$ &.$\overline{49}$ \\
\hline & 9 & 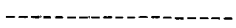 & $-\quad 7.75$ & 12.0 & 44.08 & 1,790 & 185 & 236 & 248 & 223 & 1,148 & 40 & .26 & .36 & .48 \\
\hline & 16 & --- & $-\quad 7.32$ & 11.5 & 43.76 & 1,700 & 216 & 288 & 309 & 271 & 1,316 & 43 & .56 & 4.28 & 6.32 \\
\hline & 25 & --- & -7.19 & 14.5 & 44.89 & 1,760 & 184 & 195 & 252 & 210 & 1,050 & 51 & .29 & .66 & 2.83 \\
\hline & 30 & n-n-n-n & $-\quad 7.40$ & 15.5 & 46.04 & 1,820 & 212 & 228 & 381 & 274 & 1,435 & 51 & .29 & .38 & .51 \\
\hline \multirow[t]{4}{*}{ May } & 8 & - & $-\quad 7.10$ & 17.0 & 47.13 & 1,840 & 178 & 214 & 344 & 245 & 1,261 & 45 & .21 & 2.20 & 3.00 \\
\hline & 14 & - & -6.98 & 18.5 & 47.40 & 1,810 & 175 & 212 & 250 & 212 & 1,099 & 47 & .26 & .37 & .67 \\
\hline & 23 & $---1-n-1-1$ & -6.86 & 19.0 & 44.78 & 1,670 & 134 & 182 & 186 & 167 & 805 & 40 & .36 & 1.36 & 4.09 \\
\hline & 28 & 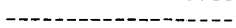 & -6.50 & 20.0 & 41.76 & 1,480 & 143 & 163 & 182 & 163 & 695 & 42 & .22 & .31 & .53 \\
\hline \multirow[t]{4}{*}{ June } & 4 & - & -5.46 & 21.0 & 36.55 & 1,200 & 206 & 246 & 227 & 226 & 736 & 37 & .26 & .35 & .50 \\
\hline & 12 & 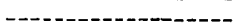 & 5.31 & 23.0 & 36.66 & 1,170 & 190 & 207 & 249 & 215 & 689 & 35 & .29 & .37 & .50 \\
\hline & 18 & - & 5.27 & 25.0 & 34.82 & 1,090 & 206 & 221 & 208 & 212 & 624 & 38 & .27 & .35 & .48 \\
\hline & 25 & & -4.94 & 26.0 & 30.09 & 877 & 191 & 362 & 218 & 257 & 654 & 18 & .30 & 38 & .51 \\
\hline
\end{tabular}

YAZOO RIVER BASIN

(51) 07272000 Sardis Lake near Sardis, Miss.

Location.-Lat $34^{\circ} 23^{\prime} 57^{\prime \prime}$, long $89^{\circ} 47^{\prime} 10^{\prime \prime}$, in NE1/4 SW $1 / 4$ sec. 12, T. 8 S., R. 6 W., Chickasaw meridian, Panola County, in gatehouse of dam on Little Tallahatchie River, 7.5 miles $(12.1 \mathrm{~km})$ southeast of Sardis, and $25.7 \mathrm{miles}(41.4 \mathrm{~km})$ upstream from head of Panola-Quitman Floodway.

Drainage area. $-1,545 \mathrm{mi}^{2}\left(4,000 \mathrm{~km}^{2}\right)$.

Gage.-Water-stage recorder. Datum of gage is at mean sea level (levels by Corps of Engineers). Prior to Oct. 1, 1958, at datum $219.43 \mathrm{ft}(66.882 \mathrm{~m})$ above mean sea level.

Maxima.-March-May 1973: Contents, 1,840,700 acre-ft $\left(2.270 \mathrm{hm}^{3}\right.$ ) April 28 (elevation 285.83 or $87.121 \mathrm{~m}$ ). 1939 to February 1973: Contents, 1,394,100 acre-ft $\left(1,720 \mathrm{hm}^{3}\right)$ May 14, 1970 (elevation, $278.32 \mathrm{ft}$ or $84.832 \mathrm{~m}$ ).

Remarks. - Reservoir is formed by hydraulic-fill earth dam, with concrete spillway and outlet tunnel on opposite ends of dam. Storage began Aug. 26, 1939; dam completed Aug. 1, 1940. Capacity, 1,569,900 acre-ft $\left(1,940 \mathrm{hm}^{3}\right)$ at elevation 281.4 $\mathrm{ft}$ of $85.77 \mathrm{~m}$ (crest of spillway), of which about $1,478,000$ acre-ft $\left(1,820 \mathrm{hm}^{3}\right)$ is available for flood-control storage and about 108,000 acre-ft $\left(133 \mathrm{hm}^{3}\right)$ of storage is maintained in conservation pool for incidental recreational purposes at elevation $236.0 \mathrm{ft}$ or $71.93 \mathrm{~m}(16.6 \mathrm{ft}$ or $5.06 \mathrm{~m}$ above sill of outlet tunnel). Water below elevation $219.4 \mathrm{ft}(66.87 \mathrm{~m})$ cannot be withdrawn through outlet tunnel. Figures given herein represent total contents.

[Elevation, in feet, and contents, in thousands of acre-ft, at 8:00 a.m., 1973]

\begin{tabular}{|c|c|c|c|c|c|c|c|}
\hline \multirow{2}{*}{\multicolumn{2}{|c|}{ Day }} & \multicolumn{2}{|c|}{ March } & \multicolumn{2}{|c|}{ April } & \multicolumn{2}{|c|}{ May } \\
\hline & & Elevation & Contents & Elevation & Contents & Elevation & Contents \\
\hline $\begin{array}{l}1 \\
2 \\
3 \\
4 \\
5\end{array}$ & 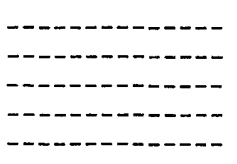 & $\begin{array}{l}273.8 \\
273.6 \\
273.6 \\
273.6 \\
273.6\end{array}$ & $\begin{array}{l}1,160.4 \\
1,153.7 \\
1,151.3 \\
1,150.8 \\
1,151.8\end{array}$ & $\begin{array}{l}284.4 \\
284.4 \\
284.3 \\
284.2 \\
284.1\end{array}$ & $\begin{array}{l}1,747.4 \\
1,748.7 \\
1,745.5 \\
1,739.3 \\
1,732.3\end{array}$ & $\begin{array}{l}285.4 \\
285.2 \\
285.0 \\
284.9 \\
284.8\end{array}$ & $\begin{array}{l}1,810.7 \\
1,798.0 \\
1,787.8 \\
1,781.5 \\
1,774.5\end{array}$ \\
\hline $\begin{array}{r}6 \\
7 \\
8 \\
9 \\
10\end{array}$ & 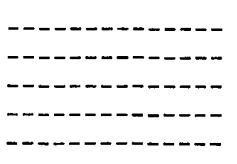 & $\begin{array}{l}273.6 \\
273.6 \\
273.8 \\
273.9 \\
274.0\end{array}$ & $\begin{array}{l}1,152.3 \\
1,153.2 \\
1,160.9 \\
1,168.1 \\
1,169.1\end{array}$ & $\begin{array}{l}284.0 \\
283.9 \\
283.9 \\
284.0 \\
283.9\end{array}$ & $\begin{array}{l}1,726.7 \\
1,721.1 \\
1,720.5 \\
1,722.3 \\
1,716.7\end{array}$ & $\begin{array}{l}284.6 \\
284.5 \\
284.4 \\
284.4 \\
284.3\end{array}$ & $\begin{array}{l}1,765.1 \\
1,755.6 \\
1,751.8 \\
1,748.7 \\
1,743.0\end{array}$ \\
\hline $\begin{array}{l}11 \\
12 \\
13 \\
14 \\
15\end{array}$ & 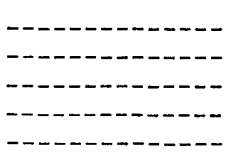 & $\begin{array}{l}274.0 \\
274.4 \\
274.9 \\
275.2 \\
276.1\end{array}$ & $\begin{array}{l}1,172.5 \\
1,189.1 \\
1,217.2 \\
1,230.7 \\
1,278.4\end{array}$ & $\begin{array}{l}283.8 \\
283.7 \\
283.6 \\
283.5 \\
283.4\end{array}$ & $\begin{array}{l}1,714.3 \\
1,708.1 \\
1,702.6 \\
1,695.8 \\
1,688.5\end{array}$ & $\begin{array}{l}284.2 \\
284.1 \\
284.0 \\
283.9 \\
283.8\end{array}$ & $\begin{array}{l}1,735.5 \\
1,729.2 \\
1,726.1 \\
1,717.4 \\
1,710.6\end{array}$ \\
\hline $\begin{array}{l}16 \\
17\end{array}$ & 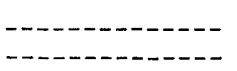 & $\begin{array}{l}279.3 \\
282.4\end{array}$ & $\begin{array}{l}1,448.2 \\
1.630 .3\end{array}$ & $\begin{array}{l}283.3 \\
283.3\end{array}$ & $\begin{array}{l}1,681.7 \\
1,681.7\end{array}$ & $\begin{array}{l}283.6 \\
283.5\end{array}$ & $\begin{array}{l}1,702.0 \\
1,692.8\end{array}$ \\
\hline
\end{tabular}


THE FJOODS

TABLE 12.-Station descriptions and discharge and suspended-sediment data-Continued

\begin{tabular}{|c|c|c|c|c|c|c|c|}
\hline & & & & & & & \\
\hline $\begin{array}{l}21 \\
22 \\
23 \\
24 \\
25\end{array}$ & 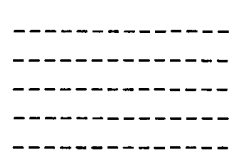 & $\begin{array}{l}284.2 \\
284.2 \\
284.1 \\
284.1 \\
284.1\end{array}$ & $\begin{array}{l}1,738.6 \\
1,736.1 \\
1,733.0 \\
1,728.6 \\
1,733.0\end{array}$ & $\begin{array}{l}283.6 \\
283.6 \\
283.7 \\
284.8 \\
285.3\end{array}$ & $\begin{array}{l}1,701.4 \\
1,698.9 \\
1,705.7 \\
1,772.0 \\
1,808.2\end{array}$ & $\begin{array}{l}283.0 \\
282.9 \\
282.8 \\
282.7 \\
282.6\end{array}$ & $\begin{array}{l}1,662.8 \\
1,656.1 \\
1,648.3 \\
1,642.9 \\
1,641.7\end{array}$ \\
\hline $\begin{array}{l}26 \\
27 \\
28 \\
20 \\
30 \\
31\end{array}$ & 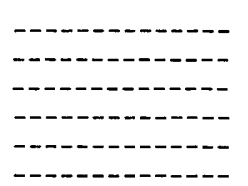 & $\begin{array}{l}284.2 \\
284.3 \\
284.2 \\
284.2 \\
284.1 \\
284.2\end{array}$ & $\begin{array}{l}1,739.3 \\
1,741.8 \\
1,739.3 \\
1,734.2 \\
1,733.0 \\
1,738.6\end{array}$ & $\begin{array}{l}285.6 \\
285.8 \\
285.8 \\
285.8 \\
285.6 \\
----\end{array}$ & $\begin{array}{l}1,826.7 \\
1,836.3 \\
1,840.7 \\
1,836.3 \\
1,824.7 \\
------\end{array}$ & $\begin{array}{l}282.6 \\
282.5 \\
282.6 \\
282.8 \\
282.8 \\
282.7\end{array}$ & $\begin{array}{l}1,637.5 \\
1,632.1 \\
1,641.7 \\
1,652.5 \\
1,651.3 \\
1,646.5\end{array}$ \\
\hline
\end{tabular}

\section{YAZOO RIVER BASIN}

(52) 07274500 Enid Lake near Enid, Miss.

Location.-Lat $34^{\circ} 09^{\prime} 29^{\prime \prime}$, long $89^{\circ} 54^{\prime} 14^{\prime \prime}$, in SW $1 / 4 \mathrm{NE}^{1 / 4}$ sec. 2, T. 11 S., R. 7 W., Chickasaw meridian, Yalobusha County, in gatehouse of dam on Yocona River, 0.8 mile $(1.3 \mathrm{~km})$ upstream from U.S. Highway $51,2.8 \mathrm{miles}(4.5 \mathrm{~km})$ upstream from Illinois Central Railroad bridge, 3.2 miles $(5.1 \mathrm{~km})$ northeast of Enid, and 13.5 miles $(21.7 \mathrm{~km}) \mathrm{upstream}$ from the mouth of Yocona River.

Drainage area. $-560 \mathrm{mi}^{2}\left(1,450 \mathrm{~km}^{2}\right)$.

Gage.-Water-stage recorder. Datum of gage is at mean sea level (levels by Corps of Engineers). Prior to May 24, 1952, nonrecording gage at same site. Prior to Oct. 1, 1958, at datum $200.00 \mathrm{ft}(60.960 \mathrm{~m})$ above mean sea level.

Maxima.-March-May 1973: Contents, 752,600 acre-ft $\left(927 \mathrm{hm}^{3}\right)$ April 27 (elevation, $271.17 \mathrm{ft}$ or $82.653 \mathrm{~m}$ ). 1951 to February 1973: Contents, 642,000 acre-ft $\left(792 \mathrm{hm}^{3}\right)$ May 13, 1970 (elevation, $267.35 \mathrm{ft}$ or $81.488 \mathrm{~m}$ ).

Remarks.-Reservoir is formed by rolled-filled earth dam with concrete spillway and outlet tunnel. Storage began July 16 , 1951. Capacity, 660,000 acre-ft $\left(814 \mathrm{hm}^{3}\right)$ at elevation $268.0 \mathrm{ft}$ or $81.68 \mathrm{~m}$ (crest of spillway) of which about 602,400 acre-ft $\left(743 \mathrm{hm}^{3}\right)$ is available for flood control and about 57,600 acre-ft $\left(71.0 \mathrm{hm}^{3}\right)$ of storage is maintained in conservation pool for incidental recreational purposes at elevation $230.0 \mathrm{ft}$ or $70.10 \mathrm{~m}$ ( $25 \mathrm{ft}$ or $7.6 \mathrm{~m}$ above sill of outlet tunnel). Water below elevation $205.0 \mathrm{ft}(62.48 \mathrm{~m})$ cannot be withdrawn through outlet tunnel. Figures given herein represent total contents.

[Elevation, in feet, and contents, in thousands of acre-ft, at 8:00 a.m., 1973]

\begin{tabular}{|c|c|c|c|c|c|c|c|}
\hline \multicolumn{2}{|c|}{ Day } & \multicolumn{2}{|c|}{ March } & \multicolumn{2}{|c|}{ April } & \multicolumn{2}{|c|}{ May } \\
\hline $\begin{array}{l}1 \\
2 \\
3 \\
4 \\
5\end{array}$ & 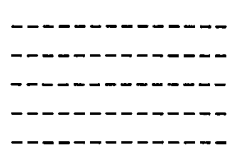 & $\begin{array}{l}256.2 \\
256.2 \\
256.3 \\
256.3 \\
256.4\end{array}$ & $\begin{array}{l}381.9 \\
380.4 \\
382.7 \\
382.9 \\
384.9\end{array}$ & $\begin{array}{l}269.6 \\
269.6 \\
269.5 \\
269.4 \\
269.3\end{array}$ & $\begin{array}{l}704.4 \\
705.2 \\
704.1 \\
700.9 \\
698.0\end{array}$ & $\begin{array}{l}270.8 \\
270.7 \\
270.7 \\
270.6 \\
270.5\end{array}$ & $\begin{array}{l}742.0 \\
738.7 \\
737.2 \\
734.2 \\
731.8\end{array}$ \\
\hline $\begin{array}{r}6 \\
7 \\
8 \\
9 \\
10\end{array}$ & 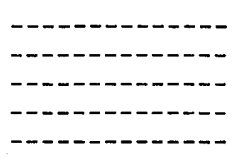 & $\begin{array}{l}256.4 \\
256.8 \\
256.9 \\
256.9 \\
256.9\end{array}$ & $\begin{array}{l}384.3 \\
393.4 \\
395.4 \\
395.6 \\
395.2\end{array}$ & $\begin{array}{l}269.2 \\
269.2 \\
269.2 \\
269.1 \\
269.1\end{array}$ & $\begin{array}{l}694.8 \\
694.2 \\
695.1 \\
691.9 \\
690.4\end{array}$ & $\begin{array}{l}270.3 \\
270.3 \\
270.3 \\
270.3 \\
270.2\end{array}$ & $\begin{array}{l}727.6 \\
727.0 \\
727.0 \\
725.2 \\
722.9\end{array}$ \\
\hline $\begin{array}{l}11 \\
12 \\
13 \\
14 \\
15\end{array}$ & 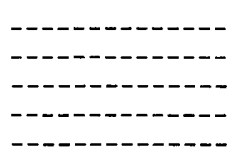 & $\begin{array}{l}257.7 \\
258.5 \\
258.7 \\
258.7 \\
261.0\end{array}$ & $\begin{array}{l}410.6 \\
427.6 \\
431.8 \\
432.6 \\
481.8\end{array}$ & $\begin{array}{l}269.0 \\
268.9 \\
268.8 \\
268.7 \\
268.6\end{array}$ & $\begin{array}{l}689.3 \\
685.2 \\
683.3 \\
679.3 \\
675.6\end{array}$ & $\begin{array}{l}270.1 \\
270.1 \\
270.0 \\
269.9 \\
269.7\end{array}$ & $\begin{array}{l}719.9 \\
720.2 \\
717.2 \\
713.7 \\
709.3\end{array}$ \\
\hline $\begin{array}{l}21 \\
22 \\
23 \\
24 \\
25\end{array}$ & 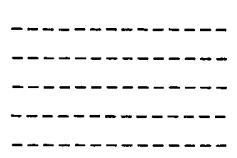 & $\begin{array}{l}268.2 \\
268.3 \\
268.4 \\
268.5 \\
268.9\end{array}$ & $\begin{array}{l}666.5 \\
669.3 \\
671.6 \\
673.0 \\
685.0\end{array}$ & $\begin{array}{l}268.8 \\
268.6 \\
268.6 \\
269.4 \\
270.5\end{array}$ & $\begin{array}{l}681.3 \\
678.4 \\
677.3 \\
698.5 \\
731.2\end{array}$ & $\begin{array}{l}268.8 \\
268.6 \\
268.4 \\
268.5 \\
268.4\end{array}$ & $\begin{array}{l}682.1 \\
676.4 \\
670.2 \\
675.0 \\
671.9\end{array}$ \\
\hline
\end{tabular}


TABLE 12.-Station descriptions and discharge and suspended-sediment data-Continued

\begin{tabular}{|c|c|c|c|c|c|c|c|}
\hline \multirow{2}{*}{\multicolumn{2}{|c|}{ Day }} & \multicolumn{2}{|c|}{ March } & \multicolumn{2}{|c|}{ April } & \multicolumn{2}{|c|}{ May } \\
\hline & & Elevation & Contents & Elevation & Contents & Elevation & Contents \\
\hline 26 & - - - - - - - - - - - & 269.0 & 689.6 & 270.8 & 742.3 & 268.3 & 667.1 \\
\hline 27 & - - - - - - - - - & 268.2 & 692.7 & 271.1 & 750.8 & 268.1 & 664.0 \\
\hline 28 & -- - - & 269.2 & 694.2 & 271.2 & 752.0 & 268.5 & 673.0 \\
\hline 29 & 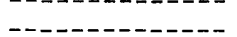 & 269.2 & 695.6 & 271.1 & 749.5 & 268.4 & 672.2 \\
\hline 30 & 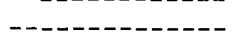 & 269.3 & 696.8 & 270.9 & 745.3 & 268.3 & 668.5 \\
\hline 31 & -------------- & 269.5 & 704.1 & - & ---- & 268.1 & 664.0 \\
\hline
\end{tabular}

YAZOO RIVER BASIN

(53) 07278000 Arkabutla Lake near Arkabutla, Miss.

Location.-Lat $34^{\circ} 45^{\prime} 26^{\prime \prime}$, long $90^{\circ} 07^{\prime} 27^{\prime \prime}$, in SW1/4 sec. 2, T. 4 S., R. 9 W., Chickasaw meridian, De Soto County, in gatehouse of dam on Coldwater River, 4 miles $(6.4 \mathrm{~km})$ north of Arkabutla, and 54.3 miles $(87.4 \mathrm{~km})$ upstream from the mouth of Coldwater River.

Drainage area. $-1,000 \mathrm{mi}^{2}\left(2,590 \mathrm{~km}^{2}\right)$, approximately.

Gage.-Water-stage recorder. Datum of gage is at mean sea level (levels by Corps of Engineers). Prior to July 1, 1942, nonrecording gage at same site. Prior to Oct. 1, 1958, at datum $191.18 \mathrm{ft}(58.272 \mathrm{~m})$ above mean sea level.

Maxima.-March-May 1973: Contents, 702,800 acre-ft $\left(867 \mathrm{~h} \mathrm{~m}^{3}\right)$ April 25 (elevation, $243.08 \mathrm{ft}$ or $74.091 \mathrm{~m}$ ).

1941 to February 1973: Contents, 649,900 acre-ft $\left(801 \mathrm{~h} \mathrm{~m}^{3}\right)$ May 21, 1953 (elevation, $241.74 \mathrm{ft}$ or $73.682 \mathrm{~m}$ ).

Remarks.-Reservoir is formed by rolled-filled earth dam with concrete spillway and outlet tunnel. Storage began Aug. 14, 1941. Dam completed Aug. 31, 1945. Capacity, 525,300 acre-ft $\left(648 \mathrm{hm}^{3}\right.$ ) at elevation $238.3 \mathrm{ft}$ or $72.63 \mathrm{~m}$ (crest of spillway), of which about 493,800 acre-ft $\left(609 \mathrm{hm}^{3}\right)$ is available for flood-control storage and about 31,500 acre-ft (38.8 $\mathrm{hm}^{3}$ ) is maintained in conservation pool for incidental recreational purposes at elevation $209.3 \mathrm{ft}$ or $63.79 \mathrm{~m}$ (18 ft or 5.5 $\mathrm{m}$ above sill of outlet gates). Water below elevation $191.3 \mathrm{ft}(58.31 \mathrm{~m})$ cannot be withdrawn through outlet tunnel. Figures given herein represent total contents.

[Elevation, in feet, and contents, in thousands of acre-ft, at 8:00 a.m., 1973]

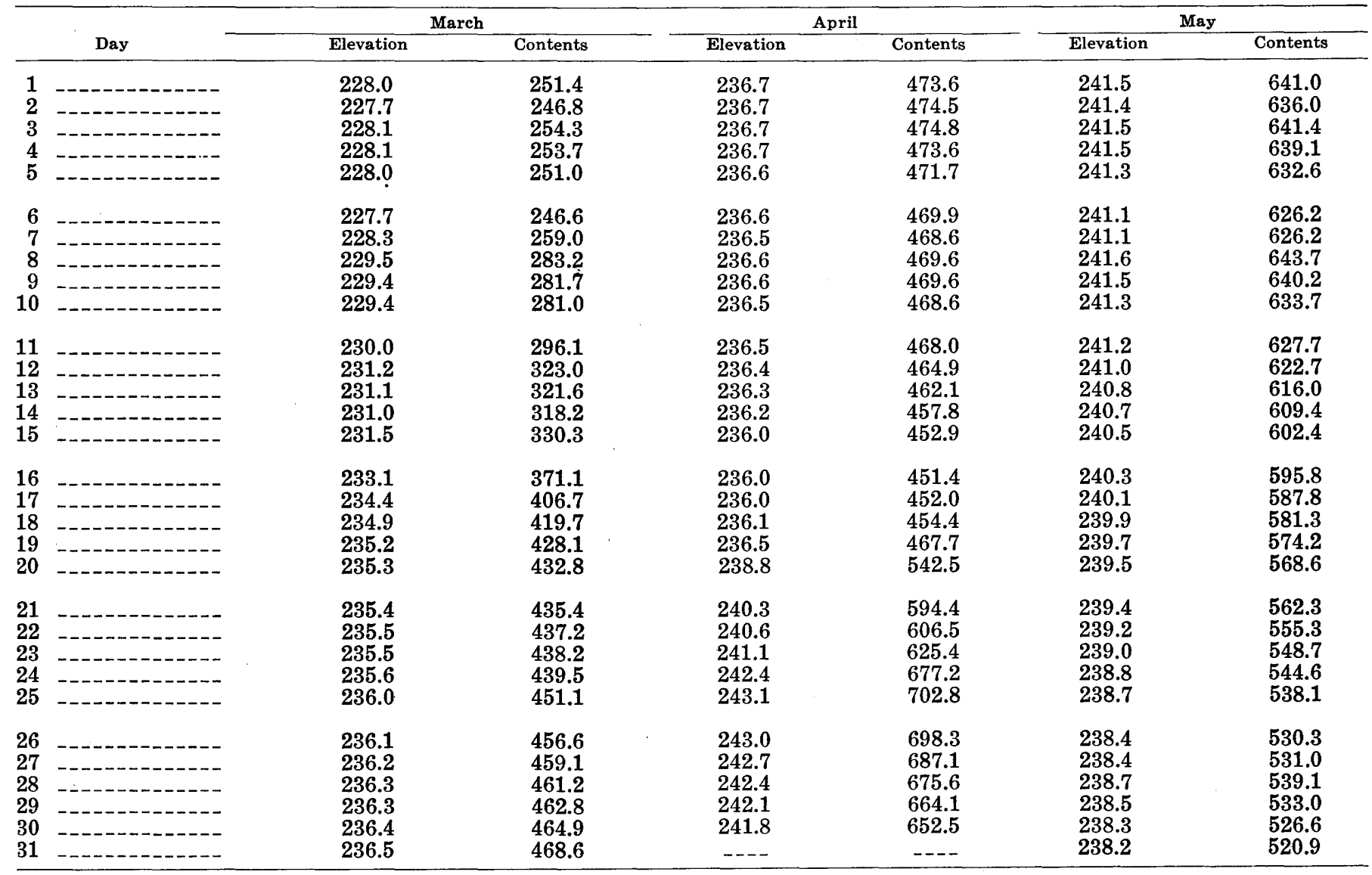


TABLE 12.-Station descriptions and discharge and suspended-sediment data-Continued

\section{YAZOO RIVER BASIN}

(54) 07284500 Grenada Lake near Grenada, Miss.

Location.-Lat $33^{\circ} 48^{\prime} 31^{\prime \prime}$, long $89^{\circ} 46^{\prime} 14^{\prime}$, in $\mathrm{NE}^{1 / 4} \mathrm{NE}^{1 / 4}$ sec. 4, T. 22 N., R. 5 E., Choctaw meridian, Grenada County, at gatehouse of dam on Yalobusha River, 2.2 miles $(3.5 \mathrm{~km})$ up stream from Batupan Creek, 3 miles (5 km) northeast of Grenada, and 63.6 miles $(102.3 \mathrm{~km})$ upstream from mouth of Yalobusha River.

Drainage area.-1,320 $\mathrm{mi}^{2}\left(3,418 \mathrm{~km}^{2}\right)$, approximately.

Gage.-Water-stage recorder. Datum of gage is at mean sea level (levels by Corps of Engineers). Prior to Dec. 19, 1953, nonrecording gage at same site. Prior to Oct. 1,1958 , at datu $160.00 \mathrm{ft}(48.768 \mathrm{~m})$ above mean sea level.

Maxima.-March-May, 1973: Contents, 1,575,600 acre-ft $\left(1,940 \mathrm{hm}^{3}\right)$ April 28 (elevation $234.48 \mathrm{ft}$ or $71.470 \mathrm{~m}$ ).

1953 to February 1973: Contents, 1,189,800 acre-ft April 15, 16, 1962 (elevation, $228.62 \mathrm{ft}$ or $69.683 \mathrm{~m}$ ).

Remarks.-Reservoir is formed by a rolled-fill earth dam with concrete spillway and outlet tunnel. Storage began June 30 , 1953. Capacity, 1,337,400 acre-ft $\left(1,650 \mathrm{hm}^{3}\right)$ at elevation $231.0 \mathrm{ft}$ or $70.41 \mathrm{~m}$ (crest of spillway), of which about $1,251,700$ acre-ft $\left(1,540 \mathrm{hm}^{3}\right)$ is available for flood-control storage and about 85,700 acre-ft $\left(106 \mathrm{hm}^{3}\right)$ of storage is maintained in conservation pool for incidental recreational purposes at elevation $193.0 \mathrm{ft}$ or $58.83 \mathrm{~m}(24 \mathrm{ft}$ or $7.3 \mathrm{~m}$ above sill of outlet gates). Water below $169.0 \mathrm{ft}(51.51 \mathrm{~m})$ cannot be withdrawn through outlet tunnel. Figures given herein represent total contents.

[Elevation, in feet, and contents, in thousands of acre-ft, at $8: 00$ a.m., 1973]

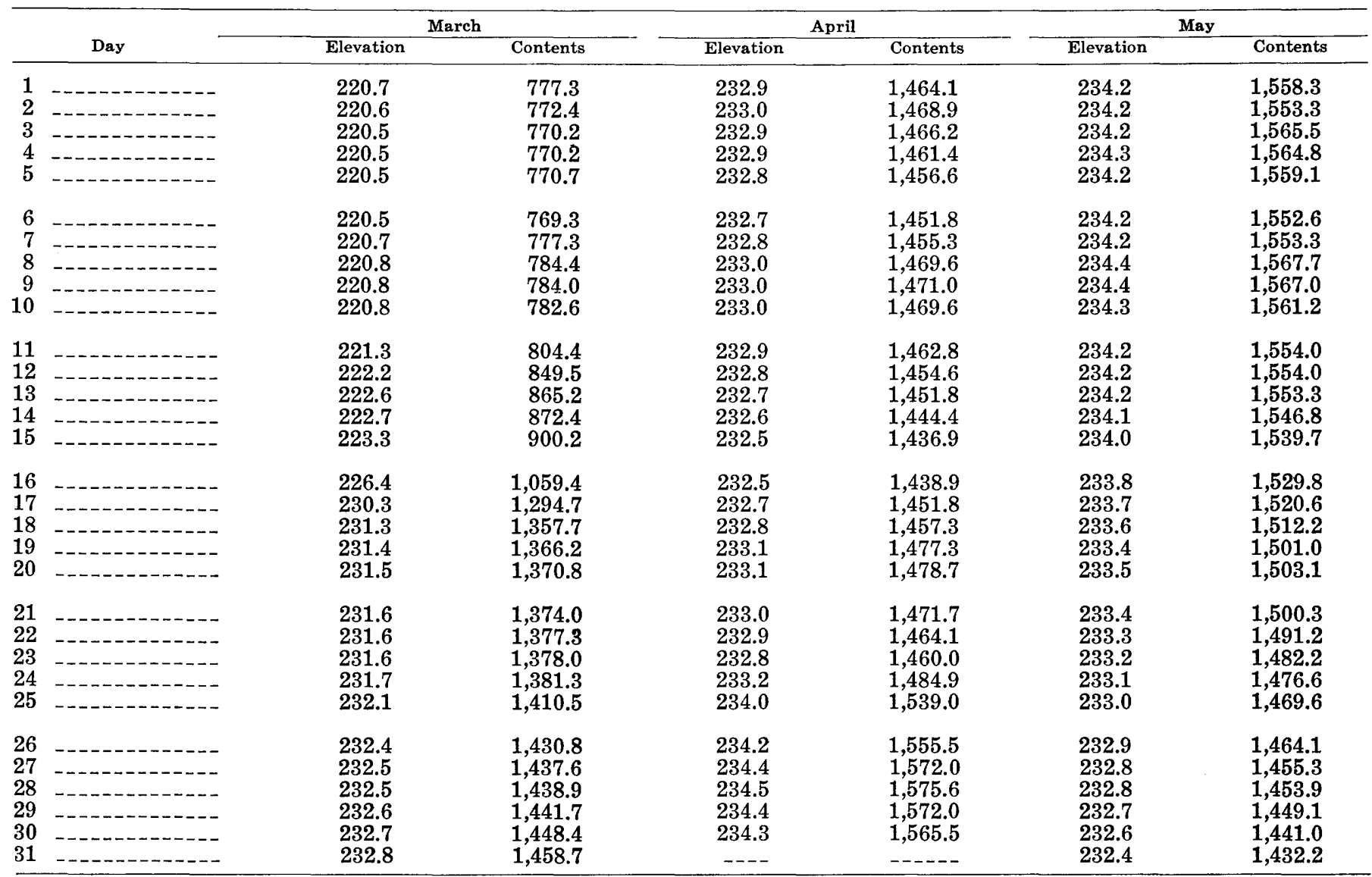

\section{YAZOO RIVER BASIN}

(55) 07287000 Yazoo River at Greenwood, Miss.

Location.-Lat $33^{\circ} 31^{\prime} 17^{\prime \prime}$, long $90^{\circ} 11^{\prime} 03^{\prime \prime}$, in NE1/4 SW1/4 sec. 10 , T. 19 N., R. 1 E. Choctaw meridian, Leflore County, on left bank $110 \mathrm{ft}(33.5 \mathrm{~m})$ downstream from bridge on U.S. Highways $49 \mathrm{E}$ and 82 (old) in Greenwood, $0.4 \mathrm{mile}(0.6 \mathrm{~km})$ downstream from Palusha Bayou, 3 miles $(4.8 \mathrm{~km})$ downstream from confluence of Little Tallahatchie and Yalobusha Rivers, and at mile $170.8(274.8 \mathrm{~km})$

Drainage area.- $-7,450 \mathrm{mi}^{2}\left(19,300 \mathrm{~km}^{2}\right)$, approximately.

Gage.-Water-stage recorder, and nonrecording gage read twice daily. Datum of gage is $92.07 \mathrm{ft}(28.063 \mathrm{~m})$ above mean sea level. Prior to Oct. 1, 1940, nonrecording gages on highway bridges $110 \mathrm{ft}(33 \mathrm{~m})$ upstream at various datums.

*Flood stage. -35 feet $(10.7 \mathrm{~m})$.

Maxima.-March-May 1973: Discharge, $43.800 \mathrm{ft}^{3} / \mathrm{s} \quad\left(1,240 \mathrm{~m}^{3} / \mathrm{s}\right)$ Mar. 20, 21 gage height, $38.37 \mathrm{ft}$ (11.695 m) Mar. 21. 1907 to February 1973: Discharge, $72,900 \mathrm{ft}^{3} / \mathrm{s}\left(2,060 \mathrm{~m}^{3} / \mathrm{s}\right)$ Jan. 19, 1932 (gage height, $40.10 \mathrm{ft}(12.222 \mathrm{~m})$.

Maximum stage known, $41.2 \mathrm{ft}(12.56 \mathrm{~m})$ in 1882 , caused by overflow from Mississippi River (discharge not determined), from reports of Mississippi River Commission. 
TABLE 12.-Station description and discharge and suspended-sediment data-Continued

Remarks.-Flow partly regulated since Aug. 26, 1939, by Sardis Lake on Little Tallahatchie River (see sta 07272000), Enid Lake on Yocona River (see station 07274500), Arkabutla Lake on Coldwater River (see station 07278000), and Grenada Lake on Yalobusha River (see station 07284500). Station data are included to show outflow from upstream impoundments; peak discharge was not exceptional.

*From reports of U.S. Department of Commerce, NOAA.

[Gage height, in feet, and discharge, in cubic feet per second, 1973]

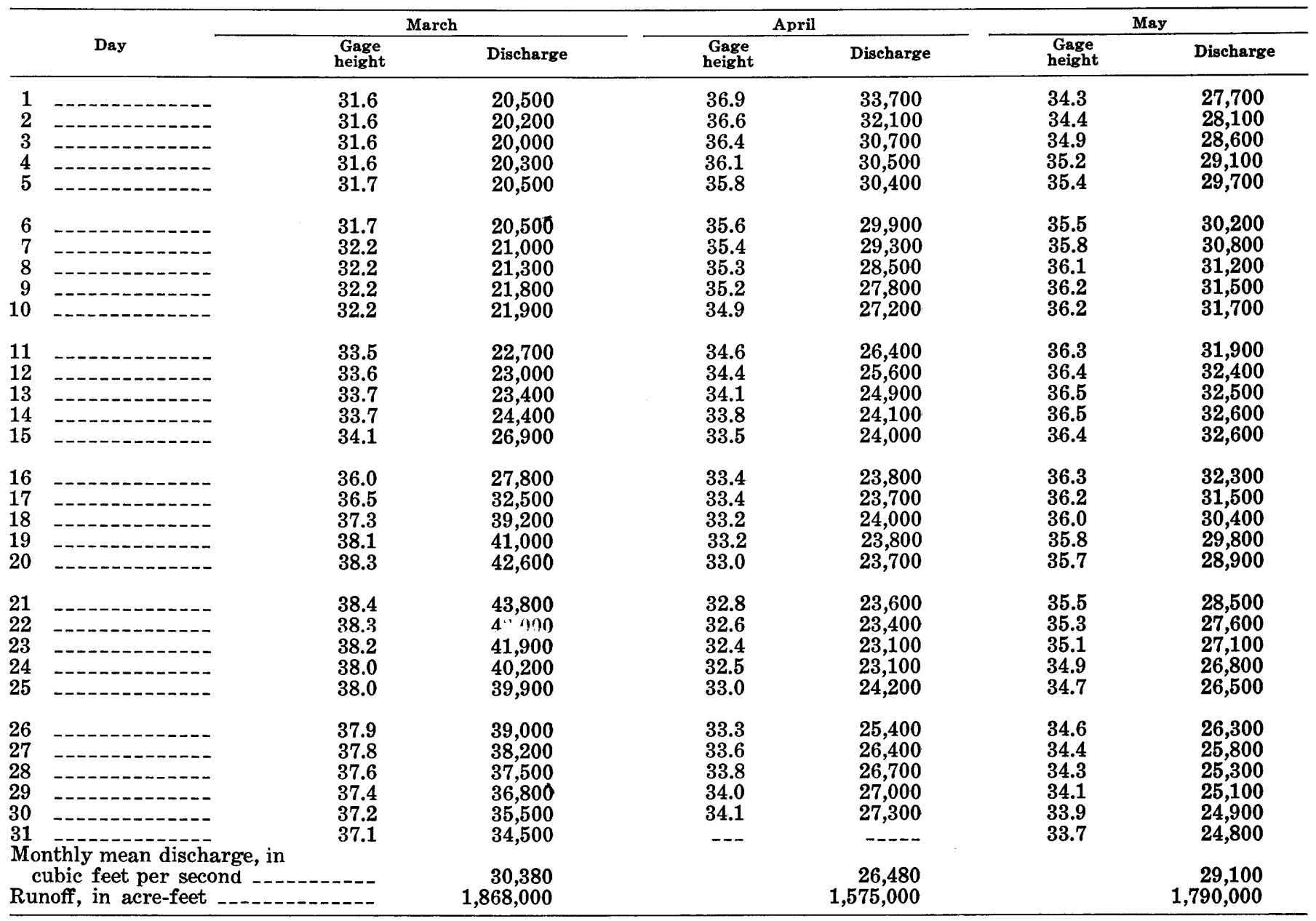

MISSISSIPPI RIVER MAIN STEM

(56) 07289000 Mississippi River at Vicksburg, Miss.

Location.-Lat $32^{\circ} 18^{\prime} 45^{\prime \prime}$, long $90^{\circ} 54^{\prime} 25^{\prime \prime}$, in T. 16 N., R. 3 E., Washington meridian, Warren County, over cavity of fourth pier from left bank at combined highway and railway bridge of Vicksburg Bridge Commission of Warren County, at southern city limits of Vicksburg, 1.5 miles $(2.4 \mathrm{~km})$ downstream from Yazoo diversion canal and at mile $430.4(692.5$ $\mathrm{km})$.

Drainage area.-1,144,500 $\mathrm{mi}^{2}\left(2,964,300 \mathrm{~km}^{2}\right)$, approximately.

Gage.-Water-stage recorder (bridge gage) maintained by Geological Survey. Jan. 1, 1963, to Dec. 31, 1967, supplementary water-stage recorder on left bank near downstream side of bridge, and since Jan. 1, 1968, on left bank at site 1.1 miles $(1.8 \mathrm{~km})$ upstream, maintained by Corps of Engineers. Datum of gage is $46.22 \mathrm{ft}(14.088 \mathrm{~m})$ above mean sea level (Corps of Engineers bench mark) or $46.16 \mathrm{ft}(14.070 \mathrm{~m}$ ) above mean gulf level. Gages used by Mississippi River Commission: Diec. 10, 1871, to Sept. 30, 1929, nonrecording gage at mouth of Yazoo diversion canal, $1.5 \mathrm{miles}(2.4 \mathrm{~km}) \mathrm{upstream}$ from bridge gage; since October 1929, nonrecording gage on Yazoo diversion canal, $1,600 \mathrm{ft}(490 \mathrm{~m}) \mathrm{upstream}$ from mouth. Gages used by U.S. Weather Bureau: May 18, 1873, to Oct. 29, 1919, nonrecording gage $0.5 \mathrm{mile}(0.8 \mathrm{~km}) \mathrm{up}-$ stream from bridge gage; Oct. 30, 1919, to Nov. 30, 1922, nonreading gage at mouth of Yazoo Canal; Dec. 1, 1922, to Aug. 31, 1934, nonrecording gage on Yazoo diversion canal; Sept. 1, 1934, to Dec. 31, 1962, nonrecording gage at bridge; Jan. 1, 1963, to Dec. 31, 1967, waterstage recorder on left bank near downstream side of bridge and since Jan. 1, 1968 , on left bank at site 1.1 miles $(1.8 \mathrm{~km})$ upstream.

All gages at same datum, but readings differ due to slope of water surface between them.

Flood stage. $43.0 \mathrm{ft}(13.11 \mathrm{~m})$. Flood stage was exceeded for 88 consecutive days (Mar. 24-June 19)

Maxima.-March-May 1973: Discharge, 1,962,000 $\mathrm{ft}^{3} / \mathrm{s}\left(55.600 \mathrm{~m}^{3} / \mathrm{s}\right)$ May 12; maximum gage height, $53.10 \mathrm{ft}(16.185 \mathrm{~m})$ May 14 at supplementary recorder. Recurrence interval of discharge is 25 years (based on figure 30 ). 
TABLE 12.-Station descriptions and discharge and suspended-sediment data-Continued

1928 to February 1973: Discharge, 2,080,000 $\mathrm{ft}^{3} / \mathrm{s}\left(58,900 \mathrm{~m}^{3} / \mathrm{s}\right)$ Feb 17, 1937; maximum gage height, $53.2 \mathrm{ft}(16.22 \mathrm{~m})$ Feb. 21, 1937;

Maximum stage known since at least 1871, $58.4 \mathrm{ft}(17.80 \mathrm{~m})$, (Corps of Engineers gage on Yazoo diversion canal), approximately $56.0 \mathrm{ft}(17.07 \mathrm{~m})$ May 4, 1927 (Geological Survey gage).

Remarks.-Natural flow of stream affected by many reservoirs and navigation dams.

[Gage height, in feet, and discharge, in cubic feet per second, 1973]

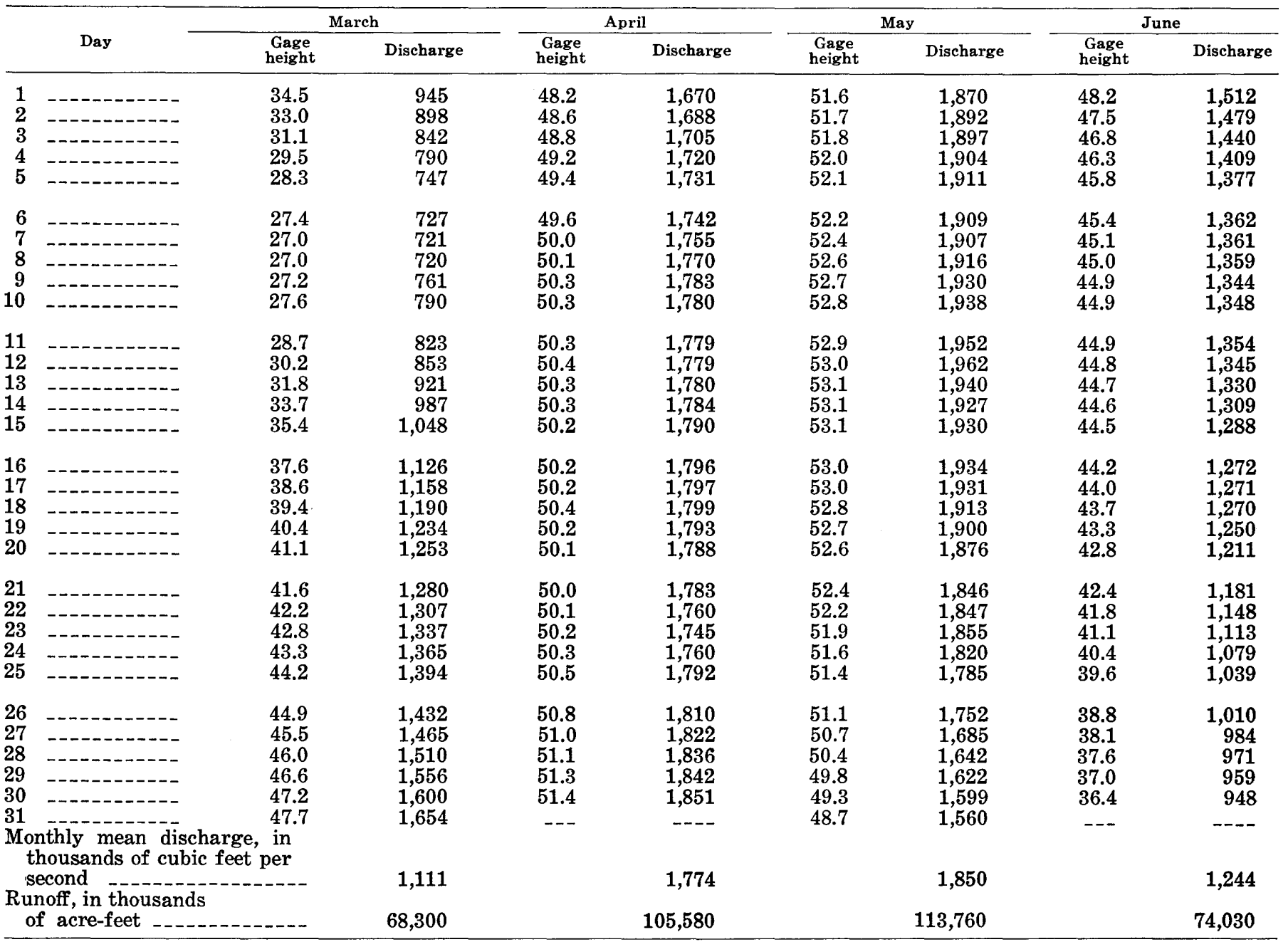

[Highest mean discharge, in thousands of cubic feet per second, for the following number of consecutive days]

\begin{tabular}{|c|c|c|c|c|c|c|c|c|c|}
\hline Period & 1 & 3 & 7 & 15 & 30 & 60 & 90 & 120 & 183 \\
\hline $1932-67$ & 2,080 & 2,070 & 2,060 & 2,030 & 1,940 & 1,740 & 1,560 & 1,450 & 1,200 \\
\hline 1973 flood :- & 1,960 & 1,950 & $\mathbf{1}, 940$ & 1,930 & 1,890 & 1,820 & 1,680 & $\mathbf{1 , 5 1 0}$ & 1,380 \\
\hline $\begin{array}{l}\text { Recurrence interval, in years, } \\
\text { for } 1973 \text { flood volumes }\end{array}$ & 25 & 35 & 40 & 45 & 50 & 90 & $>100$ & $>100$ & $>100$ \\
\hline
\end{tabular}


TABLE 12.-Station descriptions and discharge and suspended-sediment data-Continued

A verage velocity, water temperature, stage, water discharge, suspended sediment, and bed material for given days

\begin{tabular}{|c|c|c|c|c|c|c|c|c|c|c|c|c|c|c|c|}
\hline & \multirow{3}{*}{\multicolumn{2}{|c|}{ Date }} & \multirow{3}{*}{$\begin{array}{l}\text { Average } \\
\text { velocity } \\
\text { (fps) }\end{array}$} & \multirow{3}{*}{$\begin{array}{c}\text { Water } \\
\text { tempera- } \\
\text { ture } \\
\left({ }^{\circ} \mathrm{C}\right)\end{array}$} & \multirow{3}{*}{$\begin{array}{c}\text { Stage } \\
(\mathrm{ft})\end{array}$} & \multirow{3}{*}{$\begin{array}{c}\text { Discharge } \\
\left(1,000 \mathrm{ft}^{3} / \mathrm{s}\right)\end{array}$} & \multicolumn{6}{|c|}{ Suspended sediment } & \multirow{2}{*}{\multicolumn{3}{|c|}{$\begin{array}{c}\text { Bed material } \\
(\mathrm{mm})\end{array}$}} \\
\hline & & & & & & & \multicolumn{4}{|c|}{ Concentration, $\mathrm{mg} / 1$} & \multirow{2}{*}{$\begin{array}{c}\text { Discharge } \\
(1,000 \\
\text { tons/day })\end{array}$} & \multirow{2}{*}{$\begin{array}{l}\text { Percent } \\
\text { sand }\end{array}$} & & & \\
\hline & & & & & & & Right & Middle & Left & Average & & & $D_{16}$ & D50 & $\mathrm{D}_{\$ 4}$ \\
\hline \multirow[t]{4}{*}{ March } & 5 & & $-\quad 5.50$ & 9.0 & 30.23 & 759 & 282 & 218 & 261 & 254 & 520 & 34 & 0.42 & 0.65 & 1.18 \\
\hline & 12 & --- & $-\quad 5.97$ & 12.0 & 32.07 & 869 & 405 & 346 & 335 & 363 & 850 & 25 & .33 & .44 & .61 \\
\hline & 19 & -- & -7.34 & 13.0 & 42.17 & 1,256 & 694 & 505 & 423 & 541 & 1,833 & 39 & .51 & 1.14 & 2.90 \\
\hline & & --- & $-\quad 7.73$ & 12.0 & 46.79 & 1,435 & 598 & 408 & 296 & 434 & 1,682 & 47 & .35 & .48 & 2.61 \\
\hline \multirow[t]{7}{*}{ April } & 2 & -- & -8.66 & 13.5 & 50.41 & 1,752 & 755 & 492 & $33^{3} 3$ & 534 & 2,524 & 66 & .32 & .52 & 3.92 \\
\hline & 9 & & -8.71 & 13.0 & 52.17 & 1,790 & 652 & 406 & 247 & 435 & 2,102 & 62 & .34 & .54 & 3.30 \\
\hline & 18 & & $-\quad 8.65$ & 13.5 & 52.41 & 1,795 & 502 & 364 & 219 & 361 & 1,755 & 61 & .41 & .80 & 2.56 \\
\hline & 21 & & -8.79 & 15.0 & 52.03 & 1,786 & 427 & 289 & 173 & 296 & 1,431 & 62 & .36 & .52 & 1.97 \\
\hline & 23 & $\ldots$ & 8.75 & 15.0 & 52.16 & 1,755 & 430 & 241 & 150 & 273 & 1,297 & 60 & .89 & 1.62 & 2.90 \\
\hline & 28 & -.. & -9.07 & 16.0 & 53.09 & 1,840 & 398 & 232 & 167 & 265 & 1,321 & 61 & .56 & 1.16 & 4.11 \\
\hline & 30 & -1 & -9.03 & 16.0 & 53.45 & 1,852 & 349 & 242 & 167 & 253 & 1,264 & 57 & .37 & .52 & 1.64 \\
\hline \multirow[t]{8}{*}{ May } & 2 & -- & -9.17 & 18.0 & 53.70 & 1,888 & & & & & & & .76 & 1.92 & 7.40 \\
\hline & $\begin{array}{l}7 \\
9\end{array}$ & & -9.26 & 18.5 & 54.34 & 1,899 & 421 & 264 & 170 & 285 & 1,463 & 54 & .36 & .48 & .65 \\
\hline & $\begin{array}{r}9 \\
14\end{array}$ & $\cdots$ & $\begin{array}{r}9.18 \\
-\quad 8.84\end{array}$ & 18.5 & 54.75 & 1,917 & & & & & & & 1.58 & 2.97 & 5.48 \\
\hline & $\begin{array}{l}14 \\
16\end{array}$ & - & $\begin{array}{l}8.84 \\
-\quad 8.82\end{array}$ & $\begin{array}{l}19.0 \\
19.0\end{array}$ & 55.05 & 1,911 & 314 & 275 & 150 & 247 & 1,271 & 50 & .38 & 1.05 & 4.50 \\
\hline & 21 & - & $\begin{array}{r}8.82 \\
-\quad 8.55\end{array}$ & 19.0 & 55.01 & 1,911 & 403 & 238 & 159 & 267 & 1,378 & 6 & .38 & .57 & 2.24 \\
\hline & 23 & $\cdots$ & $\begin{array}{r}8.55 \\
-\quad 8.67\end{array}$ & & $\begin{array}{l}54.33 \\
53.88\end{array}$ & 1,831 & 292 & 206 & 124 & 207 & 1,025 & 58 & 1.28 & 2.38 & 4.73 \\
\hline & 28 & - & -8.43 & $\begin{array}{l}20.0 \\
21.0\end{array}$ & $\begin{array}{l}53.88 \\
52.43\end{array}$ & $\begin{array}{l}1,843 \\
1,623\end{array}$ & 333 & 168 & 116 & 205 & 1,024 & 59 & 1.14 & 2.77 & 5.60 \\
\hline & 30 & - & 8.28 & 21.0 & 51.35 & $\begin{array}{l}1,025 \\
1,550\end{array}$ & $\overline{2} \overline{5} \overline{6}$ & $\overline{167}$ & $\overline{9} \overline{3}$ & $\overline{17} \overline{2}$ & $\overline{72 \overline{1}}$ & $\overline{5} \overline{2}$ & .88 & 2.44 & 5.49 \\
\hline \multirow{8}{*}{ June } & & & 7.68 & 23.0 & 48.33 & 1,429 & 245 & 155 & 120 & 174 & 669 & 37 & .55 & 1.72 & 5.11 \\
\hline & 6 & - & 7.63 & 23.5 & 47.46 & 1,385 & 231 & 137 & 128 & 166 & 618 & 40 & .60 & 2.45 & 4.96 \\
\hline & 11 & (2)- & -7.62 & 24.0 & 46.92 & 1,377 & 280 & 184 & 142 & 203 & 754 & 40 & 1.56 & 2.75 & 5.00 \\
\hline & 13 & - & $-7.5 \overline{1}$ & 24.5 & 46.75 & 1,353 & 245 & 171 & 143 & 186 & 681 & 33 & 1.88 & 3.27 & 5.94 \\
\hline & 18 & 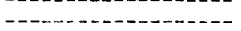 & -7.18 & 26.0 & 45.78 & 1,292 & 226 & 159 & 119 & 168 & 587 & 36 & .44 & 2.40 & 4.88 \\
\hline & 20 & - & -6.94 & 26.5 & 44.94 & 1,231 & 230 & 157 & 122 & 169 & 565 & 32 & .96 & 2.35 & 4.33 \\
\hline & 25 & - n & $-\quad 6.36$ & 27.0 & 41.65 & 1,057 & 198 & 161 & 135 & 165 & 470 & 21 & 1.66 & 3.150 & 5.64 \\
\hline & 27 & - - - - & 6.14 & 28.0 & 40.15 & 1,000 & 212 & 163 & 141 & 171 & 464 & 19 & 1.41 & 2.75 & 4.80 \\
\hline
\end{tabular}

\section{MISSISSIPPI RIVER BASIN}

(57) 07290880 Mississippi River at Natchez, Miss.

Location.-Lat $31^{\circ} 33^{\prime} 37^{\prime \prime}$, long $91^{\circ} 25^{\prime} 07^{\prime \prime}$, at bridge on U.S. Highway 84 , at Natchez at mile 359 (578 km).

Drainage area. $-1,149,400 \mathrm{mi}^{2}\left(2,976,900 \mathrm{~km}^{2}\right) ; 22,240 \mathrm{mi}^{2}\left(57,600 \mathrm{~km}^{2}\right)$ is noncontributing.

Gage.-Wire-weight gage. Datum of gage is $17.28 \mathrm{ft}(5.267 \mathrm{~m})$ above mean sea level. 1871 to date. Stages prior to 1941 0.3 miles $(0.5 \mathrm{~km})$ upstream at same datum.

Maxima.-March-May 1973: Discharge, 2,017,000 ft's $\left(57,100 \mathrm{~m}^{3} / \mathrm{s}\right)$ May 18 [gage height, $56.7 \mathrm{ft}$ (17.28 m) May 13].

1871-Feb. 1973; Discharge, 2,046,000 $\mathrm{ft}^{3} / \mathrm{s}\left(57,900 \mathrm{~m}^{3} / \mathrm{s}\right)$ Feb. 19, 1937 [gage height, 58.04 ft $(17,691 \mathrm{~m}) \mathrm{Feb} .21,1937$ ] Remarks. - Station data included in this report primarily for sediment analysis.

Average velocity, water temperature, stage, water discharge, suspended sediment, and bed material for given days

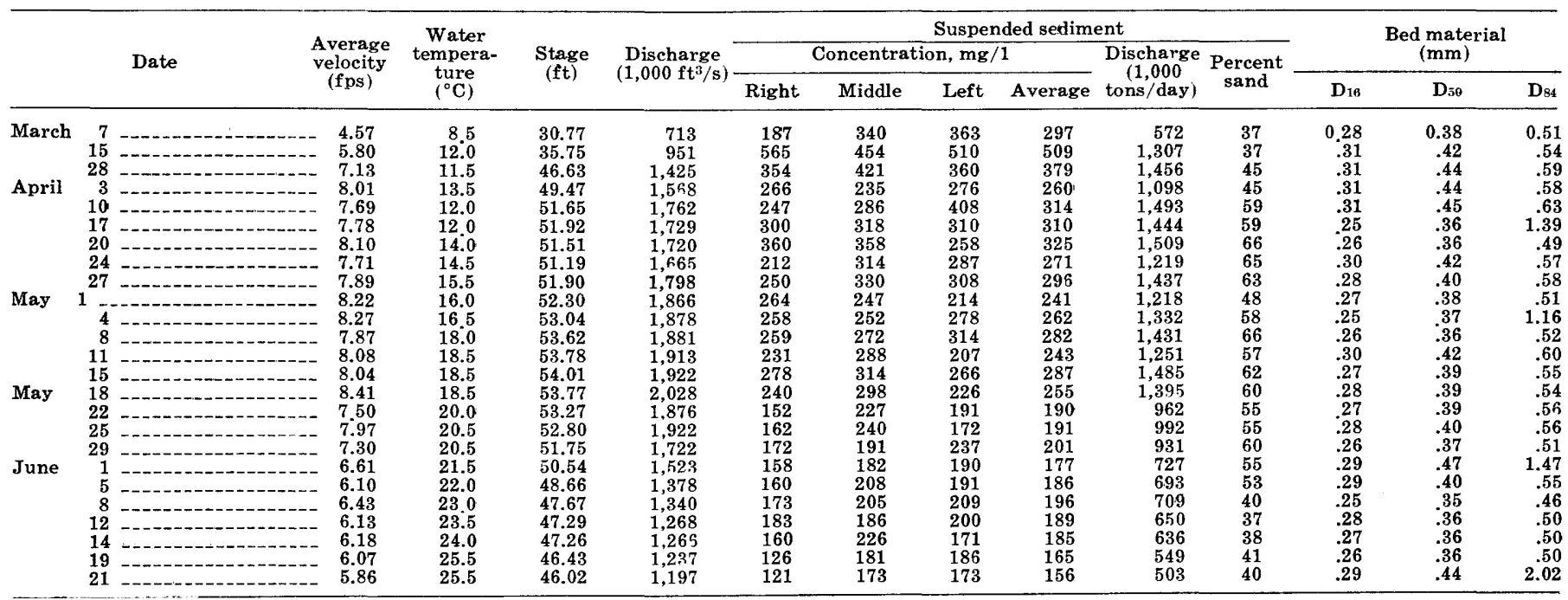

BUFFALO RIVER BASIN

(58) 07295000 Buffalo River near Woodville, Miss.

Location.-Lat $31^{\circ} 13^{\prime} 35^{\prime \prime}$, long $91^{\circ} 17^{\prime} 45^{\prime \prime}$, in SW1/4 sec. 21 , T. 3 N., R. 2 W., Washington meridian, Wilkinson County, near center of span on downstream side of bridge on U.S. Highway $61,1.5$ miles $(2.4 \mathrm{~km})$ downstream from Fords Creek, 2.8 miles $(4.5 \mathrm{~km})$ west of Wilkinson, and 8.5 miles $(13.7 \mathrm{~km})$ north of Woodville. 
TABLE 12.—Station descriptions and discharge and suspended-sediment data-Continued

Drainage area.-182 $\mathrm{mi}^{2}\left(471 \mathrm{~km}^{2}\right)$.

Gage.-Water-stage recorder. Datum of gage is $94.52 \mathrm{ft}(28.810 \mathrm{~m})$ above mean sea level. Prior to June 1 , 1942, nonrecording gage at same site. Prior to Oct. 1, 1964, at datum $3.00 \mathrm{ft}(0.914 \mathrm{~m})$ higher.

Maxima.-March-May 1973: Discharge, 65,000 $\mathrm{ft}^{3} / \mathrm{s}\left(1840 \mathrm{~m}^{3} / \mathrm{s}\right)$ March 25 (gage height ${ }^{1}, 22.3 \mathrm{ft}$ or $\left.6.80 \mathrm{~m}\right)$; Recurrance interval of discharge is 40 years.

1942 to February 1973: Discharge, $44,800 \mathrm{ft}^{3} /\left(1270 \mathrm{~m}^{3} / \mathrm{s}\right)$ Oct. 4, 1964 (gage height, $20.19 \mathrm{ft}$ or $6.154 \mathrm{~m}$ ).

${ }^{1}$ From flood mark.

[Mean discharge, in cubic feet per second, 1973]

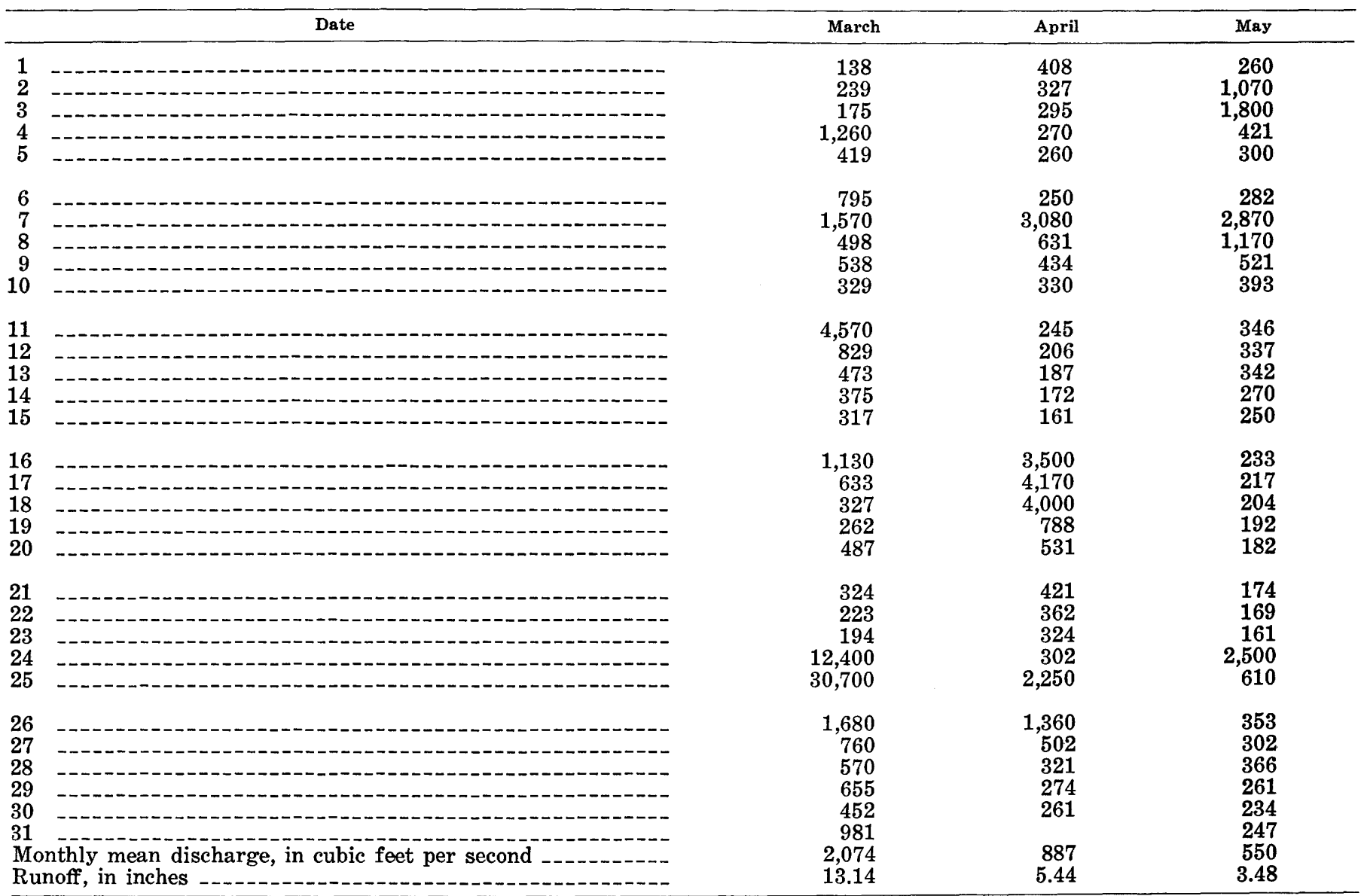

[Highest mean discharge, in cubic feet per second, for the following number of consecutive days]

\begin{tabular}{|c|c|c|c|c|c|c|c|c|c|}
\hline Period & 1 & 3 & 7 & 15 & 30 & 60 & 90 & 120 & 183 \\
\hline $1943-71$ flood 1973 & $\begin{array}{l}25,400 \\
30,700\end{array}$ & $\begin{array}{l}13,100 \\
14,900\end{array}$ & $\begin{array}{l}6,860 \\
6,760\end{array}$ & $\begin{array}{l}3,420 \\
3,540\end{array}$ & $\begin{array}{l}2,170 \\
2,310\end{array}$ & $\begin{array}{l}1,310 \\
1,560\end{array}$ & $\begin{array}{l}1,120 \\
1,240\end{array}$ & $\begin{array}{r}930 \\
1,040\end{array}$ & $\begin{array}{l}801 \\
916\end{array}$ \\
\hline $\begin{array}{l}\text { Recurrence interval, in years, } \\
\text { for } 1973 \text { flood volumes }\end{array}$ & 40 & 40 & 40 & 35 & 35 & 40 & 40 & 40 & 35 \\
\hline
\end{tabular}

\section{MISSISSIPPI RIVER MAIN STEM}

(59) 07295100 Mississippi River at Tarbert Landing, Miss.

Location.-Lat $31^{\circ} 00^{\prime} 30^{\prime \prime}$, long $91^{\circ} 37^{\prime} 25^{\prime \prime}$, Lot 6, T. 1 N., R. 5 W., Wilkinson County rear left bank at Tarbert Landing, $2 \frac{1}{2}$ miles $(3.9 \mathrm{~km})$ upstream from lower Old River at mile $306.3(492.8 \mathrm{~km})$.

Drainage area. $-1,128,900 \mathrm{mi}^{2}\left(2,923,900 \mathrm{~km}^{2}\right)$, contributing.

Gage.-Staff gage. Datum of gage is mean sea level.

Maxima.-March-May 1973: Discharge, 1,498,000 $\mathrm{ft}^{3} / \mathrm{s} \quad\left(42,400 \mathrm{~m}^{3} / \mathrm{s}\right)$ May 16 [elevation, $54.61 \mathrm{ft}$ (16.645 m)]. Recurrence interval of discharge is 40 years.

1932-February 1973: Discharge, 1,997,000 $\mathrm{ft}^{3} / \mathrm{s}\left(56,000 \mathrm{~m}^{3} / \mathrm{s}\right)$ observed on Feb. 19, 1957.

Remarks. - Discharge below the outflow channel were used for the duration table and are for Red River Landing from 192962 and Tarbert Landing from 1964-71. Stage data for this station are collected at Red River Landing, mile 301 (484 km). The discharge data are collected upstream from the diversions that are used to control flood stages in the lower basin. 
TABLE 12.-Station descriptions and discharge and suspended-sediment data-Continued

Mean discharge, in cubic feet per second, 1973

\begin{tabular}{|c|c|c|c|c|c|c|c|c|c|c|c|c|c|c|c|c|c|c|c|}
\hline \multicolumn{5}{|c|}{ March } & \multicolumn{5}{|c|}{ April } & \multicolumn{5}{|c|}{ May } & & \multicolumn{4}{|c|}{ June } \\
\hline \multirow{2}{*}{\multicolumn{2}{|c|}{ Day }} & \multirow[b]{2}{*}{$\begin{array}{c}\text { Mean } \\
\text { discharge } \\
\left(1,000 \mathrm{f}^{3} / \mathrm{s}\right)\end{array}$} & \multicolumn{2}{|c|}{ Suspend sediment } & \multirow{2}{*}{\multicolumn{2}{|c|}{ Day }} & \multirow[b]{2}{*}{$\begin{array}{c}\text { Mean }_{\text {f }} \\
\text { discharge } \\
\left(1,000 \mathrm{f}^{3} / \mathrm{s}\right)\end{array}$} & \multicolumn{2}{|c|}{ Suspend sediment } & \multirow{2}{*}{\multicolumn{2}{|c|}{ Day }} & \multirow[b]{2}{*}{$\begin{array}{c}\text { Mean } \\
\text { discharge } \\
\left(1,000 \mathrm{f}^{3} / \mathrm{s}\right)\end{array}$} & \multicolumn{2}{|c|}{ Suspend sediment } & & \multirow[b]{2}{*}{ Day } & \multirow[b]{2}{*}{$\begin{array}{c}\text { Mean } \\
\text { discharge } \\
\left(1,000 \mathrm{f}^{3} / \mathrm{s}\right)\end{array}$} & \multicolumn{2}{|c|}{ Suspend sediment } \\
\hline & & & $\begin{array}{c}\text { Mean } \\
\text { concen- } \\
\text { tration } \\
(\mathrm{mg} / 1)\end{array}$ & $\begin{array}{c}\text { Dis- } \\
\text { charge } \\
(1,000 \\
\text { tons/day })\end{array}$ & & & & $\begin{array}{c}\text { Mean } \\
\text { concen- } \\
\text { tration } \\
(\mathrm{mg} / 1)\end{array}$ & $\begin{array}{c}\text { Dis- } \\
\text { charge } \\
(1,000 \\
\text { tons/day })\end{array}$ & & & & $\begin{array}{c}\text { Mean } \\
\text { concen- } \\
\text { tration } \\
(\mathrm{mg} / 1)\end{array}$ & $\begin{array}{c}\text { Dis- } \\
\text { charge } \\
(1,000 \\
\text { tons } / \text { day })\end{array}$ & & & & $\begin{array}{l}\text { Mean } \\
\text { concen- } \\
\text { tration } \\
(\mathrm{mg} / 1)\end{array}$ & $\begin{array}{c}\text { Dis- } \\
\text { charge } \\
(1,000 \\
\text { tons/day })\end{array}$ \\
\hline 1 & $\ldots$ & 759 & 343 & 702 & 1 & & - 1,090 & 361 & 1,064 & 1 & $\ldots$ & $-1,360$ & 200 & 732 & $\mathbf{1}$ & & $-1,220$ & 170 & 558 \\
\hline 2 & $-\ldots$ & 722 & 359 & 699 & 2 & & 1,110 & 348 & 1,044 & 2 & $-\infty$. & {$\left[\begin{array}{l}1,390 \\
-1,390\end{array}\right.$} & 205 & 772 & 2 & & 1,190 & 172 & 553 \\
\hline 3 & --- & 686 & 375 & 695 & 3 & & $-1,150$ & 350 & 1,092 & 3 & -- & $-1,330$ & 219 & 783 & $\overline{3}$ & & $-1,160$ & 174 & 546 \\
\hline 4 & $\ldots$ & 654 & 391 & 691 & 4 & & 1,180 & 356 & 1,135 & 4 & -- & - 1,330 & 227 & 815 & 4 & & 1,130 & 177 & 538 \\
\hline 5 & --- & 620 & 410 & 686 & 5 & & 1,210 & 362 & 1,179 & 5 & -- & 1,400 & 212 & 802 & $\overline{5}$ & & $-1,070$ & 191 & 552 \\
\hline 6 & $-\cdots$ & 594 & 426 & 684 & 6 & & $---1,240$ & 368 & 1,232 & 6 & $-\cdots$ & $-1,390$ & 203 & 762 & 6 & & $-1,090$ & 200 & 588 \\
\hline 7 & --- & 580 & 439 & 688 & 7 & & 1,270 & 373 & 1,283 & 7 & - & 1,370 & 195 & 724 & 7 & & $-1,050$ & 215 & 606 \\
\hline 8 & $\ldots$ & 565 & 453 & 691 & 8 & & $--1,290$ & 381 & 1,329 & 8 & $\ldots$ & $-1,320$ & 190 & 678 & 8 & & 1,050 & 208 & 592 \\
\hline 9 & $\ldots$ & 559 & 462 & 698 & 9 & & $\ldots 1,290$ & 391 & 1,364 & 9 & - & 1,450 & 174 & 680 & 9 & & 1,030 & 205 & 569 \\
\hline 10 & $\ldots$ & 563 & 469 & 713 & 10 & & 1,270 & 367 & 1,258 & 10 & - & 1,390 & 209 & 786 & 10 & & 1,040 & 199 & 556 \\
\hline 11 & $\ldots$ & 582 & 467 & 734 & 11 & & -- 1,290 & 340 & 1,184 & 11 & -- & 1,350 & 250 & 914 & 11 & & 1,010 & 195 & 534 \\
\hline 12 & -- & 591 & 470 & 750 & 12 &.- & 1,350 & 310 & 1,130 & 12 & $\cdots$ & 1,430 & 236 & 910 & 12 & - & 1,010 & 260 & 711 \\
\hline 13 & --- & 618 & 468 & 781 & 13 & & -- 1,300 & 249 & 854 & 13 & & 1,420 & 229 & 878 & 13 & & $-\quad 992$ & 349 & 936 \\
\hline 14 & $\ldots$ & 660 & 461 & 821 & 14 & - & 1,340 & 185 & 672 & 14 & $\cdots$ & 1,430 & 221 & 852 & 14 & & 978 & 303 & 801 \\
\hline 15 & -.- & 709 & 452 & 865 & 15 & & -- 1,340 & 213 & 766 & 15 & -- & 1,430 & 226 & 870 & 15 & & 983 & 261 & 692 \\
\hline 16 & $\ldots$ & 745 & 447 & 899 & 16 & & _- 1,390 & 239 & 895 & 16 & - & $=1,500$ & 225 & 912 & 16 & & 1,000 & 222 & 602 \\
\hline 17 & $\ldots$ & 780 & 443 & 932 & 17 & & -_- 1,360 & 276 & 1,013 & 17 & $\ldots$ & $-1,440$ & 234 & 912 & 17 & - & 979 & 194 & 512 \\
\hline 18 & $\ldots$ & 800 & 444 & 959 & 18 & & 1,410 & 311 & 1,181 & 18 & $-\ldots$ & 1,440 & 239 & 930 & 18 & & 957 & 169 & 436 \\
\hline 19 &.-- & 814 & 448 & 984 & 19 & & -- 1,320 & 290 & 1,035 & 19 & $-\ldots$ & 1,400 & 233 & 881 & 19 & -- & 975 & 191 & 502 \\
\hline 20 & -.-. & 833 & 449 & 1,009 & 20 & & 1,370 & 258 & 954 & 20 & -- & $-1,430$ & 222 & 855 & 20 & $\ldots$ & 964 & 219 & 569 \\
\hline 21 & $\ldots$ & 857 & 448 & 1,037 & 21 & -- & 1,230 & 245 & 817 & 21 & 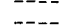 & $-1,410$ & 215 & 817 & 21 & & 937 & 211 & 533 \\
\hline 22 &.-- & 868 & 454 & 1,063 & 22 & $\ldots$ & 1,290 & 255 & 885 & 22 & $-\ldots$ & 1,390 & 208 & 780 & 22 & - & 9 . & & 500 \\
\hline 23 & $-\ldots$ & 887 & 456 & 1,091 & 23 & $\ldots$ & -_ 1,300 & 269 & 943 & 23 & $\ldots$ & $-1,370$ & 182 & 673 & 23 & $\cdots$ & 878 & 197 & 467 \\
\hline 24 & $\ldots$ & 945 & 446 & 1,138 & 24 & -- & 1,280 & 287 & 991 & 24 & $\ldots$ & 1,360 & 159 & 585 & 24 & & 856 & 208 & 492 \\
\hline 25 & -..- & 983 & 445 & 1,180 & 25 & $-\ldots$ & 1,290 & 304 & 1,053 & 25 & $\ldots$ & {$[1,300$} & 163 & 571 & 25 & - & 8 & 227 & 525 \\
\hline 26 & -- & -995 & 450 & 1,210 & 26 & $\ldots$ & 1,240 & 308 & 1,036 & 26 & $\ldots$ & $-1,370$ & 159 & 589 & 26 & -- & 85 & 206 & 472 \\
\hline 27 & $-\ldots$ & $-1,010$ & 436 & 1,183 & 27 & & _. 1,280 & 304 & 1,052 & 27 & & $-1,300$ & 163 & 573 & 27 & & 8. & $\bar{x}$ & $41 \overline{7}$ \\
\hline 28 & -- & $-1,020$ & 420 & 1,159 & 28 & & $-1,260$ & 278 & 945 & 28 & $-\ldots$ & $\begin{array}{r}-1,350 \\
-\end{array}$ & 161 & 587 & 28 & & 81 & 1 & 410 \\
\hline 29 & -- & 1,040 & 404 & 1,135 & 29 & $-\infty$ & 1,360 & 243 & 892 & 29 & $-\ldots$ & $=1,300$ & 164 & 575 & 29 & & 74 & 18 & $\mathbf{3 6 0}$ \\
\hline 30 & --- & 1,050 & 390 & 1,109 & 30 & $\ldots$ & 1,430 & 215 & 831 & 30 & $-\cdots$ & - 1,220 & 169 & 557 & 30 & (n) & 763 & 210 & 430 \\
\hline 31 & $-\cdots$ & 1,070 & 375 & 1,085 & 31 & 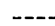 & & -- & & 31 & & 1,210 & 170 & 555 & 31 & & & - & \\
\hline To & tal =- & 24,162 & & 28,071 & & & 38,502 & & 31,110 & & & 42,570 & & 23,310 & & & 29,298 & & 16,559 \\
\hline $\begin{array}{r}\text { Mo } \\
\text { di }\end{array}$ & $\begin{array}{l}\text { nthly } \\
\text { ean } \\
\text { s- }\end{array}$ & $y$ & & & & & & & & & & & & & & & & & \\
\hline \multirow{2}{*}{\multicolumn{2}{|c|}{$\begin{array}{l}\text { charge } \\
\text { Maxi- }\end{array}$}} & 779 & & 906 & & & 1,284 & & 1,037 & & & 1,373 & & 752 & & & 977 & & 552 \\
\hline & & $-1,072$ & & 1,210 & & & 1,433 & & 1,364 & & & 1,498 & & 930 & & & 1,216 & & 936 \\
\hline \multicolumn{2}{|c|}{ mum - } & & & & & & & & & & & & & & & & & & \\
\hline $\mathrm{m}$ & um - & 559 & & 684 & & & 1,093 & & 672 & & & 1,207 & & 555 & & & 744 & & 360 \\
\hline
\end{tabular}

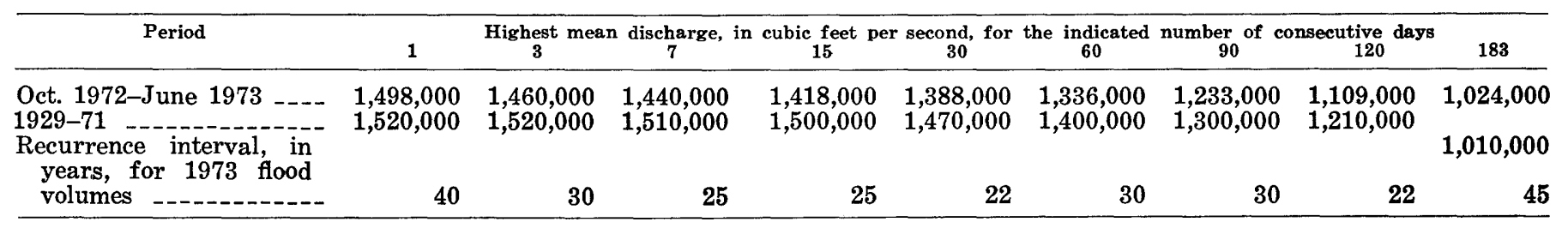

\section{RED RIVER BASIN}

(60) 07355500 Red River at Alexandria, La.

Location.-Lat $31^{\circ} 18^{\prime} 46^{\prime \prime}$, long $92^{\circ} 26^{\prime} 34^{\prime \prime}$, in SE $1 / 4$ sec. 10, T. 4 N., R. 1 W., Rapides Parish, at old bridge on U.S. Highway 165 between Alexandria and Pineville, and 1.7 miles $(2.7 \mathrm{~km})$ downstream from Bayou Rigolette.

Drainage area.-67,500 mi $\left(175,000 \mathrm{~km}^{2}\right)$, of which $5,936 \mathrm{mi}^{2}\left(15,400 \mathrm{~km}^{2}\right)$ above Denison Dam is noncontributing.

Gage-height record.- Nonrecording. Datum of gage is $44.26 \mathrm{ft}(13.490 \mathrm{~m})$ above mean sea level, datum of 1929 , supplementary adjustment of 1941 .

Discharge record.-Stage-discharge relation variable; prior to 1928 , peak discharge based on occasional discharge measurements, and since 1928 on loop curves defined by frequent discharge measurements. Discharge measurements furnished by Mississippi River Commission and Corps of Engineers.

Maxima.-March-May 1973: Discharge, 142,000 $\mathrm{ft}^{3} / \mathrm{s}\left(4,020 \mathrm{~m}^{3} / \mathrm{s}\right)$ Apr. 30 [gage height, $35.00 \mathrm{ft}(10.668 \mathrm{~m})$ ]. Recurrence interval of discharge is 3 years.

1872-February 1973: Discharge, 233,000 $\mathrm{ft}^{3} / \mathrm{s}\left(6,600 \mathrm{~m}^{3} / \mathrm{s}\right)$ Apr. 16-18, 1945 [gage height, $\left.45.2 \mathrm{ft} 13.777 \mathrm{~m}\right)$ ].

Remarks.-Regulation by Lake Texamo since October 1943 and Texarkana Reservoir since July 1953. Gage heights available from Mississippi River Commission since January 1872; from U.S. Weather Bureau since 1890; from U.S. Corps of Engineers since January 1932. Station data included in this report primarily for sediment analysis. 
THE FLOODS

TABLE 12.-Station descriptions and discharge and suspended-sediment data-Continued

Mean water discharge and suspended-sediment concentration and discharge

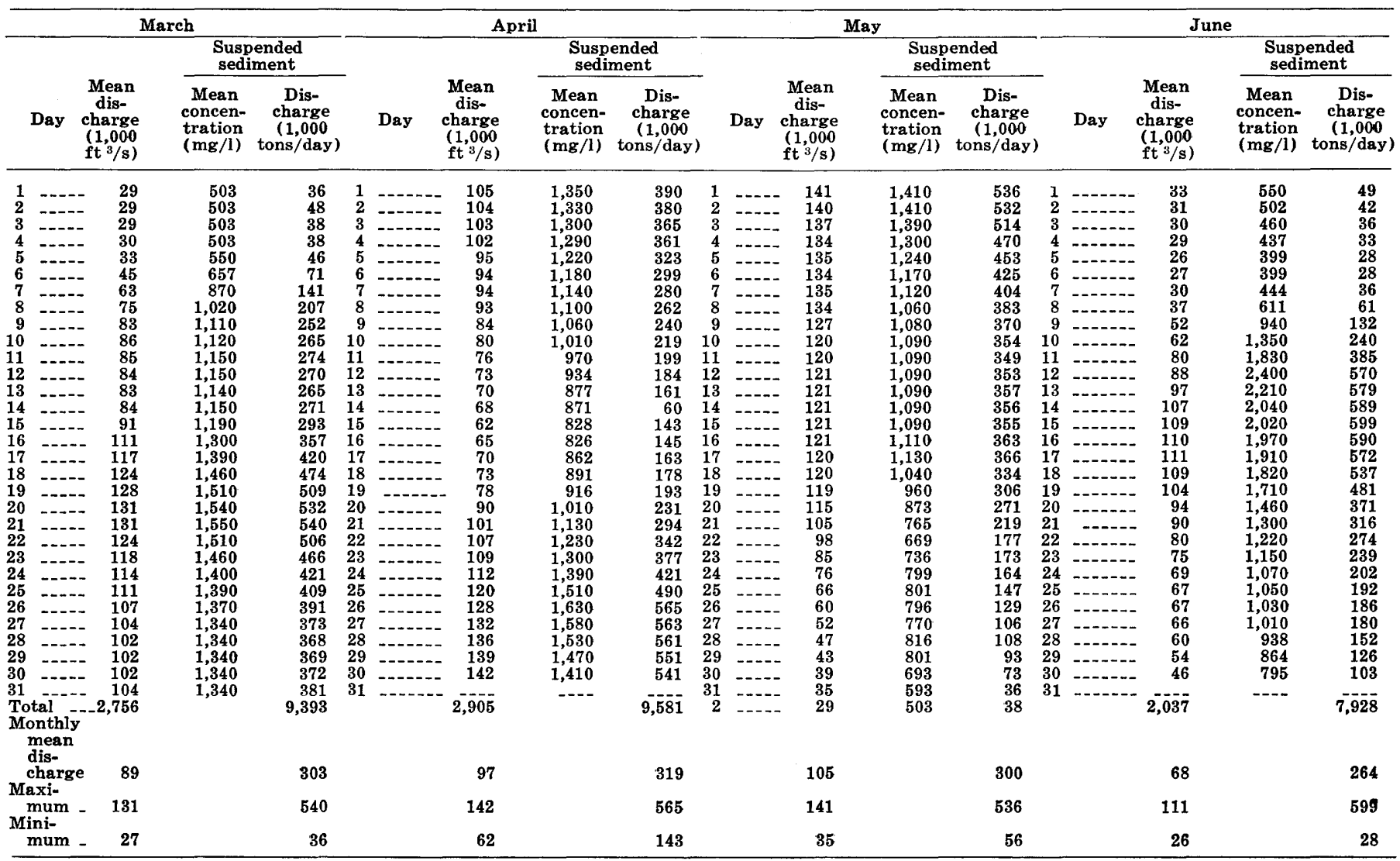

RED RIVER BASIN

(61) 07367000 Ouachita River at Monroe, La.

Location.-Lat $32^{\circ} 30^{\prime} 19^{\prime \prime}$, long $92^{\circ} 07^{\prime} 32^{\prime \prime}$, in lot 50, T. 18 N., R. 3 E., at bridge on U.S. Highway 80 at Monroe and $51 / 2$ miles $(8.8 \mathrm{~km})$ upstream from lock and dam No. 4 .

Drainage area.-15,298 $\mathrm{mi}^{2}\left(39,622 \mathrm{~km}^{2}\right)$.

Gage.-Nonrecording. Datum of gage is $31.40 \mathrm{ft}(9.571 \mathrm{~m})$ above mean sea level, datum of 1929 , supplementary adjustment of 1941. Prior to Jan. 6, 1937, gage at various sites within a half a mile $(0.8 \mathrm{~km})$.

Maxima.-March-May 1973: Maximum daily discharge, 88,900 $\mathrm{ft}^{3} / \mathrm{s}\left(2,520 \mathrm{~m}^{3} / \mathrm{s}\right)$ May 5, 6 ; gage height, $48.8 \mathrm{ft}(14.874 \mathrm{~m})$ May 10. Recurrence interval of discharge is 45 years.

1874-February 1973: Discharge, 101,000 $\mathrm{ft}^{3} / \mathrm{s}\left(2,860 \mathrm{~m}^{3} / \mathrm{s}\right)$ Feb. 2, 3, 1932 [gage height, $50.45 \mathrm{ft}$ (15.377 m) May 23, 1958].

Remarks.-Records of peak stages furnished by Mississippi River Commission and U.S. Weather Bureau since June 1884 and by Corps of Engineers since January 1932. Record from 1938 to date by U.S. Geological Survey.

Discharge, in cubic feet per second

\begin{tabular}{|c|c|c|c|c|}
\hline & Day & March & April & May \\
\hline $\begin{array}{l}1 \\
2 \\
3 \\
4 \\
5\end{array}$ & 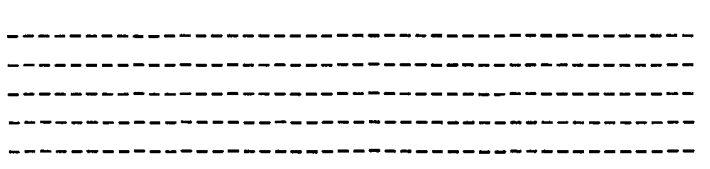 & $\begin{array}{l}51,500 \\
51,300 \\
51,100 \\
50,900 \\
50,800\end{array}$ & $\begin{array}{l}65,000 \\
65,100 \\
65,100 \\
65,100 \\
65,100\end{array}$ & $\begin{array}{l}83,600 \\
86,000 \\
87,900 \\
88,800 \\
88,900\end{array}$ \\
\hline $\begin{array}{r}6 \\
7 \\
8 \\
9 \\
10\end{array}$ & 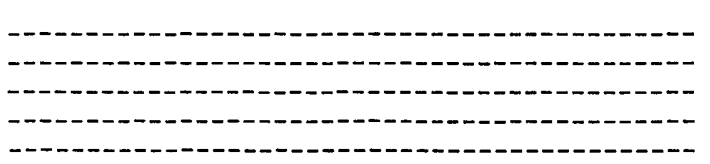 & $\begin{array}{l}50,500 \\
50,400 \\
50,200 \\
50,000 \\
49,900\end{array}$ & $\begin{array}{l}65,100 \\
65,100 \\
64,500 \\
64,400 \\
64,200\end{array}$ & $\begin{array}{l}88,900 \\
88,000 \\
87,600 \\
85,000 \\
83,200\end{array}$ \\
\hline $\begin{array}{l}11 \\
12\end{array}$ & 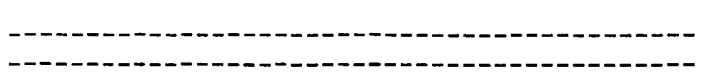 & $\begin{array}{l}50,000 \\
50,200\end{array}$ & $\begin{array}{l}63,200 \\
62,400\end{array}$ & $\begin{array}{l}82,400 \\
81,200\end{array}$ \\
\hline
\end{tabular}


TABLE 12.-Station descriptions and discharge and suspended-sediment data-Continued

Discharge, in cubic feet per second-Continued

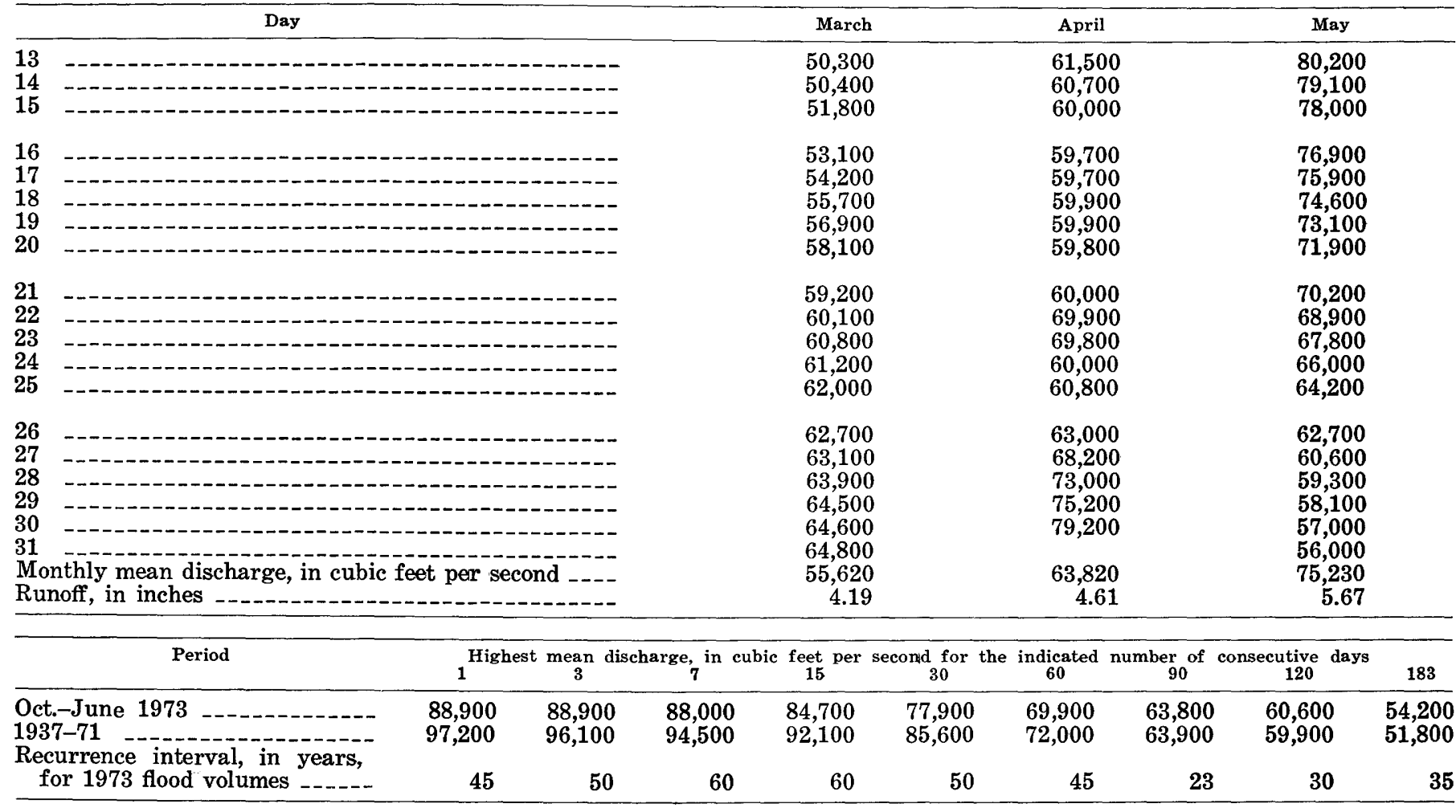

\section{RED RIVER BASIN}

(62) 07370000 Bayou Macon near Delhi, La.

Location.-Lat $32^{\circ} 27^{\prime} 25^{\prime \prime}$, long $91^{\circ} 28^{\prime} 30^{\prime \prime}$, in E 1/2 sec. 18 , T. 17 N., R. 10 E., Richland-Madison Parish line, near right bank on downstream side of bridge on U.S. Highway $80,0.2$ mile $(0.3 \mathrm{~km})$ upstream from Illinois Central Railroad bridge, and 1 mile east of Delhi.

Drainage area.- $782 \mathrm{mi}^{2}\left(2,025 \mathrm{~km}^{2}\right)$.

Gage.-Water-stage recorder. Datum of gage is $50.05 \mathrm{ft}(15.255 \mathrm{~m})$ above mean sea level (levels by Corps of Engineers). Prior to Mar. 14, 1949, nonrecording gage; Mar. 14, 1949, to Oct. 1, 1963, water-stage recorder; all gages within 2,000 $\mathrm{ft}(610 \mathrm{~m})$ downstream at same datum. Auxiliary water-stage recorder 7.7 miles $(12.4 \mathrm{~km})$ downstream at datum 46.05 ft $(14.036 \mathrm{~m})$ above means sea level. Feb. 16, 1945, to Oct. 26, 1962, auxiliary nonrecording gage; Oct. 27, 1962, to Nov. 10, 1964, auxiliary water-stage recorder; and Nov. 11, 1964, to May 10, 1965, auxiliary nonrecording gage at site 0.2 mile $(0.3 \mathrm{~km})$ upstream May 11, 1965, to Mar. 9, 1972, nonrecording gage. Prior to Oct. 1, 1964, at datum $2.00 \mathrm{ft}(0.610 \mathrm{~m})$ lower.

Maxima.-March-May 1973: Discharge, 8,780 $\mathrm{ft}^{3} /\left(249 \mathrm{~m}^{3} / \mathrm{s}\right)$ 5:00 p.m., March 17 [gage height, $22.78 \mathrm{ft}(6.943 \mathrm{~m}) 0815 \mathrm{hours}$ March 18]. Recurrence interval of discharge is 25 years.

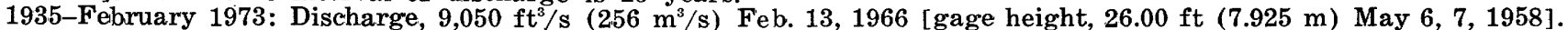

Maximum stage known, $37.5 \mathrm{ft}(11.43 \mathrm{~m})$ in March 1882, from records of U.S. Weather Bureau (affected by overflow from Mississippi River).

\section{MISSISSIPPI RIVER BASIN}

(63) 07373286 Old River Outflow Channel near Knox Landing, La.

Location.-Lat $31^{\circ} 04^{\prime} 40^{\prime \prime}$, long $91^{\circ} 35^{\prime} 50^{\prime \prime}$, at bridge on State Highway 131 at Old River Control Structure, one-half mile $(0.8 \mathrm{~km})$ from Head of Channel and at mile $312(502 \mathrm{~km}$. $)$.

Gage-height record.-Water-stage recorder. Datum of gage is mean sea level. March 31, 1961 to date.

Discharge record.-Computed daily since 1962.

Maxima.-March-May 1973: Discharge, $510,000 \mathrm{ft}^{3} / \mathrm{s}\left(14,400 \mathrm{~m}^{3} / \mathrm{s}\right.$ April 16 [elevation, $59.3 \mathrm{ft}(18.07 \mathrm{~m}) \mathrm{May} 15$ ].

1961-February 1973: Discharge, $390,000 \mathrm{ft}^{3} / \mathrm{s}\left(11,000 \mathrm{~m}^{3} / \mathrm{s}\right)$ Feb. 18, 1969 [elevation, $47.85 \mathrm{ft}(14.585 \mathrm{~m}) \mathrm{Mar} .23,1962$ ].

Water discharge and suspended-sediment data for given days

\begin{tabular}{|c|c|c|c|c|c|}
\hline \multirow[b]{2}{*}{ Date } & & \multirow[b]{2}{*}{$\begin{array}{l}\text { Discharge } \\
(1,000 \\
\left.\mathbf{f t}^{3} / \mathrm{s}\right)\end{array}$} & \multicolumn{3}{|c|}{ Suspended sediment } \\
\hline & & & $\begin{array}{l}\text { Concen- } \\
\text { tration } \\
(\mathrm{mg} / 1)\end{array}$ & $\begin{array}{l}\text { Discharge } \\
\text { (tons/day) }\end{array}$ & $\begin{array}{l}\text { Percent } \\
\text { sand }\end{array}$ \\
\hline March & $\begin{array}{r}5 \\
19 \\
21\end{array}$ & $\begin{array}{l}222 \\
294 \\
307\end{array}$ & $\begin{array}{l}264 \\
503 \\
519\end{array}$ & $\begin{array}{l}158 \\
399 \\
430\end{array}$ & $\begin{array}{l}26 \\
21 \\
33\end{array}$ \\
\hline
\end{tabular}


TABLE 12.-Station descriptions and discharge and suspended-sediment data-Continued

Water discharge and suspended-sediment data for given days-Continued

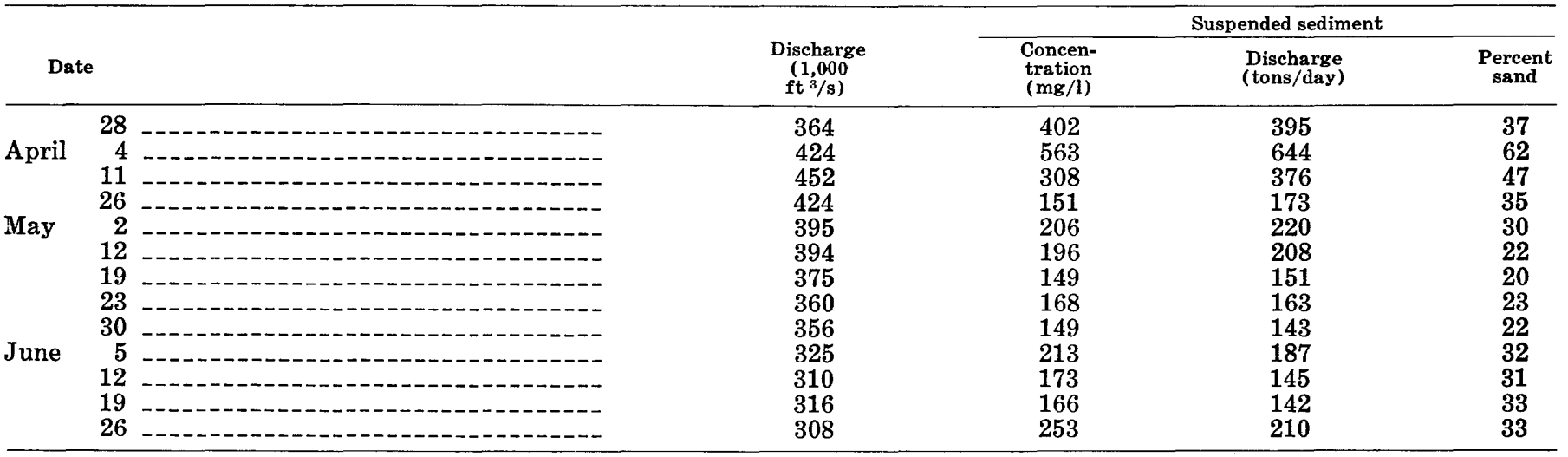

MISSISSIPPI RIVER DELTA

(64) 07373450 Thompson Creek at Jackson, La.

Location.-Lat $30^{\circ} 50^{\prime} 25^{\prime \prime}$, long $91^{\circ} 13^{\prime} 35^{\prime \prime}$, in lot 75 , T. 2 S., R. 1 W., St. Helena meridian at bridge on State Highway 10 , 0.5 mile $(0.8 \mathrm{~km})$ west of Jackson, 0.5 mile $(0.8 \mathrm{~km})$ upstream from West Fork Thompson Creek, and $1.0 \mathrm{mile}(1.6 \mathrm{~km})$ upstream from Vaughn Creek.

Drainage area. $-99.3 \mathrm{mi}^{2}\left(257.2 \mathrm{~km}^{2}\right)$

Gage.-Crest-stage gage.

Maxima.-March-May 1973: Discharge, 40,000 $\mathrm{ft}^{3} / \mathrm{s}\left(1,130 \mathrm{~m}^{3} / \mathrm{s}\right)$ March 24 [gage height, 92.26 ft (28.121 m)]. Recurrence interval of discharge is 25 years.

1949-59, 1972 to Feb. 1973: Discharge, $36,500 \mathrm{ft}^{3} / \mathrm{s}\left(1,030 \mathrm{~m}^{3} / \mathrm{s}\right)$ Apr. 13, 1955 [gage height, $91.72 \mathrm{ft}(27.956 \mathrm{~m})$ ].

\section{MISSISSIPPI RIVER BASIN}

(65) 07374510 Mississippi River at New Orleans (Carrollton), La.

Location.-Lat $29^{\circ} 56^{\prime} 05^{\prime \prime}$, long $90^{\circ} 08^{\prime} 10^{\prime \prime}$, at Corps of Engineers depot dock.

Drainage area.-1,129,910 $\mathrm{mi}^{2}\left(2,926,470 \mathrm{~km}^{2}\right)$, contributing.

Gage-height record.-Water-stage recorder. Datum of gage is mean sea level. 1872 to date. Prior to 1957 at site 0.7 mile $(1.1 \mathrm{~km})$ upstream at same datum.

Discharge record.-Intermittently 1851, 1852, 1879 to 1950,1969 , and 1971; computed daily, 1928 to 1936 and 1938 to 1944 Maxima.-March-May 1973: Discharge, 1,257,000 ft $/ \mathrm{s}\left(35,600 \mathrm{~m}^{3} / \mathrm{s}\right)$ April 15 [gage height, $18.47 \mathrm{ft}(5.630 \mathrm{~m})$, April 7 ].

1872-Feb. 1973: Discharge, 1,557,000 $\mathrm{ft}^{3} / \mathrm{s}\left(44,100 \mathrm{~m}^{3} /\right.$ May 16, 1927. Maximum gage height, $21.27 \mathrm{ft}(6.483 \mathrm{~m}) \mathrm{April}$ $25,1922$.

Remarks.-Natural flow is affected by tides and diversions upstream during floods.

Mean water discharge and suspended-sediment concentration and discharge

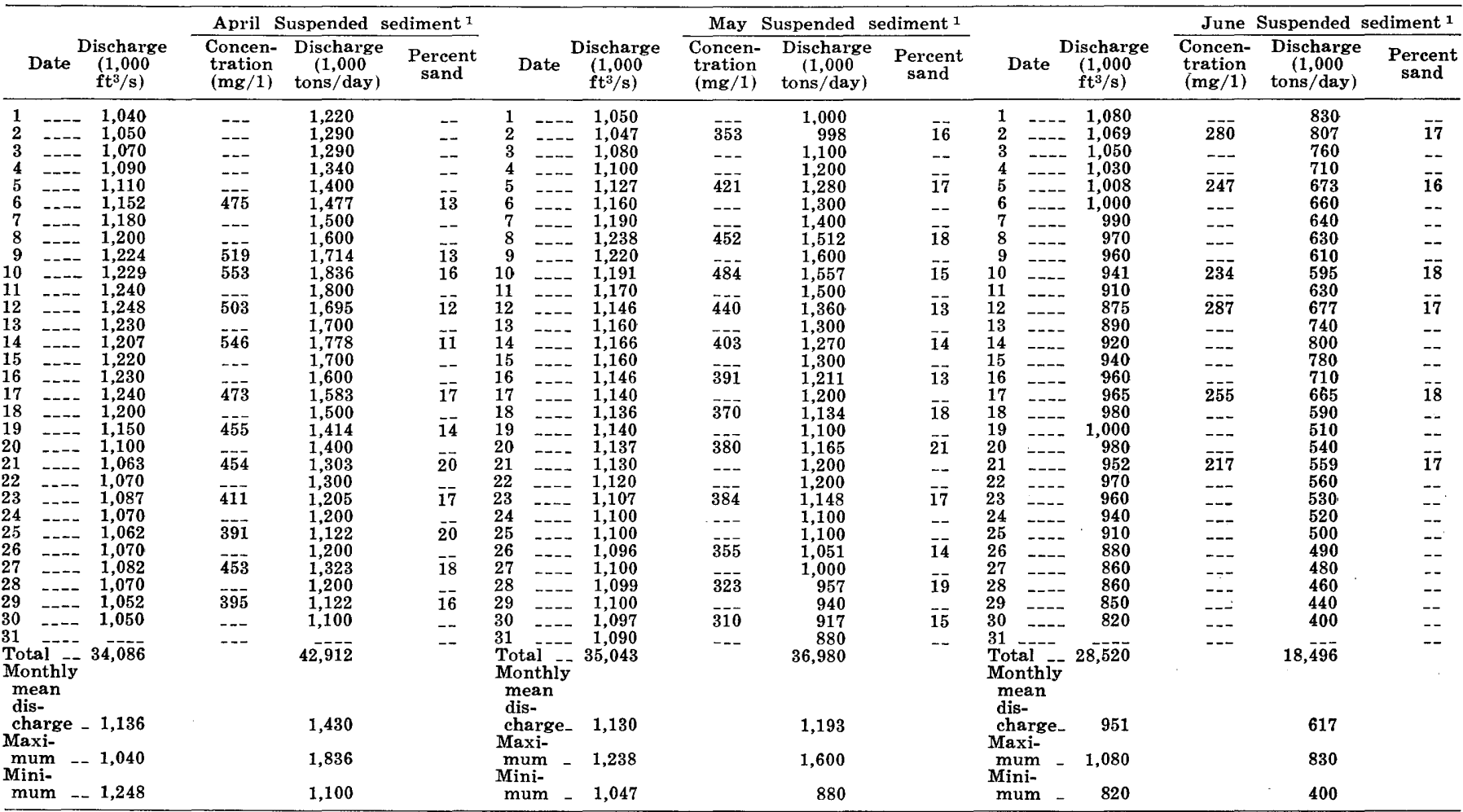

1 Suspended-sediment data based on water discharge measurements and sam ple observations at 1 to 5 day intervals. 
TABLE 12.-Station descriptions and discharge and suspended-sediment data-Continued

\author{
MISSISSIPPI RIVER DELTA \\ (66) 07377000 Amite River near Darlington, La.
}

Location.-Lat $30^{\circ} 53^{\prime} 20^{\prime \prime}$, long $90^{\circ} 50^{\prime} 40^{\prime \prime}$, in lot 72, T. 2 S., R. 4 E., St. Helena meridian, St. Helena Parish near center of span on downstream side of State Highway 10, 1.5 miles $(2.4 \mathrm{~km})$ upstream from Collins Creek, and $4.0 \mathrm{miles}(6.4 \mathrm{~km})$ west of Darlington.

Drainage area. $-580 \mathrm{mi}^{2}\left(1,502 \mathrm{~km}^{2}\right)$.

Gage.-Water-stage recorder. Datum of gage is $145.81 \mathrm{ft}(44.443 \mathrm{~m})$ above mean sea level. Mar 17,1949 , to Oct. 23, 1950, crest-stage gage; Oct. 24, 1950, to Jan. 12, 1951, nonrecording gage; Jan. 13, 1951, to May 28, 1963 water-stage recorder at former channel $700 \mathrm{ft}(213 \mathrm{~m})$ to the left; and July 30, 1963, to Feb. 12, 1964, nonrecording gage at present site. Prior to Oct. 1, 1963, datum $2.99 \mathrm{ft}(0.911 \mathrm{~m})$ higher.

Maxima.-March-May 1973: Discharge, 62,100 ft' $/ \mathrm{s}\left(1,760 \mathrm{~m}^{3} / \mathrm{s}\right)$ March 25 [gage height, $20.19 \mathrm{ft}(6.154 \mathrm{~m})$ ]. Recurrence interval of discharge is 16 years.

1949-February 1973: Discharge, 55,700 $\mathrm{ft}^{3} / \mathrm{s}\left(1,580 \mathrm{~m}^{3} / \mathrm{s}\right)$ A pr. 13, 1955 [gage height, $18.18 \mathrm{ft}(5.541 \mathrm{~m})$, site and datum then in use].

\title{
(67) 07378500 Amite River near Denham Springs, La.
}

Location.-Lat $30^{\circ} 27^{\prime} 50^{\prime \prime}$, long $90^{\circ} 59^{\prime} 25^{\prime \prime}$, in lot 2, T. 7 S., R. 2 E., St. Helena meridian, Livingston Parish, on right bank at downtown side of bridge on U.S. Highway 190, 1,000 ft (305 m) downstream from Comite River, $2.3 \mathrm{miles}(3.7 \mathrm{~km})$ south west of town of Denham Springs, and 15 miles $(24 \mathrm{~km})$ east of Baton Rouge.

Drainage area. $-1,280 \mathrm{mi}^{2}\left(3,320 \mathrm{~km}^{2}\right)$.

Gage.-Water-stage recorder. Datum of gage is $3.87 \mathrm{ft}(1.180 \mathrm{~m})$ above mean sea level. Prior to Aug. 8, 1939, nonrecording gage at same site and datum. Auxiliary water-stage recorder 3.0 miles $(4.8 \mathrm{~km})$ downstream at datum $3.12 \mathrm{ft}(0.951 \mathrm{~m})$ above mean sea level (Corps of Engineers bench mark). Oct. 1, 1945, to Dec. 23, 1952, nonrecording gage at same site and

Maxima.-March-May 1973: Discharge, 61,800 ft $/ \mathrm{s}\left(1,750 \mathrm{~m}^{3} / \mathrm{s}\right)$ 5:00 a.m., March 27 [gage height, $32.63 \mathrm{ft}(9.946 \mathrm{~m}) \quad 0730$ hours]. Recurrence interval of discharge is 16 years.

1939-February 1973: Discharge, 67,000 $\mathrm{ft}^{3} / \mathrm{s}\left(1,900 \mathrm{~m}^{3} / \mathrm{s}\right)$ May 20, 1953 [gage height, $32.46 \mathrm{ft}(9.894 \mathrm{~m})$ ].

\begin{tabular}{|c|c|c|c|c|}
\hline \multicolumn{5}{|c|}{ Discharge in cubic feet per second } \\
\hline Day & & March & April & May \\
\hline $\begin{array}{l}1 \\
2 \\
3 \\
4 \\
\mathbf{5}\end{array}$ & 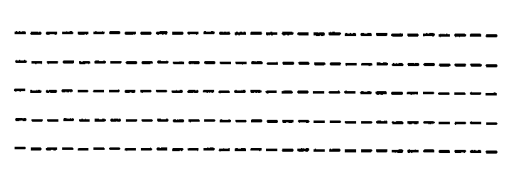 & $\begin{array}{r}954 \\
1,820 \\
1,310 \\
3,220 \\
4,530\end{array}$ & $\begin{array}{l}7,370 \\
7,460 \\
5,960 \\
3,810 \\
2,510\end{array}$ & $\begin{array}{l}2,130 \\
1,910 \\
1,980 \\
3,070 \\
4,740\end{array}$ \\
\hline $\begin{array}{r}6 \\
7 \\
8 \\
9 \\
10\end{array}$ & 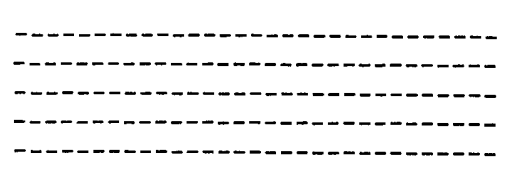 & $\begin{array}{l}4,540 \\
4,430 \\
4,520 \\
4,500 \\
4,580\end{array}$ & $\begin{array}{l}2,110 \\
5,900 \\
9,150 \\
9,000 \\
6,510\end{array}$ & $\begin{array}{r}5,080 \\
6,900 \\
10,700 \\
10,000 \\
8,100\end{array}$ \\
\hline $\begin{array}{l}11 \\
12 \\
13 \\
14 \\
15\end{array}$ & - & $\begin{array}{l}4,420 \\
6,780 \\
8,110 \\
7,400 \\
4,660\end{array}$ & $\begin{array}{l}3,950 \\
2,400 \\
1,960 \\
1,740 \\
1,590\end{array}$ & $\begin{array}{l}\mathbf{5 , 3 6 0} \\
\mathbf{3 , 2 8 0} \\
\mathbf{2 , 4 2 0} \\
3,480 \\
\mathbf{3 , 9 0 0}\end{array}$ \\
\hline $\begin{array}{l}21 \\
22 \\
23 \\
24 \\
25\end{array}$ & 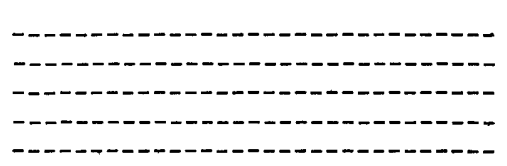 & $\begin{array}{r}3,870 \\
3,790 \\
2,630 \\
\mathbf{5 , 5 3 0} \\
\mathbf{2 4 , 8 0 0}\end{array}$ & $\begin{array}{r}17,300 \\
9,820 \\
4,260 \\
2,870 \\
2,410\end{array}$ & $\begin{array}{l}1,150 \\
1,090 \\
1,030 \\
1,020 \\
1,310\end{array}$ \\
\hline $\begin{array}{l}26 \\
27 \\
28 \\
29 \\
30 \\
31 \\
\text { Mon }\end{array}$ & nthly mean discharge, in cubic feet & $\begin{array}{r}45,500 \\
56,300 \\
31,200 \\
12,400 \\
5,550 \\
5,530\end{array}$ & $\begin{array}{l}5,570 \\
6,840 \\
6,700 \\
4,950 \\
2,890 \\
----\end{array}$ & $\begin{array}{r}2,520 \\
1,740 \\
1,210 \\
1,040 \\
950 \\
893\end{array}$ \\
\hline $\begin{aligned} \text { pe } \\
\text { Run }\end{aligned}$ & noff, in inches & $\begin{array}{r}9,130 \\
8.22\end{array}$ & $\begin{array}{r}8,140 \\
7.10\end{array}$ & $\begin{array}{r}3,090 \\
2.78\end{array}$ \\
\hline
\end{tabular}


TABLE 12.-Station descriptions and discharge and suspended-sediment data-Continued

Mean water discharge and suspended-sediment concentration and discharge

\begin{tabular}{|c|c|c|c|c|c|c|c|c|c|c|c|c|c|c|c|c|c|c|c|}
\hline & & & $\operatorname{arch}$ & & & & & ril & & & & & May & & & & & & \\
\hline & & & Suspended & sediment & & & & Suspende & d sediment & & & & Suspended & d sediment & & & & Suspende & d sediment \\
\hline & Day & $\begin{array}{c}\text { Mean } \\
\text { dis- } \\
\text { charge } \\
(1,000 \\
\left.\mathrm{ft}^{3} / \mathrm{s}\right)\end{array}$ & $\begin{array}{l}\text { Mean } \\
\text { concen- } \\
\text { tration } \\
(\mathrm{mg} / 1)\end{array}$ & $\begin{array}{c}\text { Dis- } \\
\text { charga } \\
(1,000 \\
\text { tons/day })\end{array}$ & & Day & $\begin{array}{c}\text { Mean } \\
\text { dis- } \\
\text { charge } \\
(1,000 \\
\left.\mathrm{ft}^{3} / \mathrm{s}\right)\end{array}$ & $\begin{array}{l}\text { Mean } \\
\text { concen- } \\
\text { tration } \\
(\mathrm{mg} / 1)\end{array}$ & $\begin{array}{c}\text { Dis- } \\
\text { charge } \\
(1,000 \\
\text { tons/day })\end{array}$ & & Day & $\begin{array}{c}\text { Mean } \\
\text { dis- } \\
\text { charge } \\
(1,000 \\
\left.\mathrm{ft}^{\mathrm{t}} \mathrm{i} / \mathrm{s}\right)\end{array}$ & $\begin{array}{l}\text { Mean } \\
\text { concen- } \\
\text { tration } \\
(\mathrm{mg} / 1)\end{array}$ & $\begin{array}{c}\text { Dis- } \\
\text { charge } \\
(1,000 \\
\text { tons/day })\end{array}$ & & Day & $\begin{array}{c}\text { Mean } \\
\text { dis- } \\
\text { cha } \cdot \text { ge } \\
(1,000 \\
\left.\mathrm{ft}^{\circ} / \mathrm{s}\right)\end{array}$ & $\begin{array}{l}\text { Mean } \\
\text { concen- } \\
\text { tration } \\
(\mathrm{mg} / 1)\end{array}$ & $\begin{array}{c}\text { Dis- } \\
\text { charge } \\
(1,000 \\
\text { tons/day })\end{array}$ \\
\hline 1 & --- & 408 & 336 & 370 & 1 & ------ & 550 & 438 & 651 & 1 & -.-- & 772 & 267 & 520 & 1 & --_- & 661 & 333 & 595 \\
\hline 2 & --- & 404 & 335 & 365 & 2 & $-\ldots$ & 560 & 440 & 665 & 2 & $-\ldots$ & 719 & 268 & 520 & 2 & -....- & 674 & 340 & 618 \\
\hline 3 & ---- & 387 & 341 & 356 & 3 & ---- & 571 & 441 & 680 & 3 & --- & 682 & 286 & 527 & 3 & ------ & 648 & 350 & 612 \\
\hline 4 & ---- & 371 & 348 & 349 & 4 & ---- & 572 & 423 & 654 & 4 & $\ldots$ & 685 & 302 & 559 & 4 & ------ & 601 & 359 & 583 \\
\hline 5 & --- & 354 & 356 & 340 & 5 & ------ & 573 & 407 & 629 & 5 & --.- & 725 & 316 & 618 & 5 & - & 625 & 368 & 621 \\
\hline 6 & --- & 339 & 363 & 332 & 6 & ------- & 582 & 389 & 612 & 6 & $-\cdots$ & 720 & 334 & 649 & 6 & ---- & 620 & 363 & 608 \\
\hline 7 & --- & 336 & 368 & 334 & 7 & $-\ldots$ & 597 & 372 & 600 & 7 & ---- & 709 & 354 & 678 & 7 & ------ & 579 & 363 & 567 \\
\hline 8 & --- & 335 & 373 & 337 & 8 & ----- & 606 & 356 & 583 & 8 & m. & 727 & 372 & 731 & 8 & - - & 607 & 354 & 580 \\
\hline 9 & --- & 334 & 337 & 340 & 9 & - - - - & 613 & 341 & 565 & 9 & ---- & 731 & 393 & 775 & 9 & ----- & 606 & 349 & 571 \\
\hline 10 & ---- & 331 & 383 & 342 & 10 & $--\ldots$ & 620 & 327 & 548 & 10 & --- & 740 & 414 & 828 & 10 & ----- & 549 & 351 & 520 \\
\hline 11 & -.. & 335 & 386 & 349 & 11 & - & 626 & 329 & 556 & 11 & $-\ldots$ & 759 & 436 & 893 & 11 & - & 562 & 344 & 522 \\
\hline 12 & ---- & 343 & 389 & 360 & 12 & ---- & 634 & 331 & 566 & 12 & $-\cdots$ & 781 & 458 & 965 & 12 & 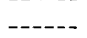 & 570 & 339 & 521 \\
\hline 13 & --- & 349 & 393 & 370 & 13 & - - - & 630 & 334 & 568 & 13 & ---- & 727 & 442 & 867 & 13 & ------ & 542 & 356 & 521 \\
\hline 14 & $--\cdots$ & 357 & 395 & 381 & 14 & ----- & 626 & 327 & 569 & 14 & --- & 742 & 418 & 838 & 14 & -..-- & 552 & 369 & 550 \\
\hline 15 & --- & 377 & 396 & 403 & 15 & ---- & 679 & 334 & 612 & 15 & --- & 736 & 399 & 792 & 15 & - - ---- & 574 & 381 & 591 \\
\hline 16 & --- & 401 & 396 & 429 & 16 & $\ldots$ & 691 & 336 & 626 & 16 & --- & 763 & 377 & 776 & 16 & -..-- & 528 & 404 & 576 \\
\hline 17 & --- & 414 & 398 & 445 & 17 & $\ldots-$ & 710 & 336 & 645 & 17 & --- & 749 & 360 & 728 & 17 & -...-- & 530 & 421 & 602 \\
\hline 18 & ---- & 425 & 401 & 460 & 18 & - & 730 & 337 & 665 & 18 & $\ldots$ & 760 & 342 & 701 & 18 & - - - & 539 & 436 & 635 \\
\hline 19 & -- & 433 & 405 & 473 & 19 & ------ & 668 & 346 & 624 & 19 & --- & 739 & 327 & 652 & 19 & -...-- & 546 & 453 & 668 \\
\hline 20 & --- & 441 & 408 & 486 & 20 & - - - - & 686 & 347 & 642 & 20 & -... & 739 & 311 & 620 & 20 & $-\cdots$ & 550 & 426 & 632 \\
\hline 21 & --- & 447 & 412 & 497 & 21 & --- - - & 674 & 332 & 605 & 21 & ---- & 737 & 296 & 589 & 21 & --_--- & 534 & 402 & 580 \\
\hline 22 & ---- & 454 & 415 & 509 & 22 & ---- & 648 & 320 & 560 & 22 & --- & 727 & 282 & 554 & 22 & $-\ldots$ & 515 & 380 & 529 \\
\hline 23 & --- & 465 & 418 & 525 & 23 & ------ & 596 & 311 & 500 & 23 & -... & 730 & 268 & 529 & 23 & ---- & 503 & 359 & 488 \\
\hline 24 & ---- & 484 & 420 & 549 & 24 & --- --- & 688 & 289 & 536 & 24 & $-\ldots$ & 749 & 273 & 552 & 24 & - - - & 513 & 336 & 466 \\
\hline 25 & -- & 500 & 422 & 570 & 25 & - . & 641 & 280 & 484 & 25 & --.- & 727 & 281 & 551 & 25 & $-\cdots$ & 463 & 323 & 404 \\
\hline 26 & --- & 515 & 425 & 591 & 26 & --- - & 683 & 264 & 486 & 26 & --- & 767 & 284 & 588 & 26 & --- & 492 & 300 & 398 \\
\hline 27 & --- & 528 & 429 & 611 & 27 & ------ & 674 & 265 & 483 & 27 & --- & 733 & 293 & 579 & 27 & - & 475 & -- & 380 \\
\hline 28 & ---- & 524 & 432 & 611 & 28 & ----- & 692 & 265 & 496 & 28 & --- & 704 & 301 & 573 & 28 & --- & 472 & --- & 370 \\
\hline 29 & $-\cdots$ & 521 & 435 & 612 & 29 & ---- & 687 & 267 & 495 & 29 & ---- & 706 & 308 & 587 & 29 & -..... & 472 & --- & 370 \\
\hline 30 & $\ldots$ & 532 & 436 & 626 & 30 & ------ & 724 & 266 & 519 & 30 & --- & 687 & 316 & 587 & 30 & --- & 452 & --- & 350 \\
\hline 31 & --- & 540 & 438 & 638 & 31 & --..-- & $\ldots$ & -- & $\ldots$ & 31 & $\ldots$ & 689 & 324 & 602 & 31 & ------ & -- & -- & --- \\
\hline Tot & tal --1 & 12,984 & & 13,960 & & & 19,231 & & 17,424 & & & 22,611 & & 20,528 & & & 16,554 & & 16,028 \\
\hline & $\begin{array}{l}\text { onthly } \\
\text { iean } \\
\text { is- }\end{array}$ & & & & & & & & & & & & & & & & & & \\
\hline $\begin{array}{l}\text { ch } \\
\mathrm{Ma}\end{array}$ & $\begin{array}{l}\text { arge_ } \\
\text { xi. }_{-}\end{array}$ & -419 & & 450 & & & 641 & & 581 & & & 729 & & 662 & & & 552 & & 534 \\
\hline$\underset{\mathrm{Mi}}{\mathbf{m}}$ & ni- & 540 & & 638 & & & 730 & & 680 & & & 781 & & 965 & & & 674 & & 668 \\
\hline & um - & 331 & & 332 & & & 550 & & 483 & & & 682 & & 520 & & & 452 & & 398 \\
\hline
\end{tabular}

\begin{tabular}{|c|c|c|c|c|c|c|c|c|c|}
\hline \multirow[b]{2}{*}{ Period } & \multicolumn{9}{|c|}{ Highest mean discharge, in cubic feet per second, for the indicated number of consecutive days } \\
\hline & 1 & 3 & 7 & 15 & 30 & 60 & 90 & 120 & 183 \\
\hline $\begin{array}{l}\text { Oct. 1972-.Tune } 1973 \\
\text { 1935-71 }\end{array}$ & $\begin{array}{l}781000 \\
619,000\end{array}$ & $\begin{array}{l}760.000 \\
619,000\end{array}$ & $\begin{array}{l}751,000 \\
615,000\end{array}$ & $\begin{array}{l}745,000 \\
608,000\end{array}$ & $\begin{array}{l}732,000 \\
590,000\end{array}$ & $\begin{array}{l}694,000 \\
540,000\end{array}$ & $\begin{array}{l}647,000 \\
492,000\end{array}$ & $\begin{array}{l}593,000 \\
457,000\end{array}$ & $\begin{array}{l}526.000 \\
408,000\end{array}$ \\
\hline
\end{tabular}

\section{MISSISSIPPI RIVER DELTA}

(71) 07381530 Morganza Floodway near Krotz Springs, La.

Location.-Lat $30^{\circ} 33^{\prime} 16^{\prime \prime}$, long $91^{\circ} 41^{\prime} 51^{\prime \prime}$, Pointe Coupee Parish, at bridge on U.S. Highway 190,5 miles (8 km) east of the town of Krotz Springs, La.

Drainage area.--Indeterminate.

Remarks. - This was the first time the Morganza Floodway was usea since it was constructed. 
THE FLOODS

TABLE 12.-Station descriptions and discharge and suspended-sediment data-Continued

Measured discharge and suspended-sediment concentration and discharge

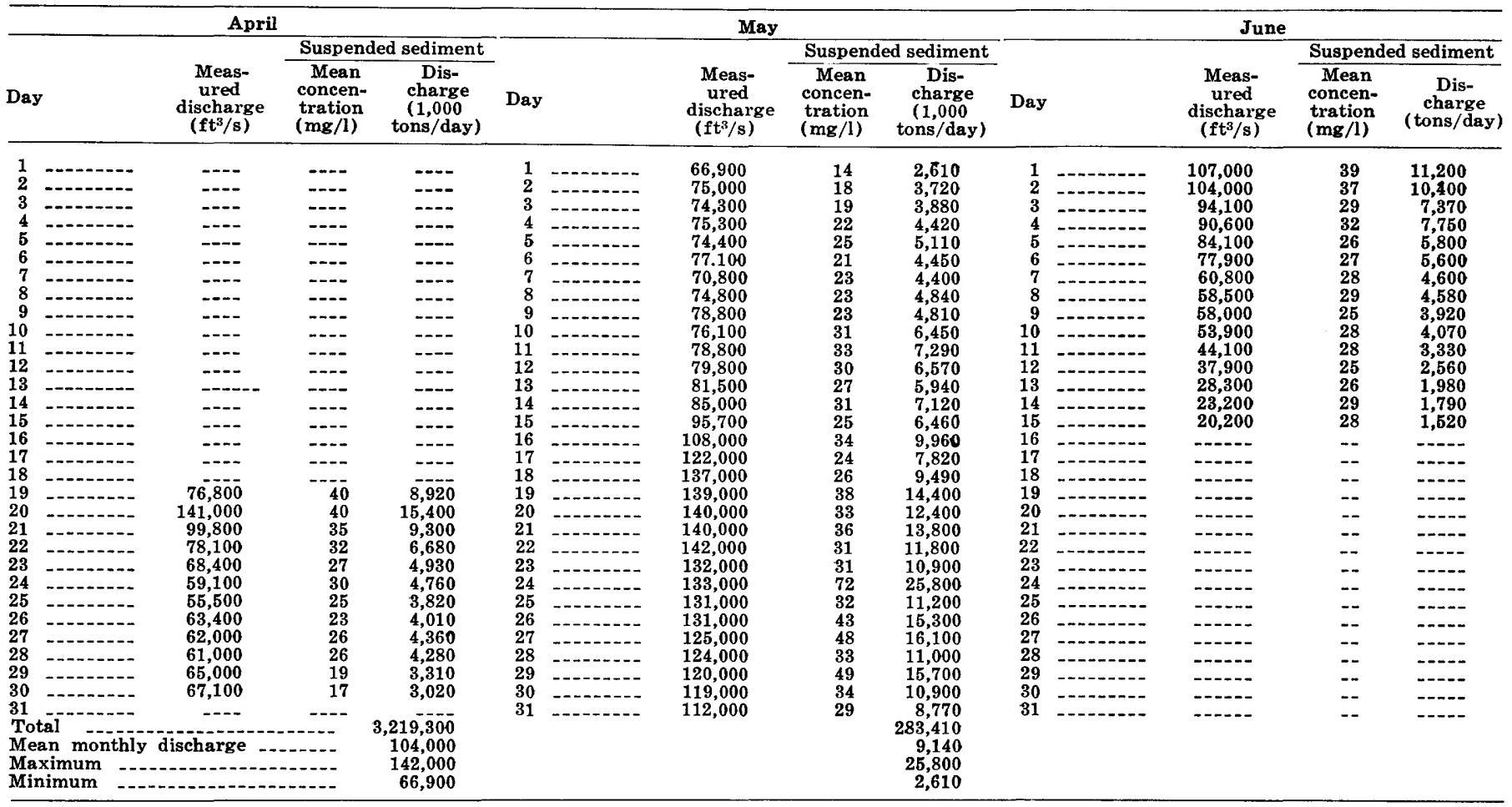

\section{MISSISSIPPI RIVER DELTA}

(72) 07381590 Wax Lake Outlet at Calumet, La.

Location.-Lat $29^{\circ} 42^{\prime} 09^{\prime \prime}$, long $91^{\circ} 22^{\prime} 07^{\prime \prime}$, St. Mary Parish, at bridge on U.S. Highway $90,0.5$ mile $(0.8 \mathrm{~km})$ west of Calumet, and 4.0 miles $(6.4 \mathrm{~km})$ west of Patterson, La.

Drainage area.-Indeterminate.

Gage.-Water-stage recorder and staff. Datum of gage is $0.14 \mathrm{ft}(0.043 \mathrm{~m})$ below mean sea level.

Discharge record.-Discharge, 1942 to 1946,1949 to 1955 , and intermittently 1957 to date.

Maxima.-March-June 1973: Gage height, $11.18 \mathrm{ft}(3.408 \mathrm{~m})$ May 27.

1942 to February 1973: Gage height, $8.4 \mathrm{ft}(2.56 \mathrm{~m})$ [affected by hurricane] June 27, 1957.

Measured discharge, 1973

\begin{tabular}{|c|c|c|c|c|c|c|c|}
\hline \multicolumn{2}{|c|}{ Date } & $\begin{array}{c}\begin{array}{c}\text { Gage height } \\
(\mathrm{ft})\end{array} \\
7.5\end{array}$ & $\begin{array}{c}\begin{array}{c}\text { Discharge } \\
\left(\mathrm{ft}^{3} / \mathrm{s}\right)\end{array} \\
214,000\end{array}$ & \multicolumn{2}{|c|}{ Date } & $\begin{array}{c}\begin{array}{c}\text { Gage height } \\
\text { (ft) }\end{array} \\
10.5\end{array}$ & $\begin{array}{c}\begin{array}{c}\text { Discharge } \\
\left(\mathrm{ft}^{3} / \mathrm{s}\right)\end{array} \\
269,000\end{array}$ \\
\hline & 13 & 7.9 & 213,000 & & 25 & 10.9 & 267,000 \\
\hline & $20 \ldots$ & 8.8 & 224,000 & & 31 & 10.8 & 257,000 \\
\hline & 24 & 9.3 & 226,000 & June & 5 - & 10.2 & 234,000 \\
\hline & $27 \ldots$ & 9.3 & 238,000 & & $8 \ldots$ & 9.6 & 236,000 \\
\hline \multirow{4}{*}{ May } & $8 \ldots$ & 10.2 & 246,000 & & 19 & 7.9 & 194,000 \\
\hline & 11 & 10.2 & 266,000 & & 21 & 7.7 & 191,000 \\
\hline & 15 & 10.3 & 245,000 & & 26 & 7.3 & 183,000 \\
\hline & 17 & 10.4 & 257,000 & & $29 \ldots$ & 6.9 & 176,000 \\
\hline
\end{tabular}


TABLE 12.-Station descriptions and discharge and suspended-sediment data-Continued

Mean water discharge and suspended-sediment concentration and discharge

\begin{tabular}{|c|c|c|c|c|c|c|c|c|c|c|c|c|c|}
\hline \multicolumn{4}{|c|}{ April } & \multicolumn{5}{|c|}{ May } & \multicolumn{5}{|c|}{ June } \\
\hline \multirow[b]{2}{*}{ Day } & \multirow[b]{2}{*}{$\begin{array}{c}\text { Mean } \\
\text { discharge } \\
(1,000 \\
\left.\mathrm{ft}^{3} / \mathrm{s}\right)\end{array}$} & \multicolumn{2}{|c|}{ Suspended sediment } & \multirow{2}{*}{\multicolumn{2}{|c|}{ Day }} & \multirow[b]{2}{*}{$\begin{array}{c}\text { Mean } \\
\text { discharge } \\
(1,000 \\
\left.\mathrm{ft}^{3} / \mathrm{s}\right)\end{array}$} & \multicolumn{2}{|c|}{ Suspended sediment } & \multirow{2}{*}{\multicolumn{2}{|c|}{ Day }} & \multirow[b]{2}{*}{$\begin{array}{c}\text { Mean } \\
\text { discharge } \\
(1,000 \\
\left.\mathrm{ft}^{3} / \mathrm{s}\right)\end{array}$} & \multicolumn{2}{|c|}{ Suspended sediment } \\
\hline & & $\begin{array}{l}\text { Mean } \\
\text { concen- } \\
\text { tration } \\
(\mathrm{mg} / \mathrm{l})\end{array}$ & $\begin{array}{c}\text { Dis- } \\
\text { charge } \\
(1,000 \\
\text { tons/day })\end{array}$ & & & & $\begin{array}{c}\text { Mean } \\
\text { concen- } \\
\text { tration } \\
(\mathrm{mg} / \mathrm{l})\end{array}$ & $\begin{array}{c}\text { Dis- } \\
\text { charge } \\
(1,000 \\
\text { tons/day })\end{array}$ & & & & $\begin{array}{c}\text { Mean } \\
\text { concen- } \\
\text { tration } \\
(\mathrm{mg} / \mathrm{l})\end{array}$ & $\begin{array}{c}\text { Dis- } \\
\text { charge } \\
(1,000 \\
\text { tons/day })\end{array}$ \\
\hline 1 - & --- & -... & 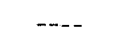 & 1 & & 241 & 362 & 236 & 1 & & 252 & --- & 208 \\
\hline $2-\cdots \cdots$ & $-\cdots$ & -- & - n & $\begin{array}{l}1 \\
2\end{array}$ & & 240 & 002 & 232 & 2 & & 248 & $\overline{----}$ & 212 \\
\hline 3 & --- & -- & -- & 3 & - & 239 & $-\ldots$ & 230 & 3 & --- & 243 & $-\cdots$ & 215 \\
\hline 4 & - & - & -- & 4 & - & 238 & $34 \overline{7}$ & 228 & 4 & $-\cdots$ & 239 & & 218 \\
\hline 5 - & --- & $-n$ & -- & 5 & 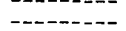 & 240 & - & 248 & 5 & $\ldots$ & 234 & $34 \overline{9}$ & 221 \\
\hline 6 - 6 & --- & $-\cdots$ & --- & 6 & -........ & 242 & $-\ldots$ & 266 & 6 & $\ldots$ & 235 & $\ldots$ & 188 \\
\hline 7 & $\cdots$ & -- & -- & 7 & $-\cdots$ & 244 & --- & 286 & 7 & -- & 235 & --- & 156 \\
\hline 8 - & --- & $\ldots$ & -- & 8 & - - . - & 246 & 454 & 302 & 8 &.-- & 236 & $\overline{2} \overline{0}$ & 133 \\
\hline $9 \begin{array}{r}9 \\
10\end{array}$ & --- & ---- & $-\cdots$ & 9 & $-\ldots \ldots$ & 253 & --.- & 296 & 9 & $\ldots$ & 229 & -_- & 127 \\
\hline $10-\infty-10-1$ & --- & --- & -- & 10 & - & 259 & --- & 293 & 10 & - & 222 & $=-$ & 121 \\
\hline $\begin{array}{ll}11 & -\cdots \\
12 & -\end{array}$ & --- & --- & - & 11 & $-\cdots-1-1$ & 266 & --- & 288 & 11 & $\ldots$ & 216 & $\ldots$ & 115 \\
\hline $12---12-1$ & --- & --- & --- & 12 & $\ldots$ & 261 & --- & 282 & 12 & $\ldots$ & 209 & 197 & 111 \\
\hline $\begin{array}{ll}13 & - \\
14 & -\end{array}$ & -- & --- & $\ldots$ & 13 & - & 256 & --- & 278 & 13 & -- & 201 & $\ldots$ & 113 \\
\hline $14-\cdots$ & --- & --- & -- & 14 & $----n---$ & 250 & $\ldots$ & 272 & 14 & --_-_-_-- & 193 & -..- & 116 \\
\hline $15---\cdots$ & ---- & --- & $\ldots$ & 15 & - & 245 & 404 & 267 & 15 & $-\ldots-1$ & 185 & 234 & 117 \\
\hline $16 \ldots$ & $\cdots$ & $-\cdots$ & -..- & 16 & - & 251 & & 260 & 16 & - & 187 & $\ldots$ & 117 \\
\hline $17 \quad-$ & --- & --- & -..- & 17 & - - - & 257 & 369 & 253 & 17 & - & 190 & $\cdots$ & 117 \\
\hline 18 - - - - - - & $-\cdots$ & $\ldots$ & --- & 18 & - & 259 & -..- & 256 & 18 & - & 192 & --- & 117 \\
\hline 19 & --- & & & 19 & - & 262 & $\cdots$ & 266 & 19 & - & 194 & $\overline{223}$ & 117 \\
\hline $20-\ldots$ & 224 & 385 & 233 & 20 & - . & 264 & _... & 270 & 20 & - & 192 & & 120 \\
\hline 21 & 224 & $\ldots$ & 234 & 21 & - & 267 &.-- & 274 & 21 & 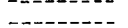 & 191 & 235 & 121 \\
\hline $22 \quad \ldots-\ldots$ & 225 & --- & 235 & 22 & $-\cdots$ & 269 & $-\overline{38} \overline{1}$ & 277 & 22 & - & 189 & $-\ldots$ & 118 \\
\hline $23-\cdots$ & 226 & --- & 236 & 23 & - & 268 & --.- & 264 & 23 & - & 188 & --- & 115 \\
\hline 24 & 226 & $38 \overline{8}$ & 237 & 24 & - & 268 & --- & 254 & 24 & $-1-1-1$ & 186 & --- & 112 \\
\hline $25 \quad-\ldots$ & 230 & $\ldots$ & 256 & 25 & - & 267 & $34 \overline{0}$ & 245 & 25 & - & 185 & --- & 109 \\
\hline 26 & 234 & --_- & 271 & 26 & -..--_- & 268 & $\ldots+\ldots$ & 242 & 26 & - & 183 & $2 \overline{15}$ & 106 \\
\hline 27 & 238 & 446 & 287 & 27 & (n-n & 270 & $-\cdots$ & 238 & 27 & 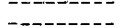 & 181 & --- & 100 \\
\hline $28 \quad-\cdots$ & 239 & $\ldots$ & 270 & 28 & 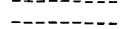 & 271 & $-\ldots$ & 232 & 28 & 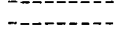 & 178 & -- & 92 \\
\hline $29-\ldots$ & 240 & $\ldots$ & 260 & 29 & $-\ldots$ & 272 & 310 & 228 & 29 & $-1-1$ & 176 & 182 & 86 \\
\hline $30-\cdots$ & 240 & --- & 246 & 30 & - & 264 & & 214 & 30 & $-0-1$ & 174 & $\ldots$ & 80 \\
\hline 31 - & &.-- & & 31 & $\ldots$ & 257 & 296 & 205 & 31 & - - & & --- & \\
\hline $\begin{array}{l}\text { Total } \\
\text { Mean }\end{array}$ & 2,546 & & 2,765 & & & 7,954 & & 7,982 & & & 6,163 & & 3,998 \\
\hline $\begin{array}{l}\text { monthly } \\
\text { dis- }\end{array}$ & & & & & & & & & & & & & \\
\hline charge - - & --- & $-\ldots$ & --- & & & 257 & & 257 & & & 205 & & 133 \\
\hline Maximum -- & --- & $\ldots$ & $\ldots$ & & & 272 & & 302 & & & 252 & & 221 \\
\hline Minimum -- & $-\ldots$ & ---- & --- & & & 238 & & 205 & & & 174 & & 80 \\
\hline
\end{tabular}

${ }^{1}$ Suspended-sediment data based on water discharge measurements and suspended-sediment samples obtained at 2- to 7-day intervals.

\section{MISSISSIPPI RIVER DELTA}

(73) 07381600 Lower Atchafalaya River at Morgan City, La.

Location.-Lat $29^{\circ} 41^{\prime} 40^{\prime \prime}$, long $91^{\circ} 12^{\prime} 39^{\prime \prime}$, U.S. Coast Guard dock on left bank, $300 \mathrm{ft}$ (91 km) downstream from new U.S. Highway 90 bridge (under construction) at Morgan City, La.

Drainage area.-Indeterminate.

Gage.-Water-stage recorder and staff. Datum of gage is $2.94 \mathrm{ft}(0.896 \mathrm{~m})$ below mean sea level.

Discharge record.-Intermittently from 1927 to date.

Maxima.-March-June 1973: Gage height, $13.6 \mathrm{ft}(4.15 \mathrm{~m})$ May 23-28.

1905 to February 1973: Gage height, $11.4 \mathrm{ft}(3.40 \mathrm{~m})$ [affected by hurricane] June 27, 1957.

Measured discharge, 1973

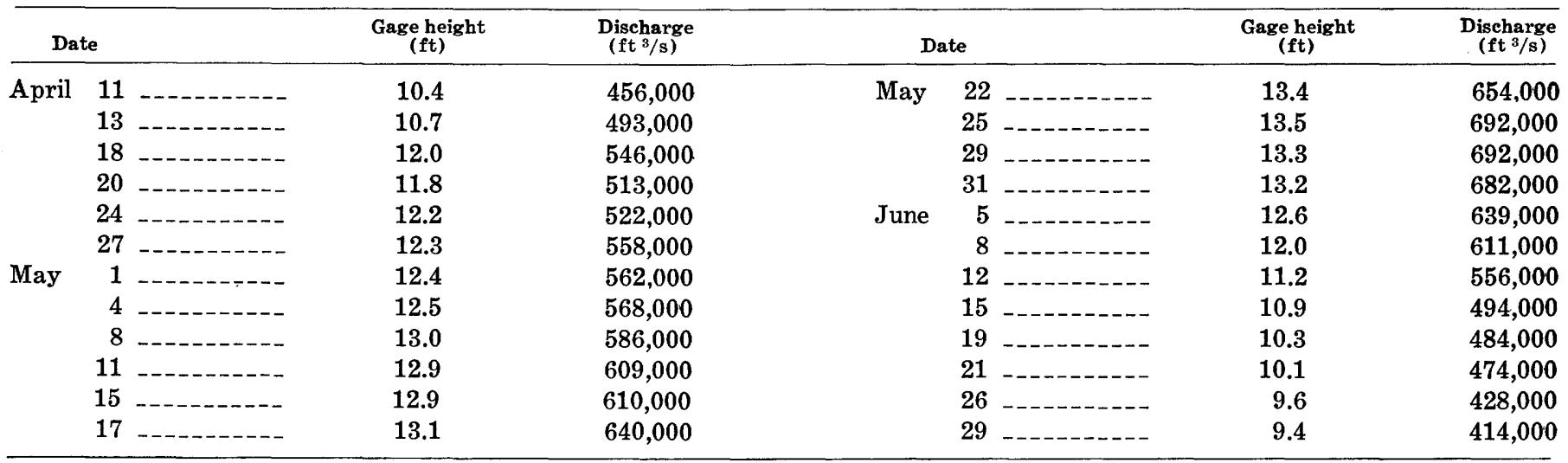


THE FLOODS

TABLE 12.-Station descriptions and discharge and suspended-sediment data-Continued

Mean water discharge and suspended-sediment concentration and discharge

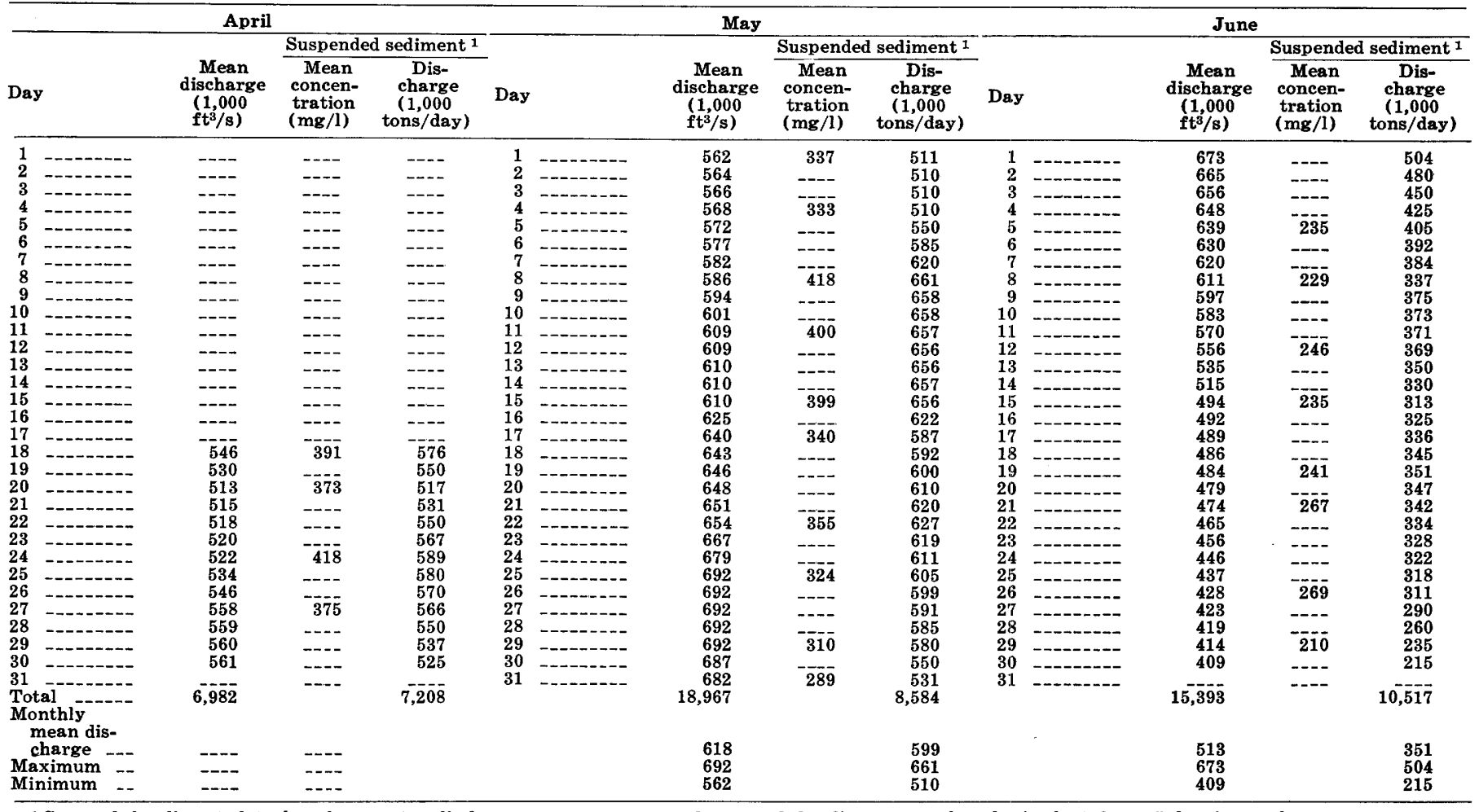

1 Suspended-sediment data based on water discharge measurements and suspended-sediment samples obtained at 2- to 5-day intervals.

\section{INDEX OF STREAM-GAGING STATION NAMES}

Station name

Amite River near Darlington, La

Amite River near Denham Springs, La

Arkabutha Lake near Arkabutha, Miss -.........

Atchafalaya River at Krotz Springs, La -.-.--.--

Bayou Macon near Delhi, La

Big Creek near Mt. Pleasant, Iowa _.............

Black River at Black Rock, Ark --

Bonnet Carre Floodway near Norco, La

Buffalo River near Woodville, Miss
Burge Branch near Arrow Rock, Mo $-\ldots$

Chariton River near Chariton, Iowa

Chariton River near Prairie Hill, Mo -

Cumberland River near Grand Rivers, $\mathbf{K y}$

East Fork Chariton River near Huntsville, Mo

Edwards River near New Boston, Ill

Elk Fork Salt River near Madison, Mo

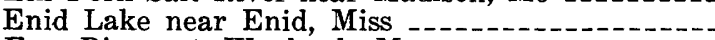

Fox River at Wayland, Mo

Fox River at Wilmot, Wis -

Grenada Lake near Grenada, Miss -.......

Hatchie River at Bolivar, Tenn

Iowa River at Iowa City, Iowa

Iowa River at Marengo, Iowa

Iowa River at Wapello, Iowa

Lake Pontchartrain near New Orleans, La

Lake Red Rock near Pella, Iowa

Little Turtle Creek at Allens Grove, Wis ........

Lower Atchafalaya River at Morgan City, La --.-

Middle Fabius River near Monticello, Mo

Middle Fork Salt River at Paris, Mo

Mississippi River at Alton, Ill

Mississippi River at Clinton, Iowa

Mississippi River at Keokuk, Iowa -

Mississippi River at Memphis, Tenn -

Mississippi River at Natchez, Miss

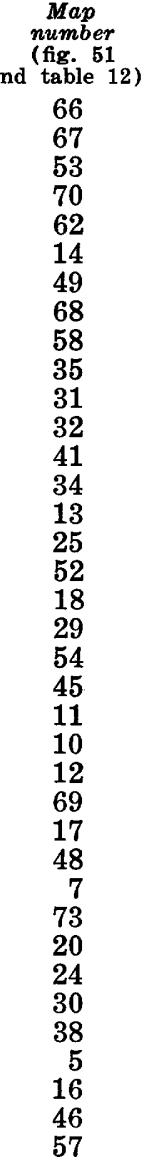

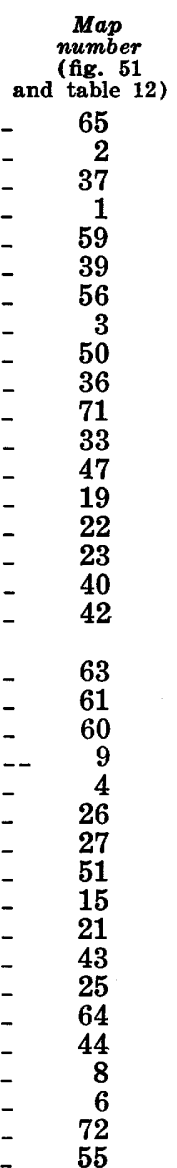

Mississippi River at New Orleans, La -........-.

Mississippi River at Prescott, Wis

Mississippi River at St. Louis, Mo _-_...-...-

Mississippi River at St. Paul, Minn -

Mississippi River at Tarbert Landing, Miss -...-

Mississippi River at Thebes, Ill

Mississippi River at Vicksburg, Miss .............

Mississippi River at Winona, Minn ..........

Mississippi River near Arkansas City, Ark

Missouri River at Hermann, Mo

Morganza Floodway near Krotz Springs, La

Mussel Fork near Musselfork, Mo _...........

Nonconnah Creek near Germantown, Tenn -...--

North Fabius River at Monticello, Mo

North River at Bethel, Mo

North River at Palmyra, Mo -.................

Ohio River at Golconda, Ill

Ohio River at Metropolis, Ill

Old River Outffow Channel near Knox

Landing, La

Ouachita River at Monroe,

Red River at Alexandria, La

Rock River near Joslin, Ill

Root River near Houston, Minn

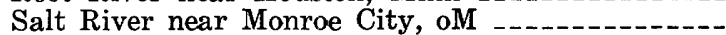

Salt River near New London, Mo

Sardis Lake near Sardis, Miss _...............

Skunk River at Augusta, Iowa -..--..--

South Fabius River near Taylor, Mo

South Fork Forked Deer River at Jackson, Tenn --

Sugar Creek at Elkhorn, Wis

Thompson Creek at Jackson, La

Turkey Creek at Fairview, Tenn

Turtle Creek near Clinton, Wis

Wapsipinicon River near DeWitt, Iowa -......

Wax Lake Outlet at Calumet, La

Yazoo River at Greenwood, Miss 


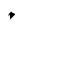

